\title{
ONREL
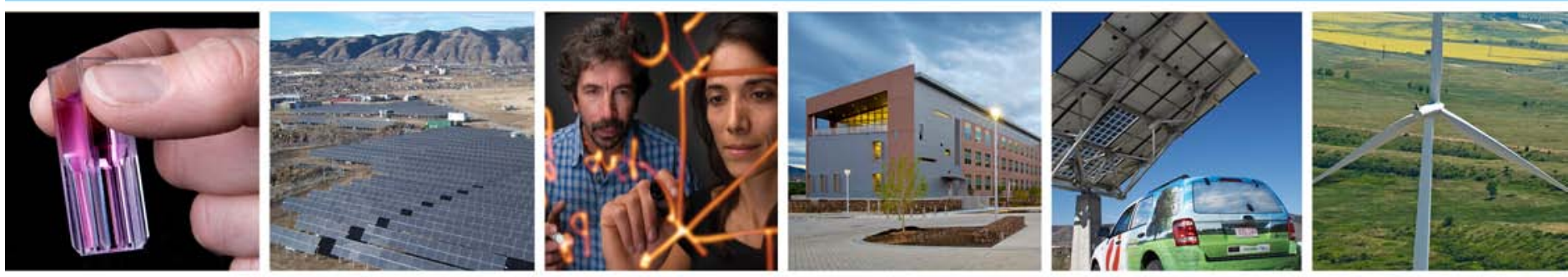

\section{U.S. Department of Energy Commercial Reference Building Models of the National Building Stock}

Michael Deru, Kristin Field, Daniel Studer, Kyle Benne, Brent Griffith, and Paul Torcellini National Renewable Energy Laboratory

Bing Liu, Mark Halverson, Dave Winiarski, and Michael Rosenberg

Pacific Northwest National Laboratory

Mehry Yazdanian

Lawrence Berkeley National Laboratory

Joe Huang

Formerly of Lawrence Berkeley National Laboratory

Drury Crawley

Formerly of the U.S. Department of Energy

NREL is a national laboratory of the U.S. Department of Energy, Office of Energy Efficiency \& Renewable Energy, operated by the Alliance for Sustainable Energy, LLC.

Technical Report

NREL/TP-5500-46861

February 2011 
National Renewable Energy Laboratory 1617 Cole Boulevard Golden, Colorado 80401 303-275-3000 • www.nrel.gov

\section{U.S. Department of Energy Commercial Reference Building Models of the National Building Stock}

Michael Deru, Kristin Field, Daniel Studer, Kyle Benne, Brent Griffith, and Paul Torcellini National Renewable Energy Laboratory

Bing Liu, Mark Halverson, Dave Winiarski, and Michael Rosenberg

Pacific Northwest National Laboratory

Mehry Yazdanian

Lawrence Berkeley National Laboratory

Joe Huang

Formerly of Lawrence Berkeley National Laboratory

Drury Crawley

Formerly of the U.S. Department of Energy

Prepared under Task No. BEC71304

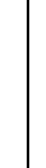

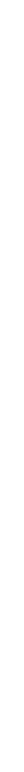

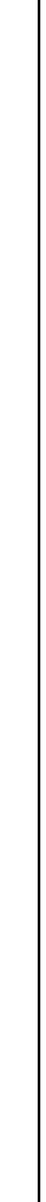

NREL is a national laboratory of the U.S. Department of Energy, Office of Energy Efficiency \& Renewable Energy, operated by the Alliance for Sustainable Energy, LLC.

\section{Technical Report}

NREL/TP-5500-46861

February 2011

Contract No. DE-AC36-08GO28308 


\section{NOTICE}

This report was prepared as an account of work sponsored by an agency of the United States government. Neither the United States government nor any agency thereof, nor any of their employees, makes any warranty, express or implied, or assumes any legal liability or responsibility for the accuracy, completeness, or usefulness of any information, apparatus, product, or process disclosed, or represents that its use would not infringe privately owned rights. Reference herein to any specific commercial product, process, or service by trade name, trademark, manufacturer, or otherwise does not necessarily constitute or imply its endorsement, recommendation, or favoring by the United States government or any agency thereof. The views and opinions of authors expressed herein do not necessarily state or reflect those of the United States government or any agency thereof.

Available electronically at http://www.osti.gov/bridge

Available for a processing fee to U.S. Department of Energy and its contractors, in paper, from:

U.S. Department of Energy

Office of Scientific and Technical Information

P.O. Box 62

Oak Ridge, TN 37831-0062

phone: 865.576 .8401

fax: 865.576 .5728

email: mailto:reports@adonis.osti.gov

Available for sale to the public, in paper, from:

U.S. Department of Commerce

National Technical Information Service

5285 Port Royal Road

Springfield, VA 22161

phone: 800.553 .6847

fax: 703.605.6900

email: orders@ntis.fedworld.gov

online ordering: http://www.ntis.gov/help/ordermethods.aspx

Cover Photos: (left to right) PIX 16416, PIX 17423, PIX 16560, PIX 17613, PIX 17436, PIX 17721

Printed on paper containing at least $50 \%$ wastepaper, including $10 \%$ post consumer waste. 


\section{Executive Summary}

The U.S. Department of Energy (DOE) Building Technologies program has set aggressive goals for energy efficiency improvements in buildings that will require collaboration between the DOE laboratories and the building industry. This report details the development of standard or reference energy models for the most common commercial buildings to serve as starting points for energy efficiency research. These models represent reasonably realistic building characteristics and construction practices. Fifteen commercial building types and one multifamily residential building were determined by consensus between DOE, the National Renewable Energy Laboratory, Pacific Northwest National Laboratory, and Lawrence Berkeley National Laboratory, and represent approximately two-thirds of the commercial building stock.

The reference buildings provide a common starting point to measure the progress of DOE energy efficiency goals for commercial buildings. The models of the reference buildings are used for DOE commercial buildings research to assess new technologies; optimize designs; analyze advanced controls; develop energy codes and standards; and to conduct lighting, daylighting, ventilation, and indoor air quality studies.

The input parameters for the building models came from several sources. Some were determined from ASHRAE Standards 90.1-2004, 62.1-2004, and 62-1999 for new construction and Standard 90.1-1989 for post-1980 construction; others were determined from studies of data and standard practices. National weighting factors are needed for each model in each location, so the relative importance of each can be factored into nationwide analyses. These factors characterize the number of buildings that are similar to each reference building type in each location. 


\section{Acronyms and Abbreviations}

\begin{tabular}{|c|c|}
\hline $\mathrm{ACH}$ & air changes per hour \\
\hline AEDG & Advanced Energy Design Guide \\
\hline $\mathrm{AF}$ & area factor \\
\hline ANSI & American National Standards Institute \\
\hline ASHRAE & American Society of Heating, Refrigerating and Air-Conditioning Engineers \\
\hline CAV & constant air volume \\
\hline CBECS & Commercial Buildings Energy Consumption Survey \\
\hline COP & coefficient of performance \\
\hline DOE & U.S. Department of Energy \\
\hline EER & energy efficiency ratio \\
\hline FCU & fan coil unit \\
\hline GGHC & Green Guide for Health Care \\
\hline HSPF & heating seasonal performance factor \\
\hline HVAC & heating, venting, and air conditioning \\
\hline IESNA & Illuminating Engineering Society of North America \\
\hline ILD & internal load density \\
\hline IRAC & individual room air conditioner \\
\hline ISH & individual space heater \\
\hline LBNL & Lawrence Berkeley National Laboratory \\
\hline LPD & lighting power density \\
\hline MZ & multizone \\
\hline NREL & National Renewable Energy Laboratory \\
\hline $\mathrm{OA}$ & outside air \\
\hline PACU & packaged air-conditioning unit \\
\hline PBA & principal building activity \\
\hline PNNL & Pacific Northwest National Laboratory \\
\hline PTAC & packaged terminal air conditioner \\
\hline PTHP & packaged terminal heat pump \\
\hline SAMSON & solar and meteorological surface observational network \\
\hline SEER & seasonal energy efficiency ratio \\
\hline SHGC & solar heat gain coefficient \\
\hline SHW & service hot water \\
\hline SS & split system \\
\hline $\mathrm{SSPC}$ & standing standards project committee \\
\hline SZ & single zone \\
\hline VAV & variable air volume \\
\hline WLCNS & wall construction \\
\hline
\end{tabular}




\section{Contents}

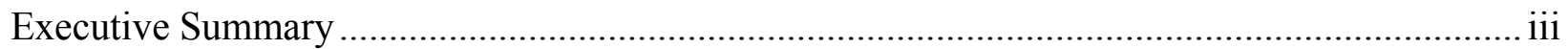

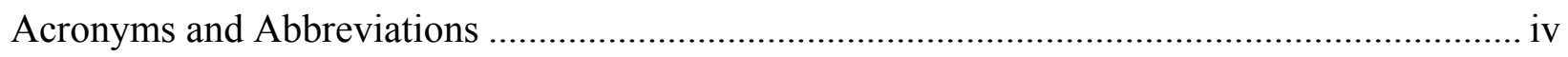

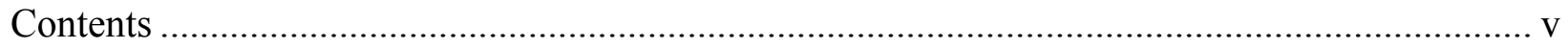

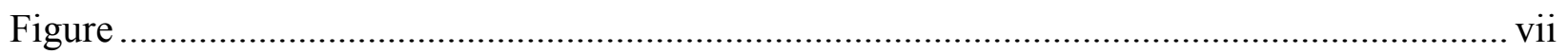

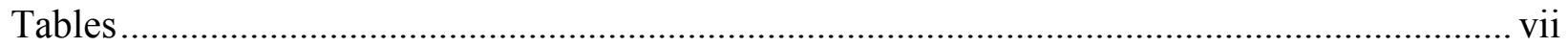

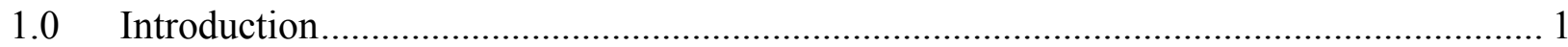

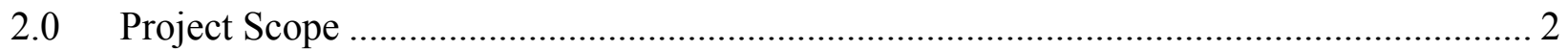

2.1 Intended Uses of the Reference Building Models..................................................... 2

2.2 Uses Not Intended for the Reference Building Models .......................................... 2

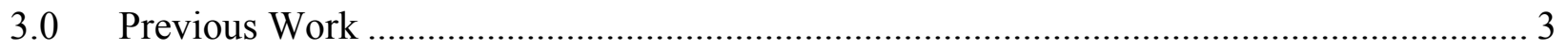

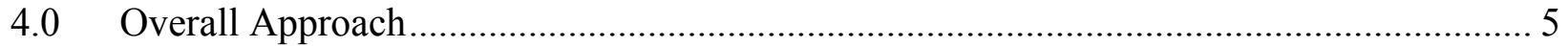

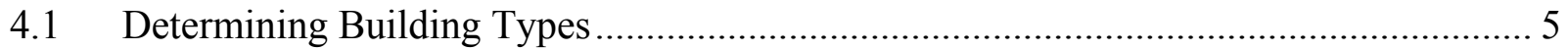

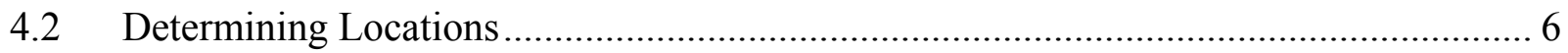

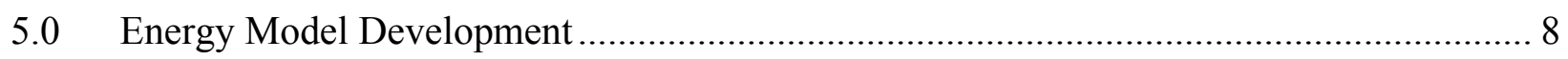

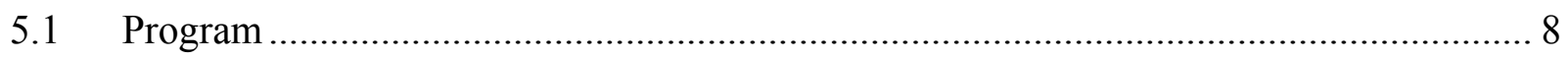

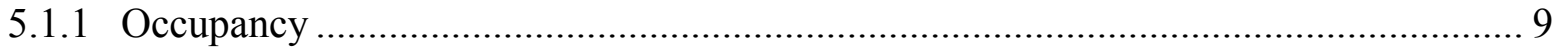

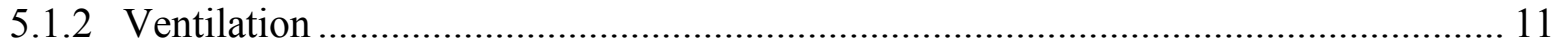

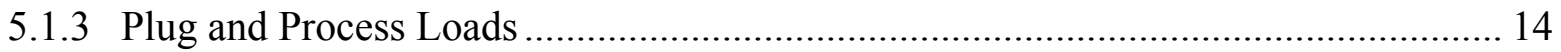

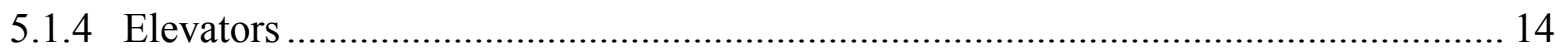

5.1.5 Commercial Kitchens ................................................................................. 15

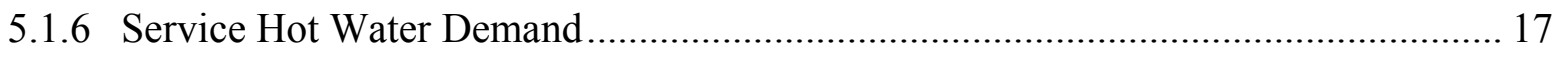

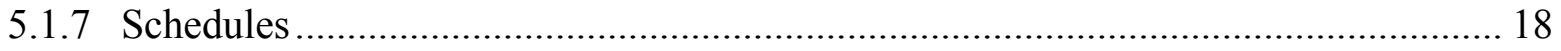

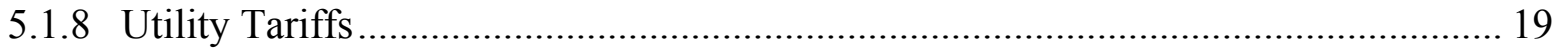

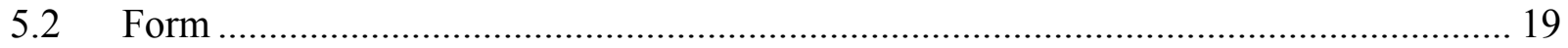

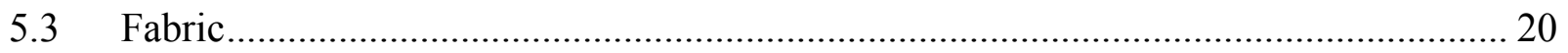

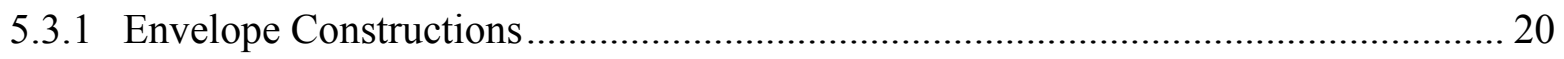

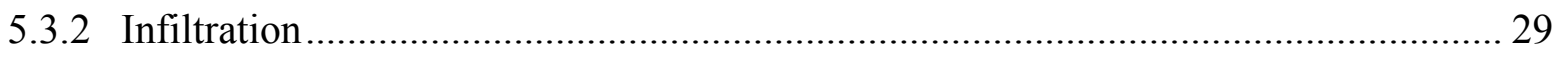

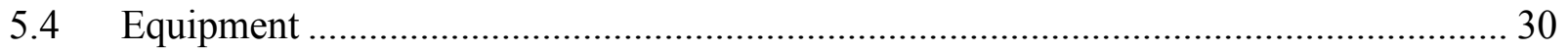

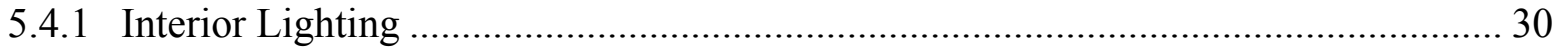

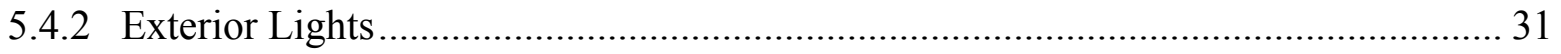

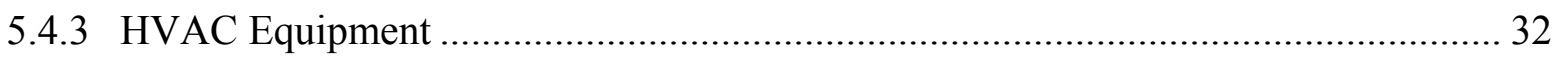




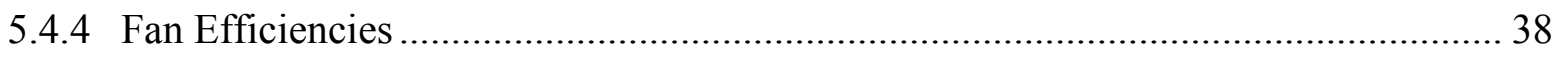

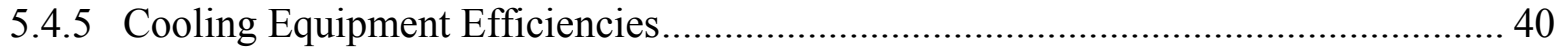

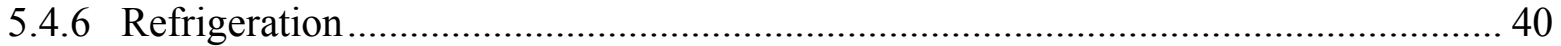

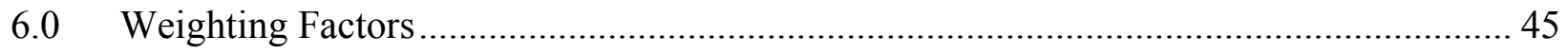

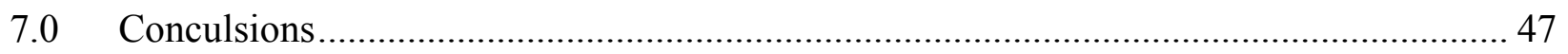

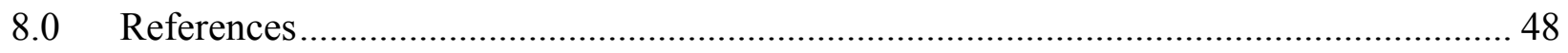

Appendix A: Reference Building Internal Loads ................................................................. 52

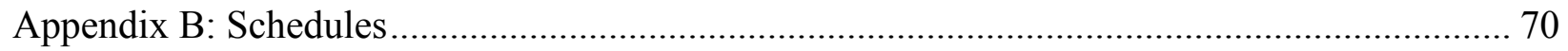




\section{Figure}

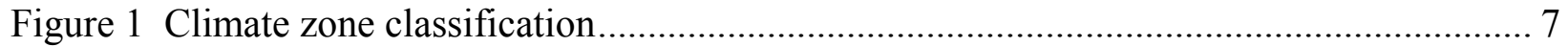

\section{Tables}

Table 1 Categorization of 2003 CBECS Data for Reference Building Models........................................ 6

Table 2 Selected Commercial Building Reference Model Locations ..................................................... 7

Table 3 Building Energy Model Input Categories ............................................................................ 8

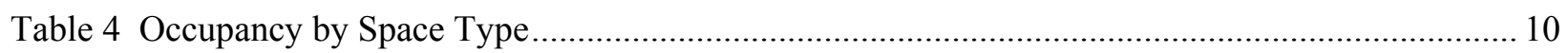

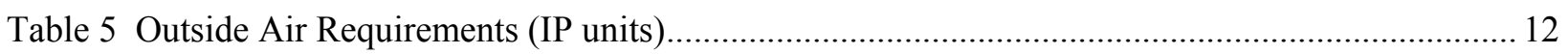

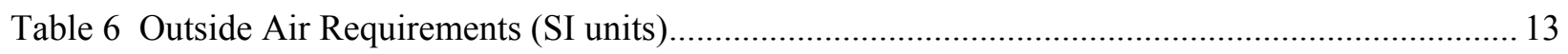

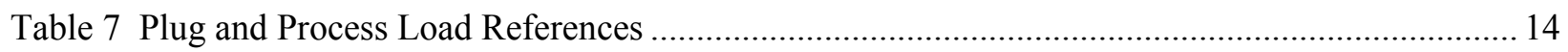

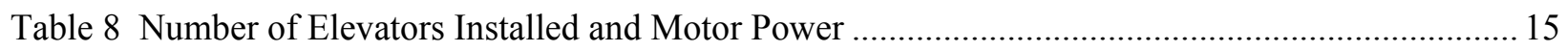

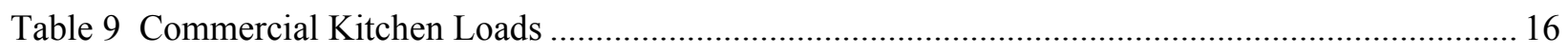

Table 10 Distribution of Kitchen Loads in Zone Energy Balance......................................................... 16

Table 11 Peak Service Hot Water Demand and Data Sources............................................................. 17

Table 12 Reference Building Model Schedule Starting Points.......................................................... 18

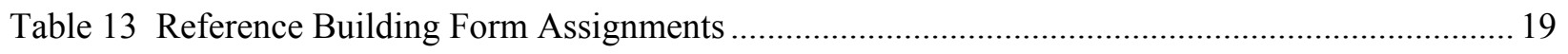

Table 14 Sources for Reference Building Form Data ...................................................................... 20

Table 15 Relationship of CBECS Roof Descriptions and Standard 90.1 Roof Constructions .................21

Table 16 Relationships Between CBECS Wall Descriptions and Standard 90.1 Wall Constructions ......22

Table 17 Recommended Roof Constructions by Building Type .......................................................... 23

Table 18 Recommended Wall Constructions by Building Type .......................................................... 24

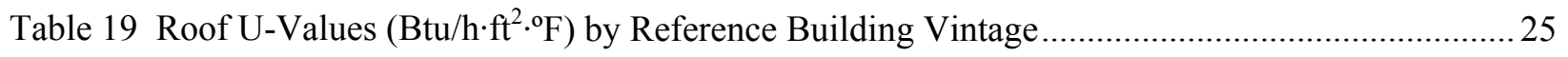

Table 20 Steel Frame Wall U-Values $\left(\mathrm{Btu} / \mathrm{h} \cdot \mathrm{ft}^{2}{ }^{\circ} \mathrm{F}\right)$ by Reference Building Vintage .............................. 25

Table 21 Mass Wall U-Values $\left(\mathrm{Btu} / \mathrm{h} \cdot \mathrm{ft}^{2} \cdot{ }^{\circ} \mathrm{F}\right)$ by Reference Building Vintage....................................... 26

Table 22 Unheated Slab-On-Grade Floor Insulation by Reference Building Vintage R-Value

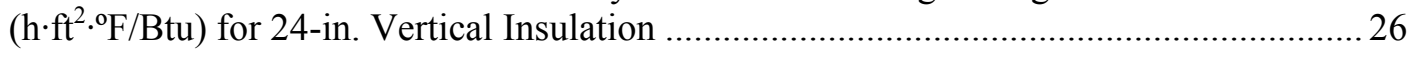

Table 23 Underground Wall Insulation by Reference Building Vintage R-Value $\left(\mathrm{h} \cdot \mathrm{ft}^{2} \cdot{ }^{\circ} \mathrm{F} / \mathrm{Btu}\right) \ldots \ldots \ldots \ldots \ldots . . .27$

Table 24 Window Overall U-Value $\left(\mathrm{Btu} / \mathrm{h} \cdot \mathrm{ft}^{2} \cdot{ }^{\circ} \mathrm{F}\right)$ by Reference Building Vintage.................................2 27

Table 25 Window Solar Heat Gain Coefficient by Reference Building Vintage ....................................2 28

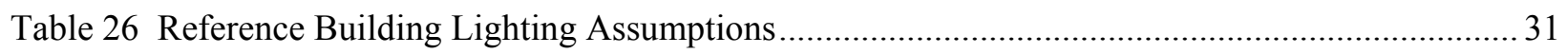

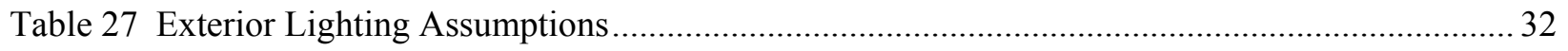

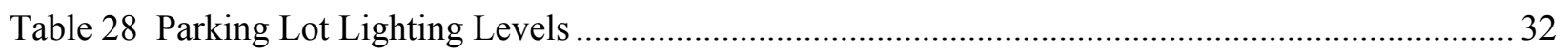

Table 29 HVAC Equipment Types for Post-1980 and New Construction ............................................ 33

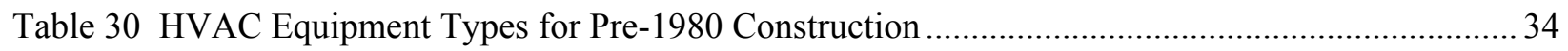


Table 31 Estimated Unitary Cooling Equipment Efficiencies for Pre-1980 Construction ........................35

Table 32 Estimated Water Chilling Equipment Efficiencies for Pre-1980 Construction ........................ 37

Table 33 Estimated Packaged Terminal Cooling Equipment Efficiencies for Pre-1980 Construction ...... 37

Table 34 Estimated Space Heating Equipment Efficiencies for Pre-1980 Construction......................... 38

Table 35 Estimated Water Heating Equipment Efficiencies for Pre-1980 Construction.......................... 38

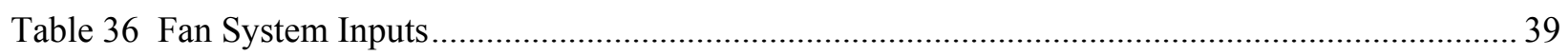

Table 37 Walk-In Refrigeration System Descriptions (IP Units) ......................................................... 41

Table 38 Walk-In Refrigeration System Descriptions (SI Units) ......................................................... 42

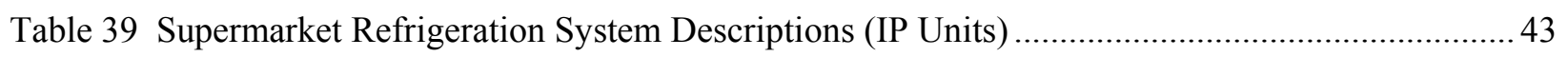

Table 40 Supermarket Refrigeration System Descriptions (SI Units) .................................................... 43

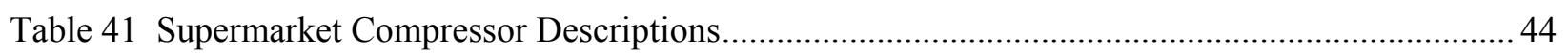

Table 42 New Construction Reference Building Weighting Factors................................................... 46

Table A-1 Reference Building Zone Internal Loads (IP units) ........................................................ 52

Table A-2 Reference Building Zone Internal Loads (SI units) ........................................................... 61

Table B-1 Quick Service Restaurant Hourly Operation Schedules ....................................................... 70

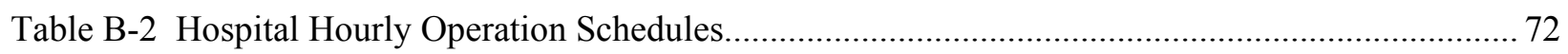

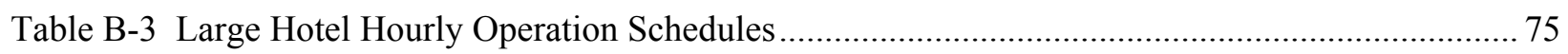

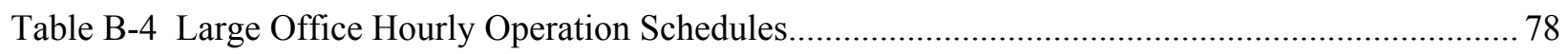

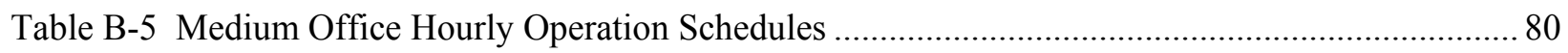

Table B-6 Midrise Apartment Hourly Operation Schedules................................................................. 83

Table B-7 Outpatient Health Care Hourly Operation Schedules .......................................................... 85

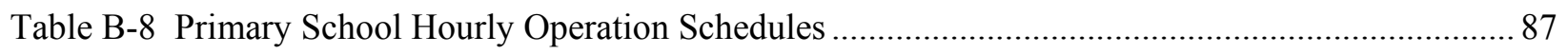

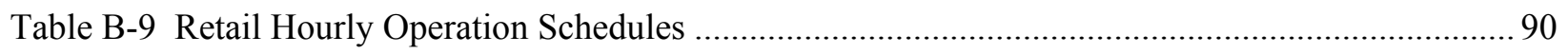

Table B-10 Secondary School Hourly Operation Schedules ............................................................. 91

Table B-11 Full Service Restaurant Hourly Operation Schedules........................................................95

Table B-12 Small Hotel Hourly Operation Schedules ......................................................................... 97

Table B-13 Small Office Hourly Operation Schedules........................................................................ 100

Table B-14 Strip Mall Hourly Operation Schedules............................................................................ 102

Table B-15 Supermarket Hourly Operation Schedules....................................................................... 103

Table B-16 Warehouse Hourly Operation Schedules …..................................................................... 107 


\subsection{Introduction}

The U.S. Department of Energy (DOE) Building Technologies program has set aggressive goals for energy efficiency improvements in buildings. This goal will require collaboration between the DOE laboratories and the building industry. Several analysis activities are under way to determine the best paths forward. Coordinating research activities and tracking progress require common points of reference.

The purpose of this project was to develop standard or reference building energy models for the most common commercial buildings to serve as starting points for analysis related to energy efficiency research. These models represent realistic building characteristics and construction practices. Fifteen commercial building types and one multifamily residential building (see Table 1 on page 14) were determined by consensus between DOE, the National Renewable Energy Laboratory (NREL), Pacific Northwest National Laboratory (PNNL), and Lawrence Berkeley National Laboratory (LBNL). These represent approximately two-thirds of the commercial building stock. The remaining one-third is composed of several building types that are not easily defined by a small number of models; however, some are similar to one or more of the 16 reference building types.

There are three versions of the reference building models for each building type: new construction, post-1980 construction, and pre-1980 construction. All have the same building form and area and the same operation schedules. The differences are reflected in the insulation values, lighting levels, and HVAC equipment types and efficiencies. The new construction models comply with the minimum requirements of ANSI/ASHRAE/IESNA Standard 90.1-2004 (ASHRAE 2004a), the post-1980 models meet the minimum requirements of Standard 90.1-1989 (ASHRAE 1989), and the pre-1980 models are built to a set of requirements developed from previous standards and other studies of construction practices.

The reference building models are described in detail in this report and are available as EnergyPlus input files (http://commercialbuildings.energy.gov/reference buildings.html). Spreadsheet scorecards document the model parameters and annual energy performance for each building type and location.

Throughout the development of the reference buildings, the DOE Building Energy Codes Program, the ASHRAE simulation working group, and Standard 90.1 subcommittees have provided in-depth review of the underlying assumptions. 


\subsection{Project Scope}

The reference building models cover 16 building types and 16 U.S. locations. They directly characterize more than $60 \%$ of the commercial building stock and are very similar to other commercial building types. The models are fully defined in the spreadsheet scorecards and are available as EnergyPlus input files.

\subsection{Intended Uses of the Reference Building Models}

The purpose of these models is to represent new and existing buildings. The reference building models will be used for DOE commercial buildings research to assess new technologies; optimize designs; analyze advanced controls; develop energy codes and standards; and to conduct lighting, daylighting, ventilation, and indoor air quality studies. They also provide a common starting point to measure the progress of DOE energy efficiency goals for commercial buildings. DOE's Building Energy Code Program and PNNL use these models for the analytical support in the development of new versions of ASHRAE Standard 90.1. The models provide consistency in modeling approaches and implementation across commercial buildings.

\subsection{Uses Not Intended for the Reference Building Models}

These reference building models are not intended to represent energy use in any particular building. Rather, they are hypothetical models with ideal operations that meet certain minimum requirements.

The reference building model definitions are not intended to act as targets to rate the energy performance of single existing or proposed buildings. The models and weighting factors are not appropriate for analysis at the state level, as the datasets used to generate the models and the weighting factors are too small to form a valid statistical model at this level. Variations of these models and weighting factors could be created for such purposes, but that is not the objective of this project. 


\subsection{Previous Work}

Several projects have created prototypical building energy models. The most familiar are from LBNL, which developed a series of prototypical buildings over several years. Huang et al.

(1991) and Huang and Franconi (1999) present extensive summaries of work in this area; Huang et al. (2005) present an analysis of 1999 building data. Three recent efforts to develop prototypical energy models of buildings include a set of standardized energy simulation models for commercial buildings from the University of Massachusetts (Stocki et al. 2005), a residential building benchmark model from the DOE Building America program (Hendron 2007), and an assessment of the entire commercial building stock by NREL (Griffith et al. 2007). Projects that focused on single building types were carried out to create the Advanced Energy Design Guides (AEDGs) for small office, small retail, warehouses, K-12 schools, highway lodging, and small healthcare (ASHRAE 2009).

Huang et al. (1991) developed 481 prototypical commercial buildings (37 building types and 13 locations) for a market assessment of cogeneration systems. The building types, sizes, and locations were selected based on the best potential to use cogeneration. The purpose of the project was to model the energy use in existing commercial building stock as closely as reasonable. The paper presents a summary of building characteristics databases, engineering studies, characterizations, and prototypes for energy simulations. The data included the Nonresidential Building Energy Consumption Survey, which later became the Commercial Buildings Energy Consumption Survey (CBECS) (EIA 2005), and F.W. Dodge building stock and forecast data (McGraw-Hill 2005). They completed sensitivity analyses to better understand the effects of building size, external wall models, thermal zoning, and HVAC types on the simulated energy use.

Huang and Franconi (1999) estimated the heating and cooling loads in existing commercial buildings by component and the efficiencies of the equipment used to meet those loads. They used 120 prototypical buildings covering 12 building types of old and new construction. The models were updated versions of the 1991 Huang et al. models based on 1989 CBECS data. The models were extrapolated to represent the regional and national building stock with weighting factors derived from the 1992 CBECS.

Stocki et al. (2005) present a set of standardized assumptions for commercial building energy analyses. They define seven building types: large office, small office, retail, education, apartment, small hotel, and hospital. These are meant to represent typical commercial buildings; however, there is little justification for the types chosen. The building sizes were based on work by Huang and Franconi (1999). Energy-related parameters conform to ASHRAE Standards 90.1-2001 (ASHRAE 2001) and 62.1-1999 (ASHRAE 1999). These models could be used to analyze energy performance of any of the seven building types in any climate; however, there is no method to extend the results beyond each type and size.

The Building America benchmark model (Hendron 2007) provides a common baseline for determining energy savings of new residential buildings. Hourly energy simulations are used to determine the savings. The size and location of the benchmark (baseline) building are set to match the proposed building, but everything else is defined by a set of modeling rules. The operating schedules are clearly defined and are used for both building simulations. 
Griffith et al. (2007) completed an assessment of the commercial building sector for the potential to reach net zero energy. They autogenerated energy simulation models for all the buildings in 1999 CBECS (EIA 2002), except refrigerated warehouses. This effort resulted in5,375 models which were used to examine potentials of different technology scenarios for the commercial building stock. While robust, the number of buildings results in a computational burden for extensive analysis. 


\subsection{Overall Approach}

It is impractical to model every new commercial building, or even to represent every building sub-sector, so we selected a small number of prevalent building types and developed weighting factors to represent a percentage of the commercial building stock. A goal was set to represent $70 \%$ of the U.S. commercial building floor area.

National data from the 2003 CBECS (EIA 2005) were used to determine the appropriate, average mix of representative buildings. We selected 16 building types and developed weighting factors to adjust for the percentage of the building stock represented by each building type for 16 locations. This mix of buildings and locations demonstrates the climatic and geographic effects in each construction vintage. The three vintages of 16 building types in 16 locations result in 768 models.

Creating energy simulation input files is tedious and time consuming, and mistakes are common. Analysis activities of the national building sub-sectors can involve creating hundreds - or even thousands - of input files. To alleviate some of the workload and minimize the potential for mistakes, we developed computer programs to create the input files for the energy simulations based on sets of easily implemented rules. The input files by location are autocreated from a seed file for each building type and vintage based on rules from appropriate energy efficiency standards for climate-variable parameters.

\subsection{Determining Building Types}

The best publicly available data on commercial buildings are from CBECS (EIA 2005), for which the 2003 version contains 5,215 buildings. The CBECS variables PBA 8 and PBAplus8 separate the commercial sector into 29 categories and 51 subcategories based on principal building activity (PBA). Analysis of the CBECS data provided the project team with the most typical building types, and the final set of building types was selected by consensus among DOE, NREL, LBNL, and PNNL. The set of 15 building types from CBECS is listed in Table 1, along with the PBA numbers. A midrise apartment building model is also included to total 16 building types. Multifamily housing buildings are not included in CBECS, and the midrise apartment model was developed from other data in a separate PNNL study (Gowri et al. 2007).

This set of 15 commercial building types represents 3,279 buildings (of 5,215) from the full CBECS dataset. This subset represents 44 billion $\mathrm{ft}^{2}\left(4.1\right.$ billion $\left.\mathrm{m}^{2}\right)$ or $62 \%$ of the total weighted floor area in the survey (64\% if the vacant buildings are removed from the total) and $65 \%$ of the total energy consumption. The remaining CBECS building types include buildings that vary significantly in size, internal loads, and operation; several building types would need to be added to reach the $70 \%$ goal. Religious worship buildings are the next-largest group of buildings, which would raise the percentage of the total weighted floor area to $67 \%$. However, they represent $74 \%$ of the new construction from 2003 to 2007 contained in the McGraw-Hill Construction Starts Database (Jarnagin and Bandyopadhyay 2010). 
Table 1 Categorization of 2003 CBECS Data for Reference Building Models

\begin{tabular}{|l|c|c|}
\hline \multicolumn{1}{|c|}{ Name } & PBA8 & PBAPLUS8 \\
\hline \hline Small Office & 2 & $2,3,4,5,6,7$ \\
\hline Medium Office & 2 & $2,3,4,5,6,7$ \\
\hline Large Office & 2 & $2,3,4,5,6,7$ \\
\hline Primary School & 14 & 28 \\
\hline Secondary School & 14 & 29 \\
\hline Stand-Alone Retail & 25 & 42 \\
\hline Strip Mall & 23 & 50 \\
\hline Supermarket & 6 & 14 \\
\hline Quick Service Restaurant & 15 & 32 \\
\hline Full Service Restaurant & 15 & 33 \\
\hline Small Hotel & 18 & 39 \\
\hline Large Hotel & 18 & 38 \\
\hline Hospital & 13 & 35 \\
\hline Outpatient Healthcare & 8 & 18,19 \\
\hline Warehouse & 5 & 9,10 \\
\hline Midrise Apartment & N/A & N/A \\
\hline
\end{tabular}

\subsection{Determining Locations}

Locations were selected to represent significant portions of the existing building stock and all U.S. climate zones. Population is a good indicator of building distribution; however, if it were the only criterion, some climate zones would not be represented. Approximately $78 \%$ of the population is located in five of the 15 climate zones. To represent all U.S. climate zones and the highest building densities, we selected the most populous cities in each climate zone.

Briggs et al. (2003) developed a climate zone classification system for DOE and ASHRAE Standard 90.1-2004 based on SAMSON (NCDC 1993) weather data, as shown in Figure 1. An important characteristic of these climate zones is that they tend to run in east-west bands across the country; subdivisions for moist, dry, and marine divide these bands. As part of this effort, PNNL developed a set of "typical" locations (cities) based on their representativeness in each climate zone. The selections had little to do with population or number of buildings.

We selected a revised set of locations as a balance of the representativeness of the climate and the number of buildings in each climate zone (see Table 2). Two locations were selected for climate zone 3B because they represent different climates within one zone, which is evident from the reference building model energy simulation results. These subclimate zones are designated as "3B-CA" for the California coast and "3B-other" for the remaining part of climate zone 3B. 


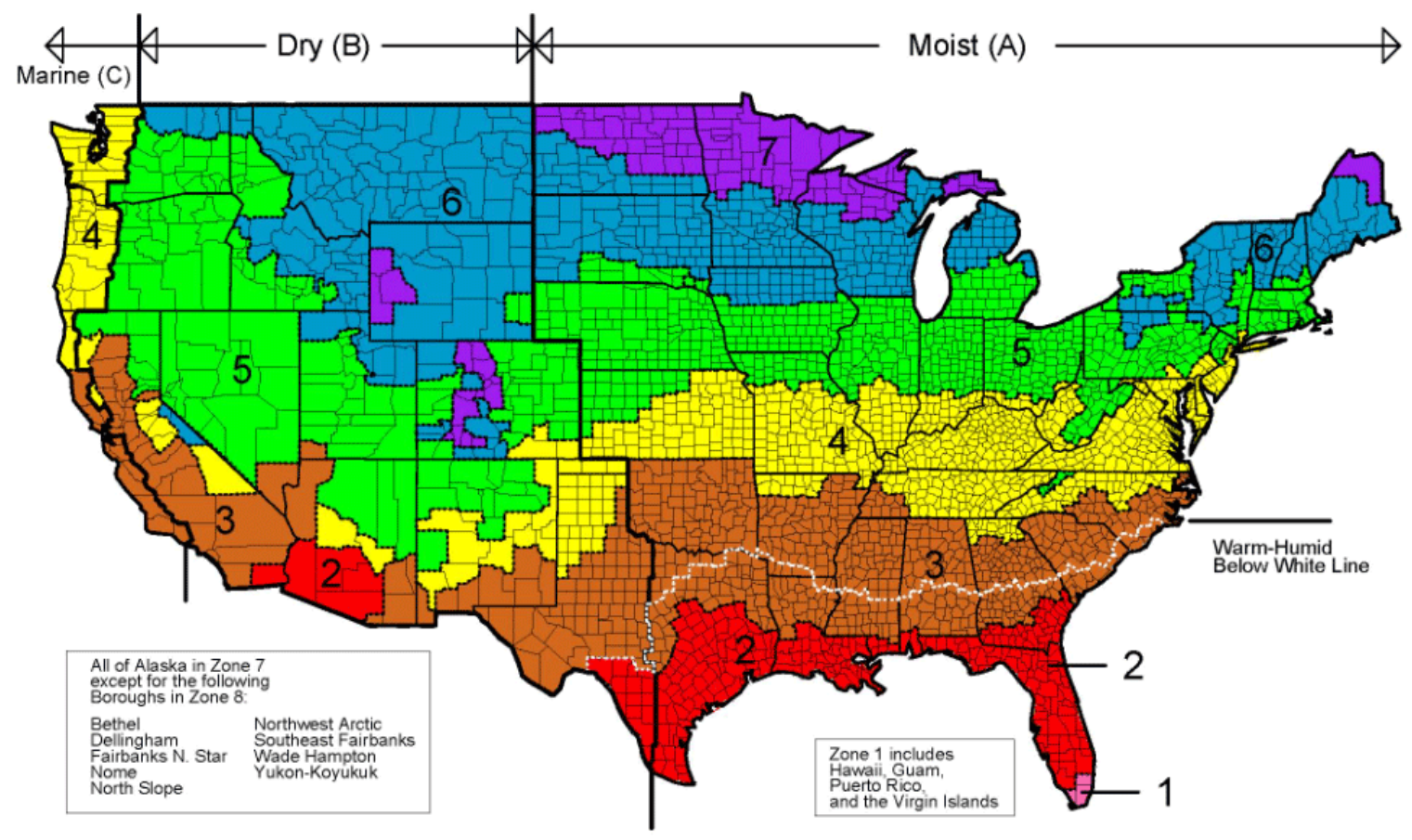

Figure 1 Climate zone classification

(Credit: Briggs et al. [2003]; DOE [2005])

Table 2 Selected Commercial Building Reference Model Locations

\begin{tabular}{|c|c|l|l|}
\hline Number & Climate Zone & \multicolumn{1}{|c|}{ Representative City } & TMY2 Weather file location \\
\hline $\mathbf{1}$ & 1A & Miami, Florida & Miami, Florida \\
\hline $\mathbf{2}$ & 2A & Houston, Texas & Houston, Texas \\
\hline $\mathbf{3}$ & 2B & Phoenix, Arizona & Phoenix, Arizona \\
\hline $\mathbf{4}$ & 3A & Atlanta, Georgia & Atlanta, Georgia \\
\hline $\mathbf{5}$ & 3B-CA & Los Angeles, California & Los Angeles, California \\
\hline $\mathbf{6}$ & 3B-other & Las Vegas, Nevada & Las Vegas, Nevada \\
\hline $\mathbf{7}$ & 3C & San Francisco, California & San Francisco, California \\
\hline $\mathbf{8}$ & 4A & Baltimore, Maryland & Baltimore, Maryland \\
\hline $\mathbf{9}$ & 4B & Albuquerque, New Mexico & Albuquerque, New Mexico \\
\hline $\mathbf{1 0}$ & 4C & Seattle, Washington & Seattle, Washington \\
\hline $\mathbf{1 1}$ & 5A & Chicago, Illinois & Chicago-O'Hare, Illinois \\
\hline $\mathbf{1 2}$ & 5B & Denver, Colorado & Boulder, Colorado \\
\hline $\mathbf{1 3}$ & 6A & Minneapolis, Minnesota & Minneapolis, Minnesota \\
\hline $\mathbf{1 4}$ & 6B & Helena, Montana & Helena, Montana \\
\hline $\mathbf{1 5}$ & $\mathbf{7}$ & Duluth, Minnesota & Duluth, Minnesota \\
\hline $\mathbf{1 6}$ & $\mathbf{8}$ & Fairbanks, Alaska & Fairbanks, Alaska \\
\hline
\end{tabular}




\subsection{Energy Model Development}

The intent of the reference building models is to characterize the energy performance of typical building types under typical operations. Detailed building energy models require several pieces of information that are not available from standard data sources; therefore, information from several sources was combined in a sensible way to represent "typical" performance. To better organize the efforts, we divided the model inputs into program, form, fabric, and equipment (see Table 3).

Table 3 Building Energy Model Input Categories

\begin{tabular}{|l|l|l|l|}
\hline \multicolumn{1}{|c|}{ Program } & \multicolumn{1}{c|}{ Form } & \multicolumn{1}{c|}{ Fabric } & \multicolumn{1}{c|}{ Equipment } \\
\hline \hline Location & Number of floors & Exterior walls & Lighting \\
\hline Total floor area & Aspect ratio & Roof & HVAC system types \\
\hline Plug and process loads & Window fraction & Floors & Water heating equipment \\
\hline Ventilation requirements & Window locations & Windows & Refrigeration \\
\hline Occupancy & Shading & Interior partitions & Component efficiency \\
\hline Space environmental conditions & Floor height & Internal mass & Control settings \\
\hline Service hot water demand & Orientation & Infiltration & \\
\hline Operating schedules & & & \\
\hline
\end{tabular}

The program and form for the small office, schools, warehouse, small hotel, and outpatient healthcare were taken, with slight modifications, from the work on the AEDGs for these building types. PNNL developed the midrise apartment model for its work to support the development of Standard 90.1. The program and form of the remaining models were developed from analysis of CBECS (EIA 2005) and Time-Saver Standards for Building Types (DeChiara and Crosbie 2001) and from experience with these building types.

The fabric and equipment parameters set by energy standards were determined from ASHRAE Standards 90.1-2004 (ASHRAE 2004a), 62.1-2004 (ASHRAE 2004b), and 62-1999 (ASHRAE 1999) for new construction and Standard 90.1-1989 (ASHRAE 1989) for post-1980 construction. NREL, PNNL, and LBNL performed research to determine the remaining model inputs. PNNL completed a series of reports analyzing 2003 CBECS and past energy standards to determine many of the energy model parameters used in these models. Winiarski et al. (2007a; 2007b; 2008) published two reports and a conference paper that analyzed envelope construction and some building form characteristics. The HVAC system types were determined from the results of a study by Winiarski et al. (2006) of system types and efficiencies for pre-1980 and post-1980 models and from input from the standing standards project committee (SSPC) 90.1 Simulation Working Group and Mechanical Subcommittee for the new construction models. Throughout the development of the reference building models, the DOE Building Energy Codes Program, the ASHRAE simulation working group, and SSPC 90.1 subcommittees have provided in-depth review of the models and the underlying assumptions.

\subsection{Program}

The building program includes the activity, location, occupancy, plug and process loads, service water heating demand, and schedules. The PBAs were determined during the process of analyzing the national building data (see Table 1). The reference building models are intended to 
look much more like real buildings as compared to the generic boxes often used for energy simulation studies. LBNL developed the original geometry characterization of the reference building models (except for the midrise apartment), including the shape, floor area, number of floors, and thermal zoning based on previous work and analysis of 2003 CBECS (EIA 2005). Nine models were completely changed and modifications were made to the other models based on input from industry and further data analysis. PNNL, NREL, and the AEDG project committees developed the models for the small office, primary and secondary schools, warehouse, small hotel, and outpatient health care for the AEDGs for these respective building types (ASHRAE 2009). NREL developed the stand-alone retail and supermarket reference building models based on work with national retailers and CBECS. NREL and PNNL developed the strip mall model from CBECS data and from a review of actual strip mall layouts.

Table 13 lists the building floor areas and many form parameters. Appendix A lists the zone level program parameters in IP units (Table A-1) and SI units (Table A-2) for each model.

\subsubsection{Occupancy}

Occupancy information is included in CBECS; however, close inspection reveals that these data are unreliable. For example, office building occupancy (based on the number of workers on the main shift from the 1999 CBECS [EIA 2002]) ranges from $334 \mathrm{ft}^{2} /$ person to $300,000 \mathrm{ft}^{2} /$ person $\left(31 \mathrm{~m}^{2} /\right.$ person to $27,871 \mathrm{~m}^{2} /$ person) with a mean of more than $25,000 \mathrm{ft}^{2} /$ person $(2,323$ $\mathrm{m}^{2} /$ person). The occupancy rates for the reference building models were instead taken from the AEDG studies for the appropriate building types and from the default occupancy rates in Standard 62.1-2004 (ASHRAE 2004b) following a recommendation by the ASHRAE 90.1 Simulation Working Group. Changes were made for dining, kitchen, storage, and shipping and receiving areas, where these occupancy rates exceed the 2003 International Building Code maximum (ICC 2003). The occupancy rates by space type are listed in Table 4, either as the total number of occupants per space or as occupant density. Appendix A lists occupancy by zone for each model.

Pless et al. (2007) documented the primary school model with 650 students and the secondary school with 1200 students; however, the occupancy densities and schedules from the energy models resulted in much higher numbers of students. The classroom occupancy schedules were adjusted by factors of 0.75 for the primary school and 0.70 for the secondary school to arrive at the student numbers documented in the project report.

The hotel guest rooms were assumed to have 1.5 occupants each, and occupancy rates for the two hotel models were assumed to be $65 \%$ to align with the industry average occupancy rate and Jiang et al. (2008). Rooms were randomly assigned occupants in the small hotel model so 50 of the 77 rooms are occupied. The occupancy, lighting, and hot water schedules for the unoccupied rooms were set to zero. The plug load schedule was set to a constant value of $20 \%$ for all rooms. The thermal zoning and the use of multipliers in the large hotel model do not allow for this type of control; therefore, a set of schedules was created to reduce the occupancy and loads to match the $65 \%$ occupancy rate across all guest rooms. 
Table 4 Occupancy by Space Type

\begin{tabular}{|c|c|c|c|c|}
\hline \multirow[b]{2}{*}{ Space Type } & \multirow{2}{*}{$\begin{array}{l}\text { Occupancy } \\
\text { per Space }\end{array}$} & \multicolumn{2}{|c|}{ Occupancy } & \multirow[b]{2}{*}{ Data Source } \\
\hline & & $\mathrm{ft}^{2} /$ person & $\mathrm{m}^{2} /$ person & \\
\hline Apartment & 3.0 & - & - & Gowri et al. 2007 \\
\hline Auditorium seating area & - & 10.8 & 1 & Pless et al. 2007 \\
\hline Cafeteria/FF dining & - & 15 & 1.4 & ICC 2003 \\
\hline Classrooms & - & 43 & 4 & Pless et al. 2007 \\
\hline Corridor (school) & - & 107.6 & 10 & Pless et al. 2007 \\
\hline Corridor (public spaces) & - & 1000 & 93 & Engineering judgment \\
\hline Hotel guest room & 1.5 & - & - & Jiang et al. 2008 \\
\hline Gym (primary school) & - & 35.8 & 3.3 & Pless et al. 2007 \\
\hline Gym (secondary school) & - & 10.8 & 1.0 & Pless et al. 2007 \\
\hline Gym, auxiliary (secondary school) & - & 35.8 & 3.3 & Pless et al. 2007 \\
\hline Kitchen (commercial) & - & 200 & 18.6 & ICC 2003 \\
\hline Laundry & - & 250 & 23. & Jiang et al. 2008 \\
\hline Library/Media center & - & 46.8 & 4.4 & Pless et al. 2007 \\
\hline Lobby (school) & 0.0 & - & - & Engineering judgment \\
\hline Lobby (hotel) & - & 33.3 & 3 & ASHRAE 2004b \\
\hline Lobby (office building) & - & 100 & 9.3 & ASHRAE 2004b \\
\hline Office & - & 200 & 18.6 & ASHRAE 2004b \\
\hline Office (apartment) & 2.0 & - & - & Gowri et al. 2007 \\
\hline Office (school) & - & 215 & 20 & Pless et al. 2007 \\
\hline Office (warehouse) & 5.0 & - & - & Liu et al. 2007 \\
\hline Reception areas & - & 33.3 & 3.1 & ASHRAE 2004b \\
\hline Restaurant dining rooms & - & 15 & & ICC 2003 \\
\hline Restroom (school) & - & 1076 & 100 & Pless et al. 2007 \\
\hline Sales & - & 66.7 & 6.2 & ASHRAE 2004b \\
\hline Shipping/Receiving & - & 300 & 28 & ICC 2003 \\
\hline Storage & - & 300 & 28 & ICC 2003 \\
\hline Supermarket & - & 125 & 11.6 & ASHRAE 2004b \\
\hline Warehouse & 0.0 & - & - & Liu et al. 2007 \\
\hline \multicolumn{5}{|l|}{ Hospital spaces } \\
\hline Critical and intensive care & - & 50 & 4.7 & Doebber et al. 2009 \\
\hline ER exam rooms and triage & - & 50 & 4.7 & ASHRAE 2004b \\
\hline Laboratory & - & 200 & 18.6 & GGHC 2007 \\
\hline Nurse's station/waiting rooms & - & 750 & 69.7 & Engineering judgment \\
\hline Operating/surgical cystoscopic rooms & - & 200 & 18.6 & GGHC 2007 \\
\hline Patient room & - & 200 & 18.6 & GGHC 2007 \\
\hline Physical therapy & - & 200 & 18.6 & GGHC 2007 \\
\hline Radiology & & 200 & 18.6 & GGHC 2007 \\
\hline \multicolumn{5}{|l|}{ Outpatient spaces } \\
\hline Nurse's station & - & 50 & 4.7 & GGHC 2007 \\
\hline Operating room & - & 50 & 4.7 & GGHC 2007 \\
\hline Procedure room & - & 50 & 4.7 & GGHC 2007 \\
\hline Exam room & - & 50 & 4.7 & GGHC 2007 \\
\hline Clean/soiled areas & - & 50 & 4.7 & GGHC 2007 \\
\hline Recovery room & - & 50 & 4.7 & GGHC 2007 \\
\hline
\end{tabular}




\subsubsection{Ventilation}

The ventilation or outside air (OA) requirements are listed by space type in Table 5 (IP units) and Table 6 (SI units). Standard 90.1-2004 refers to Standard 62-1999 as a normative reference, so the ventilation requirements from Standard 62-1999 Table 2 are used (ASHRAE 1999). The occupancy rates were taken from the AEDG technical support documents for those buildings with AEDGs and the default occupancy rates from 62.1-2004 for other building types as recommended by the Standard 90.1 Simulation Working Group. The occupancy rates in Standard 62.1-2004 are considered to be more realistic than those in 62-1999. We assumed that the ventilation requirements are the same for all vintages of reference building models because reliable data for older buildings are not available. We will reevaluate this assumption as more information about existing buildings becomes available.

The OA requirements for the hospital and the outpatient facility were determined from the 2007 Green Guide for Health Care (GGHC 2007), the 2001 Guidelines for Design and Construction of Hospital and Health Care Facilities (AIA 2001), and from Standard 62-1999.

A brief discussion of the ventilation design practices for hospitals is worthwhile. Most hospitals are designed to comply with AIA (2001). This document is updated periodically; e.g., 1987, 1992, 1996, 2001, and 2006. The Centers for Medicare and Medicaid Services references the 2001 edition, but most consultants design to the current version. Compliance is law in many states, and is a requirement for reimbursement for Medicare and Medicaid. Regardless, very few hospitals choose to not accept Medicare and Medicaid patients. In 2004 most designs probably would have complied with the 2001 edition. Today most are shifting to the 2006 edition, although it is not generally required by law. 
Table 5 Outside Air Requirements (IP units)

\begin{tabular}{|c|c|c|c|c|c|c|c|}
\hline \multirow[b]{2}{*}{ Space Type } & \multirow{2}{*}{\begin{tabular}{|c|} 
Default \\
Occupancy \\
$\mathrm{ft}^{2} /$ person \\
\end{tabular}} & \multicolumn{2}{|l|}{ OA } & \multirow{2}{*}{$\frac{\text { Total OA }}{\mathrm{cfm} / \mathrm{ft}^{2}}$} & \multicolumn{3}{|c|}{ OA Data Sources } \\
\hline & & cfm/person & $\mathrm{cfm} / \mathrm{ft}^{2}$ & & $\mathrm{ACH}$ & Occupancy & Ventilation \\
\hline Auditorium seating area & 10.8 & 15 & - & 1.39 & - & Pless et al. 2007 & ASHRAE 1999 \\
\hline Bath (cfm/room) & - & 20 & - & - & - & & ASHRAE 1999 \\
\hline Cafeteria/FF dining & 15 & 20 & - & 1.33 & - & ICC 2003 & ASHRAE 1999 \\
\hline Classrooms & 43.1 & 15 & - & 0.35 & - & Pless et al. 2007 & ASHRAE 1999 \\
\hline Corridor (school) & - & - & 0.10 & 0.10 & - & - & ASHRAE 1999 \\
\hline Corridor (public spaces) & - & - & 0.05 & 0.05 & - & - & ASHRAE 1999 \\
\hline Hotel guest room (cfm/room) & - & 30 & - & & - & - & ASHRAE 1999 \\
\hline Gym (primary school) & 35.8 & 20 & - & 0.56 & - & Pless et al. 2007 & ASHRAE 1999 \\
\hline Gym (secondary school) & 10.8 & 20 & - & 1.86 & - & Pless et al. 2007 & ASHRAE 1999 \\
\hline Kitchen (commercial) & 200 & 15 & - & 0.075 & - & ICC 2003 & ASHRAE 1999 \\
\hline Kitchen (residential, cfm/room) & - & 25 & - & - & - & - & ASHRAE 1999 \\
\hline Living areas (residential) & - & 15 & - & - & - & - & ASHRAE 1999 \\
\hline Lobby (school, treat as a corridor) & - & & 0.10 & 0.10 & - & - & ASHRAE 1999 \\
\hline Lobby (hotel) & 33.3 & 20 & - & 0.60 & - & ASHRAE 2004b & ASHRAE 1999 \\
\hline Lobby (office building) & 100 & 20 & - & 0.20 & - & ASHRAE 2004b & ASHRAE 1999 \\
\hline Office & 200 & 20 & - & 0.10 & - & ASHRAE 2004b & ASHRAE 1999 \\
\hline Reception areas & 33.3 & 15 & - & 0.45 & - & ASHRAE 2004b & ASHRAE 1999 \\
\hline Restaurant dining rooms & 15 & 20 & - & 1.33 & - & ICC 2003 & ASHRAE 1999 \\
\hline Restroom (cfm/wc or urinal) & - & 50 & - & - & - & & ASHRAE 1999 \\
\hline Sales & 66.7 & - & 0.30 & 0.30 & - & ASHRAE 2004b & ASHRAE 1999 \\
\hline Shipping/receiving & 300 & - & 0.15 & 0.15 & - & ICC 2003 & ASHRAE 1999 \\
\hline Storage & 300 & - & 0.15 & 0.15 & - & ICC 2003 & ASHRAE 1999 \\
\hline Supermarket & 125 & 15 & - & 0.12 & - & ASHRAE 2004b & ASHRAE 1999 \\
\hline Warehouse & - & - & 0.05 & 0.05 & - & - & ASHRAE 1999 \\
\hline ER waiting room & - & - & - & - & ASHRAE 2004b & - & AIA 2001 \\
\hline Operating/surgical cystoscopic rooms & - & - & - & - & Pless et al. 2007 & - & AIA 2001 \\
\hline Critical and intensive care & - & - & - & - & ASHRAE 2004b & - & AIA 2001 \\
\hline Patient room & - & - & - & - & ASHRAE 2004b & - & AIA 2001 \\
\hline Examination room & 50 & - & 0.30 & 0.30 & - & ASHRAE 2004b & GGHC 2007 \\
\hline Clean linens & - & - & 0.30 & 0.30 & - & - & GGHC 2007 \\
\hline Soiled linens & - & - & 1.50 & 1.50 & - & - & GGHC 2007 \\
\hline Nurse station & - & - & 0.15 & 0.15 & - & - & GGHC 2007 \\
\hline Physical therapy & 50 & - & 0.30 & 0.30 & - & ASHRAE 2004b & GGHC 2007 \\
\hline Radiology & - & - & 0.30 & 0.30 & - & - & GGHC 2007 \\
\hline Anesthesia storage & - & - & 1.20 & 1.20 & - & - & GGHC 2007 \\
\hline
\end{tabular}


Table 6 Outside Air Requirements (SI units)

\begin{tabular}{|c|c|c|c|c|c|c|c|}
\hline \multirow{2}{*}{ Space Type } & \multirow{2}{*}{\begin{tabular}{|c|} 
Default \\
Occupancy \\
$\mathrm{m}^{2} /$ person \\
\end{tabular}} & \multicolumn{2}{|c|}{ OA } & \multirow{2}{*}{$\begin{array}{c}\text { Total } \\
\text { OA } \\
\mathrm{L} / \mathrm{s} / \mathrm{m}^{2} \\
\end{array}$} & \multicolumn{3}{|c|}{ OA Data Sources } \\
\hline & & L/s/person & $\mathrm{L} / \mathrm{s} / \mathrm{m}^{2}$ & & $\mathrm{ACH}$ & Occupancy & Ventilation \\
\hline Auditorium seating area & 1.00 & 7.08 & - & 7.08 & - & Pless et al. 2007 & ASHRAE 1999 \\
\hline Cafeteria/FF dining & 1.39 & 9.44 & - & 6.77 & - & ICC 2003 & ASHRAE 1999 \\
\hline Classrooms & 4.00 & 7.08 & & 1.77 & - & Pless et al. 2007 & ASHRAE 1999 \\
\hline Corridor (school) & - & - & 0.51 & 0.51 & - & - & ASHRAE 1999 \\
\hline Corridor (public spaces) & - & - & 0.25 & 0.25 & - & - & ASHRAE 1999 \\
\hline Hotel guest room (cfm/room) & - & 14.16 & - & - & - & - & ASHRAE 1999 \\
\hline Gym (primary school) & 3.33 & 9.44 & - & 2.83 & - & Pless et al. 2007 & ASHRAE 1999 \\
\hline Gym (secondary school) & 1.00 & 9.44 & - & 9.44 & - & Pless et al. 2007 & ASHRAE 1999 \\
\hline Kitchen (commercial) & 18.59 & 7.08 & - & 0.38 & - & ICC 2003 & ASHRAE 1999 \\
\hline Kitchen (residential, cfm/room) & - & 11.80 & - & - & - & - & ASHRAE 1999 \\
\hline Living areas (residential) & - & 7.08 & - & - & - & - & ASHRAE 1999 \\
\hline Lobby (school, treat as a corridor) & - & & 0.51 & 0.51 & - & - & ASHRAE 1999 \\
\hline Lobby (hotel) & 3.10 & 9.44 & - & 3.05 & - & ASHRAE 2004b & ASHRAE 1999 \\
\hline Reception areas & 3.10 & 7.08 & - & 2.29 & - & ASHRAE 2004b & ASHRAE 1999 \\
\hline Restaurant dining rooms & 1.39 & 9.44 & - & 6.77 & - & ICC 2003 & ASHRAE 1999 \\
\hline Restroom (cfm/wc or urinal) & & 23.60 & - & & - & - & ASHRAE 1999 \\
\hline Sales & 6.20 & - & 1.52 & 1.52 & - & ASHRAE 2004b & ASHRAE 1999 \\
\hline Shipping/receiving & 27.88 & - & 0.76 & 0.76 & - & ICC 2003 & ASHRAE 1999 \\
\hline Storage & 27.88 & - & 0.76 & 0.76 & - & ICC 2003 & ASHRAE 1999 \\
\hline Supermarket & 11.62 & 7.08 & - & 0.61 & - & ASHRAE 2004b & ASHRAE 1999 \\
\hline Warehouse & - & - & 0.25 & 0.25 & - & - & ASHRAE 1999 \\
\hline ER waiting room & - & - & - & - & ASHRAE 2004b & - & AIA 2001 \\
\hline Operating/surgical cystoscopic rooms & - & - & - & - & Pless et al. 2007 & - & AIA 2001 \\
\hline Critical and intensive care & - & - & - & - & ASHRAE 2004b & - & AIA 2001 \\
\hline Patient room & - & - & - & - & ASHRAE 2004b & - & AIA 2001 \\
\hline Examination room & 4.65 & - & 1.52 & 1.52 & - & ASHRAE 2004b & GGHC 2007 \\
\hline Clean linens & - & - & 1.52 & 1.52 & - & - & GGHC 2007 \\
\hline Soiled linens & - & - & 7.62 & 7.62 & - & - & GGHC 2007 \\
\hline Nurse station & - & - & 0.76 & 0.76 & - & - & GGHC 2007 \\
\hline
\end{tabular}




\subsubsection{Plug and Process Loads}

Determining the plug or process load intensity is difficult because available measured data are scarce. Thus, we had to make several assumptions based on experience with a small number of buildings, previous work by Huang et al. (1991), levels from ASHRAE (1989), and the AEDG series. The plug and process loads and schedules are determined at the zone level based on the activities in each zone. The models will be updated as new data become available. Appendix A lists all the plug loads by zone for each building model in IP and SI units. Table 7 lists the main references for the plug and process loads by building type. Kitchen loads for all building models with kitchens are discussed in the Commercial Kitchen sections.

Table 7 Plug and Process Load References

\begin{tabular}{|l|l|}
\hline \multicolumn{1}{|c|}{ Building/Zone } & \multicolumn{1}{c|}{ Data Source } \\
\hline Small Office & Engineering judgment \\
\hline Medium Office & Engineering judgment \\
\hline Large Office & Engineering judgment \\
\hline Primary School & Pless et al. 2007 \\
\hline Secondary School & Pless et al. 2007 \\
\hline Stand-Alone Retail & Engineering judgment \\
\hline Strip Mall & Engineering judgment \\
\hline Supermarket & Engineering judgment \\
\hline Small Hotel & Jiang et al. 2008 \\
\hline Large Hotel & Huang et al. 1991 \\
\hline Hospital & Doebber et al. 2009, GGHC 2007 \\
\hline Outpatient Healthcare & Doebber et al. 2009, GGHC 2007 \\
\hline Warehouse & Liu et al. 2007 \\
\hline Midrise Apartment & Hendron 2007 \\
\hline
\end{tabular}

The laundry facility loads for the hotels were modified from Jiang et al. (2008), who assumed $60-\mathrm{lb}(27-\mathrm{kg})$ commercial washing machines that use $3.4 \mathrm{Btu} / \mathrm{h}(1,390 \mathrm{~W})$ of electricity per cycle and gas dryers that use $2.6 \mathrm{Btu} / \mathrm{h}(750 \mathrm{~W})$ of electricity per cycle. They also assumed $9 \mathrm{lb}(4.1$ $\mathrm{kg}$ ) of laundry per room per day and that the washed laundry retains water equal to $87.5 \%$ of its dry weight. For the assumed $65 \%$ occupancy, the small hotel requires 8 loads per day and the large hotel requires 18 loads per day. To calculate gas use, we assumed a heat of vaporization of $1000 \mathrm{Btu} / \mathrm{lb}(2,326 \mathrm{~kJ} / \mathrm{kg})$ of water and a thermal efficiency of the gas dryer of $80 \%$. The total energy use for washing and drying was divided evenly over 8 hours. (See Appendix A for the electricity and gas loads for each space.)

\subsubsection{Elevators}

Elevators are included in all buildings with multiple floors. They are modeled in EnergyPlus as a zone load but labeled as "elevators," so they are reported separately in the EnergyPlus output. The number of elevators in the reference building models was determined from rules of thumb presented by Beyer (2009) (see Table 8). The office buildings have one elevator for every $45,000 \mathrm{ft}^{2}\left(4,181 \mathrm{~m}^{2}\right)$, plus one service elevator for the large office building. The hotels have one 
elevator for every 75 rooms, and the large hotel includes one service elevator for every two public elevators, plus one additional elevator for the dining and banquet facilities on the top floor. The hospital has one public and one service elevator for every 100 beds (250 total), plus two elevators for the offices and cafeteria on the top floor. The outpatient healthcare model has the minimum recommendation of two elevators. The apartment building has one elevator for every 90 units, and the secondary school has two elevators.

Table 8 Number of Elevators Installed and Motor Power

\begin{tabular}{|l|c|c|}
\hline \multicolumn{1}{|c|}{ Building Type } & $\begin{array}{c}\text { Number of } \\
\text { Elevators }\end{array}$ & $\begin{array}{c}\text { Motor Power } \\
\text { (w/each) }\end{array}$ \\
\hline \hline Medium Office & 2 & 14,610 \\
\hline Large Office & 12 & 18,537 \\
\hline Secondary School & 2 & 14,610 \\
\hline Small Hotel & 2 & 14,610 \\
\hline Large Hotel & 6 & 18,537 \\
\hline Hospital & 8 & 18,537 \\
\hline Outpatient Healthcare & 3 & 14,610 \\
\hline Midrise Apartment & 1 & 14,610 \\
\hline
\end{tabular}

For buildings with fewer than six stories (counting the basement), we assumed the elevators use hydraulic motors with no over counter weighting, weigh 2,500 lb (1,134 kg), travel $150 \mathrm{fpm}$ (46 $\mathrm{mpm}$ ), and have a mechanical efficiency of $58 \%$. In this case, the heat gain was added to the first floor core zone. For buildings six stories and higher, we assumed the elevators use traction motors with $40 \%$ over counter weighting, weigh 2,500 lb $(1,134 \mathrm{~kg})$, travel $350 \mathrm{fpm}(1.78 \mathrm{~m} / \mathrm{s})$, and have a mechanical efficiency of $64 \%$. In this case, the heat gain was added to the top floor core zone. The following equation is used to calculate the motor power in horsepower (Baldor Electric Company 1998). The schedules were taken from ASHRAE (1989).

$$
\text { Motor } H P=\frac{W \cdot V \cdot[1-O C W]}{33,000 \cdot \eta_{m}}
$$

where

$\mathrm{W} \quad=\quad$ weight of car $(\mathrm{lb})$

$\mathrm{V} \quad=\quad$ speed of car $(\mathrm{fpm})$

OCW $=$ over counter weight (fraction of car capacity)

$\eta_{\mathrm{m}} \quad=\quad$ mechanical efficiency of elevator (fraction)

\subsubsection{Commercial Kitchens}

Six reference buildings have commercial kitchens, and the supermarket has a deli and a bakery that use similar types of equipment. Commercial kitchens have high electric and gas equipment densities for refrigeration, food preparation, and dishwashing, and often have high ventilation requirements. The internal loads in kitchens can vary tremendously depending on the types and amounts of food served. The internal loads included in the reference buildings are shown in Table 9, along with the SHW and ventilation requirements. These loads represent the installed 
capacity; actual peak demand and total energy use are determined by applying the operating schedules in Appendix B. The electricity loads include reach-in refrigerators, and some of the electric food preparation load is assumed to be in the dining zones. Walk-in coolers and freezers are modeled as separate EnergyPlus objects and are discussed in the Refrigeration section.

Table 9 Commercial Kitchen Loads

\begin{tabular}{|l|c|c|c|c|c|c|c|}
\hline \multicolumn{1}{|c|}{ Building } & $\begin{array}{c}\text { Meals } \\
\text { per } \\
\text { Day }\end{array}$ & $\begin{array}{c}\text { Gas } \\
\text { Load } \\
\mathbf{( k W )}\end{array}$ & $\begin{array}{c}\text { Electricity } \\
\text { Load } \\
\mathbf{( k W )}\end{array}$ & $\begin{array}{c}\text { Electricity } \\
\text { in Dining } \\
\text { Zone }\end{array}$ & $\begin{array}{c}\text { SHW } \\
\text { gal/h } \\
(\mathbf{L} / \mathbf{h})\end{array}$ & $\begin{array}{c}\text { SHW } \\
\text { Temp. at } \\
\text { Fixture } \\
{ }^{\circ} \mathbf{F}\left({ }^{\circ} \mathbf{C}\right)\end{array}$ & $\begin{array}{c}\text { Hooded } \\
\text { Exhaust cfm } \\
(\mathbf{L} / \mathbf{s})\end{array}$ \\
\hline Primary School & 400 & 160 & 40 & $20 \%$ & $100(379)$ & $120(49)$ & $3,300(1,557)$ \\
\hline Secondary School & 600 & 242 & 60 & $20 \%$ & $133(503)$ & $120(49)$ & $4,000(1,888)$ \\
\hline Supermarket Deli & - & 6 & 5 & - & $5(19)$ & $120(49)$ & - \\
\hline Supermarket Bakery & - & 11 & 3 & - & $5(19)$ & $120(49)$ & $2,500(1,180)$ \\
\hline Quick Service Restaurant & 800 & 150 & 50 & $30 \%$ & $40(151)$ & $120(49)$ & $3,300(1,557)$ \\
\hline Full Service Restaurant & 780 & 167 & 75 & $30 \%$ & $133(503)$ & $120(49)$ & $4,000(1,888)$ \\
\hline Large Hotel & 780 & 167 & 75 & $30 \%$ & $133(503)$ & $120(49)$ & $4,000(1,888)$ \\
\hline Hospital & 800 & 283 & 75 & $0 \%$ & $150(568)$ & $120(49)$ & $5,300(2,501)$ \\
\hline
\end{tabular}

We assume the kitchens in the full service restaurant, large hotel, and schools have similar loads and can be scaled with the estimated number of meals served each day. The kitchen electricity and gas process loads and the exhaust flow rates are based on information from Brown (2007), Fisher (2003), Smith et al. (1999), Smith and Fisher (2001), data from the California Energy Commission (CEC 2004) and SGE (2004), a review of actual kitchen designs, and examination of annual utility data from more than 1000 operating commercial kitchens. Table 10 shows the energy distribution of the kitchen loads within the EnergyPlus zone energy balance. All gas appliances are assumed to be under exhaust hoods, so a high fraction of the energy is "lost" out the exhaust hood and not added to the space load.

Table 10 Distribution of Kitchen Loads in Zone Energy Balance

\begin{tabular}{|l|c|c|c|}
\hline Fraction & $\begin{array}{c}\text { Gas } \\
\text { Equipment }\end{array}$ & $\begin{array}{c}\text { Electrical } \\
\text { Equipment }\end{array}$ & Exhaust Hoods \\
\hline \hline Lost & 0.7 & 0.20 & 1.0 \\
\hline Latent & 0.1 & 0.25 & 0.0 \\
\hline Radiant & 0.2 & 0.30 & 0.0 \\
\hline Convective & 0.0 & 0.25 & 0.0 \\
\hline
\end{tabular}

The kitchen exhaust rates are shown in the final column of Table 9. Transfer air from the dining zones is used for all or part of the make-up air requirements, depending on how much air is available from the dining areas. This transfer air is modeled with an EnergyPlus ZoneMixing object in the kitchen zone and a zero power exhaust fan in the dining zone. EnergyPlus version 4.0 has two limitations that force a modeling workaround for the exhaust fans and make-up air: 
- Exhaust fans are controlled with an on-off schedule only, and cannot have a fractional schedule; therefore, the fans are assumed to run at full flow.

- EnergyPlus does not account for the transfer air from adjacent zones when the OA requirements are calculated. It determines the OA as the maximum of the exhaust fan flow rate and the minimum OA schedule multiplied by the peak OA flow rate without consideration of the transfer air.

To work around this problem, we calculated the hourly energy use of the exhaust fans in a spreadsheet and entered it in the EnergyPlus model as an electricity load to the zones. The OA requirements for the kitchens are set with the zone sizing object and an hourly schedule.

\subsubsection{Service Hot Water Demand}

The peak service hot water (SHW) demand for each reference building space type is shown in Table 11, along with the temperatures at the fixture and the sources of data. These numbers are used in conjunction with the operating schedules to estimate the total hot water consumption. Hot water use in kitchens is included in the Commercial Kitchen section. Natural gas water heaters are used in all cases; storage tanks are kept at $140^{\circ} \mathrm{F}\left(60^{\circ} \mathrm{C}\right)$.

Table 11 Peak Service Hot Water Demand and Data Sources

\begin{tabular}{|c|c|c|c|c|c|}
\hline \multirow[b]{2}{*}{ Space Type } & \multicolumn{2}{|c|}{ Use Rate } & \multicolumn{2}{|c|}{$\begin{array}{l}\text { Temp. at } \\
\text { Fixture }\end{array}$} & \multirow[b]{2}{*}{ Data Sources } \\
\hline & gal/h & L/h & ${ }^{\circ} \mathrm{F}$ & ${ }^{\circ} \mathrm{C}$ & \\
\hline Guest room (small hotel) & 1.75 & 6.6 & 110 & 43 & Jiang et al. 2008, ASHRAE 2007 \\
\hline Guest room (large hotel) & 1.25 & 4.7 & 110 & 43 & Jiang et al. 2008, ASHRAE 2007 \\
\hline Laundry (small hotel) & 67.5 & 255.5 & 140 & 60 & Jiang et al. 2008, ASHRAE 2007 \\
\hline Laundry (large hotel) & 156.6 & 592.8 & 140 & 60 & Jiang et al. 2008, ASHRAE 2007 \\
\hline Restrooms (primary school) & 56.5 & 214.0 & 110 & 43 & ASHRAE 2007 \\
\hline Restrooms (secondary school) & 104.4 & 395.0 & 110 & 43 & ASHRAE 2007 \\
\hline Gym (secondary school) & 189.5 & 717.2 & 110 & 43 & ASHRAE 2007 \\
\hline Small office & 3.0 & 11.4 & 110 & 43 & Jarnagin et al. 2006, ASHRAE 2007 \\
\hline Medium office (per floor) & 9.9 & 37.5 & 110 & 43 & Jarnagin et al. 2006, ASHRAE 2007 \\
\hline Large office (per floor) & 21.3 & 80.6 & 110 & 43 & Jarnagin et al. 2006, ASHRAE 2007 \\
\hline Apartment & 3.5 & 13.2 & 110 & 43 & Gowri et al. 2007 \\
\hline Outpatient healthcare & 30.0 & 113.5 & 110 & 43 & Doebber et al. 2009 \\
\hline \multicolumn{6}{|l|}{ Hospital } \\
\hline ER waiting room & 1.0 & 3.8 & 120 & 49 & Engineering judgment \\
\hline Operating/surgical cystoscopic & 2.0 & 7.6 & 120 & 49 & Engineering judgment \\
\hline Laboratory & 2.0 & 7.6 & 120 & 49 & Engineering judgment \\
\hline Patient room & 1.0 & 3.8 & 120 & 49 & Engineering judgment \\
\hline
\end{tabular}

Data for the two hotel buildings are from Jiang et al. (2008) and ASHRAE (2007). Average hot water use per guest room is assumed to be $14 \mathrm{~g} /$ day $(53 \mathrm{~L} /$ day) in the small hotel and $10 \mathrm{~g} /$ day (38 L/day) in the large hotel from Table 7 (ASHRAE 2007). These total daily consumption values are the product of the peak value and the SHW schedule, which assumes a total full load equivalent consumption over 8 hours per day and gives the hourly peak loads shown in Table 11 . 
The laundry facility loads were modified from Jiang et al. (2008). We assumed $9 \mathrm{lb}(4.1 \mathrm{~kg})$ of laundry per room per day and $1.2 \mathrm{gal} / \mathrm{lb}(9.9 \mathrm{~L} / \mathrm{kg})$ of laundry of $140^{\circ} \mathrm{F}\left(60^{\circ} \mathrm{C}\right)$ hot water. The total hot water load for washing was divided evenly over 8 hours.

The average hot water use for schools is $0.6 \mathrm{gal} / \mathrm{student} /$ day $(2.3 \mathrm{~L} / \mathrm{student} /$ day $)$ for primary schools and $1.8 \mathrm{gal} / \mathrm{student} /$ day (6.8 L/student/day) in secondary schools (ASHRAE 2007). We assumed that the secondary school uses $0.6 \mathrm{gal} / \mathrm{student} / \mathrm{day}(2.3 \mathrm{~L} / \mathrm{student} / \mathrm{day})$ in the restrooms to match the use in the primary school and $1.2 \mathrm{gal} / \mathrm{student} / \mathrm{day}(4.5 \mathrm{~L} / \mathrm{student} / \mathrm{day})$ in the gymnasium showers. The primary school has 650 students and the secondary school has 1200 students. The total daily hot water use was divided over the hot water use schedule to arrive at the peak values shown in Table 11.

For the offices, we assumed $1 \mathrm{gal} /$ occupant/day (3.8 L/occupant/day) divided evenly over a 9-h occupancy period. We assumed $310 \mathrm{gal} /$ day $(1,172 \mathrm{~L} /$ day $)$ for the outpatient healthcare model over a 14-h occupancy period, with the operating rooms consuming the most SHW of all the space types. Healthcare space types consumed similar quantities of SHW in the hospital model, but most use occurred in the commercial kitchen associated with the hospital cafeteria.

\subsubsection{Schedules}

Few data are available that enable us to determine the best operating schedules for building energy simulations. We used the schedules from the AEDG Technical Support Documents for the schools, lodging, warehouse, and healthcare models and a PNNL study for the apartment model (see Table 12). For the other models we started with Standard 90.1-1989 Section 13, which includes schedules for use with the Energy Cost Budget Method (ASHRAE 1989). Schedules published in the original version of 90.1-1989 were modified by Addendum L in 1994 by a public review process, and are published with minor modifications in Section $\mathrm{G}$ of the User's Manual for 90.1-2004 (ASHRAE 2004c). Although these schedules are not perfect, no better published source of schedules has been identified. We started with these schedules and made modifications based on experience with monitoring real buildings to account for differences in zone-level and equipment operations, and lighting and plug loads. In 90.1-1989 (with addenda), the lights and equipment share the same schedules, but case study research and broad anecdotal evidence suggest that plug and process loads do not track lighting loads and that during off hours the plug loads are higher, probably because of information technology and security equipment. Therefore, we created new plug and process schedules and developed additional schedules for spaces that operate on different schedules, based on experience with monitoring buildings. All the schedules for each model are included in Appendix B.

Table 12 Reference Building Model Schedule Starting Points

\begin{tabular}{|l|l|}
\hline \multicolumn{1}{|c|}{ Principal Building Activity } & \multicolumn{1}{c|}{ Data Source } \\
\hline \hline Office & ASHRAE 1989 \\
\hline Education & Pless et al. 2007 \\
\hline Retail & ASHRAE 1989 \\
\hline Food Sales & ASHRAE 1989 \\
\hline Food Services & ASHRAE 1989 \\
\hline Lodging & Jiang et al. 2008 \\
\hline Healthcare & Doebber et al. 2009 \\
\hline Warehouse & Liu et al. 2007 \\
\hline Apartment & Gowri et al. 2007 \\
\hline
\end{tabular}




\subsubsection{Utility Tariffs}

Utility rate schedules are needed to calculate energy costs, which are important for analyzing the economics of energy efficiency and energy production technologies. Electricity and natural gas are the only two energy forms considered for the reference buildings. Utility rate schedules vary widely across the country and within each census division, and capturing this variability is difficult. Also, utility rates can vary significantly from year to year. Utility rate schedules were selected from the EnergyPlus UtilityTariffObject.imf file when locations were selected. They were taken from the Tariff Analysis Project (http://tariffs.lbl.gov/) and directly from the utility company Web sites. These data are from 2004 and may not reflect current prices.

Tax rates on utilities vary at the city and county government levels, and most utility companies do not publish these with their tariffs because they vary within the service territory. However, taxes form an important part of energy costs in the commercial sector and should be included in the modeling. These data were filled by assuming that energy taxes are equal to the state sales tax rate plus $2 \%$ to cover city and county taxes based on a brief review of utility tax rates.

\subsection{Form}

Building form parameters are listed in Table 3. The form parameters for each reference building are shown in Table 13. Aspect ratio is defined as the overall length in the east-west direction divided by the overall length in the north-south direction. Expert opinion was used to determine the aspect ratios and floor-to-floor height for each building type. Ceiling plenums are included in the large office and medium office models. The sources for the other form parameters are shown in Table 14.

Table 13 Reference Building Form Assignments

\begin{tabular}{|c|c|c|c|c|c|c|c|c|c|}
\hline \multirow[b]{2}{*}{ Building Type } & \multicolumn{2}{|c|}{ Floor Area } & \multirow{2}{*}{$\begin{array}{l}\text { Aspect } \\
\text { Ratio }\end{array}$} & \multirow{2}{*}{$\begin{array}{l}\text { No. of } \\
\text { Floors }\end{array}$} & \multicolumn{2}{|c|}{$\begin{array}{c}\text { Floor-to- } \\
\text { Floor Height }\end{array}$} & \multicolumn{2}{|c|}{$\begin{array}{c}\text { Floor-to- } \\
\text { Ceiling Height }\end{array}$} & \multirow{2}{*}{$\begin{array}{l}\text { Glazing } \\
\text { Fraction }\end{array}$} \\
\hline & $\mathrm{ft}^{2}$ & $\mathrm{~m}^{2}$ & & & $\mathrm{ft}$ & m & $\mathbf{f t}$ & m & \\
\hline Small Office & 5,500 & 511 & 1.5 & 1 & 10 & 3.05 & 10 & 3.05 & 0.21 \\
\hline Medium Office & 53,628 & 4,982 & 1.5 & 3 & 13 & 3.96 & 9 & 2.74 & 0.33 \\
\hline Large Office & 498,588 & 46,320 & 1.5 & $12^{*}$ & 13 & 3.96 & 9 & 2.74 & 0.38 \\
\hline Primary School & 73,960 & 6,871 & E-Shape & 1 & 13 & 3.96 & 13 & 3.96 & 0.35 \\
\hline Secondary School & 210,887 & 19,592 & E-Shape & 2 & 13 & 3.96 & 13 & 3.96 & 0.33 \\
\hline Stand-Alone Retail & 24,962 & 2,294 & 1.3 & 1 & 20 & 6.10 & 20 & 6.10 & 0.07 \\
\hline Strip Mall & 22,500 & 2,090 & 4.0 & 1 & 17 & 5.18 & 17 & 5.18 & 0.11 \\
\hline Supermarket & 45,000 & 4,181 & 1.5 & 1 & 20 & 6.10 & 20 & 6.10 & 0.11 \\
\hline Quick Service Restaurant & 2,500 & 232 & 1.0 & 1 & 10 & 3.05 & 10 & 3.05 & 0.14 \\
\hline Full Service Restaurant & 5,500 & 511 & 1.0 & 1 & 10 & 3.05 & 10 & 3.05 & 0.17 \\
\hline Small Hotel & 43,200 & 4,013 & 3.0 & 4 & $\begin{array}{c}11^{* *} \\
9\end{array}$ & $\begin{array}{c}3.35^{* *} \\
2.74\end{array}$ & $\begin{array}{c}11^{* *} \\
9\end{array}$ & $\begin{array}{c}3.35^{\star *} \\
2.74\end{array}$ & 0.11 \\
\hline Large Hotel & 122,120 & 11,345 & $\begin{array}{c}3.8^{* *} \\
5.1\end{array}$ & 6 & $\begin{array}{c}13^{* *} \\
10\end{array}$ & $\begin{array}{c}3.96^{* *} \\
3.05\end{array}$ & $\begin{array}{c}13^{* *} \\
10\end{array}$ & $\begin{array}{c}3.96^{* *} \\
3.05\end{array}$ & 0.27 \\
\hline Hospital & 241,351 & 22,422 & 1.3 & $5^{*}$ & 14 & 4.27 & 14 & 4.27 & 0.15 \\
\hline Outpatient Healthcare & 40,946 & 3,804 & 1.4 & 3 & 10 & 3.05 & 10 & 3.05 & 0.19 \\
\hline Warehouse & 52,045 & 4,835 & 2.2 & 1 & 28 & 8.53 & 28 & 8.53 & 0.006 \\
\hline Midrise Apartment & 33,740 & 3,135 & 2.7 & 4 & 10 & 3.05 & 10 & 3.05 & 0.15 \\
\hline
\end{tabular}

* Plus basement (not included in the table number)

** First floor 
Table 14 Sources for Reference Building Form Data

\begin{tabular}{|l|l|}
\hline \multicolumn{1}{|c|}{ Principal Building Activity } & \multicolumn{1}{c|}{ Data Source } \\
\hline Small Office & Jarnagin et al. 2006, EIA 2005 \\
\hline Medium Office & EIA 2005 \\
\hline Large Office & EIA 2005 \\
\hline Primary School & Pless et al. 2007 \\
\hline Secondary School & Pless et al. 2007 \\
\hline Stand-Alone Retail & EIA 2005 \\
\hline Strip Mall & EIA 2005 \\
\hline Supermarket & EIA 2005 \\
\hline Quick Service Restaurant & Huang et al. 1991 \\
\hline Full Service Restaurant & Huang et al. 1991 \\
\hline Small Hotel & Jiang et al. 2008 \\
\hline Large Hotel & Huang et al. 1991 \\
\hline Hospital & Huang et al. 1991 \\
\hline Outpatient Healthcare & Doebber et al. 2009 \\
\hline Warehouse & Liu et al. 2007 \\
\hline Midrise Apartment & Gowri et al. 2007 \\
\hline
\end{tabular}

\subsection{Fabric}

The fabric includes the construction types and thermal properties of the walls, roofs, floors, and windows. Winiarski et al. (2007a; 2007b) analyzed CBECS 2003 to determine pre-1980 and post-1980 construction types. They assumed that the new construction models and the post-1980 use the same construction types.

\subsubsection{Envelope Constructions}

CBECS PBAplus information was used to map data from the 2003 CBECS dataset to the reference building types. Office buildings were divided into small, medium, and large, based on the number of floors (small is defined as single story, medium as two to four stories, and large more than four stories).

CBECS provides seven categories of roof construction material plus an "other" category and a "not one major type" category. The most common roof descriptions were determined for each reference building type by percentage of roof area and fraction of buildings. (No consideration is given to skylight area.) Roof area is assumed to correspond to the building footprint. This implies that roof area is equal to the projected roof area on the building footprint. No attempt was made to estimate the relative increase in roof area for sloped roofs compared to flat roofs.

Standard 90.1-2004 defines three primary roof types based on the location of insulation relative to the roof with the following assumptions: 
- Insulation Entirely Above Deck. Has continuous insulation above the structural roof deck.

- Metal Building. Has insulation compressed between structural members.

- Attic and Other. Insulation is laid between roof joists.

A fourth option for determining roof insulation levels in Standard 90.1-2004 is defined as singlerafter roofs, a subclass of Attic and Other, in which the roof above and the ceiling below are attached to the same rafter. For these assemblies, the requirement in Standard 90.1-2004 is the lesser of two values: the attic requirement or a separate requirement that the rafter cavity be filled with fiberglass insulation. We consider single-rafter roofs in the Attic and Other classification; no further consideration is given to single-rafter roofs.

Comparison of the three ASHRAE Standard 90.1-2004 roof types with the 2003 CBECS roof descriptions indicates that the only description that can be unambiguously mapped to a Standard 90.1 roof type is the CBECS built-up classification mapped to 90.1 Insulation Entirely Above Deck. Slate, shingles, shakes, and tiles of any material map fairly well to the Standard 90.1 Attic and Other category, as these are typically installed over an attic or single-rafter roof. Less straightforward is mapping the CBECS Asphalt, Fiberglass, Other classification. This category can be mapped to 90.1's Attic and Other in the case of asphalt shingles, but could also be mapped to Insulation Entirely Above Deck in the case of a built-up roof with an asphalt topcoat. The CBECS Metal Surface category may be mapped to 90.1 Metal Building, or it may indicate that a metal roof has been used in place of shingles over an attic roof structure. The CBECS Plastic, Rubber, Synthetic category most likely maps to the Insulation Entirely Above Deck category (most commonly where a synthetic membrane is placed over foam), although commercially available recycled rubber and plastic shingles could be installed over an attic. These relationships are shown in Table 15.

Table 15 Relationship of CBECS Roof Descriptions and Standard 90.1 Roof Constructions

\begin{tabular}{|l|c|c|c|}
\hline \multirow{2}{*}{\multicolumn{2}{c|}{ CBECS Roof Descriptions }} & \multicolumn{2}{c|}{ Standard 90.1 Roof Construction } \\
\cline { 2 - 4 } & $\begin{array}{c}\text { Insulation Entirely } \\
\text { Above Deck }\end{array}$ & Metal Building & Attic and Other \\
\hline Asphalt, fiberglass, other & $\mathrm{X}$ & & $\mathrm{X}$ \\
\hline Built-up & $\mathrm{X}$ & $\mathrm{X}$ & $\mathrm{X}$ \\
\hline Concrete & & & $\mathrm{X}$ \\
\hline Metal surfacing & & & \\
\hline No one major type & & & $\mathrm{X}$ \\
\hline Other & $\mathrm{X}$ & $\mathrm{X}$ \\
\hline Plastic, rubber, synthetic & & & $\mathrm{X}$ \\
\hline Slate, tile shingles & & & \\
\hline Wood shingles, shakes, other & & & \\
\hline
\end{tabular}

CBECS provides the Wall Construction (WLCNS) statistic as a classification of the major wall construction type for each building. The CBECS WLCNS categories are:

- Brick, stone, or stucco

- Concrete block or poured concrete

- Decorative or construction glass 
- Precast concrete panels

- Sheet metal panels

- $\quad$ Siding, shingles, tiles, or shakes

- Window or vision glass

- No one major type

- Other.

For each reference building, Table 16 lists the top five CBECS WLCNS choices in decreasing order of occurrence by percentage of calculated total opaque wall area or number of buildings. To determine the percentage of total opaque wall area, we removed the window area from the frequency statistic (total wall area). Some buildings have their primary wall construction in CBECS characterized as vision or construction glass, which is not opaque. Thus, these buildings tend to rank lower than if we had ranked buildings by total wall area including glazed area.

Table 16 Relationships Between CBECS Wall Descriptions and Standard 90.1 Wall Constructions

\begin{tabular}{|l|c|c|c|c|}
\hline \multirow{2}{*}{\multicolumn{1}{c|}{ CBECS Wall Descriptions }} & \multicolumn{3}{c|}{ ASHRAE Standard 90.1 Wall Construction } \\
\cline { 2 - 5 } & Mass Wall & $\begin{array}{c}\text { Metal Building } \\
\text { Wall }\end{array}$ & $\begin{array}{c}\text { Steel Framed } \\
\text { Wall }\end{array}$ & $\begin{array}{c}\text { Wood Framed } \\
\text { and Other Wall }\end{array}$ \\
\hline \hline Brick, stone, stucco & $\mathrm{X}$ & $\mathrm{X}$ & $\mathrm{X}$ & $\mathrm{X}$ \\
\hline Concrete, block or poured & $\mathrm{X}$ & & & \\
\hline Precast concrete panels & $\mathrm{X}$ & & & \\
\hline Sheet metal panels & & & $\mathrm{X}$ & $\mathrm{X}$ \\
\hline Siding, shingles, tiles, shakes & & & $\mathrm{X}$ & \\
\hline Decorative or construction glass & & & $\mathrm{X}$ & \\
\hline Window or vision glass & & & Unknown & Unknown \\
\hline No major type & Unknown & Unknown & Unknown & Unknown \\
\hline Other & Unknown & Unknown & & \\
\hline
\end{tabular}

Standard 90.1-2004 defines four wall types based on the functional performance of the wall, with the following assumptions:

- Mass Wall. Has continuous insulation.

- Metal Building Wall. Has insulation compressed between metal members, possibly augmented by continuous insulation to decrease the overall $\mathrm{U}$-factor.

- Steel Framed Wall. Is a simple frame wall with different structural members (and therefore different thermal bypass factors).

- Wood Framed and Other Wall. Is a simple frame wall with different structural members (and therefore different thermal bypass factors).

Mass Wall in Standard 90.1-2004 must be defined as a wall with a heat capacity exceeding $7 \mathrm{Btu} / \mathrm{ft}^{2} \cdot{ }^{\circ} \mathrm{F}\left(143 \mathrm{MJ} / \mathrm{m}^{2} \cdot{ }^{\circ} \mathrm{C}\right)$ or $5 \mathrm{Btu} / \mathrm{ft}^{2} \cdot{ }^{\circ} \mathrm{F}\left(102 \mathrm{MJ} / \mathrm{m}^{2} \cdot{ }^{\circ} \mathrm{C}\right)$, provided that it has a material unit weight not greater than $120 \mathrm{lb} / \mathrm{ft}^{3}\left(4.7 \mathrm{GJ} / \mathrm{m}^{3}\right)$. The $7 \mathrm{Btu} / \mathrm{ft}^{2} \cdot{ }^{\circ} \mathrm{F}$ is for any weight wall; the $5 \mathrm{Btu} / \mathrm{ft}^{2} \cdot{ }^{\circ} \mathrm{F}\left(102 \mathrm{MJ} / \mathrm{m}^{2} \cdot{ }^{\circ} \mathrm{C}\right)$ is only for walls lighter than $120 \mathrm{lb} / \mathrm{ft}^{3}\left(4.7 \mathrm{GJ} / \mathrm{m}^{3}\right)$. Thus, regardless of insulation type and placement, walls exceeding this level of heat capacity are treated as mass walls for setting minimum U-factor requirements. The definition is such that a 4 -in. $(10-\mathrm{cm})$ brick facing on a frame wall construction does not create a mass wall under the Standard 90.1 definition. 
Comparing the four Standard 90.1-2004 wall types with the 2003 CBECS wall descriptions indicates that the brick, stone, and stucco description could conceivably be mapped to any one of the four ASHRAE 90.1 WLCNSs. This is problematic because the brick, stone, and stucco description is the single most common in the 2003 CBECS for all the reference building types examined in this analysis. These relationships between the Standard 90.1-2004 roof types and the 2003 CBECS wall descriptions are shown in Table 16.

The recommended roof and wall constructions for each model and each construction vintage are shown in Table 17 and Table 18. Winiarski et al. (2006) recommended an attic roof construction for the new construction small hotel; however, Jiang et al. (2008) recommended insulation entirely above deck for the roof, which is used in the reference small hotel model. Gowri et al. (2007) determined the constructions for the midrise apartment building model and assumed they were the same for all vintages of the reference building.

Table 17 Recommended Roof Constructions by Building Type

\begin{tabular}{|c|c|c|c|}
\hline Building Type & Pre-1980 & Post-1980 & New Construction \\
\hline Small Office & $\begin{array}{l}\text { Insulation entirely } \\
\text { above deck }\end{array}$ & Attic and other & Attic and other \\
\hline Medium Office & $\begin{array}{l}\text { Insulation entirely } \\
\text { above deck }\end{array}$ & $\begin{array}{l}\text { Insulation entirely } \\
\text { above deck }\end{array}$ & $\begin{array}{l}\text { Insulation entirely } \\
\text { above deck }\end{array}$ \\
\hline Large Office & $\begin{array}{l}\text { Insulation entirely } \\
\text { above deck }\end{array}$ & $\begin{array}{l}\text { Insulation entirely } \\
\text { above deck }\end{array}$ & $\begin{array}{l}\text { Insulation entirely } \\
\text { above deck }\end{array}$ \\
\hline Primary School & $\begin{array}{l}\text { Insulation entirely } \\
\text { above deck }\end{array}$ & $\begin{array}{l}\text { Insulation entirely } \\
\text { above deck }\end{array}$ & $\begin{array}{l}\text { Insulation entirely } \\
\text { above deck }\end{array}$ \\
\hline Secondary School & $\begin{array}{l}\text { Insulation entirely } \\
\text { above deck }\end{array}$ & $\begin{array}{l}\text { Insulation entirely } \\
\text { above deck }\end{array}$ & $\begin{array}{l}\text { Insulation entirely } \\
\text { above deck }\end{array}$ \\
\hline Stand-Alone Retail & $\begin{array}{l}\text { Insulation entirely } \\
\text { above deck }\end{array}$ & $\begin{array}{l}\text { Insulation entirely } \\
\text { above deck }\end{array}$ & $\begin{array}{l}\text { Insulation entirely } \\
\text { above deck }\end{array}$ \\
\hline Strip Mall & $\begin{array}{l}\text { Insulation entirely } \\
\text { above deck }\end{array}$ & $\begin{array}{l}\text { Insulation entirely } \\
\text { above deck }\end{array}$ & $\begin{array}{l}\text { Insulation entirely } \\
\text { above deck }\end{array}$ \\
\hline Supermarket & $\begin{array}{l}\text { Insulation entirely } \\
\text { above deck }\end{array}$ & $\begin{array}{l}\text { Insulation entirely } \\
\text { above deck }\end{array}$ & $\begin{array}{l}\text { Insulation entirely } \\
\text { above deck }\end{array}$ \\
\hline Quick Service Restaurant & $\begin{array}{l}\text { Insulation entirely } \\
\text { above deck }\end{array}$ & Attic and other & Attic and other \\
\hline Full Service Restaurant & $\begin{array}{l}\text { Insulation entirely } \\
\text { above deck }\end{array}$ & Attic and other & Attic and other \\
\hline Small Hotel & Attic and other & Attic and other & $\begin{array}{l}\text { Insulation entirely } \\
\text { above deck }\end{array}$ \\
\hline Large Hotel & $\begin{array}{l}\text { Insulation entirely } \\
\text { above deck }\end{array}$ & $\begin{array}{l}\text { Insulation entirely } \\
\text { above deck }\end{array}$ & $\begin{array}{l}\text { Insulation entirely } \\
\text { above deck }\end{array}$ \\
\hline Hospital & $\begin{array}{l}\text { Insulation entirely } \\
\text { above deck }\end{array}$ & $\begin{array}{l}\text { Insulation entirely } \\
\text { above deck }\end{array}$ & $\begin{array}{l}\text { Insulation entirely } \\
\text { above deck }\end{array}$ \\
\hline Outpatient Healthcare & $\begin{array}{l}\text { Insulation entirely } \\
\text { above deck }\end{array}$ & $\begin{array}{l}\text { Insulation entirely } \\
\text { above deck }\end{array}$ & $\begin{array}{l}\text { Insulation entirely } \\
\text { above deck }\end{array}$ \\
\hline Warehouse & $\begin{array}{l}\text { Insulation entirely } \\
\text { above deck }\end{array}$ & Metal building roof & Metal building roof \\
\hline Midrise Apartment & $\begin{array}{l}\text { Insulation entirely } \\
\text { above deck }\end{array}$ & $\begin{array}{l}\text { Insulation entirely } \\
\text { above deck }\end{array}$ & $\begin{array}{l}\text { Insulation entirely } \\
\text { above deck }\end{array}$ \\
\hline
\end{tabular}


Table 18 Recommended Wall Constructions by Building Type

\begin{tabular}{|l|l|l|l|}
\hline \multicolumn{1}{|c|}{ Building Type } & \multicolumn{1}{c|}{ Pre-1980 } & \multicolumn{1}{c|}{ Post-1980 } & \multicolumn{1}{c|}{ Construction } \\
\hline Small Office & Steel frame & Mass & Mass \\
\hline Medium Office & Steel frame & Steel frame & Steel frame \\
\hline Large Office & Mass & Mass & Mass \\
\hline Primary School & Steel frame & Steel frame & Steel frame \\
\hline Secondary School & Steel frame & Steel frame & Steel frame \\
\hline Stand-Alone Retail & Steel frame & Mass & Mass \\
\hline Strip Mall & Steel frame & Steel frame & Steel frame \\
\hline Supermarket & Mass & Mass & Mass \\
\hline Quick Service Restaurant & Mass & Wood frame & Wood frame \\
\hline Full Service Restaurant & Steel frame & Steel frame & Steel frame \\
\hline Small Hotel & Steel frame & Steel frame & Steel frame \\
\hline Large Hotel & Mass & Mass & Mass \\
\hline Hospital & Mass & Mass & Mass \\
\hline Outpatient Healthcare & Steel frame & Steel frame & Steel frame \\
\hline Warehouse & Metal building & Metal building & Metal building \\
\hline Midrise Apartment & Steel frame & Steel frame & Steel frame \\
\hline
\end{tabular}

The choice of a wall or roof type for a reference building has energy implications. Versions of ASHRAE Standard 90 (dating back to 90-75) have different assembly U-factor requirements for different wall and roof types. For example, Standard 90.1-2004 has a variation for roof assembly U-factor of 0.034 to 0.065 (depending on roof type) in Zone 5 (typical of Chicago, Illinois). This same building in the same location could show a variation in wall assembly U-factor of 0.084 to 0.113 for lightweight construction.

The overall U-values of opaque constructions and fenestrations must be determined for the different vintages of baseline building models. The new construction reference building models follow Standard 90.1-2004; the post-1980 models follow Standard 90.1-1989. For the pre-1980 models, we chose to follow values from Briggs et al. (1987), who estimated envelope thermal properties by construction year for office buildings. We estimated the envelope thermal properties from the Briggs paper for 1970 construction and assumed that these values apply across all building and construction types. Table 19 through Table 25 show the roof and wall Uvalues, slab-on-grade and underground R-values, window U-values, and solar heat gain coefficients (SHGCs) for all construction types and for the three vintages of reference buildings. The U-values include the interior and exterior film coefficients from Standard 90.1-2004.

Standard 90.1-2004 contains residential and nonresidential construction performance parameters. The residential constructions are more stringent and should be used for whole buildings or floors of buildings where $50 \%$ or more of the spaces adjacent to the exterior walls are used primarily for living and sleeping quarters. This definition requires that the residential constructions be used for the small hotel and midrise apartment, for floors $2-4$ of the hospital, and for floors 2-6 of the large hotel. 
Table 19 Roof U-Values (Btu/h. $\left.\mathrm{ft}^{2} \cdot{ }^{\circ} \mathrm{F}\right)$ by Reference Building Vintage

\begin{tabular}{|l|c|c|c|c|c|c|}
\hline \multicolumn{1}{|c|}{ Location } & $\begin{array}{c}\mathbf{9 0 . 1 - 2 0 0 4} \\
\text { Climate } \\
\text { Zone }\end{array}$ & $\begin{array}{c}\mathbf{9 0 . 1 - 1 9 8 9} \\
\text { Table }\end{array}$ & $\begin{array}{c}\text { Pre- } \\
\mathbf{1 9 8 0}\end{array}$ & $\begin{array}{c}\text { Post- } \\
\mathbf{1 9 8 0}\end{array}$ & $\begin{array}{c}\text { New Construction } \\
\text { Insulation } \\
\text { Above Deck }\end{array}$ & $\begin{array}{c}\text { New } \\
\text { Construction } \\
\text { Attic }\end{array}$ \\
\hline Miami, FL & 1A & $8 \mathrm{~A}-15$ & 0.100 & 0.074 & 0.063 & 0.034 \\
\hline Houston, TX & 2A & $8 \mathrm{~A}-10$ & 0.100 & 0.066 & 0.063 & 0.034 \\
\hline Phoenix, AZ & 2B & $8 \mathrm{~A}-18$ & 0.100 & 0.046 & 0.063 & 0.034 \\
\hline Atlanta, GA & 3A & $8 \mathrm{~A}-8$ & 0.100 & 0.072 & 0.063 & 0.034 \\
\hline Los Angeles, CA & 3B-CA & $8 \mathrm{~A}-6$ & 0.100 & 0.100 & 0.063 & 0.034 \\
\hline Las Vegas, NV & 3B-other & $8 \mathrm{~A}-14$ & 0.100 & 0.048 & 0.063 & 0.034 \\
\hline San Francisco, CA & 3C & $8 \mathrm{~A}-5$ & 0.100 & 0.088 & 0.063 & 0.034 \\
\hline Baltimore, MD & 4A & $8 \mathrm{~A}-25$ & 0.086 & 0.058 & 0.063 & 0.034 \\
\hline Albuquerque, NM & 4B & $8 \mathrm{~A}-23$ & 0.089 & 0.059 & 0.063 & 0.034 \\
\hline Seattle, WA & 4C & $8 \mathrm{~A}-19$ & 0.085 & 0.064 & 0.063 & 0.034 \\
\hline Chicago, IL & 5A & $8 \mathrm{~A}-26$ & 0.072 & 0.053 & 0.063 & 0.034 \\
\hline Denver, CO & 5B & $8 \mathrm{~A}-28$ & 0.076 & 0.051 & 0.063 & 0.034 \\
\hline Minneapolis, MN & 6A & $8 \mathrm{~A}-33$ & 0.060 & 0.045 & 0.063 & 0.027 \\
\hline Helena, MT & 6B & $8 \mathrm{~A}-32$ & 0.060 & 0.049 & 0.063 & 0.027 \\
\hline Duluth, MN & 7 & $8 \mathrm{~A}-36$ & 0.060 & 0.040 & 0.063 & 0.027 \\
\hline Fairbanks, AK & 8 & $8 \mathrm{~A}-38$ & 0.060 & 0.031 & 0.048 & 0.027 \\
\hline
\end{tabular}

Table 20 Steel Frame Wall U-Values $\left(B t u / h \cdot \mathrm{ft}^{2} \cdot{ }^{\circ} \mathrm{F}\right)$ by Reference Building Vintage

\begin{tabular}{|c|c|c|c|c|c|c|c|c|}
\hline \multirow[b]{2}{*}{ Location } & \multirow{2}{*}{$\begin{array}{c}90.1-2004 \\
\text { Climate } \\
\text { Zone }\end{array}$} & \multirow[b]{2}{*}{$\begin{array}{c}90.1-1989 \\
\text { Table }\end{array}$} & \multicolumn{2}{|c|}{ Pre-1980 } & \multicolumn{2}{|c|}{ Post-1980 } & \multicolumn{2}{|c|}{ New Construction } \\
\hline & & & $\begin{array}{c}\text { Btul } \\
h \cdot \mathrm{ft}^{2} \cdot{ }^{\circ} \mathrm{F}\end{array}$ & $\mathrm{W} / \mathrm{m}^{2} \cdot \mathrm{K}$ & $\begin{array}{c}\text { Btul } \\
h \cdot \mathrm{ft}^{2} \cdot{ }^{\circ} \mathrm{F}\end{array}$ & $\mathrm{W} / \mathrm{m}^{2} \cdot \mathrm{K}$ & $\begin{array}{c}\text { Btul } \\
h \cdot \mathrm{ft}^{2} \cdot{ }^{\circ} \mathrm{F}\end{array}$ & $\mathrm{W} / \mathrm{m}^{2} \cdot \mathrm{K}$ \\
\hline Miami, FL & $1 \mathrm{~A}$ & $8 A-15$ & 0.230 & 1.306 & 1.000 & 5.678 & 0.124 & 0.704 \\
\hline Houston, TX & $2 \mathrm{~A}$ & $8 \mathrm{~A}-10$ & 0.230 & 1.306 & 0.150 & 0.852 & 0.124 & 0.704 \\
\hline Phoenix, AZ & 2B & $8 A-18$ & 0.230 & 1.306 & 0.240 & 1.363 & 0.124 & 0.704 \\
\hline Atlanta, GA & $3 \mathrm{~A}$ & $8 A-8$ & 0.225 & 1.278 & 0.130 & 0.738 & 0.124 & 0.704 \\
\hline Los Angeles, CA & 3B-CA & $8 A-6$ & 0.230 & 1.306 & 0.220 & 1.249 & 0.124 & 0.704 \\
\hline Las Vegas NV & 3B-other & $8 \mathrm{~A}-14$ & 0.230 & 1.306 & 0.160 & 0.909 & 0.124 & 0.704 \\
\hline San Francisco, CA & $3 C$ & $8 A-5$ & 0.224 & 1.272 & 0.130 & 0.738 & 0.124 & 0.704 \\
\hline Baltimore, MD & $4 \mathrm{~A}$ & $8 \mathrm{~A}-25$ & 0.178 & 1.011 & 0.089 & 0.505 & 0.124 & 0.704 \\
\hline Albuquerque, NM & $4 \mathrm{~B}$ & $8 A-23$ & 0.184 & 1.045 & 0.100 & 0.568 & 0.124 & 0.704 \\
\hline Seattle, WA & $4 \mathrm{C}$ & $8 \mathrm{~A}-19$ & 0.175 & 0.994 & 0.092 & 0.522 & 0.124 & 0.704 \\
\hline Chicago, IL & $5 \mathrm{~A}$ & $8 A-26$ & 0.156 & 0.886 & 0.082 & 0.466 & 0.084 & 0.477 \\
\hline Denver, CO & $5 B$ & $8 A-28$ & 0.161 & 0.914 & 0.082 & 0.466 & 0.084 & 0.477 \\
\hline Minneapolis, MN & $6 \mathrm{~A}$ & $8 A-33$ & 0.145 & 0.823 & 0.065 & 0.369 & 0.084 & 0.477 \\
\hline Helena, MT & $6 \mathrm{~B}$ & $8 A-32$ & 0.145 & 0.823 & 0.072 & 0.409 & 0.084 & 0.477 \\
\hline Duluth, MN & 7 & $8 A-36$ & 0.136 & 0.772 & 0.058 & 0.329 & 0.064 & 0.363 \\
\hline Fairbanks, AK & 8 & $8 A-38$ & 0.125 & 0.710 & 0.045 & 0.256 & 0.064 & 0.363 \\
\hline
\end{tabular}


Table 21 Mass Wall U-Values (Btu/h/ft ${ }^{2} \cdot{ }^{\circ} \mathrm{F}$ ) by Reference Building Vintage

\begin{tabular}{|c|c|c|c|c|c|c|c|c|}
\hline \multirow[b]{2}{*}{ Location } & \multirow{2}{*}{$\begin{array}{c}90.1-2004 \\
\text { Climate } \\
\text { Zone }\end{array}$} & \multirow[b]{2}{*}{$\begin{array}{c}90.1-1989 \\
\text { Table }\end{array}$} & \multicolumn{2}{|c|}{ Pre-1980 } & \multicolumn{2}{|c|}{ Post-1980 } & \multicolumn{2}{|c|}{ New Construction } \\
\hline & & & $\begin{array}{c}\text { Btul } \\
h \cdot \mathrm{ft}^{2} \cdot{ }^{\circ} \mathrm{F}\end{array}$ & $\mathrm{W} / \mathrm{m}^{2} \cdot \mathrm{K}$ & $\begin{array}{c}\text { Btul } \\
\mathrm{h} \cdot \mathrm{ft}^{2} \cdot{ }^{\circ} \mathrm{F}\end{array}$ & $\mathrm{W} / \mathrm{m}^{2} \cdot \mathrm{K}$ & $\begin{array}{c}\text { Btul } \\
h \cdot \mathrm{ft}^{2} \cdot{ }^{\circ} \mathrm{F}\end{array}$ & $\mathrm{W} / \mathrm{m}^{2} \cdot \mathrm{K}$ \\
\hline Miami, FL & $1 \mathrm{~A}$ & $8 \mathrm{~A}-15$ & 0.230 & 1.306 & 1.000 & 5.678 & 0.580 & 3.293 \\
\hline Houston, TX & $2 \mathrm{~A}$ & $8 A-10$ & 0.230 & 1.306 & 0.340 & 1.931 & 0.580 & 3.293 \\
\hline Phoenix, AZ & $2 \mathrm{~B}$ & $8 A-18$ & 0.230 & 1.306 & 0.410 & 2.328 & 0.580 & 3.293 \\
\hline Atlanta, GA & $3 A$ & $8 A-8$ & 0.225 & 1.278 & 0.290 & 1.647 & 0.151 & 0.857 \\
\hline Los Angeles, CA & $3 B-C A$ & $8 A-6$ & 0.230 & 1.306 & 1.000 & 5.678 & 0.151 & 0.857 \\
\hline Las Vegas, NV & 3B-other & $8 A-14$ & 0.230 & 1.306 & 0.290 & 1.647 & 0.580 & 3.293 \\
\hline San Francisco, CA & $3 C$ & $8 A-5$ & 0.224 & 1.272 & 0.490 & 2.782 & 0.580 & 3.293 \\
\hline Baltimore, MD & $4 \mathrm{~A}$ & $8 A-25$ & 0.178 & 1.011 & 0.120 & 0.681 & 0.580 & 3.293 \\
\hline Albuquerque, NM & $4 \mathrm{~B}$ & $8 A-23$ & 0.184 & 1.045 & 0.190 & 1.079 & 0.151 & 0.857 \\
\hline Seattle, WA & $4 \mathrm{C}$ & $8 A-19$ & 0.175 & 0.994 & 0.100 & 0.568 & 0.151 & 0.857 \\
\hline Chicago, IL & $5 \mathrm{~A}$ & $8 A-26$ & 0.156 & 0.886 & 0.100 & 0.568 & 0.151 & 0.857 \\
\hline Denver, CO & $5 B$ & $8 A-28$ & 0.161 & 0.914 & 0.140 & 0.795 & 0.151 & 0.857 \\
\hline Minneapolis, MN & $6 \mathrm{~A}$ & $8 A-33$ & 0.145 & 0.823 & 0.071 & 0.403 & 0.123 & 0.698 \\
\hline Helena, MT & $6 B$ & $8 \mathrm{~A}-32$ & 0.145 & 0.823 & 0.079 & 0.449 & 0.123 & 0.698 \\
\hline Duluth, MN & 7 & $8 A-36$ & 0.136 & 0.772 & 0.061 & 0.346 & 0.123 & 0.698 \\
\hline Fairbanks, AK & 8 & $8 A-38$ & 0.125 & 0.710 & 0.047 & 0.267 & 0.104 & 0.591 \\
\hline
\end{tabular}

Table 22 Unheated Slab-On-Grade Floor Insulation by Reference Building Vintage R-Value $\left(\mathrm{h} \cdot \mathrm{ft}^{2} \cdot{ }^{\circ} \mathrm{F} / \mathrm{Btu}\right)$ for 24 -in. Vertical Insulation

\begin{tabular}{|c|c|c|c|c|c|}
\hline Location & $\begin{array}{c}90.1-2004 \\
\text { Climate Zone }\end{array}$ & $\begin{array}{c}90.1-1989 \\
\text { Table }\end{array}$ & Pre-1980 & Post-1980 & $\begin{array}{c}\text { New } \\
\text { Construction }\end{array}$ \\
\hline Miami, FL & $1 \mathrm{~A}$ & $8 A-15$ & 0.0 & 0.0 & NR \\
\hline Houston, TX & $2 \mathrm{~A}$ & $8 A-10$ & 0.0 & 0.0 & NR \\
\hline Phoenix, AZ & $2 B$ & $8 A-18$ & 0.0 & 0.0 & NR \\
\hline Atlanta, GA & $3 \mathrm{~A}$ & $8 \mathrm{~A}-8$ & 0.0 & 6.0 & NR \\
\hline Los Angeles, CA & 3B-CA & $8 A-6$ & 0.0 & 0.0 & NR \\
\hline Las Vegas, NV & 3B-other & $8 A-14$ & 0.0 & 0.0 & NR \\
\hline San Francisco, CA & $3 C$ & $8 A-5$ & 0.0 & 6.0 & NR \\
\hline Baltimore, MD & $4 \mathrm{~A}$ & $8 A-25$ & 0.0 & 8.0 & NR \\
\hline Albuquerque, NM & $4 \mathrm{~B}$ & $8 A-23$ & 0.0 & 7.0 & NR \\
\hline Seattle, WA & $4 \mathrm{C}$ & $8 A-19$ & 0.0 & 8.0 & NR \\
\hline Chicago, IL & $5 \mathrm{~A}$ & $8 A-26$ & 0.0 & 8.0 & NR \\
\hline Denver, CO & $5 B$ & $8 A-28$ & 0.0 & 8.0 & NR \\
\hline Minneapolis, MN & $6 \mathrm{~A}$ & $8 \mathrm{~A}-33$ & 0.0 & 8.0 & NR \\
\hline Helena, MT & $6 B$ & $8 A-32$ & 0.0 & 8.0 & NR \\
\hline Duluth, MN & 7 & $8 A-36$ & 0.0 & 8.0 & NR \\
\hline Fairbanks, AK & 8 & $8 A-38$ & 0.0 & 8.0 & 10.0 \\
\hline
\end{tabular}




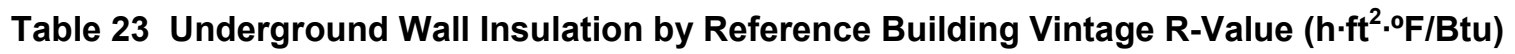

\begin{tabular}{|c|c|c|c|c|c|}
\hline Location & $\begin{array}{c}90.1-2004 \\
\text { Climate Zone }\end{array}$ & $\begin{array}{c}90.1-1989 \\
\text { Table }\end{array}$ & Pre-1980 & Post-1980 & $\begin{array}{c}\text { New } \\
\text { Construction }\end{array}$ \\
\hline Miami, FL & $1 \mathrm{~A}$ & $8 A-15$ & 0.0 & 0.0 & NR \\
\hline Houston, TX & $2 \mathrm{~A}$ & $8 \mathrm{~A}-10$ & 0.0 & 0.0 & NR \\
\hline Phoenix, AZ & $2 B$ & $8 A-18$ & 0.0 & 0.0 & NR \\
\hline Atlanta, GA & $3 A$ & $8 A-8$ & 0.0 & 7.0 & NR \\
\hline Los Angeles, CA & 3B-CA & $8 A-6$ & 0.0 & 0.0 & NR \\
\hline Las Vegas, NV & 3B-other & $8 \mathrm{~A}-14$ & 0.0 & 0.0 & NR \\
\hline San Francisco, CA & $3 C$ & $8 A-5$ & 0.0 & 7.0 & NR \\
\hline Baltimore, MD & $4 \mathrm{~A}$ & $8 \mathrm{~A}-25$ & 0.0 & 9.0 & NR \\
\hline Albuquerque, NM & $4 \mathrm{~B}$ & $8 A-23$ & 0.0 & 8.0 & NR \\
\hline Seattle, WA & $4 C$ & $8 A-19$ & 0.0 & 9.0 & NR \\
\hline Chicago, IL & $5 A$ & $8 A-26$ & 0.0 & 10.0 & NR \\
\hline Denver, CO & $5 B$ & $8 A-28$ & 0.0 & 10.0 & NR \\
\hline Minneapolis, MN & $6 \mathrm{~A}$ & $8 A-33$ & 0.0 & 12.0 & NR \\
\hline Helena, MT & $6 \mathrm{~B}$ & $8 \mathrm{~A}-32$ & 0.0 & 11.0 & NR \\
\hline Duluth, MN & 7 & $8 A-36$ & 0.0 & 13.0 & 7.5 \\
\hline Fairbanks, AK & 8 & $8 A-38$ & 0.0 & 16.0 & 7.5 \\
\hline
\end{tabular}

Table 24 Window Overall U-Value (Btu/h·ft $\left.{ }^{2} \cdot{ }^{\circ} \mathrm{F}\right)$ by Reference Building Vintage

\begin{tabular}{|c|c|c|c|c|c|}
\hline Location & $\begin{array}{c}90.1-2004 \\
\text { Climate Zone }\end{array}$ & $\begin{array}{c}90.1-1989 \\
\text { Table }\end{array}$ & Pre-1980 & Post-1980 & $\begin{array}{c}\text { New } \\
\text { Construction }\end{array}$ \\
\hline Miami, FL & $1 \mathrm{~A}$ & $8 A-15$ & 1.22 & 1.22 & 1.22 \\
\hline Houston, TX & $2 \mathrm{~A}$ & $8 A-10$ & 1.22 & 1.22 & 1.22 \\
\hline Phoenix, AZ & $2 \mathrm{~B}$ & $8 \mathrm{~A}-18$ & 1.22 & 1.22 & 1.22 \\
\hline Atlanta, GA & $3 \mathrm{~A}$ & $8 \mathrm{~A}-8$ & 1.22 & 0.72 & 0.57 \\
\hline Los Angeles, CA & 3B-CA & $8 A-6$ & 1.22 & 1.22 & 0.57 \\
\hline Las Vegas, NV & 3B-other & $8 A-14$ & 1.22 & 1.22 & 0.57 \\
\hline San Francisco, CA & $3 C$ & $8 A-5$ & 1.22 & 0.72 & 1.22 \\
\hline Baltimore, MD & $4 \mathrm{~A}$ & $8 A-25$ & 1.22 & 0.59 & 0.57 \\
\hline Albuquerque, NM & $4 \mathrm{~B}$ & $8 A-23$ & 1.22 & 0.72 & 0.57 \\
\hline Seattle, WA & $4 C$ & $8 \mathrm{~A}-19$ & 1.22 & 0.72 & 0.57 \\
\hline Chicago, IL & $5 A$ & $8 A-26$ & 0.62 & 0.59 & 0.57 \\
\hline Denver, CO & $5 \mathrm{~B}$ & $8 A-28$ & 0.62 & 0.59 & 0.57 \\
\hline Minneapolis, MN & $6 \mathrm{~A}$ & $8 A-33$ & 0.62 & 0.52 & 0.57 \\
\hline Helena, MT & $6 \mathrm{~B}$ & $8 A-32$ & 0.62 & 0.52 & 0.57 \\
\hline Duluth, MN & 7 & $8 A-36$ & 0.62 & 0.52 & 0.57 \\
\hline Fairbanks, AK & 8 & $8 A-38$ & 0.62 & 0.52 & 0.35 \\
\hline
\end{tabular}


Table 25 Window Solar Heat Gain Coefficient by Reference Building Vintage

\begin{tabular}{|c|c|c|c|c|c|}
\hline Location & $\begin{array}{c}90.1-2004 \\
\text { Climate Zone }\end{array}$ & $\begin{array}{c}90.1-1989 \\
\text { Table }\end{array}$ & Pre-1980 & Post-1980 & $\begin{array}{c}\text { New } \\
\text { Construction }\end{array}$ \\
\hline Miami, FL & $1 \mathrm{~A}$ & $8 A-15$ & 0.54 & 0.25 & 0.25 \\
\hline Houston, TX & $2 \mathrm{~A}$ & $8 A-10$ & 0.54 & 0.25 & 0.25 \\
\hline Phoenix, AZ & $2 B$ & $8 A-18$ & 0.54 & 0.25 & 0.25 \\
\hline Atlanta, GA & $3 A$ & $8 \mathrm{~A}-8$ & 0.54 & 0.25 & 0.25 \\
\hline Los Angeles, CA & $3 B-C A$ & $8 A-6$ & 0.54 & 0.44 & 0.25 \\
\hline Las Vegas, NV & 3B-other & $8 A-14$ & 0.54 & 0.25 & 0.25 \\
\hline San Francisco, CA & $3 C$ & $8 A-5$ & 0.54 & 0.39 & 0.34 \\
\hline Baltimore, MD & $4 \mathrm{~A}$ & $8 \mathrm{~A}-25$ & 0.54 & 0.36 & 0.39 \\
\hline Albuquerque, NM & $4 \mathrm{~B}$ & $8 \mathrm{~A}-23$ & 0.54 & 0.36 & 0.39 \\
\hline Seattle, WA & $4 \mathrm{C}$ & $8 \mathrm{~A}-19$ & 0.54 & 0.39 & 0.39 \\
\hline Chicago, IL & $5 \mathrm{~A}$ & $8 A-26$ & 0.41 & 0.39 & 0.39 \\
\hline Denver, CO & $5 \mathrm{~B}$ & $8 \mathrm{~A}-28$ & 0.41 & 0.39 & 0.39 \\
\hline Minneapolis, MN & $6 \mathrm{~A}$ & $8 A-33$ & 0.41 & 0.39 & 0.39 \\
\hline Helena, MT & $6 B$ & $8 A-32$ & 0.41 & 0.39 & 0.39 \\
\hline Duluth, MN & 7 & $8 \mathrm{~A}-36$ & 0.41 & 0.49 & 0.49 \\
\hline Fairbanks, AK & 8 & $8 A-38$ & 0.41 & NR & NR \\
\hline
\end{tabular}

Standard 90.1-2004 has different roof U-values depending on the construction type; the U-value for Attic and Other is typically about half that for Insulation Entirely Above Deck. Standard 90.1-1989 has only one value for the roof U-value, and the Briggs paper does not differentiate by construction type. Therefore, we use the same roof $U$-value for all construction types in the pre1980 and post-1980 constructions.

Standard 90.1-1989 has varying levels of insulation for mass walls, depending on the internal load density (ILD), the wall heat capacity, the amount of fenestration, and the location of the insulation. We made the following assumptions:

- The ILD for all building types is $1.5-3 \mathrm{~W} / \mathrm{ft}^{2}$.

- The heat capacity of the walls is greater than $15 \mathrm{Btu} / \mathrm{ft}^{2} \cdot{ }^{\circ} \mathrm{F}$.

- The percent fenestration is in the lower of the two ranges.

- The insulation is on the interior of the mass wall.

Briggs et al. (1987) published wall U-values for mass walls only. Thus, we used the same value for the pre-1980 steel frame wall construction. This paper does not include underground walls, and we assumed that there is no insulation on pre-1980 underground walls for all locations.

Standard 90.1-1989 contains ranges of window U-values and shading coefficients, depending on the window-to-wall glazing fraction and ILD. We assumed the highest U-values from 90.1-1989 for the post-1980 reference buildings, which agree very closely with other versions of Standard 90.1 for most locations. We used the SHGC from Standard 90.1-1999 for the post-1980 reference buildings. For the pre-1980 reference buildings, we assumed the windows in climate zones $1-4$ are single glazed 0.25 -in. $(.6-\mathrm{cm})$ bronze tinted glass and for climate zones $5-8$, double-glazed bronze and clear glass windows. For new construction following 90.1-2004, we 
assumed all windows are fixed except the midrise apartment building, which is assumed to have operable windows.

\subsubsection{Infiltration}

Infiltration is different in each building and varies continuously with changing environmental and building operating conditions. Modeling approaches to infiltration are typically very simple because of the lack of knowledge about the sizes and distribution of cracks in the building envelope, the permeability of the envelope, the flow of air internal to the building, and the pressure distribution in and around the building. EnergyPlus allows a simple approach and a more detailed air flow nodal network approach to infiltration modeling. We chose the simple approach to simplify the assumptions needed and to decrease simulation run times.

The simple method has an empirical correlation that modifies the infiltration as a function of wind speed and temperature difference across the envelope. The difficulty in using this equation is determining valid coefficients for each building type in each location. The EnergyPlus documentation presents two sets of correlation coefficients, both of which were derived from a small number of measurements taken from published reports. These coefficients vary dramatically and provide very different results that cause great uncertainty in determining which numbers to use. Therefore, we chose to model a fixed infiltration rate (which may not be realistic for hourly modeling), but we feel that it can represent the average impact over a year.

Even in the simple model, we have to make assumptions about the infiltration level and how it is affected by the operation of the mechanical ventilation systems. A proposed addendum to Standard 90.1-2004 included an airtightness level for building envelopes. This document proposed that one approach to meeting the standard would be to perform a pressurization test to show that the building leakage does not exceed $0.4 \mathrm{cfm} / \mathrm{ft}^{2}$ at $0.3 \mathrm{in}$. w.c. $\left(2 \mathrm{~L} / \mathrm{s} / \mathrm{m}^{2}\right.$ at $\left.75 \mathrm{~Pa}\right)$ of above-grade envelope area (exterior walls and roof). This airtightness level provides a number that can be used for the energy simulations and was assumed to be the level for new construction reference building models.

For existing buildings, we turn to measured airtightness data. Persily (1998) collected data from 139 buildings that showed a wide scatter in airtightness and little correlation between building age and airtightness. The average leakage rate across all building types and locations was 1.5 $\mathrm{cfm} / \mathrm{ft}^{2}$ at 0.3 in. w.c. $\left(7.5 \mathrm{~L} / \mathrm{s} / \mathrm{m}^{2}\right.$ at $\left.75 \mathrm{~Pa}\right)$ of above-grade envelope area. This number is used for the pre-1980 and post-1980 reference building models.

Several assumptions have to be made to go from leakage rates to the simple infiltration model in the building energy simulation. The infiltration was calculated based on the above-grade envelope area (exterior walls and roof), then converted to a pressure of 0.016 in. w.c. (4 Pa), assuming a flow exponent of 0.65 . This lower pressure was assumed to be the average pressure difference across the envelope without pressurization or depressurization from the HVAC and exhaust fans.

Infiltration is often assumed to drop to zero when buildings are pressurized in energy models, because there is a lack of evidence about what really happens and lack of knowledge about how to model it in an energy simulation. We assumed that the uncontrolled infiltration is reduced to $25 \%$ of the value calculated at 0.016 in. w.c. ( $4 \mathrm{~Pa}$ ) when the ventilation system is running. When the ventilation system is off (no OA), the infiltration is modeled at the full leakage rate calculated at 0.016 in. w.c. (4 Pa). Infiltration is modeled at constant air changes per hour 
$(\mathrm{ACH})$. We assumed that constant $\mathrm{ACH}$ models the average effects over the year and in different locations. This is a gross simplification, but is necessary without moving to more complicated flow network simulations.

\subsection{Equipment}

The equipment category includes interior and exterior lighting, HVAC, SWH equipment, and commercial refrigeration systems.

\subsubsection{Interior Lighting}

We used the building area method or the space-by-space method from Standard 90.1-2004 to determine maximum lighting power densities (LPDs) for the new construction models and Standard 90.1-1989 for the existing building models (see Table 26). For space types not defined in Standard 90.1-2004 for the hospital and outpatient models, we took LPD values from GGHC (2007). The LPDs for each zone in each building are listed in Appendix A.

The LPDs in the strip mall were divided into three levels: high in two stores, medium in three stores, and low in five stores to simulate a mix of stores based on research from Liu et al. (2006). We assumed that the typical pre-1980 building lighting systems were updated to at least the Standard 90.1-1989 LPDs. Standard 90.1-1989 provides prescriptive criteria and system performance criteria approaches for determining the allowed lighting power. The prescriptive criteria approach provides building-level LPDs. The system performance criteria approach provides space-level LPDs and an area factor (AF) multiplier. The LPD for reference buildings with multiple space types was determined as the product of the allowable unit power density from ASHRAE (1989). The AF is defined as

$$
\begin{aligned}
& \mathrm{AF}=0.2+0.8\left(1 / 0.9^{\mathrm{n}}\right) \\
& \mathrm{n}=\frac{10.21(\mathrm{CH}-2.5)}{\sqrt{\mathrm{A}_{\mathrm{r}}}}-1
\end{aligned}
$$

where

$\begin{array}{lll}\mathrm{AF} & = & \text { area factor } \\ \mathrm{A}_{\mathrm{r}} & = & \text { room area, } \mathrm{ft}^{2} \\ \mathrm{CH} & = & \text { ceiling height, } \mathrm{ft}\end{array}$


Table 26 Reference Building Lighting Assumptions

\begin{tabular}{|c|c|c|}
\hline Building Type & $\begin{array}{l}\text { Existing Stock Models } \\
\text { (ASHRAE 90.1-1989) }\end{array}$ & $\begin{array}{l}\text { New Construction Models } \\
\text { (ASHRAE 90.1-2004) }\end{array}$ \\
\hline Small Office & Table 6-5 Offices & Table 9.5 .1 office \\
\hline Medium Office & Table 6-5 Offices & Table 9.5 .1 office \\
\hline Large Office & Table 6-5 Offices & Table 9.5 .1 office \\
\hline Primary School & $\begin{array}{l}\text { Table 6-6a by space type } \\
\text { (classroom } \mathrm{AF}=1.0 \text { ) }\end{array}$ & Table 9.6 .1 by space type \\
\hline Secondary School & $\begin{array}{l}\text { Table 6-6a by space type } \\
\text { (classroom AF = 1.0) }\end{array}$ & Table 9.6 .1 by space type \\
\hline Stand-Alone Retail & $\begin{array}{l}\text { Table 6-6b retail space type C; } \\
\text { Table 6-6a fine storage for back }\end{array}$ & $\begin{array}{l}\text { Table 9.6.1 sales area, active } \\
\text { storage }\end{array}$ \\
\hline Strip Mall & $\begin{array}{l}\text { 2 Stores: } 5.6 \mathrm{~W} / \mathrm{ft} 2(60.26 \mathrm{~W} / \mathrm{m} 2) \\
\text { (Table 6-6b space type A) } \\
\text { 3 Stores: } 3.3 \mathrm{~W} / \mathrm{ft} 2(35.51 \mathrm{~W} / \mathrm{m} 2) \\
\text { (Table 6-6b space type C) } \\
5 \text { Stores: } 2.7 \mathrm{~W} / \mathrm{ft} 2(29.05 \mathrm{~W} / \mathrm{m} 2) \\
\text { (Table 6-6b space type F) }\end{array}$ & $\begin{array}{l}2 \text { Stores: } 2.23 \mathrm{~W} / \mathrm{ft} 2(24 \mathrm{~W} / \mathrm{m} 2) \\
\text { (Table } 9.6 .1 \text { retail plus accent } \\
\text { lighting) } \\
3 \text { Stores: } 1.7 \mathrm{~W} / \mathrm{ft} 2(18.3 \mathrm{~W} / \mathrm{m} 2) \\
\text { (Table } 9.6 .1 \text { retail) } \\
5 \text { Stores: } 1.28 \mathrm{~W} / \mathrm{ft} 2(13.8 \mathrm{~W} / \mathrm{m} 2)\end{array}$ \\
\hline Supermarket & $\begin{array}{l}\text { Table } 6-6 b \text { retail space type } E ; \\
\text { Table } 6-6 \text { a office category } 1 ; \\
\text { Table } 6-6 \text { a fine storage for back }\end{array}$ & $\begin{array}{l}\text { Table } 9.6 .1 \text { sales area, active } \\
\text { storage }\end{array}$ \\
\hline Quick Service Restaurant & Table 6-6a by space type & Table 9.6.1 family dining; food prep \\
\hline Full Service Restaurant & Table 6-6a by space type & Table 9.6.1 family dining; food prep \\
\hline Small Hotel & Table $6-6 b$ by space type & Table 9.6 .1 by space type \\
\hline Large Hotel & Table $6-6 b$ by space type & Table 9.6 .1 by space type \\
\hline Hospital & Table $6-6 b$ by space type & Table 9.6 .1 by space type \\
\hline Outpatient Healthcare & $\begin{array}{l}\text { Table } 6-5 \text { offices and } \\
\text { Table } 6.6 \mathrm{~b} \text { dental suite/ } \\
\text { examination }\end{array}$ & $\begin{array}{l}\text { Table } 9.6 .1 \text { by space type } \\
\text { GGHC } 2007 \\
\text { Table L-1 where appropriate }\end{array}$ \\
\hline Warehouse & Table $6-6 a$ by space type & $\begin{array}{l}\text { Table } 9.6 .1 \text { office, bulk storage, } \\
\text { fine storage }\end{array}$ \\
\hline Midrise Apartment & $\begin{array}{l}\text { Hendron 2007, 90.1-1989 } \\
\text { Table 6-6a for corridor }\end{array}$ & $\begin{array}{l}\text { Hendron } 2007,90.1-2004 \\
\text { Table } 9.6 .1 \text { for corridor }\end{array}$ \\
\hline
\end{tabular}

\subsubsection{Exterior Lights}

Exterior lighting is included in all reference building models following the values shown in Table 27 and Table 28. All exterior lighting operates on an astronomical clock that turns on the lights when the sun is down and turns them off when the sun is up. Exterior façade lighting is included in all buildings around the perimeter of the building per area of the first floor exterior walls plus the first floor plenum exterior walls. Exterior lights were added to the main entryway doors and other exterior doors in all models. Exterior canopy lights were included in the small hotel, large hotel, and hospital emergency room entrances. The hotel canopies are considered to be high traffic areas and the hospital emergency room entrance is considered to be a low traffic 
area for Standard 90.1-1989. The quick service restaurant model includes lighting for the drivethrough window. Standard 90.1-1989 does not have a category for drive-through windows; therefore, we used the Standard 90.1-2004 value for the existing stock models.

Table 27 Exterior Lighting Assumptions

\begin{tabular}{|l|c|c|}
\hline \multicolumn{1}{|c|}{ Area } & $\begin{array}{c}\text { Existing Stock Models } \\
(\mathbf{9 0 . 1 - 1 9 8 9 )}\end{array}$ & $\begin{array}{c}\text { New Construction Models } \\
(\mathbf{9 0 . 1 - 2 0 0 4 )}\end{array}$ \\
\hline Façade & $0.25 \mathrm{~W} / \mathrm{ft}^{2}\left(2.69 \mathrm{~W} / \mathrm{m}^{2}\right)$ & $0.2 \mathrm{~W} / \mathrm{ft}^{2}\left(2.15 \mathrm{~W} / \mathrm{m}^{2}\right)$ \\
\hline Main entry doors & $30 \mathrm{~W} / \mathrm{ft}(98.4 \mathrm{~W} / \mathrm{m})$ & $30 \mathrm{~W} / \mathrm{ft}^{2}(98.4 \mathrm{~W} / \mathrm{m})$ \\
\hline Other doors & $25 \mathrm{~W} / \mathrm{ft}^{2}(82.0 \mathrm{~W} / \mathrm{m})$ & $20 \mathrm{~W} / \mathrm{ft}(65.6 \mathrm{~W} / \mathrm{m})$ \\
\hline Canopy (heavy traffic) & $10 \mathrm{~W} / \mathrm{ft}^{2}\left(108 \mathrm{~W} / \mathrm{m}^{2}\right)$ & $1.25 \mathrm{~W} / \mathrm{ft}^{2}\left(13.5 \mathrm{~W} / \mathrm{m}^{2}\right)$ \\
\hline Canopy (light traffic) & $4 \mathrm{~W} / \mathrm{ft}^{2}\left(43 \mathrm{~W} / \mathrm{m}^{2}\right)$ & $1.25 \mathrm{~W} / \mathrm{ft}^{2}\left(13.5 \mathrm{~W} / \mathrm{m}^{2}\right)$ \\
\hline Drive through & - & $400 \mathrm{~W}$ \\
\hline Parking lot & $0.18 \mathrm{~W} / \mathrm{ft}^{2}\left(1.9 \mathrm{~W} / \mathrm{m}^{2}\right)$ & $0.15 \mathrm{~W} / \mathrm{ft}^{2}\left(1.6 \mathrm{~W} / \mathrm{m}^{2}\right)$ \\
\hline
\end{tabular}

Table 28 Parking Lot Lighting Levels

\begin{tabular}{|l|c|c|c|}
\hline \multirow{2}{*}{\multicolumn{1}{c|}{ Building Type }} & Parking Lot Area & $\begin{array}{c}\text { Total Parking Lot Lighting Level } \\
\text { Models }\end{array}$ & $\begin{array}{c}\text { Exing Stock } \\
\text { Models }\end{array}$ \\
\hline Small Office & $8,910 \mathrm{ft}^{2}\left(828 \mathrm{~m}^{2}\right)$ & $1,604 \mathrm{~W}$ & $1,337 \mathrm{~W}$ \\
\hline Medium Office & $86,832 \mathrm{ft}^{2}\left(8,067 \mathrm{~m}^{2}\right)$ & $15,630 \mathrm{~W}$ & $13,025 \mathrm{~W}$ \\
\hline Large Office & $325,087 \mathrm{ft}^{2}\left(30,201 \mathrm{~m}^{2}\right)$ & $58,516 \mathrm{~W}$ & $48,763 \mathrm{~W}$ \\
\hline Primary School & $14,718 \mathrm{ft}^{2}\left(1,367 \mathrm{~m}^{2}\right)$ & $2,649 \mathrm{~W}$ & $2,208 \mathrm{~W}$ \\
\hline Secondary School & $59,263 \mathrm{ft}^{2}\left(5,506 \mathrm{~m}^{2}\right)$ & $10,667 \mathrm{~W}$ & $8,889 \mathrm{~W}$ \\
\hline Stand-Alone Retail & $35,018 \mathrm{ft}^{2}\left(3,253 \mathrm{~m}^{2}\right)$ & $6,303 \mathrm{~W}$ & $5,253 \mathrm{~W}$ \\
\hline Strip Mall & $42,368 \mathrm{ft}^{2}\left(3,936 \mathrm{~m}^{2}\right)$ & $7,626 \mathrm{~W}$ & $6,355 \mathrm{~W}$ \\
\hline Supermarket & $63,810 \mathrm{ft}^{2}\left(5,928 \mathrm{~m}^{2}\right)$ & $11,486 \mathrm{~W}$ & $9,572 \mathrm{~W}$ \\
\hline Quick Service Restaurant & $10,125 \mathrm{ft}^{2}\left(941 \mathrm{~m}^{2}\right)$ & $1,823 \mathrm{~W}$ & $1,519 \mathrm{~W}$ \\
\hline Full Service Restaurant & $22,275 \mathrm{ft}^{2}\left(2,069 \mathrm{~m}^{2}\right)$ & $4,010 \mathrm{~W}$ & $3,341 \mathrm{~W}$ \\
\hline Small Hotel & $33,696 \mathrm{ft}^{2}\left(3,130 \mathrm{~m}^{2}\right)$ & $6,065 \mathrm{~W}$ & $5,054 \mathrm{~W}$ \\
\hline Large Hotel & $88,544 \mathrm{ft}^{2}\left(8,226 \mathrm{~m}^{2}\right)$ & $15,938 \mathrm{~W}$ & $13,282 \mathrm{~W}$ \\
\hline Hospital & $77,493 \mathrm{ft}^{2}\left(7,199 \mathrm{~m}^{2}\right)$ & $13,949 \mathrm{~W}$ & $11,624 \mathrm{~W}$ \\
\hline Outpatient Healthcare & $82,924 \mathrm{ft}^{2}\left(7,704 \mathrm{~m}^{2}\right)$ & $14,926 \mathrm{~W}$ & $12,439 \mathrm{~W}$ \\
\hline Warehouse & $20,048 \mathrm{ft}^{2}\left(1,862 \mathrm{~m}^{2}\right)$ & $3,609 \mathrm{~W}$ & $3,007 \mathrm{~W}$ \\
\hline Midrise Apartment & $28,578 \mathrm{ft}^{2}\left(2,655 \mathrm{~m}^{2}\right)$ & $5,144 \mathrm{~W}$ & $4,287 \mathrm{~W}$ \\
\hline
\end{tabular}

\subsubsection{HVAC Equipment}

ASHRAE (2004) specifies HVAC equipment for baseline buildings. This information is used to develop reference buildings and does not necessarily represent typical construction practices. Winiarski et al. (2006) performed an analysis of 2003 CBECS to estimate typical HVAC system types by building type to use with the reference buildings. They examined the data in two sets: 
all buildings with a construction year of 1980 or earlier and the remaining buildings built after 1980. The final equipment types selected represented the largest percentage of floor area. The results for post-1980 and new construction are shown in Table 29 and for pre-1980 construction in Table 30. Strip malls were not included and are assumed to have the same systems as the stand-alone retail model. The number of chillers and condenser type (air or water) were determined by discussions with the ASHRAE Standard 90.1 mechanical subcommittee.

Table 29 HVAC Equipment Types for Post-1980 and New Construction

\begin{tabular}{|c|c|c|c|}
\hline Building Type & Heating & Cooling & Air Distribution \\
\hline Small Office & Furnace & $\begin{array}{l}\text { PACU (packaged air- } \\
\text { conditioning unit) }\end{array}$ & $\begin{array}{l}\text { SZ CAV (single-zone } \\
\text { constant air volume) }\end{array}$ \\
\hline Medium Office & Furnace & PACU & $\begin{array}{l}\text { MZ VAV (multizone } \\
\text { variable air volume) }\end{array}$ \\
\hline Large Office & Boiler & $\begin{array}{l}\text { Chiller (2) - water } \\
\text { cooled }\end{array}$ & MZ VAV \\
\hline Primary School & Boiler & PACU & CAV \\
\hline Secondary School & Boiler & Chiller - air cooled & MZ VAV \\
\hline Stand-Alone Retail & Furnace & PACU & SZ CAV \\
\hline Strip Mall & Furnace & PACU & SZ CAV \\
\hline Supermarket & Furnace & PACU & CAV \\
\hline Quick Service Restaurant & Furnace & PACU & SZ CAV \\
\hline Full Service Restaurant & Furnace & PACU & SZ CAV \\
\hline Small Hotel & $\begin{array}{l}\text { ISH (individual } \\
\text { space heater), } \\
\text { furnace }\end{array}$ & $\begin{array}{l}\text { IRAC (individual room } \\
\text { air conditioner), PACU }\end{array}$ & SZ CAV \\
\hline Large Hotel & Boiler & Chiller (2) - air cooled & $\begin{array}{l}\text { FCU (fan coil unit) } \\
\text { and } \mathrm{VAV}^{*}\end{array}$ \\
\hline Hospital & Boiler & Chiller - water cooled & $\mathrm{CAV}$ and $\mathrm{VAV}^{* *}$ \\
\hline Outpatient Healthcare & Furnace & PACU & $\mathrm{CAV}$ and $\mathrm{VAV} \mathrm{V}^{* *}$ \\
\hline Warehouse & ISH, furnace & PACU & SZ CAV \\
\hline Midrise Apartment & Furnace & PACU-SS (split system) & SZ CAV \\
\hline
\end{tabular}

* Hotels may be characterized with two system types serving different areas. Both multizone systems (VAV or CAV) may serve public spaces (lobby/conference rooms), whereas single zone fan coil systems may be common for living areas.

${ }^{* *}$ Hospitals may use CAV systems in some operating and critical care type areas with variable air flow used for pressurization, but classic VAV multizone systems in areas such as offices. CBECS buildings reporting VAV are significantly less common in pre-1980 construction (67\% versus $95 \%$ in post-1980 hospitals). 
Table 30 HVAC Equipment Types for Pre-1980 Construction

\begin{tabular}{|l|l|l|l|}
\hline \multicolumn{1}{|c|}{ Building Type } & \multicolumn{1}{c|}{ Heating } & \multicolumn{1}{c|}{ Cooling } & \multicolumn{1}{c|}{ Air Distribution } \\
\hline Small Office & Furnace & PACU & SZ CAV \\
\hline Medium Office & Furnace & PACU & SZ CAV \\
\hline Large Office & Boiler & Chiller (2) - water cooled & MZ VAV \\
\hline Primary School & Boiler & PACU & CAV \\
\hline Secondary School & Boiler & PACU & CAV \\
\hline Stand-Alone Retail & Furnace & PACU & SZ CAV \\
\hline Strip Mall & Furnace & PACU & SZ CAV \\
\hline Supermarket & Furnace & PACU & CAV \\
\hline Quick Service Restaurant & Furnace & PACU & SZ CAV \\
\hline Full Service Restaurant & Furnace & PACU & SZ CAV \\
\hline Small Hotel & ISH & IRAC & SZ CAV \\
\hline Large Hotel & Boiler & Chiller $(2)-$ air cooled & FCU and MZ CAV* \\
\hline Hospital & Boiler & Chiller - water cooled & FCU, CAV and VAV** \\
\hline Outpatient Healthcare & Furnace & PACU & CAV and VAV** \\
\hline Warehouse & Furnace, ISH & PACU & SZ CAV \\
\hline Midrise Apartment & Furnace & PACU-SS & SZ CAV \\
\hline
\end{tabular}

* Hotels may be characterized with two system types serving different areas. Both multizone systems (VAV or CAV) may serve public spaces (lobby/conference rooms), whereas single zone fan coil systems may be common for living areas.

** Hospitals may use CAV systems in some operating and critical care type areas with variable air flow used for pressurization, but classic VAV multizone systems in areas such as offices. CBECS buildings reporting VAV are significantly less common in pre-1980 construction (67\% versus $95 \%$ in post-1980 hospitals).

Equipment sizing for all reference building models is determined from design day runs by EnergyPlus for each location with a sizing factor of 1.2. Nominal coefficient of performance (COP), energy efficiency ratio (EER), seasonal energy efficiency ratio (SEER), and boiler and furnace efficiencies are taken from the appropriate energy standard based on equipment type and size. Performance curves and HVAC system models are used to model how performance might vary when operating away from the nominal operation point using the models available in EnergyPlus. Economizer operation is determined from the cooling system size and climate zone following 90.1-2004 requirements. Exception (e) to Section 6.5.1 in 90.1-2004 for systems serving residential spaces eliminates the requirement for economizers for systems smaller than 27 tons and 56 tons, depending on climate zone. Moreover, economizers are not used in any healthcare critical systems that are required to operate within specified humidity constraints.

The equipment efficiencies are determined from 90.1-2004 for the new construction reference building models, 90.1-1989 for the post-1980 reference building models, and from an analysis of historical equipment efficiencies and equipment lifetimes for the pre-1980 reference building models (Winiarski and Halverson 2008). The equipment efficiencies for pre-1980 reference building models for cooling equipment are shown in Table 31, for space heating equipment in Table 32, and for water heating equipment in Table 33 through Table 35. 
Table 31 Estimated Unitary Cooling Equipment Efficiencies for Pre-1980 Construction

\begin{tabular}{|c|c|c|c|c|c|c|}
\hline Equipment Category & $\begin{array}{l}\text { Capacity } \\
\text { (Btu/h) }\end{array}$ & Heating Section & Equipment Subcategory & \begin{tabular}{|c|}
$\begin{array}{c}\text { Efficiency } \\
\text { Metric }\end{array}$ \\
\end{tabular} & $\begin{array}{c}\text { Average } \\
\text { Efficiency }\end{array}$ & $\begin{array}{c}\text { Life } \\
\text { (years) }\end{array}$ \\
\hline \multirow{10}{*}{ Air conditioners, air cooled } & \multirow{2}{*}{$0-65,000$} & Any & Single package & SEER & 11.06 & 15 \\
\hline & & Any & Split & SEER & 11.09 & 15 \\
\hline & \multirow{2}{*}{$\begin{array}{l}65,000- \\
135,000\end{array}$} & Electric or none & Split and single package & EER & 9.63 & 15 \\
\hline & & Other & Split and single package & EER & 9.63 & 15 \\
\hline & \multirow{2}{*}{$\begin{array}{c}135,000- \\
240,000\end{array}$} & Electric or none & Split and single package & EER & 9.28 & 15 \\
\hline & & Other & Split and single package & EER & 9.28 & 15 \\
\hline & \multirow{2}{*}{$\begin{array}{c}240,000- \\
760,000\end{array}$} & Electric or none & Split and single package & EER & 8.92 & 15 \\
\hline & & Other & Split and single package & EER & 8.92 & 15 \\
\hline & \multirow{2}{*}{$>760,000$} & Electric or none & Split and single package & EER & 8.63 & 15 \\
\hline & & Other & Split and single package & EER & 8.63 & 15 \\
\hline \multirow{8}{*}{ Air conditioners, water or evaporatively cooled } & \multirow{2}{*}{$0-65,000$} & Any & Split and single package & EER & 10.50 & 19 \\
\hline & & Any & Split and single package & EER & 10.50 & 19 \\
\hline & \multirow{2}{*}{$\begin{array}{l}65,000- \\
135,000\end{array}$} & Electric or none & Split and single package & EER & 10.75 & 19 \\
\hline & & Other & Split and single package & EER & 10.58 & 19 \\
\hline & \multirow{2}{*}{$\begin{array}{c}135,000- \\
240,000\end{array}$} & Electric or none & Split and single package & EER & 10.04 & 19 \\
\hline & & Other & Split and single package & EER & 9.87 & 19 \\
\hline & \multirow{2}{*}{$>240,000$} & Electric or none & Split and single package & EER & 10.04 & 19 \\
\hline & & Other & Split and single package & EER & 9.87 & 19 \\
\hline \multirow{8}{*}{ Heat pumps, air cooled } & \multirow{2}{*}{$0-65,000$} & Any & Single package & SEER & 11.33 & 15 \\
\hline & & Any & Split & SEER & 11.33 & 15 \\
\hline & \multirow{2}{*}{$\begin{array}{l}65,000- \\
135,000\end{array}$} & Electric or none & Split and single package & EER & 9.61 & 15 \\
\hline & & Other & Split and single package & EER & 9.61 & 15 \\
\hline & \multirow{2}{*}{$\begin{array}{c}135,000- \\
240,000\end{array}$} & Electric or none & Split and single package & EER & 9.27 & 15 \\
\hline & & Other & Split and single package & EER & 9.27 & 15 \\
\hline & \multirow{2}{*}{$>240,000$} & Electric or none & Split and single package & EER & 8.92 & 15 \\
\hline & & Other & Split and single package & EER & 8.92 & 15 \\
\hline \multirow{4}{*}{ Heat pumps, water source } & $0-17,000$ & All & All & EER & 10.09 & 19 \\
\hline & $17,000-65,000$ & All & All & EER & 10.46 & 19 \\
\hline & $\begin{array}{l}65,000- \\
135,000\end{array}$ & All & All & EER & 10.99 & 19 \\
\hline & $135,000-$ & All & All & EER & 10.99 & 19 \\
\hline
\end{tabular}




\begin{tabular}{|c|c|c|c|c|c|c|}
\hline Equipment Category & $\begin{array}{c}\text { Capacity } \\
\text { (Btu/h) }\end{array}$ & Heating Section & Equipment Subcategory & $\begin{array}{c}\text { Efficiency } \\
\text { Metric }\end{array}$ & $\begin{array}{l}\text { Average } \\
\text { Efficiency }\end{array}$ & $\begin{array}{c}\text { Life } \\
\text { (years) }\end{array}$ \\
\hline & 240,000 & & & & & \\
\hline Heat pumps, ground water source & $0-135,000$ & All & All & EER & 14.53 & 19 \\
\hline Heat pumps, ground source & $0-135,000$ & All & All & EER & 11.89 & 19 \\
\hline \multirow{8}{*}{ Heat pumps, air cooled } & \multirow{2}{*}{$0-65,000$} & Any & Single package & HSPF & 6.93 & 19 \\
\hline & & Any & Split & HSPF & 7.04 & 19 \\
\hline & \multirow{2}{*}{$\begin{array}{l}65,000- \\
135,000\end{array}$} & Electric or none & Split and single package & COP47 & 3.03 & 19 \\
\hline & & Other & Split and single package & COP47 & 3.03 & 19 \\
\hline & \multirow{2}{*}{$\begin{array}{c}135,000- \\
240,000\end{array}$} & Electric or none & Split and single package & COP47 & 2.94 & 19 \\
\hline & & Other & Split and single package & COP47 & 2.94 & 19 \\
\hline & \multirow{2}{*}{$>240,000$} & Electric or none & Split and single package & COP47 & 2.94 & 19 \\
\hline & & Other & Split and single package & COP47 & 2.94 & 19 \\
\hline \multirow[b]{2}{*}{ Heat pumps, water source } & $0-17,000$ & All & All & COP68 & 3.88 & 19 \\
\hline & $\begin{array}{l}17,000- \\
135,000\end{array}$ & All & All & COP68 & 3.88 & 19 \\
\hline Heat pumps, ground water source & $0-135,000$ & All & All & COP50 & NA & 19 \\
\hline Heat pumps, ground source & $0-135,000$ & All & All & COP32 & NA & 19 \\
\hline
\end{tabular}

COP32 heating COP at $32^{\circ} \mathrm{F}$ ground source temperature

COP47 heating COP at $47^{\circ} \mathrm{F}$ outdoor air source temperature

COP50 heating COP at $50^{\circ} \mathrm{F}$ ground water source temperature

COP68 heating COP at $68^{\circ} \mathrm{F}$ water source temperature

HSPF heating seasonal performance factor

NA

analysis incomplete 
Table 32 Estimated Water Chilling Equipment Efficiencies for Pre-1980 Construction

\begin{tabular}{|c|c|c|c|c|c|}
\hline Equipment Category & $\begin{array}{c}\text { Capacity } \\
\text { (tons) }\end{array}$ & $\begin{array}{l}\text { Equipment } \\
\text { Subcategory }\end{array}$ & $\begin{array}{l}\text { Efficiency } \\
\text { Metric }\end{array}$ & $\begin{array}{c}\text { Average } \\
\text { Efficiency }\end{array}$ & $\begin{array}{c}\text { Life } \\
\text { (years) }\end{array}$ \\
\hline \multirow{3}{*}{ Chiller, air cooled, electrically operated } & $<150$ & All & COP & 2.70 & 23 \\
\hline & $150-300$ & All & COP & 2.64 & 23 \\
\hline & $>300$ & All & COP & 2.64 & 23 \\
\hline \multirow{3}{*}{ Chiller, water cooled, electrically operated } & $<150$ & Reciprocating & COP & 3.98 & 23 \\
\hline & $150-300$ & Reciprocating & $\mathrm{COP}$ & 3.98 & 23 \\
\hline & $>300$ & Reciprocating & COP & 3.98 & 23 \\
\hline \multirow{3}{*}{ Chiller, water cooled, electrically operated } & $<150$ & Screw/scroll & COP & 4.13 & 23 \\
\hline & $150-300$ & Screw/scroll & $\mathrm{COP}$ & 4.50 & 23 \\
\hline & $>300$ & Screw/scroll & COP & 5.11 & 23 \\
\hline \multirow{3}{*}{ Chiller, water cooled, electrically operated } & $<150$ & Centrifugal & COP & 4.53 & 23 \\
\hline & $150-300$ & Centrifugal & COP & 4.93 & 23 \\
\hline & $>300$ & Centrifugal & $\mathrm{COP}$ & 5.54 & 23 \\
\hline Chiller, air cooled, absorption, single effect & All & - & COP & 0.55 & 23 \\
\hline Chiller, water cooled absorption, single effect & All & - & COP & 0.69 & 23 \\
\hline Chiller, double effect, direct fired & All & - & $\mathrm{COP}$ & 0.98 & 23 \\
\hline Chiller, double effect, indirect fired & All & - & COP & 0.98 & 23 \\
\hline
\end{tabular}

Table 33 Estimated Packaged Terminal Cooling Equipment Efficiencies for Pre-1980 Construction

\begin{tabular}{|l|c|c|c|c|}
\hline \multicolumn{1}{|c|}{ Equipment Category } & $\begin{array}{c}\text { Capacity } \\
\text { (Btu/h) }\end{array}$ & $\begin{array}{c}\text { Efficiency } \\
\text { Metric }\end{array}$ & $\begin{array}{c}\text { Average } \\
\text { Efficiency }\end{array}$ & $\begin{array}{c}\text { Life } \\
\text { (years) }\end{array}$ \\
\hline \hline \multirow{2}{*}{ PTAC } & 9,000 & EER & 9.79 & 10 \\
\cline { 2 - 5 } & 12,000 & EER & 9.22 & 10 \\
\hline \multirow{2}{*}{ PTHP } & 9,000 & EER & 9.67 & 10 \\
\cline { 2 - 5 } & 12,000 & EER & 9.09 & 10 \\
\hline \multirow{2}{*}{ PTHP-heating } & 9,000 & COP47 & 2.86 & 10 \\
\cline { 2 - 5 } & 12,000 & COP47 & 2.78 & 10 \\
\hline \multirow{2}{*}{ PTAC < $42 \times 16$ in. } & 9,000 & EER & 8.82 & 10 \\
\cline { 2 - 5 } & 12,000 & EER & 8.24 & 10 \\
\hline \multirow{2}{*}{ PTHP < $42 \times 16$ in. } & 9,000 & EER & 8.76 & 10 \\
\cline { 2 - 5 } & 12,000 & EER & 8.18 & 10 \\
\hline \multirow{2}{*}{ PTHP heating < 42 $\times 16$ in. } & 9,000 & COP47 & 2.69 & 10 \\
\cline { 2 - 5 } & 12,000 & COP47 & 2.60 & 10 \\
\hline
\end{tabular}

COP47 heating COP at $47^{\circ} \mathrm{F}$ outdoor air source temperature

HSPF heating seasonal performance factor

NA analysis incomplete

PTAC packaged terminal air-conditioning

PTHP packaged terminal heat pump 
Table 34 Estimated Space Heating Equipment Efficiencies for Pre-1980 Construction

\begin{tabular}{|l|c|c|c|c|}
\hline \multicolumn{1}{|c|}{ Equipment Category } & Capacity & $\begin{array}{c}\text { Efficiency } \\
\text { Metric }\end{array}$ & $\begin{array}{c}\text { Average } \\
\text { Efficiency }\end{array}$ & $\begin{array}{c}\text { Life } \\
\text { (years) }\end{array}$ \\
\hline \hline \multirow{2}{*}{ Furnace } & $<225 \mathrm{kBtu} / \mathrm{h}$ & $\mathrm{E}_{\mathrm{c}}$ & 0.80 & 15 \\
\cline { 2 - 5 } & $\geq 225 \mathrm{kBtu} / \mathrm{h}$ & $\mathrm{E}_{\mathrm{c}}$ & 0.80 & 15 \\
\hline Duct furnace & All & $\mathrm{E}_{\mathrm{c}}$ & 0.80 & 15 \\
\hline Unit heater, gas & All & $\mathrm{E}_{\mathrm{c}}$ & 0.80 & 15 \\
\hline \multirow{3}{*}{ Boiler, gas, hot water } & $<300 \mathrm{kBtu} / \mathrm{h}$ & $\mathrm{E}_{\mathrm{t}}$ & 0.73 & 30 \\
\cline { 2 - 5 } & $300-2500 \mathrm{kBtu} / \mathrm{h}$ & $\mathrm{E}_{\mathrm{t}}$ & 0.74 & 30 \\
\cline { 2 - 5 } & $>2500 \mathrm{kBtu} / \mathrm{h}$ & $\mathrm{E}_{\mathrm{t}}$ & 0.76 & 30 \\
\hline
\end{tabular}

$E_{c} \quad$ combustion efficiency (1-flue losses)

$E_{t} \quad$ thermal efficiency

Table 35 Estimated Water Heating Equipment Efficiencies for Pre-1980 Construction

\begin{tabular}{|c|c|c|c|c|}
\hline Equipment Category & Capacity & $\begin{array}{l}\text { Efficiency } \\
\text { Metric }\end{array}$ & $\begin{array}{c}\text { Average } \\
\text { Efficiency }\end{array}$ & $\begin{array}{c}\begin{array}{c}\text { Life } \\
\text { (years) }\end{array} \\
\end{array}$ \\
\hline \multirow{2}{*}{ Electric storage water heater } & $<12 \mathrm{~kW}$ & EF & NA & 7 \\
\hline & $>12 \mathrm{~kW}$ & SL & NA & 7 \\
\hline \multirow{5}{*}{ Gas storage water heater } & $<75,000 \mathrm{Btu} / \mathrm{h}$ & EF & NA & 7 \\
\hline & \multirow{2}{*}{$>75,000,<155,000 \mathrm{Btu} / \mathrm{h}$} & $E_{t}$ & 0.80 & 7 \\
\hline & & SL & NA & 7 \\
\hline & \multirow{2}{*}{$>155,000 \mathrm{Btu} / \mathrm{h}$} & $E_{t}$ & 0.80 & 7 \\
\hline & & SL & NA & 7 \\
\hline \multirow{4}{*}{ Gas instantaneous water heater } & 50-200 kBtu/h & EF & NA & 15 \\
\hline & $>200 \mathrm{Kbtu} / \mathrm{h},<10 \mathrm{gal}$ & $E_{t}$ & 0.80 & 15 \\
\hline & \multirow{2}{*}{$>200 \mathrm{Kbtu} / \mathrm{h},>10 \mathrm{gal}$} & $E_{t}$ & 0.79 & 15 \\
\hline & & SL & NA & 15 \\
\hline \multirow{3}{*}{ Hot water supply boiler, gas } & $>300,<12,500 \mathrm{kBtu} / \mathrm{h},<10 \mathrm{gal}$ & $E_{t}$ & 0.79 & 25 \\
\hline & \multirow{2}{*}{$>300,<12,500 \mathrm{kBtu} / \mathrm{h},>10 \mathrm{gal}$} & $E_{t}$ & 0.78 & 25 \\
\hline & & SL & NA & 25 \\
\hline \multicolumn{5}{|c|}{$E_{c} \quad$ combustion efficiency (1-flue losses) } \\
\hline \multicolumn{5}{|l|}{ EF energy factor } \\
\hline \multicolumn{5}{|l|}{$E_{t} \quad$ thermal efficiency } \\
\hline \multicolumn{5}{|l|}{ SL standby loss (rating to be $d e$} \\
\hline
\end{tabular}

\subsubsection{Fan Efficiencies}

EnergyPlus requires the fan pressure rise, total efficiency, motor efficiency, and fraction of the motor in the air stream. For all cases, we assumed that the fraction of the motor in the air stream is 1.0. The other inputs are summarized in Table 34 for each fan type. Electrical motor efficiencies must comply with the requirements of the Energy Policy Act of 1992, which are 
listed in Table 10.8 of Standard 90.1-2004. To simplify the standard implementation, we assume all motors are open, four-pole, 1800-rpm. Table 36 lists nominal motor efficiency. The actual motor efficiency is determined for each case automatically by applying the standard after a sizing run is completed. Fan system flow rates are determined by EnergyPlus during system sizing.

Table 36 Fan System Inputs

\begin{tabular}{|c|c|c|c|c|c|}
\hline \multirow[b]{2}{*}{ System Type } & \multicolumn{2}{|c|}{ Pressure Rise } & \multirow{2}{*}{$\begin{array}{c}\text { Fan } \\
\text { Mechanical } \\
\text { Efficiency }\end{array}$} & \multirow{2}{*}{$\begin{array}{c}\text { Total Fan } \\
\text { Efficiency** }\end{array}$} & \multirow{2}{*}{$\begin{array}{l}\text { Nominal } \\
\text { Motor } \\
\text { Efficiency }\end{array}$} \\
\hline & in. w.c. & $\mathrm{Pa}$ & & & \\
\hline Exhaust fans* & 0.5 & 125 & (a) & 0.338 & (a) \\
\hline Unit heaters & 0.2 & 50 & 0.650 & 0.536 & 0.825 \\
\hline PTAC and FCU fans & 1.33 & 330 & 0.650 & 0.520 & 0.800 \\
\hline CAV $<7,487 \mathrm{cfm}$ & 2.5 & 622 & 0.650 & (b) & (c) \\
\hline $\mathrm{CAV} \geq 7,487 \mathrm{cfm},<20,000 \mathrm{cfm}$ & 4.46 & 1110 & 0.650 & (b) & (c) \\
\hline $\mathrm{CAV} \geq 20,000 \mathrm{cfm}$ & 4.09 & 1,018 & 0.650 & (b) & (c) \\
\hline VAV $<4,648 \mathrm{cfm}$ & 4.0 & 995 & 0.650 & (b) & (c) \\
\hline VAV $\geq 4,648 \mathrm{cfm},<20,000 \mathrm{cfm}$ & 6.32 & 1572 & 0.650 & (b) & (c) \\
\hline$V A V \geq 20,000 \mathrm{cfm}$ & 5.58 & 1388 & 0.650 & (b) & (c) \\
\hline
\end{tabular}

* Exhaust fans are modeled as exterior loads, so only the total efficiency is important.

** Total fan efficiency is the product of fan mechanical efficiency and nominal motor efficiency. For example, a nominal motor efficiency of $85 \%$ and a fan mechanical efficiency of $65 \%$ produce a total fan efficiency of $55.25 \%$.

Motor nameplate horsepower is assumed to be the first available motor size in ASHRAE 90.1-2004, Table 10.8 greater than $110 \%$ of the motor brake horsepower, as calculated by the pressure rise and fan mechanical efficiency shown in Table 38 and the fan airflow as sized in the EnergyPlus simulation.

Exhaust fans typically have lower total efficiencies than space-conditioning fans. We assume a pressure rise of 0.5 in. w.c. (125 Pa) and a total fan efficiency of 0.338 for reference building exhaust fans. Because the heat from exhaust fans is released to the outdoors, only their total efficiencies are important. For space-conditioning fans, nominal motor efficiency would be important if one were to test the effect of lessening the fraction of motor heat in the air stream. Although the reference building models use 1.0 for that fraction, nominal motor efficiencies were chosen from 90.1-2004, Table 10.8, for consistency with typical practice. The two remaining model inputs that determine the power draw of the fan and the amount of fan heat gained by the space are fan mechanical efficiency and pressure rise. For simplicity, the reference building models use one fan mechanical efficiency value, 0.65 , and vary the pressure rise to achieve the desired fan power.

For unit heaters, we assumed a pressure rise of 0.2 in. w.c. (50 Pa) and a fan motor efficiency of 0.825. For all PTACs and FCUs, we assumed a pressure rise of 1.33 in. w.c. (330 Pa) and a motor efficiency of 0.80 . This corresponds to a power per flow rate of $0.3 \mathrm{~W} / \mathrm{cfm}\left(636 \mathrm{~W} / \mathrm{m}^{3} / \mathrm{s}\right)$, corresponding with Standard 90.1-2007, Appendix G methodology. The pressure rise values of constant- and variable-volume air handlers are chosen to most closely approximate the fan power limitation determined in Standard 90.1-2004, Table 6.5.3.1. Below $5 \mathrm{hp}(3.7 \mathrm{~kW})$, which corresponds to $7,487 \mathrm{cfm}$ at $2.5 \mathrm{in}$. w.c. $\left(3.53 \mathrm{~m}^{3} / \mathrm{S}\right.$ at $\left.620 \mathrm{~Pa}\right)$ for constant-volume fans and $4,648 \mathrm{cfm}$ at $4.0 \mathrm{in}$. w.c. $\left(2.19 \mathrm{~m}^{3} / \mathrm{s}\right.$ at $\left.1000 \mathrm{~Pa}\right)$ for variable-volume, fans are not regulated by these limitations. Representative pressure rises are assumed in these cases (see Table 34). 
Additionally, 2.0 in. w.c. (498 Pa) is added to fans in the hospital and outpatient healthcare models to account for extra filtration.

\subsubsection{Cooling Equipment Efficiencies}

EnergyPlus requires the efficiency of cooling equipment to be input as the COP for the compressors and condenser fans. We used an automated routine that looks up the equipment efficiencies from Standard 90.1-2004 based on equipment type and size determined from an EnergyPlus sizing run. These efficiencies reported in Standard 90.1-2004 include the energy of the supply air fan. The efficiencies of small residential size equipment are reported as SEER, which must first be converted to EER. We use an approximation developed by Nexant for the Public Utilities Commission of Texas (2003), based on data from Carrier Corporation for conversion from SEER to EER.

$$
\mathrm{EER}=\mathrm{SEER} \cdot 0.697+2.0394
$$

The COP of a unit is simply the cooling power output $\left(\mathrm{Q}_{\text {cool }}\right)$ divided by the electrical power input $\left(\mathrm{P}_{\text {elec }}\right)$ in consistent units:

$$
\mathrm{COP}=\mathrm{Q}_{\text {cool }} / \mathrm{P}_{\text {elec }}
$$

The EER is the cooling power output in Btu divided by the electrical power input in $\mathrm{W}$ and requires a simple unit conversion to arrive at the COP:

$$
\mathrm{COP}=\mathrm{EER} / 3.412
$$

However, energy modeling software requires the $\mathrm{COP}_{\text {comp }}$ of the compressor as an input, not the overall COP of the cooling equipment. The EER values specified in ASHRAE 90.1-2004 refer to overall efficiencies, so an extra calculation must be done to obtain $\mathrm{COP}_{\text {comp }}$. The $\mathrm{COP}_{\text {comp }}$ value is calculated by subtracting the power of the supply fan rated at ARI standard conditions from the total power input to the unit. To approximate subtraction at ARI standard conditions,

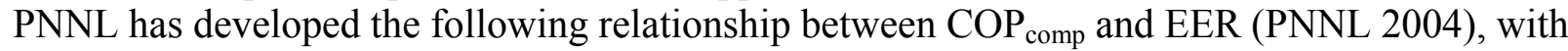
$\mathrm{R}=0.12$ as a reasonable value to represent a broad class of products. $\mathrm{R}$ represents the ratio of supply fan power to total equipment power at the rating condition.

$$
C O P_{\text {comp }}=\frac{(E E R / 3.413)+R}{1-R}
$$

\subsubsection{Refrigeration}

Walk-in coolers and freezers are included in all commercial kitchens, based on data from Westphalen et al. (1996). The kitchen refrigeration systems are listed in Table 37 and Table 38. The refrigeration systems in the supermarket reference building are based on Westphalen et al. (2006) Faramarzi and Walker (2004), Deru and MacDonald (2007), and MacDonald and Deru (2007). The supermarket refrigeration systems are listed in Table 39 through Table 41. 
Table 37 Walk-In Refrigeration System Descriptions (IP Units)

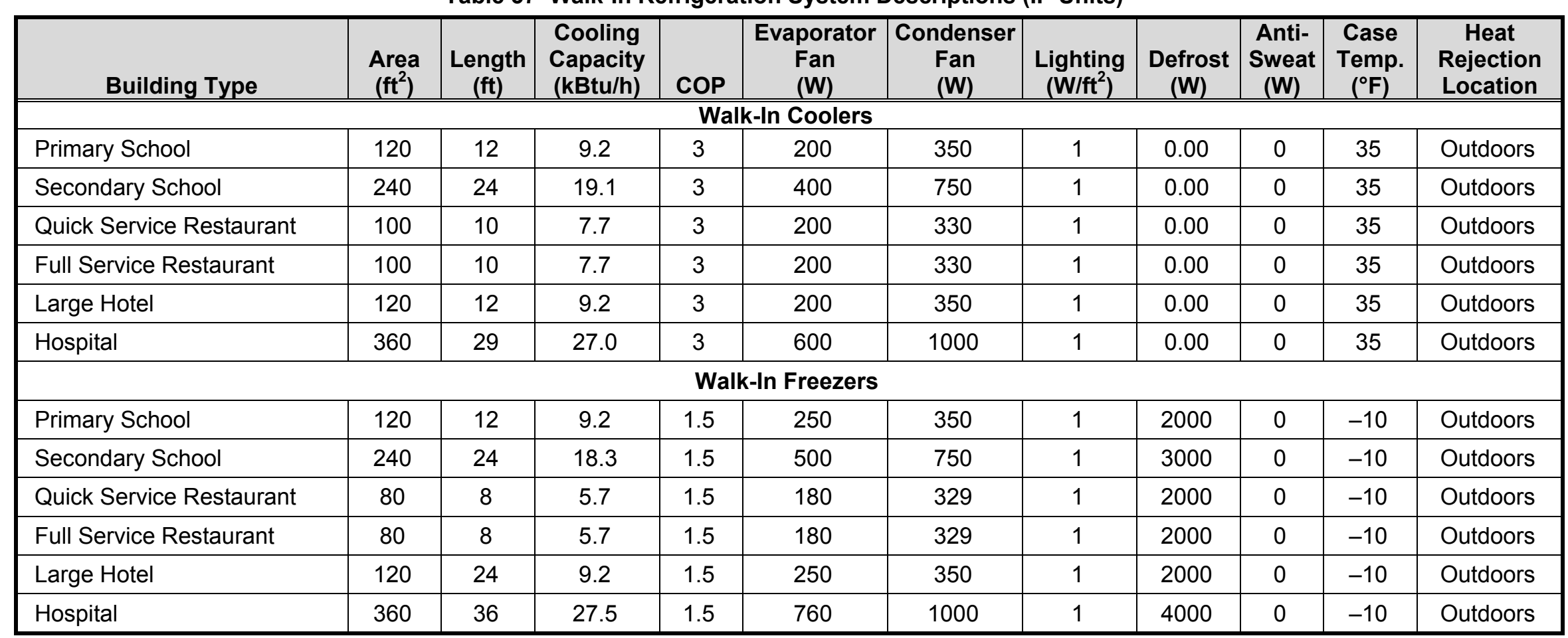


Table 38 Walk-In Refrigeration System Descriptions (SI Units)

\begin{tabular}{|c|c|c|c|c|c|c|c|c|c|c|c|}
\hline Building Type & $\begin{array}{c}\text { Area } \\
\left(m^{2}\right)\end{array}$ & $\begin{array}{c}\text { Length } \\
(\mathrm{m})\end{array}$ & $\begin{array}{c}\text { Cooling } \\
\text { Capacity } \\
\text { (kW) }\end{array}$ & COP & $\begin{array}{l}\text { Evaporator } \\
\text { Fan } \\
\text { (W) }\end{array}$ & $\begin{array}{c}\text { Condenser } \\
\text { Fan } \\
\text { (W) }\end{array}$ & $\begin{array}{l}\text { Lighting } \\
\left(\mathrm{W} / \mathrm{m}^{2}\right)\end{array}$ & $\begin{array}{c}\text { Defros } \\
t(W)\end{array}$ & $\begin{array}{c}\text { Anti- } \\
\text { Sweat } \\
\text { (W) }\end{array}$ & $\begin{array}{c}\text { Case } \\
\text { Temp. } \\
\left({ }^{\circ} \mathrm{C}\right) \\
\end{array}$ & $\begin{array}{c}\text { Heat } \\
\text { Rejection } \\
\text { Location }\end{array}$ \\
\hline \multicolumn{12}{|c|}{ Walk-In Coolers } \\
\hline Secondary School & 22.3 & 7.3 & 5.6 & 3 & 400 & 750 & 10.8 & 0.00 & 0 & 1.7 & Outdoors \\
\hline Quick Service Restaurant & 9.3 & 3.0 & 2.2 & 3 & 200 & 330 & 10.8 & 0.00 & 0 & 1.7 & Outdoors \\
\hline Full Service Restaurant & 9.3 & 3.0 & 2.2 & 3 & 200 & 330 & 10.8 & 0.00 & 0 & 1.7 & Outdoors \\
\hline Hospital & 33.5 & 8.9 & 7.9 & 3 & 600 & 1000 & 10.8 & 0.00 & 0 & 1.7 & Outdoors \\
\hline \multicolumn{12}{|c|}{ Walk-In Freezers } \\
\hline Primary School & 11.2 & 3.7 & 2.7 & 1.5 & 250 & 350 & 10.8 & 2000 & 0 & -23.3 & Outdoors \\
\hline Secondary School & 22.3 & 7.3 & 5.4 & 1.5 & 500 & 750 & 10.8 & 3000 & 0 & -23.3 & Outdoors \\
\hline Quick Service Restaurant & 7.4 & 2.4 & 1.7 & 1.5 & 180 & 329 & 10.8 & 2000 & 0 & -23.3 & Outdoors \\
\hline
\end{tabular}


Table 39 Supermarket Refrigeration System Descriptions (IP Units)

\begin{tabular}{|c|c|c|c|c|c|c|c|c|c|c|}
\hline Building Type & $\begin{array}{l}\text { Area } \\
\left(\mathrm{ft}^{2}\right)\end{array}$ & $\begin{array}{c}\text { Length } \\
\text { (ft) }\end{array}$ & $\begin{array}{l}\text { Cooling } \\
\text { Capacity } \\
\text { (Btu/h/ft) } \\
\end{array}$ & $\begin{array}{c}\text { Evaporator } \\
\text { Fan } \\
\text { (W/ft) } \\
\end{array}$ & $\begin{array}{l}\text { Lighting } \\
\text { (W/ft) }\end{array}$ & $\begin{array}{c}\text { Defrost } \\
\text { (W/ft) }\end{array}$ & $\begin{array}{l}\text { Anti- } \\
\text { Sweat } \\
\text { (W/ft) }\end{array}$ & $\begin{array}{l}\text { SST } \\
\left({ }^{\circ} \mathrm{F}\right)\end{array}$ & $\begin{array}{c}\text { Case } \\
\text { Temp. } \\
\left({ }^{\circ} \mathrm{F}\right) \\
\end{array}$ & $\begin{array}{c}\text { Compresso } \\
\text { r Rack }\end{array}$ \\
\hline \multicolumn{11}{|c|}{ Medium Temperature } \\
\hline Other multideck cases & & 260 & 1500 & 12.5 & 18.3 & 0 & 0 & 15 & 36 & A \\
\hline Meat walk-in & 400 & 50 & 400 & 50 & 400 & 50 & 0 & 15 & 36 & $\mathrm{C}$ \\
\hline Reach-in cases & & 268 & 560 & 20 & 33 & 400 & 71 & -25 & 5 & B \\
\hline Single-level open cases & & 128 & 550 & 10 & 0 & 420 & 24 & -25 & 10 & B \\
\hline Walk-in freezer & 1000 & 125 & 640 & 32 & 8 & 232 & 0 & -25 & -10 & $\mathrm{D}$ \\
\hline
\end{tabular}

Table 40 Supermarket Refrigeration System Descriptions (SI Units)

\begin{tabular}{|c|c|c|c|c|c|c|c|c|c|c|}
\hline Building Type & $\begin{array}{l}\text { Area } \\
\left(\mathrm{m}^{2}\right)\end{array}$ & $\begin{array}{l}\text { Length } \\
\text { (m) }\end{array}$ & $\begin{array}{c}\text { Cooling } \\
\text { Capacity } \\
\text { (W/m) }\end{array}$ & $\begin{array}{c}\text { Evaporator } \\
\text { Fan } \\
(\mathrm{W} / \mathrm{m}) \\
\end{array}$ & $\begin{array}{c}\text { Lighting } \\
(\mathrm{W} / \mathrm{m})\end{array}$ & $\begin{array}{c}\text { Defrost } \\
(W / m)\end{array}$ & $\begin{array}{l}\text { Anti- } \\
\text { Sweat } \\
\text { (W/m) }\end{array}$ & $\begin{array}{l}\text { SST } \\
\left({ }^{\circ} \mathrm{C}\right)\end{array}$ & $\begin{array}{c}\text { Case } \\
\text { Temp. } \\
\left({ }^{\circ} \mathrm{C}\right)\end{array}$ & $\begin{array}{c}\text { Compresso } \\
\text { r Rack }\end{array}$ \\
\hline \multicolumn{11}{|c|}{ Medium Temperature } \\
\hline Other multideck cases & & 79.2 & 1442 & 41 & 60 & 0 & 0 & -9.4 & 2.2 & A \\
\hline Meat walk-in & 37.2 & 15.2 & 385 & 164 & 1312 & 164 & 0 & -9.4 & 2.2 & $\mathrm{C}$ \\
\hline Reach-in cases & & 81.7 & 538 & 66 & 108 & 1312 & 233 & -31.7 & -15.0 & $B$ \\
\hline Single-level open cases & & 39.0 & 529 & 33 & 0 & 1378 & 79 & -31.7 & -12.2 & $B$ \\
\hline Walk-in freezer & 92.9 & 38.0 & 615 & 105 & 26 & 761 & 0 & -31.7 & -23.3 & $\mathrm{D}$ \\
\hline
\end{tabular}


Table 41 Supermarket Compressor Descriptions

\begin{tabular}{|c|l|c|c|c|c|}
\hline $\begin{array}{c}\text { Compressor } \\
\text { Rack }\end{array}$ & \multicolumn{1}{|c|}{ System Type } & COP & $\begin{array}{c}\text { Condenser } \\
\text { Fan } \\
\text { (W) }\end{array}$ & $\begin{array}{c}\text { Condenser } \\
\text { Type }\end{array}$ & $\begin{array}{c}\text { Heat } \\
\text { Rejection } \\
\text { Location }\end{array}$ \\
\hline A & Medium temperature & 2.5 & 4500 & Air cooled & Outdoors \\
\hline B & Low temperature & 1.3 & 4500 & Air cooled & Outdoors \\
\hline C & Medium temperature & 2.5 & 4500 & Air cooled & Outdoors \\
\hline D & Low temperature & 1.3 & 4500 & Air cooled & Outdoors \\
\hline
\end{tabular}




\subsection{Weighting Factors}

The weighting factors characterize the number of buildings that are similar to each reference building type in each location. The weighting factors allow information from the individual reference buildings to be expanded to represent all buildings of this type in a region or combined to represent the whole country. Data for developing the weighting factors for U.S. commercial buildings are limited; CBECS is the best publicly available source for existing buildings. The database provides a wealth of information about the operational characteristics of buildings, but the number of buildings is limited and some of the data are masked to protect building identity. These limitations make it difficult to develop reliable statistical analysis across all building types and locations. The economic census from the U.S. Department of Commerce (U.S. Census Bureau 2005) contains economic data for commercial building activity by building type. However, it is difficult to determine building area from these data and to divide the building types into the subtypes such as small, medium, and large office buildings.

The McGraw-Hill Construction Projects Starts Database draws from permit data for new commercial building starts in the United States and represents more than $90 \%$ of new commercial buildings. Data are collected in real time and the collection process is independently monitored to ensure most U.S. commercial construction is covered. The strength of this database lies in the number of samples, the frequency of data collection, the detailed data about location of the projects down to the local community level, and the fact that high-rise residential buildings are included (contrary to CBECS). A weakness is the lack of characteristic data.

Jarnagin and Bandyopadhyay (2010) analyzed the McGraw-Hill database from 2003 to 2007 to develop weighting factors for the new construction reference buildings. Total building area for each model type and climate zone was determined over the five-year period. These numbers were divided by five to find the annual average then divided by the area of the reference buildings to find the weighting factors shown in Table 42.

Weighting factors for the pre-1980 and post-1980 reference buildings have not been developed, because adequate data about the existing building stock have not been identified. Weighting factors may be developed when data become available. 
Table 42 New Construction Reference Building Weighting Factors

\begin{tabular}{|c|c|c|c|c|c|c|c|c|c|c|c|c|c|c|c|}
\hline \multirow{2}{*}{ Building Type } & \multicolumn{15}{|c|}{ Climate Zone } \\
\hline & $1 \mathrm{~A}$ & $2 A$ & 2B & 3A & 3B & $3 C$ & 4A & 4B & $4 C$ & $5 A$ & $5 B$ & $6 A$ & $6 B$ & 7 & 8 \\
\hline Small Office & 201.9 & 2559.5 & 695.7 & 2316.1 & 1142.2 & 187.0 & 2251.0 & 113.9 & 294.8 & 2213.0 & 774.1 & 580.2 & 72.7 & 77.8 & 11.3 \\
\hline Medium Office & 31.9 & 200.5 & 72.0 & 188.9 & 176.4 & 33.5 & 293.5 & 9.0 & 48.3 & 261.4 & 84.4 & 73.6 & 8.6 & 8.1 & 1.7 \\
\hline Large Office & 2.7 & 8.6 & 1.6 & 11.8 & 7.6 & 3.1 & 30.0 & 0.0 & 4.1 & 11.7 & 3.2 & 3.5 & 0.0 & 0.3 & 0.0 \\
\hline Primary School & 11.4 & 167.0 & 29.4 & 169.0 & 79.8 & 8.5 & 160.1 & 5.4 & 16.8 & 164.6 & 40.0 & 30.1 & 6.7 & 4.2 & 0.6 \\
\hline Secondary School & 10.1 & 95.5 & 14.4 & 118.8 & 51.4 & 6.9 & 126.3 & 4.0 & 15.2 & 143.2 & 27.5 & 26.1 & 5.4 & 4.7 & 0.8 \\
\hline Stand-Alone Retail & 118.9 & 1176.9 & 268.5 & 1264.6 & 662.8 & 101.3 & 1349.3 & 63.1 & 227.1 & 1818.0 & 420.0 & 502.7 & 48.3 & 57.5 & 7.2 \\
\hline Strip Mall & 80.8 & 582.6 & 149.1 & 600.2 & 367.9 & 60.8 & 592.9 & 13.2 & 62.8 & 601.5 & 118.4 & 89.8 & 9.4 & 4.0 & 0.8 \\
\hline Supermarket & 3.2 & 48.5 & 13.9 & 58.2 & 36.0 & 4.9 & 93.8 & 1.6 & 10.8 & 113.4 & 15.6 & 24.7 & 2.8 & 3.0 & 0.5 \\
\hline $\begin{array}{l}\text { Quick Service } \\
\text { Restaurant }\end{array}$ & 41.3 & 484.9 & 107.4 & 538.8 & 334.3 & 36.6 & 471.0 & 28.2 & 75.7 & 680.1 & 135.8 & 134.3 & 16.4 & 18.9 & 1.2 \\
\hline $\begin{array}{l}\text { Full Service } \\
\text { Restaurant }\end{array}$ & 21.7 & 254.0 & 59.1 & 267.7 & 114.2 & 13.9 & 305.9 & 14.0 & 24.6 & 344.2 & 74.7 & 74.6 & 9.6 & 8.8 & 0.3 \\
\hline Small Hotel & 3.1 & 88.1 & 9.1 & 82.0 & 34.8 & 6.7 & 96.3 & 6.2 & 12.0 & 111.7 & 27.4 & 32.6 & 9.4 & 6.3 & 1.2 \\
\hline Large Hotel & 11.8 & 67.3 & 13.5 & 68.8 & 85.9 & 11.4 & 103.8 & 4.0 & 13.3 & 99.6 & 21.6 & 24.6 & 6.3 & 4.2 & 0.4 \\
\hline Hospital & 2.2 & 26.2 & 5.3 & 25.6 & 14.9 & 2.1 & 33.7 & 1.2 & 5.8 & 44.5 & 12.0 & 12.1 & 1.3 & 1.8 & 0.1 \\
\hline $\begin{array}{l}\text { Outpatient } \\
\text { Healthcare }\end{array}$ & 12.0 & 183.4 & 43.4 & 187.8 & 88.8 & 19.8 & 264.3 & 7.5 & 58.5 & 342.0 & 70.4 & 110.7 & 10.8 & 12.6 & 0.7 \\
\hline Warehouse & 88.8 & 658.6 & 147.6 & 754.2 & 584.3 & 39.1 & 621.8 & 17.2 & 110.7 & 910.1 & 175.0 & 118.4 & 12.5 & 11.0 & 0.6 \\
\hline Midrise Apartment & 100.8 & 428.9 & 36.6 & 323.6 & 338.1 & 102.2 & 664.3 & 8.6 & 145.5 & 439.9 & 124.9 & 122.9 & 22.1 & 12.7 & 0.0 \\
\hline
\end{tabular}




\subsection{Conculsions}

The reference building models represent important starting points for energy simulation exercises and form standard reference points for building energy analysis projects. The models are being used for research projects by DOE, national laboratories, and industry to perform research on advanced building systems, assess the impact of new policies, and advance building energy codes and standards. They continue to evolve and expand; new versions are available for public use. The models are available as EnergyPlus input files on the DOE Web site (http://commercialbuildings.energy.gov/reference buildings.html). Spreadsheet scorecards are also available for each building type to document the model parameters and annual energy performance by location. 


\subsection{References}

AIA. (2001). AIA Guidelines for Design and Construction of Hospital and Health Care Facilities: 2001 Edition. Washington, D.C.: American Institute of Architects.

ASHRAE. (1989). Energy Efficient Design of New Buildings Except Low-Rise Residential Buildings. ANSI/ASHRAE/IESNA Standard 90.1-1989. Atlanta, GA: American Society of Heating, Refrigerating and Air-Conditioning Engineers.

ASHRAE. (1999). Ventilation for Acceptable Indoor Air Quality. ANSI/ASHRAE Standard 62-1999. Atlanta, GA: American Society of Heating, Refrigerating and Air-Conditioning Engineers.

ASHRAE. (2001). Energy Standard for Buildings Except Low-Rise Residential Buildings. ANSI/ ASHRAE/IESNA Standard 90.1-2001. Atlanta, GA: American Society of Heating, Refrigerating and Air-Conditioning Engineers.

ASHRAE. (2004a). Energy Standard for Buildings Except Low-Rise Residential Buildings. ANSI/ ASHRAE/IESNA Standard 90.1-2004. Atlanta, GA: American Society of Heating, Refrigerating and Air-Conditioning Engineers.

ASHRAE. (2004b). Ventilation for Acceptable Indoor Air Quality. ANSI/ASHRAE Standard 62.1-2004. Atlanta, GA: American Society of Heating, Refrigerating and Air-Conditioning Engineers.

ASHRAE. (2004c). 90.1 User's Manual ANSI/ASHRAE/IESNA Standard 90.1-2004. Atlanta, GA: American Society of Heating, Refrigerating and Air-Conditioning Engineers.

ASHRAE. (2007). 2007 ASHRAE HVAC Applications Handbook. Atlanta, GA: American Society of Heating, Refrigerating and Air-Conditioning Engineers.

ASHRAE. (2009). Advanced Energy Design Guides. Atlanta, GA: American Society of Heating, Refrigerating and Air-Conditioning Engineers. Available at www.ashrae.org/ publications/page/1604. Last accessed October 2009.

Baldor Electric Company. (1998). Baldor Motors and Drives: AC Elevator Drives. Fort Smith, AR: Baldor Electric Company.

Beyer, R. (2009). "Specification Series: Elevators - First Things First." Atlanta, GA: Elevator Advisors, Inc. First appeared in Architectural Record, November 1992. McGraw-Hill, Inc. Available at www.elevatoradvisors.com/docs/BeyerSpecSeries.pdf. Last accessed October 2009.

Briggs, R.S.; Crawley, D.B.; Schliesing, J.S. (1987). Analysis and Categorization of the Office Building Stock, Topical Report. Des Plains, IL: Gas Technology Institute. GRI-87/0244.

Briggs, R.S.; Lucas, R.G.; Taylor, T. (2003). "Climate Classification for Building Energy Codes and Standards: Part 2 - Zone Definitions, Maps and Comparisons, Technical and Symposium Papers." ASHRAE Winter Meeting, Chicago, IL, January 2003. Atlanta, GA: American Society of Heating, Refrigerating and Air-Conditioning Engineers. Available at http://resourcecenter.pnl.gov/html/ ResourceCenter/1420.html. Last accessed October 2009. 
Brown, S.L. (2007). "Dedicated Outdoor Air System for Commercial Kitchen Ventilation." ASHRAE Journal 49(7), 24-35. Atlanta, GA: American Society of Heating, Refrigerating and Air-Conditioning Engineers.

CEC. (2004). Design Guide 2 Improving Commercial Kitchen Ventilation System Performance: Optimizing Makeup Air. Sacramento, CA: California Energy Commission.

DeChiara, J.; Crosbie, M.J. (2001). Time-Saver Standards for Building Types, $4^{\text {th }}$ ed. McGrawHill Professional.

Deru, M.; MacDonald, M. (2007). "Wal-Mart Experience: Part Two.” ASHRAE Journal 49(10):22-27. Golden, CO: National Renewable Energy Laboratory, NREL/JA-550-42503. Available at www.nrel.gov/docs/fy09osti/45742.pdf. Last accessed October 2009.

DOE. (2005). Map of DOE's Proposed Climate Zones. Available at www.energycodes.gov/ implement/pdfs/color_map_climate_zones_Mar03. Last accessed July 2010.

Doebber, I.; Bonnema, E.; Pless, S.; Torcellini, P. (2009). Technical Support Document: Development of the Advanced Energy Design Guide for Small Hospitals and Health Care Facilities - 30\% Energy Savings. Golden, CO: National Renewable Energy Laboratory, NREL/TP-550-46314. Available at www.nrel.gov/docs/fy10osti/46314.pdf. Last accessed October 2009.

EIA. (2002). 1999 Commercial Buildings Energy Consumption Survey. Washington, DC: EIA. Available at www.eia.doe.gov/emeu/cbecs/1999publicuse/99microdat.html. Last accessed October 2009.

EIA. (2005). 2003 Commercial Buildings Energy Consumption Survey. Washington, DC: Energy Information Administration. Available at www.eia.doe.gov/emeu/cbecs/ cbecs2003/introduction.html. Last accessed October 2009.

Faramarzi, R.T.; Walker, D.H. (2004). Investigation of Secondary Loop Supermarket Refrigeration Systems. 500-04-013. Sacramento, CA: California Energy Commission.

Fisher, D. (2003). "Predicting Energy Consumption." ASHRAE Journal 45(6), K8-K13. Atlanta, GA: American Society of Heating, Refrigerating and Air-Conditioning Engineers.

GGHC. (2007). Green Guide for Health Care: Best Practices for Creating High Performance Healing Environments, Version 2.2. www.gghc.org. Last accessed October 2009.

Gowri, K.; Halverson, M.A.; Richman, E.E. (2007). Analysis of Energy Saving Impacts of ASHRAE 90.1-2004 for the State of New York. Richland, WA: Pacific Northwest National Laboratory, PNNL-16770.

Griffith, B.; Long, N.; Torcellini, P.; Judkoff, R.: Crawley, D.; Ryan, J. (2007). Assessment of the Technical Potential for Achieving Net Zero-Energy Buildings in the Commercial Sector. Golden, CO: National Renewable Energy Laboratory. NREL/TP-550-41957. Available at www.nrel.gov/docs/fy08osti/41957.pdf. Last accessed February 2010.

Hendron, R. (2007). Building America Research Benchmark Definition, Updated December 20, 2007. Golden, CO: National Renewable Energy Laboratory, NREL/TP-550-42662. Available at www.nrel.gov/docs/fy08osti/42662.pdf. Last accessed October 2009. 
Huang, J.; Akbari, H.; Rainer, L.; Ritshard, R. (1991). 481 Prototypical Commercial Buildings for 20 Urban Market Areas. Berkeley, CA: Lawrence Berkeley National Laboratory.

Huang, J.; Franconi, E. (1999). Commercial Heating and Cooling Loads Component Analysis. Berkeley, CA: Lawrence Berkeley National Laboratory, LBL-37208.

Huang, J.; Roberson, J.A.; Sezgen, O. (2005). Analysis of 1999 CBECS Data by Commercial Building Type. Draft. Berkeley, CA: Lawrence Berkeley National Laboratory, LBNL-57457.

ICC. (2003). 2003 International Building Code. Country Club Hills, IL: International Code Council, Inc.

Jarnagin, R.E.; Liu, B.; Winiarski, D.W.; McBride, M.F.; Suharli, L.; Walden, D. (2006). Technical Support Document: The Development of the Advanced Energy Design Guide for Small Office Buildings. Richland, WA: Pacific Northwest National Laboratory, PNNL-16250.

Jarnagin, R.E.; Bandyopadhyay, G. (2010). Determination of Weighting Factors for the ASHRAE Commercial Building Prototypes for Standard 90.1-2010. Richland, WA: Pacific Northwest National Laboratory, PNNL-19116.

Jiang, W.; Jarnagin, R.E.; Gowri, K.; McBride, M.; Liu, B. (2008). Technical Support Document: The Development of the Advanced Energy Design Guide for Highway Lodging Buildings. Richland, WA: Pacific Northwest National Laboratory, PNNL-17875.

Liu, B.; Jarnagin, R.E.; Winiarski, D.W.; Jiang, W.; McBride, M.; Crall, G.C. (2006). Technical Support Document: The Development of the Advanced Energy Design Guide for Small Retail Buildings. Richland, WA: Pacific Northwest National Laboratory, PNNL-16031.

Liu, B.; Jarnagin, R.E.; Jiang, W.; Gowri, K. (2007). Technical Support Document: The Development of the Advanced Energy Design Guide for Small Warehouse and Self-Storage Buildings. Richland, WA: Pacific Northwest National Laboratory, PNNL-17056.

MacDonald, M.; Deru, M. (2007). "Wal-Mart Experience: Part One." ASHRAE Journal 49(9) 14-25; Golden, CO: National Renewable Energy Laboratory, NREL/JA-550-42015. Available at www.nrel.gov/docs/fy09osti/45742.pdf. Last accessed October 2009.

McGraw Hill. (2005). Dodge Database. McGraw Hill Construction. Available at http://dodge.construction.com/. Last accessed October 2009.

NCDC. (1993). Solar and Meteorological Surface Observational Network (SAMSON), 19611990, 3-volume CD-ROM set. NCDC, Asheville, NC: National Climatic Data Center.

Persily, A.K. (1998). Airtightness of Commercial and Institutional Buildings, Proceedings of ASHRAE Thermal Envelopes VII Conference. Atlanta, GA: American Society of Heating, Refrigerating and Air-Conditioning Engineers.

Pless, S.; Torcellini, P.; Long, N. (2007). Technical Support Document: Development of the Advanced Energy Design Guide for K-12 Schools-30\% Energy Savings. Golden, CO: National Renewable Energy Laboratory, NREL /TP-550-42114. Available at www.nrel.gov/docs/ fy07osti/42114.pdf. Last accessed October 2009.

PNNL. (2004). Technical Support Document: Energy Efficiency Program for Commercial and Industrial Equipment: Advanced Notice of Proposed Rulemaking for Commercial Unitary Air 
Conditioners and Heat Pumps. For the U.S. Department of Energy. Richland, WA: Pacific Northwest National Laboratory.

Public Utilities Commission of Texas. (2003). Deemed Savings, Installation \& Efficiency Standards: Commercial and Industrial Cooling Equipment. Boulder, CO: Nexant, Inc. Available at www.puc.state.tx.us/rules/rulemake/27903/16 25.184-14.pdf. Last accessed October 2009.

SGE. (2004). Design Guide 1 Improving Commercial Kitchen Ventilation System Performance: Selecting and Sizing Exhaust Hoods. Rancho Cucamonga, CA: Southern California Edison.

Smith, V.A.; Fisher, D.R. (2001). "Estimating Food Service Loads and Profiles.” ASHRAE Transactions 2001, 107(2). Atlanta, GA: American Society of Heating, Refrigerating and AirConditioning Engineers.

Smith, V.A.; Young, R.; Spata, A.J.; Fisher, D. (1999). "Virtual vs. Real: Modeling the Energy Performance of a Quick Service Restaurant." ASHRAE Transactions 1999, 105. Atlanta, GA: American Society of Heating, Refrigerating and Air-Conditioning Engineers.

Stocki, M.; Curcija, D.C.; Bhandari, M.S. (2005). The Development of Standardized Whole Building Simulation Assumptions for Energy Analysis for a Set of Commercial Buildings (draft May 31 2005). Amherst, MA: University of Massachusetts.

U.S. Census Bureau. (2005). 2002 Economic Census: Sector 23: Construction: Geographic Area Series: Value of Construction Work for Establishments by Type of Construction: 2002. Washington, DC: U.S. Department of Commerce. Available at http://factfinder.census.gov/ servlet/IBQTable? bm=y\&-geo_id=\&-ds_name=EC0223A6\&-_lang=en. Last accessed October 2009.

Westphalen, D.; Zogg, R.A.; Varone, A.F.; Foran, M.A. (1996). Energy Savings Potential for Commercial Refrigeration Equipment. For the U.S. Department of Energy. Cambridge, MA: Arthur D. Little, Inc.

Winiarski, D.W.; Jiang, W.; Halverson, M.A. (2006). Review of Pre- and Post-1980 Buildings in CBECS - HVAC Equipment. Richland, WA: Pacific Northwest National Laboratory.

Winiarski D.W.; Halverson, M.A.; Jiang, W. (2007a). Analysis of Building Envelope Construction in 2003 CBECS Pre-1980 Buildings. Richland, WA: Pacific Northwest National Laboratory. PNNL-SA-55594.

Winiarski, D.W.; Jiang, W; Halverson, M.A. (2007b). Analysis of Building Envelope Construction in 2003 CBECS Post-1980 Buildings. Richland, WA: Pacific Northwest National Laboratory. PNNL-SA-55888.

Winiarski, D.W.; Halverson, M.A.; Jiang, W. (2008). “DOE’s Commercial Building Benchmarks - Development of Typical Construction Practices for Building Envelope and Mechanical Systems from the 2003 CBECS." In Proceedings of 2008 Summer Study on Energy Efficiency in Buildings, American Council for an Energy Efficient Economy.

Winiarski, D.W.; Halverson, M.A. (2008). Equipment Efficiency for Existing Benchmark Buildings. Internal report. Richland, WA: Pacific Northwest National Laboratory. 


\section{Appendix A Reference Building Internal Loads}

Table A-1 Reference Building Zone Internal Loads (IP units)

\begin{tabular}{|c|c|c|c|c|c|c|c|c|c|c|c|}
\hline Building Type/Zone & $\begin{array}{c}\text { Area } \\
\mathrm{ft}^{2}\end{array}$ & $\begin{array}{l}\text { Vol. } \\
\mathrm{ft}^{3}\end{array}$ & $\begin{array}{c}\mathrm{ft}^{2} \mathrm{l} \\
\text { person }\end{array}$ & $\begin{array}{c}1989 \\
\text { Lights } \\
\text { Wft }^{2}\end{array}$ & \begin{tabular}{|c|}
2004 \\
Lights \\
$\mathrm{Wft}^{2}$ \\
\end{tabular} & $\begin{array}{l}\text { Elec. } \\
\text { Proc. } \\
\text { W/ft }\end{array}$ & $\begin{array}{c}\text { Gas } \\
\text { Proc. } \\
\text { W/ft }\end{array}$ & $\begin{array}{l}\text { Vent. } \\
\text { cfm }\end{array}$ & $\begin{array}{c}\text { Exhst } \\
\text { cfm }\end{array}$ & $\begin{array}{l}\text { Infil. } \\
\text { ACH }\end{array}$ & $\begin{array}{l}\text { SWH } \\
\text { gal/h }\end{array}$ \\
\hline Quick Service Restaurant & 2,501 & 25,015 & & & & & & & & & \\
\hline Dining & 1,250 & 12,508 & 15.0 & 1.44 & 2.1 & 12.0 & 0.0 & 1667.3 & 0.0 & 0.64 & 0.0 \\
\hline Kitchen & 1,250 & 12,508 & 200.0 & 1.55 & 1.2 & 28.0 & 120.0 & 93.8 & 3300.0 & 0.64 & 40.0 \\
\hline Attic & 2,501 & 9,264 & 0.0 & 0.00 & 0.0 & 0.0 & 0.0 & 0.0 & 0.0 & 1.00 & 0.0 \\
\hline Hospital & 241,350 & $3,138,208$ & & & & & & & & & \\
\hline Basement & 40,250 & 322,083 & 400.0 & 0.70 & 1.1 & 0.8 & 0.0 & 2012.5 & 0.0 & 0.00 & 0.0 \\
\hline ER_Exam1_Mult4_FIr_1 & 300 & 4,201 & 50.0 & 3.84 & 2.7 & 1.5 & 0.0 & 140.0 & 0.0 & 0.24 & 1.0 \\
\hline ER_Exam2_Flr_1 & 300 & 4,201 & 50.0 & 3.84 & 2.7 & 4.0 & 0.0 & 140.0 & 0.0 & 0.42 & 1.0 \\
\hline ER_Exam3_Mult4_FIr_1 & 300 & 4,201 & 50.0 & 3.84 & 2.7 & 1.5 & 0.0 & 140.0 & 0.0 & 0.18 & 1.0 \\
\hline ER_Exam4_FIr_1 & 300 & 4,201 & 50.0 & 3.84 & 2.7 & 4.0 & 0.0 & 140.0 & 0.0 & 0.42 & 1.0 \\
\hline ER_Exam5_Mult4_FIr_1 & 300 & 4,201 & 50.0 & 3.84 & 2.7 & 2.0 & 0.0 & 140.0 & 0.0 & 0.24 & 1.0 \\
\hline Office1_Mult4_FIr_1 & 150 & 2,101 & 142.9 & 2.40 & 1.1 & 1.1 & 0.0 & 21.0 & 0.0 & 0.24 & 0.0 \\
\hline Lobby_FIr_1 & 15,875 & 222,303 & 140.0 & 1.29 & 1.5 & 0.1 & 0.0 & 2267.8 & 0.0 & 0.07 & 0.0 \\
\hline Corridor_FIr_1 & 6,125 & 85,772 & 1000.0 & 1.36 & 1.0 & 0.0 & 0.0 & 306.2 & 0.0 & 0.04 & 0.0 \\
\hline ER_NurseStat_Flr_1 & 13,300 & 186,248 & 160.0 & 2.10 & 1.1 & 1.4 & 0.0 & 6208.3 & 0.0 & 0.02 & 0.0 \\
\hline OR1_FIr_2 & 600 & 8,402 & 200.0 & 9.75 & 2.2 & 4.0 & 0.0 & 420.1 & 0.0 & 0.30 & 2.0 \\
\hline OR2_Mult5_Flr_2 & 600 & 8,402 & 200.0 & 9.75 & 2.2 & 4.0 & 0.0 & 420.1 & 0.0 & 0.12 & 2.0 \\
\hline OR3_Flr_2 & 600 & 8,402 & 200.0 & 9.75 & 2.2 & 4.0 & 0.0 & 420.1 & 0.0 & 0.18 & 2.0 \\
\hline OR4_FIr_2 & 2,400 & 33,609 & 200.0 & 7.89 & 2.2 & 4.0 & 0.0 & 1680.5 & 0.0 & 0.00 & 6.0 \\
\hline IC_PatRoom1_Mult5_FIr_2 & 225 & 3,150 & 200.0 & 3.84 & 0.8 & 3.0 & 0.0 & 105.0 & 0.0 & 0.24 & 0.0 \\
\hline IC_PatRoom2_Flr_2 & 300 & 4,201 & 200.0 & 3.84 & 0.8 & 3.0 & 0.0 & 140.0 & 0.0 & 0.42 & 0.0 \\
\hline IC_PatRoom3_Mult6_FIr_2 & 225 & 3,150 & 200.0 & 3.84 & 0.8 & 3.0 & 0.0 & 105.0 & 0.0 & 0.24 & 0.0 \\
\hline ICU_FIr_2 & 6,652 & 93,147 & 50.0 & 3.84 & 0.8 & 3.0 & 0.0 & 3104.9 & 0.0 & 0.09 & 0.0 \\
\hline ICU_NurseSat_FIr_2 & 7,199 & 100,806 & 200.0 & 2.17 & 1.0 & 2.0 & 0.0 & 719.9 & 0.0 & 0.00 & 0.0 \\
\hline Corridor_FIr_2 & 6,125 & 85,772 & 1000.0 & 1.36 & 1.0 & 0.0 & 0.0 & 122.5 & 0.0 & 0.04 & 0.0 \\
\hline OR_NurseSat_FIr_2 & 10,900 & 152,639 & 140.0 & 2.12 & 1.2 & 1.0 & 0.0 & 1557.1 & 0.0 & 0.05 & 0.0 \\
\hline PatRoom1_Mult10_Flr_3 & 225 & 3,150 & 200.0 & 2.19 & 0.7 & 2.0 & 0.0 & 105.0 & 0.0 & 0.24 & 1.0 \\
\hline PatRoom2_Flr_3 & 375 & 5,252 & 200.0 & 2.19 & 0.7 & 2.0 & 0.0 & 175.1 & 0.0 & 0.38 & 1.0 \\
\hline PatRoom3_Mult10_Flr_3 & 218 & 3,046 & 200.0 & 2.19 & 0.7 & 2.0 & 0.0 & 101.5 & 0.0 & 0.24 & 1.0 \\
\hline PatRoom4_Flr_3 & 375 & 5,252 & 200.0 & 2.19 & 0.7 & 2.0 & 0.0 & 175.1 & 0.0 & 0.38 & 1.0 \\
\hline PatRoom5_Mult10_FIr_3 & 225 & 3,150 & 200.0 & 2.19 & 0.7 & 2.0 & 0.0 & 105.0 & 0.0 & 0.24 & 1.0 \\
\hline PhysTherapy_FIr_3 & 5,250 & 73,519 & 200.0 & 2.50 & 0.9 & 1.5 & 0.0 & 393.7 & 0.0 & 0.00 & 1.0 \\
\hline PatRoom6_Flr_3 & 300 & 4,201 & 200.0 & 2.19 & 0.7 & 2.0 & 0.0 & 140.0 & 0.0 & 0.42 & 1.0 \\
\hline PatRoom7_Mult10_Flr_3 & 218 & 3,046 & 200.0 & 2.19 & 0.7 & 2.0 & 0.0 & 101.5 & 0.0 & 0.24 & 1.0 \\
\hline PatRoom8_FIr_3 & 300 & 4,201 & 200.0 & 2.19 & 0.7 & 2.0 & 0.0 & 140.0 & 0.0 & 0.42 & 1.0 \\
\hline NurseSat_Lobby_Flr_3 & 9,750 & 136,534 & 140.0 & 2.13 & 1.2 & 1.0 & 0.0 & 1392.8 & 0.0 & 0.00 & 0.0 \\
\hline Lab_Flr_3 & 2,850 & 39,910 & 200.0 & 2.10 & 1.4 & 4.0 & 0.0 & 285.0 & 0.0 & 0.00 & 2.0 \\
\hline Corridor_SE_Flr_3 & 6,100 & 85,422 & 1000.0 & 1.36 & 1.0 & 0.0 & 0.0 & 305.0 & 0.0 & 0.02 & 0.0 \\
\hline Corridor_NW_FIr_3 & 6,100 & 85,422 & 1000.0 & 1.36 & 1.0 & 0.0 & 0.0 & 305.0 & 0.0 & 0.02 & 0.0 \\
\hline PatRoom1_Mult10_FIr_4 & 225 & 3,150 & 200.0 & 2.19 & 0.7 & 2.0 & 0.0 & 105.0 & 0.0 & 0.24 & 1.0 \\
\hline PatRoom2_Flr_4 & 375 & 5,252 & 200.0 & 2.19 & 0.7 & 2.0 & 0.0 & 175.1 & 0.0 & 0.38 & 1.0 \\
\hline $\begin{array}{l}\text { PatRoom3_Mult10_Flr_4 } \\
\end{array}$ & 218 & 3,046 & 200.0 & 2.19 & 0.7 & 2.0 & 0.0 & 101.5 & 0.0 & 0.24 & 1.0 \\
\hline 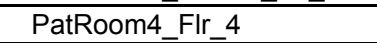 & 375 & 5,252 & 200.0 & 2.19 & 0.7 & 2.0 & 0.0 & 175.1 & 0.0 & 0.38 & 1.0 \\
\hline PatRoom5_Mult10_FIr_4 & 225 & 3,150 & 200.0 & 2.19 & 0.7 & 2.0 & 0.0 & 105.0 & 0.0 & 0.24 & 1.0 \\
\hline Radiology_FIr_4 & 5,250 & 73,519 & 200.0 & 2.21 & 0.4 & 10.0 & 0.0 & 393.7 & 0.0 & 0.00 & 1.0 \\
\hline 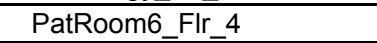 & 300 & 4,201 & 200.0 & 2.19 & 0.7 & 2.0 & 0.0 & 140.0 & 0.0 & 0.42 & 1.0 \\
\hline PatRoom7_Mult10_FIr_4 & 218 & 3,046 & 200.0 & 2.19 & 0.7 & 2.0 & 0.0 & 101.5 & 0.0 & 0.24 & 1.0 \\
\hline $\begin{array}{l}\text { PatRoom8_Flr_4 } \\
\end{array}$ & 300 & 4,201 & 200.0 & 2.19 & 0.7 & 2.0 & 0.0 & 140.0 & 0.0 & 0.42 & 1.0 \\
\hline NurseSat_Lobby_FIr_4 & 9,750 & 136,534 & 140.0 & 2.13 & 1.2 & 1.0 & 0.0 & 1392.8 & 0.0 & 0.00 & 0.0 \\
\hline Lab_Flr_4 & 2,850 & 39,910 & 200.0 & 2.10 & 1.4 & 4.0 & 0.0 & 285.0 & 0.0 & 0.00 & 2.0 \\
\hline Corridor_SE_FIr_4 & 6,100 & 85,422 & \begin{tabular}{|l|}
1000.0 \\
\end{tabular} & 1.36 & 1.0 & 0.0 & 0.0 & 305.0 & 0.0 & 0.02 & 0.0 \\
\hline
\end{tabular}




\begin{tabular}{|c|c|c|c|c|c|c|c|c|c|c|c|}
\hline Building Type/Zone & $\underset{\mathrm{ft}^{2}}{\text { Area }}$ & $\begin{array}{c}\text { Vol. } \\
\mathrm{ft}^{3}\end{array}$ & $\begin{array}{c}\mathrm{ft}^{2} l \\
\text { person }\end{array}$ & $\begin{array}{c}1989 \\
\text { Lights } \\
\text { Wft }^{2}\end{array}$ & $\begin{array}{c}2004 \\
\text { Lights }_{\text {Wft }^{2}}\end{array}$ & $\begin{array}{l}\text { Elec. } \\
\text { Proc. } \\
\text { W/ft }^{2}\end{array}$ & $\begin{array}{l}\text { Gas } \\
\text { Proc. } \\
\text { W/ft }\end{array}$ & $\begin{array}{l}\text { Vent. } \\
\text { cfm }\end{array}$ & $\begin{array}{c}\text { Exhst } \\
\text { cfm }\end{array}$ & $\begin{array}{l}\text { Infil. } \\
\text { ACH }\end{array}$ & $\begin{array}{l}\text { SWH } \\
\text { gal/h }\end{array}$ \\
\hline Corridor_NW_Flr_4 & 6,100 & 85,422 & 1000.0 & 1.36 & 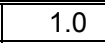 & 0.0 & 0.0 & \begin{tabular}{ll|}
305.0 \\
\end{tabular} & 0.0 & 0.02 & 0.0 \\
\hline Dining_Flr_5 & 7,500 & 105,027 & 100.0 & 2.58 & 0.9 & 1.0 & 0.0 & 1500.0 & 0.0 & 0.34 & 0.0 \\
\hline NurseSat_Flr_5 & 11,200 & 156,840 & 140.0 & 2.12 & 1.2 & 1.0 & 0.0 & 1600.0 & 0.0 & 0.28 & 0.0 \\
\hline Kitchen_Flr_5 5 & 10,000 & 140,036 & 200.0 & 1.42 & 1.2 & 7.5 & 28.3 & 750.0 & 5300.0 & 0.33 & 150.0 \\
\hline Office1_Flr_5 & 750 & 10,506 & 142.9 & 2.40 & 1.1 & 1.0 & 0.0 & 105.0 & 0.0 & 0.52 & 0.0 \\
\hline Office2_Mult5_FIr_5 & 750 & 10,503 & 142.9 & 2.40 & 1.1 & 1.0 & 0.0 & 105.0 & 0.0 & 0.37 & 0.0 \\
\hline Office3_FIr_5 & 750 & 10,503 & 142.9 & 2.40 & 1.1 & 1.0 & 0.0 & 105.0 & 0.0 & 0.52 & 0.0 \\
\hline Office4_Mult6_FIr_5 & 150 & 2,101 & 142.9 & 2.40 & 1.1 & 1.0 & 0.0 & 20.0 & 0.0 & 0.49 & 0.0 \\
\hline Corridor_FIr_5 & 5,400 & 75,620 & 1000.0 & 1.36 & 1.0 & 0.0 & 0.0 & 270.0 & 0.0 & 0.29 & 0.0 \\
\hline Large Hotel & 122,116 & $1,242,549$ & & & & & & & & & \\
\hline Basement & 21,300 & 170,443 & 400.0 & 0.70 & 1.0 & 0.5 & 0.0 & 1065.0 & 0.0 & 0.00 & 0.0 \\
\hline Retail_1_Flr_1 & 722 & 9,385 & 66.7 & 3.54 & 1.5 & 1.0 & 0.0 & 216.6 & 0.0 & 0.56 & 0.0 \\
\hline Retail_2_Flr_1 & 836 & 10,868 & 66.7 & 3.54 & 1.5 & 1.0 & 0.0 & 250.8 & 0.0 & 0.09 & 0.0 \\
\hline Mech_Flr_1 & 1,768 & 22,983 & 0.0 & 0.80 & 1.5 & 0.5 & 0.0 & 88.4 & 0.0 & 0.11 & 0.0 \\
\hline Storage_Flr_1 & 1,020 & 13,260 & 500.0 & 0.37 & 0.9 & 0.3 & 0.0 & 153.0 & 0.0 & 0.11 & 0.0 \\
\hline Laundry_Flr_1 & 840 & 10,920 & 250.0 & 1.14 & 0.6 & 5.7 & 49.8 & 50.4 & 500.0 & 0.30 & 156.6 \\
\hline Cafe_Flr_1 & 2,033 & 26,428 & 15.0 & 1.46 & 1.3 & 0.5 & 0.0 & 2710.5 & 0.0 & 0.50 & 0.0 \\
\hline Lobby_Flr_1 & 14,081 & 183,056 & 33.3 & 1.88 & 1.1 & 0.8 & 0.0 & 8449.6 & 0.0 & 0.10 & 0.0 \\
\hline Room_1_Flr_3 & 420 & 4,200 & 280.0 & 1.77 & 1.1 & 0.6 & 0.0 & 30.0 & 0.0 & 0.37 & 1.3 \\
\hline Room_2_Flr_3 & 420 & 4,200 & 280.0 & 1.77 & 1.1 & 0.6 & 0.0 & 30.0 & 0.0 & 0.37 & 1.3 \\
\hline Room_3_Mult19_Flr_3 & 264 & 2,640 & 176.0 & 1.77 & 1.1 & 0.6 & 0.0 & 30.0 & 0.0 & 0.16 & 23.8 \\
\hline Room_4_Mult19_FIr_3 & 264 & 2,640 & 176.0 & 1.77 & 1.1 & 0.6 & 0.0 & 30.0 & 0.0 & 0.16 & 23.8 \\
\hline Room_5_Flr_3 & 420 & 4,200 & 280.0 & 1.77 & 1.1 & 0.6 & 0.0 & 30.0 & 0.0 & 0.37 & 1.3 \\
\hline Room_6_Flr_3 & 420 & 4,200 & 280.0 & 1.77 & 1.1 & 0.6 & 0.0 & 30.0 & 0.0 & 0.37 & 1.3 \\
\hline Corridor_Flr_3 & 4,191 & 41,915 & 1000.0 & 1.22 & 0.5 & 0.0 & 0.0 & 209.6 & 0.0 & 0.04 & 0.0 \\
\hline Room_1_Flr_6 & 420 & 4,200 & 280.0 & 1.77 & 1.1 & 0.6 & 0.0 & 30.0 & 0.0 & 0.72 & 1.3 \\
\hline Room_2_Flr_6 & 420 & 4,200 & 280.0 & 1.77 & 1.1 & 0.6 & 0.0 & 30.0 & 0.0 & 0.72 & 1.3 \\
\hline Room_3_Mult9_FIr_6 & 264 & 2,640 & 176.0 & 1.77 & 1.1 & 0.6 & 0.0 & 30.0 & 0.0 & 1.28 & 11.3 \\
\hline Banquet_FIr_6 & 3,570 & 35,699 & 15.0 & 2.56 & 1.3 & 6.3 & 0.0 & 4759.9 & 0.0 & 0.46 & 0.0 \\
\hline Dining_Flr_6 & 3,570 & 35,699 & 15.0 & 2.56 & 1.3 & 6.3 & 0.0 & 4759.9 & 0.0 & 0.46 & 0.0 \\
\hline Kitchen_FIr_6 & 1,112 & 11,120 & 200.0 & 1.56 & 1.2 & 47.2 & 149.9 & 83.4 & 4000.0 & 0.66 & 133.0 \\
\hline Corridor_FIr_6 & 4,436 & 44,361 & 1000.0 & 1.22 & 0.5 & 0.0 & 0.0 & 221.8 & 0.0 & 0.48 & 0.0 \\
\hline Large Office & 498,588 & $6,291,164$ & & & & & & & & & \\
\hline Basement & 38,353 & 306,899 & 400.0 & 0.70 & 1.0 & 0.4 & 0.0 & 1917.6 & 0.0 & 0.00 & 0.0 \\
\hline Perimeter_bot_ZN_3 & 3,374 & 30,371 & 200.0 & 1.50 & 1.0 & 0.7 & 0.0 & 337.4 & 0.0 & 0.25 & 0.0 \\
\hline Perimeter_bot_ZN_2 & 2,174 & 19,572 & 200.0 & 1.50 & 1.0 & 0.7 & 0.0 & 217.4 & 0.0 & 0.26 & 0.0 \\
\hline Perimeter_bot_ZN_1 & 3,374 & 30,371 & 200.0 & 1.50 & 1.0 & 0.7 & 0.0 & 337.4 & 0.0 & 0.25 & 0.0 \\
\hline Perimeter_bot_ZN_4 & 2,174 & 19,572 & 200.0 & 1.50 & 1.0 & 0.7 & 0.0 & 217.4 & 0.0 & 0.26 & 0.0 \\
\hline Core_bottom & 27,258 & 245,391 & 200.0 & 1.50 & 1.0 & 0.7 & 0.0 & 2725.8 & 0.0 & 0.00 & 21.3 \\
\hline Perimeter_mid_ZN_3 & 3,374 & 30,371 & 200.0 & 1.50 & 1.0 & 0.7 & 0.0 & 337.4 & 0.0 & 0.25 & 0.0 \\
\hline Perimeter_mid_ZN_2 & 2,174 & 19,572 & 200.0 & 1.50 & 1.0 & 0.7 & 0.0 & 217.4 & 0.0 & 0.26 & 0.0 \\
\hline Perimeter_mid_ZN_1 & 3,374 & 30,371 & 200.0 & 1.50 & 1.0 & 0.7 & 0.0 & 337.4 & 0.0 & 0.25 & 0.0 \\
\hline Perimeter_mid_ZN_4 & 2,174 & 19,572 & 200.0 & 1.50 & 1.0 & 0.7 & 0.0 & 217.4 & 0.0 & 0.26 & 0.0 \\
\hline Core_mid & 27,258 & 245,391 & 200.0 & 1.50 & 1.0 & 0.7 & 0.0 & 2725.8 & 0.0 & 0.00 & 21.3 \\
\hline Perimeter_top_ZN_3 & 3,374 & 30,371 & 200.0 & 1.50 & 1.0 & 0.7 & 0.0 & 337.4 & 0.0 & 0.65 & 0.0 \\
\hline Perimeter_top_ZN_2 & 2,174 & 19,572 & 200.0 & 1.50 & 1.0 & 0.7 & 0.0 & 217.4 & 0.0 & 0.66 & 0.0 \\
\hline Perimeter_top_ZN_1 & 3,374 & 30,371 & 200.0 & 1.50 & 1.0 & 0.7 & 0.0 & 337.4 & 0.0 & 0.65 & 0.0 \\
\hline Perimeter_top_ZN_4 & 2,174 & 19,572 & 200.0 & 1.50 & 1.0 & 0.7 & 0.0 & 217.4 & 0.0 & 0.66 & 0.0 \\
\hline Core_top & 27,258 & 245,391 & 200.0 & 1.50 & 1.0 & 0.7 & 0.0 & 2725.8 & 0.0 & 0.40 & 21.3 \\
\hline Groundfloor_plenum & 38,353 & 153,412 & 0.0 & 0.00 & 0.0 & 0.0 & 0.0 & 0.0 & 0.0 & 0.07 & 0.0 \\
\hline Midfloor_plenum & 38,353 & 153,412 & 0.0 & 0.00 & 0.0 & 0.0 & 0.0 & 0.0 & 0.0 & 0.07 & 0.0 \\
\hline Topfloor_plenum & 38,353 & 153,412 & 0.0 & 0.00 & 0.0 & 0.0 & 0.0 & 0.0 & 0.0 & 0.97 & 0.0 \\
\hline Medium Office & 53,628 & 697,161 & & & & & & & & & \\
\hline Perimeter_bot_ZN_3 & 2,232 & 20,086 & 200.0 & 1.57 & 1.0 & 0.7 & 0.0 & 223.2 & 0.0 & 0.26 & 0.0 \\
\hline Perimeter_bot_ZN_2 & 1,413 & 12,716 & 200.0 & 1.57 & 1.0 & 0.7 & 0.0 & 141.3 & 0.0 & 0.28 & 0.0 \\
\hline Perimeter_bot_ZN_1 & 2,232 & 20,086 & 200.0 & 1.57 & 1.0 & 0.7 & 0.0 & 223.2 & 0.0 & 0.26 & 0.0 \\
\hline
\end{tabular}




\begin{tabular}{|c|c|c|c|c|c|c|c|c|c|c|c|}
\hline Building Type/Zone & $\begin{array}{c}\text { Area } \\
\mathrm{ft}^{2}\end{array}$ & $\begin{array}{l}\text { Vol. } \\
\mathrm{ft}^{3}\end{array}$ & $\begin{array}{c}\mathrm{ft}^{2} l \\
\text { person }\end{array}$ & $\begin{array}{c}1989 \\
\text { Lights } \\
\text { Wft }^{2}\end{array}$ & \begin{tabular}{|c|}
2004 \\
Lights \\
Wft $^{2}$
\end{tabular} & $\begin{array}{l}\text { Elec. } \\
\text { Proc. } \\
\text { W/ft }^{2}\end{array}$ & $\begin{array}{l}\text { Gas } \\
\text { Proc. } \\
\text { W/ft' }\end{array}$ & $\begin{array}{l}\text { Vent. } \\
\text { cfm }\end{array}$ & $\begin{array}{c}\text { Exhst } \\
\text { cfm }\end{array}$ & $\begin{array}{l}\text { Infil. } \\
\text { ACH }\end{array}$ & $\begin{array}{l}\text { SWH } \\
\text { gal/h }\end{array}$ \\
\hline Perimeter_bot_ZN_4 & $\begin{array}{ll}1,413 \\
\end{array}$ & 12,715 & 200.0 & 1.57 & $\overline{c 1.0}$ & 0.7 & $\overline{0.0}$ & 141.3 & 0.0 & 0.28 & 0.0 \\
\hline Core_bottom & 10,587 & 95,280 & 200.0 & 1.57 & 1.0 & 0.7 & 0.0 & 1058.7 & 0.0 & 0.00 & 9.9 \\
\hline Perimeter_mid_ZN_3 & 2,232 & 20,086 & 200.0 & 1.57 & 1.0 & 0.7 & 0.0 & 223.2 & 0.0 & 0.26 & 0.0 \\
\hline Perimeter_mid_ZN_2 & 1,413 & 12,716 & 200.0 & 1.57 & 1.0 & 0.7 & 0.0 & 141.3 & 0.0 & 0.28 & 0.0 \\
\hline Perimeter_mid_ZN_1 & 2,232 & 20,086 & 200.0 & 1.57 & 1.0 & 0.7 & 0.0 & 223.2 & 0.0 & 0.26 & 0.0 \\
\hline Perimeter_mid_ZN_4 & 1,413 & 12,715 & 200.0 & 1.57 & 1.0 & 0.7 & 0.0 & 141.3 & 0.0 & 0.28 & 0.0 \\
\hline Core_mid & 10,587 & 95,280 & 200.0 & 1.57 & 1.0 & 0.7 & 0.0 & 1058.7 & 0.0 & 0.00 & 9.9 \\
\hline Perimeter_top_ZN_3 & 2,232 & 20,086 & 200.0 & 1.57 & 1.0 & 0.7 & 0.0 & 223.2 & 0.0 & 0.66 & 0.0 \\
\hline Perimeter_top_ZN_2 & 1,413 & 12,716 & 200.0 & 1.57 & 1.0 & 0.7 & 0.0 & 141.3 & 0.0 & 0.67 & 0.0 \\
\hline Perimeter_top_ZN_1 & 2,232 & 20,086 & 200.0 & 1.57 & 1.0 & 0.7 & 0.0 & 223.2 & 0.0 & 0.66 & 0.0 \\
\hline Perimeter_top_ZN_4 & 1,413 & 12,715 & 200.0 & 1.57 & 1.0 & 0.7 & 0.0 & 141.3 & 0.0 & 0.67 & 0.0 \\
\hline Core_top & 10,587 & 95,280 & 200.0 & 1.57 & 1.0 & 0.7 & 0.0 & 1058.7 & 0.0 & 0.40 & 9.9 \\
\hline Firstfloor_plenum & 17,876 & 71,504 & 0.0 & 0.00 & 0.0 & 0.0 & 0.0 & 0.0 & 0.0 & 0.11 & 0.0 \\
\hline Midfloor_plenum & 17,876 & 71,504 & 0.0 & 0.00 & 0.0 & 0.0 & 0.0 & 0.0 & 0.0 & 0.11 & 0.0 \\
\hline Topfloor_plenum & 17,876 & 71,504 & 0.0 & 0.00 & 0.0 & 0.0 & 0.0 & 0.0 & 0.0 & 1.00 & 0.0 \\
\hline Midrise Apartment & 33,741 & 337,378 & & & & & & & & & \\
\hline G SW APARTMENT & 950 & 9,498 & 380.0 & 0.36 & 0.4 & 0.5 & 0.0 & 90.0 & 0.0 & 0.24 & 3.5 \\
\hline G NW APARTMENT & 950 & 9,498 & 380.0 & 0.36 & 0.4 & 0.5 & 0.0 & 90.0 & 0.0 & 0.24 & 3.5 \\
\hline OFFICE & 950 & 9,498 & 474.9 & 2.04 & 1.0 & 1.2 & 0.0 & 40.0 & 0.0 & 0.24 & 0.0 \\
\hline G NE APARTMENT & 950 & 9,498 & 380.0 & 0.36 & 0.4 & 0.5 & 0.0 & 90.0 & 0.0 & 0.24 & 3.5 \\
\hline G N1 APARTMENT & 950 & 9,498 & 380.0 & 0.36 & 0.4 & 0.5 & 0.0 & 90.0 & 0.0 & 0.14 & 3.5 \\
\hline G N2 APARTMENT & 950 & 9,498 & 380.0 & 0.36 & 0.4 & 0.5 & 0.0 & 90.0 & 0.0 & 0.14 & 3.5 \\
\hline G S1 APARTMENT & 950 & 9,498 & 380.0 & 0.36 & 0.4 & 0.5 & 0.0 & 90.0 & 0.0 & 0.14 & 3.5 \\
\hline G S2 APARTMENT & 950 & 9,498 & 380.0 & 0.36 & 0.4 & 0.5 & 0.0 & 90.0 & 0.0 & 0.14 & 3.5 \\
\hline M SW APARTMENT & 950 & 9,498 & 380.0 & 0.36 & 0.4 & 0.5 & 0.0 & 90.0 & 0.0 & 0.24 & 3.5 \\
\hline M NW APARTMENT & 950 & 9,498 & 380.0 & 0.36 & 0.4 & 0.5 & 0.0 & 90.0 & 0.0 & 0.24 & 3.5 \\
\hline M SE APARTMENT & 950 & 9,498 & 380.0 & 0.36 & 0.4 & 0.5 & 0.0 & 90.0 & 0.0 & 0.24 & 3.5 \\
\hline M NE APARTMENT & 950 & 9,498 & 380.0 & 0.36 & 0.4 & 0.5 & 0.0 & 90.0 & 0.0 & 0.24 & 3.5 \\
\hline M N1 APARTMENT & 950 & 9,498 & 380.0 & 0.36 & 0.4 & 0.5 & 0.0 & 90.0 & 0.0 & 0.14 & 3.5 \\
\hline M N2 APARTMENT & 950 & 9,498 & 380.0 & 0.36 & 0.4 & 0.5 & 0.0 & 90.0 & 0.0 & 0.14 & 3.5 \\
\hline M S1 APARTMENT & 950 & 9,498 & 380.0 & 0.36 & 0.4 & 0.5 & 0.0 & 90.0 & 0.0 & 0.14 & 3.5 \\
\hline M S2 APARTMENT & 950 & 9,498 & 380.0 & 0.36 & 0.4 & 0.5 & 0.0 & 90.0 & 0.0 & 0.14 & 3.5 \\
\hline T SW APARTMENT & 950 & 9,498 & 380.0 & 0.36 & 0.4 & 0.5 & 0.0 & 90.0 & 0.0 & 0.59 & 3.5 \\
\hline T NW APARTMENT & 950 & 9,498 & 380.0 & 0.36 & 0.4 & 0.5 & 0.0 & 90.0 & 0.0 & 0.59 & 3.5 \\
\hline T SE APARTMENT & 950 & 9,498 & 380.0 & 0.36 & 0.4 & 0.5 & 0.0 & 90.0 & 0.0 & 0.59 & 3.5 \\
\hline T NE APARTMENT & 950 & 9,498 & 380.0 & 0.36 & 0.4 & 0.5 & 0.0 & 90.0 & 0.0 & 0.59 & 3.5 \\
\hline T N1 APARTMENT & 950 & 9,498 & 380.0 & 0.36 & 0.4 & 0.5 & 0.0 & 90.0 & 0.0 & 0.50 & 3.5 \\
\hline T N2 APARTMENT & 950 & 9,498 & 380.0 & 0.36 & 0.4 & 0.5 & 0.0 & 90.0 & 0.0 & 0.50 & 3.5 \\
\hline TS1 APARTMENT & 950 & 9,498 & 380.0 & 0.36 & 0.4 & 0.5 & 0.0 & 90.0 & 0.0 & 0.50 & 3.5 \\
\hline T S2 APARTMENT & 950 & 9,498 & 380.0 & 0.36 & 0.4 & 0.5 & 0.0 & 90.0 & 0.0 & 0.50 & 3.5 \\
\hline T CORRIDOR & 836 & 8,359 & 0.0 & 0.92 & 0.5 & 0.0 & 0.0 & 41.8 & 0.0 & 0.40 & 0.0 \\
\hline G CORRIDOR & 836 & 8,359 & 0.0 & 0.92 & 0.5 & 0.0 & 0.0 & 41.8 & 0.0 & 0.05 & 0.0 \\
\hline M CORRIDOR & 836 & 8,359 & 0.0 & 0.92 & 0.5 & 0.0 & 0.0 & 41.8 & 0.0 & 0.05 & 0.0 \\
\hline Outpatient Health Care & 40,946 & 421,380 & & & & & & & & & \\
\hline Floor 1 Anesthesia & 108 & 1,080 & 0.0 & & 3.0 & 2.0 & 0.0 & 129.6 & 144.0 & 0.30 & 1.0 \\
\hline Floor $1 \mathrm{Bio} \mathrm{Haz}$ & 56 & 560 & 0.0 & & 0.9 & 0.1 & 0.0 & 8.4 & 0.0 & 0.00 & 0.0 \\
\hline Floor 1 Café & 420 & 4,200 & 10.8 & & 0.9 & 1.0 & 0.0 & 780.4 & 0.0 & 0.17 & 0.0 \\
\hline Floor 1 Clean & 126 & 1,260 & 53.8 & & 1.2 & 2.0 & 0.0 & 37.8 & 0.0 & 0.00 & 0.0 \\
\hline Floor 1 Clean Work & 165 & 1,650 & 53.8 & & 1.2 & 2.0 & 0.0 & 49.5 & 0.0 & 0.00 & 0.0 \\
\hline Floor 1 Dictation & 126 & 1,260 & 215.3 & & 1.1 & 1.1 & 0.0 & 11.7 & 0.0 & 0.00 & 0.0 \\
\hline Floor 1 Dressing Room & 45 & 450 & 215.3 & & 1.1 & 1.1 & 0.0 & 4.2 & 0.0 & 0.71 & 0.0 \\
\hline Floor 1 Electrical Room & 98 & 980 & 0.0 & & 1.5 & 5.0 & 0.0 & 4.9 & 0.0 & 0.25 & 0.0 \\
\hline Floor 1 Elevator Pump Room & 91 & 910 & 0.0 & & 1.5 & 5.0 & 0.0 & 4.5 & 0.0 & 0.78 & 0.0 \\
\hline Floor 1 Humid & 54 & 540 & 215.3 & & 1.1 & 1.1 & 0.0 & 5.0 & 0.0 & 0.00 & 0.0 \\
\hline Floor 1 IT Hall & 140 & 1,400 & 0.0 & & 1.0 & 0.4 & 0.0 & 7.0 & 0.0 & 0.00 & 0.0 \\
\hline Floor 1 IT Room & 112 & 1,120 & 215.3 & & 1.1 & 1.1 & 0.0 & 10.4 & 0.0 & 0.00 & 0.0 \\
\hline
\end{tabular}




\begin{tabular}{|c|c|c|c|c|c|c|c|c|c|c|c|}
\hline Building Type/Zone & $\begin{array}{c}\text { Area } \\
\mathrm{ft}^{2}\end{array}$ & $\begin{array}{c}\text { Vol. } \\
\mathrm{ft}^{3}\end{array}$ & $\begin{array}{c}\mathrm{ft}^{2} \mathrm{I} \\
\text { person }\end{array}$ & $\begin{array}{c}1989 \\
\text { Lights } \\
\text { Wft }^{2}\end{array}$ & $\begin{array}{c}2004 \\
\text { Lights } \\
\text { Wft }^{2} \\
\end{array}$ & $\begin{array}{l}\text { Elec. } \\
\text { Proc. } \\
\text { W/ft }^{2} \\
\end{array}$ & $\begin{array}{c}\text { Gas } \\
\text { Proc. } \\
\text { W/ft }^{2} \\
\end{array}$ & $\begin{array}{l}\text { Vent. } \\
\text { cfm }\end{array}$ & $\begin{array}{l}\text { Exhst } \\
\text { cfm }\end{array}$ & $\begin{array}{l}\text { Infil. } \\
\text { ACH } \\
\end{array}$ & $\begin{array}{l}\text { SWH } \\
\text { gal/h }\end{array}$ \\
\hline Floor 1 Lobby & 2622 & 6,220 & 35.9 & & 1.3 & 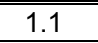 & 0.0 & 260.0 & $\overline{0.0}$ & 0.13 & $\begin{array}{c}0.0 \\
\end{array}$ \\
\hline Floor 1 Lobby Hall & 240 & 2,400 & 0.0 & & 1.0 & 0.4 & 0.0 & 12.0 & 0.0 & 0.00 & 0.0 \\
\hline Floor 1 Lobby Toilet & 54 & 540 & 0.0 & & 0.9 & 0.4 & 0.0 & 108.0 & 90.0 & 0.40 & 0.0 \\
\hline Floor 1 Locker Room & 660 & 6,600 & 71.8 & & 0.8 & 3.0 & 0.0 & 138.0 & 0.0 & 0.12 & 0.0 \\
\hline Floor 1 Locker Room Hall & 496 & 4,960 & 0.0 & & 1.0 & 0.4 & 0.0 & 24.8 & 0.0 & 0.00 & 0.0 \\
\hline Floor 1 Lounge & 360 & 3,600 & 71.8 & & 0.8 & 3.0 & 0.0 & 75.3 & 0.0 & 0.00 & 0.0 \\
\hline Floor 1 Med Gas & 56 & 560 & 0.0 & & 0.9 & 0.1 & 0.0 & 8.4 & 0.0 & 0.96 & 0.0 \\
\hline Floor $1 \mathrm{MRI}$ Control Room & 168 & 1,680 & 53.8 & & 0.4 & 10.0 & 0.0 & 50.4 & 168.0 & 0.11 & 1.0 \\
\hline Floor $1 \mathrm{MRI}$ Hall & 147 & 1,470 & 0.0 & & 1.0 & 0.4 & 0.0 & 7.3 & 0.0 & 0.00 & 0.0 \\
\hline Floor 1 MRI Room & 440 & 4,400 & 53.8 & & 0.4 & 10.0 & 0.0 & 132.0 & 440.0 & 0.00 & 1.0 \\
\hline Floor 1 MRI Toilet & 54 & 540 & 0.0 & & 0.9 & 0.4 & 0.0 & 108.0 & 90.0 & 0.40 & 0.0 \\
\hline Floor 1 Nourishment & 182 & 1,820 & 53.8 & & 1.0 & 2.0 & 0.0 & 67.6 & 0.0 & 0.00 & 0.0 \\
\hline Floor 1 Nurse Hall & 496 & 4,960 & 0.0 & & 1.0 & 0.4 & 0.0 & 24.8 & 0.0 & 0.00 & 0.0 \\
\hline Floor 1 Nurse Janitor & 54 & 540 & 0.0 & & 0.9 & 0.1 & 0.0 & 8.1 & 0.0 & 0.00 & 0.0 \\
\hline Floor 1 Nurse Station & 261 & 2,610 & 53.8 & & 1.0 & 2.0 & 0.0 & 97.0 & 0.0 & 0.00 & 0.0 \\
\hline Floor 1 Nurse Toilet & 54 & 540 & 0.0 & & 0.9 & 0.4 & 0.0 & 108.0 & 90.0 & 0.00 & 0.0 \\
\hline Floor 1 Office & 483 & 4,830 & 215.3 & & 1.1 & 1.1 & 0.0 & 44.9 & 0.0 & 0.00 & 0.0 \\
\hline Floor 1 Operating Room 1 & 460 & 4,600 & 53.8 & & 2.2 & 4.0 & 7.0 & 230.0 & 0.0 & 0.33 & 6.0 \\
\hline Floor 1 Operating Room 2 & 480 & 4,800 & 53.8 & & 2.2 & 4.0 & 7.0 & 240.0 & 0.0 & 0.18 & 6.0 \\
\hline Floor 1 Operating Room 3 & 476 & 4,760 & 53.8 & & 2.2 & 4.0 & 7.0 & 238.0 & 0.0 & 0.00 & 6.0 \\
\hline Floor 1 PACU & 108 & 1,080 & 53.8 & & 0.8 & 3.0 & 0.0 & 36.0 & 0.0 & 0.00 & 1.0 \\
\hline Floor 1 Pre-Op Hall & 528 & 5,280 & 0.0 & & 1.0 & 0.4 & 0.0 & 26.4 & 0.0 & 0.00 & 0.0 \\
\hline Floor 1 Pre-Op Room 1 & 189 & 1,890 & 107.6 & & 0.7 & 2.0 & 0.0 & 63.0 & 0.0 & 0.08 & 1.0 \\
\hline Floor 1 Pre-Op Room 2 & 338 & 3,380 & 107.6 & & 0.7 & 2.0 & 0.0 & 112.7 & 0.0 & 0.00 & 1.0 \\
\hline Floor 1 Pre-Op Toilet & 54 & 540 & 0.0 & & 0.9 & 0.4 & 0.0 & 108.0 & 90.0 & 0.40 & 0.0 \\
\hline Floor 1 Procedure Room & 285 & 2,850 & 53.8 & & 2.7 & 3.0 & 0.0 & 142.5 & 0.0 & 0.24 & 1.0 \\
\hline Floor 1 Reception & 509 & 5,090 & 35.9 & & 1.3 & 1.1 & 0.0 & 212.8 & 0.0 & 0.09 & 0.0 \\
\hline Floor 1 Reception Hall & 128 & 1,280 & 0.0 & & 1.0 & 0.4 & 0.0 & 6.4 & 0.0 & 0.00 & 0.0 \\
\hline Floor 1 Recovery Room & 540 & 5,400 & 53.8 & & 0.8 & 3.0 & 0.0 & 180.0 & 0.0 & 0.30 & 1.0 \\
\hline Floor 1 Scheduling & 119 & 1,190 & 215.3 & & 1.1 & 1.1 & 0.0 & 11.1 & 0.0 & 0.21 & 0.0 \\
\hline Floor 1 Scrub & 84 & 840 & 0.0 & & 1.0 & 0.4 & 0.0 & 4.2 & 0.0 & 0.00 & 0.0 \\
\hline Floor 1 Soil & 126 & 1,260 & 53.8 & & 1.2 & 2.0 & 0.0 & 189.0 & 210.0 & 0.00 & 0.0 \\
\hline Floor 1 Soil Hold & 56 & 560 & 53.8 & & 1.2 & 2.0 & 0.0 & 84.0 & 93.3 & 0.00 & 0.0 \\
\hline Floor 1 Soil Work & 180 & 1,800 & 53.8 & & 1.2 & 2.0 & 0.0 & 270.0 & 300.0 & 0.00 & 0.0 \\
\hline Floor 1 Step Down & 300 & 3,000 & 53.8 & & 0.8 & 3.0 & 0.0 & 100.0 & 0.0 & 0.44 & 1.0 \\
\hline Floor 1 Sterile Hall & 616 & 6,160 & 0.0 & & 1.0 & 0.4 & 0.0 & 30.8 & 0.0 & 0.05 & 0.0 \\
\hline Floor 1 Sterile Storage & 396 & 3,960 & 0.0 & & 0.9 & 0.1 & 0.0 & 59.4 & 0.0 & 0.00 & 0.0 \\
\hline Floor 1 Storage & 920 & 9,200 & 0.0 & & 0.9 & 0.1 & 0.0 & 138.0 & 0.0 & 0.24 & 0.0 \\
\hline Floor 1 Sub-Sterile & 196 & 1,960 & 0.0 & & 1.0 & 0.4 & 0.0 & 9.8 & 0.0 & 0.26 & 0.0 \\
\hline Floor 1 Utility Hall & 256 & 2,560 & 0.0 & & 1.0 & 0.4 & 0.0 & 12.8 & 0.0 & 0.22 & 0.0 \\
\hline Floor 1 Utility Janitor & 42 & 420 & 0.0 & & 0.9 & 0.1 & 0.0 & 6.3 & 0.0 & 0.00 & 0.0 \\
\hline Floor 1 Utility Room & 360 & 3,600 & 0.0 & & 0.9 & 0.1 & 0.0 & 54.0 & 0.0 & 0.18 & 0.0 \\
\hline Floor 1 Vestibule & 72 & 720 & 0.0 & & 1.0 & 0.4 & 0.0 & 3.6 & 0.0 & 0.40 & 0.0 \\
\hline Floor 2 Conference & 336 & 3,360 & 21.5 & & 1.3 & 1.0 & 0.0 & 312.2 & 0.0 & 0.43 & 0.0 \\
\hline Floor 2 Conference Toilet & 64 & 640 & 0.0 & & 0.9 & 0.4 & 0.0 & 128.0 & 106.7 & 0.00 & 0.0 \\
\hline Floor 2 Dictation & 70 & 700 & 215.3 & & 1.1 & 1.1 & 0.0 & 6.5 & 0.0 & 0.00 & 0.0 \\
\hline Floor 2 Exam 1 & 360 & 3,600 & 53.8 & & 1.5 & 1.1 & 0.0 & 108.0 & 0.0 & 0.42 & 0.0 \\
\hline Floor 2 Exam 2 & 540 & 5,400 & 53.8 & & 1.5 & 1.1 & 0.0 & 162.0 & 0.0 & 0.12 & 0.0 \\
\hline Floor 2 Exam 3 & 720 & 7,200 & 53.8 & & 1.5 & 1.1 & 0.0 & 216.0 & 0.0 & 0.12 & 0.0 \\
\hline Floor 2 Exam 4 & 84 & 840 & 53.8 & & 1.5 & 1.1 & 0.0 & 25.2 & 0.0 & 0.30 & 0.0 \\
\hline Floor 2 Exam 5 & 350 & 3,500 & 53.8 & & 1.5 & 1.1 & 0.0 & 105.0 & 0.0 & 0.26 & 0.0 \\
\hline Floor 2 Exam 6 & 225 & 2,250 & 53.8 & & 1.5 & 1.1 & 0.0 & 67.5 & 0.0 & 0.24 & 0.0 \\
\hline Floor 2 Exam 7 & 792 & 7,920 & 53.8 & & 1.5 & 1.1 & 0.0 & 237.6 & 0.0 & 0.11 & 0.0 \\
\hline Floor 2 Exam 8 & 270 & 2,700 & 53.8 & & 1.5 & 1.1 & 0.0 & 81.0 & 0.0 & 0.24 & 0.0 \\
\hline Floor 2 Exam 9 & 396 & 3,960 & 53.8 & & 1.5 & 1.1 & 0.0 & 118.8 & 0.0 & 0.11 & 0.0 \\
\hline Floor 2 Exam Hall 1 & 180 & 1,800 & 0.0 & & 1.0 & 0.4 & 0.0 & 9.0 & 0.0 & 0.12 & 0.0 \\
\hline
\end{tabular}




\begin{tabular}{|c|c|c|c|c|c|c|c|c|c|c|c|}
\hline Building Type/Zone & $\begin{array}{c}\text { Area } \\
\mathrm{ft}^{2}\end{array}$ & $\begin{array}{c}\text { Vol. } \\
\mathrm{ft}^{3}\end{array}$ & $\begin{array}{c}\mathrm{ft}^{2} \mathrm{I} \\
\text { person }\end{array}$ & \begin{tabular}{|c|}
1989 \\
$\begin{array}{c}\text { Lights } \\
\mathrm{Wft}^{2}\end{array}$ \\
\end{tabular} & $\begin{array}{c}2004 \\
\text { Lights } \text { Wft }^{2} \\
\end{array}$ & $\begin{array}{l}\text { Elec. } \\
\text { Proc. } \\
\text { W/ft }^{2} \\
\end{array}$ & $\begin{array}{c}\text { Gas } \\
\text { Proc. } \\
\text { W/ft }^{2} \\
\end{array}$ & $\begin{array}{c}\text { Vent. } \\
\text { cfm }\end{array}$ & $\begin{array}{c}\text { Exhst } \\
\text { cfm }\end{array}$ & $\begin{array}{l}\text { Infil. } \\
\text { ACH } \\
\end{array}$ & $\begin{array}{l}\text { SWH } \\
\text { gal/h }\end{array}$ \\
\hline Floor 2 Exam Hall 2 & 180 & $\overline{11,800}$ & 0.0 & & $\overline{c 1.0}$ & 0.4 & 0.0 & 9.0 & 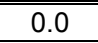 & 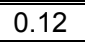 & 0.0 \\
\hline Floor 2 Exam Hall 3 & 180 & 1,800 & 0.0 & & 1.0 & 0.4 & 0.0 & 9.0 & 0.0 & 0.12 & 0.0 \\
\hline Floor 2 Exam Hall 4 & 198 & 1,980 & 0.0 & & 1.0 & 0.4 & 0.0 & 9.9 & 0.0 & 0.11 & 0.0 \\
\hline Floor 2 Exam Hall 5 & 198 & 1,980 & 0.0 & & 1.0 & 0.4 & 0.0 & 9.9 & 0.0 & 0.11 & 0.0 \\
\hline Floor 2 Exam Hall 6 & 198 & 1,980 & 0.0 & & 1.0 & 0.4 & 0.0 & 9.9 & 0.0 & 0.11 & 0.0 \\
\hline Floor 2 Janitor & 63 & 630 & 0.0 & & 0.9 & 0.1 & 0.0 & 9.4 & 0.0 & 0.91 & 0.0 \\
\hline Floor 2 Lounge & 80 & 800 & 71.8 & & 0.8 & 3.0 & 0.0 & 16.7 & 0.0 & 0.00 & 0.0 \\
\hline Floor 2 Nurse Station 1 & 150 & 1,500 & 53.8 & & 1.0 & 2.0 & 0.0 & 55.7 & 0.0 & 0.00 & 0.0 \\
\hline Floor 2 Nurse Station 2 & 180 & 1,800 & 53.8 & & 1.0 & 2.0 & 0.0 & 66.9 & 0.0 & 0.00 & 0.0 \\
\hline Floor 2 Office & 560 & 5,600 & 215.3 & & 1.1 & 1.1 & 0.0 & 52.0 & 0.0 & 0.26 & 0.0 \\
\hline Floor 2 Office Hall & 444 & 4,440 & 0.0 & & 1.0 & 0.4 & 0.0 & 22.2 & 0.0 & 0.00 & 0.0 \\
\hline Floor 2 Reception & 984 & 9,840 & 35.9 & & 1.3 & 1.1 & 0.0 & 411.4 & 0.0 & 0.18 & 0.0 \\
\hline Floor 2 Reception Hall & 564 & 5,640 & 0.0 & & 1.0 & 0.4 & 0.0 & 28.2 & 0.0 & 0.60 & 0.0 \\
\hline Floor 2 Reception Toilet & 126 & 1,260 & 0.0 & & 0.9 & 0.4 & 0.0 & 252.0 & 210.0 & 0.00 & 0.0 \\
\hline Floor 2 Scheduling 1 & 324 & 3,240 & 215.3 & & 1.1 & 1.1 & 0.0 & 30.1 & 0.0 & 0.00 & 0.0 \\
\hline Floor 2 Scheduling 2 & 342 & 3,420 & 215.3 & & 1.1 & 1.1 & 0.0 & 31.8 & 0.0 & 0.00 & 0.0 \\
\hline Floor 2 Storage 1 & 56 & 560 & 0.0 & & 0.9 & 0.1 & 0.0 & 8.4 & 0.0 & 0.00 & 0.0 \\
\hline Floor 2 Storage 2 & 120 & 1,200 & 0.0 & & 0.9 & 0.1 & 0.0 & 18.0 & 0.0 & 0.00 & 0.0 \\
\hline Floor 2 Storage 3 & 144 & 1,440 & 0.0 & & 0.9 & 0.1 & 0.0 & 21.6 & 0.0 & 0.00 & 0.0 \\
\hline Floor 2 Utility & 126 & 1,260 & 0.0 & & 0.9 & 0.1 & 0.0 & 18.9 & 0.0 & 0.26 & 0.0 \\
\hline Floor 2 Work & 1,690 & 16,900 & 215.3 & & 1.1 & 1.1 & 0.0 & 157.0 & 0.0 & 0.05 & 0.0 \\
\hline Floor 2 Work Hall & 834 & 8,340 & 0.0 & & 1.0 & 0.4 & 0.0 & 41.7 & 0.0 & 0.03 & 0.0 \\
\hline Floor 2 Work Toilet & 54 & 540 & 0.0 & & 0.9 & 0.4 & 0.0 & 108.0 & 0.0 & 0.40 & 0.0 \\
\hline Floor 2 X-Ray & 900 & 9,000 & 53.8 & & 0.4 & 10.0 & 0.0 & 270.0 & 0.0 & 0.00 & 1.0 \\
\hline Floor 3 Dressing Room & 42 & 420 & 215.3 & & 1.1 & 1.1 & 0.0 & 3.9 & 0.0 & 0.00 & 0.0 \\
\hline Floor 3 Elevator Hall & 370 & 3,700 & 0.0 & & 1.0 & 0.4 & 0.0 & 18.5 & 0.0 & 0.04 & 0.0 \\
\hline Floor 3 Humid & 108 & 1,080 & 215.3 & & 1.1 & 1.1 & 0.0 & 10.0 & 0.0 & 0.00 & 0.0 \\
\hline Floor 3 Janitor & 63 & 630 & 0.0 & & 0.9 & 0.1 & 0.0 & 9.4 & 0.0 & 0.91 & 0.0 \\
\hline Floor 3 Locker & 120 & 1,200 & 71.8 & & 0.8 & 3.0 & 0.0 & 25.1 & 0.0 & 0.00 & 0.0 \\
\hline Floor 3 Lounge & 759 & 7,590 & 71.8 & & 0.8 & 3.0 & 0.0 & 158.7 & 0.0 & 0.11 & 0.0 \\
\hline Floor 3 Lounge Toilet & 192 & 1,920 & 0.0 & & 0.9 & 0.4 & 0.0 & 384.0 & 320.0 & 0.22 & 0.0 \\
\hline Floor 3 Mechanical & 350 & 3,500 & 0.0 & & 1.5 & 5.0 & 0.0 & 17.5 & 0.0 & 0.26 & 0.0 \\
\hline Floor 3 Mechanical Hall & 300 & 3,000 & 0.0 & & 1.0 & 0.4 & 0.0 & 15.0 & 0.0 & 0.00 & 0.0 \\
\hline Floor 3 Office & 3,036 & 30,360 & 215.3 & & 1.1 & 1.1 & 0.0 & 282.1 & 0.0 & 0.09 & 0.0 \\
\hline Floor 3 Office Hall & 834 & 8,340 & 0.0 & & 1.0 & 0.4 & 0.0 & 41.7 & 0.0 & 0.03 & 0.0 \\
\hline Floor 3 Office Toilet & 54 & 540 & 0.0 & & 0.9 & 0.4 & 0.0 & 108.0 & 90.0 & 0.40 & 0.0 \\
\hline Floor 3 Physical Therapy 1 & 1,300 & 13,000 & 53.8 & & 0.9 & 1.5 & 0.0 & 362.3 & 0.0 & 0.23 & 1.0 \\
\hline Floor 3 Physical Therapy 2 & 592 & 5,920 & 53.8 & & 0.9 & 1.5 & 0.0 & 165.0 & 0.0 & 0.00 & 1.0 \\
\hline Floor 3 Physical Therapy Toilet & 84 & 840 & 0.0 & & 0.9 & 0.4 & 0.0 & 168.0 & 140.0 & 0.00 & 0.0 \\
\hline Floor 3 Storage 1 & 108 & 1,080 & 0.0 & & 0.9 & 0.1 & 0.0 & 16.2 & 0.0 & 0.00 & 0.0 \\
\hline Floor 3 Storage 2 & 84 & 840 & 0.0 & & 0.9 & 0.1 & 0.0 & 12.6 & 0.0 & 0.00 & 0.0 \\
\hline Floor 3 Treatment & 476 & 4,760 & 53.8 & & 1.5 & 1.1 & 0.0 & 142.8 & 0.0 & 0.00 & 0.0 \\
\hline Floor 3 Undeveloped 1 & 2,268 & 22,680 & 215.3 & & 1.1 & 1.1 & 0.0 & 340.2 & 0.0 & 0.11 & 0.0 \\
\hline Floor 3 Undeveloped 2 & 1,152 & 11,520 & 215.3 & & 1.1 & 1.1 & 0.0 & 172.8 & 0.0 & 0.17 & 0.0 \\
\hline Floor 3 Utility & 216 & 2,160 & 0.0 & & 0.9 & 0.1 & 0.0 & 32.4 & 0.0 & 0.00 & 0.0 \\
\hline Floor 3 Work & 574 & 5,740 & 215.3 & & 1.1 & 1.1 & 0.0 & 53.3 & 0.0 & 0.26 & 0.0 \\
\hline NE Stair & 168 & 5,040 & 0.0 & & 1.0 & 0.4 & 0.0 & 8.4 & 0.0 & 0.74 & 0.0 \\
\hline NW Elevator & 140 & 4,200 & 0.0 & & 1.0 & 0.4 & 0.0 & 7.0 & 0.0 & 0.69 & 0.0 \\
\hline NW Stair & 192 & 5,760 & 0.0 & & 1.0 & 0.4 & 0.0 & 9.6 & 0.0 & 0.74 & 0.0 \\
\hline SW Stair & 96 & 2,880 & 0.0 & & 1.0 & 0.4 & 0.0 & 4.8 & 0.0 & 0.74 & 0.0 \\
\hline Retail & 24,692 & 494,171 & & & & & & & & & \\
\hline Back_Space & 4,089 & 81,836 & 300.0 & 1.17 & 0.8 & 0.8 & 0.0 & 613.4 & 0.0 & 0.37 & 0.0 \\
\hline Core_Retail & 17,227 & 344,775 & 66.7 & 3.37 & 1.7 & 0.3 & 0.0 & 5168.2 & 0.0 & 0.22 & 0.0 \\
\hline Point_of_Sale & 1,623 & 32,487 & 66.7 & 3.37 & 1.7 & 2.0 & 0.0 & 487.0 & 0.0 & 0.40 & 0.0 \\
\hline Front_Retail & 1,623 & 32,487 & 66.7 & 3.37 & 1.7 & 0.3 & 0.0 & 487.0 & 0.0 & 0.40 & 0.0 \\
\hline Front_Entry & 129 & 2,585 & 66.7 & 3.37 & 1.1 & 0.0 & 0.0 & 0.0 & 0.0 & 0.54 & 0.0 \\
\hline
\end{tabular}




\begin{tabular}{|c|c|c|c|c|c|c|c|c|c|c|c|}
\hline Building Type/Zone & $\begin{array}{c}\text { Area } \\
\mathrm{ft}^{2}\end{array}$ & $\begin{array}{c}\text { Vol. } \\
\mathrm{ft}^{3}\end{array}$ & $\begin{array}{c}\mathrm{ft}^{2} / \\
\text { person }\end{array}$ & $\begin{array}{c}1989 \\
\text { Lights } \\
\text { Wft }^{2} \\
\end{array}$ & $\begin{array}{c}2004 \\
\text { Lights } \\
\text { Wft }^{2} \\
\end{array}$ & $\begin{array}{l}\text { Elec. } \\
\text { Proc. } \\
\text { W/ft }\end{array}$ & $\begin{array}{l}\text { Gas } \\
\text { Proc. } \\
\text { W/ft }\end{array}$ & $\begin{array}{l}\text { Vent. } \\
\text { cfm }\end{array}$ & $\begin{array}{l}\text { Exhst } \\
\text { cfm }\end{array}$ & $\begin{array}{l}\text { Infil. } \\
\text { ACH }\end{array}$ & $\begin{array}{l}\text { sWh } \\
\text { gal/h }\end{array}$ \\
\hline Primary Education & 73,959 & 970,588 & & & & & & & & & \\
\hline $\begin{array}{l}\text { CORNER_CLASS_1_POD_1_Z } \\
\text { N_1_FLR_1 }\end{array}$ & 1,066 & 13,985 & 43.1 & 2.00 & 1.4 & 1.4 & 0.0 & 371.3 & 0.0 & 0.49 & 0.0 \\
\hline $\begin{array}{l}\text { MULT_CLASS_1_POD_1_ZN_1 } \\
\text { FLR_1 }\end{array}$ & 5,134 & 67,380 & 43.1 & 2.00 & 1.4 & 1.4 & 0.0 & 1788.8 & 0.0 & 0.39 & 0.0 \\
\hline $\begin{array}{l}\text { CORRIDOR_POD_1_ZN_1_FL } \\
\text { R_1 }\end{array}$ & 2,067 & 27,122 & 107.6 & 2.00 & 0.5 & 0.4 & 0.0 & 206.7 & 0.0 & 0.29 & 0.0 \\
\hline $\begin{array}{l}\text { CORNER_CLASS_2_POD_1_Z } \\
\text { N_1_FLR_1 }\end{array}$ & 1,066 & 13,985 & 43.1 & 2.00 & 1.4 & 1.4 & 0.0 & 371.3 & 0.0 & 0.49 & 0.0 \\
\hline $\begin{array}{l}\text { MULT_CLASS_2_POD_1_ZN_1 } \\
\text { FLR_1 }\end{array}$ & 5,134 & 67,380 & 43.1 & 2.00 & 1.4 & 1.4 & 0.0 & 1788.8 & 0.0 & 0.39 & 0.0 \\
\hline $\begin{array}{l}\text { CORNER_CLASS_1_POD_2_Z } \\
\text { N_1_FLR_1 }\end{array}$ & 1,066 & 13,985 & 43.1 & 2.00 & 1.4 & 1.4 & 0.0 & 371.3 & 0.0 & 0.49 & 0.0 \\
\hline $\begin{array}{l}\text { MULT_CLASS_1_POD_2_ZN_1 } \\
\text { FLR_1 }\end{array}$ & 5,134 & 67,380 & 43.1 & 2.00 & 1.4 & 1.4 & 0.0 & 1788.8 & 0.0 & 0.39 & 0.0 \\
\hline $\begin{array}{l}\text { CORRIDOR_POD_2_ZN_1_FL } \\
\text { R_1 }\end{array}$ & 2,067 & 27,122 & 107.6 & 0.90 & 0.5 & 0.4 & 0.0 & 206.7 & 0.0 & 0.29 & 0.0 \\
\hline $\begin{array}{l}\text { CORNER_CLASS_2_POD_2_Z } \\
\text { N_1_FLR_1 }\end{array}$ & 1,066 & 13,985 & 43.1 & 2.00 & 1.4 & 1.4 & 0.0 & 371.3 & 0.0 & 0.49 & 0.0 \\
\hline $\begin{array}{l}\text { MULT_CLASS_2_POD_2_ZN_1 } \\
\text { FLR_1 }\end{array}$ & 5,134 & 67,380 & 43.1 & 2.00 & 1.4 & 1.4 & 0.0 & 1788.8 & 0.0 & 0.39 & 0.0 \\
\hline $\begin{array}{l}\text { CORNER_CLASS_1_POD_3_Z } \\
\text { N_1_FLR_1 }\end{array}$ & 1,066 & 13,985 & 43.1 & 2.00 & 1.4 & 1.4 & 0.0 & 371.3 & 0.0 & 0.49 & 0.0 \\
\hline $\begin{array}{l}\text { MULT_CLASS_1_POD_3_ZN_1 } \\
\text { FLR_1 }\end{array}$ & 5,134 & 67,380 & 43.1 & 2.00 & 1.4 & 1.4 & 0.0 & 1788.8 & 0.0 & 0.39 & 0.0 \\
\hline $\begin{array}{l}\text { CORRIDOR_POD_3_ZN_1_FL } \\
\text { R_1 }\end{array}$ & 2,067 & 27,122 & 107.6 & 0.90 & 0.5 & 0.4 & 0.0 & \begin{tabular}{|l}
206.7 \\
\end{tabular} & 0.0 & 0.29 & 0.0 \\
\hline $\begin{array}{l}\text { CORNER_CLASS_2_POD_3_Z } \\
\text { N_1_FLR_1 }\end{array}$ & 1,066 & 13,985 & 43.1 & 2.00 & 1.4 & 1.4 & 0.0 & 371.3 & 0.0 & 0.49 & 0.0 \\
\hline $\begin{array}{l}\text { MULT_CLASS_2_POD_3_ZN_1 } \\
\text { FLR_1 }\end{array}$ & 3,391 & 44,496 & 43.1 & 2.00 & 1.4 & 0.7 & 0.0 & 1181.3 & 0.0 & 0.39 & 0.0 \\
\hline $\begin{array}{l}\text { COMPUTER_CLASS_ZN_1_FL } \\
\text { R_1 }\end{array}$ & 1,744 & 22,884 & 35.8 & 2.00 & 1.4 & 1.9 & 0.0 & \begin{tabular}{|l|}
729.7 \\
\end{tabular} & 0.0 & 0.39 & 0.0 \\
\hline $\begin{array}{l}\text { MAIN_CORRIDOR_ZN_1_FLR_ } \\
1\end{array}$ & 5,877 & 77,127 & 0.0 & 1.04 & 0.5 & 0.4 & 0.0 & \begin{tabular}{|l|}
587.7 \\
\end{tabular} & 0.0 & 0.29 & 0.0 \\
\hline LOBBY_ZN_1_FLR_1 & 1,841 & 24,155 & 0.0 & 1.14 & 1.3 & 0.4 & 0.0 & 184.1 & 0.0 & 0.39 & 0.0 \\
\hline MECH_ZN_1_FLR_1 & 2,713 & 35,597 & \begin{tabular}{|l|}
1076.4 \\
\end{tabular} & 0.77 & 1.5 & 0.9 & 0.0 & 135.6 & 0.0 & 0.27 & 0.0 \\
\hline BATH_ZN_1_FLR_1 & 2,045 & 26,839 & 1076.4 & 0.90 & 0.9 & 0.4 & 0.0 & 600.0 & 600.0 & 0.33 & 56.5 \\
\hline OFFICES_ZN_1_FLR_1 & 4,747 & 62,295 & 215.3 & 1.89 & 1.1 & 1.0 & 0.0 & 441.0 & 0.0 & 0.38 & 0.0 \\
\hline GYM_ZN_1_FLR_1 & 3,843 & 50,429 & 35.8 & 1.07 & 1.4 & 0.5 & 0.0 & 2144.1 & 0.0 & 0.32 & 0.0 \\
\hline KITCHEN_ZN_1_FLR_1 & 1,808 & 23,731 & 71.8 & 1.60 & 1.2 & 17.7 & 88.7 & 377.8 & 3300.0 & 0.32 & 100.0 \\
\hline CAFETERIA_ZN_1_FLR_1 & 3,391 & 44,496 & 15.0 & 1.40 & 1.4 & 2.4 & 0.0 & 4520.8 & 0.0 & 0.40 & 0.0 \\
\hline $\begin{array}{l}\text { LIBRARY_MEDIA_CENTER_Z } \\
\text { N_1_FLR_1 }\end{array}$ & 4,295 & 56,362 & 46.8 & 2.11 & 1.3 & 1.4 & 0.0 & 1375.9 & 0.0 & 0.38 & 0.0 \\
\hline Secondary Education & 210,886 & $3,362,522$ & & & & & & & & & \\
\hline $\begin{array}{l}\text { CORNER_CLASS_1_POD_1_Z } \\
\text { N_1_FLR_1 }\end{array}$ & 1,066 & 13,985 & 43.1 & 2.00 & 1.4 & 0.9 & 0.0 & 371.3 & 0.0 & 0.22 & 0.0 \\
\hline $\begin{array}{l}\text { CORNER_CLASS_1_POD_1_Z } \\
\text { N_1_FLR_2 }\end{array}$ & 1,066 & 13,985 & 43.1 & 2.00 & 1.4 & 0.9 & 0.0 & 371.3 & 0.0 & 0.49 & 0.0 \\
\hline $\begin{array}{l}\text { MULT_CLASS_1_POD_1_ZN_1 } \\
\text { FLR_1 }\end{array}$ & 5,134 & 67,380 & 43.1 & 2.00 & 1.4 & 0.9 & 0.0 & 1788.8 & 0.0 & 0.12 & 0.0 \\
\hline $\begin{array}{l}\text { MULT_CLASS_1_POD_1_ZN_1 } \\
\text { FLR_2 }\end{array}$ & 5,134 & 67,380 & 43.1 & 2.00 & 1.4 & 0.9 & 0.0 & 1788.8 & 0.0 & 0.39 & 0.0 \\
\hline $\begin{array}{l}\text { CORRIDOR_POD_1_ZN_1_FL } \\
\text { R_1 }\end{array}$ & 3,444 & 45,203 & 107.6 & 0.86 & 0.5 & 0.4 & 0.0 & 344.4 & 0.0 & 0.02 & 0.0 \\
\hline $\begin{array}{l}\text { CORRIDOR_POD_1_ZN_1_FL } \\
\text { R_2 }\end{array}$ & 3,444 & 45,203 & 107.6 & 0.86 & 0.5 & 0.4 & 0.0 & 344.4 & 0.0 & 0.29 & 0.0 \\
\hline $\begin{array}{l}\text { CORNER_CLASS_2_POD_1_Z } \\
\text { N_1_FLR_1 }\end{array}$ & 1,066 & 13,985 & 43.1 & 2.00 & 1.4 & 0.9 & 0.0 & 371.3 & 0.0 & 0.22 & 0.0 \\
\hline CORNER_CLASS_2_POD_1_Z & 1,066 & 13,985 & 43.1 & 2.00 & 1.4 & 0.9 & 0.0 & 371.3 & 0.0 & 0.49 & 0.0 \\
\hline
\end{tabular}




\begin{tabular}{|c|c|c|c|c|c|c|c|c|c|c|c|}
\hline Building Type/Zone & $\begin{array}{c}\text { Area } \\
\mathrm{ft}^{2}\end{array}$ & $\begin{array}{l}\text { Vol. } \\
\mathrm{ft}^{3}\end{array}$ & $\begin{array}{c}\mathrm{ft}^{2} l \\
\text { person }\end{array}$ & $\begin{array}{c}1989 \\
\text { Lights } \\
\text { Wft }^{2}\end{array}$ & $\begin{array}{c}2004 \\
\text { Lights } \\
\text { Wft }^{2} \\
\end{array}$ & $\begin{array}{l}\text { Elec. } \\
\text { Proc. } \\
\text { W/ft }^{2}\end{array}$ & $\begin{array}{l}\text { Gas } \\
\text { Proc. } \\
\text { W/ft }\end{array}$ & $\begin{array}{l}\text { Vent. } \\
\text { cfm }\end{array}$ & $\begin{array}{c}\text { Exhst } \\
\text { cfm }\end{array}$ & $\begin{array}{l}\text { Infil. } \\
\text { ACH } \\
\end{array}$ & $\begin{array}{l}\text { SWH } \\
\text { gal/h }\end{array}$ \\
\hline $\begin{array}{l}\text { N_1_FLR_2 } \\
\end{array}$ & & & & & & & & & & & \\
\hline $\begin{array}{l}\text { MULT_CLASS_2_POD_1_ZN_1 } \\
\text { FLR_1 }\end{array}$ & 5,134 & 67,380 & 43.1 & 2.00 & 1.4 & 0.9 & 0.0 & 1788.8 & 0.0 & 0.12 & 0.0 \\
\hline $\begin{array}{l}\text { MULT_CLASS_2_POD_1_ZN_1 } \\
\text { FLR_2 }\end{array}$ & 5,134 & 67,380 & 43.1 & 2.00 & 1.4 & 0.9 & 0.0 & 1788.8 & 0.0 & 0.39 & 0.0 \\
\hline $\begin{array}{l}\text { CORNER_CLASS_1_POD_2_Z } \\
\text { N_1_FLR_1 }\end{array}$ & 1,066 & 13,985 & 43.1 & 2.00 & 1.4 & 0.9 & 0.0 & 371.3 & 0.0 & 0.22 & 0.0 \\
\hline $\begin{array}{l}\text { CORNER_CLASS_1_POD_2_Z } \\
\text { N_1_FLR_2 }\end{array}$ & 1,066 & 13,985 & 43.1 & 2.00 & 1.4 & 0.9 & 0.0 & 371.3 & 0.0 & 0.49 & 0.0 \\
\hline $\begin{array}{l}\text { MULT_CLASS_1_POD_2_ZN_1 } \\
\text { FLR_1 }\end{array}$ & 5,134 & 67,380 & 43.1 & 2.00 & 1.4 & 0.9 & 0.0 & 1788.8 & 0.0 & 0.12 & 0.0 \\
\hline $\begin{array}{l}\text { MULT_CLASS_1_POD_2_ZN_1 } \\
\text { FLR_2 }\end{array}$ & 5,134 & 67,380 & 43.1 & 2.00 & 1.4 & 0.9 & 0.0 & 1788.8 & 0.0 & 0.39 & 0.0 \\
\hline $\begin{array}{l}\text { CORRIDOR_POD_2_ZN_1_FL } \\
\text { R_1 }\end{array}$ & 3,444 & 45,203 & 107.6 & 0.86 & 0.5 & 0.4 & 0.0 & 344.4 & 0.0 & 0.02 & 0.0 \\
\hline $\begin{array}{l}\text { CORRIDOR_POD_2_ZN_1_FL } \\
\text { R_2 }\end{array}$ & 3,444 & 45,203 & 107.6 & 0.86 & 0.5 & 0.4 & 0.0 & 344.4 & 0.0 & 0.29 & 0.0 \\
\hline $\begin{array}{l}\text { CORNER_CLASS_2_POD_2_Z } \\
\text { N_1_FLR_1 }\end{array}$ & 1,066 & 13,985 & 43.1 & 2.00 & 1.4 & 0.9 & 0.0 & 371.3 & 0.0 & 0.22 & 0.0 \\
\hline $\begin{array}{l}\text { CORNER_CLASS_2_POD_2_Z } \\
\text { N_1_FLR_2 }\end{array}$ & 1,066 & 13,985 & 43.1 & 2.00 & 1.4 & 0.9 & 0.0 & 371.3 & 0.0 & 0.49 & 0.0 \\
\hline $\begin{array}{l}\text { MULT_CLASS_2_POD_2_ZN_1 } \\
\text { FLR_1 }\end{array}$ & 5,134 & 67,380 & 43.1 & 2.00 & 1.4 & 0.9 & 0.0 & 1788.8 & 0.0 & 0.12 & 0.0 \\
\hline $\begin{array}{l}\text { MULT_CLASS_2_POD_2_ZN_1 } \\
\text { FLR_2 }\end{array}$ & 5,134 & 67,380 & 43.1 & 2.00 & 1.4 & 0.9 & 0.0 & 1788.8 & 0.0 & 0.39 & 0.0 \\
\hline $\begin{array}{l}\text { CORNER_CLASS_1_POD_3_Z } \\
\text { N_1_FLR_1 }\end{array}$ & 1,066 & 13,985 & 43.1 & 2.00 & 1.4 & 0.9 & 0.0 & 371.3 & 0.0 & 0.22 & 0.0 \\
\hline $\begin{array}{l}\text { CORNER_CLASS_1_POD_3_Z } \\
\text { N_1_FLR_2 }\end{array}$ & 1,066 & 13,985 & 43.1 & 2.00 & 1.4 & 0.9 & 0.0 & 371.3 & 0.0 & 0.49 & 0.0 \\
\hline $\begin{array}{l}\text { MULT_CLASS_1_POD_3_ZN_1 } \\
\text { FLR_1 }\end{array}$ & 5,134 & 67,380 & 43.1 & 2.00 & 1.4 & 0.9 & 0.0 & 1788.8 & 0.0 & 0.12 & 0.0 \\
\hline $\begin{array}{l}\text { MULT_CLASS_1_POD_3_ZN_1 } \\
\text { FLR_2 }\end{array}$ & 5,134 & 67,380 & 43.1 & 2.00 & 1.4 & 1.9 & 0.0 & 1788.8 & 0.0 & 0.39 & 0.0 \\
\hline $\begin{array}{l}\text { CORRIDOR_POD_3_ZN_1_FL } \\
\text { R_1 }\end{array}$ & 3,444 & 45,203 & 107.6 & 0.86 & 0.5 & 0.4 & 0.0 & 344.4 & 0.0 & 0.02 & 0.0 \\
\hline $\begin{array}{l}\text { CORRIDOR_POD_3_ZN_1_FL } \\
\text { R } 2\end{array}$ & 3,444 & 45,203 & 107.6 & 0.86 & 0.5 & 0.4 & 0.0 & 344.4 & 0.0 & 0.29 & 0.0 \\
\hline $\begin{array}{l}\text { CORNER_CLASS_2_POD_3_Z } \\
\text { N } 1 \mathrm{FLR}^{-1} 1\end{array}$ & 1,066 & 13,985 & 43.1 & 2.00 & 1.4 & 0.9 & 0.0 & 371.3 & 0.0 & 0.22 & 0.0 \\
\hline $\begin{array}{l}\text { CORNER_CLASS_2_POD_3_Z } \\
\text { N_1_FLR_2 }\end{array}$ & 1,066 & 13,985 & 43.1 & 2.00 & 1.4 & 0.9 & 0.0 & 371.3 & 0.0 & 0.49 & 0.0 \\
\hline $\begin{array}{l}\text { MULT_CLASS_2_POD_3_ZN_1 } \\
\text { FLR_1 }\end{array}$ & 5,134 & 67,380 & 43.1 & 2.00 & 1.4 & 0.9 & 0.0 & 1788.8 & 0.0 & 0.12 & 0.0 \\
\hline $\begin{array}{l}\text { MULT_CLASS_2_POD_3_ZN_1 } \\
\text { FLR } 2\end{array}$ & 5,134 & 67,380 & 43.1 & 2.00 & 1.4 & 1.9 & 0.0 & 1788.8 & 0.0 & 0.39 & 0.0 \\
\hline MAIN_CORRIDOR_ZN_1_FLR & 12,271 & 161,035 & 0.0 & 1.00 & 0.5 & 0.4 & 0.0 & 1227.1 & 0.0 & 0.05 & 0.0 \\
\hline $\begin{array}{l}\text { MAIN_CORRIDOR_ZN_1_FLR } \\
2\end{array}$ & 12,271 & 161,035 & 0.0 & 1.00 & 0.5 & 0.4 & 0.0 & 1227.1 & 0.0 & 0.32 & 0.0 \\
\hline LOBBY_ZN_1_FLR_1 & 2,260 & 29,664 & 0.0 & 1.12 & 1.3 & 0.4 & 0.0 & 226.0 & 0.0 & 0.08 & 0.0 \\
\hline LOBBY_ZN_1_FLR_2 & 2,260 & 29,664 & 0.0 & 1.12 & 1.3 & 0.4 & 0.0 & 226.0 & 0.0 & 0.35 & 0.0 \\
\hline BATHROOMS ZN 1 FLR 1 & 2,260 & 29,664 & 107.6 & 0.89 & 0.9 & 0.4 & 0.0 & 600.0 & 0.0 & 0.15 & 52.2 \\
\hline BATHROOMS ZN 1 FLR 2 & 2,260 & 29,664 & 107.6 & 0.89 & 0.9 & 0.4 & 0.0 & 600.0 & 0.0 & 0.42 & 52.2 \\
\hline OFFICES_ZN_1_FLR_1 & 5,726 & 75,150 & 215.3 & 1.87 & 1.1 & 1.0 & 0.0 & 532.0 & 0.0 & 0.11 & 0.0 \\
\hline OFFICES_ZN_1_FLR_2 & 5,726 & 75,150 & 215.3 & 1.87 & 1.1 & 1.0 & 0.0 & 532.0 & 0.0 & 0.38 & 0.0 \\
\hline GYM_ZN_1_FLR_1 & 21,269 & 558,254 & 10.8 & 1.06 & 1.4 & 0.5 & 0.0 & 39520.0 & 0.0 & 0.14 & 189.5 \\
\hline AUX_GYM_ZN_1_FLR_1 & 13,433 & 352,582 & 35.8 & 1.10 & 1.4 & 0.5 & 0.0 & 7495.5 & 0.0 & 0.20 & 0.0 \\
\hline AUDITORIUM_ZN_1_FLR_1 & 10,635 & 279,127 & 10.8 & 1.12 & 0.9 & 0.5 & 0.0 & 14820.0 & 0.0 & 0.21 & 0.0 \\
\hline KITCHEN_ZN_1_FLR_1 & 2,325 & 30,512 & 71.8 & 1.56 & 1.2 & 20.7 & 104.0 & 485.8 & 4000.0 & 0.05 & 133.0 \\
\hline LIBRARY MEDIA CENTER Z Z & 9,042 & 118,657 & 46.8 & 0.00 & 1.3 & 0.9 & 0.0 & 2896.6 & 0.0 & 0.35 & 0.0 \\
\hline
\end{tabular}




\begin{tabular}{|c|c|c|c|c|c|c|c|c|c|c|c|}
\hline Building Type/Zone & $\begin{array}{l}\text { Area } \\
\mathrm{ft}^{2}\end{array}$ & $\begin{array}{c}\text { Vol. } \\
\mathrm{ft}^{3}\end{array}$ & $\begin{array}{c}\mathrm{ft}^{2} \mathrm{I} \\
\text { person }\end{array}$ & $\begin{array}{c}1989 \\
\text { Lights } \\
\text { Wft }^{2}\end{array}$ & $\begin{array}{c}2004 \\
\text { Lights } \\
\mathrm{Wft}^{2}\end{array}$ & $\begin{array}{l}\text { Elec. } \\
\text { Proc. } \\
\text { W/ft }^{2}\end{array}$ & $\begin{array}{l}\text { Gas } \\
\text { Proc. } \\
\text { W/ft }\end{array}$ & $\begin{array}{c}\text { Vent. } \\
\text { cfm }\end{array}$ & $\begin{array}{c}\text { Exhst } \\
\text { cfm }\end{array}$ & $\begin{array}{l}\text { Infil. } \\
\text { ACH }\end{array}$ & $\begin{array}{l}\text { SWH } \\
\text { gal/h }\end{array}$ \\
\hline \multicolumn{12}{|l|}{ N_1_FLR_2 } \\
\hline CAFETERIA_ZN_1_FLR_1 & 6,717 & 88,145 & 15.0 & 1.34 & 1.4 & 1.8 & 0.0 & 8955.6 & 0.0 & 0.09 & 0.0 \\
\hline MECH_ZN_1_FLR_1 & 3,681 & 48,310 & 1076.4 & 0.75 & 1.5 & 0.4 & 0.0 & 184.1 & 0.0 & 0.00 & 0.0 \\
\hline MECH_ZN_1_FLR_2 & 3,681 & 48,310 & 1076.4 & 0.75 & 1.5 & 0.4 & 0.0 & 184.1 & 0.0 & 0.00 & 0.0 \\
\hline Full Service Restaurant & 5,502 & 55,035 & & & & & & & & & \\
\hline Dining & 4,001 & 40,025 & 15.0 & 2.54 & 2.1 & 5.6 & 0.0 & 5335.3 & 0.0 & 0.52 & 0.0 \\
\hline Kitchen & 1,501 & 15,009 & 200.0 & 1.52 & 1.2 & 35.0 & 111.3 & 112.5 & 4000.0 & 0.63 & 133.0 \\
\hline Attic & 5,502 & 30,239 & 0.0 & 0.00 & 0.0 & 0.0 & 0.0 & 0.0 & 0.0 & 1.00 & 0.0 \\
\hline Supermarket & 45,002 & 900,272 & & & & & & & & & \\
\hline Office & 956 & 19,131 & 200.0 & 1.98 & 1.1 & 0.8 & 0.0 & 95.6 & 0.0 & 0.41 & 0.0 \\
\hline DryStorage & 6,694 & 133,914 & 300.0 & 1.11 & 0.8 & 0.8 & 0.0 & 1004.1 & 0.0 & 0.32 & 0.0 \\
\hline Deli & 2,419 & 48,390 & 125.0 & 2.78 & 1.7 & 5.0 & 2.5 & 725.7 & 0.0 & 0.29 & 5.0 \\
\hline Sales & 25,025 & 500,642 & 125.0 & 2.78 & 1.7 & 0.5 & 0.0 & 7507.6 & 0.0 & 0.20 & 0.0 \\
\hline Produce & 7,657 & 153,181 & 125.0 & 2.78 & 1.7 & 0.5 & 0.0 & 2297.1 & 0.0 & 0.27 & 0.0 \\
\hline Bakery & 2,250 & 45,014 & 125.0 & 2.78 & 1.7 & 5.0 & 2.5 & 675.0 & 2500.0 & 0.34 & 5.0 \\
\hline Small Hotel & 43,202 & 410,418 & & & & & & & & & \\
\hline REARSTAIRSFLR1 & 216 & 2,377 & 0.0 & 0.92 & 0.6 & 0.0 & 0.0 & 0.0 & 0.0 & 0.58 & 0.0 \\
\hline CORRIDORFLR1 & 1,620 & 17,820 & 0.0 & 0.88 & 0.5 & 0.0 & 0.0 & 0.0 & 0.0 & 0.07 & 0.0 \\
\hline REARSTORAGEFLR1 & 216 & 2,377 & 0.0 & 0.46 & 0.8 & 0.0 & 0.0 & 81.0 & 0.0 & 0.58 & 0.0 \\
\hline FRONTLOUNGEFLR1 & 1,755 & 19,307 & 33.2 & 1.31 & 1.1 & 1.4 & 0.0 & 0.0 & 0.0 & 0.19 & 0.0 \\
\hline RESTROOMFLR1 & 351 & 3,861 & 351.0 & 1.10 & 0.9 & 1.0 & 0.0 & \begin{tabular}{|l|}
794.1 \\
\end{tabular} & 0.0 & 0.13 & 0.0 \\
\hline MEETINGROOMFLR1 & 864 & 9,505 & 20.1 & 2.13 & 1.3 & 1.2 & 0.0 & 0.0 & 400.0 & 0.13 & 0.0 \\
\hline MECHANICALROOMFLR1 & 351 & 3,861 & 0.0 & 0.96 & 1.5 & 0.0 & 0.0 & 858.5 & 0.0 & 0.13 & 0.0 \\
\hline GUESTROOM101 & 351 & 3,861 & 234.0 & 1.92 & 1.1 & 1.3 & 0.0 & 17.6 & 0.0 & 0.13 & 1.8 \\
\hline GUESTROOM102 & 351 & 3,861 & 234.0 & 1.92 & 1.1 & 1.3 & 0.0 & 30.0 & 0.0 & 0.13 & 1.8 \\
\hline GUESTROOM103 & 351 & 3,861 & 234.0 & 1.92 & 1.1 & 1.3 & 0.0 & 30.0 & 0.0 & 0.13 & 1.8 \\
\hline GUESTROOM104 & 351 & 3,861 & 234.0 & 1.92 & 1.1 & 1.3 & 0.0 & 30.0 & 0.0 & 0.13 & 1.8 \\
\hline GUESTROOM105 & 351 & 3,861 & 234.0 & 1.92 & 1.1 & 1.3 & 0.0 & 30.0 & 0.0 & 0.13 & 1.8 \\
\hline EMPLOYEELOUNGEFLR1 & 351 & 3,861 & 31.9 & 1.65 & 1.2 & 7.2 & 0.0 & 30.0 & 0.0 & 0.13 & 0.0 \\
\hline LAUNDRYROOMFLR1 & 1,053 & 11,583 & 95.7 & 1.04 & 0.6 & 2.0 & 17.1 & 165.3 & 0.0 & 0.13 & 67.5 \\
\hline ELEVATORCOREFLR1 & 162 & 1,782 & 0.0 & 0.00 & 0.0 & 11.9 & 0.0 & 275.1 & 0.0 & 0.13 & 0.0 \\
\hline EXERCISECENTERFLR1 & 351 & 3,861 & 31.9 & 1.37 & 0.9 & 1.1 & 0.0 & 162.0 & 0.0 & 0.13 & 0.0 \\
\hline $\begin{array}{l}\text { FRONTOFFICEFLR1 } \\
\end{array}$ & 1,404 & 15,444 & 140.4 & 2.01 & 1.1 & 1.2 & 0.0 & 220.3 & 0.0 & 0.13 & 0.0 \\
\hline FRONTSTAIRSFLR1 & 216 & 2,376 & 0.0 & 0.92 & 0.6 & 0.0 & 0.0 & 200.1 & 0.0 & 0.58 & 0.0 \\
\hline FRONTSTORAGEFLR1 & 135 & 1,485 & 0.0 & 0.53 & 0.8 & 0.0 & 0.0 & 0.0 & 0.0 & 0.13 & 0.0 \\
\hline REARSTAIRSFLR2 & 216 & 1,944 & 0.0 & 0.82 & 0.6 & 0.0 & 0.0 & 0.0 & 0.0 & 0.58 & 0.0 \\
\hline CORRIDORFLR2 & 1,350 & 12,150 & 0.0 & 0.86 & 0.5 & 0.0 & 0.0 & 0.0 & 0.0 & 0.06 & 0.0 \\
\hline REARSTORAGEFLR2 & 216 & 1,945 & 0.0 & 0.41 & 0.8 & 0.0 & 0.0 & 67.5 & 0.0 & 0.58 & 0.0 \\
\hline GUESTROOM201 & 351 & 3,159 & 234.0 & 1.74 & 1.1 & 1.3 & 0.0 & 0.0 & 0.0 & 0.41 & 1.8 \\
\hline GUESTROOM202_205 & 1,404 & 12,637 & 234.0 & 1.74 & 1.1 & 1.3 & 0.0 & 30.0 & 0.0 & 0.13 & 7.0 \\
\hline GUESTROOM206_208 & 1,134 & 10,207 & 252.0 & 1.74 & 1.1 & 1.3 & 0.0 & 120.0 & 0.0 & 0.13 & 5.3 \\
\hline GUESTROOM209_212 & 1,404 & 12,637 & 234.0 & 1.74 & 1.1 & 1.3 & 0.0 & 90.0 & 0.0 & 0.13 & 7.0 \\
\hline GUESTROOM213 & 351 & 3,159 & 234.0 & 1.74 & 1.1 & 1.3 & 0.0 & 120.0 & 0.0 & 0.13 & 1.8 \\
\hline GUESTROOM214 & 351 & 3,159 & 234.0 & 1.74 & 1.1 & 1.3 & 0.0 & 30.0 & 0.0 & 0.13 & 1.8 \\
\hline GUESTROOM215_218 & 1,404 & 12,636 & 234.0 & 1.74 & 1.1 & 1.3 & 0.0 & 30.0 & 0.0 & 0.13 & 7.0 \\
\hline ELEVATORCOREFLR2 & 162 & 1,458 & 0.0 & 0.00 & 0.0 & 0.0 & 0.0 & 120.0 & 0.0 & 0.13 & 0.0 \\
\hline GUESTROOM219 & 351 & 3,159 & 234.0 & 1.74 & 1.1 & 1.3 & 0.0 & 0.0 & 0.0 & 0.13 & 1.8 \\
\hline GUESTROOM220_223 & 1,404 & 12,636 & 234.0 & 1.74 & 1.1 & 1.3 & 0.0 & 30.0 & 0.0 & 0.13 & 7.0 \\
\hline GUESTROOM224 & 351 & 3,159 & 234.0 & 1.74 & 1.1 & 1.3 & 0.0 & 120.0 & 0.0 & 0.13 & 1.8 \\
\hline FRONTSTORAGEFLR2 & 135 & 1,215 & 0.0 & 0.45 & 0.8 & 0.0 & 0.0 & 30.0 & 0.0 & 0.13 & 0.0 \\
\hline FRONTSTAIRSFLR2 & 216 & 1,944 & 0.0 & 0.82 & 0.6 & 0.0 & 0.0 & 0.0 & 0.0 & 0.58 & 0.0 \\
\hline REARSTAIRSFLR3 & 216 & 1,944 & 0.0 & 0.82 & 0.6 & 0.0 & 0.0 & 0.0 & 0.0 & 0.58 & 0.0 \\
\hline CORRIDORFLR3 & 1,350 & 12,150 & 0.0 & 0.86 & 0.5 & 0.0 & 0.0 & 0.0 & 0.0 & 0.06 & 0.0 \\
\hline REARSTORAGEFLR3 & 216 & 1,945 & 0.0 & 0.41 & 0.8 & 0.0 & 0.0 & 67.5 & 0.0 & 0.58 & 0.0 \\
\hline GUESTROOM301 & 351 & 3,159 & 234.0 & 1.74 & 1.1 & 1.3 & 0.0 & 0.0 & 0.0 & 0.41 & 1.8 \\
\hline GUESTROOM302_305 & 1,404 & 12,637 & 234.0 & 1.74 & 1.1 & 1.3 & 0.0 & 30.0 & 0.0 & 0.13 & 7.0 \\
\hline
\end{tabular}




\begin{tabular}{|c|c|c|c|c|c|c|c|c|c|c|c|}
\hline Building Type/Zone & $\begin{array}{c}\text { Area } \\
\mathrm{ft}^{2}\end{array}$ & $\begin{array}{c}\text { Vol. } \\
\mathrm{ft}^{3}\end{array}$ & $\begin{array}{c}\mathrm{ft}^{2} \mathrm{I} \\
\text { person }\end{array}$ & $\begin{array}{c}1989 \\
\text { Lights } \\
\text { Wft }^{2}\end{array}$ & $\begin{array}{c}2004 \\
\text { Lights } \\
\text { Wft }^{2} \\
\end{array}$ & $\begin{array}{l}\text { Elec. } \\
\text { Proc. } \\
\text { W/ft }\end{array}$ & $\begin{array}{l}\text { Gas } \\
\text { Proc. } \\
\text { W/ft }^{2}\end{array}$ & $\begin{array}{c}\text { Vent. } \\
\text { cfm }\end{array}$ & $\begin{array}{c}\text { Exhst } \\
\text { cfm }\end{array}$ & $\begin{array}{l}\text { Infil. } \\
\text { ACH }\end{array}$ & $\begin{array}{l}\text { SWH } \\
\text { gal/h }\end{array}$ \\
\hline "GUESTROOM306_308 & 1,134 & 10,207 & 252.0 & 1.74 & 1.1 & 1.3 & 0.0 & 120.0 & 0.0 & 0.13 & 5.3 \\
\hline GUESTROOM309_312 & 1,404 & 12,637 & 234.0 & 1.74 & 1.1 & 1.3 & 0.0 & 90.0 & 0.0 & 0.13 & 7.0 \\
\hline GUESTROOM313 & 351 & 3,159 & 234.0 & 1.74 & 1.1 & 1.3 & 0.0 & 120.0 & 0.0 & 0.13 & 1.8 \\
\hline GUESTROOM314 & 351 & 3,159 & 234.0 & 1.74 & 1.1 & 1.3 & 0.0 & 30.0 & 0.0 & 0.13 & 1.8 \\
\hline GUESTROOM315_318 & 1,404 & 12,636 & 234.0 & 1.74 & 1.1 & 1.3 & 0.0 & 30.0 & 0.0 & 0.13 & 7.0 \\
\hline ELEVATORCOREFLR3 & 162 & 1,458 & 0.0 & 0.00 & 0.0 & 0.0 & 0.0 & 120.0 & 0.0 & 0.13 & 0.0 \\
\hline GUESTROOM319 & 351 & 3,159 & 234.0 & 1.74 & 1.1 & 1.3 & 0.0 & 0.0 & 0.0 & 0.13 & 1.8 \\
\hline GUESTROOM320_323 & 1,404 & 12,636 & 234.0 & 1.74 & 1.1 & 1.3 & 0.0 & 30.0 & 0.0 & 0.13 & 7.0 \\
\hline GUESTROOM324 & 351 & 3,159 & 234.0 & 1.74 & 1.1 & 1.3 & 0.0 & 120.0 & 0.0 & 0.13 & 1.8 \\
\hline FRONTSTORAGEFLR3 & 135 & 1,215 & 0.0 & 0.45 & 0.8 & 0.0 & 0.0 & 30.0 & 0.0 & 0.13 & 0.0 \\
\hline FRONTSTAIRSFLR3 & 216 & 1,944 & 0.0 & 0.82 & 0.6 & 0.0 & 0.0 & 0.0 & 0.0 & 0.58 & 0.0 \\
\hline REARSTAIRSFLR4 & 216 & 1,944 & 0.0 & 0.41 & 0.6 & 0.0 & 0.0 & 0.0 & 0.0 & 0.98 & 0.0 \\
\hline CORRIDORFLR4 & 1,350 & 12,150 & 0.0 & 0.86 & 0.5 & 0.0 & 0.0 & 0.0 & 0.0 & 0.45 & 0.0 \\
\hline REARSTORAGEFLR4 & 216 & 1,945 & 0.0 & 0.41 & 0.8 & 0.0 & 0.0 & 67.5 & 0.0 & 0.98 & 0.0 \\
\hline GUESTROOM401 & 351 & 3,159 & 234.0 & 1.74 & 1.1 & 1.3 & 0.0 & 0.0 & 0.0 & 0.80 & 1.8 \\
\hline GUESTROOM402_405 & 1,404 & 12,637 & 234.0 & 1.74 & 1.1 & 1.3 & 0.0 & 30.0 & 0.0 & 0.53 & 7.0 \\
\hline GUESTROOM406_408 & 1,134 & 10,207 & 252.0 & 1.74 & 1.1 & 1.3 & 0.0 & 120.0 & 0.0 & 0.53 & 5.3 \\
\hline GUESTROOM409_412 & 1,404 & 12,637 & 234.0 & 1.74 & 1.1 & 1.3 & 0.0 & 90.0 & 0.0 & 0.53 & 7.0 \\
\hline GUESTROOM413 & 351 & 3,159 & 234.0 & 1.74 & 1.1 & 1.3 & 0.0 & 120.0 & 0.0 & 0.53 & 1.8 \\
\hline GUESTROOM414 & 351 & 3,159 & 234.0 & 1.74 & 1.1 & 1.3 & 0.0 & 30.0 & 0.0 & 0.53 & 1.8 \\
\hline GUESTROOM415_418 & 1,404 & 12,636 & 234.0 & 1.74 & 1.1 & 1.3 & 0.0 & 30.0 & 0.0 & 0.53 & 7.0 \\
\hline ELEVATORCOREFLR4 & 162 & 1,458 & 0.0 & 0.00 & 0.0 & 0.0 & 0.0 & 120.0 & 0.0 & 0.53 & 0.0 \\
\hline GUESTROOM419 & 351 & 3,159 & 234.0 & 1.74 & 1.1 & 1.3 & 0.0 & 0.0 & 0.0 & 0.53 & 1.8 \\
\hline GUESTROOM420_423 & 1,404 & 12,636 & 234.0 & 1.74 & 1.1 & 1.3 & 0.0 & 30.0 & 0.0 & 0.53 & 7.0 \\
\hline GUESTROOM424 & 351 & 3,159 & 234.0 & 1.74 & 1.1 & 1.3 & 0.0 & 120.0 & 0.0 & 0.53 & 1.8 \\
\hline FRONTSTORAGEFLR4 & 135 & 1,215 & 0.0 & 0.45 & 0.8 & 0.0 & 0.0 & 30.0 & 0.0 & 0.53 & 0.0 \\
\hline FRONTSTAIRSFLR4 & 216 & 1,944 & 0.0 & 0.82 & 0.6 & 0.0 & 0.0 & 0.0 & 0.0 & 0.98 & 0.0 \\
\hline Small Office & 5,502 & 55,056 & & & & & & & & & \\
\hline Core_ZN & 1,611 & 16,120 & 200.0 & 1.81 & 1.0 & 0.8 & 0.0 & 161.1 & 0.0 & 0.00 & 3.0 \\
\hline Perimeter_ZN_1 & 1,221 & 12,220 & 200.0 & 1.81 & 1.0 & 0.8 & 0.0 & 122.1 & 0.0 & 0.62 & 0.0 \\
\hline Perimeter_ZN_2 & 724 & 7,249 & 200.0 & 1.81 & 1.0 & 0.8 & 0.0 & 72.4 & 0.0 & 0.66 & 0.0 \\
\hline Perimeter_ZN_3 & 1,221 & 12,220 & 200.0 & 1.81 & 1.0 & 0.8 & 0.0 & 122.1 & 0.0 & 0.62 & 0.0 \\
\hline Perimeter_ZN_4 & 724 & 7,249 & 200.0 & 1.81 & 1.0 & 0.8 & 0.0 & 72.4 & 0.0 & 0.66 & 0.0 \\
\hline Attic & 6,114 & 25,433 & 0.0 & 0.00 & 0.0 & 0.0 & 0.0 & 0.0 & 0.0 & 1.00 & 0.0 \\
\hline Strip Mall & 22,500 & 382,500 & & & & & & & & & \\
\hline LGStore1 & 3,750 & 63,750 & 66.7 & 5.60 & 2.2 & 0.4 & 0.0 & 1125.0 & 0.0 & 0.38 & 0.0 \\
\hline SMStore1 & 1,875 & 31,875 & 66.7 & 5.60 & 2.2 & 0.4 & 0.0 & 562.5 & 0.0 & 0.31 & 0.0 \\
\hline SMStore2 & 1,875 & 31,875 & 66.7 & 3.30 & 1.7 & 0.4 & 0.0 & 562.5 & 0.0 & 0.31 & 0.0 \\
\hline SMStore3 & 1,875 & 31,875 & 66.7 & 3.30 & 1.7 & 0.4 & 0.0 & 562.5 & 0.0 & 0.31 & 0.0 \\
\hline SMStore4 & 1,875 & 31,875 & 66.7 & 3.30 & 1.7 & 0.4 & 0.0 & 562.5 & 0.0 & 0.31 & 0.0 \\
\hline LGStore2 & 3,750 & 63,750 & 66.7 & 2.70 & 1.3 & 0.4 & 0.0 & 1125.0 & 0.0 & 0.31 & 0.0 \\
\hline SMStore5 & 1,875 & 31,875 & 66.7 & 2.70 & 1.3 & 0.4 & 0.0 & 562.5 & 0.0 & 0.31 & 0.0 \\
\hline SMStore6 & 1,875 & 31,875 & 66.7 & 2.70 & 1.3 & 0.4 & 0.0 & 562.5 & 0.0 & 0.31 & 0.0 \\
\hline SMStore7 & 1,875 & 31,875 & 66.7 & 2.70 & 1.3 & 0.4 & 0.0 & 562.5 & 0.0 & 0.31 & 0.0 \\
\hline SMStore8 & 1,875 & 31,875 & 66.7 & 2.70 & 1.3 & 0.4 & 0.0 & 562.5 & 0.0 & 0.45 & 0.0 \\
\hline Warehouse & 52,045 & $1,385,797$ & & & & & & & & & \\
\hline Office & 2,550 & 35,695 & 510.0 & 2.02 & 1.1 & 0.8 & 0.0 & 100.0 & 0.0 & 0.16 & 0.0 \\
\hline FineStorage & 14,999 & 384,244 & 0.0 & 1.08 & 1.4 & 0.0 & 0.0 & 749.9 & 0.0 & 0.22 & 0.0 \\
\hline BulkStorage & 34,497 & 965,859 & 0.0 & 0.31 & 0.9 & 0.2 & 0.0 & 80001.0 & 0.0 & 0.19 & 0.0 \\
\hline
\end{tabular}


Table A-2 Reference Building Zone Internal Loads (SI units)

\begin{tabular}{|c|c|c|c|c|c|c|c|c|c|c|c|}
\hline Building Type/Zone & $\begin{array}{c}\text { Area } \\
\mathrm{m}^{2}\end{array}$ & $\begin{array}{l}\text { Vol. } \\
\mathrm{m}^{3}\end{array}$ & $\begin{array}{c}\mathrm{m}^{2} I \\
\text { person }\end{array}$ & $\begin{array}{c}1989 \\
\text { Lights } \\
W^{2}\end{array}$ & $\begin{array}{c}2004 \\
\text { Lights } \\
W^{2}\end{array}$ & $\begin{array}{l}\text { Elec. } \\
\text { Proc. } \\
\text { W/m }\end{array}$ & $\begin{array}{l}\text { Gas } \\
\text { Proc. } \\
\text { W/m }\end{array}$ & $\begin{array}{l}\text { Vent. } \\
\text { L/s }\end{array}$ & $\begin{array}{c}\text { Exhst } \\
\text { L/s }\end{array}$ & $\begin{array}{l}\text { Infil. } \\
\text { ACH }\end{array}$ & $\begin{array}{l}\text { SWH } \\
\text { L/h }\end{array}$ \\
\hline Quick Service Restaurant & 232 & 708 & & & & & & & & & \\
\hline Dining & 116 & 354 & 1.39 & 15.45 & 22.60 & 129.1 & 0.0 & 833.6 & 0.0 & 0.64 & 0.0 \\
\hline Kitchen & 116 & 354 & 18.58 & 16.64 & 12.91 & 301.3 & 1291.7 & 50.0 & 1557.4 & 0.64 & 151.4 \\
\hline Attic & 232 & 262 & & & & & & & & 1.00 & 0.0 \\
\hline Hospital & 22,422 & 88,864 & & & & & & & & & \\
\hline Basement & 3,739 & 9,120 & 37.16 & 7.53 & 11.84 & 8.1 & 0.0 & 1006.2 & 0.0 & 0.00 & 0.0 \\
\hline ER_Exam1_Mult4_Flr_1 & 28 & 119 & 4.65 & 41.35 & 29.05 & 16.1 & 0.0 & 66.1 & 0.0 & 0.24 & 3.8 \\
\hline ER_Exam2_Flr_1 & 28 & 119 & 4.65 & 41.35 & 29.05 & 43.0 & 0.0 & 66.1 & 0.0 & 0.42 & 3.8 \\
\hline ER_Exam3_Mult4_Flr_1 & 28 & 119 & 4.65 & 41.35 & 29.05 & 16.1 & 0.0 & 66.1 & 0.0 & 0.18 & 3.8 \\
\hline ER_Exam4_Flr_1 & 28 & 119 & 4.65 & 41.35 & 29.05 & 43.0 & 0.0 & 66.1 & 0.0 & 0.42 & 3.8 \\
\hline ER_Exam5_Mult4_FIr_1 & 28 & 119 & 4.65 & 41.35 & 29.05 & 21.5 & 0.0 & 66.1 & 0.0 & 0.24 & 3.8 \\
\hline Office1_Mult4_Flr_1 & 14 & 60 & 13.27 & 25.78 & 11.84 & 11.8 & 0.0 & 10.5 & 0.0 & 0.24 & 0.0 \\
\hline Lobby_Flr 1 & 1,475 & 6,295 & 13.01 & 13.91 & 15.82 & 1.1 & 0.0 & 1133.9 & 0.0 & 0.07 & 0.0 \\
\hline Corridor_Flr_1 & 569 & 2,429 & 92.90 & 14.59 & 10.76 & 0.0 & 0.0 & 142.3 & 0.0 & 0.04 & 0.0 \\
\hline ER_NurseStat_FIr_1 & 1,236 & 5,274 & 14.86 & 22.63 & 12.05 & 14.6 & 0.0 & 2930.0 & 0.0 & 0.02 & 0.0 \\
\hline OR1_FIr_2 & 56 & 238 & 18.58 & 104.94 & 23.67 & 43.0 & 0.0 & 198.3 & 0.0 & 0.30 & 7.6 \\
\hline OR2_Mult5_Flr_2 & 56 & 238 & 18.58 & 104.94 & 23.67 & 43.0 & 0.0 & 198.3 & 0.0 & 0.12 & 7.6 \\
\hline OR3_Flr_2 & 56 & 238 & 18.58 & 104.94 & 23.67 & 43.0 & 0.0 & 198.3 & 0.0 & 0.18 & 7.6 \\
\hline OR4_FIr_2 & 223 & 952 & 18.58 & 84.88 & 23.67 & 43.0 & 0.0 & 793.1 & 0.0 & 0.00 & 22.7 \\
\hline IC_PatRoom1_Mult5_Flr_2 & 21 & 89 & 18.58 & 41.35 & 8.61 & 32.3 & 0.0 & 49.6 & 0.0 & 0.24 & 0.0 \\
\hline IC_PatRoom2_FIr_2 & 28 & 119 & 18.58 & 41.35 & 8.61 & 32.3 & 0.0 & 66.1 & 0.0 & 0.42 & 0.0 \\
\hline IC_PatRoom3_Mult6_FIr_2 & 21 & 89 & 18.58 & 41.35 & 8.61 & 32.3 & 0.0 & 49.6 & 0.0 & 0.24 & 0.0 \\
\hline ICU_FIr_2 & 618 & 2,638 & 4.65 & 41.35 & 8.61 & 32.3 & 0.0 & 1465.4 & 0.0 & 0.09 & 0.0 \\
\hline ICU_NurseSat_FIr_2 & 669 & 2,855 & 18.58 & 23.34 & 10.76 & 21.5 & 0.0 & 359.9 & 0.0 & 0.00 & 0.0 \\
\hline Corridor_Flr_2 & 569 & 2,429 & 92.90 & 14.59 & 10.76 & 0.0 & 0.0 & 142.3 & 0.0 & 0.04 & 0.0 \\
\hline OR_NurseSat_FIr_2 & 1,013 & 4,322 & 13.01 & 22.84 & 12.70 & 11.2 & 0.0 & 778.6 & 0.0 & 0.05 & 0.0 \\
\hline PatRoom1_Mult10_Flr_3 & 21 & 89 & 18.58 & 23.56 & 7.53 & 21.5 & 0.0 & 49.6 & 0.0 & 0.24 & 3.8 \\
\hline PatRoom2_Flr_3 & 35 & 149 & 18.58 & 23.56 & 7.53 & 21.5 & 0.0 & 82.6 & 0.0 & 0.38 & 3.8 \\
\hline PatRoom3_Mult10_Flr_3 & 20 & 86 & 18.58 & 23.56 & 7.53 & 21.5 & 0.0 & 47.9 & 0.0 & 0.24 & 3.8 \\
\hline PatRoom4_FIr_3 & 35 & 149 & 18.58 & 23.56 & 7.53 & 21.5 & 0.0 & 82.6 & 0.0 & 0.38 & 3.8 \\
\hline PatRoom5_Mult10_Flr_3 & 21 & 89 & 18.58 & 23.56 & 7.53 & 21.5 & 0.0 & 49.6 & 0.0 & 0.24 & 3.8 \\
\hline PhysTherapy_Flr_3 & 488 & 2,082 & 18.58 & 26.93 & 9.68 & 16.4 & 0.0 & 210.0 & 0.0 & 0.00 & 3.8 \\
\hline PatRoom6_FIr_3 & 28 & 119 & 18.58 & 23.56 & 7.53 & 21.5 & 0.0 & 66.1 & 0.0 & 0.42 & 3.8 \\
\hline PatRoom7_Mult10_Flr_3 & 20 & 86 & 18.58 & 23.56 & 7.53 & 21.5 & 0.0 & 47.9 & 0.0 & 0.24 & 3.8 \\
\hline PatRoom8 Flr 3 & 28 & 119 & 18.58 & 23.56 & 7.53 & 21.5 & 0.0 & 66.1 & 0.0 & 0.42 & 3.8 \\
\hline NurseSat_Lobby_FIr_3 & 906 & 3,866 & 13.01 & 22.96 & 12.70 & 11.2 & 0.0 & 696.4 & 0.0 & 0.00 & 0.0 \\
\hline Lab_Flr_3 & 265 & 1,130 & 18.58 & 22.65 & 15.06 & 43.0 & 0.0 & 142.5 & 0.0 & 0.00 & 7.6 \\
\hline Corridor_SE_Flr_3 & 567 & 2,419 & 92.90 & 14.60 & 10.76 & 0.0 & 0.0 & 141.7 & 0.0 & 0.02 & 0.0 \\
\hline Corridor_NW_Flr_3 & 567 & 2,419 & 92.90 & 14.60 & 10.76 & 0.0 & 0.0 & 141.7 & 0.0 & 0.02 & 0.0 \\
\hline PatRoom1_Mult10_Flr_4 & 21 & 89 & 18.58 & 23.56 & 7.53 & 21.5 & 0.0 & 49.6 & 0.0 & 0.24 & 3.8 \\
\hline PatRoom2_Flr_4 & 35 & 149 & 18.58 & 23.56 & 7.53 & 21.5 & 0.0 & 82.6 & 0.0 & 0.38 & 3.8 \\
\hline PatRoom3_Mult10_FIr_4 & 20 & 86 & 18.58 & 23.56 & 7.53 & 21.5 & 0.0 & 47.9 & 0.0 & 0.24 & 3.8 \\
\hline PatRoom4_Flr_4 & 35 & 149 & 18.58 & 23.56 & 7.53 & 21.5 & 0.0 & 82.6 & 0.0 & 0.38 & 3.8 \\
\hline PatRoom5 Mult10 Flr 4 & 21 & 89 & 18.58 & 23.56 & 7.53 & 21.5 & 0.0 & 49.6 & 0.0 & 0.24 & 3.8 \\
\hline Radiology_Flr_4 & 488 & 2,082 & 18.58 & 23.82 & 4.30 & 53.1 & 0.0 & 210.0 & 0.0 & 0.00 & 3.8 \\
\hline PatRoom6_Flr_4 & 28 & 119 & 18.58 & 23.56 & 7.53 & 21.5 & 0.0 & 66.1 & 0.0 & 0.42 & 3.8 \\
\hline PatRoom7_Mult10_Flr_4 & 20 & 86 & 18.58 & 23.56 & 7.53 & 21.5 & 0.0 & 47.9 & 0.0 & 0.24 & 3.8 \\
\hline PatRoom8_Flr_4 & 28 & 119 & 18.58 & 23.56 & 7.53 & 21.5 & 0.0 & 66.1 & 0.0 & 0.42 & 3.8 \\
\hline NurseSat_Lobby_FIr_4 & 906 & 3,866 & 13.01 & 22.96 & 12.70 & 11.2 & 0.0 & 696.4 & 0.0 & 0.00 & 0.0 \\
\hline Lab_Flr_ 4 & 265 & 1,130 & 18.58 & 22.65 & 15.06 & 43.0 & 0.0 & 142.5 & 0.0 & 0.00 & 7.6 \\
\hline Corridor_SE_FIr_4 & 567 & 2,419 & 92.90 & 14.60 & 10.76 & 0.0 & 0.0 & 141.7 & 0.0 & 0.02 & 0.0 \\
\hline Corridor_NW_Flr_4 & 567 & 2,419 & 92.90 & 14.60 & 10.76 & 0.0 & 0.0 & 141.7 & 0.0 & 0.02 & 0.0 \\
\hline Dining_Flr_5 & 697 & 2,974 & 9.29 & 27.72 & 9.68 & 10.8 & 0.0 & 750.0 & 0.0 & 0.34 & 0.0 \\
\hline NurseSat_Flr_5 & 1,041 & 4,441 & 13.01 & 22.81 & 12.70 & 11.2 & 0.0 & 800.0 & 0.0 & 0.28 & 0.0 \\
\hline Kitchen_Flr_5 & 929 & 3,965 & 18.58 & 15.29 & 12.91 & 80.7 & 304.8 & 400.0 & 2501.3 & 0.33 & 567.8 \\
\hline Office1_FIr 5 & 70 & 298 & 13.27 & 25.78 & 11.84 & 10.8 & 0.0 & 52.5 & 0.0 & 0.52 & 0.0 \\
\hline Office2_Mult5_Flr_5 & 70 & 297 & 13.27 & 25.78 & 11.84 & 10.8 & 0.0 & 52.5 & 0.0 & 0.37 & 0.0 \\
\hline Office3_FIr_5 & 70 & 297 & 13.27 & 25.78 & 11.84 & 10.8 & 0.0 & 52.5 & 0.0 & 0.52 & 0.0 \\
\hline Office4_Mult6_FIr_5 & 14 & 60 & 13.94 & 25.78 & 11.84 & 10.8 & 0.0 & 10.0 & 0.0 & 0.49 & 0.0 \\
\hline
\end{tabular}




\begin{tabular}{|c|c|c|c|c|c|c|c|c|c|c|c|}
\hline Building Type/Zone & $\begin{array}{c}\text { Area } \\
\mathrm{m}^{2}\end{array}$ & $\begin{array}{l}\text { Vol. } \\
\mathrm{m}^{3}\end{array}$ & $\underset{\text { person }}{\mathbf{m}^{2} /}$ & $\begin{array}{c}1989 \\
\text { Lights } \\
W^{2}\end{array}$ & \begin{tabular}{|c|}
2004 \\
Lights \\
$W^{2}$
\end{tabular} & $\begin{array}{l}\text { Elec. } \\
\text { Proc. } \\
\text { W/m }\end{array}$ & $\begin{array}{l}\text { Gas } \\
\text { Proc. } \\
\text { W/m }\end{array}$ & $\begin{array}{l}\text { Vent. } \\
\text { L/s }\end{array}$ & $\begin{array}{c}\text { Exhst } \\
\text { L/s }\end{array}$ & $\begin{array}{l}\text { Infil. } \\
\mathrm{ACH}\end{array}$ & $\begin{array}{c}\text { SWH } \\
\text { L/h }\end{array}$ \\
\hline Corridor_Flr_5 & $\overline{502}$ & 2,141 & 92.90 & 14.60 & 10.76 & 0.0 & 0.0 & 125.4 & 0.0 & 0.29 & 0.0 \\
\hline Large Hotel & 11,345 & 35,185 & & & & & & & & & \\
\hline Basement & 1,979 & 4,826 & 37.16 & 7.53 & 10.76 & 5.4 & 0.0 & 502.6 & 0.0 & 0.00 & 0.0 \\
\hline Retail_1_Flr_1 & 67 & 266 & 6.19 & 38.09 & 16.14 & 10.8 & 0.0 & 102.2 & 0.0 & 0.56 & 0.0 \\
\hline Retail_2_Flr_1 & 78 & 308 & 6.19 & 38.09 & 16.14 & 10.8 & 0.0 & 118.4 & 0.0 & 0.09 & 0.0 \\
\hline Mech_Flr 1 & 164 & 651 & 0.00 & 8.60 & 16.14 & 5.4 & 0.0 & 41.7 & 0.0 & 0.11 & 0.0 \\
\hline Storage_Flr_1 & 95 & 375 & 46.45 & 3.96 & 9.68 & 2.7 & 0.0 & 72.2 & 0.0 & 0.11 & 0.0 \\
\hline Laundry_FIr_1 & 78 & 309 & 23.23 & 12.23 & 6.46 & 61.7 & 535.9 & 23.8 & 236.0 & 0.30 & 592.8 \\
\hline Cafe_Flr_1 & 189 & 748 & 1.39 & 15.74 & 13.99 & 5.4 & 0.0 & 1279.1 & 0.0 & 0.50 & 0.0 \\
\hline Lobby_Flr_1 & 1,308 & 5,184 & 3.10 & 20.28 & 11.84 & 8.1 & 0.0 & 3987.4 & 0.0 & 0.10 & 0.0 \\
\hline Room_1_Flr_3 & 39 & 119 & 26.01 & 19.09 & 11.84 & 6.8 & 0.0 & 14.2 & 0.0 & 0.37 & 4.7 \\
\hline Room_2_Flr_3 & 39 & 119 & 26.01 & 19.09 & 11.84 & 6.8 & 0.0 & 14.2 & 0.0 & 0.37 & 4.7 \\
\hline Room_3_Mult19_Flr_3 & 25 & 75 & 16.35 & 19.09 & 11.84 & 10.5 & 0.0 & 14.2 & 0.0 & 0.16 & 89.9 \\
\hline Room_4_Mult19_Flr_3 & 25 & 75 & 16.35 & 19.09 & 11.84 & 10.5 & 0.0 & 14.2 & 0.0 & 0.16 & 89.9 \\
\hline Room_5_Flr_3 & 39 & 119 & 26.01 & 19.09 & 11.84 & 6.8 & 0.0 & 14.2 & 0.0 & 0.37 & 4.7 \\
\hline Room_6_Flr_3 & 39 & 119 & 26.01 & 19.09 & 11.84 & 6.8 & 0.0 & 14.2 & 0.0 & 0.37 & 4.7 \\
\hline Corridor_FIr_3 & 389 & 1,187 & 92.90 & 13.11 & 5.38 & 0.0 & 0.0 & 98.9 & 0.0 & 0.04 & 0.0 \\
\hline Room_1_Flr_6 & 39 & 119 & 26.01 & 19.09 & 11.84 & 6.8 & 0.0 & 14.2 & 0.0 & 0.72 & 4.7 \\
\hline Room_2_Flr_6 & 39 & 119 & 26.01 & 19.09 & 11.84 & 6.8 & 0.0 & 14.2 & 0.0 & 0.72 & 4.7 \\
\hline Room_3_Mult9_Flr_6 & 25 & 75 & 16.35 & 19.09 & 11.84 & 10.5 & 0.0 & 14.2 & 0.0 & 1.28 & 42.6 \\
\hline Banquet_FIr_6 & 332 & 1,011 & 1.39 & 27.55 & 13.99 & 67.8 & 0.0 & 2246.2 & 0.0 & 0.46 & 0.0 \\
\hline Dining_Flr_6 & 332 & 1,011 & 1.39 & 27.55 & 13.99 & 67.8 & 0.0 & 2246.2 & 0.0 & 0.46 & 0.0 \\
\hline Kitchen_Flr_6 & 103 & 315 & 18.58 & 16.83 & 12.91 & 508.0 & 1612.8 & 39.4 & 1887.8 & 0.66 & 503.5 \\
\hline Corridor_Flr_6 & 412 & 1,256 & 92.90 & 13.08 & 5.38 & 0.0 & 0.0 & 104.7 & 0.0 & 0.48 & 0.0 \\
\hline Large Office & 46,320 & 178,146 & & & & & & & & & \\
\hline Basement & 3,563 & 8,690 & 37.16 & 7.53 & 10.76 & 10.76 & 0.0 & 958.8 & 0.0 & 0.15 & 0.0 \\
\hline Perimeter_bot_ZN_3 & 313 & 860 & 18.58 & 16.14 & 10.76 & 10.76 & 0.0 & 168.7 & 0.0 & 0.30 & 0.0 \\
\hline Perimeter_bot_ZN_2 & 202 & 554 & 18.58 & 16.14 & 10.76 & 10.76 & 0.0 & 108.7 & 0.0 & 0.30 & 0.0 \\
\hline Perimeter_bot_ZN_1 & 313 & 860 & 18.58 & 16.14 & 10.76 & 10.76 & 0.0 & 168.7 & 0.0 & 0.30 & 0.0 \\
\hline Perimeter_bot_ZN_4 & 202 & 554 & 18.58 & 16.14 & 10.76 & 10.76 & 0.0 & 108.7 & 0.0 & 0.30 & 0.0 \\
\hline Core_bottom & 2,532 & 6,949 & 18.58 & 16.14 & 10.76 & 10.76 & 0.0 & 1362.9 & 0.0 & 0.15 & 80.6 \\
\hline Perimeter_mid_ZN_3 & 313 & 860 & 18.58 & 16.14 & 10.76 & 10.76 & 0.0 & 168.7 & 0.0 & 0.30 & 0.0 \\
\hline Perimeter_mid_ZN_2 & 202 & 554 & 18.58 & 16.14 & 10.76 & 10.76 & 0.0 & 108.7 & 0.0 & 0.30 & 0.0 \\
\hline Perimeter_mid_ZN_1 & 313 & 860 & 18.58 & 16.14 & 10.76 & 10.76 & 0.0 & 168.7 & 0.0 & 0.30 & 0.0 \\
\hline Perimeter_mid_ZN_4 & 202 & 554 & 18.58 & 16.14 & 10.76 & 10.76 & 0.0 & 108.7 & 0.0 & 0.30 & 0.0 \\
\hline Core_mid & 2,532 & 6,949 & 18.58 & 16.14 & 10.76 & 10.76 & 0.0 & 1362.9 & 0.0 & 0.15 & 80.6 \\
\hline Perimeter_top_ZN_3 & 313 & 860 & 18.58 & 16.14 & 10.76 & 10.76 & 0.0 & 168.7 & 0.0 & 0.30 & 0.0 \\
\hline Perimeter_top_ZN_2 & 202 & 554 & 18.58 & 16.14 & 10.76 & 10.76 & 0.0 & 108.7 & 0.0 & 0.30 & 0.0 \\
\hline Perimeter_top_ZN_1 & 313 & 860 & 18.58 & 16.14 & 10.76 & 10.76 & 0.0 & 168.7 & 0.0 & 0.30 & 0.0 \\
\hline Perimeter_top_ZN_4 & 202 & 554 & 18.58 & 16.14 & 10.76 & 10.76 & 0.0 & 108.7 & 0.0 & 0.30 & 0.0 \\
\hline Core_top & 2,532 & 6,949 & 18.58 & 16.14 & 10.76 & 10.76 & 0.0 & 1362.9 & 0.0 & 0.15 & 80.6 \\
\hline Groundfloor_plenum & 3,563 & 4,344 & & & & & & & & 0.00 & 0.0 \\
\hline Midfloor_plenum & 3,563 & 4,344 & & & & & & & & 0.00 & 0.0 \\
\hline Topfloor_plenum & 3,563 & 4,344 & & & & & & & & 0.00 & 0.0 \\
\hline Medium Office & 4,982 & 19,741 & & & & & & & & & \\
\hline Perimeter_bot_ZN_3 & 207 & 569 & 18.58 & 16.89 & 10.76 & 10.76 & 0.0 & 111.6 & 0.0 & 0.26 & 0.0 \\
\hline Perimeter_bot_ZN_2 & 131 & 360 & 18.58 & 16.89 & 10.76 & 10.76 & 0.0 & 70.6 & 0.0 & 0.28 & 0.0 \\
\hline Perimeter_bot_ZN_1 & 207 & 569 & 18.58 & 16.89 & 10.76 & 10.76 & 0.0 & 111.6 & 0.0 & 0.26 & 0.0 \\
\hline Perimeter_bot_ZN_4 & 131 & 360 & 18.58 & 16.89 & 10.76 & 10.76 & 0.0 & 70.6 & 0.0 & 0.28 & 0.0 \\
\hline Core_bottom & 984 & 2,698 & 18.58 & 16.89 & 10.76 & 10.76 & 0.0 & 529.3 & 0.0 & 0.00 & 37.5 \\
\hline Perimeter_mid_ZN_3 & 207 & 569 & 18.58 & 16.89 & 10.76 & 10.76 & 0.0 & 111.6 & 0.0 & 0.26 & 0.0 \\
\hline Perimeter_mid_ZN_2 & 131 & 360 & 18.58 & 16.89 & 10.76 & 10.76 & 0.0 & 70.6 & 0.0 & 0.28 & 0.0 \\
\hline Perimeter_mid_ZN_1 & 207 & 569 & 18.58 & 16.89 & 10.76 & 10.76 & 0.0 & 111.6 & 0.0 & 0.26 & 0.0 \\
\hline Perimeter_mid_ZN_4 & 131 & 360 & 18.58 & 16.89 & 10.76 & 10.76 & 0.0 & 70.6 & 0.0 & 0.28 & 0.0 \\
\hline Core_mid & 984 & 2,698 & 18.58 & 16.89 & 10.76 & 10.76 & 0.0 & 529.3 & 0.0 & 0.00 & 37.5 \\
\hline Perimeter_top_ZN_3 & 207 & 569 & 18.58 & 16.89 & 10.76 & 10.76 & 0.0 & 111.6 & 0.0 & 0.66 & 0.0 \\
\hline Perimeter_top_ZN_2 & 131 & 360 & 18.58 & 16.89 & 10.76 & 10.76 & 0.0 & 70.6 & 0.0 & 0.67 & 0.0 \\
\hline
\end{tabular}




\begin{tabular}{|c|c|c|c|c|c|c|c|c|c|c|c|}
\hline Building Type/Zone & $\begin{array}{l}\text { Area } \\
\mathrm{m}^{2}\end{array}$ & $\begin{array}{l}\text { Vol. } \\
\mathrm{m}^{3}\end{array}$ & $\underset{\text { person }}{\mathbf{m}^{2} l}$ & $\begin{array}{c}1989 \\
\text { Lights } \\
W^{2}\end{array}$ & \begin{tabular}{|c|}
2004 \\
Lights \\
$W^{2}$
\end{tabular} & $\begin{array}{l}\text { Elec. } \\
\text { Proc. } \\
\text { W/m }\end{array}$ & $\begin{array}{l}\text { Gas } \\
\text { Proc. } \\
\text { W/m }\end{array}$ & $\begin{array}{c}\text { Vent. } \\
\text { L/s }\end{array}$ & $\begin{array}{c}\text { Exhst } \\
\text { L/s }\end{array}$ & $\begin{array}{l}\text { Infil. } \\
\mathrm{ACH}\end{array}$ & $\begin{array}{c}\text { SWH } \\
\text { L/h }\end{array}$ \\
\hline Perimeter_top_ZN_1 & 207 & 569 & 18.58 & 16.89 & 10.76 & 10.76 & 0.0 & 111.6 & 0.0 & 0.66 & 0.0 \\
\hline Perimeter_top_ZN_4 & 131 & 360 & 18.58 & 16.89 & 10.76 & 10.76 & 0.0 & 70.6 & 0.0 & 0.67 & 0.0 \\
\hline Core_top & 984 & 2,698 & 18.58 & 16.89 & 10.76 & 10.76 & 0.0 & 529.3 & 0.0 & 0.40 & 37.5 \\
\hline Firstfloor_plenum & 1,661 & 2,025 & & & & & & & & 0.11 & 0.0 \\
\hline Midfloor_plenum & 1,661 & 2,025 & & & & & & & & 0.11 & 0.0 \\
\hline Topfloor_plenum & 1,661 & 2,025 & & & & & & & & 1.00 & 0.0 \\
\hline Midrise Apartment & 3,135 & 9,553 & & & & & & & & & \\
\hline G SW APARTMENT & 88 & 269 & 35.30 & 3.87 & 3.88 & 5.4 & 0.0 & 42.5 & 0.0 & 0.24 & 13.2 \\
\hline G NW APARTMENT & 88 & 269 & 35.30 & 3.87 & 3.88 & 5.4 & 0.0 & 42.5 & 0.0 & 0.24 & 13.2 \\
\hline OFFICE & 88 & 269 & 44.12 & 21.99 & 10.76 & 12.9 & 0.0 & 18.9 & 0.0 & 0.24 & 0.0 \\
\hline G NE APARTMENT & 88 & 269 & 35.30 & 3.87 & 3.88 & 5.4 & 0.0 & 42.5 & 0.0 & 0.24 & 13.2 \\
\hline G N1 APARTMENT & 88 & 269 & 35.30 & 3.87 & 3.88 & 5.4 & 0.0 & 42.5 & 0.0 & 0.14 & 13.2 \\
\hline G N2 APARTMENT & 88 & 269 & 35.30 & 3.87 & 3.88 & 5.4 & 0.0 & 42.5 & 0.0 & 0.14 & 13.2 \\
\hline G S1 APARTMENT & 88 & 269 & 35.30 & 3.87 & 3.88 & 5.4 & 0.0 & 42.5 & 0.0 & 0.14 & 13.2 \\
\hline G S2 APARTMENT & 88 & 269 & 35.30 & 3.87 & 3.88 & 5.4 & 0.0 & 42.5 & 0.0 & 0.14 & 13.2 \\
\hline M SW APARTMENT & 88 & 269 & 35.30 & 3.87 & 3.88 & 5.4 & 0.0 & 42.5 & 0.0 & 0.24 & 13.2 \\
\hline M NW APARTMENT & 88 & 269 & 35.30 & 3.87 & 3.88 & 5.4 & 0.0 & 42.5 & 0.0 & 0.24 & 13.2 \\
\hline M SE APARTMENT & 88 & 269 & 35.30 & 3.87 & 3.88 & 5.4 & 0.0 & 42.5 & 0.0 & 0.24 & 13.2 \\
\hline M NE APARTMENT & 88 & 269 & 35.30 & 3.87 & 3.88 & 5.4 & 0.0 & 42.5 & 0.0 & 0.24 & 13.2 \\
\hline M N1 APARTMENT & 88 & 269 & 35.30 & 3.87 & 3.88 & 5.4 & 0.0 & 42.5 & 0.0 & 0.14 & 13.2 \\
\hline M N2 APARTMENT & 88 & 269 & 35.30 & 3.87 & 3.88 & 5.4 & 0.0 & 42.5 & 0.0 & 0.14 & 13.2 \\
\hline M S1 APARTMENT & 88 & 269 & 35.30 & 3.87 & 3.88 & 5.4 & 0.0 & 42.5 & 0.0 & 0.14 & 13.2 \\
\hline M S2 APARTMENT & 88 & 269 & 35.30 & 3.87 & 3.88 & 5.4 & 0.0 & 42.5 & 0.0 & 0.14 & 13.2 \\
\hline T SW APARTMENT & 88 & 269 & 35.30 & 3.87 & 3.88 & 5.4 & 0.0 & 42.5 & 0.0 & 0.59 & 13.2 \\
\hline T NW APARTMENT & 88 & 269 & 35.30 & 3.87 & 3.88 & 5.4 & 0.0 & 42.5 & 0.0 & 0.59 & 13.2 \\
\hline T SE APARTMENT & 88 & 269 & 35.30 & 3.87 & 3.88 & 5.4 & 0.0 & 42.5 & 0.0 & 0.59 & 13.2 \\
\hline T NE APARTMENT & 88 & 269 & 35.30 & 3.87 & 3.88 & 5.4 & 0.0 & 42.5 & 0.0 & 0.59 & 13.2 \\
\hline T N1 APARTMENT & 88 & 269 & 35.30 & 3.87 & 3.88 & 5.4 & 0.0 & 42.5 & 0.0 & 0.50 & 13.2 \\
\hline T N2 APARTMENT & 88 & 269 & 35.30 & 3.87 & 3.88 & 5.4 & 0.0 & 42.5 & 0.0 & 0.50 & 13.2 \\
\hline T S1 APARTMENT & 88 & 269 & 35.30 & 3.87 & 3.88 & 5.4 & 0.0 & 42.5 & 0.0 & 0.50 & 13.2 \\
\hline T S2 APARTMENT & 88 & 269 & 35.30 & 3.87 & 3.88 & 5.4 & 0.0 & 42.5 & 0.0 & 0.50 & 13.2 \\
\hline T CORRIDOR & 78 & 237 & 0.00 & 9.91 & 5.38 & 0.0 & 0.0 & 19.7 & 0.0 & 0.40 & 0.0 \\
\hline G CORRIDOR & 78 & 237 & 0.00 & 9.91 & 5.38 & 0.0 & 0.0 & 19.7 & 0.0 & 0.05 & 0.0 \\
\hline M CORRIDOR & 78 & 237 & 0.00 & 9.91 & 5.38 & 0.0 & 0.0 & 19.7 & 0.0 & 0.05 & 0.0 \\
\hline Outpatient Health Care & 3,804 & 11,932 & & & & & & & & & \\
\hline Floor 1 Anesthesia & 10 & 31 & 0.00 & & 32.29 & 21.5 & 0.0 & 61.2 & 68.0 & 0.30 & 3.8 \\
\hline Floor $1 \mathrm{Bio} \mathrm{Haz}$ & 5 & 16 & 0.00 & & 9.69 & 1.1 & 0.0 & 4.0 & 0.0 & 0.00 & 0.0 \\
\hline Floor 1 Café & 39 & 119 & 1.00 & & 9.69 & 10.8 & 0.0 & 368.3 & 0.0 & 0.17 & 0.0 \\
\hline Floor 1 Clean & 12 & 36 & 5.00 & & 12.92 & 21.5 & 0.0 & 17.8 & 0.0 & 0.00 & 0.0 \\
\hline Floor 1 Clean Work & 15 & 47 & 5.00 & & 12.92 & 21.5 & 0.0 & 23.4 & 0.0 & 0.00 & 0.0 \\
\hline Floor 1 Dictation & 12 & 36 & 20.00 & & 11.84 & 11.8 & 0.0 & 5.5 & 0.0 & 0.00 & 0.0 \\
\hline Floor 1 Dressing Room & 4 & 13 & 20.00 & & 11.84 & 11.8 & 0.0 & 2.0 & 0.0 & 0.71 & 0.0 \\
\hline Floor 1 Electrical Room & 9 & 28 & 0.00 & & 16.15 & 53.8 & 0.0 & 2.3 & 0.0 & 0.25 & 0.0 \\
\hline Floor 1 Elevator Pump Room & 8 & 26 & 0.00 & & 16.15 & 53.8 & 0.0 & 2.1 & 0.0 & 0.78 & 0.0 \\
\hline Floor 1 Humid & 5 & 15 & 20.00 & & 11.84 & 11.8 & 0.0 & 2.4 & 0.0 & 0.00 & 0.0 \\
\hline Floor 1 IT Hall & 13 & 40 & 0.00 & & 10.76 & 4.3 & 0.0 & 3.3 & 0.0 & 0.00 & 0.0 \\
\hline Floor 1 IT Room & 10 & 32 & 20.00 & & 11.84 & 11.8 & 0.0 & 4.9 & 0.0 & 0.00 & 0.0 \\
\hline Floor 1 Lobby & 58 & 176 & 3.33 & & 13.99 & 11.8 & 0.0 & 122.7 & 0.0 & 0.13 & 0.0 \\
\hline Floor 1 Lobby Hall & 22 & 68 & 0.00 & & 10.76 & 4.3 & 0.0 & 5.7 & 0.0 & 0.00 & 0.0 \\
\hline Floor 1 Lobby Toilet & 5 & 15 & 0.00 & & 9.69 & 4.3 & 0.0 & 51.0 & 42.5 & 0.40 & 0.0 \\
\hline Floor 1 Locker Room & 61 & 187 & 6.67 & & 8.61 & 32.3 & 0.0 & 65.1 & 0.0 & 0.12 & 0.0 \\
\hline Floor 1 Locker Room Hall & 46 & 140 & 0.00 & & 10.76 & 4.3 & 0.0 & 11.7 & 0.0 & 0.00 & 0.0 \\
\hline Floor 1 Lounge & 33 & 102 & 6.67 & & 8.61 & 32.3 & 0.0 & 35.5 & 0.0 & 0.00 & 0.0 \\
\hline Floor 1 Med Gas & 5 & 16 & 0.00 & & 9.69 & 1.1 & 0.0 & 4.0 & 0.0 & 0.96 & 0.0 \\
\hline Floor $1 \mathrm{MRI}$ Control Room & 16 & 48 & 5.00 & & 4.31 & 107.6 & 0.0 & 23.8 & 79.3 & 0.11 & 3.8 \\
\hline Floor $1 \mathrm{MRI}$ Hall & 14 & 42 & 0.00 & & 10.76 & 4.3 & 0.0 & 3.5 & 0.0 & 0.00 & 0.0 \\
\hline
\end{tabular}




\begin{tabular}{|c|c|c|c|c|c|c|c|c|c|c|c|}
\hline Building Type/Zone & $\begin{array}{c}\text { Area } \\
\mathrm{m}^{2}\end{array}$ & $\begin{array}{l}\text { Vol. } \\
\mathrm{m}^{3}\end{array}$ & $\begin{array}{c}\mathrm{m}^{2} \mathrm{I} \\
\text { person }\end{array}$ & $\begin{array}{c}1989 \\
\text { Lights } \\
W^{2}\end{array}$ & \begin{tabular}{|c|}
2004 \\
Lights \\
$\mathrm{Wm}^{2}$ \\
\end{tabular} & $\begin{array}{l}\text { Elec. } \\
\text { Proc. } \\
\mathrm{W} / \mathrm{m}^{2}\end{array}$ & $\begin{array}{l}\text { Gas } \\
\text { Proc. } \\
\text { W/m }\end{array}$ & $\begin{array}{c}\text { Vent. } \\
\text { L/s }\end{array}$ & $\begin{array}{c}\text { Exhst } \\
\text { L/s }\end{array}$ & $\begin{array}{l}\text { Infil. } \\
\text { ACH }\end{array}$ & $\begin{array}{c}\text { SWH } \\
\text { L/h }\end{array}$ \\
\hline Floor 1 MRI Room & 41 & 125 & 5.00 & & 4.31 & 107.6 & 0.0 & 62.3 & 207.7 & 0.00 & 3.8 \\
\hline Floor $1 \mathrm{MRI}$ Toilet & 5 & 15 & 0.00 & & 9.69 & 4.3 & 0.0 & 51.0 & 42.5 & 0.40 & 0.0 \\
\hline Floor 1 Nourishment & 17 & 52 & 5.00 & & 10.76 & 21.5 & 0.0 & 31.9 & 0.0 & 0.00 & 0.0 \\
\hline Floor 1 Nurse Hall & 46 & 140 & 0.00 & & 10.76 & 4.3 & 0.0 & 11.7 & 0.0 & 0.00 & 0.0 \\
\hline Floor 1 Nurse Janitor & 5 & 15 & 0.00 & & 9.69 & 1.1 & 0.0 & 3.8 & 0.0 & 0.00 & 0.0 \\
\hline Floor 1 Nurse Station & 24 & 74 & 5.00 & & 10.76 & 21.5 & 0.0 & 45.8 & 0.0 & 0.00 & 0.0 \\
\hline Floor 1 Nurse Toilet & 5 & 15 & 0.00 & & 9.69 & 4.3 & 0.0 & 51.0 & 42.5 & 0.00 & 0.0 \\
\hline Floor 1 Office & 45 & 137 & 20.00 & & 11.84 & 11.8 & 0.0 & 21.2 & 0.0 & 0.00 & 0.0 \\
\hline Floor 1 Operating Room 1 & 43 & 130 & 5.00 & & 23.68 & 43.1 & 75.3 & 108.5 & 0.0 & 0.33 & 22.7 \\
\hline Floor 1 Operating Room 2 & 45 & 136 & 5.00 & & 23.68 & 43.1 & 75.3 & 113.3 & 0.0 & 0.18 & 22.7 \\
\hline Floor 1 Operating Room 3 & 44 & 135 & 5.00 & & 23.68 & 43.1 & 75.3 & 112.3 & 0.0 & 0.00 & 22.7 \\
\hline Floor 1 PACU & 10 & 31 & 5.00 & & 8.61 & 32.3 & 0.0 & 17.0 & 0.0 & 0.00 & 3.8 \\
\hline Floor 1 Pre-Op Hall & 49 & 150 & 0.00 & & 10.76 & 4.3 & 0.0 & 12.5 & 0.0 & 0.00 & 0.0 \\
\hline Floor 1 Pre-Op Room 1 & 18 & 54 & 10.00 & & 7.53 & 21.5 & 0.0 & 29.7 & 0.0 & 0.08 & 3.8 \\
\hline Floor 1 Pre-Op Room 2 & 31 & 96 & 10.00 & & 7.53 & 21.5 & 0.0 & 53.2 & 0.0 & 0.00 & 3.8 \\
\hline Floor 1 Pre-Op Toilet & 5 & 15 & 0.00 & & 9.69 & 4.3 & 0.0 & 51.0 & 42.5 & 0.40 & 0.0 \\
\hline Floor 1 Procedure Room & 26 & 81 & 5.00 & & 29.06 & 32.3 & 0.0 & 67.2 & 0.0 & 0.24 & 3.8 \\
\hline Floor 1 Reception & 47 & 144 & 3.33 & & 13.99 & 11.8 & 0.0 & 100.4 & 0.0 & 0.09 & 0.0 \\
\hline Floor 1 Reception Hall & 12 & 36 & 0.00 & & 10.76 & 4.3 & 0.0 & 3.0 & 0.0 & 0.00 & 0.0 \\
\hline Floor 1 Recovery Room & 50 & 153 & 5.00 & & 8.61 & 32.3 & 0.0 & 84.9 & 0.0 & 0.30 & 3.8 \\
\hline Floor 1 Scheduling & 11 & 34 & 20.00 & & 11.84 & 11.8 & 0.0 & 5.2 & 0.0 & 0.21 & 0.0 \\
\hline Floor 1 Scrub & 8 & 24 & 0.00 & & 10.76 & 4.3 & 0.0 & 2.0 & 0.0 & 0.00 & 0.0 \\
\hline Floor 1 Soil & 12 & 36 & 5.00 & & 12.92 & 21.5 & 0.0 & 89.2 & 99.1 & 0.00 & 0.0 \\
\hline Floor 1 Soil Hold & 5 & 16 & 5.00 & & 12.92 & 21.5 & 0.0 & 39.6 & 44.0 & 0.00 & 0.0 \\
\hline Floor 1 Soil Work & 17 & 51 & 5.00 & & 12.92 & 21.5 & 0.0 & 127.4 & 141.6 & 0.00 & 0.0 \\
\hline Floor 1 Step Down & 28 & 85 & 5.00 & & 8.61 & 32.3 & 0.0 & 47.2 & 0.0 & 0.44 & 3.8 \\
\hline Floor 1 Sterile Hall & 57 & 174 & 0.00 & & 10.76 & 4.3 & 0.0 & 14.5 & 0.0 & 0.05 & 0.0 \\
\hline Floor 1 Sterile Storage & 37 & 112 & 0.00 & & 9.69 & 1.1 & 0.0 & 28.0 & 0.0 & 0.00 & 0.0 \\
\hline Floor 1 Storage & 85 & 261 & 0.00 & & 9.69 & 1.1 & 0.0 & 65.1 & 0.0 & 0.24 & 0.0 \\
\hline Floor 1 Sub-Sterile & 18 & 56 & 0.00 & & 10.76 & 4.3 & 0.0 & 4.6 & 0.0 & 0.26 & 0.0 \\
\hline Floor 1 Utility Hall & 24 & 72 & 0.00 & & 10.76 & 4.3 & 0.0 & 6.0 & 0.0 & 0.22 & 0.0 \\
\hline Floor 1 Utility Janitor & 4 & 12 & 0.00 & & 9.69 & 1.1 & 0.0 & 3.0 & 0.0 & 0.00 & 0.0 \\
\hline Floor 1 Utility Room & 33 & 102 & 0.00 & & 9.69 & 1.1 & 0.0 & 25.5 & 0.0 & 0.18 & 0.0 \\
\hline Floor 1 Vestibule & 7 & 20 & 0.00 & & 10.76 & 4.3 & 0.0 & 1.7 & 0.0 & 0.40 & 0.0 \\
\hline Floor 2 Conference & 31 & 95 & 2.00 & & 13.99 & 10.8 & 0.0 & 147.3 & 0.0 & 0.43 & 0.0 \\
\hline Floor 2 Conference Toilet & 6 & 18 & 0.00 & & 9.69 & 4.3 & 0.0 & 60.4 & 50.3 & 0.00 & 0.0 \\
\hline Floor 2 Dictation & 7 & 20 & 20.00 & & 11.84 & 11.8 & 0.0 & 3.1 & 0.0 & 0.00 & 0.0 \\
\hline Floor 2 Exam 1 & 33 & 102 & 5.00 & & 16.15 & 11.8 & 0.0 & 51.0 & 0.0 & 0.42 & 0.0 \\
\hline Floor 2 Exam 2 & 50 & 153 & 5.00 & & 16.15 & 11.8 & 0.0 & 76.4 & 0.0 & 0.12 & 0.0 \\
\hline Floor 2 Exam 3 & 67 & 204 & 5.00 & & 16.15 & 11.8 & 0.0 & 101.9 & 0.0 & 0.12 & 0.0 \\
\hline Floor 2 Exam 4 & 8 & 24 & 5.00 & & 16.15 & 11.8 & 0.0 & 11.9 & 0.0 & 0.30 & 0.0 \\
\hline Floor 2 Exam 5 & 33 & 99 & 5.00 & & 16.15 & 11.8 & 0.0 & 49.5 & 0.0 & 0.26 & 0.0 \\
\hline Floor 2 Exam 6 & 21 & 64 & 5.00 & & 16.15 & 11.8 & 0.0 & 31.9 & 0.0 & 0.24 & 0.0 \\
\hline Floor 2 Exam 7 & 74 & 224 & 5.00 & & 16.15 & 11.8 & 0.0 & 112.1 & 0.0 & 0.11 & 0.0 \\
\hline Floor 2 Exam 8 & 25 & 76 & 5.00 & & 16.15 & 11.8 & 0.0 & 38.2 & 0.0 & 0.24 & 0.0 \\
\hline Floor 2 Exam 9 & 37 & 112 & 5.00 & & 16.15 & 11.8 & 0.0 & 56.1 & 0.0 & 0.11 & 0.0 \\
\hline Floor 2 Exam Hall 1 & 17 & 51 & 0.00 & & 10.76 & 4.3 & 0.0 & 4.2 & 0.0 & 0.12 & 0.0 \\
\hline Floor 2 Exam Hall 2 & 17 & 51 & 0.00 & & 10.76 & 4.3 & 0.0 & 4.2 & 0.0 & 0.12 & 0.0 \\
\hline Floor 2 Exam Hall 3 & 17 & 51 & 0.00 & & 10.76 & 4.3 & 0.0 & 4.2 & 0.0 & 0.12 & 0.0 \\
\hline Floor 2 Exam Hall 4 & 18 & 56 & 0.00 & & 10.76 & 4.3 & 0.0 & 4.7 & 0.0 & 0.11 & 0.0 \\
\hline Floor 2 Exam Hall 5 & 18 & 56 & 0.00 & & 10.76 & 4.3 & 0.0 & 4.7 & 0.0 & 0.11 & 0.0 \\
\hline Floor 2 Exam Hall 6 & 18 & 56 & 0.00 & & 10.76 & 4.3 & 0.0 & 4.7 & 0.0 & 0.11 & 0.0 \\
\hline Floor 2 Janitor & 6 & 18 & 0.00 & & 9.69 & 1.1 & 0.0 & 4.5 & 0.0 & 0.91 & 0.0 \\
\hline Floor 2 Lounge & 7 & 23 & 6.67 & & 8.61 & 32.3 & 0.0 & 7.9 & 0.0 & 0.00 & 0.0 \\
\hline Floor 2 Nurse Station 1 & 14 & 42 & 5.00 & & 10.76 & 21.5 & 0.0 & 26.3 & 0.0 & 0.00 & 0.0 \\
\hline Floor 2 Nurse Station 2 & 17 & 51 & 5.00 & & 10.76 & 21.5 & 0.0 & 31.6 & 0.0 & 0.00 & 0.0 \\
\hline
\end{tabular}




\begin{tabular}{|c|c|c|c|c|c|c|c|c|c|c|c|}
\hline Building Type/Zone & $\underset{\mathrm{m}^{2}}{\text { Area }}$ & $\begin{array}{l}\text { Vol. } \\
\mathbf{m}^{3}\end{array}$ & $\begin{array}{c}\mathbf{m}^{2} l \\
\text { person }\end{array}$ & $\begin{array}{c}1989 \\
\text { Lights } \\
W^{2}\end{array}$ & $\begin{array}{c}2004 \\
\text { Lights } \\
\mathrm{Wm}^{2}\end{array}$ & $\begin{array}{l}\text { Elec. } \\
\text { Proc. } \\
\text { W/m }\end{array}$ & $\begin{array}{l}\text { Gas } \\
\text { Proc. } \\
\text { W/m }\end{array}$ & $\begin{array}{l}\text { Vent. } \\
\text { L/s }\end{array}$ & $\begin{array}{c}\text { Exhst } \\
\text { L/s }\end{array}$ & $\begin{array}{l}\text { Infil. } \\
\text { ACH }\end{array}$ & $\begin{array}{c}\text { SWH } \\
\text { L/h }\end{array}$ \\
\hline Floor 2 Office & $\overline{52}$ & 159 & 20.00 & & 111.84 & 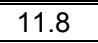 & 0.0 & 24.6 & 0.0 & 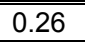 & 0.0 \\
\hline Floor 2 Office Hall & 41 & 126 & 0.00 & & 10.76 & 4.3 & 0.0 & 10.5 & 0.0 & 0.00 & 0.0 \\
\hline Floor 2 Reception & 91 & 279 & 3.33 & & 13.99 & 11.8 & 0.0 & 194.1 & 0.0 & 0.18 & 0.0 \\
\hline Floor 2 Reception Hall & 52 & 160 & 0.00 & & 10.76 & 4.3 & 0.0 & 13.3 & 0.0 & 0.60 & 0.0 \\
\hline Floor 2 Reception Toilet & 12 & 36 & 0.00 & & 9.69 & 4.3 & 0.0 & 118.9 & 99.1 & 0.00 & 0.0 \\
\hline Floor 2 Scheduling 1 & 30 & 92 & 20.00 & & 11.84 & 11.8 & 0.0 & 14.2 & 0.0 & 0.00 & 0.0 \\
\hline Floor 2 Scheduling 2 & 32 & 97 & 20.00 & & 11.84 & 11.8 & 0.0 & 15.0 & 0.0 & 0.00 & 0.0 \\
\hline Floor 2 Storage 1 & 5 & 16 & 0.00 & & 9.69 & 1.1 & 0.0 & 4.0 & 0.0 & 0.00 & 0.0 \\
\hline Floor 2 Storage 2 & 11 & 34 & 0.00 & & 9.69 & 1.1 & 0.0 & 8.5 & 0.0 & 0.00 & 0.0 \\
\hline Floor 2 Storage 3 & 13 & 41 & 0.00 & & 9.69 & 1.1 & 0.0 & 10.2 & 0.0 & 0.00 & 0.0 \\
\hline Floor 2 Utility & 12 & 36 & 0.00 & & 9.69 & 1.1 & 0.0 & 8.9 & 0.0 & 0.26 & 0.0 \\
\hline Floor 2 Work & 157 & 479 & 20.00 & & 11.84 & 11.8 & 0.0 & 74.1 & 0.0 & 0.05 & 0.0 \\
\hline Floor 2 Work Hall & 77 & 236 & 0.00 & & 10.76 & 4.3 & 0.0 & 19.7 & 0.0 & 0.03 & 0.0 \\
\hline Floor 2 Work Toilet & 5 & 15 & 0.00 & & 9.69 & 4.3 & 0.0 & 51.0 & 42.5 & 0.40 & 0.0 \\
\hline Floor 2 X-Ray & 84 & 255 & 5.00 & & 4.31 & 107.6 & 0.0 & 127.4 & 0.0 & 0.00 & 3.8 \\
\hline Floor 3 Dressing Room & 4 & 12 & 20.00 & & 11.84 & 11.8 & 0.0 & 1.8 & 0.0 & 0.00 & 0.0 \\
\hline Floor 3 Elevator Hall & 34 & 105 & 0.00 & & 10.76 & 4.3 & 0.0 & 8.7 & 0.0 & 0.04 & 0.0 \\
\hline Floor 3 Humid & 10 & 31 & 20.00 & & 11.84 & 11.8 & 0.0 & 4.7 & 0.0 & 0.00 & 0.0 \\
\hline Floor 3 Janitor & 6 & 18 & 0.00 & & 9.69 & 1.1 & 0.0 & 4.5 & 0.0 & 0.91 & 0.0 \\
\hline Floor 3 Locker & 11 & 34 & 6.67 & & 8.61 & 32.3 & 0.0 & 11.8 & 0.0 & 0.00 & 0.0 \\
\hline Floor 3 Lounge & 71 & 215 & 6.67 & & 8.61 & 32.3 & 0.0 & 74.9 & 0.0 & 0.11 & 0.0 \\
\hline Floor 3 Lounge Toilet & 18 & 54 & 0.00 & & 9.69 & 4.3 & 0.0 & 181.2 & 151.0 & 0.22 & 0.0 \\
\hline Floor 3 Mechanical & 33 & 99 & 0.00 & & 16.15 & 53.8 & 0.0 & 8.3 & 0.0 & 0.26 & 0.0 \\
\hline Floor 3 Mechanical Hall & 28 & 85 & 0.00 & & 10.76 & 4.3 & 0.0 & 7.1 & 0.0 & 0.00 & 0.0 \\
\hline Floor 3 Office & 282 & 860 & 20.00 & & 11.84 & 11.8 & 0.0 & 133.1 & 0.0 & 0.09 & 0.0 \\
\hline Floor 3 Office Hall & 77 & 236 & 0.00 & & 10.76 & 4.3 & 0.0 & 19.7 & 0.0 & 0.03 & 0.0 \\
\hline Floor 3 Office Toilet & 5 & 15 & 0.00 & & 9.69 & 4.3 & 0.0 & 51.0 & 42.5 & 0.40 & 0.0 \\
\hline Floor 3 Physical Therapy 1 & 121 & 368 & 5.00 & & 9.69 & 16.2 & 0.0 & 171.0 & 0.0 & 0.23 & 3.8 \\
\hline Floor 3 Physical Therapy 2 & 55 & 168 & 5.00 & & 9.69 & 16.2 & 0.0 & 77.9 & 0.0 & 0.00 & 3.8 \\
\hline Floor 3 Physical Therapy Toilet & 8 & 24 & 0.00 & & 9.69 & 4.3 & 0.0 & 79.3 & 66.1 & 0.00 & 0.0 \\
\hline Floor 3 Storage 1 & 10 & 31 & 0.00 & & 9.69 & 1.1 & 0.0 & 7.6 & 0.0 & 0.00 & 0.0 \\
\hline Floor 3 Storage 2 & 8 & 24 & 0.00 & & 9.69 & 1.1 & 0.0 & 5.9 & 0.0 & 0.00 & 0.0 \\
\hline Floor 3 Treatment & 44 & 135 & 5.00 & & 16.15 & 11.8 & 0.0 & 67.4 & 0.0 & 0.00 & 0.0 \\
\hline Floor 3 Undeveloped 1 & 211 & 642 & 20.00 & & 11.84 & 11.8 & 0.0 & 160.5 & 0.0 & 0.11 & 0.0 \\
\hline Floor 3 Undeveloped 2 & 107 & 326 & 20.00 & & 11.84 & 11.8 & 0.0 & 81.5 & 0.0 & 0.17 & 0.0 \\
\hline Floor 3 Utility & 20 & 61 & 0.00 & & 9.69 & 1.1 & 0.0 & 15.3 & 0.0 & 0.00 & 0.0 \\
\hline Floor 3 Work & 53 & 163 & 20.00 & & 11.84 & 11.8 & 0.0 & 25.2 & 0.0 & 0.26 & 0.0 \\
\hline NE Stair & 16 & 143 & 0.00 & & 10.76 & 4.3 & 0.0 & 4.0 & 0.0 & 0.74 & 0.0 \\
\hline NW Elevator & 13 & 119 & 0.00 & & 10.76 & 4.3 & 0.0 & 3.3 & 0.0 & 0.69 & 0.0 \\
\hline NW Stair & 18 & 163 & 0.00 & & 10.76 & 4.3 & 0.0 & 4.5 & 0.0 & 0.74 & 0.0 \\
\hline SW Stair & 9 & 82 & 0.00 & & 10.76 & 4.3 & 0.0 & 2.3 & 0.0 & 0.74 & 0.0 \\
\hline Retail & 2,294 & 13,993 & & & & & & & & & \\
\hline Back_Space & 380 & 2,317 & 27.87 & 12.55 & 8.61 & 8.1 & 0.0 & 284.9 & 0.0 & 0.37 & 0.0 \\
\hline Core_Retail & 1,600 & 9,763 & 6.19 & 36.25 & 18.29 & 3.2 & 0.0 & 2400.7 & 0.0 & 0.22 & 0.0 \\
\hline Point_of_Sale & 151 & 920 & 6.19 & 36.25 & 18.29 & 21.5 & 0.0 & 226.2 & 0.0 & 0.40 & 0.0 \\
\hline Front_Retail & 151 & 920 & 6.19 & 36.25 & 18.29 & 3.2 & 0.0 & 226.2 & 0.0 & 0.40 & 0.0 \\
\hline Front_Entry & 12 & 73 & 6.19 & 36.25 & 11.84 & 0.0 & 0.0 & 0.0 & 0.0 & 0.54 & 0.0 \\
\hline Primary Education & 6,871 & 27,484 & & & & & & & & & \\
\hline $\begin{array}{l}\text { CORNER_CLASS_1_POD_1_ZN } \\
\text { _1_FLR_1 }\end{array}$ & 99 & 396 & 4.00 & 21.52 & 15.06 & 15.0 & 0.0 & 198.0 & 0.0 & 0.49 & 0.0 \\
\hline $\begin{array}{l}\text { MULT_CLASS_1_POD_1_ZN_1_ } \\
\text { FLR_1 }\end{array}$ & 477 & 1,908 & 4.00 & 21.52 & 15.06 & 15.0 & 0.0 & 954.0 & 0.0 & 0.39 & 0.0 \\
\hline $\begin{array}{l}\text { CORRIDOR_POD_1_ZN_1_FLR_ } \\
1\end{array}$ & 192 & 768 & 10.00 & 21.52 & 5.38 & 4.0 & 0.0 & 96.0 & 0.0 & 0.29 & 0.0 \\
\hline $\begin{array}{l}\text { CORNER_CLASS_2_POD_1_ZN } \\
\text { 1_FLR_1 }\end{array}$ & 99 & 396 & 4.00 & 21.52 & 15.06 & 15.0 & 0.0 & 198.0 & 0.0 & 0.49 & 0.0 \\
\hline
\end{tabular}




\begin{tabular}{|c|c|c|c|c|c|c|c|c|c|c|c|}
\hline Building Type/Zone & $\begin{array}{c}\text { Area } \\
\mathrm{m}^{2}\end{array}$ & $\begin{array}{l}\text { Vol. } \\
\mathrm{m}^{3}\end{array}$ & $\begin{array}{c}\mathrm{m}^{2} l \\
\text { person }\end{array}$ & $\begin{array}{c}1989 \\
\text { Lights } \\
W^{2}\end{array}$ & \begin{tabular}{|c|}
2004 \\
Lights \\
$W^{2}$
\end{tabular} & $\begin{array}{l}\text { Elec. } \\
\text { Proc. } \\
\text { W/m }\end{array}$ & $\begin{array}{l}\text { Gas } \\
\text { Proc. } \\
\text { W/m }\end{array}$ & $\begin{array}{c}\text { Vent. } \\
\text { L/s }\end{array}$ & $\begin{array}{c}\text { Exhst } \\
\text { L/s }\end{array}$ & $\begin{array}{l}\text { Infil. } \\
\mathrm{ACH}\end{array}$ & $\begin{array}{c}\text { SWH } \\
\text { L/h }\end{array}$ \\
\hline $\begin{array}{l}\text { MULT_CLASS_2_POD_1_ZN_1_ } \\
\text { FLR_1 }\end{array}$ & 477 & 1,908 & 4.00 & 21.52 & 15.06 & 15.0 & 0.0 & 954.0 & 0.0 & 0.39 & 0.0 \\
\hline $\begin{array}{l}\text { CORNER_CLASS_1_POD_2_ZN } \\
\text { 1_FLR_1 }\end{array}$ & 99 & 396 & 4.00 & 21.52 & 15.06 & 15.0 & 0.0 & 198.0 & 0.0 & 0.49 & 0.0 \\
\hline $\begin{array}{l}\text { MULT_CLASS_1_POD_2_ZN_1_ } \\
\text { FLR_1 }\end{array}$ & 477 & 1,908 & 4.00 & 21.52 & 15.06 & 15.0 & 0.0 & 954.0 & 0.0 & 0.39 & 0.0 \\
\hline $\begin{array}{l}\text { CORRIDOR_POD_2_ZN_1_FLR_ } \\
1\end{array}$ & 192 & 768 & 10.00 & 9.69 & 5.38 & 4.0 & 0.0 & 96.0 & 0.0 & 0.29 & 0.0 \\
\hline $\begin{array}{l}\text { CORNER_CLASS_2_POD_2_ZN } \\
\text { 1_FLR_1 }\end{array}$ & 99 & 396 & 4.00 & 21.52 & 15.06 & 15.0 & 0.0 & 198.0 & 0.0 & 0.49 & 0.0 \\
\hline $\begin{array}{l}\text { MULT_CLASS_2_POD_2_ZN_1_ } \\
\text { FLR_1 }\end{array}$ & 477 & 1,908 & 4.00 & 21.52 & 15.06 & 15.0 & 0.0 & 954.0 & 0.0 & 0.39 & 0.0 \\
\hline $\begin{array}{l}\text { CORNER_CLASS_1_POD_3_ZN } \\
1 \text { FLR } 1\end{array}$ & 99 & 396 & 4.00 & 21.52 & 15.06 & 15.0 & 0.0 & 198.0 & 0.0 & 0.49 & 0.0 \\
\hline $\begin{array}{l}\text { MULT_CLASS_1_POD_3_ZN_1_ } \\
\text { FLR_1 }\end{array}$ & 477 & 1,908 & 4.00 & 21.52 & 15.06 & 15.0 & 0.0 & 954.0 & 0.0 & 0.39 & 0.0 \\
\hline $\begin{array}{l}\text { CORRIDOR_POD_3_ZN_1_FLR_ } \\
1\end{array}$ & 192 & 768 & 10.00 & 9.69 & 5.38 & 4.0 & 0.0 & 96.0 & 0.0 & 0.29 & 0.0 \\
\hline $\begin{array}{l}\text { CORNER_CLASS_2_POD_3_ZN } \\
\text { 1_FLR_1 }\end{array}$ & 99 & 396 & 4.00 & 21.52 & 15.06 & 15.0 & 0.0 & 198.0 & 0.0 & 0.49 & 0.0 \\
\hline $\begin{array}{l}\text { MULT_CLASS_2_POD_3_ZN_1_ } \\
\text { FLR_1 }\end{array}$ & 315 & 1,260 & 4.00 & 21.52 & 15.06 & 8.1 & 0.0 & 630.0 & 0.0 & 0.39 & 0.0 \\
\hline $\begin{array}{l}\text { COMPUTER_CLASS_ZN_1_FLR } \\
1\end{array}$ & 162 & 648 & 3.33 & 21.52 & 15.06 & 20.0 & 0.0 & 389.2 & 0.0 & 0.39 & 0.0 \\
\hline MAIN_CORRIDOR_ZN_1_FLR_1 & 546 & 2,184 & 0.00 & 11.14 & 5.38 & 4.0 & 0.0 & 273.0 & 0.0 & 0.29 & 0.0 \\
\hline LOBBY_ZN_1_FLR_1 & 171 & 684 & 0.00 & 12.26 & 13.99 & 4.0 & 0.0 & 85.5 & 0.0 & 0.39 & 0.0 \\
\hline MECH_ZN_1_FLR_1 & 252 & 1,008 & 100.00 & 8.26 & 16.14 & 10.0 & 0.0 & 63.0 & 0.0 & 0.27 & 0.0 \\
\hline BATH_ZN_1_FLR_1 & 190 & 760 & 100.00 & 9.70 & 9.68 & 4.0 & 0.0 & 300.0 & 283.2 & 0.33 & 4.00 \\
\hline OFFICES_ZN_1_FLR_1 & 441 & 1,764 & 20.00 & 20.33 & 11.84 & 10.8 & 0.0 & 220.5 & 0.0 & 0.38 & 0.0 \\
\hline GYM_ZN_1_FLR_1 & 357 & 1,428 & 3.33 & 11.47 & 15.06 & 5.0 & 0.0 & 1072.1 & 0.0 & 0.32 & 0.0 \\
\hline KITCHEN_ZN_1_FLR_1 & 168 & 672 & 6.67 & 17.20 & 12.91 & 190.5 & 954.1 & 201.5 & 1557.4 & 0.32 & 4.00 \\
\hline CAFETERIA_ZN_1_FLR_1 & 315 & 1,260 & 1.39 & 15.05 & 15.06 & 25.4 & 0.0 & 2260.4 & 0.0 & 0.40 & 0.0 \\
\hline $\begin{array}{l}\text { LIBRARY_MEDIA_CENTER_ZN_ } \\
\text { 1_FLR_1 }\end{array}$ & 399 & 1,596 & 4.35 & 22.75 & 13.99 & 15.0 & 0.0 & 733.8 & 0.0 & 0.38 & 0.0 \\
\hline Secondary Education & 19,592 & 95,216 & & & & & & & & & \\
\hline $\begin{array}{l}\text { CORNER_CLASS_1_POD_1_ZN } \\
\text { 1_FLR_1 }\end{array}$ & 99 & 396 & 4.00 & 21.52 & 15.06 & 10.0 & 0.0 & 198.0 & 0.0 & 0.22 & 0.0 \\
\hline $\begin{array}{l}\text { CORNER_CLASS_1_POD_1_ZN } \\
\text { _1_FLR_2 }\end{array}$ & 99 & 396 & 4.00 & 21.52 & 15.06 & 10.0 & 0.0 & 198.0 & 0.0 & 0.49 & 0.0 \\
\hline $\begin{array}{l}\text { MULT_CLASS_1_POD_1_ZN_1_ } \\
\text { FLR_1 }\end{array}$ & 477 & 1,908 & 4.00 & 21.52 & 15.06 & 10.0 & 0.0 & 954.0 & 0.0 & 0.12 & 0.0 \\
\hline $\begin{array}{l}\text { MULT_CLASS_1_POD_1_ZN_1_ } \\
\text { FLR_2 }\end{array}$ & 477 & 1,908 & 4.00 & 21.52 & 15.06 & 10.0 & 0.0 & 954.0 & 0.0 & 0.39 & 0.0 \\
\hline $\begin{array}{l}\text { CORRIDOR_POD_1_ZN_1_FLR } \\
\text { _1 }\end{array}$ & 320 & 1,280 & 10.00 & 9.25 & 5.38 & 4.0 & 0.0 & 160.0 & 0.0 & 0.02 & 0.0 \\
\hline $\begin{array}{l}\text { CORRIDOR_POD_1_ZN_1_FLR } \\
2\end{array}$ & 320 & 1,280 & 10.00 & 9.25 & 5.38 & 4.0 & 0.0 & 160.0 & 0.0 & 0.29 & 0.0 \\
\hline $\begin{array}{l}\text { CORNER_CLASS_2_POD_1_ZN } \\
\text { _1_FLR_1 }\end{array}$ & 99 & 396 & 4.00 & 21.52 & 15.06 & 10.0 & 0.0 & 198.0 & 0.0 & 0.22 & 0.0 \\
\hline $\begin{array}{l}\text { CORNER_CLASS_2_POD_1_ZN } \\
\text { 1_FLR_2 }\end{array}$ & 99 & 396 & 4.00 & 21.52 & 15.06 & 10.0 & 0.0 & 198.0 & 0.0 & 0.49 & 0.0 \\
\hline $\begin{array}{l}\text { MULT_CLASS_2_POD_1_ZN_1_ } \\
\text { FLR 1 }\end{array}$ & 477 & 1,908 & 4.00 & 21.52 & 15.06 & 10.0 & 0.0 & 954.0 & 0.0 & 0.12 & 0.0 \\
\hline $\begin{array}{l}\text { MULT_CLASS_2_POD_1_ZN_1_ } \\
\text { FLR_2 }\end{array}$ & 477 & 1,908 & 4.00 & 21.52 & 15.06 & 10.0 & 0.0 & 954.0 & 0.0 & 0.39 & 0.0 \\
\hline $\begin{array}{l}\text { CORNER_CLASS_1_POD_2_ZN } \\
\text { 1_FLR_1 }\end{array}$ & 99 & 396 & 4.00 & 21.52 & 15.06 & 10.0 & 0.0 & 198.0 & 0.0 & 0.22 & 0.0 \\
\hline $\begin{array}{l}\text { CORNER_CLASS_1_POD_2_ZN } \\
\text { 1_FLR_2 }\end{array}$ & 99 & 396 & 4.00 & 21.52 & 15.06 & 10.0 & 0.0 & 198.0 & 0.0 & 0.49 & 0.0 \\
\hline MULT_CLASS_1_POD_2_ZN_1 & 477 & 1,908 & 4.00 & 21.52 & 15.06 & 10.0 & 0.0 & 954.0 & 0.0 & 0.12 & 0.0 \\
\hline
\end{tabular}




\begin{tabular}{|c|c|c|c|c|c|c|c|c|c|c|c|}
\hline Building Type/Zone & $\begin{array}{c}\text { Area } \\
\mathrm{m}^{2}\end{array}$ & $\begin{array}{l}\text { Vol. } \\
\mathrm{m}^{3}\end{array}$ & $\begin{array}{c}\mathrm{m}^{2} l \\
\text { person }\end{array}$ & \begin{tabular}{|c}
1989 \\
Lights \\
$W^{2}$
\end{tabular} & \begin{tabular}{|c}
2004 \\
Lights \\
$W^{2}$
\end{tabular} & $\begin{array}{l}\text { Elec. } \\
\text { Proc. } \\
\text { W/m }\end{array}$ & \begin{tabular}{|c} 
Gas \\
Proc. \\
W/m
\end{tabular} & $\begin{array}{l}\text { Vent. } \\
\text { L/s }\end{array}$ & $\begin{array}{c}\text { Exhst } \\
\text { L/s }\end{array}$ & $\begin{array}{l}\text { Infil. } \\
\mathrm{ACH}\end{array}$ & $\begin{array}{c}\text { SWH } \\
\text { L/h }\end{array}$ \\
\hline \multicolumn{12}{|l|}{$\begin{array}{l}\text { FLR_1 } \\
\end{array}$} \\
\hline $\begin{array}{l}\text { MULT_CLASS_1_POD_2_ZN_1_ } \\
\text { FLR_2 }\end{array}$ & 477 & 1,908 & 4.00 & 21.52 & 15.06 & 10.0 & 0.0 & 954.0 & 0.0 & 0.39 & 0.0 \\
\hline $\begin{array}{l}\text { CORRIDOR_POD_2_ZN_1_FLR } \\
\text { _1 }\end{array}$ & 320 & 1,280 & 10.00 & 9.25 & 5.38 & 4.0 & 0.0 & 160.0 & 0.0 & 0.02 & 0.0 \\
\hline $\begin{array}{l}\text { CORRIDOR_POD_2_ZN_1_FLR } \\
2\end{array}$ & 320 & 1,280 & 10.00 & 9.25 & 5.38 & 4.0 & 0.0 & 160.0 & 0.0 & 0.29 & 0.0 \\
\hline $\begin{array}{l}\text { CORNER_CLASS_2_POD_2_ZN } \\
\text { 1_FLR_1 }\end{array}$ & 99 & 396 & 4.00 & 21.52 & 15.06 & 10.0 & 0.0 & 198.0 & 0.0 & 0.22 & 0.0 \\
\hline $\begin{array}{l}\text { CORNER_CLASS_2_POD_2_ZN } \\
\text { 1_FLR_2 }\end{array}$ & 99 & 396 & 4.00 & 21.52 & 15.06 & 10.0 & 0.0 & 198.0 & 0.0 & 0.49 & 0.0 \\
\hline $\begin{array}{l}\text { MULT_CLASS_2_POD_2_ZN_1_ } \\
\text { FLR_1 }\end{array}$ & 477 & 1,908 & 4.00 & 21.52 & 15.06 & 10.0 & 0.0 & 954.0 & 0.0 & 0.12 & 0.0 \\
\hline $\begin{array}{l}\text { MULT_CLASS_2_POD_2_ZN_1_ } \\
\text { FLR_2 }\end{array}$ & 477 & 1,908 & 4.00 & 21.52 & 15.06 & 10.0 & 0.0 & 954.0 & 0.0 & 0.39 & 0.0 \\
\hline $\begin{array}{l}\text { CORNER_CLASS_1_POD_3_ZN } \\
\text { 1_FLR_1 }\end{array}$ & 99 & 396 & 4.00 & 21.52 & 15.06 & 10.0 & 0.0 & 198.0 & 0.0 & 0.22 & 0.0 \\
\hline $\begin{array}{l}\text { CORNER_CLASS_1_POD_3_ZN } \\
\text { 1_FLR_2 }\end{array}$ & 99 & 396 & 4.00 & 21.52 & 15.06 & 10.0 & 0.0 & 198.0 & 0.0 & 0.49 & 0.0 \\
\hline $\begin{array}{l}\text { MULT_CLASS_1_POD_3_ZN_1_ } \\
\text { FLR 1 }\end{array}$ & 477 & 1,908 & 4.00 & 21.52 & 15.06 & 10.0 & 0.0 & 954.0 & 0.0 & 0.12 & 0.0 \\
\hline $\begin{array}{l}\text { MULT_CLASS_1_POD_3_ZN_1_ } \\
\text { FLR_2 }\end{array}$ & 477 & 1,908 & 4.00 & 21.52 & 15.06 & 20.0 & 0.0 & 954.0 & 0.0 & 0.39 & 0.0 \\
\hline $\begin{array}{l}\text { CORRIDOR_POD_3_ZN_1_FLR } \\
\text { _1 }\end{array}$ & 320 & 1,280 & 10.00 & 9.25 & 5.38 & 4.0 & 0.0 & 160.0 & 0.0 & 0.02 & 0.0 \\
\hline $\begin{array}{l}\text { CORRIDOR_POD_3_ZN_1_FLR } \\
2\end{array}$ & 320 & 1,280 & 10.00 & 9.25 & 5.38 & 4.0 & 0.0 & 160.0 & 0.0 & 0.29 & 0.0 \\
\hline $\begin{array}{l}\text { CORNER_CLASS_2_POD_3_ZN } \\
\text { 1_FLR_1 }\end{array}$ & 99 & 396 & 4.00 & 21.52 & 15.06 & 10.0 & 0.0 & 198.0 & 0.0 & 0.22 & 0.0 \\
\hline $\begin{array}{l}\text { CORNER_CLASS_2_POD_3_ZN } \\
\text { 1_FLR_2 }\end{array}$ & 99 & 396 & 4.00 & 21.52 & 15.06 & 10.0 & 0.0 & 198.0 & 0.0 & 0.49 & 0.0 \\
\hline $\begin{array}{l}\text { MULT_CLASS_2_POD_3_ZN_1_ } \\
\text { FLR_1 }\end{array}$ & 477 & 1,908 & 4.00 & 21.52 & 15.06 & 10.0 & 0.0 & 954.0 & 0.0 & 0.12 & 0.0 \\
\hline $\begin{array}{l}\text { MULT_CLASS_2_POD_3_ZN_1_ } \\
\text { FLR_2 }\end{array}$ & 477 & 1,908 & 4.00 & 21.52 & 15.06 & 20.0 & 0.0 & 954.0 & 0.0 & 0.39 & 0.0 \\
\hline MAIN_CORRIDOR_ZN_1_FLR_1 & 1,140 & 4,560 & 0.00 & 10.74 & 5.38 & 4.0 & 0.0 & 570.0 & 0.0 & 0.05 & 0.0 \\
\hline MAIN_CORRIDOR_ZN_1_FLR_2 & 1,140 & 4,560 & 0.00 & 10.74 & 5.38 & 4.0 & 0.0 & 570.0 & 0.0 & 0.32 & 0.0 \\
\hline LOBBY_ZN_1_FLR_1 & 210 & 840 & 0.00 & 12.00 & 13.99 & 4.0 & 0.0 & 105.0 & 0.0 & 0.08 & 0.0 \\
\hline LOBBY_ZN_1_FLR_2 & 210 & 840 & 0.00 & 12.00 & 13.99 & 4.0 & 0.0 & 105.0 & 0.0 & 0.35 & 0.0 \\
\hline BATHROOMS_ZN_1_FLR_1 & 210 & 840 & 10.00 & 9.60 & 9.68 & 4.0 & 0.0 & 300.0 & 0.0 & 0.15 & 4.00 \\
\hline BATHROOMS_ZN_1_FLR_2 & 210 & 840 & 10.00 & 9.60 & 9.68 & 4.0 & 0.0 & 300.0 & 0.0 & 0.42 & 4.00 \\
\hline OFFICES_ZN_1_FLR_1 & 532 & 2,128 & 20.00 & 20.09 & 11.84 & 10.8 & 0.0 & 266.0 & 0.0 & 0.11 & 0.0 \\
\hline OFFICES_ZN_1_FLR_2 & 532 & 2,128 & 20.00 & 20.09 & 11.84 & 10.8 & 0.0 & 266.0 & 0.0 & 0.38 & 0.0 \\
\hline GYM_ZN_1_FLR_1 & 1,976 & 15,808 & 1.00 & 11.38 & 15.06 & 5.0 & 0.0 & 19760.0 & 0.0 & 0.14 & 717.2 \\
\hline AUX_GYM_ZN_1_FLR_1 & 1,248 & 9,984 & 3.33 & 11.81 & 15.06 & 5.0 & 0.0 & 3747.7 & 0.0 & 0.20 & 0.0 \\
\hline AUDITORIUM_ZN_1_FLR_1 & 988 & 7,904 & 1.00 & 12.08 & 9.68 & 5.0 & 0.0 & 7904.0 & 0.0 & 0.21 & 0.0 \\
\hline KITCHEN_ZN_1_FLR_1 & 216 & 864 & 6.67 & 16.76 & 12.91 & 222.2 & 1119.0 & 259.1 & 1887.8 & 0.05 & 4.00 \\
\hline $\begin{array}{l}\text { LIBRARY_MEDIA_CENTER_ZN_ } \\
\text { 1_FLR_2 }\end{array}$ & 840 & 3,360 & 4.35 & 0.00 & 13.99 & 10.0 & 0.0 & 1544.8 & 0.0 & 0.35 & 0.0 \\
\hline CAFETERIA_ZN_1_FLR_1 & 624 & 2,496 & 1.39 & 14.38 & 15.06 & 19.3 & 0.0 & \begin{tabular}{|l|l|}
4477.8 \\
\end{tabular} & 0.0 & 0.09 & 0.0 \\
\hline MECH_ZN_1_FLR_1 & 342 & 1,368 & 100.00 & 8.05 & 16.14 & 4.0 & 0.0 & 85.5 & 0.0 & 0.00 & 0.0 \\
\hline MECH_ZN_1_FLR_2 & 342 & 1,368 & 100.00 & 8.05 & 16.14 & 4.0 & 0.0 & 85.5 & 0.0 & 0.00 & 0.0 \\
\hline Full Service Restaurant & 511 & 1,558 & & & & & & & & & \\
\hline Dining & 372 & 1,133 & 1.39 & 27.38 & 22.60 & 60.3 & 0.0 & \begin{tabular}{|l|}
2667.7 \\
\end{tabular} & 0.0 & 0.52 & 0.0 \\
\hline Kitchen & 139 & 425 & 18.58 & 16.37 & 12.91 & 376.6 & 1197.9 & 60.0 & 1887.8 & 0.63 & 503.5 \\
\hline Attic & 511 & 856 & & & & & & & & 1.00 & \\
\hline Supermarket & 4,181 & 25,493 & & & & & & & & & \\
\hline Office & 89 & 542 & 18.58 & 21.36 & 11.84 & 8.1 & 0.0 & 47.8 & 0.0 & 0.41 & 0.0 \\
\hline
\end{tabular}




\begin{tabular}{|c|c|c|c|c|c|c|c|c|c|c|c|}
\hline Building Type/Zone & $\begin{array}{c}\text { Area } \\
\mathrm{m}^{2}\end{array}$ & $\begin{array}{l}\text { Vol. } \\
\mathbf{m}^{3}\end{array}$ & $\begin{array}{c}\mathbf{m}^{2} I \\
\text { person }\end{array}$ & $\begin{array}{c}1989 \\
\text { Lights } \\
W^{2}\end{array}$ & $\begin{array}{c}2004 \\
\text { Lights } \\
W^{2}\end{array}$ & $\begin{array}{l}\text { Elec. } \\
\text { Proc. } \\
\text { W/m }\end{array}$ & $\begin{array}{l}\text { Gas } \\
\text { Proc. } \\
\text { W/m }\end{array}$ & $\begin{array}{c}\text { Vent. } \\
\text { L/s }\end{array}$ & $\begin{array}{c}\text { Exhst } \\
\text { L/s }\end{array}$ & $\begin{array}{l}\text { Infil. } \\
\text { ACH }\end{array}$ & $\begin{array}{c}\text { SWH } \\
\text { L/h }\end{array}$ \\
\hline Dry Storage & 622 & 3,792 & 27.87 & 11.90 & 8.61 & 8.1 & 0.0 & 2466.4 & 0.0 & 0.32 & 0.0 \\
\hline Deli & 225 & 1,370 & 11.61 & 29.94 & 18.29 & 53.8 & 26.9 & 337.1 & 0.0 & 0.29 & 18.9 \\
\hline Sales & 2,325 & 14,177 & 11.61 & 29.94 & 18.29 & 5.4 & 0.0 & 3487.4 & 0.0 & 0.20 & 0.0 \\
\hline Produce & 711 & 4,338 & 11.61 & 29.94 & 18.29 & 5.4 & 0.0 & 1067.0 & 0.0 & 0.27 & 0.0 \\
\hline Bakery & 209 & 1,275 & 11.61 & 29.94 & 18.29 & 53.8 & 26.9 & 313.6 & 1179.9 & 0.34 & 18.9 \\
\hline Small Hotel & 4,014 & 11,622 & & & & & & & & & \\
\hline REARSTAIRSFLR1 & 20 & 67 & & 9.95 & 6.46 & 0.0 & 0.0 & 0.0 & 0.0 & 0.58 & 0.0 \\
\hline CORRIDORFLR1 & 151 & 505 & & 9.50 & 5.38 & 0.0 & 0.0 & 37.6 & 0.0 & 0.07 & 0.0 \\
\hline REARSTORAGEFLR1 & 20 & 67 & & 4.98 & 8.61 & 0.0 & 0.0 & 0.0 & 0.0 & 0.58 & 0.0 \\
\hline FRONTLOUNGEFLR1 & 163 & 547 & 3.08 & 14.15 & 11.84 & 15.4 & 0.0 & 423.5 & 0.0 & 0.19 & 0.0 \\
\hline RESTROOMFLR1 & 33 & 109 & 32.61 & 11.82 & 9.68 & 10.8 & 0.0 & 0.0 & 200.0 & 0.13 & 0.0 \\
\hline MEETINGROOMFLR1 & 80 & 269 & 1.87 & 22.91 & 13.99 & 12.9 & 0.0 & 429.3 & 0.0 & 0.13 & 0.0 \\
\hline MECHANICALROOMFLR1 & 33 & 109 & & 10.34 & 16.14 & 0.0 & 0.0 & 8.2 & 0.0 & 0.13 & 0.0 \\
\hline GUESTROOM101 & 33 & 109 & 21.74 & 20.68 & 11.84 & 14.3 & 0.0 & 14.2 & 0.0 & 0.13 & 0.2 \\
\hline GUESTROOM102 & 33 & 109 & \begin{tabular}{|l|}
21.74 \\
\end{tabular} & 20.68 & 11.84 & 14.3 & 0.0 & 14.2 & 0.0 & 0.13 & 0.2 \\
\hline GUESTROOM103 & 33 & 109 & 21.74 & 20.68 & 11.84 & 14.3 & 0.0 & 14.2 & 0.0 & 0.13 & 0.2 \\
\hline GUESTROOM104 & 33 & 109 & 21.74 & 20.68 & 11.84 & 14.3 & 0.0 & 14.2 & 0.0 & 0.13 & 0.2 \\
\hline GUESTROOM105 & 33 & 109 & 21.74 & 20.68 & 11.84 & 14.3 & 0.0 & 14.2 & 0.0 & 0.13 & 0.2 \\
\hline EMPLOYEELOUNGEFLR1 & 33 & 109 & 2.96 & 17.73 & 12.91 & 77.2 & 0.0 & 88.1 & 0.0 & 0.13 & 0.0 \\
\hline LAUNDRYROOMFLR1 & 98 & 328 & 8.89 & 11.18 & 6.46 & 21.9 & 184.2 & 143.1 & 0.0 & 0.13 & 2.6 \\
\hline ELEVATORCOREFLR1 & 15 & 50 & & 0.00 & 0.00 & 128.4 & 0.0 & 75.3 & 0.0 & 0.13 & 0.0 \\
\hline EXERCISECENTERFLR1 & 33 & 109 & 2.96 & \begin{tabular}{|l|}
14.77 \\
\end{tabular} & 9.68 & 11.5 & 0.0 & 110.2 & 0.0 & 0.13 & 0.0 \\
\hline FRONTOFFICEFLR1 & 130 & 437 & 13.04 & 21.67 & 11.84 & 12.9 & 0.0 & 100.0 & 0.0 & 0.13 & 0.0 \\
\hline FRONTSTAIRSFLR1 & 20 & 67 & & 9.95 & 6.46 & 0.0 & 0.0 & 0.0 & 0.0 & 0.58 & 0.0 \\
\hline FRONTSTORAGEFLR1 & 13 & 42 & & 5.75 & 8.61 & 0.0 & 0.0 & 0.0 & 0.0 & 0.13 & 0.0 \\
\hline REARSTAIRSFLR2 & 20 & 55 & & 8.77 & 6.46 & 0.0 & 0.0 & 0.0 & 0.0 & 0.58 & 0.0 \\
\hline CORRIDORFLR2 & 125 & 344 & & 9.22 & 5.38 & 0.0 & 0.0 & 31.4 & 0.0 & 0.06 & 0.0 \\
\hline REARSTORAGEFLR2 & 20 & 55 & & 4.39 & 8.61 & 0.0 & 0.0 & 0.0 & 0.0 & 0.58 & 0.0 \\
\hline GUESTROOM201 & 33 & 89 & \begin{tabular}{|l|}
21.74 \\
\end{tabular} & 18.77 & 11.84 & 14.3 & 0.0 & 14.2 & 0.0 & 0.41 & 0.2 \\
\hline GUESTROOM202_205 & 130 & 358 & \begin{tabular}{|l|}
21.74 \\
\end{tabular} & 18.77 & 11.84 & 14.3 & 0.0 & 56.6 & 0.0 & 0.13 & 0.2 \\
\hline GUESTROOM206_208 & 105 & 289 & 23.41 & 18.77 & 11.84 & 14.3 & 0.0 & 42.5 & 0.0 & 0.13 & 0.2 \\
\hline GUESTROOM209_212 & 130 & 358 & 21.74 & 18.77 & 11.84 & 14.3 & 0.0 & 56.6 & 0.0 & 0.13 & 0.2 \\
\hline GUESTROOM213 & 33 & 89 & 21.74 & \begin{tabular}{|l|}
18.77 \\
\end{tabular} & 11.84 & 14.3 & 0.0 & 14.2 & 0.0 & 0.13 & 0.2 \\
\hline GUESTROOM214 & 33 & 89 & \begin{tabular}{|l|}
21.74 \\
\end{tabular} & \begin{tabular}{|l|}
18.77 \\
\end{tabular} & 11.84 & 14.3 & 0.0 & 14.2 & 0.0 & 0.13 & 0.2 \\
\hline GUESTROOM215_218 & 130 & 358 & 21.74 & 18.77 & 11.84 & 14.3 & 0.0 & 56.6 & 0.0 & 0.13 & 0.2 \\
\hline ELEVATORCOREFLR2 & 15 & 41 & & 0.00 & 0.00 & 0.0 & 0.0 & 0.0 & 0.0 & 0.13 & 0.0 \\
\hline GUESTROOM219 & 33 & 89 & \begin{tabular}{|l|}
21.74 \\
\end{tabular} & 18.77 & 11.84 & 14.3 & 0.0 & 14.2 & 0.0 & 0.13 & 0.2 \\
\hline GUESTROOM220_223 & 130 & 358 & \begin{tabular}{|l|}
21.74 \\
\end{tabular} & 18.77 & 11.84 & 14.3 & 0.0 & 56.6 & 0.0 & 0.13 & 0.2 \\
\hline GUESTROOM224 & 33 & 89 & \begin{tabular}{|l|}
21.74 \\
\end{tabular} & 18.77 & 11.84 & 14.3 & 0.0 & 14.2 & 0.0 & 0.13 & 0.2 \\
\hline FRONTSTORAGEFLR2 & 13 & 34 & & 4.89 & 8.61 & 0.0 & 0.0 & 0.0 & 0.0 & 0.13 & 0.0 \\
\hline FRONTSTAIRSFLR2 & 20 & 55 & & 8.77 & 6.46 & 0.0 & 0.0 & 0.0 & 0.0 & 0.58 & 0.0 \\
\hline REARSTAIRSFLR3 & 20 & 55 & & 8.77 & 6.46 & 0.0 & 0.0 & 0.0 & 0.0 & 0.58 & 0.0 \\
\hline CORRIDORFLR3 & 125 & 344 & & 9.22 & 5.38 & 0.0 & 0.0 & 31.4 & 0.0 & 0.06 & 0.0 \\
\hline REARSTORAGEFLR3 & 20 & 55 & & 4.39 & 8.61 & 0.0 & 0.0 & 0.0 & 0.0 & 0.58 & 0.0 \\
\hline GUESTROOM301 & 33 & 89 & 21.74 & 18.77 & 11.84 & 14.3 & 0.0 & 14.2 & 0.0 & 0.41 & 0.2 \\
\hline GUESTROOM302_305 & 130 & 358 & 21.74 & 18.77 & 11.84 & 14.3 & 0.0 & 56.6 & 0.0 & 0.13 & 0.2 \\
\hline GUESTROOM306_308 & 105 & 289 & 23.41 & \begin{tabular}{|l|}
18.77 \\
\end{tabular} & 11.84 & 14.3 & 0.0 & 42.5 & 0.0 & 0.13 & 0.2 \\
\hline GUESTROOM309_312 & 130 & 358 & 21.74 & 18.77 & 11.84 & 14.3 & 0.0 & 56.6 & 0.0 & 0.13 & 0.2 \\
\hline GUESTROOM313 & 33 & 89 & 21.74 & 18.77 & 11.84 & 14.3 & 0.0 & 14.2 & 0.0 & 0.13 & 0.2 \\
\hline GUESTROOM314 & 33 & 89 & 21.74 & 18.77 & 11.84 & 14.3 & 0.0 & 14.2 & 0.0 & 0.13 & 0.2 \\
\hline GUESTROOM315_318 & 130 & 358 & 21.74 & 18.77 & 11.84 & 14.3 & 0.0 & 56.6 & 0.0 & 0.13 & 0.2 \\
\hline ELEVATORCOREFLR3 & 15 & 41 & & 0.00 & 0.00 & 0.0 & 0.0 & 0.0 & 0.0 & 0.13 & 0.0 \\
\hline GUESTROOM319 & 33 & 89 & 21.74 & 18.77 & 11.84 & 14.3 & 0.0 & 14.2 & 0.0 & 0.13 & 0.2 \\
\hline GUESTROOM320_323 & 130 & 358 & 21.74 & 18.77 & 11.84 & 14.3 & 0.0 & 56.6 & 0.0 & 0.13 & 0.2 \\
\hline GUESTROOM324 & 33 & 89 & 21.74 & 18.77 & 11.84 & 14.3 & 0.0 & 14.2 & 0.0 & 0.13 & 0.2 \\
\hline FRONTSTORAGEFLR3 & 13 & 34 & & 4.89 & 8.61 & 0.0 & 0.0 & 0.0 & 0.0 & 0.13 & 0.0 \\
\hline
\end{tabular}




\begin{tabular}{|c|c|c|c|c|c|c|c|c|c|c|c|}
\hline Building Type/Zone & $\begin{array}{c}\text { Area } \\
\mathrm{m}^{2}\end{array}$ & $\begin{array}{l}\text { Vol. } \\
\mathrm{m}^{3}\end{array}$ & $\begin{array}{c}\mathrm{m}^{2} l \\
\text { person }\end{array}$ & \begin{tabular}{|c|}
1989 \\
Lights \\
$\mathrm{Wm}^{2}$ \\
\end{tabular} & \begin{tabular}{|c|}
2004 \\
Lights \\
$\mathrm{Wm}^{2}$ \\
\end{tabular} & $\begin{array}{l}\text { Elec. } \\
\text { Proc. } \\
\mathrm{W} / \mathrm{m}^{2}\end{array}$ & $\begin{array}{c}\text { Gas } \\
\text { Proc. } \\
\text { W/m }\end{array}$ & $\begin{array}{c}\text { Vent. } \\
\text { L/s }\end{array}$ & $\begin{array}{c}\text { Exhst } \\
\text { L/s }\end{array}$ & $\begin{array}{l}\text { Infil. } \\
\text { ACH }\end{array}$ & $\begin{array}{c}\text { SWH } \\
\text { L/h }\end{array}$ \\
\hline "FRONTSTAIRSFLR3 & 20 & 55 & & 8.77 & 6.46 & 0.0 & 0.0 & 0.0 & 0.0 & 0.58 & 0.0 \\
\hline REARSTAIRSFLR4 & 20 & 55 & & 4.39 & 6.46 & 0.0 & 0.0 & 0.0 & 0.0 & 0.98 & 0.0 \\
\hline CORRIDORFLR4 & 125 & 344 & & 9.22 & 5.38 & 0.0 & 0.0 & 31.4 & 0.0 & 0.45 & 0.0 \\
\hline REARSTORAGEFLR4 & 20 & 55 & & 4.39 & 8.61 & 0.0 & 0.0 & 0.0 & 0.0 & 0.98 & 0.0 \\
\hline GUESTROOM401 & 33 & 89 & 21.74 & 18.77 & 11.84 & 14.3 & 0.0 & 14.2 & 0.0 & 0.80 & 0.2 \\
\hline GUESTROOM402_405 & 130 & 358 & 21.74 & 18.77 & 11.84 & 14.3 & 0.0 & 56.6 & 0.0 & 0.53 & 0.2 \\
\hline GUESTROOM406_408 & 105 & 289 & 23.41 & 18.77 & 11.84 & 14.3 & 0.0 & 42.5 & 0.0 & 0.53 & 0.2 \\
\hline GUESTROOM409_412 & 130 & 358 & 21.74 & 18.77 & 11.84 & 14.3 & 0.0 & 56.6 & 0.0 & 0.53 & 0.2 \\
\hline GUESTROOM413 & 33 & 89 & 21.74 & 18.77 & 11.84 & 14.3 & 0.0 & 14.2 & 0.0 & 0.53 & 0.2 \\
\hline GUESTROOM414 & 33 & 89 & 21.74 & 18.77 & 11.84 & 14.3 & 0.0 & 14.2 & 0.0 & 0.53 & 0.2 \\
\hline GUESTROOM415_418 & 130 & 358 & 21.74 & 18.77 & 11.84 & 14.3 & 0.0 & 56.6 & 0.0 & 0.53 & 0.2 \\
\hline ELEVATORCOREFLR4 & 15 & 41 & & 0.00 & 0.00 & 0.0 & 0.0 & 0.0 & 0.0 & 0.53 & 0.0 \\
\hline GUESTROOM419 & 33 & 89 & 21.74 & 18.77 & 11.84 & 14.3 & 0.0 & 14.2 & 0.0 & 0.53 & 0.2 \\
\hline GUESTROOM420_423 & 130 & 358 & 21.74 & 18.77 & 11.84 & 14.3 & 0.0 & 56.6 & 0.0 & 0.53 & 0.2 \\
\hline GUESTROOM424 & 33 & 89 & 21.74 & 18.77 & 11.84 & 14.3 & 0.0 & 14.2 & 0.0 & 0.53 & 0.2 \\
\hline FRONTSTORAGEFLR4 & 13 & 34 & & 4.89 & 8.61 & 0.0 & 0.0 & 0.0 & 0.0 & 0.53 & 0.0 \\
\hline FRONTSTAIRSFLR4 & 20 & 55 & & 8.77 & 6.46 & 0.0 & 0.0 & 0.0 & 0.0 & 0.98 & 0.0 \\
\hline Small Office & 511 & 1,559 & & & & & & & & & \\
\hline Core_ZN & 150 & 456 & 18.58 & 19.48 & 10.76 & 10.76 & 0.0 & 80.5 & 0.0 & 0.00 & 11.4 \\
\hline Perimeter_ZN_1 & 113 & 346 & 18.58 & 19.48 & 10.76 & 10.76 & 0.0 & 61.1 & 0.0 & 0.62 & 0.0 \\
\hline Perimeter_ZN_2 & 67 & 205 & 18.58 & 19.48 & 10.76 & 10.76 & 0.0 & 36.2 & 0.0 & 0.66 & 0.0 \\
\hline Perimeter_ZN_3 & 113 & 346 & 18.58 & 19.48 & 10.76 & 10.76 & 0.0 & 61.1 & 0.0 & 0.62 & 0.0 \\
\hline Perimeter_ZN_4 & 67 & 205 & 18.58 & 19.48 & 10.76 & 10.76 & 0.0 & 36.2 & 0.0 & 0.66 & 0.0 \\
\hline Attic & 568 & 720 & 0.00 & & 0.00 & 0.0 & 0.0 & 0.0 & 0.0 & 1.00 & 0.0 \\
\hline Strip Mall & 2,090 & 10,831 & & & & & & & & & \\
\hline LGStore1 & 348 & 1,805 & 6.19 & 60.26 & 23.99 & 4.3 & 0.0 & 522.6 & 0.0 & 0.38 & 0.0 \\
\hline SMStore1 & 174 & 903 & 6.19 & 60.26 & 23.99 & 4.3 & 0.0 & 261.3 & 0.0 & 0.31 & 0.0 \\
\hline SMStore2 & 174 & 903 & 6.19 & 35.51 & 18.29 & 4.3 & 0.0 & 261.3 & 0.0 & 0.31 & 0.0 \\
\hline SMStore3 & 174 & 903 & 6.19 & 35.51 & 18.29 & 4.3 & 0.0 & 261.3 & 0.0 & 0.31 & 0.0 \\
\hline SMStore4 & 174 & 903 & 6.19 & 35.51 & 18.29 & 4.3 & 0.0 & 261.3 & 0.0 & 0.31 & 0.0 \\
\hline LGStore2 & 348 & 1,805 & 6.19 & 29.05 & 13.77 & 4.3 & 0.0 & 522.6 & 0.0 & 0.31 & 0.0 \\
\hline SMStore5 & 174 & 903 & 6.19 & 29.05 & 13.77 & 4.3 & 0.0 & 261.3 & 0.0 & 0.31 & 0.0 \\
\hline SMStore6 & 174 & 903 & 6.19 & 29.05 & 13.77 & 4.3 & 0.0 & 261.3 & 0.0 & 0.31 & 0.0 \\
\hline SMStore7 & 174 & 903 & 6.19 & 29.05 & 13.77 & 4.3 & 0.0 & 261.3 & 0.0 & 0.31 & 0.0 \\
\hline SMStore8 & 174 & 903 & 6.19 & 29.05 & 13.77 & 4.3 & 0.0 & 261.3 & 0.0 & 0.45 & 0.0 \\
\hline Warehouse & 4,835 & 39,241 & & & & & & & & & \\
\hline Office & 237 & 1,011 & 47.38 & 21.69 & \begin{tabular}{|l|}
11.84 \\
\end{tabular} & 8.1 & 0.0 & 50.0 & 0.0 & 0.16 & 0.0 \\
\hline Fine Storage & 1,393 & 10,881 & 0.00 & 11.64 & 15.06 & 0.0 & 0.0 & 348.4 & 0.0 & 0.22 & 0.0 \\
\hline Bulk Storage & 3,205 & 27,350 & 0.00 & 3.34 & 9.68 & 2.6 & 0.0 & 37758.1 & 0.0 & 0.19 & 0.0 \\
\hline
\end{tabular}




\section{Appendix B Schedules}

Table B-1 Quick Service Restaurant Hourly Operation Schedules

\begin{tabular}{|c|c|c|c|c|c|c|c|c|c|c|c|c|c|c|c|c|c|c|c|c|c|c|c|c|c|}
\hline Schedule & Day of Week & 1 & 2 & 3 & 4 & 5 & 6 & 7 & 8 & 9 & 10 & 11 & 12 & 13 & 14 & 15 & 16 & 17 & 18 & 19 & 20 & 21 & 22 & 23 & 24 \\
\hline ALWAYS_ON & All & $\overline{c 1}$ & $\overline{c 1}$ & $\overline{c 1}$ & $\overline{c 1}$ & $\overline{c 1}$ & $\overline{\overline{1}}$ & $\overline{\overline{1}}$ & $\overline{c 1}$ & $\overline{c 1}$ & $\overline{c 1}$ & 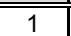 & $\overline{c 1}$ & $\overline{c 1}$ & $\overline{c 1}$ & $\overline{c 1}$ & $\overline{c 1}$ & 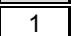 & $\overline{c 1}$ & $\overline{c 1}$ & $\overline{c 1}$ & $\overline{c 1}$ & $\overline{c 1}$ & $\overline{c 1}$ & $\overline{17}$ \\
\hline ACTIVITY_SCH & All & 120 & 120 & \begin{tabular}{|l|}
120 \\
\end{tabular} & \begin{tabular}{|l|}
120 \\
\end{tabular} & \begin{tabular}{|l|}
120 \\
\end{tabular} & \begin{tabular}{|l|}
120 \\
\end{tabular} & \begin{tabular}{|l|}
120 \\
\end{tabular} & \begin{tabular}{|l|}
120 \\
\end{tabular} & 120 & 120 & 120 & 120 & 120 & 120 & 120 & 120 & 120 & 120 & 120 & \begin{tabular}{|l|}
120 \\
\end{tabular} & \begin{tabular}{|l|}
120 \\
\end{tabular} & 120 & \begin{tabular}{|l|}
120 \\
\end{tabular} & 120 \\
\hline AIR_VELO_SCH & All & 0.2 & \begin{tabular}{|l|}
0.2 \\
\end{tabular} & 0.2 & 0.2 & 0.2 & 0.2 & 0.2 & 0.2 & 0.2 & 0.2 & 0.2 & 0.2 & 0.2 & 0.2 & \begin{tabular}{|l|}
0.2 \\
\end{tabular} & \begin{tabular}{|l|}
0.2 \\
\end{tabular} & 0.2 & 0.2 & 0.2 & 0.2 & 0.2 & 0.2 & 0.2 & 0.2 \\
\hline \multirow[t]{5}{*}{ BLDG_EQUIP_SCH } & Weekday & 0.1 & \begin{tabular}{|l|}
0.1 \\
\end{tabular} & \begin{tabular}{|l|}
0.1 \\
\end{tabular} & \begin{tabular}{|l|}
0.1 \\
\end{tabular} & \begin{tabular}{|l|}
0.1 \\
\end{tabular} & \begin{tabular}{|l|}
0.1 \\
\end{tabular} & 0.35 & \begin{tabular}{|l|}
0.35 \\
\end{tabular} & 0.25 & 0.25 & 0.35 & 0.35 & 0.35 & 0.35 & 0.25 & 0.25 & 0.25 & 0.35 & 0.35 & 0.35 & \begin{tabular}{|l|}
0.25 \\
\end{tabular} & 0.25 & 0.25 & 0.25 \\
\hline & Sat & 0.1 & \begin{tabular}{|l|}
0.1 \\
\end{tabular} & \begin{tabular}{|l|}
0.1 \\
\end{tabular} & \begin{tabular}{|l|}
0.1 \\
\end{tabular} & \begin{tabular}{|l|}
0.1 \\
\end{tabular} & \begin{tabular}{|l|}
0.1 \\
\end{tabular} & 0.35 & \begin{tabular}{|l|}
0.35 \\
\end{tabular} & 0.25 & 0.25 & 0.35 & 0.35 & 0.35 & 0.35 & 0.25 & 0.25 & 0.25 & 0.35 & 0.35 & 0.35 & 0.25 & 0.25 & 0.25 & 0.25 \\
\hline & SummerDesign & 0.35 & 0.35 & 0.35 & 0.35 & 0.35 & 0.35 & 0.35 & 0.35 & 0.35 & 0.35 & 0.35 & 0.35 & 0.35 & 0.35 & 0.35 & 0.35 & 0.35 & 0.35 & 0.35 & 0.35 & 0.35 & 0.35 & 0.35 & 0.35 \\
\hline & WinterDesign & 0 & 0 & 0 & 0 & 0 & 0 & 0 & 0 & 0 & 0 & 0 & 0 & 0 & 0 & 0 & 0 & 0 & 0 & 0 & 0 & 0 & 0 & 0 & 0 \\
\hline & Sun, Hol, Other & 0.1 & \begin{tabular}{|l|}
0.1 \\
\end{tabular} & \begin{tabular}{|l|}
0.1 \\
\end{tabular} & \begin{tabular}{|l|}
0.1 \\
\end{tabular} & \begin{tabular}{|l|}
0.1 \\
\end{tabular} & \begin{tabular}{|l|}
0.1 \\
\end{tabular} & 0.35 & \begin{tabular}{|l|}
0.35 \\
\end{tabular} & 0.25 & 0.25 & 0.35 & 0.35 & 0.35 & 0.35 & \begin{tabular}{|l|}
0.25 \\
\end{tabular} & \begin{tabular}{|l|}
0.25 \\
\end{tabular} & 0.25 & \begin{tabular}{|l|}
0.35 \\
\end{tabular} & \begin{tabular}{|l|}
0.35 \\
\end{tabular} & 0.35 & \begin{tabular}{|l|}
0.25 \\
\end{tabular} & 0.25 & \begin{tabular}{|l|}
0.25 \\
\end{tabular} & 0.25 \\
\hline \multirow[t]{3}{*}{ BLDG_LIGHT_SCH } & \begin{tabular}{|l|} 
SummerDesign \\
\end{tabular} & 1 & 1 & 1 & 1 & 1 & 1 & 1 & 1 & 1 & 1 & 1 & 1 & 1 & 1 & 1 & 1 & 1 & 1 & 1 & 1 & 1 & 1 & 1 & 1 \\
\hline & WinterDesign & 0 & 0 & 0 & 0 & 0 & 0 & 0 & 0 & 0 & 0 & 0 & 0 & 0 & 0 & 0 & 0 & 0 & 0 & 0 & 0 & 0 & 0 & 0 & 0 \\
\hline & $\begin{array}{l}\text { Weekday, Sat, Sun, } \\
\text { Hol, Other }\end{array}$ & 0.45 & 0.15 & 0.15 & 0.15 & 0.15 & 0.45 & 0.9 & 0.9 & 0.9 & 0.9 & 0.9 & 0.9 & 0.9 & 0.9 & 0.9 & 0.9 & 0.9 & 0.9 & 0.9 & 0.9 & 0.9 & 0.9 & 0.9 & 0.9 \\
\hline \multirow[t]{4}{*}{ BLDG_OCC_SCH } & WD & 0.05 & 0 & 0 & 0 & 0 & 0.05 & \begin{tabular}{|l|}
0.1 \\
\end{tabular} & 0.4 & 0.4 & 0.3 & 0.2 & 0.5 & 0.8 & 0.7 & 0.4 & \begin{tabular}{|l|}
0.2 \\
\end{tabular} & \begin{tabular}{|l|}
0.25 \\
\end{tabular} & 0.5 & \begin{tabular}{|l|}
0.55 \\
\end{tabular} & \begin{tabular}{|l|}
0.55 \\
\end{tabular} & \begin{tabular}{|l|}
0.55 \\
\end{tabular} & 0.5 & \begin{tabular}{|l|}
0.35 \\
\end{tabular} & \begin{tabular}{|l|}
0.2 \\
\end{tabular} \\
\hline & \begin{tabular}{|l|} 
SummerDesign \\
\end{tabular} & 1 & 1 & 1 & 1 & 1 & 1 & 1 & 1 & 1 & 1 & 1 & 1 & 1 & 1 & 1 & 1 & 1 & 1 & 1 & 1 & 1 & 1 & 1 & 1 \\
\hline & WinterDesign & 0 & 0 & 0 & 0 & 0 & 0 & 0 & 0 & 0 & 0 & 0 & 0 & 0 & 0 & 0 & 0 & 0 & 0 & 0 & 0 & 0 & 0 & 0 & 0 \\
\hline & Sat, Sun, Hol, Other & 0.05 & 0 & 0 & 0 & 0 & 0.05 & 0.05 & 0.3 & 0.3 & 0.3 & 0.2 & 0.45 & 0.6 & 0.5 & 0.35 & 0.3 & 0.3 & 0.3 & 0.55 & 0.55 & 0.55 & 0.5 & 0.35 & 0.2 \\
\hline \multirow[t]{3}{*}{ GAS_EQUIP_SCH } & \begin{tabular}{|l|} 
SummerDesign \\
\end{tabular} & 0.25 & 0.25 & 0.25 & 0.25 & 0.25 & 0.25 & 0.25 & 0.25 & 0.25 & 0.25 & 0.25 & 0.25 & 0.25 & 0.25 & 0.25 & 0.25 & 0.25 & 0.25 & 0.25 & 0.25 & 0.25 & 0.25 & 0.25 & 0.25 \\
\hline & WinterDesign & 0 & 0 & 0 & 0 & 0 & 0 & 0 & 0 & 0 & 0 & 0 & 0 & 0 & 0 & 0 & 0 & 0 & 0 & 0 & 0 & 0 & 0 & 0 & 0 \\
\hline & Other & 0.02 & 0.02 & 0.02 & 0.02 & 0.02 & 0.03 & 0.09 & 0.14 & 0.1 & 0.1 & 0.22 & 0.27 & 0.24 & 0.21 & 0.14 & 0.13 & 0.15 & 0.17 & 0.17 & 0.17 & 0.15 & 0.14 & 0.12 & 0.02 \\
\hline \multirow[t]{3}{*}{ INFIL_HALF_ON_SCH } & WD, SummerDesign & 1 & 1 & 1 & 1 & 1 & \begin{tabular}{|l|}
0.5 \\
\end{tabular} & \begin{tabular}{|l|}
0.5 \\
\end{tabular} & \begin{tabular}{|l|}
0.5 \\
\end{tabular} & 0.5 & 0.5 & \begin{tabular}{|l|}
0.5 \\
\end{tabular} & \begin{tabular}{|l|}
0.5 \\
\end{tabular} & \begin{tabular}{|l|}
0.5 \\
\end{tabular} & 0.5 & \begin{tabular}{|l|}
0.5 \\
\end{tabular} & \begin{tabular}{|l|}
0.5 \\
\end{tabular} & \begin{tabular}{|l|}
0.5 \\
\end{tabular} & \begin{tabular}{|l|}
0.5 \\
\end{tabular} & \begin{tabular}{|l|}
0.5 \\
\end{tabular} & \begin{tabular}{|l|}
0.5 \\
\end{tabular} & \begin{tabular}{|l|}
0.5 \\
\end{tabular} & 0.5 & 0.5 & \begin{tabular}{|l|}
0.5 \\
\end{tabular} \\
\hline & Sat, WinterDesign & 1 & 1 & 1 & 1 & 1 & \begin{tabular}{|l|}
0.5 \\
\end{tabular} & 0.5 & 0.5 & 0.5 & 0.5 & 0.5 & 0.5 & 0.5 & 0.5 & \begin{tabular}{|l|}
0.5 \\
\end{tabular} & \begin{tabular}{|l|}
0.5 \\
\end{tabular} & 0.5 & 0.5 & 0.5 & 0.5 & 0.5 & 0.5 & 0.5 & 0.5 \\
\hline & Sun, Hol, Other & 1 & 1 & 1 & 1 & 1 & 0.5 & 0.5 & 0.5 & 0.5 & 0.5 & 0.5 & 0.5 & 0.5 & 0.5 & 0.5 & 0.5 & 0.5 & 0.5 & 0.5 & 0.5 & 0.5 & 0.5 & 0.5 & 0.5 \\
\hline Kitchen_Exhaust_SCH & All & 1 & 0 & 0 & 0 & 0 & 1 & 1 & 1 & 1 & 1 & 1 & 1 & 1 & 1 & 1 & 1 & 1 & 1 & 1 & 1 & 1 & 1 & 1 & 1 \\
\hline WORK_EFF_SCH & All & 0 & 0 & 0 & 0 & 0 & 0 & 0 & 0 & 0 & 0 & 0 & 0 & 0 & 0 & 0 & 0 & 0 & 0 & 0 & 0 & 0 & 0 & 0 & 0 \\
\hline \multirow[t]{3}{*}{ CLOTHING_SCH } & All & 1 & 1 & 1 & 1 & 1 & 1 & 1 & 1 & 1 & 1 & 1 & 1 & 1 & 1 & 1 & 1 & 1 & 1 & 1 & 1 & 1 & 1 & 1 & 1 \\
\hline & All & 0.5 & 0.5 & \begin{tabular}{|l|}
0.5 \\
\end{tabular} & \begin{tabular}{|l|}
0.5 \\
\end{tabular} & \begin{tabular}{|l|}
0.5 \\
\end{tabular} & \begin{tabular}{|l|}
0.5 \\
\end{tabular} & \begin{tabular}{|l|}
0.5 \\
\end{tabular} & 0.5 & 0.5 & 0.5 & 0.5 & 0.5 & 0.5 & 0.5 & 0.5 & 0.5 & 0.5 & 0.5 & 0.5 & 0.5 & 0.5 & 0.5 & 0.5 & 0.5 \\
\hline & All & 1 & 1 & 1 & 1 & 1 & 1 & 1 & 1 & 1 & 1 & 1 & 1 & 1 & 1 & 1 & 1 & 1 & 1 & 1 & 1 & 1 & 1 & 1 & 1 \\
\hline Dual Zone Control Type Sched & All & 4 & 4 & 4 & 4 & 4 & 4 & 4 & 4 & 4 & 4 & 4 & 4 & 4 & 4 & 4 & 4 & 4 & 4 & 4 & 4 & 4 & 4 & 4 & 4 \\
\hline \multirow[t]{2}{*}{ CLGSETP_KITCHEN_SCH } & WinterDesign & 30 & 30 & 30 & 30 & 30 & 30 & 30 & 30 & 30 & 30 & 30 & 30 & 30 & 30 & 30 & 30 & 30 & 30 & 30 & 30 & 30 & 30 & 30 & 30 \\
\hline & Other & 26 & 30 & 30 & 30 & 30 & 26 & 26 & 26 & 26 & 26 & 26 & 26 & 26 & 26 & 26 & 26 & 26 & 26 & 26 & 26 & 26 & 26 & 26 & 26 \\
\hline \multirow[t]{3}{*}{ HTGSETP_KITCHEN_SCH } & SummerDesign & 15.6 & \begin{tabular}{|l|}
15.6 \\
\end{tabular} & \begin{tabular}{|l|}
15.6 \\
\end{tabular} & \begin{tabular}{|l|}
15.6 \\
\end{tabular} & \begin{tabular}{|l|}
15.6 \\
\end{tabular} & \begin{tabular}{|l|}
15.6 \\
\end{tabular} & \begin{tabular}{|l|}
15.6 \\
\end{tabular} & \begin{tabular}{|l|}
15.6 \\
\end{tabular} & \begin{tabular}{|l|}
15.6 \\
\end{tabular} & \begin{tabular}{|l|}
15.6 \\
\end{tabular} & \begin{tabular}{|l|}
15.6 \\
\end{tabular} & \begin{tabular}{|l|}
15.6 \\
\end{tabular} & \begin{tabular}{|l|}
15.6 \\
\end{tabular} & \begin{tabular}{|l|}
15.6 \\
\end{tabular} & 15.6 & 15.6 & 15.6 & 15.6 & 15.6 & 15.6 & \begin{tabular}{|l|}
15.6 \\
\end{tabular} & 15.6 & \begin{tabular}{|l|}
15.6 \\
\end{tabular} & 15.6 \\
\hline & WinterDesign & 19 & 19 & 19 & 19 & 19 & 19 & 19 & 19 & 19 & 19 & 19 & 19 & 19 & 19 & 19 & 19 & 19 & 19 & 19 & 19 & 19 & 19 & 19 & 19 \\
\hline & Other & 19 & 15.6 & 15.6 & 15.6 & 15.6 & 19 & 19 & 19 & 19 & 19 & 19 & 19 & 19 & 19 & 19 & 19 & 19 & 19 & 19 & 19 & 19 & 19 & 19 & 19 \\
\hline \multirow[t]{2}{*}{ CLGSETP_SCH } & WinterDesign & 30 & 30 & 30 & 30 & 30 & 30 & 30 & 30 & 30 & 30 & 30 & 30 & 30 & 30 & 30 & 30 & 30 & 30 & 30 & 30 & 30 & 30 & 30 & 30 \\
\hline & Other & 24 & 30 & 30 & 30 & 30 & 24 & 24 & 24 & 24 & 24 & 24 & 24 & 24 & 24 & 24 & 24 & 24 & 24 & 24 & 24 & 24 & 24 & 24 & \begin{tabular}{|l|}
24 \\
\end{tabular} \\
\hline \multirow[t]{3}{*}{ HTGSETP_SCH } & SummerDesign & 15.6 & 15.6 & 15.6 & 15.6 & 15.6 & 15.6 & 15.6 & 15.6 & 15.6 & 15.6 & 15.6 & 15.6 & 15.6 & 15.6 & 15.6 & 15.6 & 15.6 & 15.6 & 15.6 & 15.6 & 15.6 & 15.6 & 15.6 & 15.6 \\
\hline & WinterDesign & 21 & 21 & 21 & 21 & 21 & 21 & 21 & 21 & 21 & 21 & 21 & 21 & 21 & 21 & 21 & 21 & 21 & 21 & 21 & 21 & \begin{tabular}{|l|}
21 \\
\end{tabular} & 21 & 21 & 21 \\
\hline & Other & 21 & 15.6 & 15.6 & 15.6 & 15.6 & 21 & 21 & 21 & 21 & 21 & 21 & 21 & 21 & 21 & 21 & 21 & 21 & 21 & 21 & 21 & 21 & 21 & 21 & 21 \\
\hline HVACOperationSchd & All & 1 & 0 & 0 & 0 & 0 & 1 & 1 & 1 & 1 & 1 & 1 & 1 & 1 & 1 & 1 & 1 & 1 & 1 & 1 & 1 & 1 & 1 & 1 & 1 \\
\hline MinOA_Sched & All & 1 & 0 & 0 & 0 & 0 & 1 & 1 & 1 & 1 & 1 & 1 & 1 & 1 & 1 & 1 & 1 & 1 & 1 & 1 & 1 & 1 & 1 & 1 & 1 \\
\hline
\end{tabular}




\begin{tabular}{|c|c|c|c|c|c|c|c|c|c|c|c|c|c|c|c|c|c|c|c|c|c|c|c|c|c|}
\hline Schedule & Day of Week & 1 & 2 & 3 & 4 & 5 & 6 & 7 & 8 & 9 & 10 & 11 & 12 & 13 & 14 & 15 & 16 & 17 & 18 & 19 & 20 & 21 & 22 & 23 & 24 \\
\hline $\begin{array}{l}\text { Kitchen_Case:1_WALKINFREEZER_ } \\
\text { CaseCreditReduxSched }\end{array}$ & All & 0.2 & 0.2 & 0.2 & 0.2 & 0.2 & 0.2 & 0.2 & 0.4 & 0.4 & 0.4 & 0.4 & 0.4 & 0.4 & 0.4 & 0.4 & 0.4 & 0.4 & 0.4 & 0.4 & 0.4 & 0.4 & 0.2 & 0.2 & 0.2 \\
\hline $\begin{array}{l}\text { Kitchen_Case:1_WALKINFREEZER_ } \\
\text { CaseDefrost2aDaySched }\end{array}$ & All & 0 & 0 & 0 & 0 & 0 & 0 & 0 & 0 & 0 & 0 & 0 & 0 & 0 & 0 & 0 & 0 & 0 & 0 & 0 & 0 & 0 & 0 & 0 & 0 \\
\hline $\begin{array}{l}\text { Kitchen_Case:1_WALKINFREEZER_ } \\
\text { CaseDripDown2aDaySched }\end{array}$ & All & 0 & 0 & 0 & 0 & 0 & 0 & 0 & 0 & 0 & 0 & 0 & 0 & 0 & 0 & 0 & 0 & 0 & 0 & 0 & 0 & 0 & 0 & 0 & 0 \\
\hline $\begin{array}{l}\text { Kitchen_Case:1_WALKINFREEZER_ } \\
\text { WalkInStockingSched }\end{array}$ & Tue, Fri & 0 & 0 & 0 & 0 & 725 & 417 & 290 & 0 & 0 & 0 & 0 & 0 & 0 & 0 & 0 & 0 & 0 & 0 & 0 & 0 & 0 & 0 & 0 & 0 \\
\hline & Other & 0 & 0 & 0 & 0 & 125 & \begin{tabular}{|l|}
117 \\
\end{tabular} & 90 & 0 & 0 & 0 & 0 & 0 & 0 & 0 & 0 & 0 & 0 & 0 & 0 & \begin{tabular}{|l|}
125 \\
\end{tabular} & 117 & 90 & 0 & 0 \\
\hline $\begin{array}{l}\text { Kitchen_Case:2_SELFCONTAINEDD } \\
\text { ISPLAYCASE_CaseStockingSched }\end{array}$ & All & 0 & 0 & 0 & 0 & 0 & 0 & 50 & 70 & 70 & 80 & 70 & 50 & 50 & 80 & 90 & 80 & 0 & 0 & 0 & 0 & 0 & 0 & 0 & 0 \\
\hline BLDG_SWH_SCH & WD, SummerDesign & 0.2 & 0 & 0 & 0 & 0 & 0 & 0.15 & 0.6 & 0.55 & 0.45 & 0.4 & 0.45 & 0.4 & 0.35 & \begin{tabular}{|l|}
0.3 \\
\end{tabular} & \begin{tabular}{|l|}
0.3 \\
\end{tabular} & \begin{tabular}{|l|}
0.3 \\
\end{tabular} & 0.4 & 0.55 & 0.6 & 0.5 & 0.55 & 0.45 & 0.25 \\
\hline & \begin{tabular}{|l} 
Sat, WinterDesign \\
\end{tabular} & 0.2 & 0 & 0 & 0 & 0 & 0 & \begin{tabular}{|l|}
0.15 \\
\end{tabular} & 0.15 & \begin{tabular}{|l|}
0.15 \\
\end{tabular} & \begin{tabular}{|l|}
0.5 \\
\end{tabular} & \begin{tabular}{|l|}
0.45 \\
\end{tabular} & \begin{tabular}{|l|}
0.5 \\
\end{tabular} & \begin{tabular}{|l|}
0.5 \\
\end{tabular} & \begin{tabular}{|l|}
0.45 \\
\end{tabular} & \begin{tabular}{|l|}
0.4 \\
\end{tabular} & \begin{tabular}{|l|}
0.4 \\
\end{tabular} & \begin{tabular}{|l|}
0.35 \\
\end{tabular} & \begin{tabular}{|l|}
0.4 \\
\end{tabular} & \begin{tabular}{|l|}
0.55 \\
\end{tabular} & \begin{tabular}{|l|}
0.55 \\
\end{tabular} & 0.5 & \begin{tabular}{|l|}
0.55 \\
\end{tabular} & \begin{tabular}{|l|l|}
0.4 \\
\end{tabular} & \begin{tabular}{|l|}
0.3 \\
\end{tabular} \\
\hline & Sun, Hol, Other & 0.25 & 0 & 0 & 0 & 0 & 0 & 0.15 & 0.15 & \begin{tabular}{|l|}
0.15 \\
\end{tabular} & \begin{tabular}{|l|}
0.15 \\
\end{tabular} & \begin{tabular}{|l|}
0.5 \\
\end{tabular} & \begin{tabular}{|l|}
0.5 \\
\end{tabular} & \begin{tabular}{|l|}
0.4 \\
\end{tabular} & \begin{tabular}{|l|}
0.4 \\
\end{tabular} & \begin{tabular}{|l|}
0.3 \\
\end{tabular} & \begin{tabular}{|l|}
0.3 \\
\end{tabular} & \begin{tabular}{|l|}
0.3 \\
\end{tabular} & \begin{tabular}{|l|}
0.4 \\
\end{tabular} & \begin{tabular}{|l|}
0.5 \\
\end{tabular} & \begin{tabular}{|l|}
0.5 \\
\end{tabular} & 0.4 & 0.5 & 0.4 & 0.2 \\
\hline $\begin{array}{l}\text { Kitchen Water Equipment Hot Supply } \\
\text { Temp Sched }\end{array}$ & All & 49 & 49 & 49 & 49 & 49 & 49 & 49 & 49 & 49 & 49 & 49 & 49 & 49 & 49 & 49 & 49 & 49 & 49 & 49 & 49 & 49 & 49 & 49 & 49 \\
\hline $\begin{array}{l}\text { Kitchen Water Equipment Latent fract } \\
\text { sched }\end{array}$ & All & 0.05 & 0.05 & 0.05 & 0.05 & 0.05 & 0.05 & 0.05 & 0.05 & 0.05 & 0.05 & 0.05 & 0.05 & 0.05 & 0.05 & 0.05 & 0.05 & 0.05 & 0.05 & 0.05 & 0.05 & 0.05 & 0.05 & 0.05 & 0.05 \\
\hline $\begin{array}{l}\text { Kitchen Water Equipment Sensible } \\
\text { fract sched }\end{array}$ & All & 0.2 & 0.2 & 0.2 & 0.2 & 0.2 & 0.2 & 0.2 & 0.2 & 0.2 & 0.2 & 0.2 & 0.2 & 0.2 & 0.2 & 0.2 & 0.2 & 0.2 & 0.2 & 0.2 & 0.2 & 0.2 & 0.2 & 0.2 & 0.2 \\
\hline $\begin{array}{l}\text { Kitchen Water Equipment Temp } \\
\text { Sched }\end{array}$ & All & 49 & 49 & 49 & 49 & 49 & 49 & 49 & 49 & 49 & 49 & 49 & 49 & 49 & 49 & 49 & 49 & 49 & 49 & 49 & 49 & 49 & 49 & 49 & 49 \\
\hline PlantOnSched & \begin{tabular}{|l} 
All \\
\end{tabular} & 1 & 1 & 1 & 1 & 1 & 1 & 1 & 1 & 1 & 1 & 1 & 1 & 1 & 1 & 1 & 1 & 1 & 1 & 1 & 1 & 1 & 1 & 1 & 1 \\
\hline $\begin{array}{l}\text { SWHSys } 1 \text { Water Heater Ambient } \\
\text { Temperature Schedule Name }\end{array}$ & All & 22 & 22 & 22 & 22 & 22 & 22 & 22 & 22 & 22 & 22 & 22 & 22 & 22 & 22 & 22 & 22 & 22 & 22 & 22 & 22 & 22 & 22 & 22 & 22 \\
\hline $\begin{array}{l}\text { SWHSys } 1 \text { Water Heater Setpoint } \\
\text { Temperature Schedule Name }\end{array}$ & All & 60 & 60 & 60 & 60 & 60 & 60 & 60 & 60 & 60 & 60 & 60 & 60 & 60 & 60 & 60 & 60 & 60 & 60 & 60 & 60 & 60 & 60 & 60 & 60 \\
\hline SWHSys1-Loop-Temp-Schedule & All & 60 & 60 & 60 & 60 & 60 & 60 & 60 & 60 & 60 & 60 & 60 & 60 & 60 & 60 & 60 & 60 & 60 & 60 & 60 & 60 & 60 & 60 & 60 & 60 \\
\hline
\end{tabular}


Table B-2 Hospital Hourly Operation Schedules

\begin{tabular}{|c|c|c|c|c|c|c|c|c|c|c|c|c|c|c|c|c|c|c|c|c|c|c|c|c|c|}
\hline Schedule & Day of Week & 1 & 2 & 3 & 4 & 5 & 6 & 7 & 8 & 9 & 10 & 11 & 12 & 13 & 14 & 15 & 16 & 17 & 18 & 19 & 20 & 21 & 22 & 23 & 24 \\
\hline ALWAYS_ON & All & 1 & 1 & 1 & 1 & 1 & 1 & 1 & 1 & 1 & 1 & 1 & 1 & 1 & 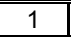 & 1 & 1 & 1 & 1 & 1 & 1 & 1 & 1 & 1 & 1 \\
\hline \multirow[t]{5}{*}{ Kitchen_Exhaust_SCH } & WD & 0 & 0 & 0 & 0 & 0 & 1 & 1 & 1 & 1 & 1 & 1 & 1 & 1 & 1 & 1 & 1 & 1 & 1 & 0 & 0 & 0 & 0 & 0 & 0 \\
\hline & SummerDesign & 0 & 0 & 0 & 0 & 0 & 1 & 1 & 1 & 1 & 1 & 1 & 1 & 1 & 1 & 1 & 1 & 1 & 1 & 0 & 0 & 0 & 0 & 0 & 0 \\
\hline & WinterDesign & 0 & 0 & 0 & 0 & 0 & 0 & 0 & 1 & 1 & 1 & 1 & 1 & 1 & 1 & 1 & 0 & 0 & 0 & 0 & 0 & 0 & 0 & 0 & 0 \\
\hline & Sats & 0 & 0 & 0 & 0 & 0 & 0 & 0 & 1 & 1 & 1 & 1 & 1 & 1 & 1 & 1 & 0 & 0 & 0 & 0 & 0 & 0 & 0 & 0 & 0 \\
\hline & Other & 0 & 0 & 0 & 0 & 0 & 0 & 0 & 0 & 0 & 0 & 0 & 0 & 0 & 0 & 0 & 0 & 0 & 0 & 0 & 0 & 0 & 0 & 0 & 0 \\
\hline \multirow[t]{5}{*}{ ADMIN_EQUIP_SCH } & WD & 0.3 & 0.3 & 0.3 & 0.3 & 0.5 & 0.5 & 1 & 1 & 1 & 1 & 1 & 1 & 1 & 1 & 1 & 1 & 1 & 1 & 0.5 & 0.5 & 0.3 & 0.3 & 0.3 & 0.3 \\
\hline & SummerDesign & 0.3 & 0.3 & 0.3 & 0.3 & 0.5 & 0.5 & 1 & 1 & 1 & 1 & 1 & 1 & 1 & 1 & 1 & 1 & 1 & 1 & 0.5 & 0.5 & 0.3 & 0.3 & 0.3 & 0.3 \\
\hline & WinterDesign & 0.3 & 0.3 & 0.3 & 0.3 & 0.3 & 0.3 & 0.3 & \begin{tabular}{|l|}
0.3 \\
\end{tabular} & \begin{tabular}{|l|}
0.3 \\
\end{tabular} & \begin{tabular}{|l|}
0.3 \\
\end{tabular} & \begin{tabular}{|l|}
0.3 \\
\end{tabular} & \begin{tabular}{|l|}
0.3 \\
\end{tabular} & \begin{tabular}{|l|}
0.3 \\
\end{tabular} & \begin{tabular}{|l|}
0.3 \\
\end{tabular} & \begin{tabular}{|l|}
0.3 \\
\end{tabular} & \begin{tabular}{|l|}
0.3 \\
\end{tabular} & \begin{tabular}{|l|}
0.3 \\
\end{tabular} & \begin{tabular}{|l|}
0.3 \\
\end{tabular} & \begin{tabular}{|l|}
0.3 \\
\end{tabular} & 0.3 & \begin{tabular}{|l|}
0.3 \\
\end{tabular} & \begin{tabular}{|l|}
0.3 \\
\end{tabular} & \begin{tabular}{|l|}
0.3 \\
\end{tabular} & 0.3 \\
\hline & Sat & 0.3 & 0.3 & 0.3 & 0.3 & 0.3 & 0.3 & 0.3 & 0.5 & 0.5 & 0.8 & 0.8 & 0.8 & \begin{tabular}{|l|}
0.8 \\
\end{tabular} & \begin{tabular}{|l|}
0.8 \\
\end{tabular} & \begin{tabular}{|l|}
0.8 \\
\end{tabular} & \begin{tabular}{|l|}
0.5 \\
\end{tabular} & 0.5 & 0.5 & 0.5 & 0.5 & 0.3 & 0.3 & 0.3 & 0.3 \\
\hline & Other & 0.3 & 0.3 & 0.3 & 0.3 & 0.3 & 0.3 & 0.3 & 0.3 & 0.5 & \begin{tabular}{|l|}
0.5 \\
\end{tabular} & \begin{tabular}{|l|}
0.5 \\
\end{tabular} & \begin{tabular}{|l|}
0.5 \\
\end{tabular} & \begin{tabular}{|l|}
0.5 \\
\end{tabular} & \begin{tabular}{|l|}
0.5 \\
\end{tabular} & \begin{tabular}{|l|}
0.5 \\
\end{tabular} & \begin{tabular}{|l|}
0.5 \\
\end{tabular} & \begin{tabular}{|l|}
0.5 \\
\end{tabular} & \begin{tabular}{|l|}
0.3 \\
\end{tabular} & \begin{tabular}{|l|}
0.3 \\
\end{tabular} & 0.3 & 0.3 & \begin{tabular}{|l|}
0.3 \\
\end{tabular} & 0.3 & 0.3 \\
\hline \multirow[t]{5}{*}{ ADMIN_LIGHT_SCH } & WD & 0.1 & 0.1 & 0.1 & 0.1 & 0.3 & 0.3 & 0.6 & 0.9 & 0.9 & 0.9 & 0.9 & 0.9 & \begin{tabular}{|l|}
0.9 \\
\end{tabular} & \begin{tabular}{|l|}
0.9 \\
\end{tabular} & \begin{tabular}{|l|}
0.9 \\
\end{tabular} & \begin{tabular}{|l|}
0.9 \\
\end{tabular} & 0.9 & 0.9 & \begin{tabular}{|l|}
0.6 \\
\end{tabular} & 0.6 & 0.3 & 0.3 & 0.1 & 0.1 \\
\hline & SummerDesign & 0.1 & 0.1 & 0.1 & 0.1 & 0.3 & 0.3 & 0.6 & 0.9 & \begin{tabular}{|l|}
0.9 \\
\end{tabular} & \begin{tabular}{|l|}
0.9 \\
\end{tabular} & \begin{tabular}{|l|}
0.9 \\
\end{tabular} & \begin{tabular}{|l|}
0.9 \\
\end{tabular} & \begin{tabular}{|l|}
0.9 \\
\end{tabular} & \begin{tabular}{|l|}
0.9 \\
\end{tabular} & \begin{tabular}{|l|}
0.9 \\
\end{tabular} & \begin{tabular}{|l|}
0.9 \\
\end{tabular} & 0.9 & \begin{tabular}{|l|}
0.9 \\
\end{tabular} & \begin{tabular}{|l|}
0.6 \\
\end{tabular} & 0.6 & 0.3 & 0.3 & 0.1 & 0.1 \\
\hline & WinterDesign & 0.1 & 0.1 & 0.1 & 0.1 & 0.1 & 0.1 & 0.1 & 0.3 & \begin{tabular}{|l|}
0.3 \\
\end{tabular} & \begin{tabular}{|l|}
0.4 \\
\end{tabular} & \begin{tabular}{|l|}
0.4 \\
\end{tabular} & \begin{tabular}{|l|}
0.4 \\
\end{tabular} & \begin{tabular}{|l|}
0.4 \\
\end{tabular} & \begin{tabular}{|l|}
0.4 \\
\end{tabular} & \begin{tabular}{|l|}
0.4 \\
\end{tabular} & \begin{tabular}{|l|}
0.3 \\
\end{tabular} & \begin{tabular}{|l|}
0.3 \\
\end{tabular} & \begin{tabular}{|l|}
0.3 \\
\end{tabular} & \begin{tabular}{|l|}
0.3 \\
\end{tabular} & \begin{tabular}{|l|}
0.3 \\
\end{tabular} & \begin{tabular}{|l|}
0.1 \\
\end{tabular} & \begin{tabular}{|l|}
0.1 \\
\end{tabular} & \begin{tabular}{|l|}
0.1 \\
\end{tabular} & 0.1 \\
\hline & Sat & 0.1 & 0.1 & 0.1 & 0.1 & 0.1 & 0.1 & 0.1 & 0.3 & \begin{tabular}{|l|}
0.3 \\
\end{tabular} & \begin{tabular}{|l|}
0.4 \\
\end{tabular} & \begin{tabular}{|l|}
0.4 \\
\end{tabular} & \begin{tabular}{|l|}
0.4 \\
\end{tabular} & \begin{tabular}{|l|}
0.4 \\
\end{tabular} & \begin{tabular}{|l|}
0.4 \\
\end{tabular} & \begin{tabular}{|l|}
0.4 \\
\end{tabular} & \begin{tabular}{|l|}
0.3 \\
\end{tabular} & \begin{tabular}{|l|}
0.3 \\
\end{tabular} & \begin{tabular}{|l|}
0.3 \\
\end{tabular} & \begin{tabular}{|l|}
0.3 \\
\end{tabular} & \begin{tabular}{|l|}
0.3 \\
\end{tabular} & \begin{tabular}{|l|}
0.1 \\
\end{tabular} & \begin{tabular}{|l|}
0.1 \\
\end{tabular} & \begin{tabular}{|l|}
0.1 \\
\end{tabular} & 0.1 \\
\hline & Other & 0.05 & 0.05 & 0.05 & 0.05 & 0.05 & 0.05 & 0.05 & 0.05 & \begin{tabular}{|l|}
0.1 \\
\end{tabular} & \begin{tabular}{|l|}
0.1 \\
\end{tabular} & \begin{tabular}{|l|}
0.1 \\
\end{tabular} & \begin{tabular}{|l|}
0.1 \\
\end{tabular} & \begin{tabular}{|l|}
0.1 \\
\end{tabular} & \begin{tabular}{|l|}
0.1 \\
\end{tabular} & \begin{tabular}{|l|}
0.1 \\
\end{tabular} & \begin{tabular}{|l|}
0.1 \\
\end{tabular} & \begin{tabular}{|l|}
0.1 \\
\end{tabular} & \begin{tabular}{|l|}
0.05 \\
\end{tabular} & 0.05 & 0.05 & 0.05 & 0.05 & 0.05 & 0.05 \\
\hline \multirow[t]{5}{*}{ ADMIN_OCC_SCH } & WD & 0.05 & 0.05 & 0.05 & 0.05 & 0.2 & 0.2 & \begin{tabular}{|l|}
0.5 \\
\end{tabular} & \begin{tabular}{|l|}
0.9 \\
\end{tabular} & \begin{tabular}{|l|}
0.9 \\
\end{tabular} & \begin{tabular}{|l|}
0.9 \\
\end{tabular} & \begin{tabular}{|l|}
0.9 \\
\end{tabular} & \begin{tabular}{|l|}
0.9 \\
\end{tabular} & \begin{tabular}{|l|}
0.9 \\
\end{tabular} & \begin{tabular}{|l|}
0.9 \\
\end{tabular} & \begin{tabular}{|l|}
0.9 \\
\end{tabular} & \begin{tabular}{|l|}
0.9 \\
\end{tabular} & \begin{tabular}{|l|}
0.9 \\
\end{tabular} & \begin{tabular}{|l|}
0.9 \\
\end{tabular} & \begin{tabular}{|l|}
0.5 \\
\end{tabular} & \begin{tabular}{|l|}
0.5 \\
\end{tabular} & \begin{tabular}{|l|}
0.2 \\
\end{tabular} & \begin{tabular}{|l|}
0.2 \\
\end{tabular} & 0.05 & 0.05 \\
\hline & SummerDesign & 0.05 & 0.05 & 0.05 & 0.05 & 0.2 & 0.2 & 0.5 & 0.9 & 0.9 & 0.9 & 0.9 & 0.9 & \begin{tabular}{|l|}
0.9 \\
\end{tabular} & \begin{tabular}{|l|}
0.9 \\
\end{tabular} & \begin{tabular}{|l|}
0.9 \\
\end{tabular} & \begin{tabular}{|l|}
0.9 \\
\end{tabular} & 0.9 & 0.9 & 0.5 & 0.5 & 0.2 & 0.2 & 0.05 & 0.05 \\
\hline & WinterDesign & 0.05 & 0.05 & 0.05 & 0.05 & 0.05 & 0.05 & 0.05 & 0.2 & 0.2 & 0.3 & 0.3 & 0.3 & \begin{tabular}{|l|}
0.3 \\
\end{tabular} & \begin{tabular}{|l|}
0.3 \\
\end{tabular} & \begin{tabular}{|l|}
0.3 \\
\end{tabular} & \begin{tabular}{|l|}
0.2 \\
\end{tabular} & 0.2 & 0.2 & \begin{tabular}{|l|}
0.2 \\
\end{tabular} & 0.2 & 0.05 & 0.05 & 0.05 & 0.05 \\
\hline & Sat & 0.05 & 0.05 & 0.05 & 0.05 & 0.05 & 0.05 & 0.05 & \begin{tabular}{|l|}
0.2 \\
\end{tabular} & \begin{tabular}{|l|}
0.2 \\
\end{tabular} & \begin{tabular}{|l|}
0.3 \\
\end{tabular} & \begin{tabular}{|l|}
0.3 \\
\end{tabular} & \begin{tabular}{|l|}
0.3 \\
\end{tabular} & \begin{tabular}{|l|}
0.3 \\
\end{tabular} & \begin{tabular}{|l|}
0.3 \\
\end{tabular} & \begin{tabular}{|l|}
0.3 \\
\end{tabular} & \begin{tabular}{|l|}
0.2 \\
\end{tabular} & \begin{tabular}{|l|}
0.2 \\
\end{tabular} & \begin{tabular}{|l|}
0.2 \\
\end{tabular} & \begin{tabular}{|l|}
0.2 \\
\end{tabular} & \begin{tabular}{|l|}
0.2 \\
\end{tabular} & 0.05 & 0.05 & 0.05 & 0.05 \\
\hline & Sun, Hol, Other & 0 & 0 & 0 & 0 & 0 & 0 & 0 & 0 & 0.05 & 0.05 & 0.05 & 0.05 & 0.05 & 0.05 & 0.05 & 0.05 & 0.05 & 0 & 0 & 0 & 0 & 0 & 0 & 0 \\
\hline \multirow[t]{3}{*}{ BLDG_ELEVATORS } & WD, SummerDesign & 0.2 & 0.2 & 0.2 & 0.2 & 0.2 & 0.2 & 0.2 & 0.5 & 0.75 & 1 & 1 & 1 & 0.75 & 1 & 1 & 1 & 1 & 1 & 0.52 & 0.52 & 0.52 & 0.28 & 0.2 & 0.2 \\
\hline & Sat, WinterDesign & 0.2 & 0.2 & 0.2 & 0.2 & 0.2 & 0.2 & 0.2 & 0.4 & 0.46 & \begin{tabular}{|l|}
0.7 \\
\end{tabular} & \begin{tabular}{|l|}
0.7 \\
\end{tabular} & \begin{tabular}{|l|}
0.7 \\
\end{tabular} & 0.51 & 0.51 & 0.51 & 0.51 & 0.51 & 0.25 & 0.2 & 0.2 & 0.2 & 0.2 & 0.2 & 0.2 \\
\hline & Other & 0.2 & 0.2 & 0.2 & 0.2 & 0.2 & 0.2 & 0.2 & 0.2 & 0.4 & 0.4 & 0.4 & 0.4 & \begin{tabular}{|l|}
0.4 \\
\end{tabular} & \begin{tabular}{|l|}
0.4 \\
\end{tabular} & \begin{tabular}{|l|}
0.4 \\
\end{tabular} & \begin{tabular}{|l|}
0.4 \\
\end{tabular} & 0.2 & 0.2 & 0.2 & 0.2 & 0.2 & 0.2 & 0.2 & 0.2 \\
\hline \multirow[t]{5}{*}{ BLDG_LIGHT_SCH } & WD & 0.1 & 0.1 & 0.1 & 0.1 & 0.1 & 0.1 & 0.1 & 0.5 & \begin{tabular}{|l|}
0.9 \\
\end{tabular} & \begin{tabular}{|l|}
0.9 \\
\end{tabular} & \begin{tabular}{|l|}
0.9 \\
\end{tabular} & \begin{tabular}{|l|}
0.9 \\
\end{tabular} & \begin{tabular}{|l|}
0.9 \\
\end{tabular} & \begin{tabular}{|l|}
0.9 \\
\end{tabular} & \begin{tabular}{|l|}
0.9 \\
\end{tabular} & \begin{tabular}{|l|}
0.9 \\
\end{tabular} & \begin{tabular}{|l|l|}
0.3 \\
\end{tabular} & \begin{tabular}{|l|l|}
0.3 \\
\end{tabular} & \begin{tabular}{|l|}
0.3 \\
\end{tabular} & \begin{tabular}{|l|}
0.3 \\
\end{tabular} & \begin{tabular}{|l|}
0.3 \\
\end{tabular} & \begin{tabular}{|l|}
0.3 \\
\end{tabular} & \begin{tabular}{|l|}
0.3 \\
\end{tabular} & 0.1 \\
\hline & SummerDesign & 1 & 1 & 1 & 1 & 1 & 1 & 1 & 1 & 1 & 1 & 1 & 1 & 1 & 1 & 1 & 1 & 1 & 1 & 1 & 1 & 1 & 1 & 1 & 1 \\
\hline & WinterDesign & 0 & 0 & 0 & 0 & 0 & 0 & 0 & 0 & 0 & 0 & 0 & 0 & 0 & 0 & 0 & 0 & 0 & 0 & 0 & 0 & 0 & 0 & 0 & 0 \\
\hline & Sat & 0.1 & 0.1 & 0.1 & 0.1 & 0.1 & 0.1 & 0.1 & 0.2 & \begin{tabular}{|l|}
0.4 \\
\end{tabular} & \begin{tabular}{|l|}
0.4 \\
\end{tabular} & \begin{tabular}{|l|}
0.4 \\
\end{tabular} & \begin{tabular}{|l|}
0.4 \\
\end{tabular} & \begin{tabular}{|l|}
0.4 \\
\end{tabular} & \begin{tabular}{|l|}
0.4 \\
\end{tabular} & \begin{tabular}{|l|}
0.4 \\
\end{tabular} & \begin{tabular}{|l|}
0.4 \\
\end{tabular} & 0.4 & 0.4 & \begin{tabular}{|l|}
0.1 \\
\end{tabular} & \begin{tabular}{|l|}
0.1 \\
\end{tabular} & 0.1 & 0.1 & 0.1 & 0.1 \\
\hline & Other & 0.05 & 0.05 & 0.05 & 0.05 & 0.05 & 0.05 & 0.05 & 0.05 & \begin{tabular}{|l|}
0.1 \\
\end{tabular} & \begin{tabular}{|l|}
0.1 \\
\end{tabular} & \begin{tabular}{|l|}
0.1 \\
\end{tabular} & \begin{tabular}{|l|}
0.1 \\
\end{tabular} & \begin{tabular}{|l|}
0.1 \\
\end{tabular} & \begin{tabular}{|l|}
0.1 \\
\end{tabular} & \begin{tabular}{|l|}
0.1 \\
\end{tabular} & \begin{tabular}{|l|}
0.1 \\
\end{tabular} & 0.05 & 0.05 & 0.05 & 0.05 & 0.05 & 0.05 & 0.05 & 0.05 \\
\hline \multirow[t]{5}{*}{ CRITICAL_EQUIP_SCH } & WD & 0.5 & 0.5 & 0.5 & 0.5 & 0.5 & 0.5 & 1 & 1 & 1 & 1 & 1 & 1 & 1 & 1 & 1 & 1 & 1 & 1 & \begin{tabular}{|l|}
0.8 \\
\end{tabular} & \begin{tabular}{|l|}
0.8 \\
\end{tabular} & \begin{tabular}{|l|}
0.5 \\
\end{tabular} & \begin{tabular}{|l|}
0.5 \\
\end{tabular} & \begin{tabular}{|l|}
0.5 \\
\end{tabular} & 0.5 \\
\hline & SummerDesign & 0.5 & 0.5 & 0.5 & 0.5 & 0.5 & 0.5 & 1 & 1 & 1 & 1 & 1 & 1 & 1 & 1 & 1 & 1 & 1 & 1 & \begin{tabular}{|l|}
0.8 \\
\end{tabular} & \begin{tabular}{|l|}
0.8 \\
\end{tabular} & \begin{tabular}{|l|}
0.5 \\
\end{tabular} & \begin{tabular}{|l|}
0.5 \\
\end{tabular} & \begin{tabular}{|l|}
0.5 \\
\end{tabular} & 0.5 \\
\hline & WinterDesign & 0.3 & 0.3 & 0.3 & 0.3 & 0.3 & 0.3 & 0.3 & 0.3 & \begin{tabular}{|l|}
0.3 \\
\end{tabular} & \begin{tabular}{|l|}
0.3 \\
\end{tabular} & \begin{tabular}{|l|}
0.3 \\
\end{tabular} & \begin{tabular}{|l|}
0.3 \\
\end{tabular} & \begin{tabular}{|l|}
0.3 \\
\end{tabular} & \begin{tabular}{|l|}
0.3 \\
\end{tabular} & 0.3 & 0.3 & 0.3 & 0.3 & 0.3 & 0.3 & 0.3 & 0.3 & 0.3 & 0.3 \\
\hline & Sat & 0.5 & 0.5 & 0.5 & 0.5 & 0.5 & 0.5 & 1 & 1 & 1 & 1 & 1 & 1 & 1 & 1 & 1 & 1 & 1 & 1 & \begin{tabular}{|l|}
0.8 \\
\end{tabular} & \begin{tabular}{|l|}
0.8 \\
\end{tabular} & 0.5 & 0.5 & 0.5 & 0.5 \\
\hline & Sun, Hol, Other & 0.5 & 0.5 & 0.5 & 0.5 & 0.5 & 0.5 & 1 & 1 & 1 & 1 & 1 & 1 & 1 & 1 & 1 & 1 & 1 & 1 & 0.8 & 0.8 & 0.5 & 0.5 & 0.5 & 0.5 \\
\hline \multirow[t]{5}{*}{ CRITICAL_LIGHT_SCH } & WD & 0.5 & 0.5 & 0.5 & 0.5 & 0.7 & 0.7 & 0.9 & 0.9 & 0.9 & 0.9 & 0.9 & 0.9 & \begin{tabular}{|l|}
0.9 \\
\end{tabular} & 0.9 & 0.9 & 0.9 & 0.9 & 0.9 & \begin{tabular}{|l|}
0.7 \\
\end{tabular} & \begin{tabular}{|l|}
0.7 \\
\end{tabular} & \begin{tabular}{|l|}
0.7 \\
\end{tabular} & \begin{tabular}{|l|}
0.7 \\
\end{tabular} & 0.5 & 0.5 \\
\hline & SummerDesign & 0.5 & 0.5 & 0.5 & 0.5 & 0.7 & 0.7 & 0.9 & 0.9 & \begin{tabular}{|l|}
0.9 \\
\end{tabular} & \begin{tabular}{|l|}
0.9 \\
\end{tabular} & \begin{tabular}{|l|}
0.9 \\
\end{tabular} & \begin{tabular}{|l|}
0.9 \\
\end{tabular} & \begin{tabular}{|l|}
0.9 \\
\end{tabular} & 0.9 & 0.9 & 0.9 & \begin{tabular}{|l|l|}
0.9 \\
\end{tabular} & \begin{tabular}{|l|l|}
0.9 \\
\end{tabular} & \begin{tabular}{|l|}
0.7 \\
\end{tabular} & \begin{tabular}{|l|}
0.7 \\
\end{tabular} & \begin{tabular}{|l|}
0.7 \\
\end{tabular} & \begin{tabular}{|l|}
0.7 \\
\end{tabular} & 0.5 & 0.5 \\
\hline & WinterDesign & 0.5 & 0.5 & 0.5 & 0.5 & 0.7 & 0.7 & 0.9 & \begin{tabular}{|l|}
0.9 \\
\end{tabular} & \begin{tabular}{|l|}
0.9 \\
\end{tabular} & \begin{tabular}{|l|}
0.9 \\
\end{tabular} & \begin{tabular}{|l|}
0.9 \\
\end{tabular} & \begin{tabular}{|l|}
0.9 \\
\end{tabular} & \begin{tabular}{|l|}
0.9 \\
\end{tabular} & \begin{tabular}{|l|}
0.9 \\
\end{tabular} & \begin{tabular}{|l|}
0.9 \\
\end{tabular} & \begin{tabular}{|l|}
0.9 \\
\end{tabular} & 0.9 & \begin{tabular}{|l|}
0.9 \\
\end{tabular} & \begin{tabular}{|l|}
0.7 \\
\end{tabular} & \begin{tabular}{|l|}
0.7 \\
\end{tabular} & \begin{tabular}{|l|}
0.7 \\
\end{tabular} & \begin{tabular}{|l|}
0.7 \\
\end{tabular} & 0.5 & 0.5 \\
\hline & Sat & 0.5 & 0.5 & 0.5 & 0.5 & 0.7 & 0.7 & \begin{tabular}{|l|}
0.9 \\
\end{tabular} & \begin{tabular}{|l|}
0.9 \\
\end{tabular} & \begin{tabular}{|l|}
0.9 \\
\end{tabular} & \begin{tabular}{|l|}
0.9 \\
\end{tabular} & \begin{tabular}{|l|}
0.9 \\
\end{tabular} & \begin{tabular}{|l|}
0.9 \\
\end{tabular} & \begin{tabular}{|l|}
0.9 \\
\end{tabular} & \begin{tabular}{|l|}
0.9 \\
\end{tabular} & \begin{tabular}{|l|}
0.9 \\
\end{tabular} & \begin{tabular}{|l|}
0.9 \\
\end{tabular} & \begin{tabular}{|l|}
0.9 \\
\end{tabular} & \begin{tabular}{|l|}
0.9 \\
\end{tabular} & \begin{tabular}{|l|}
0.7 \\
\end{tabular} & \begin{tabular}{|l|}
0.7 \\
\end{tabular} & \begin{tabular}{|l|}
0.7 \\
\end{tabular} & \begin{tabular}{|l|}
0.7 \\
\end{tabular} & \begin{tabular}{|l|}
0.5 \\
\end{tabular} & 0.5 \\
\hline & Other & 0.5 & 0.5 & 0.5 & 0.5 & 0.7 & 0.7 & 0.9 & \begin{tabular}{|l|}
0.9 \\
\end{tabular} & \begin{tabular}{|l|}
0.9 \\
\end{tabular} & \begin{tabular}{|l|}
0.9 \\
\end{tabular} & \begin{tabular}{|l|}
0.9 \\
\end{tabular} & \begin{tabular}{|l|}
0.9 \\
\end{tabular} & \begin{tabular}{|l|}
0.9 \\
\end{tabular} & \begin{tabular}{|l|}
0.9 \\
\end{tabular} & \begin{tabular}{|l|}
0.9 \\
\end{tabular} & \begin{tabular}{|l|}
0.9 \\
\end{tabular} & \begin{tabular}{|l|}
0.9 \\
\end{tabular} & \begin{tabular}{|l|}
0.9 \\
\end{tabular} & \begin{tabular}{|l|}
0.7 \\
\end{tabular} & \begin{tabular}{|l|}
0.7 \\
\end{tabular} & \begin{tabular}{|l|}
0.7 \\
\end{tabular} & \begin{tabular}{|l|}
0.7 \\
\end{tabular} & \begin{tabular}{|l|}
0.5 \\
\end{tabular} & 0.5 \\
\hline \multirow[t]{5}{*}{ CRITICAL_OCC_SCH } & WD & 0.4 & 0.4 & 0.4 & 0.4 & 0.65 & 0.65 & \begin{tabular}{|l|}
0.9 \\
\end{tabular} & 0.9 & 0.9 & 0.9 & 0.9 & 0.9 & \begin{tabular}{|l|}
0.9 \\
\end{tabular} & \begin{tabular}{|l|}
0.9 \\
\end{tabular} & \begin{tabular}{|l|}
0.9 \\
\end{tabular} & \begin{tabular}{|l|}
0.9 \\
\end{tabular} & 0.9 & 0.9 & 0.65 & 0.65 & 0.65 & 0.65 & 0.4 & 0.4 \\
\hline & SummerDesign & 0.4 & 0.4 & 0.4 & 0.4 & 0.65 & 0.65 & \begin{tabular}{|l|}
0.9 \\
\end{tabular} & \begin{tabular}{|l|}
0.9 \\
\end{tabular} & \begin{tabular}{|l|}
0.9 \\
\end{tabular} & \begin{tabular}{|l|}
0.9 \\
\end{tabular} & \begin{tabular}{|l|}
0.9 \\
\end{tabular} & \begin{tabular}{|l|}
0.9 \\
\end{tabular} & \begin{tabular}{|l|}
0.9 \\
\end{tabular} & \begin{tabular}{|l|}
0.9 \\
\end{tabular} & \begin{tabular}{|l|}
0.9 \\
\end{tabular} & \begin{tabular}{|l|}
0.9 \\
\end{tabular} & 0.9 & 0.9 & 0.65 & 0.65 & 0.65 & 0.65 & 0.4 & 0.4 \\
\hline & WinterDesign & 0.4 & 0.4 & 0.4 & 0.4 & 0.65 & 0.65 & \begin{tabular}{|l|}
0.9 \\
\end{tabular} & \begin{tabular}{|l|}
0.9 \\
\end{tabular} & \begin{tabular}{|l|}
0.9 \\
\end{tabular} & \begin{tabular}{|l|}
0.9 \\
\end{tabular} & \begin{tabular}{|l|}
0.9 \\
\end{tabular} & \begin{tabular}{|l|}
0.9 \\
\end{tabular} & \begin{tabular}{|l|}
0.9 \\
\end{tabular} & \begin{tabular}{|l|}
0.9 \\
\end{tabular} & \begin{tabular}{|l|}
0.9 \\
\end{tabular} & \begin{tabular}{|l|}
0.9 \\
\end{tabular} & \begin{tabular}{|l|}
0.9 \\
\end{tabular} & \begin{tabular}{|l|}
0.9 \\
\end{tabular} & 0.65 & 0.65 & 0.65 & 0.65 & 0.4 & 0.4 \\
\hline & Sat & 0.4 & 0.4 & 0.4 & 0.4 & 0.65 & 0.65 & \begin{tabular}{|l|}
0.9 \\
\end{tabular} & 0.9 & 0.9 & 0.9 & 0.9 & 0.9 & \begin{tabular}{|l|}
0.9 \\
\end{tabular} & \begin{tabular}{|l|}
0.9 \\
\end{tabular} & \begin{tabular}{|l|}
0.9 \\
\end{tabular} & \begin{tabular}{|l|}
0.9 \\
\end{tabular} & 0.9 & 0.9 & 0.65 & 0.65 & 0.65 & 0.65 & 0.4 & 0.4 \\
\hline & Other & 0.4 & 0.4 & 0.4 & 0.4 & 0.65 & 0.65 & 0.9 & 0.9 & \begin{tabular}{|l|}
0.9 \\
\end{tabular} & \begin{tabular}{|l|}
0.9 \\
\end{tabular} & \begin{tabular}{|l|}
0.9 \\
\end{tabular} & \begin{tabular}{|l|}
0.9 \\
\end{tabular} & \begin{tabular}{|l|}
0.9 \\
\end{tabular} & \begin{tabular}{|l|}
0.9 \\
\end{tabular} & \begin{tabular}{|l|}
0.9 \\
\end{tabular} & \begin{tabular}{|l|}
0.9 \\
\end{tabular} & \begin{tabular}{|l|}
0.9 \\
\end{tabular} & \begin{tabular}{|l|}
0.9 \\
\end{tabular} & \begin{tabular}{|l|}
0.65 \\
\end{tabular} & \begin{tabular}{|l|}
0.65 \\
\end{tabular} & \begin{tabular}{|l|}
0.65 \\
\end{tabular} & \begin{tabular}{|l|}
0.65 \\
\end{tabular} & 0.4 & \begin{tabular}{|l|}
0.4 \\
\end{tabular} \\
\hline
\end{tabular}




\begin{tabular}{|c|c|c|c|c|c|c|c|c|c|c|c|c|c|c|c|c|c|c|c|c|c|c|c|c|c|}
\hline Schedule & Day of Week & 1 & 2 & 3 & 4 & 5 & 6 & 7 & 8 & 9 & 10 & 11 & 12 & 13 & 14 & 15 & 16 & 17 & 18 & 19 & 20 & 21 & 22 & 23 & 24 \\
\hline \multirow[t]{4}{*}{ 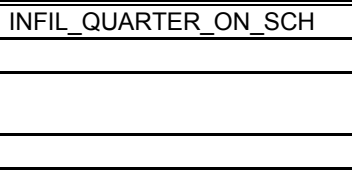 } & WD & 0.25 & 0.25 & 0.25 & 0.25 & 0.25 & 0.25 & 0.25 & 0.25 & 0.25 & 0.25 & 0.25 & 0.25 & 0.25 & 0.25 & 0.25 & 0.25 & 0.25 & 0.25 & 0.25 & 0.25 & 0.25 & 0.25 & 0.25 & 0.25 \\
\hline & Sat & 0.25 & 0.25 & 0.25 & 0.25 & 0.25 & 0.25 & 0.25 & 0.25 & 0.25 & 0.25 & 0.25 & 0.25 & 0.25 & 0.25 & 0.25 & 0.25 & 0.25 & 0.25 & 0.25 & 0.25 & 0.25 & 0.25 & 0.25 & 0.25 \\
\hline & $\begin{array}{l}\text { SummerDesign, } \\
\text { WinterDesign }\end{array}$ & 1 & 1 & 1 & 1 & 1 & 1 & 1 & 1 & 1 & 1 & 1 & 1 & 1 & 1 & 1 & 1 & 1 & 1 & 1 & 1 & 1 & 1 & 1 & 1 \\
\hline & Other & 0.25 & 0.25 & 0.25 & 0.25 & 0.25 & 0.25 & 0.25 & 0.25 & 0.25 & 0.25 & 0.25 & 0.25 & 0.25 & 0.25 & 0.25 & 0.25 & 0.25 & 0.25 & 0.25 & 0.25 & 0.25 & 0.25 & 0.25 & 0.25 \\
\hline \multirow[t]{5}{*}{ Kitchen_Elec_Equip_SCH } & Weekday & \begin{tabular}{|l|}
0.1 \\
\end{tabular} & 0.1 & 0.1 & 0.1 & 0.1 & 0.1 & 0.25 & 0.35 & 0.35 & 0.25 & 0.35 & 0.35 & 0.35 & 0.25 & 0.25 & 0.25 & 0.35 & 0.35 & 0.35 & 0.25 & 0.25 & 0.25 & 0.25 & 0.25 \\
\hline & Sat & \begin{tabular}{|l|}
0.1 \\
\end{tabular} & 0.1 & 0.1 & 0.1 & 0.1 & 0.1 & 0.25 & 0.35 & 0.35 & 0.25 & 0.35 & 0.35 & 0.35 & 0.25 & 0.25 & 0.25 & 0.35 & 0.35 & 0.35 & 0.25 & 0.25 & 0.25 & 0.25 & 0.25 \\
\hline & SummerDesign & 0.35 & 0.35 & 0.35 & 0.35 & 0.35 & 0.35 & 0.35 & 0.35 & 0.35 & 0.35 & 0.35 & 0.35 & 0.35 & 0.35 & 0.35 & 0.35 & 0.35 & 0.35 & 0.35 & 0.35 & 0.35 & 0.35 & 0.35 & 0.35 \\
\hline & \begin{tabular}{|l|} 
WinterDesign \\
\end{tabular} & 0 & 0 & 0 & 0 & 0 & 0 & 0 & 0 & 0 & 0 & 0 & 0 & 0 & 0 & 0 & 0 & 0 & 0 & 0 & 0 & 0 & 0 & 0 & 0 \\
\hline & Other & 0.1 & 0.1 & 0.1 & 0.1 & 0.1 & 0.1 & 0.25 & 0.35 & 0.35 & 0.25 & 0.35 & 0.35 & 0.35 & 0.25 & 0.25 & 0.25 & 0.35 & 0.35 & 0.35 & 0.25 & 0.25 & 0.25 & 0.25 & 0.25 \\
\hline \multirow[t]{4}{*}{ Kitchen_Gas_Equip_SCH } & WD, Sat & 0.02 & 0.02 & 0.02 & 0.02 & 0.02 & 0.05 & 0.1 & 0.15 & 0.2 & 0.15 & 0.25 & 0.25 & 0.25 & 0.2 & 0.15 & 0.2 & 0.3 & 0.3 & 0.3 & 0.2 & 0.2 & 0.15 & 0.1 & 0.05 \\
\hline & SummerDesign & 0.25 & 0.25 & 0.25 & 0.25 & 0.25 & 0.25 & 0.25 & 0.25 & 0.25 & 0.25 & 0.25 & 0.25 & 0.25 & 0.25 & 0.25 & 0.25 & 0.25 & 0.25 & 0.25 & 0.25 & 0.25 & 0.25 & 0.25 & 0.25 \\
\hline & \begin{tabular}{|l|} 
WinterDesign \\
\end{tabular} & 0 & 0 & 0 & 0 & 0 & 0 & 0 & 0 & 0 & 0 & 0 & 0 & 0 & 0 & 0 & 0 & 0 & 0 & 0 & 0 & 0 & 0 & 0 & 0 \\
\hline & Other & 0.02 & 0.02 & 0.02 & 0.02 & 0.02 & 0.05 & 0.1 & 0.15 & 0.2 & 0.15 & 0.25 & 0.25 & 0.25 & 0.2 & 0.15 & 0.2 & \begin{tabular}{|l|}
0.3 \\
\end{tabular} & 0.3 & 0.3 & 0.2 & 0.2 & 0.15 & \begin{tabular}{|l|}
0.1 \\
\end{tabular} & 0.05 \\
\hline WORK_EFF_SCH & All & 0 & 0 & 0 & 0 & 0 & 0 & 0 & 0 & 0 & 0 & 0 & 0 & 0 & 0 & 0 & 0 & 0 & 0 & 0 & 0 & 0 & 0 & 0 & 0 \\
\hline \multirow[t]{3}{*}{ CLOTHING_SCH } & All & 1 & 1 & 1 & 1 & 1 & 1 & 1 & 1 & 1 & 1 & 1 & 1 & 1 & 1 & 1 & 1 & 1 & 1 & 1 & 1 & 1 & 1 & 1 & 1 \\
\hline & All & 0.5 & 0.5 & 0.5 & 0.5 & 0.5 & 0.5 & 0.5 & 0.5 & 0.5 & \begin{tabular}{|l|}
0.5 \\
\end{tabular} & \begin{tabular}{|l|}
0.5 \\
\end{tabular} & \begin{tabular}{|l|}
0.5 \\
\end{tabular} & \begin{tabular}{|l|}
0.5 \\
\end{tabular} & \begin{tabular}{|l|}
0.5 \\
\end{tabular} & \begin{tabular}{|l|}
0.5 \\
\end{tabular} & \begin{tabular}{|l|}
0.5 \\
\end{tabular} & \begin{tabular}{|l|l|}
0.5 \\
\end{tabular} & \begin{tabular}{|l|}
0.5 \\
\end{tabular} & \begin{tabular}{|l|}
0.5 \\
\end{tabular} & \begin{tabular}{|l|}
0.5 \\
\end{tabular} & 0.5 & 0.5 & 0.5 & 0.5 \\
\hline & All & 1 & 1 & 1 & 1 & 1 & 1 & 1 & 1 & 1 & 1 & 1 & 1 & 1 & 1 & 1 & 1 & 1 & 1 & 1 & 1 & 1 & 1 & 1 & 1 \\
\hline ACTIVITY_SCH & All & 120 & 120 & 120 & 120 & 120 & 120 & 120 & 120 & 120 & 120 & 120 & 120 & 120 & 120 & 120 & 120 & 120 & 120 & 120 & 120 & 120 & 120 & 120 & 120 \\
\hline AIR_VELO_SCH & All & 0.2 & 0.2 & 0.2 & 0.2 & 0.2 & 0.2 & 0.2 & 0.2 & \begin{tabular}{|l|}
0.2 \\
\end{tabular} & \begin{tabular}{|l|}
0.2 \\
\end{tabular} & \begin{tabular}{|l|}
0.2 \\
\end{tabular} & 0.2 & \begin{tabular}{|l|}
0.2 \\
\end{tabular} & \begin{tabular}{|l|}
0.2 \\
\end{tabular} & \begin{tabular}{|l|}
0.2 \\
\end{tabular} & \begin{tabular}{|l|}
0.2 \\
\end{tabular} & \begin{tabular}{|l|}
0.2 \\
\end{tabular} & \begin{tabular}{|l|}
0.2 \\
\end{tabular} & \begin{tabular}{|l|}
0.2 \\
\end{tabular} & \begin{tabular}{|l|}
0.2 \\
\end{tabular} & 0.2 & 0.2 & 0.2 & 0.2 \\
\hline \multirow[t]{5}{*}{ ADMIN_CLGSETP_SCH } & WD & 25 & 25 & 25 & 25 & 25 & 22.2 & 22.2 & 22.2 & 22.2 & 22.2 & 22.2 & 22.2 & 22.2 & 22.2 & 22.2 & 22.2 & 22.2 & 22.2 & 25 & 25 & 25 & 25 & 25 & 25 \\
\hline & \begin{tabular}{|l|} 
SummerDesign \\
\end{tabular} & 25 & 25 & 25 & 25 & 25 & 22.2 & \begin{tabular}{|l|}
22.2 \\
\end{tabular} & 22.2 & \begin{tabular}{|l|}
22.2 \\
\end{tabular} & \begin{tabular}{|l|}
22.2 \\
\end{tabular} & \begin{tabular}{|l|}
22.2 \\
\end{tabular} & \begin{tabular}{|l|}
22.2 \\
\end{tabular} & 22.2 & 22.2 & 22.2 & 22.2 & 22.2 & 22.2 & 25 & 25 & 25 & 25 & 25 & 25 \\
\hline & \begin{tabular}{|l|} 
WinterDesign \\
\end{tabular} & 25 & 25 & 25 & 25 & 25 & 25 & 25 & 22.2 & 22.2 & 22.2 & 22.2 & 22.2 & 22.2 & 22.2 & 22.2 & 25 & 25 & 25 & 25 & 25 & 25 & 25 & 25 & 25 \\
\hline & Sats & 25 & 25 & 25 & 25 & 25 & 25 & 25 & 22.2 & 22.2 & 22.2 & 22.2 & 22.2 & 22.2 & 22.2 & \begin{tabular}{|l|}
22.2 \\
\end{tabular} & 25 & 25 & 25 & 25 & 25 & 25 & 25 & 25 & 25 \\
\hline & Other & 25 & 25 & 25 & 25 & 25 & 25 & 25 & 25 & 25 & 25 & 25 & 25 & 25 & 25 & 25 & 25 & 25 & 25 & 25 & 25 & 25 & 25 & 25 & 25 \\
\hline \multirow[t]{5}{*}{ ADMIN_HTGSETP_SCH } & WD & 18.3 & 18.3 & 18.3 & 18.3 & 18.3 & 21.1 & 21.1 & 21.1 & 21.1 & 21.1 & 21.1 & 21.1 & 21.1 & 21.1 & 21.1 & 21.1 & 21.1 & 21.1 & 18.3 & 18.3 & 18.3 & 18.3 & 18.3 & 18.3 \\
\hline & \begin{tabular}{|l|} 
SummerDesign \\
\end{tabular} & 18.3 & 18.3 & 18.3 & 18.3 & 18.3 & 21.1 & 21.1 & 21.1 & 21.1 & 21.1 & 21.1 & 21.1 & 21.1 & 21.1 & 21.1 & 21.1 & 21.1 & 21.1 & 18.3 & 18.3 & 18.3 & 18.3 & 18.3 & 18.3 \\
\hline & WinterDesign & 18.3 & 18.3 & 18.3 & 18.3 & 18.3 & 18.3 & \begin{tabular}{|l|}
18.3 \\
\end{tabular} & \begin{tabular}{|l|}
21.1 \\
\end{tabular} & \begin{tabular}{|l|}
21.1 \\
\end{tabular} & \begin{tabular}{|l|}
21.1 \\
\end{tabular} & \begin{tabular}{|l|}
21.1 \\
\end{tabular} & \begin{tabular}{|l|}
21.1 \\
\end{tabular} & \begin{tabular}{|l|}
21.1 \\
\end{tabular} & \begin{tabular}{|l|}
21.1 \\
\end{tabular} & \begin{tabular}{|l|}
21.1 \\
\end{tabular} & 18.3 & 18.3 & 18.3 & 18.3 & \begin{tabular}{|l|}
18.3 \\
\end{tabular} & 18.3 & 18.3 & 18.3 & 18.3 \\
\hline & Sats & 18.3 & 18.3 & 18.3 & 18.3 & 18.3 & 18.3 & 18.3 & 21.1 & 21.1 & 21.1 & 21.1 & 21.1 & 21.1 & 21.1 & 21.1 & 18.3 & 18.3 & 18.3 & 18.3 & 18.3 & 18.3 & 18.3 & 18.3 & 18.3 \\
\hline & Other & 18.3 & 18.3 & 18.3 & 18.3 & 18.3 & 18.3 & 18.3 & 18.3 & 18.3 & 18.3 & 18.3 & 18.3 & 18.3 & 18.3 & 18.3 & 18.3 & 18.3 & 18.3 & 18.3 & 18.3 & 18.3 & 18.3 & 18.3 & 18.3 \\
\hline \multirow[t]{5}{*}{ Kitchen_CLGSETP_SCH } & WD & 30 & 30 & 30 & 30 & 30 & 26 & 26 & 26 & 26 & 26 & 26 & 26 & 26 & 26 & 26 & 26 & 26 & 26 & 30 & 30 & 30 & 30 & 30 & 30 \\
\hline & SummerDesign & 30 & 30 & 30 & 30 & 30 & 26 & 26 & 26 & 26 & 26 & 26 & 26 & 26 & 26 & 26 & 26 & 26 & 26 & 30 & 30 & 30 & 30 & 30 & 30 \\
\hline & WinterDesign & 30 & 30 & 30 & 30 & 30 & 30 & 30 & 26 & 26 & 26 & 26 & 26 & 26 & 26 & 26 & 30 & 30 & 30 & 30 & 30 & 30 & 30 & 30 & 30 \\
\hline & Sats & 30 & 30 & 30 & 30 & 30 & 30 & 30 & 26 & 26 & 26 & 26 & 26 & 26 & 26 & 26 & 30 & 30 & 30 & 30 & 30 & 30 & 30 & 30 & 30 \\
\hline & Other & 30 & 30 & 30 & 30 & 30 & 30 & 30 & 30 & 30 & 30 & 30 & 30 & 30 & 30 & 30 & 30 & 30 & 30 & 30 & 30 & 30 & 30 & 30 & 30 \\
\hline \multirow[t]{5}{*}{ Kitchen_HTGSETP_SCH } & WD & 15.6 & 15.6 & 15.6 & 15.6 & 15.6 & 19 & 19 & 19 & 19 & 19 & 19 & 19 & 19 & 19 & 19 & 19 & 19 & 19 & 15.6 & 15.6 & 15.6 & 15.6 & 15.6 & 15.6 \\
\hline & \begin{tabular}{|l|} 
SummerDesign \\
\end{tabular} & 15.6 & 15.6 & 15.6 & 15.6 & 15.6 & 19 & 19 & 19 & 19 & 19 & 19 & 19 & 19 & 19 & 19 & 19 & 19 & 19 & 15.6 & 15.6 & 15.6 & 15.6 & 15.6 & 15.6 \\
\hline & WinterDesign & 15.6 & 15.6 & 15.6 & 15.6 & 15.6 & 15.6 & 15.6 & 19 & 19 & 19 & 19 & 19 & 19 & 19 & 19 & 15.6 & 15.6 & 15.6 & 15.6 & 15.6 & 15.6 & 15.6 & 15.6 & 15.6 \\
\hline & Sats & 15.6 & 15.6 & 15.6 & 15.6 & 15.6 & 15.6 & 15.6 & 19 & 19 & 19 & 19 & 19 & 19 & 19 & 19 & 15.6 & 15.6 & 15.6 & 15.6 & 15.6 & 15.6 & 15.6 & 15.6 & 15.6 \\
\hline & Other & 15.6 & 15.6 & 15.6 & 15.6 & 15.6 & 15.6 & 15.6 & 15.6 & 15.6 & 15.6 & 15.6 & 15.6 & 15.6 & 15.6 & 15.6 & 15.6 & 15.6 & 15.6 & 15.6 & 15.6 & 15.6 & 15.6 & 15.6 & 15.6 \\
\hline CRITICAL_CLGSETP_SCH & All & 22.2 & 22.2 & 22.2 & 22.2 & 22.2 & 22.2 & 22.2 & 22.2 & 22.2 & 22.2 & 22.2 & 22.2 & 22.2 & 22.2 & 22.2 & 22.2 & 22.2 & 22.2 & 22.2 & 22.2 & 22.2 & 22.2 & 22.2 & 22.2 \\
\hline CRITICAL_HTGSETP_SCH & All & 21.1 & 21.1 & 21.1 & 21.1 & 21.1 & 21.1 & 21.1 & 21.1 & 21.1 & 21.1 & 21.1 & 21.1 & 21.1 & 21.1 & 21.1 & 21.1 & 21.1 & 21.1 & 21.1 & 21.1 & 21.1 & 21.1 & 21.1 & 21.1 \\
\hline OR_CLGSETP_SCH & All & 22.2 & 22.2 & 22.2 & 22.2 & 22.2 & 22.2 & 18.3 & 18.3 & 18.3 & 18.3 & 18.3 & 18.3 & 18.3 & 18.3 & 18.3 & 18.3 & 18.3 & 22.2 & 22.2 & 22.2 & 22.2 & 22.2 & 22.2 & 22.2 \\
\hline OR_HTGSETP_SCH & All & 18.3 & 18.3 & 18.3 & 18.3 & 18.3 & 18.3 & \begin{tabular}{|l|}
18.3 \\
\end{tabular} & 18.3 & 18.3 & 18.3 & 18.3 & 18.3 & 18.3 & 18.3 & 18.3 & 18.3 & 18.3 & 18.3 & 18.3 & 18.3 & 18.3 & 18.3 & 18.3 & 18.3 \\
\hline Dual Zone Control Type Sched & All & 4 & 4 & 4 & 4 & 4 & 4 & 4 & 4 & 4 & 4 & 4 & 4 & 4 & 4 & 4 & 4 & 4 & 4 & 4 & 4 & 4 & 4 & 4 & 4 \\
\hline $\begin{array}{l}\text { MaxRelHumSetSch } \\
\end{array}$ & All & 60 & 60 & 60 & 60 & 60 & 60 & 60 & 60 & 60 & 60 & 60 & 60 & 60 & 60 & 60 & 60 & 60 & 60 & 60 & 60 & 60 & 60 & 60 & 60 \\
\hline
\end{tabular}




\begin{tabular}{|c|c|c|c|c|c|c|c|c|c|c|c|c|c|c|c|c|c|c|c|c|c|c|c|c|c|}
\hline Schedule & Day of Week & 1 & 2 & 3 & 4 & 5 & 6 & 7 & 8 & 9 & 10 & 11 & 12 & 13 & 14 & 15 & 16 & 17 & 18 & 19 & 20 & 21 & 22 & 23 & 24 \\
\hline MinRelHumSetSch & All & 40 & 40 & 40 & 40 & 40 & 40 & 40 & 40 & 40 & 40 & 40 & 40 & 40 & 40 & 40 & 40 & 40 & 40 & 40 & 40 & 40 & 40 & 40 & 40 \\
\hline CAV_SAT_SCH & All & 11.1 & 11.1 & 11.1 & 11.1 & 11.1 & \begin{tabular}{|l|}
11.1 \\
\end{tabular} & \begin{tabular}{|l|}
11.1 \\
\end{tabular} & 11.1 & 11.1 & \begin{tabular}{|l|}
11.1 \\
\end{tabular} & \begin{tabular}{|l|}
11.1 \\
\end{tabular} & \begin{tabular}{|l|}
11.1 \\
\end{tabular} & \begin{tabular}{|l|}
11.1 \\
\end{tabular} & 11.1 & \begin{tabular}{|l|}
11.1 \\
\end{tabular} & \begin{tabular}{|l|}
11.1 \\
\end{tabular} & \begin{tabular}{|l|}
11.1 \\
\end{tabular} & 11.1 & 11.1 & 11.1 & 11.1 & 11.1 & 11.1 & 11.1 \\
\hline Heating-Supply-Air-Temp-Sch & All & 16 & 16 & 16 & 16 & 16 & 16 & 16 & 16 & 16 & 16 & 16 & 16 & 16 & 16 & 16 & 16 & 16 & 16 & 16 & 16 & 16 & 16 & 16 & 16 \\
\hline $\begin{array}{l}\text { Seasonal-Reset-Supply-Air-Temp- } \\
\text { Sch }\end{array}$ & All & 11.1 & 11.1 & 11.1 & 11.1 & 11.1 & 11.1 & 11.1 & 11.1 & 11.1 & 11.1 & 11.1 & 11.1 & 11.1 & 11.1 & 11.1 & 11.1 & 11.1 & 11.1 & 11.1 & 11.1 & 11.1 & 11.1 & 11.1 & 11.1 \\
\hline HVACOperationSchd & All & 1 & 1 & 1 & 1 & 1 & 1 & 1 & 1 & 1 & 1 & 1 & 1 & 1 & 1 & 1 & 1 & 1 & 1 & 1 & 1 & 1 & 1 & 1 & 1 \\
\hline CAV_OAminFracSchedule & All & 0.33 & 0.33 & 0.33 & 0.33 & 0.33 & 0.33 & 0.33 & 0.33 & 0.33 & 0.33 & 0.33 & 0.33 & 0.33 & 0.33 & 0.33 & 0.33 & 0.33 & 0.33 & 0.33 & 0.33 & 0.33 & 0.33 & 0.33 & 0.33 \\
\hline VAV_OAminFracSchedule & All & 0.25 & 0.25 & 0.25 & 0.25 & 0.25 & 0.25 & 0.25 & 0.25 & 0.25 & 0.25 & 0.25 & 0.25 & 0.25 & 0.25 & 0.25 & 0.25 & 0.25 & 0.25 & 0.25 & 0.25 & 0.25 & 0.25 & 0.25 & 0.25 \\
\hline CW-Loop-Temp-Schedule & All & \begin{tabular}{|l|}
6.7 \\
\end{tabular} & 6.7 & \begin{tabular}{|l|}
6.7 \\
\end{tabular} & \begin{tabular}{|l|}
6.7 \\
\end{tabular} & 6.7 & \begin{tabular}{|l|}
6.7 \\
\end{tabular} & \begin{tabular}{|l|}
6.7 \\
\end{tabular} & 6.7 & 6.7 & 6.7 & 6.7 & 6.7 & 6.7 & 6.7 & 6.7 & 6.7 & 6.7 & 6.7 & 6.7 & 6.7 & 6.7 & 6.7 & 6.7 & 6.7 \\
\hline HW-Loop-Temp-Schedule & All & 82.2 & 82.2 & 82.2 & 82.2 & 82.2 & 82.2 & 82.2 & 82.2 & 82.2 & 82.2 & 82.2 & 82.2 & 82.2 & 82.2 & 82.2 & 82.2 & 82.2 & 82.2 & 82.2 & 82.2 & 82.2 & 82.2 & 82.2 & 82.2 \\
\hline PlantOnSched & All & 1 & 1 & 1 & 1 & 1 & 1 & 1 & 1 & 1 & 1 & 1 & 1 & 1 & 1 & 1 & 1 & 1 & 1 & 1 & 1 & 1 & 1 & 1 & 1 \\
\hline $\begin{array}{l}\text { Kitchen_Flr_5_C } \\
\text { EZER_CaseCrre }\end{array}$ & A & 0.2 & 0.2 & 0.2 & \begin{tabular}{|l|}
0.2 \\
\end{tabular} & \begin{tabular}{|l}
0.2 \\
\end{tabular} & 0.2 & 0.2 & 0.4 & 0.4 & 0.4 & 0.4 & 0.4 & 0.4 & 0.4 & 0.4 & 0.4 & 0.4 & 0.4 & 0.4 & 0.4 & 0.4 & 0.2 & 0.2 & 0.2 \\
\hline $\begin{array}{l}\text { Kitchen_Flr_5_C } \\
\text { EZER_CaseDefr }\end{array}$ & Al & 0 & 0 & 0 & 0 & 0 & 0 & 0 & 0 & 0 & 0 & 0 & 0 & 0 & 0 & 0 & 0 & 0 & 0 & 0 & 0 & 0 & 0 & 0 & 0 \\
\hline $\begin{array}{l}\text { Kitchen_Flr_5_Case:1_WAL } \\
\text { EZER_CaseDripDown2aDay }\end{array}$ & All & 0 & 0 & 0 & 0 & 0 & 0 & 0 & 0 & 0 & 0 & 0 & 0 & 0 & 0 & 0 & 0 & 0 & 0 & 0 & 0 & 0 & 0 & 0 & 0 \\
\hline $\begin{array}{l}\text { Kitchen_FIr_5_Case:1_WALKINFRE } \\
\text { EZER_WalkInStockingSched }\end{array}$ & Tue, Fri & 0 & 0 & 0 & 0 & 725 & 417 & 290 & 0 & 0 & 0 & 0 & 0 & 0 & 0 & 0 & 0 & 0 & 0 & 0 & 0 & 0 & 0 & 0 & 0 \\
\hline & Other & 7 & 8 & 0 & 0 & 125 & 117 & 90 & 0 & 0 & 0 & 0 & 0 & 0 & 0 & 0 & 0 & 0 & 0 & 0 & 125 & 117 & 90 & 0 & 0 \\
\hline $\begin{array}{l}\text { Kitchen_FIr_5_Case:2_SELFCONT } \\
\text { AINEDDISPLAYCASE_CaseStockin } \\
\text { gSched }\end{array}$ & All & 0 & 0 & 0 & 0 & 0 & 0 & 50 & 70 & 70 & 80 & 70 & 50 & 50 & 80 & 90 & 80 & 0 & 0 & 0 & 0 & 0 & 0 & 0 & 0 \\
\hline BLDG_SWH_EXTD_SCH & WD, SummerDesign & 0.3 & 0.3 & 0.3 & 0.3 & 0.3 & 0.3 & 0.3 & 0.5 & 0.58 & 0.66 & 0.78 & 0.82 & 0.71 & 0.82 & 0.78 & 0.74 & 0.63 & 0.41 & 0.35 & 0.35 & 0.35 & 0.3 & 0.3 & 0.3 \\
\hline & Other & 0.3 & 0.3 & \begin{tabular}{|l|}
0.3 \\
\end{tabular} & 0.3 & 0.3 & 0.3 & 0.3 & 0.3 & 0.4 & 0.5 & 0.6 & 0.6 & 0.6 & 0.6 & 0.6 & 0.6 & 0.6 & 0.5 & 0.3 & 0.3 & 0.3 & 0.3 & 0.3 & 0.3 \\
\hline BLDG_SWH_SCH & WD, S & 0.01 & 0.01 & 0.01 & 0.01 & 0.01 & 0.01 & 0.01 & 0.17 & 0.58 & 0.66 & 0.78 & 0.82 & 0.71 & 0.82 & 0.78 & 0.74 & 0.63 & 0.41 & 0.18 & 0.18 & 0.18 & 0.1 & 0.01 & 0.01 \\
\hline & Sat, Wir & 0.01 & 0.01 & 0.01 & 0.01 & 0.01 & 0.01 & 0.01 & 0.01 & 0.2 & 0.28 & 0.3 & 0.3 & 0.24 & 0.24 & 0.23 & 0.23 & 0.23 & 0.1 & 0.01 & 0.01 & 0.01 & 0.01 & 0.01 & 0.01 \\
\hline & Sun, $\mathrm{Hol}, \mathrm{C}$ & 0.01 & 0.01 & 0.01 & 0.01 & 0.01 & 0.01 & 0.01 & 0.01 & 0.01 & 0.01 & 0.01 & 0.01 & 0.01 & 0.01 & 0.01 & 0.01 & 0.01 & 0.01 & 0.01 & 0.01 & 0.01 & 0.01 & 0.01 & 0.01 \\
\hline $\begin{array}{l}\text { Water Equipment Hot Supply Temp } \\
\text { Sched }\end{array}$ & All & 4 & 49 & 49 & 49 & 49 & 49 & 49 & 49 & 49 & 49 & 49 & 49 & 49 & 49 & 49 & 49 & 49 & 49 & 49 & 49 & 49 & 49 & 49 & 49 \\
\hline Water Equipment Latent fract sched & All & 0.05 & 0.05 & 0.05 & 0.05 & 0.05 & 0.05 & 0.05 & 0.05 & 0.05 & 0.05 & 0.05 & 0.05 & 0.05 & 0.05 & 0.05 & 0.05 & 0.05 & 0.05 & 0.05 & 0.05 & 0.05 & 0.05 & 0.05 & 0.05 \\
\hline $\begin{array}{l}\text { Water Equipment Sensible fract } \\
\text { sched }\end{array}$ & All & 0.2 & 0.2 & 0.2 & 0.2 & 0.2 & 0.2 & 0.2 & 0.2 & 0.2 & 0.2 & 0.2 & 0.2 & 0.2 & 0.2 & 0.2 & 0.2 & 0.2 & 0.2 & 0.2 & 0.2 & 0.2 & 0.2 & 0.2 & 0.2 \\
\hline Water Equipment Temp Sched & All & 49 & 49 & 49 & 49 & 49 & 49 & 49 & 49 & 49 & 49 & 49 & 49 & 49 & 49 & 49 & 49 & 49 & 49 & 49 & 49 & 49 & 49 & 49 & 49 \\
\hline $\begin{array}{l}\text { SWHSys1 Water Heater Ambient } \\
\text { Temperature Schedule Name }\end{array}$ & A & 2 & 2 & 2 & 2 & 2 & 22 & 22 & 22 & 22 & 22 & 22 & 22 & 22 & 22 & 22 & 22 & 22 & 22 & 22 & 22 & 22 & 22 & 22 & 22 \\
\hline $\begin{array}{l}\text { SWHSys } 1 \text { Water Heater Setpoint } \\
\text { Temperature Schedule Name }\end{array}$ & All & 6 & 60 & 60 & 60 & 60 & 60 & 60 & 60 & 60 & 60 & 60 & 60 & 60 & 60 & 60 & 60 & 60 & 60 & 60 & 60 & 60 & 60 & 60 & 60 \\
\hline SWHSys1-Loop-Temp-Schedule & All & 60 & 60 & 60 & 60 & 60 & 60 & 60 & 60 & 60 & 60 & 60 & 60 & 60 & 60 & 60 & 60 & 60 & 60 & 60 & 60 & 60 & 60 & 60 & 60 \\
\hline
\end{tabular}


Table B-3 Large Hotel Hourly Operation Schedules

\begin{tabular}{|c|c|c|c|c|c|c|c|c|c|c|c|c|c|c|c|c|c|c|c|c|c|c|c|c|c|}
\hline Schedule & Day of Week & 1 & 2 & 3 & 4 & 5 & 6 & 7 & 8 & 9 & 10 & 11 & 12 & 13 & 14 & 15 & 16 & 17 & 18 & 19 & 20 & 21 & 22 & 23 & 24 \\
\hline $\begin{array}{l}\text { ALWAYS_ON } \\
\end{array}$ & All & $\overline{c 1}$ & $\overline{c 1}$ & $\bar{~} 1$ & $\bar{~} 1$ & 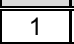 & 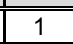 & $\bar{~} 1$ & $\bar{~} 1$ & 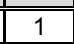 & 1 & 1 & $\overline{c 1}$ & 11 & $\overline{c 1}$ & $\overline{c 1}$ & 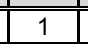 & $\overline{11}$ & 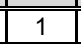 & 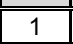 & $\overline{c 1}$ & 1 & 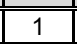 & 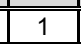 & $\overline{11}$ \\
\hline ACTIVITY_SCH & All & 120 & 120 & 120 & 120 & \begin{tabular}{|l|}
120 \\
\end{tabular} & 120 & 120 & 120 & 120 & 120 & 120 & 120 & 120 & 120 & 120 & 120 & 120 & 120 & 120 & 120 & 120 & 120 & 120 & 120 \\
\hline AIR_VELO_SCH & All & \begin{tabular}{|l|}
0.2 \\
\end{tabular} & \begin{tabular}{|l|}
0.2 \\
\end{tabular} & \begin{tabular}{|l|}
0.2 \\
\end{tabular} & \begin{tabular}{|l|}
0.2 \\
\end{tabular} & \begin{tabular}{|l|}
0.2 \\
\end{tabular} & \begin{tabular}{|l|}
0.2 \\
\end{tabular} & \begin{tabular}{|l|}
0.2 \\
\end{tabular} & 0.2 & \begin{tabular}{|l|}
0.2 \\
\end{tabular} & \begin{tabular}{|l|}
0.2 \\
\end{tabular} & 0.2 & \begin{tabular}{|l|}
0.2 \\
\end{tabular} & \begin{tabular}{|l|}
0.2 \\
\end{tabular} & \begin{tabular}{|l|}
0.2 \\
\end{tabular} & \begin{tabular}{|l|}
0.2 \\
\end{tabular} & 0.2 & 0.2 & \begin{tabular}{|l|}
0.2 \\
\end{tabular} & \begin{tabular}{|l|}
0.2 \\
\end{tabular} & \begin{tabular}{|l|}
0.2 \\
\end{tabular} & \begin{tabular}{|l|}
0.2 \\
\end{tabular} & 0.2 & 0.2 & 0.2 \\
\hline BLDG_ELEVATORS & All & 0.05 & 0.05 & 0.05 & 0.05 & \begin{tabular}{|l|}
0.1 \\
\end{tabular} & \begin{tabular}{|l|}
0.2 \\
\end{tabular} & \begin{tabular}{|l|l|}
0.4 \\
\end{tabular} & 0.5 & 0.5 & 0.35 & 0.15 & 0.15 & 0.15 & 0.15 & 0.15 & 0.15 & 0.35 & 0.5 & \begin{tabular}{|l|}
0.5 \\
\end{tabular} & 0.4 & \begin{tabular}{|l|}
0.4 \\
\end{tabular} & 0.3 & 0.2 & 0.1 \\
\hline \multirow[t]{5}{*}{ BLDG_EQUIP_SCH } & WD & \begin{tabular}{|l|}
0.3 \\
\end{tabular} & 0.25 & \begin{tabular}{|l|}
0.2 \\
\end{tabular} & \begin{tabular}{|l|}
0.2 \\
\end{tabular} & \begin{tabular}{|l|}
0.2 \\
\end{tabular} & 0.3 & \begin{tabular}{|l|}
0.5 \\
\end{tabular} & 0.6 & 0.5 & \begin{tabular}{|l|}
0.5 \\
\end{tabular} & \begin{tabular}{|l|}
0.35 \\
\end{tabular} & 0.35 & 0.35 & 0.35 & 0.35 & 0.35 & \begin{tabular}{|l|}
0.35 \\
\end{tabular} & 0.35 & \begin{tabular}{|l|}
0.7 \\
\end{tabular} & 0.9 & 0.95 & \begin{tabular}{|l|}
0.9 \\
\end{tabular} & 0.7 & 0.4 \\
\hline & Sat & \begin{tabular}{|l|}
0.3 \\
\end{tabular} & \begin{tabular}{|l|}
0.3 \\
\end{tabular} & \begin{tabular}{|l|}
0.2 \\
\end{tabular} & \begin{tabular}{|l|}
0.2 \\
\end{tabular} & \begin{tabular}{|l|}
0.2 \\
\end{tabular} & \begin{tabular}{|l|}
0.2 \\
\end{tabular} & \begin{tabular}{|l|}
0.4 \\
\end{tabular} & 0.4 & 0.5 & \begin{tabular}{|l|}
0.5 \\
\end{tabular} & \begin{tabular}{|l|}
0.4 \\
\end{tabular} & 0.35 & 0.35 & 0.35 & 0.35 & 0.35 & \begin{tabular}{|l|}
0.35 \\
\end{tabular} & 0.35 & \begin{tabular}{|l|}
0.7 \\
\end{tabular} & \begin{tabular}{|l|}
0.8 \\
\end{tabular} & \begin{tabular}{|l|}
0.8 \\
\end{tabular} & \begin{tabular}{|l|l}
0.8 \\
\end{tabular} & 0.7 & 0.4 \\
\hline & SummerDesign & 1 & 1 & 1 & 1 & 1 & 1 & 1 & 1 & 1 & 1 & 1 & 1 & 1 & 1 & 1 & 1 & 1 & 1 & 1 & 1 & 1 & 1 & 1 & 1 \\
\hline & \begin{tabular}{|l|} 
WinterDesign \\
\end{tabular} & 0 & 0 & 0 & 0 & 0 & 0 & 0 & 0 & 0 & 0 & 0 & 0 & 0 & 0 & 0 & 0 & 0 & 0 & 0 & 0 & 0 & 0 & 0 & 0 \\
\hline & Sun, $\mathrm{Hol}$, Other & \begin{tabular}{|l|}
0.4 \\
\end{tabular} & \begin{tabular}{|l|}
0.4 \\
\end{tabular} & \begin{tabular}{|l|}
0.3 \\
\end{tabular} & \begin{tabular}{|l|}
0.3 \\
\end{tabular} & \begin{tabular}{|l|}
0.3 \\
\end{tabular} & \begin{tabular}{|l|}
0.3 \\
\end{tabular} & \begin{tabular}{|l|}
0.4 \\
\end{tabular} & 0.5 & 0.5 & \begin{tabular}{|l|}
0.4 \\
\end{tabular} & 0.4 & \begin{tabular}{|l|}
0.4 \\
\end{tabular} & \begin{tabular}{|l|}
0.4 \\
\end{tabular} & 0.3 & \begin{tabular}{|l|}
0.3 \\
\end{tabular} & 0.3 & 0.3 & \begin{tabular}{|l|}
0.3 \\
\end{tabular} & \begin{tabular}{|l|}
0.6 \\
\end{tabular} & \begin{tabular}{|l|}
0.8 \\
\end{tabular} & 0.9 & 0.7 & 0.6 & 0.4 \\
\hline \multirow[t]{5}{*}{ BLDG_LIGHT_SCH } & WD & \begin{tabular}{|l|}
0.2 \\
\end{tabular} & 0.15 & \begin{tabular}{|l|}
0.1 \\
\end{tabular} & \begin{tabular}{|l|}
0.1 \\
\end{tabular} & \begin{tabular}{|l|}
0.1 \\
\end{tabular} & \begin{tabular}{|l|}
0.2 \\
\end{tabular} & \begin{tabular}{|l|}
0.4 \\
\end{tabular} & 0.5 & \begin{tabular}{|l|}
0.4 \\
\end{tabular} & \begin{tabular}{|l|}
0.4 \\
\end{tabular} & \begin{tabular}{|l|}
0.25 \\
\end{tabular} & 0.25 & 0.25 & 0.25 & 0.25 & 0.25 & \begin{tabular}{|l|}
0.25 \\
\end{tabular} & 0.25 & \begin{tabular}{|l|}
0.6 \\
\end{tabular} & \begin{tabular}{|l|}
0.8 \\
\end{tabular} & \begin{tabular}{|l|}
0.9 \\
\end{tabular} & 0.8 & 0.6 & 0.3 \\
\hline & Sat & \begin{tabular}{|l|}
0.2 \\
\end{tabular} & \begin{tabular}{|l|}
0.2 \\
\end{tabular} & \begin{tabular}{|l|}
0.1 \\
\end{tabular} & \begin{tabular}{|l|}
0.1 \\
\end{tabular} & \begin{tabular}{|l|}
0.1 \\
\end{tabular} & \begin{tabular}{|l|}
0.1 \\
\end{tabular} & \begin{tabular}{|l|}
0.3 \\
\end{tabular} & 0.3 & \begin{tabular}{|l|}
0.4 \\
\end{tabular} & \begin{tabular}{|l|}
0.4 \\
\end{tabular} & \begin{tabular}{|l|}
0.3 \\
\end{tabular} & 0.25 & 0.25 & 0.25 & 0.25 & \begin{tabular}{|l|}
0.25 \\
\end{tabular} & \begin{tabular}{|l|}
0.25 \\
\end{tabular} & 0.25 & \begin{tabular}{|l|}
0.6 \\
\end{tabular} & \begin{tabular}{|l|}
0.7 \\
\end{tabular} & \begin{tabular}{|l|}
0.7 \\
\end{tabular} & 0.7 & 0.6 & 0.3 \\
\hline & SummerDesign & 1 & 1 & 1 & 1 & \begin{tabular}{|l|l|}
1 \\
\end{tabular} & 1 & 1 & 1 & 1 & 1 & 1 & 1 & 1 & 1 & 1 & 1 & 1 & 1 & 1 & 1 & 1 & 1 & 1 & 1 \\
\hline & \begin{tabular}{|l|} 
WinterDesign \\
\end{tabular} & 0 & 0 & 0 & 0 & 0 & 0 & 0 & 0 & 0 & 0 & 0 & 0 & 0 & 0 & 0 & 0 & 0 & 0 & 0 & 0 & 0 & 0 & 0 & 0 \\
\hline & Sun, Hol, Other & \begin{tabular}{|l|}
0.3 \\
\end{tabular} & \begin{tabular}{|l|}
0.3 \\
\end{tabular} & \begin{tabular}{|l|}
0.2 \\
\end{tabular} & 0.2 & \begin{tabular}{|l|}
0.2 \\
\end{tabular} & \begin{tabular}{|l|}
0.2 \\
\end{tabular} & 0.3 & 0.4 & 0.4 & \begin{tabular}{|l|}
0.3 \\
\end{tabular} & 0.3 & 0.3 & \begin{tabular}{|l|}
0.3 \\
\end{tabular} & 0.2 & 0.2 & 0.2 & 0.2 & \begin{tabular}{|l|}
0.2 \\
\end{tabular} & \begin{tabular}{|l|}
0.5 \\
\end{tabular} & \begin{tabular}{|l|}
0.7 \\
\end{tabular} & \begin{tabular}{|l|}
0.8 \\
\end{tabular} & 0.6 & 0.5 & 0.3 \\
\hline \multirow[t]{5}{*}{ BLDG_OCC_SCH } & WD & \begin{tabular}{|l|}
0.9 \\
\end{tabular} & \begin{tabular}{|l|}
0.9 \\
\end{tabular} & \begin{tabular}{|l|}
0.9 \\
\end{tabular} & 0.9 & \begin{tabular}{|l|}
0.9 \\
\end{tabular} & \begin{tabular}{|l|}
0.9 \\
\end{tabular} & \begin{tabular}{|l|}
0.7 \\
\end{tabular} & 0.4 & \begin{tabular}{|l|}
0.4 \\
\end{tabular} & 0.2 & 0.2 & 0.2 & \begin{tabular}{|l|}
0.2 \\
\end{tabular} & 0.2 & \begin{tabular}{|l|}
0.2 \\
\end{tabular} & 0.3 & 0.5 & 0.5 & \begin{tabular}{|l|}
0.5 \\
\end{tabular} & \begin{tabular}{|l|}
0.7 \\
\end{tabular} & \begin{tabular}{|l|l}
0.7 \\
\end{tabular} & 0.8 & 0.9 & 0.9 \\
\hline & \begin{tabular}{|l|} 
SummerDesign \\
\end{tabular} & 1 & 1 & 11 & 1 & \begin{tabular}{|l|}
1 \\
\end{tabular} & 1 & 1 & 1 & 1 & 11 & 1 & 1 & 1 & 1 & 1 & 1 & 1 & 1 & 1 & 1 & 1 & 1 & 1 & 1 \\
\hline & \begin{tabular}{|l|} 
Sat \\
\end{tabular} & \begin{tabular}{|l|}
0.9 \\
\end{tabular} & \begin{tabular}{|l|}
0.9 \\
\end{tabular} & \begin{tabular}{|l|}
0.9 \\
\end{tabular} & 0.9 & \begin{tabular}{|l|}
0.9 \\
\end{tabular} & 0.9 & \begin{tabular}{|l|}
0.7 \\
\end{tabular} & 0.5 & 0.5 & \begin{tabular}{|l|}
0.3 \\
\end{tabular} & 0.3 & 0.3 & \begin{tabular}{|l|}
0.3 \\
\end{tabular} & 0.3 & 0.3 & 0.3 & 0.3 & 0.5 & \begin{tabular}{|l|}
0.6 \\
\end{tabular} & 0.6 & \begin{tabular}{|l|}
0.6 \\
\end{tabular} & 0.7 & 0.7 & \begin{tabular}{|l|}
0.7 \\
\end{tabular} \\
\hline & WinterDesign & 0 & 0 & 0 & 0 & 0 & 0 & 0 & 0 & 0 & 0 & 0 & 0 & 0 & 0 & 0 & 0 & 0 & 0 & 0 & 0 & 0 & 0 & 0 & 0 \\
\hline & Sun, Hol, Other & \begin{tabular}{|l|}
0.7 \\
\end{tabular} & 0.7 & \begin{tabular}{|l|}
0.7 \\
\end{tabular} & \begin{tabular}{|l|}
0.7 \\
\end{tabular} & \begin{tabular}{|l|l}
0.7 \\
\end{tabular} & \begin{tabular}{|l|} 
\\
\end{tabular} & \begin{tabular}{|l|}
0.7 \\
\end{tabular} & 0.7 & 0.5 & \begin{tabular}{|l|}
0.5 \\
\end{tabular} & 0.5 & \begin{tabular}{|l|}
0.3 \\
\end{tabular} & \begin{tabular}{|l|}
0.3 \\
\end{tabular} & 0.2 & \begin{tabular}{|l|}
0.2 \\
\end{tabular} & 0.2 & 0.3 & 0.4 & \begin{tabular}{|l|}
0.4 \\
\end{tabular} & 0.6 & 0.6 & 0.8 & 0.8 & 0.8 \\
\hline \multirow[t]{3}{*}{ CLOTHING_SCH } & \begin{tabular}{|l|l} 
All \\
\end{tabular} & \begin{tabular}{|l|l|}
1 \\
\end{tabular} & 1 & \begin{tabular}{|l|}
1 \\
\end{tabular} & \begin{tabular}{|l|}
1 \\
\end{tabular} & \begin{tabular}{|c|}
1 \\
\end{tabular} & 1 & 1 & 1 & 1 & \begin{tabular}{|l|l|}
1 & \\
\end{tabular} & 1 & 1 & \begin{tabular}{|l}
1 \\
\end{tabular} & 1 & 1 & 1 & 1 & 1 & \begin{tabular}{|c|}
1 \\
\end{tabular} & 1 & 1 & 1 & 1 & 1 \\
\hline & All & \begin{tabular}{|l|}
0.5 \\
\end{tabular} & \begin{tabular}{|l|}
0.5 \\
\end{tabular} & 0.5 & 0.5 & \begin{tabular}{|l|}
0.5 \\
\end{tabular} & 0.5 & 0.5 & 0.5 & 0.5 & 0.5 & 0.5 & 0.5 & \begin{tabular}{|l|}
0.5 \\
\end{tabular} & 0.5 & 0.5 & 0.5 & 0.5 & 0.5 & \begin{tabular}{|l|}
0.5 \\
\end{tabular} & 0.5 & 0.5 & 0.5 & 0.5 & 0.5 \\
\hline & All & 1 & 1 & \begin{tabular}{|l|}
1 \\
\end{tabular} & 1 & \begin{tabular}{|c|}
1 \\
\end{tabular} & 1 & 1 & 1 & 1 & \begin{tabular}{|l|}
1 \\
\end{tabular} & 11 & 1 & \begin{tabular}{|l|}
1 \\
\end{tabular} & 1 & 1 & 1 & 1 & 1 & \begin{tabular}{|c|}
1 \\
\end{tabular} & 1 & 1 & 1 & 1 & 1 \\
\hline \multirow[t]{4}{*}{ GuestRoom_Eqp_Sch } & WD & \begin{tabular}{|l|}
0.2 \\
\end{tabular} & \begin{tabular}{|l|}
0.2 \\
\end{tabular} & \begin{tabular}{|l|}
0.2 \\
\end{tabular} & \begin{tabular}{|l|}
0.2 \\
\end{tabular} & \begin{tabular}{|l|}
0.2 \\
\end{tabular} & \begin{tabular}{|l|}
0.2 \\
\end{tabular} & \begin{tabular}{|l|}
0.62 \\
\end{tabular} & \begin{tabular}{l|l}
0.9 \\
\end{tabular} & 0.43 & \begin{tabular}{|l|}
0.43 \\
\end{tabular} & \begin{tabular}{|l|}
0.26 \\
\end{tabular} & 0.26 & \begin{tabular}{|l|}
0.26 \\
\end{tabular} & \begin{tabular}{|l|}
0.26 \\
\end{tabular} & 0.26 & \begin{tabular}{|l|}
0.26 \\
\end{tabular} & \begin{tabular}{|l|l|}
0.26 \\
\end{tabular} & \begin{tabular}{|l|}
0.51 \\
\end{tabular} & 0.51 & 0.49 & \begin{tabular}{|l|}
0.66 \\
\end{tabular} & 0.7 & \begin{tabular}{|l|}
0.35 \\
\end{tabular} & 0.2 \\
\hline & Sat, Sun, $\mathrm{Hol}$ & \begin{tabular}{|l|}
0.2 \\
\end{tabular} & 0.2 & \begin{tabular}{|l|}
0.2 \\
\end{tabular} & \begin{tabular}{|l|}
0.2 \\
\end{tabular} & \begin{tabular}{|l|}
0.2 \\
\end{tabular} & \begin{tabular}{|l|}
0.2 \\
\end{tabular} & \begin{tabular}{|l|}
0.3 \\
\end{tabular} & 0.62 & \begin{tabular}{|l|}
0.9 \\
\end{tabular} & \begin{tabular}{|l|}
0.62 \\
\end{tabular} & \begin{tabular}{|l|}
0.29 \\
\end{tabular} & \begin{tabular}{|l|}
0.29 \\
\end{tabular} & \begin{tabular}{|l|}
0.29 \\
\end{tabular} & \begin{tabular}{|l|}
0.29 \\
\end{tabular} & \begin{tabular}{|l|}
0.29 \\
\end{tabular} & \begin{tabular}{|l|}
0.29 \\
\end{tabular} & \begin{tabular}{|l|}
0.29 \\
\end{tabular} & 0.43 & \begin{tabular}{|l|}
0.51 \\
\end{tabular} & \begin{tabular}{ll|}
0.49 \\
\end{tabular} & \begin{tabular}{|l|}
0.66 \\
\end{tabular} & 0.7 & 0.35 & 0.2 \\
\hline & \begin{tabular}{|l|} 
WinterDesign \\
\end{tabular} & 0 & 0 & 0 & 0 & 0 & 0 & 0 & 0 & 0 & \begin{tabular}{|l|}
0 \\
\end{tabular} & 0 & 0 & 0 & 0 & 0 & 0 & 0 & 0 & 0 & 0 & 0 & 0 & 0 & 0 \\
\hline & \begin{tabular}{|l|} 
SummerDesign, \\
CustomDay1, \\
CustomDay2
\end{tabular} & 1 & 1 & 1 & 1 & 1 & 1 & 1 & 1 & 1 & 1 & 1 & 1 & 1 & 1 & 1 & 1 & 1 & 1 & 1 & 1 & 1 & 1 & 1 & 1 \\
\hline \multirow[t]{4}{*}{ GuestRoom_Ltg_Sch_Base } & WD & 0.22 & 0.17 & \begin{tabular}{|l|}
0.11 \\
\end{tabular} & \begin{tabular}{|l|}
0.11 \\
\end{tabular} & \begin{tabular}{|l|}
0.11 \\
\end{tabular} & 0.22 & \begin{tabular}{|l|l|}
0.44 \\
\end{tabular} & 0.56 & 0.44 & \begin{tabular}{|l|l|}
0.44 \\
\end{tabular} & \begin{tabular}{|l|l|}
0.28 \\
\end{tabular} & 0.28 & 0.28 & 0.28 & 0.28 & \begin{tabular}{|l|}
0.28 \\
\end{tabular} & \begin{tabular}{|l|}
0.28 \\
\end{tabular} & 0.28 & \begin{tabular}{|l|}
0.67 \\
\end{tabular} & 0.89 & 1 & 0.89 & 0.67 & 0.33 \\
\hline & Sat, Sun, Hol & \begin{tabular}{|l|}
0.26 \\
\end{tabular} & \begin{tabular}{|l|}
0.26 \\
\end{tabular} & \begin{tabular}{|l|}
0.11 \\
\end{tabular} & \begin{tabular}{|l|}
0.11 \\
\end{tabular} & \begin{tabular}{|l|}
0.11 \\
\end{tabular} & \begin{tabular}{|l|}
0.11 \\
\end{tabular} & \begin{tabular}{|l|}
0.41 \\
\end{tabular} & \begin{tabular}{|l|}
0.41 \\
\end{tabular} & \begin{tabular}{|l|}
0.56 \\
\end{tabular} & \begin{tabular}{|l|}
0.56 \\
\end{tabular} & \begin{tabular}{|l|}
0.41 \\
\end{tabular} & \begin{tabular}{|l|}
0.33 \\
\end{tabular} & \begin{tabular}{|l|}
0.33 \\
\end{tabular} & \begin{tabular}{|l|}
0.33 \\
\end{tabular} & \begin{tabular}{|l|l|}
0.33 \\
\end{tabular} & \begin{tabular}{|l|}
0.33 \\
\end{tabular} & \begin{tabular}{|l|}
0.33 \\
\end{tabular} & \begin{tabular}{|l|}
0.33 \\
\end{tabular} & \begin{tabular}{|l|}
0.85 \\
\end{tabular} & \begin{tabular}{|l|l|}
1 & \\
\end{tabular} & 1 & 1 & 0.85 & \begin{tabular}{|l}
0.41 \\
\end{tabular} \\
\hline & WinterDesign & \begin{tabular}{|l|l|}
0 & \\
\end{tabular} & \begin{tabular}{|l|l|}
0 & \\
\end{tabular} & \begin{tabular}{|l|l|}
0 & \\
\end{tabular} & \begin{tabular}{|l|l|}
0 & \\
\end{tabular} & \begin{tabular}{|l|l|}
0 & \\
\end{tabular} & 0 & \begin{tabular}{|l|l|}
0 & \\
\end{tabular} & 0 & \begin{tabular}{|l|l|}
0 & \\
\end{tabular} & \begin{tabular}{|l|l|}
0 & \\
\end{tabular} & 0 & 0 & \begin{tabular}{|l|l|}
0 & \\
\end{tabular} & 0 & 0 & 0 & 0 & 0 & \begin{tabular}{|l|l|}
0 & \\
\end{tabular} & 0 & 0 & 0 & 0 & 0 \\
\hline & $\begin{array}{l}\text { SummerDesign, } \\
\text { CustomDay1, } \\
\text { CustomDay2 }\end{array}$ & 1 & 1 & 1 & 1 & 1 & 1 & 1 & 1 & 1 & 1 & 1 & 1 & 1 & 1 & 1 & 1 & 1 & 1 & 1 & 1 & 1 & 1 & 1 & 1 \\
\hline \multirow[t]{4}{*}{ GuestRoom_Occ_Sch } & WD & 0.65 & 0.65 & 0.65 & 0.65 & \begin{tabular}{|l|}
0.65 \\
\end{tabular} & 0.65 & 0.5 & 0.28 & 0.28 & 0.13 & \begin{tabular}{|l|}
0.13 \\
\end{tabular} & 0.13 & 0.13 & 0.13 & 0.13 & 0.2 & \begin{tabular}{|l|}
0.35 \\
\end{tabular} & 0.35 & \begin{tabular}{|l|}
0.35 \\
\end{tabular} & 0.5 & 0.5 & 0.58 & 0.65 & 0.65 \\
\hline & Sat, Sun, $\mathrm{Hol}$ & 0.65 & 0.65 & 0.65 & 0.65 & \begin{tabular}{|l|l|}
0.65 \\
\end{tabular} & 0.65 & \begin{tabular}{|l|}
0.5 \\
\end{tabular} & 0.34 & 0.34 & \begin{tabular}{|l|}
0.2 \\
\end{tabular} & \begin{tabular}{|l|}
0.2 \\
\end{tabular} & \begin{tabular}{|l|}
0.2 \\
\end{tabular} & \begin{tabular}{|l|}
0.2 \\
\end{tabular} & 0.2 & \begin{tabular}{|l|}
0.2 \\
\end{tabular} & 0.2 & \begin{tabular}{|l|}
0.2 \\
\end{tabular} & 0.34 & \begin{tabular}{|l|}
0.35 \\
\end{tabular} & 0.65 & 0.65 & 0.5 & 0.5 & 0.5 \\
\hline & \begin{tabular}{|l|} 
WinterDesign \\
\end{tabular} & 0 & 0 & 0 & 0 & \begin{tabular}{|l|}
0 \\
\end{tabular} & 0 & 0 & 0 & 0 & 0 & 0 & 0 & 0 & 0 & 0 & 0 & 0 & 0 & 0 & 0 & 0 & 0 & 0 & 0 \\
\hline & \begin{tabular}{|l|} 
SummerDesign, \\
CustomDay1, \\
CustomDay2
\end{tabular} & 1 & 1 & 1 & 1 & 1 & 1 & 1 & 1 & 1 & 1 & 1 & 1 & 1 & 1 & 1 & 1 & 1 & 1 & 1 & 1 & 1 & 1 & 1 & 1 \\
\hline & All & 0.25 & 0.25 & 0.25 & 0.25 & \begin{tabular}{|l|}
0.25 \\
\end{tabular} & 0.25 & 0.25 & 0.25 & 0.25 & 0.25 & \begin{tabular}{|l|l|}
0.25 \\
\end{tabular} & 0.25 & 0.25 & 0.25 & 0.25 & 0.25 & \begin{tabular}{|l|}
0.25 \\
\end{tabular} & 0.25 & \begin{tabular}{|l|}
0.25 \\
\end{tabular} & 0.25 & 0.25 & 0.25 & 0.25 & 0.25 \\
\hline \multirow{5}{*}{ Kitchen_Elec_Equip_SCH } & \begin{tabular}{|l|} 
Weekday \\
\end{tabular} & \begin{tabular}{|l|}
0.1 \\
\end{tabular} & \begin{tabular}{|l|}
0.1 \\
\end{tabular} & \begin{tabular}{|l|}
0.1 \\
\end{tabular} & \begin{tabular}{|l|}
0.1 \\
\end{tabular} & \begin{tabular}{|l|}
0.1 \\
\end{tabular} & \begin{tabular}{|l|}
0.1 \\
\end{tabular} & \begin{tabular}{|l|}
0.25 \\
\end{tabular} & 0.35 & \begin{tabular}{|l|}
0.35 \\
\end{tabular} & \begin{tabular}{|l|}
0.25 \\
\end{tabular} & \begin{tabular}{|l|}
0.35 \\
\end{tabular} & \begin{tabular}{|l|}
0.35 \\
\end{tabular} & \begin{tabular}{|l|}
0.35 \\
\end{tabular} & \begin{tabular}{|l|}
0.25 \\
\end{tabular} & \begin{tabular}{|l|}
0.25 \\
\end{tabular} & \begin{tabular}{|l|}
0.25 \\
\end{tabular} & \begin{tabular}{|l|}
0.35 \\
\end{tabular} & \begin{tabular}{|l|}
0.35 \\
\end{tabular} & \begin{tabular}{|l|}
0.35 \\
\end{tabular} & \begin{tabular}{|l|}
0.25 \\
\end{tabular} & 0.25 & \begin{tabular}{|l|}
0.25 \\
\end{tabular} & 0.25 & 0.25 \\
\hline & Sat & \begin{tabular}{|l|}
0.1 \\
\end{tabular} & \begin{tabular}{|l|}
0.1 \\
\end{tabular} & \begin{tabular}{|l|}
0.1 \\
\end{tabular} & \begin{tabular}{|l|}
0.1 \\
\end{tabular} & \begin{tabular}{|l|}
0.1 \\
\end{tabular} & \begin{tabular}{|l|}
0.1 \\
\end{tabular} & \begin{tabular}{|l|}
0.25 \\
\end{tabular} & \begin{tabular}{|l|}
0.35 \\
\end{tabular} & \begin{tabular}{|l|}
0.35 \\
\end{tabular} & \begin{tabular}{|l|}
0.25 \\
\end{tabular} & 0.35 & \begin{tabular}{|l|}
0.35 \\
\end{tabular} & \begin{tabular}{|l|}
0.35 \\
\end{tabular} & \begin{tabular}{|l|}
0.25 \\
\end{tabular} & \begin{tabular}{|l|}
0.25 \\
\end{tabular} & \begin{tabular}{|l|}
0.25 \\
\end{tabular} & \begin{tabular}{|l|}
0.35 \\
\end{tabular} & \begin{tabular}{|l|}
0.35 \\
\end{tabular} & \begin{tabular}{|l|}
0.35 \\
\end{tabular} & 0.25 & 0.25 & \begin{tabular}{|l|}
0.25 \\
\end{tabular} & 0.25 & 0.25 \\
\hline & SummerDesign & 0.35 & 0.35 & 0.35 & 0.35 & 0.35 & 0.35 & 0.35 & 0.35 & 0.35 & 0.35 & \begin{tabular}{|l|}
0.35 \\
\end{tabular} & \begin{tabular}{|l|}
0.35 \\
\end{tabular} & \begin{tabular}{|l|}
0.35 \\
\end{tabular} & \begin{tabular}{|l|}
0.35 \\
\end{tabular} & \begin{tabular}{|l|}
0.35 \\
\end{tabular} & \begin{tabular}{|l|}
0.35 \\
\end{tabular} & \begin{tabular}{|l|}
0.35 \\
\end{tabular} & \begin{tabular}{|l|}
0.35 \\
\end{tabular} & \begin{tabular}{|l|}
0.35 \\
\end{tabular} & 0.35 & \begin{tabular}{|l|}
0.35 \\
\end{tabular} & 0.35 & 0.35 & 0.35 \\
\hline & \begin{tabular}{|l|} 
WinterDesign \\
\end{tabular} & \begin{tabular}{|l|l|}
0 \\
\end{tabular} & \begin{tabular}{|l|l|}
0 \\
\end{tabular} & \begin{tabular}{|l|l|}
0 \\
\end{tabular} & \begin{tabular}{|l|l|}
0 & \\
\end{tabular} & \begin{tabular}{|l|l|}
0 \\
0
\end{tabular} & \begin{tabular}{|l|l|}
0 \\
\end{tabular} & \begin{tabular}{|l|l|}
0 & \\
\end{tabular} & \begin{tabular}{|l|}
0 \\
\end{tabular} & \begin{tabular}{|l|l|}
0 \\
\end{tabular} & \begin{tabular}{|l|l|}
0 \\
\end{tabular} & \begin{tabular}{|c|}
0 \\
0
\end{tabular} & \begin{tabular}{|l|l|}
0 \\
\end{tabular} & \begin{tabular}{|l|l|}
0 & \\
\end{tabular} & \begin{tabular}{|l|}
0 \\
\end{tabular} & \begin{tabular}{|l|l|}
0 \\
\end{tabular} & \begin{tabular}{|c|}
0 \\
\end{tabular} & \begin{tabular}{|l|}
0 \\
0
\end{tabular} & \begin{tabular}{|l|}
0 \\
\end{tabular} & \begin{tabular}{|l|}
0 \\
0 \\
\end{tabular} & \begin{tabular}{|l|l|}
0 \\
\end{tabular} & \begin{tabular}{|l|}
0 \\
\end{tabular} & \begin{tabular}{|c|}
0 \\
\end{tabular} & 0 & 0 \\
\hline & Sun, Hol, Other & \begin{tabular}{|l|}
0.1 \\
\end{tabular} & \begin{tabular}{|l|}
0.1 \\
\end{tabular} & \begin{tabular}{|l|}
0.1 \\
\end{tabular} & \begin{tabular}{|l|}
0.1 \\
\end{tabular} & \begin{tabular}{|l|}
0.1 \\
\end{tabular} & \begin{tabular}{|l|}
0.1 \\
\end{tabular} & 0.25 & 0.35 & 0.35 & \begin{tabular}{|l|}
0.25 \\
\end{tabular} & \begin{tabular}{|l|l|}
0.35 \\
\end{tabular} & 0.35 & 0.35 & 0.25 & 0.25 & \begin{tabular}{|l|}
0.25 \\
\end{tabular} & \begin{tabular}{|l|}
0.35 \\
\end{tabular} & 0.35 & \begin{tabular}{|l|}
0.35 \\
\end{tabular} & 0.25 & 0.25 & 0.25 & 0.25 & 0.25 \\
\hline
\end{tabular}




\begin{tabular}{|c|c|c|c|c|c|c|c|c|c|c|c|c|c|c|c|c|c|c|c|c|c|c|c|c|c|}
\hline Schedule & Day of Week & 1 & 2 & 3 & 4 & 5 & 6 & 7 & 8 & 9 & 10 & 11 & 12 & 13 & 14 & 15 & 16 & 17 & 18 & 19 & 20 & 21 & 22 & 23 & 24 \\
\hline \multirow[t]{4}{*}{ Kitchen_Gas_Equip_SCH } & WD, Sat & 0.02 & 0.02 & 0.02 & 0.02 & 0.02 & 0.05 & \begin{tabular}{|l|}
0.1 \\
\end{tabular} & 0.15 & 0.2 & 0.15 & 0.25 & 0.25 & 0.25 & 0.2 & 0.15 & \begin{tabular}{|l|}
0.2 \\
\end{tabular} & 0.3 & \begin{tabular}{|l|}
0.3 \\
\end{tabular} & 0.3 & 0.2 & \begin{tabular}{|l|}
0.2 \\
\end{tabular} & \begin{tabular}{|l|}
0.15 \\
\end{tabular} & 0.1 & 0.05 \\
\hline & SummerDesign & 0.25 & 0.25 & 0.25 & 0.25 & 0.25 & 0.25 & 0.25 & 0.25 & 0.25 & 0.25 & \begin{tabular}{|l|}
0.25 \\
\end{tabular} & 0.25 & \begin{tabular}{|l|}
0.25 \\
\end{tabular} & \begin{tabular}{|l|}
0.25 \\
\end{tabular} & 0.25 & \begin{tabular}{|l|}
0.25 \\
\end{tabular} & \begin{tabular}{|l|}
0.25 \\
\end{tabular} & \begin{tabular}{|l|}
0.25 \\
\end{tabular} & 0.25 & 0.25 & \begin{tabular}{|l|}
0.25 \\
\end{tabular} & \begin{tabular}{|l|}
0.25 \\
\end{tabular} & 0.25 & 0.25 \\
\hline & \begin{tabular}{|l} 
WinterDesign \\
\end{tabular} & \begin{tabular}{|l|}
0 \\
\end{tabular} & \begin{tabular}{|l|l|}
0 \\
\end{tabular} & 0 & 0 & 0 & 0 & 0 & 0 & 0 & 0 & 0 & 0 & \begin{tabular}{|c|}
0 \\
\end{tabular} & 0 & 0 & \begin{tabular}{|c|}
0 \\
\end{tabular} & \begin{tabular}{|c|}
0 \\
\end{tabular} & 0 & 0 & 0 & \begin{tabular}{|l|}
0 \\
\end{tabular} & 0 & 0 & 0 \\
\hline & Sun, Hol, Other & \begin{tabular}{|l|}
0.02 \\
\end{tabular} & \begin{tabular}{|l|}
0.02 \\
\end{tabular} & 0.02 & 0.02 & 0.02 & \begin{tabular}{|l|l|}
0.05 \\
\end{tabular} & \begin{tabular}{|l|}
0.1 \\
\end{tabular} & 0.15 & \begin{tabular}{|l|}
0.2 \\
\end{tabular} & \begin{tabular}{|l|l|}
0.15 \\
\end{tabular} & \begin{tabular}{|l|}
0.25 \\
\end{tabular} & \begin{tabular}{|l|}
0.25 \\
\end{tabular} & \begin{tabular}{|l|}
0.25 \\
\end{tabular} & 0.2 & 0.15 & \begin{tabular}{|l|}
0.2 \\
\end{tabular} & 0.3 & \begin{tabular}{|l|}
0.3 \\
\end{tabular} & 0.3 & 0.2 & \begin{tabular}{|l|}
0.2 \\
\end{tabular} & \begin{tabular}{|l|}
0.15 \\
\end{tabular} & 0.1 & 0.05 \\
\hline \multirow[t]{3}{*}{ LaundryRoom_Eqp_Elec_Sch } & \begin{tabular}{|l} 
WD, Sat, Sun, $\mathrm{Hol}$ \\
\end{tabular} & \begin{tabular}{|l|l|}
0 \\
\end{tabular} & \begin{tabular}{|l|l|}
0 \\
\end{tabular} & 0 & 0 & 0 & 0 & 0 & 0 & 1 & 1 & 1 & 1 & \begin{tabular}{|c|}
1 \\
\end{tabular} & 1 & 1 & \begin{tabular}{|c|c|}
1 \\
\end{tabular} & 0 & 0 & 0 & 0 & 0 & 0 & 0 & 0 \\
\hline & \begin{tabular}{|l|} 
WinterDesign \\
\end{tabular} & 0 & 0 & 0 & 0 & 0 & 0 & 0 & 0 & 0 & 0 & 0 & 0 & 0 & 0 & 0 & 0 & 0 & 0 & 0 & 0 & 0 & 0 & 0 & 0 \\
\hline & \begin{tabular}{|l} 
SummerDesign, \\
CustomDay1, \\
CustomDay2
\end{tabular} & 1 & 1 & 1 & 1 & 1 & 1 & 1 & 1 & 1 & 1 & 1 & 1 & 1 & 1 & 1 & 1 & 1 & 1 & 1 & 1 & 1 & 1 & 1 & 1 \\
\hline \multirow{3}{*}{ LaundryRoom_Eqp_Gas_Sch } & WD, Sat, Sun, Hol & 0 & 0 & 0 & 0 & 0 & 0 & 0 & 0 & 0 & 1 & 1 & 1 & 1 & 1 & 1 & 1 & 1 & 0 & 0 & 0 & 0 & 0 & 0 & 0 \\
\hline & \begin{tabular}{|l|} 
WinterDesign \\
\end{tabular} & 0 & 0 & 0 & 0 & 0 & 0 & 0 & 0 & 0 & 0 & 0 & 0 & 0 & 0 & 0 & 0 & 0 & 0 & 0 & 0 & 0 & 0 & 0 & 0 \\
\hline & \begin{tabular}{|l|} 
SummerDesign, \\
CustomDay1, \\
CustomDay2 \\
\end{tabular} & 1 & 1 & 1 & 1 & 1 & 1 & 1 & 1 & 1 & 1 & 1 & 1 & 1 & 1 & 1 & 1 & 1 & 1 & 1 & 1 & 1 & 1 & 1 & 1 \\
\hline \multirow[t]{4}{*}{ Lobby_Occ_Sch } & WD & \begin{tabular}{|l|}
0.1 \\
\end{tabular} & \begin{tabular}{|l|}
0.1 \\
\end{tabular} & 0.1 & 0.1 & 0.1 & \begin{tabular}{|l|}
0.3 \\
\end{tabular} & \begin{tabular}{|l|}
0.7 \\
\end{tabular} & 0.7 & 0.7 & 0.7 & 0.2 & 0.2 & \begin{tabular}{|l|}
0.2 \\
\end{tabular} & 0.2 & 0.2 & \begin{tabular}{|l|}
0.2 \\
\end{tabular} & \begin{tabular}{|l|}
0.4 \\
\end{tabular} & \begin{tabular}{|l|}
0.4 \\
\end{tabular} & 0.2 & \begin{tabular}{|l|}
0.2 \\
\end{tabular} & \begin{tabular}{|l|}
0.2 \\
\end{tabular} & \begin{tabular}{|l|}
0.2 \\
\end{tabular} & 0.1 & 0.1 \\
\hline & Sat, Sun, Hol & \begin{tabular}{|l|}
0.1 \\
\end{tabular} & \begin{tabular}{|l|}
0.1 \\
\end{tabular} & 0.1 & \begin{tabular}{|l|}
0.1 \\
\end{tabular} & 0.1 & \begin{tabular}{|l|}
0.1 \\
\end{tabular} & 0.3 & \begin{tabular}{|l|}
0.7 \\
\end{tabular} & \begin{tabular}{|l|} 
\\
\end{tabular} & 0.7 & 0.2 & 0.2 & 0.2 & 0.2 & 0.2 & \begin{tabular}{|l|}
0.2 \\
\end{tabular} & \begin{tabular}{|l|}
0.2 \\
\end{tabular} & 0.2 & 0.2 & 0.2 & 0.2 & 0.2 & 0.1 & 0.1 \\
\hline & \begin{tabular}{|l|} 
WinterDesign \\
\end{tabular} & 0 & 0 & 0 & 0 & 0 & 0 & \begin{tabular}{|l|}
0 \\
\end{tabular} & 0 & 0 & 0 & 0 & 0 & \begin{tabular}{|l|l|}
0 \\
\end{tabular} & 0 & 0 & \begin{tabular}{|c|}
0 \\
\end{tabular} & \begin{tabular}{|c|c|}
0 \\
\end{tabular} & 0 & 0 & 0 & 0 & 0 & 0 & 0 \\
\hline & \begin{tabular}{|l} 
SummerDesign, \\
CustomDay1, \\
CustomDay2
\end{tabular} & 1 & 1 & 1 & 1 & 1 & 1 & 1 & 1 & 1 & 1 & 1 & 1 & 1 & 1 & 1 & 1 & 1 & 1 & 1 & 1 & 1 & 1 & 1 & 1 \\
\hline$\overline{\text { WORK_EFF_SCH }}$ & All & 0 & 0 & 0 & 0 & 0 & 0 & 0 & 0 & 0 & 0 & 0 & 0 & 0 & 0 & 0 & 0 & 0 & 0 & 0 & 0 & 0 & 0 & 0 & 0 \\
\hline Kitchen_Exhaust_SCH & All & 0 & 0 & 0 & 0 & 0 & 0 & 0 & 1 & 1 & 1 & 1 & 1 & 1 & 1 & 1 & 1 & 1 & 1 & 1 & 1 & 1 & 1 & 1 & 1 \\
\hline CLGSETP_SCH & \begin{tabular}{|lll} 
All \\
\end{tabular} & 30 & 30 & 30 & 30 & 30 & 30 & 30 & 24 & 24 & 24 & 24 & 24 & 24 & 24 & 24 & 24 & 24 & 24 & 24 & 24 & 24 & 24 & 24 & 24 \\
\hline HTGSETP_SCH & All & 16 & 16 & 16 & 16 & 16 & 16 & 16 & 21 & 21 & 21 & 21 & 21 & 21 & 21 & 21 & \begin{tabular}{|l|}
21 \\
\end{tabular} & \begin{tabular}{|l|}
21 \\
\end{tabular} & \begin{tabular}{|l|}
21 \\
\end{tabular} & 21 & 21 & \begin{tabular}{|l|}
21 \\
\end{tabular} & \begin{tabular}{|l|}
21 \\
\end{tabular} & 21 & 21 \\
\hline Corr_CLGSETP_SCH & All & 30 & 30 & 30 & 30 & 30 & 30 & 30 & 30 & 30 & 30 & 30 & 30 & 30 & 30 & 30 & \begin{tabular}{|l|}
30 \\
\end{tabular} & 30 & 30 & 30 & 30 & 30 & 30 & 30 & 30 \\
\hline Corr_HTGSETP_SCH & All & 16 & 16 & 16 & 16 & 16 & 16 & 16 & 16 & 16 & 16 & 16 & 16 & 16 & 16 & 16 & \begin{tabular}{|c|}
16 \\
\end{tabular} & 16 & 16 & 16 & 16 & \begin{tabular}{|c|}
16 \\
\end{tabular} & \begin{tabular}{|c|}
16 \\
\end{tabular} & 16 & 16 \\
\hline Guest_CLGSETP_SCH & All & \begin{tabular}{|l|}
24 \\
\end{tabular} & 24 & 24 & 24 & 24 & 24 & 24 & 24 & 24 & 24 & 24 & 24 & 24 & 24 & 24 & 24 & 24 & 24 & 24 & 24 & 24 & \begin{tabular}{|l|}
24 \\
\end{tabular} & 24 & 24 \\
\hline Guest_HTGSETP_SCH & All & 21 & 21 & 21 & 21 & 21 & 21 & \begin{tabular}{|l|}
21 \\
\end{tabular} & 21 & 21 & 21 & 21 & 21 & 21 & 21 & 21 & 21 & 21 & \begin{tabular}{|l|}
21 \\
\end{tabular} & 21 & 21 & \begin{tabular}{|l|}
21 \\
\end{tabular} & 21 & 21 & 21 \\
\hline Kitchen_CLGSETP_SCH & All & \begin{tabular}{|l|}
30 \\
\end{tabular} & 30 & 30 & 30 & 30 & 30 & 30 & 26 & 26 & 26 & 26 & 26 & 26 & 26 & 26 & 26 & 26 & 26 & 26 & 26 & \begin{tabular}{|l|}
26 \\
\end{tabular} & \begin{tabular}{|l|}
26 \\
\end{tabular} & 26 & 26 \\
\hline Kitchen_HTGSETP_SCH & All & 16 & \begin{tabular}{|c|}
16 \\
\end{tabular} & 16 & 16 & 16 & 16 & 16 & \begin{tabular}{|l|l|}
19 \\
\end{tabular} & 19 & 19 & \begin{tabular}{|l|l|}
19 \\
\end{tabular} & 19 & \begin{tabular}{|l|}
19 \\
19
\end{tabular} & \begin{tabular}{|l|l|}
19 \\
\end{tabular} & \begin{tabular}{|l|l|}
19 \\
\end{tabular} & \begin{tabular}{|l|}
19 \\
\end{tabular} & \begin{tabular}{|l|}
19 \\
\end{tabular} & 19 & 19 & 19 & 19 & \begin{tabular}{|l|l|}
19 \\
\end{tabular} & 19 & 19 \\
\hline Dual Zone Control Type Sched & All & 4 & 4 & 4 & 4 & 4 & 4 & 4 & 4 & 4 & 4 & 4 & 4 & 4 & 4 & 4 & 4 & 4 & 4 & 4 & 4 & 4 & 4 & 4 & 4 \\
\hline HVACOperationSchd & All & 0 & 0 & 0 & 0 & 0 & 0 & 0 & 1 & 1 & 1 & 1 & 1 & 1 & 1 & 1 & 1 & 1 & 1 & 1 & 1 & 1 & 1 & 1 & 1 \\
\hline MinOA_Sched & All & 0 & 0 & 0 & 0 & 0 & 0 & 0 & 1 & 1 & 1 & 1 & 1 & 1 & 1 & 1 & 1 & \begin{tabular}{|c|c|}
1 \\
\end{tabular} & 1 & 1 & 1 & 1 & 1 & 1 & 1 \\
\hline Seasonal-Reset-Supply-Air-Temp-Sch & All & 13 & 13 & 13 & 13 & 13 & 13 & 13 & 13 & 13 & 13 & 13 & 13 & 13 & 13 & 13 & 13 & 13 & 13 & 13 & 13 & 13 & 13 & 13 & 13 \\
\hline CW-Loop-Temp-Schedule & All & \begin{tabular}{|l|}
6.7 \\
\end{tabular} & \begin{tabular}{|l|}
6.7 \\
\end{tabular} & 6.7 & 6.7 & 6.7 & 6.7 & \begin{tabular}{|l|}
6.7 \\
\end{tabular} & 6.7 & 6.7 & 6.7 & 6.7 & 6.7 & \begin{tabular}{|l|}
6.7 \\
\end{tabular} & 6.7 & 6.7 & \begin{tabular}{|l|}
6.7 \\
\end{tabular} & 6.7 & \begin{tabular}{|l|}
6.7 \\
\end{tabular} & 6.7 & 6.7 & \begin{tabular}{|l|}
6.7 \\
\end{tabular} & \begin{tabular}{|l|}
6.7 \\
\end{tabular} & 6.7 & 6.7 \\
\hline HW-Loop-Temp-Schedule & All & 60 & 60 & 60 & 60 & 60 & 60 & 60 & 60 & 60 & 60 & 60 & 60 & 60 & 60 & \begin{tabular}{|c|}
60 \\
-1
\end{tabular} & 60 & 60 & 60 & 60 & 60 & 60 & 60 & 60 & 60 \\
\hline PlantOnSched & All & 1 & 1 & 1 & 1 & 1 & 1 & 1 & 1 & 1 & 1 & 1 & 1 & 1 & 1 & 1 & 1 & 1 & 1 & 1 & 1 & 1 & 1 & 1 & 1 \\
\hline $\begin{array}{l}\text { Kitchen_FIr_6_Case:1_WALKINFREEZER__ } \\
\text { CaseCreditReduuxSched }\end{array}$ & All & 0.2 & 0.2 & 0.2 & 0.2 & \begin{tabular}{|l} 
\\
\end{tabular} & \begin{tabular}{|l} 
\\
\end{tabular} & 0.2 & 0.4 & \begin{tabular}{|l|l} 
\\
\end{tabular} & \begin{tabular}{|l|l} 
\\
\end{tabular} & \begin{tabular}{|l} 
\\
\end{tabular} & 0.4 & \begin{tabular}{|l|} 
\\
\end{tabular} & \begin{tabular}{|l} 
\\
\end{tabular} & \begin{tabular}{|l|} 
\\
\end{tabular} & \begin{tabular}{|l|} 
\\
\end{tabular} & 0.4 & \begin{tabular}{|l|} 
\\
\end{tabular} & 0.4 & 0.4 & 0.4 & \begin{tabular}{|l|} 
\\
\end{tabular} & 0.2 & 0.2 \\
\hline $\begin{array}{l}\text { Kitchen_Flr_6_Case:1_WALKINFREEZER_ } \\
\text { CaseDefrost2aDaySched }\end{array}$ & All & 0 & 0 & 0 & 0 & 0 & 0 & 0 & 0 & 0 & 0 & 0 & 0 & 0 & 0 & 0 & 0 & 0 & 0 & 0 & 0 & 0 & 0 & 0 & 0 \\
\hline $\begin{array}{l}\text { Kitchen_FIr_6_Case:1_WALKINFREEZER__ } \\
\text { CaseDripDown2aDaySched }\end{array}$ & All & 0 & 0 & 0 & 0 & 0 & 0 & 0 & 0 & 0 & 0 & 0 & 0 & 0 & 0 & 0 & 0 & 0 & 0 & 0 & 0 & 0 & 0 & 0 & 0 \\
\hline $\begin{array}{l}\text { Kitchen_FIr_6_Case:1_WALKINFREEZER_ } \\
\text { WalkInStockingSched }\end{array}$ & Tue, Fri & 0 & 0 & 0 & 0 & 725 & \begin{tabular}{|l|} 
\\
\end{tabular} 177 & 290 & 0 & 0 & 0 & 0 & 0 & 0 & 0 & 0 & 0 & 0 & 0 & 0 & 0 & 0 & 0 & 0 & 0 \\
\hline & \begin{tabular}{|l|l|} 
Other \\
\end{tabular} & 0 & 0 & 0 & 0 & \begin{tabular}{|l|}
125 \\
\end{tabular} & \begin{tabular}{|l|}
117 \\
\end{tabular} & 90 & 0 & 0 & 0 & 0 & 0 & 0 & 0 & 0 & 0 & 0 & 0 & 0 & 125 & \begin{tabular}{|l|}
117 \\
\end{tabular} & \begin{tabular}{|l|}
90 \\
\end{tabular} & 0 & 0 \\
\hline $\begin{array}{l}\text { Kitchen_FIr_6_Case:2_SELFCONTAINEDD } \\
\text { ISPLAYCASE_CaseStockingSched }\end{array}$ & All & 0 & 0 & 0 & 0 & 0 & 0 & 50 & 70 & 70 & 80 & 70 & 50 & 50 & 80 & 90 & 80 & 0 & 0 & 0 & 0 & 0 & 0 & 0 & 0 \\
\hline
\end{tabular}




\begin{tabular}{|c|c|c|c|c|c|c|c|c|c|c|c|c|c|c|c|c|c|c|c|c|c|c|c|c|c|}
\hline Schedule & Day of Week & 1 & 2 & 3 & 4 & 5 & 6 & 7 & 8 & 9 & 10 & 11 & 12 & 13 & 14 & 15 & 16 & 17 & 18 & 19 & 20 & 21 & 22 & 23 & 24 \\
\hline Kitchen_SWH_SCH & WD, SummerDesign & 0.2 & 0.15 & 0.15 & 0.15 & 0.2 & 0.25 & 0.5 & 0.6 & 0.55 & 0.45 & 0.4 & 0.45 & 0.4 & 0.35 & 0.3 & 0.3 & 0.3 & 0.4 & 0.55 & 0.6 & 0.5 & 0.55 & 0.45 & 0.25 \\
\hline & Sat, WinterDesign & 0.2 & 0.15 & 0.15 & 0.15 & 0.2 & 0.25 & 0.4 & 0.5 & 0.5 & 0.5 & 0.45 & 0.5 & 0.5 & 0.45 & 0.4 & 0.4 & 0.35 & 0.4 & 0.55 & 0.55 & 0.5 & 0.55 & 0.4 & 0.3 \\
\hline & Sun, Hol, Other & 0.25 & 0.2 & 0.2 & 0.2 & 0.2 & 0.3 & 0.5 & 0.5 & 0.5 & 0.55 & 0.5 & 0.5 & 0.4 & 0.4 & 0.3 & 0.3 & 0.3 & 0.4 & 0.5 & 0.5 & 0.4 & 0.5 & 0.4 & 0.2 \\
\hline GuestRoom_SWH_Sch & WD & 0.2 & 0.15 & 0.15 & 0.15 & 0.2 & 0.35 & 0.6 & 0.8 & 0.55 & 0.4 & 0.3 & 0.2 & 0.2 & 0.2 & 0.2 & 0.2 & 0.2 & 0.3 & 0.55 & 0.4 & 0.4 & \begin{tabular}{|l|}
0.6 \\
\end{tabular} & 0.45 & 0.25 \\
\hline & Other & 0.2 & 0.15 & 0.15 & 0.15 & 0.2 & 0.25 & 0.35 & 0.6 & 0.8 & 0.55 & 0.4 & 0.3 & 0.2 & 0.2 & 0.2 & 0.2 & 0.2 & 0.25 & 0.3 & 0.4 & 0.4 & 0.4 & \begin{tabular}{|l|}
0.6 \\
\end{tabular} & 0.35 \\
\hline LaundryRoom_SWH_Sch & All & 0 & 0 & 0 & 0 & 0 & 0 & 0 & 0 & 1 & 1 & 1 & 1 & 1 & 1 & 1 & 1 & 0 & 0 & 0 & 0 & 0 & 0 & 0 & 0 \\
\hline Water Equipment Latent fract sched & All & 0.05 & 0.05 & 0.05 & 0.05 & 0.05 & 0.05 & 0.05 & 0.05 & 0.05 & 0.05 & 0.05 & 0.05 & 0.05 & 0.05 & 0.05 & 0.05 & 0.05 & 0.05 & 0.05 & 0.05 & 0.05 & 0.05 & 0.05 & 0.05 \\
\hline Water Equipment Sensible fract sched & All & 0.2 & 0.2 & 0.2 & 0.2 & 0.2 & 0.2 & 0.2 & 0.2 & 0.2 & 0.2 & 0.2 & 0.2 & 0.2 & 0.2 & 0.2 & 0.2 & 0.2 & 0.2 & 0.2 & 0.2 & 0.2 & 0.2 & 0.2 & 0.2 \\
\hline $\begin{array}{l}\text { Guest Room Water Equipment Hot Supply } \\
\text { Temp Sched }\end{array}$ & All & 43.3 & 43.3 & 43.3 & 43.3 & 43.3 & 43.3 & 43.3 & 43.3 & 43.3 & 43.3 & 43.3 & 43.3 & 43.3 & 43.3 & 43.3 & 43.3 & 43.3 & 43.3 & 43.3 & 43.3 & 43.3 & 43.3 & 43.3 & 43.3 \\
\hline Guest Room Water Equipment Temp Sched & All & 43.3 & 43.3 & 43.3 & 43.3 & 43.3 & 43.3 & 43.3 & 43.3 & 43.3 & 43.3 & 43.3 & 43.3 & 43.3 & 43.3 & 43.3 & 43.3 & 43.3 & 43.3 & 43.3 & 43.3 & 43.3 & 43.3 & 43.3 & 43.3 \\
\hline $\begin{array}{l}\text { Kitchen Water Equipment Hot Supply Temp } \\
\text { Sched }\end{array}$ & All & 49 & 49 & 49 & 49 & 49 & 49 & 49 & 49 & 49 & 49 & 49 & 49 & 49 & 49 & 49 & 49 & 49 & 49 & 49 & 49 & 49 & 49 & 49 & 49 \\
\hline Kitchen Water Equipment Temp Sched & All & 49 & 49 & 49 & 49 & 49 & 49 & 49 & 49 & 49 & 49 & 49 & 49 & 49 & 49 & 49 & 49 & 49 & 49 & 49 & 49 & 49 & 49 & 49 & 49 \\
\hline $\begin{array}{l}\text { Laundry Water Equipment Hot Supply Temp } \\
\text { Sched }\end{array}$ & All & 60 & 60 & 60 & 60 & 60 & 60 & 60 & 60 & 60 & 60 & 60 & 60 & 60 & 60 & 60 & 60 & 60 & 60 & 60 & 60 & 60 & 60 & 60 & 60 \\
\hline Laundry Water Equipment Temp Sched & All & 60 & 60 & 60 & 60 & 60 & 60 & 60 & 60 & 60 & 60 & 60 & 60 & 60 & 60 & 60 & 60 & 60 & 60 & 60 & 60 & 60 & 60 & 60 & 60 \\
\hline $\begin{array}{l}\text { SWHSys } 1 \text { Water Heater Ambient } \\
\text { Temperature Schedule Name }\end{array}$ & All & 22 & 22 & 22 & 22 & 22 & 22 & 22 & 22 & 22 & 22 & 22 & 22 & 22 & 22 & 22 & 22 & 22 & 22 & 22 & 22 & 22 & 22 & 22 & 22 \\
\hline $\begin{array}{l}\text { SWHSys } 1 \text { Water Heater Setpoint } \\
\text { Temperature Schedule Name }\end{array}$ & All & 60 & 60 & 60 & 60 & 60 & 60 & 60 & 60 & 60 & 60 & 60 & 60 & 60 & 60 & 60 & 60 & 60 & 60 & 60 & 60 & 60 & 60 & 60 & 60 \\
\hline \begin{tabular}{|l|} 
SWHSys1-Loop-Temp-Schedule \\
\end{tabular} & All & 60 & 60 & 60 & 60 & 60 & 60 & 60 & 60 & 60 & 60 & 60 & 60 & 60 & 60 & 60 & 60 & 60 & 60 & 60 & 60 & 60 & 60 & 60 & 60 \\
\hline
\end{tabular}


Table B-4 Large Office Hourly Operation Schedules

\begin{tabular}{|c|c|c|c|c|c|c|c|c|c|c|c|c|c|c|c|c|c|c|c|c|c|c|c|c|c|}
\hline Schedule & Day of Week & 1 & 2 & 3 & 4 & 5 & 6 & 7 & 8 & 9 & 10 & 11 & 12 & 13 & 14 & 15 & 16 & 17 & 18 & 19 & 20 & 21 & 22 & 23 & 24 \\
\hline ALWAYS_ON & All & 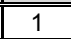 & $\bar{~} 1$ & $\bar{~} 1$ & $\overline{11}$ & $\overline{11}$ & $\overline{11}$ & 1 & 1 & 1 & 1 & 1 & 1 & 1 & 1 & 1 & 1 & 1 & 1 & 1 & 1 & 1 & 1 & 1 & 1 \\
\hline BLDG_ELEVATORS & All & 0.05 & 0.05 & 0.05 & 0.05 & 0.1 & 0.2 & 0.4 & 0.5 & 0.5 & 0.35 & 0.15 & 0.15 & 0.15 & 0.15 & 0.15 & 0.15 & 0.35 & \begin{tabular}{|l|}
0.5 \\
\end{tabular} & \begin{tabular}{|l|}
0.5 \\
\end{tabular} & 0.4 & 0.4 & 0.3 & 0.2 & 0.1 \\
\hline \multirow[t]{3}{*}{ INFIL_QUARTER_ON_SCH } & WD, SummerDesign & 1 & 1 & 1 & 1 & 1 & 1 & 0.25 & 0.25 & 0.25 & 0.25 & 0.25 & 0.25 & 0.25 & 0.25 & 0.25 & 0.25 & 0.25 & 0.25 & 0.25 & 0.25 & 0.25 & 0.25 & 1 & 1 \\
\hline & Sat, WinterDesign & 1 & 1 & 1 & 1 & 1 & 1 & 0.25 & 0.25 & 0.25 & 0.25 & 0.25 & 0.25 & 0.25 & 0.25 & 0.25 & 0.25 & 0.25 & 0.25 & 1 & 1 & 1 & 1 & 1 & 1 \\
\hline & Sun, Hol, Other & 1 & 1 & 1 & 1 & 1 & 1 & 1 & 1 & 1 & 1 & 1 & 1 & 1 & 1 & 1 & 1 & 1 & 1 & 1 & 1 & 1 & 1 & 1 & 1 \\
\hline \multirow[t]{4}{*}{ BLDG_OCC_SCH } & SummerDesign & 0 & 0 & 0 & 0 & 0 & 0 & 1 & 1 & 1 & 1 & 1 & 1 & 1 & 1 & 1 & 1 & 1 & 1 & 1 & 1 & 1 & 1 & 0.05 & 0.05 \\
\hline & WD & 0 & 0 & 0 & 0 & 0 & 0 & \begin{tabular}{|l|}
0.1 \\
\end{tabular} & \begin{tabular}{|l|}
0.2 \\
\end{tabular} & 0.95 & 0.95 & 0.95 & 0.95 & \begin{tabular}{|l|}
0.5 \\
\end{tabular} & 0.95 & 0.95 & 0.95 & 0.95 & \begin{tabular}{|l|}
0.7 \\
\end{tabular} & \begin{tabular}{|l|}
0.4 \\
\end{tabular} & \begin{tabular}{|l|l|}
0.4 \\
\end{tabular} & \begin{tabular}{|l|}
0.1 \\
\end{tabular} & \begin{tabular}{|l|}
0.1 \\
\end{tabular} & 0.05 & 0.05 \\
\hline & Sat & 0 & 0 & 0 & 0 & 0 & 0 & 0.1 & \begin{tabular}{|l|}
0.1 \\
\end{tabular} & \begin{tabular}{|l|}
0.5 \\
\end{tabular} & \begin{tabular}{|l|}
0.5 \\
\end{tabular} & \begin{tabular}{|l|}
0.5 \\
\end{tabular} & \begin{tabular}{|l|}
0.5 \\
\end{tabular} & \begin{tabular}{|l|}
0.5 \\
\end{tabular} & \begin{tabular}{|l|}
0.5 \\
\end{tabular} & \begin{tabular}{|l|}
0.1 \\
\end{tabular} & \begin{tabular}{|l|}
0.1 \\
\end{tabular} & \begin{tabular}{|l|}
0.1 \\
\end{tabular} & 0 & 0 & 0 & 0 & 0 & 0 & 0 \\
\hline & Other & 0 & 0 & 0 & 0 & 0 & 0 & 0 & 0 & 0 & 0 & 0 & 0 & 0 & 0 & 0 & 0 & 0 & 0 & 0 & 0 & 0 & 0 & 0 & 0 \\
\hline \multirow[t]{5}{*}{ BLDG_LIGHT_SCH } & WD & 0.05 & 0.05 & 0.05 & 0.05 & 0.05 & 0.1 & 0.1 & 0.3 & 0.9 & 0.9 & 0.9 & 0.9 & 0.9 & \begin{tabular}{|l|}
0.9 \\
\end{tabular} & \begin{tabular}{|l|}
0.9 \\
\end{tabular} & \begin{tabular}{|l|}
0.9 \\
\end{tabular} & \begin{tabular}{|l|}
0.9 \\
\end{tabular} & \begin{tabular}{|l|l|}
0.7 \\
\end{tabular} & 0.5 & 0.5 & 0.3 & 0.3 & \begin{tabular}{|l|}
0.1 \\
\end{tabular} & 0.05 \\
\hline & Sat & 0.05 & 0.05 & 0.05 & 0.05 & 0.05 & 0.05 & 0.1 & \begin{tabular}{|l|}
0.1 \\
\end{tabular} & 0.5 & 0.5 & 0.5 & 0.5 & \begin{tabular}{|l|}
0.5 \\
\end{tabular} & \begin{tabular}{|l|}
0.5 \\
\end{tabular} & 0.15 & 0.15 & 0.15 & 0.05 & 0.05 & 0.05 & 0.05 & 0.05 & 0.05 & 0.05 \\
\hline & SummerDesign & 1 & 1 & 1 & 1 & 1 & 1 & 1 & 1 & 1 & 1 & 1 & 1 & 1 & 1 & 1 & 1 & 1 & 1 & 1 & 1 & 1 & 1 & 1 & 1 \\
\hline & \begin{tabular}{|l|} 
WinterDesign \\
\end{tabular} & 0 & 0 & 0 & 0 & 0 & 0 & 0 & 0 & 0 & 0 & 0 & 0 & 0 & 0 & 0 & 0 & 0 & 0 & 0 & 0 & 0 & 0 & 0 & 0 \\
\hline & Other & 0.05 & 0.05 & 0.05 & 0.05 & 0.05 & 0.05 & 0.05 & 0.05 & 0.05 & 0.05 & 0.05 & 0.05 & 0.05 & 0.05 & 0.05 & 0.05 & 0.05 & 0.05 & 0.05 & \begin{tabular}{|l|}
0.05 \\
\end{tabular} & \begin{tabular}{|l|}
0.05 \\
\end{tabular} & 0.05 & \begin{tabular}{|l|}
0.05 \\
\end{tabular} & 0.05 \\
\hline \multirow[t]{5}{*}{ BLDG_EQUIP_SCH } & WD & 0.4 & 0.4 & 0.4 & 0.4 & 0.4 & 0.4 & 0.4 & 0.4 & 0.9 & 0.9 & 0.9 & 0.9 & 0.8 & \begin{tabular}{|l|}
0.9 \\
\end{tabular} & \begin{tabular}{|l|}
0.9 \\
\end{tabular} & \begin{tabular}{|l|}
0.9 \\
\end{tabular} & 0.9 & 0.8 & 0.6 & 0.6 & 0.5 & 0.5 & 0.4 & 0.4 \\
\hline & Sat & 0.3 & 0.3 & 0.3 & 0.3 & 0.3 & 0.3 & \begin{tabular}{|l|}
0.4 \\
\end{tabular} & \begin{tabular}{|l|}
0.4 \\
\end{tabular} & \begin{tabular}{|l|}
0.5 \\
\end{tabular} & \begin{tabular}{|l|}
0.5 \\
\end{tabular} & \begin{tabular}{|l|}
0.5 \\
\end{tabular} & \begin{tabular}{|l|}
0.5 \\
\end{tabular} & \begin{tabular}{|l|}
0.5 \\
\end{tabular} & \begin{tabular}{|l|}
0.5 \\
\end{tabular} & 0.35 & 0.35 & 0.35 & \begin{tabular}{|l|}
0.3 \\
\end{tabular} & 0.3 & 0.3 & 0.3 & 0.3 & 0.3 & 0.3 \\
\hline & SummerDesign & 1 & 1 & 1 & 1 & 1 & 1 & 1 & 1 & 1 & 1 & 1 & 1 & 1 & 1 & 1 & 1 & 1 & 1 & 1 & 1 & 1 & 1 & 1 & 1 \\
\hline & WinterDesign & 0 & 0 & 0 & 0 & 0 & 0 & 0 & 0 & 0 & 0 & 0 & 0 & 0 & 0 & 0 & 0 & 0 & 0 & 0 & 0 & 0 & 0 & 0 & 0 \\
\hline & Other & 0.3 & 0.3 & 0.3 & 0.3 & 0.3 & 0.3 & 0.3 & \begin{tabular}{|l|}
0.3 \\
\end{tabular} & \begin{tabular}{|l|}
0.3 \\
\end{tabular} & \begin{tabular}{|l|}
0.3 \\
\end{tabular} & \begin{tabular}{|l|}
0.3 \\
\end{tabular} & \begin{tabular}{|l|}
0.3 \\
\end{tabular} & \begin{tabular}{|l|}
0.3 \\
\end{tabular} & \begin{tabular}{|l|}
0.3 \\
\end{tabular} & \begin{tabular}{|l|}
0.3 \\
\end{tabular} & \begin{tabular}{|l|}
0.3 \\
\end{tabular} & \begin{tabular}{|l|}
0.3 \\
\end{tabular} & \begin{tabular}{|l|}
0.3 \\
\end{tabular} & \begin{tabular}{|l|}
0.3 \\
\end{tabular} & \begin{tabular}{|l|}
0.3 \\
\end{tabular} & \begin{tabular}{|l|}
0.3 \\
\end{tabular} & \begin{tabular}{|l|}
0.3 \\
\end{tabular} & \begin{tabular}{|l|}
0.3 \\
\end{tabular} & 0.3 \\
\hline ACTIVITY_SCH & All & 120 & 120 & 120 & 120 & 120 & 120 & 120 & 120 & 120 & 120 & 120 & 120 & 120 & 120 & 120 & 120 & 120 & 120 & 120 & \begin{tabular}{|l|}
120 \\
\end{tabular} & \begin{tabular}{|l|}
120 \\
\end{tabular} & \begin{tabular}{|l|}
120 \\
\end{tabular} & \begin{tabular}{|l|}
120 \\
\end{tabular} & 120 \\
\hline WORK_EFF_SCH & All & 0 & 0 & 0 & 0 & 0 & 0 & 0 & 0 & 0 & 0 & 0 & 0 & 0 & 0 & 0 & 0 & 0 & 0 & 0 & 0 & 0 & 0 & 0 & 0 \\
\hline AIR_VELO_SCH & All & \begin{tabular}{|l|}
0.2 \\
\end{tabular} & 0.2 & 0.2 & 0.2 & 0.2 & \begin{tabular}{|l|}
0.2 \\
\end{tabular} & \begin{tabular}{|l|}
0.2 \\
\end{tabular} & \begin{tabular}{|l|}
0.2 \\
\end{tabular} & \begin{tabular}{|l|}
0.2 \\
\end{tabular} & \begin{tabular}{|l|}
0.2 \\
\end{tabular} & \begin{tabular}{|l|}
0.2 \\
\end{tabular} & \begin{tabular}{|l|}
0.2 \\
\end{tabular} & \begin{tabular}{|l|}
0.2 \\
\end{tabular} & \begin{tabular}{|l|}
0.2 \\
\end{tabular} & \begin{tabular}{|l|}
0.2 \\
\end{tabular} & 0.2 & 0.2 & 0.2 & 0.2 & 0.2 & \begin{tabular}{|l|}
0.2 \\
\end{tabular} & \begin{tabular}{|l|}
0.2 \\
\end{tabular} & \begin{tabular}{|l|}
0.2 \\
\end{tabular} & 0.2 \\
\hline \multirow[t]{3}{*}{ CLOTHING_SCH } & All & 1 & 1 & 1 & 1 & 1 & 1 & 1 & 1 & 1 & 1 & 1 & 1 & 1 & 1 & 1 & 1 & 1 & 1 & 1 & 1 & 1 & 1 & 1 & 1 \\
\hline & All & 0.5 & 0.5 & 0.5 & 0.5 & 0.5 & 0.5 & \begin{tabular}{|l|}
0.5 \\
\end{tabular} & \begin{tabular}{|l|}
0.5 \\
\end{tabular} & \begin{tabular}{|l|}
0.5 \\
\end{tabular} & \begin{tabular}{|l|}
0.5 \\
\end{tabular} & \begin{tabular}{|l|}
0.5 \\
\end{tabular} & \begin{tabular}{|l|}
0.5 \\
\end{tabular} & \begin{tabular}{|l|l}
0.5 \\
\end{tabular} & 0.5 & \begin{tabular}{|l|l}
0.5 \\
\end{tabular} & 0.5 & \begin{tabular}{|l|}
0.5 \\
\end{tabular} & \begin{tabular}{|l|}
0.5 \\
\end{tabular} & \begin{tabular}{|l|}
0.5 \\
\end{tabular} & \begin{tabular}{|l|l|}
0.5 \\
\end{tabular} & \begin{tabular}{|l|l|}
0.5 \\
\end{tabular} & \begin{tabular}{|l|l|}
0.5 \\
\end{tabular} & \begin{tabular}{|l|l|}
0.5 \\
\end{tabular} & 0.5 \\
\hline & All & 1 & 1 & 1 & 1 & 1 & 1 & 1 & 1 & 1 & 1 & 1 & 1 & 1 & 1 & 1 & 1 & 1 & 1 & 1 & 1 & 1 & 1 & 1 & 1 \\
\hline \multirow[t]{4}{*}{ CLGSETP_SCH } & WD, SummerDesign & 26.7 & 26.7 & 26.7 & 26.7 & 26.7 & 26.7 & 24 & 24 & 24 & 24 & 24 & 24 & 24 & 24 & 24 & 24 & 24 & 24 & 24 & 24 & 24 & 24 & 26.7 & 26.7 \\
\hline & Sat & 26.7 & 26.7 & 26.7 & 26.7 & 26.7 & 26.7 & 24 & 24 & 24 & 24 & 24 & 24 & 24 & 24 & 24 & 24 & 24 & 24 & 26.7 & 26.7 & 26.7 & 26.7 & 26.7 & 26.7 \\
\hline & WinterD & 26.7 & 26.7 & 26.7 & 26.7 & 26.7 & 26.7 & 26.7 & 26.7 & 26.7 & 26.7 & 26.7 & 26.7 & 26.7 & 26.7 & 26.7 & 26.7 & 26.7 & 26.7 & 26.7 & 26.7 & 26.7 & 26.7 & 26.7 & 26.7 \\
\hline & Other & 26.7 & 26.7 & 26.7 & 26.7 & 26.7 & 26.7 & 26.7 & 26.7 & 26.7 & 26.7 & 26.7 & 26.7 & \begin{tabular}{|l|}
26.7 \\
\end{tabular} & \begin{tabular}{|l|}
26.7 \\
\end{tabular} & \begin{tabular}{|l|}
26.7 \\
\end{tabular} & \begin{tabular}{|l|}
26.7 \\
\end{tabular} & \begin{tabular}{|l|}
26.7 \\
\end{tabular} & \begin{tabular}{|l|}
26.7 \\
\end{tabular} & 26.7 & 26.7 & 26.7 & 26.7 & 26.7 & 26.7 \\
\hline \multirow[t]{5}{*}{ HTGSETP_SCH } & WD & 15.6 & 15.6 & 15.6 & 15.6 & 15.6 & 15.6 & 21 & 21 & 21 & 21 & 21 & 21 & 21 & 21 & 21 & 21 & 21 & 21 & 21 & \begin{tabular}{|l|}
21 \\
\end{tabular} & \begin{tabular}{|l|}
21 \\
\end{tabular} & \begin{tabular}{|l|}
21 \\
\end{tabular} & 15.6 & 15.6 \\
\hline & Summe & 15.6 & 15.6 & 15.6 & 15.6 & 15.6 & 15.6 & 15.6 & 15.6 & 15.6 & 15.6 & 15.6 & 15.6 & 15.6 & 15.6 & 15.6 & 15.6 & 15.6 & 15.6 & 15.6 & 15.6 & 15.6 & 15.6 & 15.6 & 15.6 \\
\hline & Sat & 15.6 & 15.6 & 15.6 & 15.6 & 15.6 & 15.6 & 21 & 21 & 21 & 21 & 21 & 21 & 21 & 21 & 21 & 21 & 21 & 21 & 15.6 & 15.6 & 15.6 & 15.6 & 15.6 & 15.6 \\
\hline & WinterDesign & 21 & 21 & 21 & 21 & 21 & 21 & 21 & 21 & 21 & 21 & 21 & 21 & 21 & 21 & 21 & 21 & 21 & 21 & 21 & 21 & 21 & 21 & 21 & 21 \\
\hline & Other & 15.6 & 15.6 & 15.6 & 15.6 & 15.6 & 15.6 & 15.6 & 15.6 & 15.6 & 15.6 & 15.6 & 15.6 & 15.6 & 15.6 & 15.6 & 15.6 & 15.6 & 15.6 & 15.6 & 15.6 & 15.6 & 15.6 & 15.6 & 15.6 \\
\hline Seasonal-Reset-Supply-Air-Temp-Sch & All & 12.8 & 12.8 & 12.8 & 12.8 & 12.8 & 12.8 & 12.8 & 12.8 & 12.8 & 12.8 & 12.8 & 12.8 & 12.8 & 12.8 & 12.8 & 12.8 & 12.8 & 12.8 & 12.8 & 12.8 & 12.8 & 12.8 & 12.8 & 12.8 \\
\hline \multirow[t]{3}{*}{ MinOA_MotorizedDamper_Sched } & WD, SummerDesign & 0 & 0 & 0 & 0 & 0 & 0 & 0 & 1 & 1 & 1 & 1 & 1 & 1 & 1 & 1 & 1 & 1 & 1 & 1 & 1 & 1 & 1 & 0 & 0 \\
\hline & Sat, WinterDesign & 0 & 0 & 0 & 0 & 0 & 0 & 0 & 1 & 1 & 4 & 1 & 1 & 1 & 1 & 1 & 1 & 1 & 1 & 0 & 0 & 0 & 0 & 0 & 0 \\
\hline & Other & 0 & 0 & 0 & 0 & 0 & 0 & 0 & 0 & 0 & 0 & 0 & 0 & 0 & 0 & 0 & 0 & 0 & 0 & 0 & 0 & 0 & 0 & 0 & 0 \\
\hline Dual Zone Control Type Sched & All & 4 & 4 & 4 & 4 & 4 & 4 & 4 & 4 & 4 & 4 & 4 & 4 & 4 & 4 & 4 & 4 & 4 & 4 & 4 & 4 & 4 & 4 & 4 & 4 \\
\hline \multirow[t]{3}{*}{ HVACOperationSchd } & WD, Sun & 0 & 0 & 0 & 0 & 0 & 0 & 1 & 1 & 1 & 1 & 1 & 1 & 1 & 1 & 1 & 1 & 1 & 1 & 1 & 1 & 1 & 1 & 0 & 0 \\
\hline & Sat, WinterDesign & 0 & 0 & 0 & 0 & 0 & 0 & 1 & 1 & 1 & 1 & 1 & 1 & 1 & 1 & 1 & 1 & 1 & 1 & 0 & 0 & 0 & 0 & 0 & 0 \\
\hline & Other & 0 & 0 & 0 & 0 & 0 & 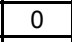 & 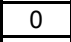 & 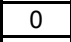 & 0 & 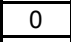 & 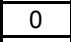 & 0 & 0 & 0 & 0 & 0 & 0 & 0 & 0 & 0 & 0 & 0 & 0 & 0 \\
\hline CW-Loop-Temp-Schedule & All & 6.7 & 6.7 & 6.7 & 6.7 & 6.7 & 6.7 & 6.7 & 6.7 & 6.7 & 6.7 & 6.7 & 6.7 & 6.7 & 6.7 & 6.7 & 6.7 & 6.7 & 6.7 & 6.7 & 6.7 & 6.7 & 6.7 & 6.7 & 6.7 \\
\hline HW-Loop-Temp-Schedule & All & 82.2 & 82.2 & 82.2 & 82.2 & 82.2 & 82.2 & 82.2 & 82.2 & 82.2 & 82.2 & 82.2 & 82.2 & 82.2 & 82.2 & 82.2 & 82.2 & 82.2 & 82.2 & 82.2 & 82.2 & 82.2 & 82.2 & 82.2 & 82.2 \\
\hline
\end{tabular}




\begin{tabular}{|c|c|c|c|c|c|c|c|c|c|c|c|c|c|c|c|c|c|c|c|c|c|c|c|c|c|}
\hline Schedule & Day of Week & 1 & 2 & 3 & 4 & 5 & 6 & 7 & 8 & 9 & 10 & 11 & 12 & 13 & 14 & 15 & 16 & 17 & 18 & 19 & 20 & 21 & 22 & 23 & 24 \\
\hline BLDG_SWH_SCH & WD, SummerDesign & 0.05 & 0.05 & 0.05 & 0.05 & 0.05 & 0.08 & 0.07 & 0.19 & 0.35 & 0.38 & 0.39 & 0.47 & 0.57 & 0.54 & 0.34 & 0.33 & 0.44 & 0.26 & 0.21 & 0.15 & 0.17 & 0.08 & 0.05 & 0.05 \\
\hline & Sat, WinterDesign & 0.05 & 0.05 & 0.05 & 0.05 & 0.05 & 0.08 & 0.07 & 0.11 & 0.15 & 0.21 & 0.19 & 0.23 & 0.2 & 0.19 & 0.15 & 0.13 & 0.14 & 0.07 & 0.07 & \begin{tabular}{|l|}
0.07 \\
\end{tabular} & \begin{tabular}{|l|}
0.07 \\
\end{tabular} & 0.09 & 0.05 & 0.05 \\
\hline & Other & 0.04 & 0.04 & 0.04 & 0.04 & 0.04 & 0.07 & 0.04 & 0.04 & 0.04 & 0.04 & 0.04 & 0.06 & 0.06 & 0.09 & 0.06 & 0.04 & 0.04 & 0.04 & 0.04 & 0.04 & 0.04 & 0.07 & 0.04 & 0.04 \\
\hline Water Equipment Latent fract sched & All & 0.05 & 0.05 & 0.05 & 0.05 & 0.05 & 0.05 & 0.05 & 0.05 & 0.05 & 0.05 & 0.05 & 0.05 & 0.05 & 0.05 & 0.05 & 0.05 & 0.05 & 0.05 & 0.05 & 0.05 & 0.05 & 0.05 & 0.05 & 0.05 \\
\hline Water Equipment Sensible fract sched & All & 0.2 & 0.2 & 0.2 & 0.2 & 0.2 & 0.2 & 0.2 & 0.2 & 0.2 & 0.2 & 0.2 & 0.2 & 0.2 & 0.2 & 0.2 & 0.2 & 0.2 & 0.2 & 0.2 & 0.2 & 0.2 & 0.2 & 0.2 & 0.2 \\
\hline $\begin{array}{l}\text { SWHSys } 1 \text { Water Heater Ambient } \\
\text { Temperature Schedule Name }\end{array}$ & All & 22 & 22 & 22 & 22 & 22 & 22 & 22 & 22 & 22 & 22 & 22 & 22 & 22 & 22 & 22 & 22 & 22 & 22 & 22 & 22 & 22 & 22 & 22 & 22 \\
\hline Water Equipment Temp Sched & All & 43.3 & 43.3 & 43.3 & 43.3 & 43.3 & 43.3 & 43.3 & 43.3 & 43.3 & 43.3 & 43.3 & 43.3 & 43.3 & 43.3 & 43.3 & 43.3 & 43.3 & 43.3 & 43.3 & 43.3 & 43.3 & 43.3 & 43.3 & 43.3 \\
\hline $\begin{array}{l}\text { Water Equipment Hot Supply Temp } \\
\text { Sched }\end{array}$ & All & 43.3 & 43.3 & 43.3 & 43.3 & 43.3 & 43.3 & 43.3 & 43.3 & 43.3 & 43.3 & 43.3 & 43.3 & 43.3 & 43.3 & 43.3 & 43.3 & 43.3 & 43.3 & 43.3 & 43.3 & 43.3 & 43.3 & 43.3 & 43.3 \\
\hline $\begin{array}{l}\text { SWHSys1 Water Heater Setpoint } \\
\text { Temperature Schedule Name }\end{array}$ & All & 60 & 60 & 60 & 60 & 60 & 60 & 60 & 60 & 60 & 60 & 60 & 60 & 60 & 60 & 60 & 60 & 60 & 60 & 60 & 60 & 60 & 60 & 60 & 60 \\
\hline SWHSys1-Loop-Temp-Schedule & All & 60 & 60 & 60 & 60 & 60 & 60 & 60 & 60 & 60 & 60 & 60 & 60 & 60 & 60 & 60 & 60 & 60 & 60 & 60 & 60 & 60 & 60 & 60 & 60 \\
\hline
\end{tabular}


Table B-5 Medium Office Hourly Operation Schedules

\begin{tabular}{|c|c|c|c|c|c|c|c|c|c|c|c|c|c|c|c|c|c|c|c|c|c|c|c|c|c|}
\hline Schedule & Day of Week & 1 & 2 & 3 & 4 & 5 & 6 & 7 & 8 & 9 & 10 & 11 & 12 & 13 & 14 & 15 & 16 & 17 & 18 & 19 & 20 & 21 & 22 & 23 & 24 \\
\hline ALWAYS_ON & All & $\overline{c 1}$ & 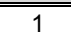 & $\overline{c 1}$ & $\overline{c 1}$ & $\overline{c 1}$ & 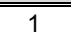 & $\overline{c 1}$ & $\overline{c 1}$ & 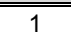 & $\bar{~} 1$ & $\overline{11}$ & $\overline{11}$ & $\overline{\overline{1}}$ & $\bar{~} 1$ & $\overline{11}$ & $\overline{\overline{1}}$ & $\bar{~} 1$ & $\overline{c 1}$ & 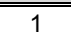 & 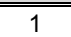 & $\overline{\overline{1}}$ & $\bar{~} 1$ & $\overline{c 1}$ & $\overline{11}$ \\
\hline ACTIVITY_SCH & All & 120 & 120 & 120 & 120 & 120 & 120 & 120 & 120 & 120 & 120 & 120 & 120 & 120 & 120 & 120 & 120 & 120 & 120 & 120 & 120 & 120 & 120 & 120 & 120 \\
\hline AIR_VELO_SCH & All & 0.2 & 0.2 & 0.2 & 0.2 & 0.2 & 0.2 & 0.2 & 0.2 & 0.2 & 0.2 & 0.2 & 0.2 & 0.2 & 0.2 & 0.2 & \begin{tabular}{|l|}
0.2 \\
\end{tabular} & 0.2 & 0.2 & 0.2 & 0.2 & 0.2 & 0.2 & 0.2 & 0.2 \\
\hline \multirow[t]{3}{*}{ BLDG_ELEVATORS } & WD, SummerDesign & 0 & 0 & 0 & 0 & 0 & 0 & 0 & 0.35 & 0.69 & 0.43 & 0.37 & 0.43 & 0.58 & 0.48 & 0.37 & \begin{tabular}{|l|l|}
0.37 \\
\end{tabular} & 0.46 & 0.62 & 0.12 & 0.04 & 0.04 & 0 & 0 & 0 \\
\hline & Sat, WinterDesign & 0 & 0 & 0 & 0 & 0 & 0 & 0 & 0.16 & 0.14 & 0.21 & 0.18 & 0.25 & 0.21 & 0.13 & 0.08 & \begin{tabular}{|l|l|}
0.04 \\
\end{tabular} & 0.05 & 0.06 & 0 & 0 & 0 & 0 & 0 & 0 \\
\hline & Sun, Hol, Other & 0 & 0 & 0 & 0 & 0 & 0 & 0 & 0 & 0 & 0 & 0 & 0 & 0 & 0 & 0 & 0 & 0 & 0 & 0 & 0 & 0 & 0 & 0 & 0 \\
\hline \multirow[t]{4}{*}{ BLDG_OCC_SCH } & \begin{tabular}{|l|} 
SummerDesign \\
\end{tabular} & 0 & 0 & 0 & 0 & 0 & 0 & 1 & 1 & 1 & 1 & 1 & 1 & 1 & 1 & 1 & 1 & 1 & 1 & 1 & 1 & 1 & 1 & 0.05 & 0.05 \\
\hline & WD & 0 & 0 & 0 & 0 & 0 & 0 & 0.1 & 0.2 & 0.95 & 0.95 & 0.95 & 0.95 & 0.5 & 0.95 & 0.95 & \begin{tabular}{|l|}
0.95 \\
\end{tabular} & 0.95 & 0.7 & 0.4 & 0.4 & 0.1 & 0.1 & 0.05 & 0.05 \\
\hline & Sat & 0 & 0 & 0 & 0 & 0 & 0 & 0.1 & 0.1 & 0.5 & 0.5 & 0.5 & 0.5 & 0.5 & 0.5 & 0.1 & \begin{tabular}{|l|}
0.1 \\
\end{tabular} & 0.1 & 0 & 0 & 0 & 0 & 0 & 0 & 0 \\
\hline & Other & 0 & 0 & 0 & 0 & 0 & 0 & 0 & 0 & 0 & 0 & 0 & 0 & 0 & 0 & 0 & 0 & 0 & 0 & 0 & 0 & 0 & 0 & 0 & 0 \\
\hline \multirow[t]{5}{*}{ BLDG_LIGHT_SCH } & WD & 0.05 & 0.05 & 0.05 & 0.05 & 0.05 & 0.1 & 0.1 & 0.3 & 0.9 & 0.9 & 0.9 & 0.9 & 0.9 & 0.9 & 0.9 & \begin{tabular}{|l|}
0.9 \\
\end{tabular} & 0.9 & 0.7 & 0.5 & 0.5 & 0.3 & 0.3 & 0.1 & 0.05 \\
\hline & Sat & 0.05 & 0.05 & 0.05 & 0.05 & 0.05 & 0.05 & 0.1 & 0.1 & 0.5 & 0.5 & 0.5 & 0.5 & 0.5 & 0.5 & 0.15 & \begin{tabular}{|l|}
0.15 \\
\end{tabular} & 0.15 & 0.05 & 0.05 & 0.05 & 0.05 & 0.05 & 0.05 & 0.05 \\
\hline & SummerDesign & 1 & 1 & 1 & 1 & 1 & 1 & 1 & 1 & 1 & 1 & 1 & 1 & 1 & 1 & 1 & 1 & 1 & 1 & 1 & 1 & 1 & 1 & 1 & 1 \\
\hline & WinterDesign & 0 & 0 & 0 & 0 & 0 & 0 & 0 & 0 & 0 & 0 & 0 & 0 & 0 & 0 & 0 & 0 & 0 & 0 & 0 & 0 & 0 & 0 & 0 & 0 \\
\hline & Other & 0.05 & 0.05 & 0.05 & 0.05 & 0.05 & 0.05 & 0.05 & 0.05 & 0.05 & 0.05 & 0.05 & 0.05 & 0.05 & 0.05 & 0.05 & \begin{tabular}{|l|}
0.05 \\
\end{tabular} & 0.05 & 0.05 & 0.05 & 0.05 & 0.05 & 0.05 & 0.05 & 0.05 \\
\hline \multirow[t]{5}{*}{ BLDG_EQUIP_SCH } & WD & 0.4 & 0.4 & 0.4 & 0.4 & 0.4 & 0.4 & 0.4 & 0.4 & 0.9 & 0.9 & 0.9 & 0.9 & 0.8 & 0.9 & 0.9 & 0.9 & 0.9 & 0.8 & 0.6 & 0.6 & 0.5 & 0.5 & 0.4 & 0.4 \\
\hline & Sat & 0.3 & 0.3 & 0.3 & 0.3 & 0.3 & 0.3 & 0.4 & 0.4 & 0.5 & 0.5 & 0.5 & 0.5 & 0.5 & 0.5 & 0.35 & 0.35 & 0.35 & 0.3 & 0.3 & 0.3 & 0.3 & 0.3 & 0.3 & 0.3 \\
\hline & SummerDesign & 1 & 1 & 1 & 1 & 1 & 1 & 1 & 1 & 1 & 1 & 1 & 1 & 1 & 1 & 1 & 1 & 1 & 1 & 1 & 1 & 1 & 1 & 1 & 1 \\
\hline & \begin{tabular}{|l|} 
WinterDesign \\
\end{tabular} & 0 & 0 & 0 & 0 & 0 & 0 & 0 & 0 & 0 & 0 & 0 & 0 & 0 & 0 & 0 & 0 & 0 & 0 & 0 & 0 & 0 & 0 & 0 & 0 \\
\hline & Other & 0.3 & 0.3 & 0.3 & 0.3 & 0.3 & 0.3 & 0.3 & 0.3 & 0.3 & 0.3 & 0.3 & 0.3 & 0.3 & 0.3 & 0.3 & 0.3 & 0.3 & 0.3 & 0.3 & 0.3 & 0.3 & 0.3 & 0.3 & 0.3 \\
\hline \multirow[t]{3}{*}{ CLOTHING_SCH } & All & 1 & 1 & 1 & 1 & 1 & 1 & 1 & 1 & 1 & 1 & 1 & 1 & 1 & 1 & 1 & 1 & 1 & 1 & 1 & 1 & 1 & 1 & 1 & 1 \\
\hline & All & 0.5 & 0.5 & 0.5 & 0.5 & 0.5 & 0.5 & 0.5 & 0.5 & 0.5 & 0.5 & 0.5 & 0.5 & 0.5 & 0.5 & 0.5 & \begin{tabular}{|l|}
0.5 \\
\end{tabular} & 0.5 & 0.5 & 0.5 & 0.5 & 0.5 & 0.5 & 0.5 & 0.5 \\
\hline & All & 1 & 1 & 1 & 1 & 1 & 1 & 1 & 1 & 1 & 1 & 1 & 1 & 1 & 1 & 1 & 1 & 1 & 1 & 1 & 1 & 1 & 1 & 1 & 1 \\
\hline \multirow[t]{3}{*}{ INFIL_QUARTER_ON_SCH } & WD, SummerDesign & 1 & 1 & 1 & 1 & 1 & 1 & 0.25 & 0.25 & 0.25 & 0.25 & 0.25 & 0.25 & 0.25 & 0.25 & 0.25 & \begin{tabular}{|l|}
0.25 \\
\end{tabular} & 0.25 & 0.25 & 0.25 & 0.25 & 0.25 & 0.25 & 1 & 1 \\
\hline & Sat, WinterDesign & 1 & 1 & 1 & 1 & 1 & 1 & 0.25 & 0.25 & 0.25 & 0.25 & 0.25 & 0.25 & 0.25 & 0.25 & 0.25 & 0.25 & 0.25 & 0.25 & 1 & 1 & 1 & 1 & 1 & 1 \\
\hline & Sun, Hol, Other & 1 & 1 & 1 & 1 & 1 & 1 & 1 & 1 & 1 & 1 & 1 & 1 & 1 & 1 & 1 & 1 & 1 & 1 & 1 & 1 & 1 & 1 & 1 & 1 \\
\hline WORK_EFF_SCH & All & 0 & 0 & 0 & 0 & 0 & 0 & 0 & 0 & 0 & 0 & 0 & 0 & 0 & 0 & 0 & 0 & 0 & 0 & 0 & 0 & 0 & 0 & 0 & 0 \\
\hline $\begin{array}{l}\text { Dual Zone Control Type } \\
\text { Sched }\end{array}$ & All & 4 & 4 & 4 & 4 & 4 & 4 & 4 & 4 & 4 & 4 & 4 & 4 & 4 & 4 & 4 & 4 & 4 & 4 & 4 & 4 & 4 & 4 & 4 & 4 \\
\hline \multirow[t]{4}{*}{ CLGSETP_SCH } & WD, SummerDesign & 26.7 & 26.7 & 26.7 & 26.7 & 26.7 & 26.7 & 24 & 24 & 24 & 24 & 24 & 24 & 24 & 24 & 24 & 24 & 24 & 24 & 24 & 24 & 24 & 24 & 26.7 & 26.7 \\
\hline & Sat & 26.7 & 26.7 & 26.7 & 26.7 & 26.7 & 26.7 & 24 & 24 & 24 & 24 & 24 & 24 & 24 & 24 & 24 & 24 & 24 & 24 & 26.7 & 26.7 & 26.7 & 26.7 & 26.7 & 26.7 \\
\hline & WinterDesign & 26.7 & 26.7 & 26.7 & 26.7 & 26.7 & 26.7 & 26.7 & 26.7 & 26.7 & 26.7 & 26.7 & 26.7 & 26.7 & 26.7 & 26.7 & \begin{tabular}{|l|}
26.7 \\
\end{tabular} & 26.7 & 26.7 & 26.7 & 26.7 & 26.7 & 26.7 & 26.7 & 26.7 \\
\hline & Other & 26.7 & 26.7 & 26.7 & 26.7 & 26.7 & 26.7 & 26.7 & 26.7 & 26.7 & 26.7 & 26.7 & 26.7 & 26.7 & 26.7 & 26.7 & \begin{tabular}{|l|l|}
26.7 \\
\end{tabular} & 26.7 & 26.7 & 26.7 & 26.7 & 26.7 & 26.7 & 26.7 & 26.7 \\
\hline \multirow[t]{5}{*}{ HTGSETP_SCH } & WD & 15.6 & 15.6 & 15.6 & 15.6 & 15.6 & 15.6 & 21 & 21 & 21 & 21 & 21 & 21 & 21 & 21 & 21 & 21 & 21 & 21 & 21 & 21 & 21 & 21 & 15.6 & 15.6 \\
\hline & SummerDesign & 15.6 & 15.6 & 15.6 & 15.6 & 15.6 & 15.6 & 15.6 & 15.6 & 15.6 & 15.6 & 15.6 & 15.6 & 15.6 & 15.6 & 15.6 & 15.6 & 15.6 & 15.6 & 15.6 & 15.6 & 15.6 & 15.6 & 15.6 & 15.6 \\
\hline & Sat & 15.6 & 15.6 & 15.6 & 15.6 & 15.6 & 15.6 & 21 & 21 & 21 & 21 & 21 & 21 & 21 & 21 & 21 & 21 & 21 & 21 & 15.6 & 15.6 & 15.6 & 15.6 & 15.6 & 15.6 \\
\hline & WinterDesign & 21 & 21 & 21 & 21 & 21 & 21 & 21 & 21 & 21 & 21 & 21 & 21 & 21 & 21 & 21 & 21 & 21 & 21 & 21 & 21 & 21 & 21 & 21 & 21 \\
\hline & Other & 15.6 & 15.6 & 15.6 & 15.6 & 15.6 & 15.6 & 15.6 & 15.6 & 15.6 & 15.6 & 15.6 & 15.6 & 15.6 & 15.6 & 15.6 & 15.6 & 15.6 & 15.6 & 15.6 & 15.6 & 15.6 & 15.6 & 15.6 & 15.6 \\
\hline \multirow[t]{3}{*}{ HVACOperationSchd } & WD, SummerDesign & 0 & 0 & 0 & 0 & 0 & 0 & 1 & 1 & 1 & 1 & 1 & 1 & 1 & 1 & 1 & 1 & 1 & 1 & 1 & 1 & 1 & 1 & 0 & 0 \\
\hline & Sat, WinterDesign & 0 & 0 & 0 & 0 & 0 & 0 & 1 & 1 & 1 & 1 & 1 & 1 & 1 & 1 & 1 & 1 & 1 & 1 & 0 & 0 & 0 & 0 & 0 & 0 \\
\hline & Other & 0 & 0 & 0 & 0 & 0 & 0 & 0 & 0 & 0 & 0 & 0 & 0 & 0 & 0 & 0 & 0 & 0 & 0 & 0 & 0 & 0 & 0 & 0 & 0 \\
\hline \multirow[t]{2}{*}{$\begin{array}{l}\text { MinOA_MotorizedDamper_S } \\
\text { ched }\end{array}$} & WD, SummerDesign & 0 & 0 & 0 & 0 & 0 & 0 & 0 & 1 & 1 & 1 & 1 & 1 & 1 & 1 & 1 & 1 & 1 & 1 & 1 & 1 & 1 & 1 & 0 & 0 \\
\hline & Sat, WinterDesign & 0 & 0 & 0 & 0 & 0 & 0 & 0 & 1 & 1 & 1 & 1 & 1 & 1 & 1 & 1 & 1 & 1 & 1 & 0 & 0 & 0 & 0 & 0 & 0 \\
\hline
\end{tabular}




\begin{tabular}{|c|c|c|c|c|c|c|c|c|c|c|c|c|c|c|c|c|c|c|c|c|c|c|c|c|c|}
\hline Schedule & Day of Week & 1 & 2 & 3 & 4 & 5 & 6 & 7 & 8 & 9 & 10 & 11 & 12 & 13 & 14 & 15 & 16 & 17 & 18 & 19 & 20 & 21 & 22 & 23 & 24 \\
\hline & Other & 0 & 0 & 0 & 0 & 0 & 0 & 0 & 0 & 0 & 0 & 0 & 0 & 0 & 0 & 0 & 0 & 0 & 0 & 0 & 0 & 0 & 0 & 0 & 0 \\
\hline $\begin{array}{l}\text { Seasonal-Reset-Supply-Air- } \\
\text { Temp-Sch }\end{array}$ & All & 12.8 & 12.8 & 12.8 & 12.8 & 12.8 & 12.8 & 12.8 & 12.8 & 12.8 & 12.8 & 12.8 & 12.8 & 12.8 & 12.8 & 12.8 & 12.8 & 12.8 & 12.8 & 12.8 & 12.8 & 12.8 & 12.8 & 12.8 & 12.8 \\
\hline \multirow[t]{3}{*}{ BLDG_SWH_SCH } & WD, SummerDesign & 0.05 & 0.05 & 0.05 & 0.05 & 0.05 & 0.08 & 0.07 & 0.19 & 0.35 & 0.38 & 0.39 & 0.47 & 0.57 & 0.54 & 0.34 & 0.33 & 0.44 & 0.26 & 0.21 & 0.15 & 0.17 & 0.08 & 0.05 & 0.05 \\
\hline & Sat, WinterDesign & 0.05 & 0.05 & 0.05 & 0.05 & 0.05 & 0.08 & 0.07 & 0.11 & 0.15 & 0.21 & 0.19 & 0.23 & 0.2 & 0.19 & 0.15 & 0.13 & 0.14 & 0.07 & 0.07 & 0.07 & 0.07 & 0.09 & 0.05 & 0.05 \\
\hline & Sun, Hol, Other & 0.04 & 0.04 & 0.04 & 0.04 & 0.04 & 0.07 & 0.04 & 0.04 & 0.04 & 0.04 & 0.04 & 0.06 & 0.06 & 0.09 & 0.06 & 0.04 & 0.04 & 0.04 & 0.04 & 0.04 & 0.04 & 0.07 & 0.04 & 0.04 \\
\hline $\begin{array}{l}\text { Water Equipment Latent } \\
\text { fract sched }\end{array}$ & All & 0.05 & 0.05 & 0.05 & 0.05 & 0.05 & 0.05 & 0.05 & 0.05 & 0.05 & 0.05 & 0.05 & 0.05 & 0.05 & 0.05 & 0.05 & 0.05 & 0.05 & 0.05 & 0.05 & 0.05 & 0.05 & 0.05 & 0.05 & 0.05 \\
\hline $\begin{array}{l}\text { Water Equipment Sensible } \\
\text { fract sched }\end{array}$ & All & 0.2 & 0.2 & 0.2 & 0.2 & 0.2 & 0.2 & 0.2 & 0.2 & 0.2 & 0.2 & 0.2 & 0.2 & 0.2 & 0.2 & 0.2 & 0.2 & 0.2 & 0.2 & 0.2 & 0.2 & 0.2 & 0.2 & 0.2 & 0.2 \\
\hline $\begin{array}{l}\text { Water Equipment Hot Supply } \\
\text { Temp Sched }\end{array}$ & All & 43.3 & 43.3 & 43.3 & 43.3 & 43.3 & 43.3 & 43.3 & 43.3 & 43.3 & 43.3 & 43.3 & 43.3 & 43.3 & 43.3 & 43.3 & 43.3 & 43.3 & 43.3 & 43.3 & 43.3 & 43.3 & 43.3 & 43.3 & 43.3 \\
\hline $\begin{array}{l}\text { Water Equipment Temp } \\
\text { Sched }\end{array}$ & All & 43.3 & 43.3 & 43.3 & 43.3 & 43.3 & 43.3 & 43.3 & 43.3 & 43.3 & 43.3 & 43.3 & 43.3 & 43.3 & 43.3 & 43.3 & 43.3 & 43.3 & 43.3 & 43.3 & 43.3 & 43.3 & 43.3 & 43.3 & 43.3 \\
\hline $\begin{array}{l}\text { SWHSys1 Water Heater } \\
\text { Ambient Temperature } \\
\text { Schedule Name }\end{array}$ & All & 22 & 22 & 22 & 22 & 22 & 22 & 22 & 22 & 22 & 22 & 22 & 22 & 22 & 22 & 22 & 22 & 22 & 22 & 22 & 22 & 22 & 22 & 22 & 22 \\
\hline $\begin{array}{l}\text { SWHSys } 1 \text { Water Heater } \\
\text { Setpoint Temperature } \\
\text { Schedule Name }\end{array}$ & All & 60 & 60 & 60 & 60 & 60 & 60 & 60 & 60 & 60 & 60 & 60 & 60 & 60 & 60 & 60 & 60 & 60 & 60 & 60 & 60 & 60 & 60 & 60 & 60 \\
\hline $\begin{array}{l}\text { SWHSys1-Loop-Temp- } \\
\text { Schedule }\end{array}$ & All & 60 & 60 & 60 & 60 & 60 & 60 & 60 & 60 & 60 & 60 & 60 & 60 & 60 & 60 & 60 & 60 & 60 & 60 & 60 & 60 & 60 & 60 & 60 & 60 \\
\hline ALWAYS_ON & All & 1 & 1 & 1 & 1 & 1 & 1 & 1 & 1 & 1 & 1 & 1 & 1 & 1 & 1 & 1 & 1 & 1 & 1 & 1 & 1 & 1 & 1 & 1 & 1 \\
\hline ACTIVITY_SCH & All & 120 & 120 & 120 & 120 & 120 & 120 & 120 & 120 & 120 & 120 & 120 & 120 & 120 & 120 & 120 & 120 & 120 & 120 & 120 & 120 & 120 & 120 & 120 & 120 \\
\hline AIR_VELO_SCH & All & 0.2 & 0.2 & 0.2 & 0.2 & 0.2 & 0.2 & 0.2 & 0.2 & 0.2 & 0.2 & 0.2 & 0.2 & 0.2 & 0.2 & 0.2 & 0.2 & 0.2 & 0.2 & 0.2 & 0.2 & 0.2 & 0.2 & 0.2 & 0.2 \\
\hline \multirow[t]{3}{*}{ BLDG_ELEVATORS } & WD, SummerDesign & 0 & 0 & 0 & 0 & 0 & 0 & 0 & 0.35 & 0.69 & 0.43 & 0.37 & 0.43 & 0.58 & 0.48 & 0.37 & 0.37 & 0.46 & 0.62 & 0.12 & 0.04 & 0.04 & 0 & 0 & 0 \\
\hline & Sat, WinterDesign & 0 & 0 & 0 & 0 & 0 & 0 & 0 & 0.16 & 0.14 & 0.21 & 0.18 & 0.25 & 0.21 & 0.13 & 0.08 & 0.04 & 0.05 & 0.06 & 0 & 0 & 0 & 0 & 0 & 0 \\
\hline & Sun, $\mathrm{Hol}$, Other & 0 & 0 & 0 & 0 & 0 & 0 & 0 & 0 & 0 & 0 & 0 & 0 & 0 & 0 & 0 & 0 & 0 & 0 & 0 & 0 & 0 & 0 & 0 & 0 \\
\hline \multirow[t]{4}{*}{ BLDG_OCC_SCH } & SummerDesign & 0 & 0 & 0 & 0 & 0 & 0 & 1 & 1 & 1 & 1 & 1 & 1 & 1 & 1 & 1 & 1 & 1 & 1 & 1 & 1 & 1 & 1 & 0.05 & 0.05 \\
\hline & WD & 0 & 0 & 0 & 0 & 0 & 0 & 0.1 & 0.2 & 0.95 & 0.95 & 0.95 & 0.95 & 0.5 & 0.95 & 0.95 & 0.95 & 0.95 & 0.7 & 0.4 & 0.4 & 0.1 & 0.1 & 0.05 & 0.05 \\
\hline & Sat & 0 & 0 & 0 & 0 & 0 & 0 & 0.1 & 0.1 & 0.5 & 0.5 & 0.5 & 0.5 & 0.5 & 0.5 & 0.1 & 0.1 & 0.1 & 0 & 0 & 0 & 0 & 0 & 0 & 0 \\
\hline & Other & 0 & 0 & 0 & 0 & 0 & 0 & 0 & 0 & 0 & 0 & 0 & 0 & 0 & 0 & 0 & 0 & 0 & 0 & 0 & 0 & 0 & 0 & 0 & 0 \\
\hline \multirow[t]{5}{*}{ BLDG_LIGHT_SCH } & WD & 0.05 & 0.05 & 0.05 & 0.05 & 0.05 & 0.1 & 0.1 & 0.3 & 0.9 & 0.9 & 0.9 & 0.9 & 0.9 & 0.9 & 0.9 & 0.9 & 0.9 & 0.7 & 0.5 & 0.5 & 0.3 & 0.3 & 0.1 & 0.05 \\
\hline & Sat & 0.05 & 0.05 & 0.05 & 0.05 & 0.05 & 0.05 & 0.1 & 0.1 & 0.5 & 0.5 & 0.5 & 0.5 & 0.5 & 0.5 & 0.15 & 0.15 & 0.15 & 0.05 & 0.05 & 0.05 & 0.05 & 0.05 & 0.05 & 0.05 \\
\hline & SummerDesign & 1 & 1 & 1 & 1 & 1 & 1 & 1 & 1 & 1 & 1 & 1 & 1 & 1 & 1 & 1 & 1 & 1 & 1 & 1 & 1 & 1 & 1 & 1 & 1 \\
\hline & WinterDesign & 0 & 0 & 0 & 0 & 0 & 0 & 0 & 0 & 0 & 0 & 0 & 0 & 0 & 0 & 0 & 0 & 0 & 0 & 0 & 0 & 0 & 0 & 0 & 0 \\
\hline & Other & 0.05 & 0.05 & 0.05 & 0.05 & 0.05 & 0.05 & 0.05 & 0.05 & 0.05 & 0.05 & 0.05 & 0.05 & 0.05 & 0.05 & 0.05 & 0.05 & 0.05 & 0.05 & 0.05 & 0.05 & 0.05 & 0.05 & 0.05 & 0.05 \\
\hline \multirow[t]{5}{*}{ BLDG_EQUIP_SCH } & WD & 0.4 & 0.4 & 0.4 & 0.4 & 0.4 & 0.4 & 0.4 & 0.4 & 0.9 & 0.9 & 0.9 & 0.9 & 0.8 & 0.9 & 0.9 & 0.9 & 0.9 & 0.8 & 0.6 & 0.6 & 0.5 & 0.5 & 0.4 & 0.4 \\
\hline & Sat & 0.3 & 0.3 & 0.3 & 0.3 & 0.3 & 0.3 & 0.4 & 0.4 & 0.5 & 0.5 & 0.5 & 0.5 & 0.5 & 0.5 & 0.35 & 0.35 & 0.35 & 0.3 & 0.3 & 0.3 & 0.3 & 0.3 & 0.3 & 0.3 \\
\hline & SummerDesign & 1 & 1 & 1 & 1 & 1 & 1 & 1 & 1 & 1 & 1 & 1 & 1 & 1 & 1 & 1 & 1 & 1 & 1 & 1 & 1 & 1 & 1 & 1 & 1 \\
\hline & WinterDesign & 0 & 0 & 0 & 0 & 0 & 0 & 0 & 0 & 0 & 0 & 0 & 0 & 0 & 0 & 0 & 0 & 0 & 0 & 0 & 0 & 0 & 0 & 0 & 0 \\
\hline & Other & 0.3 & 0.3 & 0.3 & 0.3 & 0.3 & 0.3 & 0.3 & 0.3 & 0.3 & 0.3 & 0.3 & 0.3 & 0.3 & 0.3 & 0.3 & 0.3 & 0.3 & 0.3 & 0.3 & 0.3 & 0.3 & 0.3 & 0.3 & 0.3 \\
\hline \multirow[t]{3}{*}{ CLOTHING_SCH } & All & 1 & 1 & 1 & 1 & 1 & 1 & 1 & 1 & 1 & 1 & 1 & 1 & 1 & 1 & 1 & 1 & 1 & 1 & 1 & 1 & 1 & 1 & 1 & 1 \\
\hline & All & 0.5 & 0.5 & 0.5 & 0.5 & 0.5 & 0.5 & 0.5 & 0.5 & 0.5 & 0.5 & 0.5 & 0.5 & 0.5 & 0.5 & 0.5 & 0.5 & 0.5 & 0.5 & 0.5 & 0.5 & 0.5 & 0.5 & 0.5 & 0.5 \\
\hline & All & 1 & 1 & 1 & 1 & 1 & 1 & 1 & 1 & 1 & 1 & 1 & 1 & 1 & 1 & 1 & 1 & 1 & 1 & 1 & 1 & 1 & 1 & 1 & 1 \\
\hline \multirow[t]{3}{*}{ INFIL_QUARTER_ON_SCH } & WD, SummerDesign & 1 & 1 & 1 & 1 & 1 & 1 & 0.25 & 0.25 & 0.25 & 0.25 & 0.25 & 0.25 & 0.25 & 0.25 & 0.25 & 0.25 & 0.25 & 0.25 & 0.25 & 0.25 & 0.25 & 0.25 & 1 & 1 \\
\hline & Sat, WinterDesign & 1 & 1 & 1 & 1 & 1 & 1 & 0.25 & 0.25 & 0.25 & 0.25 & 0.25 & 0.25 & 0.25 & 0.25 & 0.25 & 0.25 & 0.25 & 0.25 & 1 & 1 & 1 & 1 & 1 & 1 \\
\hline & Sun, Hol, Other & 1 & 1 & 1 & 1 & 1 & 1 & 1 & 1 & 1 & 1 & 1 & 1 & 1 & 1 & 1 & 1 & 1 & 1 & 1 & 1 & 1 & 1 & 1 & 1 \\
\hline
\end{tabular}




\begin{tabular}{|c|c|c|c|c|c|c|c|c|c|c|c|c|c|c|c|c|c|c|c|c|c|c|c|c|c|}
\hline Schedule & Day of Week & 1 & 2 & 3 & 4 & 5 & 6 & 7 & 8 & 9 & 10 & 11 & 12 & 13 & 14 & 15 & 16 & 17 & 18 & 19 & 20 & 21 & 22 & 23 & 24 \\
\hline WORK_EFF_SCH & All & 0 & 0 & 0 & 0 & 0 & 0 & 0 & 0 & 0 & 0 & 0 & 0 & 0 & 0 & 0 & 0 & 0 & 0 & 0 & 0 & 0 & 0 & 0 & 0 \\
\hline $\begin{array}{l}\text { Dual Zone Control Type } \\
\text { Sched }\end{array}$ & All & 4 & 4 & 4 & 4 & 4 & 4 & 4 & 4 & 4 & 4 & 4 & 4 & 4 & 4 & 4 & 4 & 4 & 4 & 4 & 4 & 4 & 4 & 4 & 4 \\
\hline CLGSETP_SCH & WD, SummerDesign & 26.7 & 26.7 & 26.7 & 26.7 & 26.7 & 26.7 & 24 & 24 & 24 & 24 & 24 & 24 & 24 & 24 & 24 & 24 & 24 & 24 & 24 & 24 & 24 & 24 & 26.7 & 26.7 \\
\hline & Sat & 26.7 & 26.7 & 26.7 & 26.7 & 26.7 & 26.7 & 24 & 24 & 24 & 24 & 24 & 24 & 24 & 24 & 24 & 24 & 24 & 24 & 26.7 & 26.7 & \begin{tabular}{|l|}
26.7 \\
\end{tabular} & \begin{tabular}{|l|}
26.7 \\
\end{tabular} & 26.7 & 26.7 \\
\hline & WinterDesign & 26.7 & 26.7 & 26.7 & 26.7 & 26.7 & 26.7 & 26.7 & 26.7 & 26.7 & 26.7 & 26.7 & 26.7 & 26.7 & 26.7 & 26.7 & 26.7 & 26.7 & 26.7 & 26.7 & 26.7 & 26.7 & 26.7 & 26.7 & 26.7 \\
\hline & Other & 26.7 & 26.7 & 26.7 & 26.7 & 26.7 & 26.7 & \begin{tabular}{|l}
26.7 \\
\end{tabular} & 26.7 & 26.7 & 26.7 & 26.7 & 26.7 & 26.7 & 26.7 & 26.7 & 26.7 & 26.7 & 26.7 & 26.7 & 26.7 & \begin{tabular}{|l}
26.7 \\
\end{tabular} & \begin{tabular}{|l}
26.7 \\
\end{tabular} & 26.7 & 26.7 \\
\hline
\end{tabular}


Table B-6 Midrise Apartment Hourly Operation Schedules

\begin{tabular}{|c|c|c|c|c|c|c|c|c|c|c|c|c|c|c|c|c|c|c|c|c|c|c|c|c|c|}
\hline Schedule & Day of Week & 1 & 2 & 3 & 4 & 5 & 6 & 7 & 8 & 9 & 10 & 11 & 12 & 13 & 14 & 15 & 16 & 17 & 18 & 19 & 20 & 21 & 22 & 23 & 24 \\
\hline ALWAYS_ON & All & 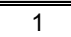 & 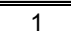 & $\overline{c 1}$ & 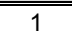 & $\bar{~} 1$ & 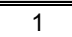 & 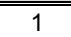 & $\overline{11}$ & 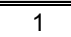 & 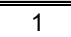 & 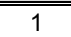 & $\bar{~} 1$ & 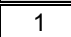 & 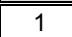 & $\overline{11}$ & 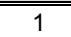 & 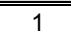 & 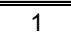 & 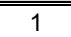 & 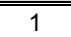 & 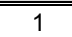 & $\overline{11}$ & $\overline{11}$ & 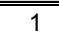 \\
\hline BLDG_ELEVATORS & All & 0.05 & 0.05 & 0.05 & 0.05 & 0.1 & 0.2 & 0.4 & 0.5 & 0.5 & 0.35 & 0.15 & 0.15 & 0.15 & 0.15 & 0.15 & 0.15 & 0.35 & 0.5 & 0.5 & 0.4 & 0.4 & 0.3 & 0.2 & 0.1 \\
\hline INFIL_SCH & All & 1 & 1 & 1 & 1 & 1 & 1 & 1 & 1 & 1 & 1 & 1 & 1 & 1 & 1 & 1 & 1 & 1 & 1 & 1 & 1 & 1 & 1 & 1 & 1 \\
\hline \multirow[t]{2}{*}{ OFFICE_INFIL_SCH } & WD & 1 & 1 & 1 & 1 & 1 & 1 & 1 & 1 & 0.25 & 0.25 & 0.25 & 0.25 & 0.25 & 0.25 & 0.25 & 0.25 & 0.25 & 1 & 1 & 1 & 1 & 1 & 1 & 1 \\
\hline & Other & 1 & 1 & 1 & 1 & 1 & 1 & 1 & 1 & 1 & 1 & 1 & 1 & 1 & 1 & 1 & 1 & 1 & 1 & 1 & 1 & 1 & 1 & 1 & 1 \\
\hline APT_OCC_SCH & All & 1 & 1 & 1 & 1 & 1 & 1 & 1 & 0.85 & 0.39 & 0.25 & 0.25 & 0.25 & 0.25 & 0.25 & 0.25 & 0.25 & 0.3 & 0.52 & 0.87 & 0.87 & 0.87 & 1 & 1 & 1 \\
\hline \multirow[t]{2}{*}{ OFF_OCC_SCH } & $\begin{array}{l}\text { WD, SummerDesign, } \\
\text { WinterDesign }\end{array}$ & 0 & 0 & 0 & 0 & 0 & 0 & 0 & 0 & 1 & 1 & 1 & 1 & 0.5 & 1 & 1 & 1 & 1 & 0 & 0 & 0 & 0 & 0 & 0 & 0 \\
\hline & Other & 0 & 0 & 0 & 0 & 0 & 0 & 0 & 0 & 0 & 0 & 0 & 0 & 0 & 0 & 0 & 0 & 0 & 0 & 0 & 0 & 0 & 0 & 0 & 0 \\
\hline APT_LIGHT_SCH & All & \begin{tabular}{|l|}
0.07 \\
\end{tabular} & 0.07 & \begin{tabular}{|l|l|}
0.07 \\
\end{tabular} & 0.07 & 0.19 & 0.39 & 0.44 & 0.39 & 0.17 & 0.12 & 0.12 & 0.12 & 0.12 & 0.12 & 0.12 & 0.21 & 0.44 & 0.62 & 0.83 & 0.99 & 1 & 0.69 & 0.38 & 0.16 \\
\hline \multirow[t]{2}{*}{ OFF_LIGHT_SCH } & WD, SummerDesign & \begin{tabular}{|l|}
0.18 \\
\end{tabular} & 0.18 & 0.18 & 0.18 & 0.18 & 0.18 & 0.18 & 0.18 & 0.9 & 0.9 & 0.9 & 0.9 & 0.8 & 0.9 & 0.9 & 0.9 & 0.9 & 0.18 & 0.18 & 0.18 & 0.18 & 0.18 & 0.18 & 0.18 \\
\hline & Other & \begin{tabular}{|l|}
0.18 \\
\end{tabular} & 0.18 & 0.18 & 0.18 & 0.18 & 0.18 & 0.18 & 0.18 & 0.18 & 0.18 & 0.18 & 0.18 & \begin{tabular}{|l|}
0.18 \\
\end{tabular} & \begin{tabular}{|l|}
0.18 \\
\end{tabular} & \begin{tabular}{|l|}
0.18 \\
\end{tabular} & \begin{tabular}{|l|}
0.18 \\
\end{tabular} & 0.18 & 0.18 & 0.18 & 0.18 & 0.18 & 0.18 & 0.18 & 0.18 \\
\hline COR_LIGHT_SCH & All & 1 & 1 & 1 & 1 & 1 & 1 & 1 & 1 & 1 & 1 & 1 & 1 & 1 & 1 & 1 & 1 & 1 & 1 & 1 & 1 & 1 & 1 & 1 & 1 \\
\hline APT_EQP_SCH & All & 0.45 & 0.41 & 0.39 & 0.38 & 0.38 & 0.43 & 0.54 & 0.65 & 0.66 & 0.67 & 0.69 & 0.7 & 0.69 & 0.66 & 0.65 & \begin{tabular}{|l|}
0.68 \\
\end{tabular} & 0.8 & 1 & 1 & 0.93 & 0.89 & 0.85 & 0.71 & 0.58 \\
\hline \multirow[t]{2}{*}{ OFF_EQP_SCH } & WD, SummerDesign & 0.33 & 0.33 & 0.33 & 0.33 & 0.33 & 0.33 & 0.33 & 0.5 & 1 & 1 & 1 & 1 & 0.94 & 1 & 1 & 1 & 1 & 0.5 & 0.33 & 0.33 & 0.33 & 0.33 & 0.33 & 0.33 \\
\hline & Other & 0.33 & 0.33 & 0.33 & 0.33 & 0.33 & 0.33 & 0.33 & 0.33 & 0.33 & 0.33 & 0.33 & 0.33 & 0.33 & 0.33 & \begin{tabular}{|l|}
0.33 \\
\end{tabular} & \begin{tabular}{|l|}
0.33 \\
\end{tabular} & 0.33 & 0.33 & 0.33 & 0.33 & 0.33 & 0.33 & 0.33 & 0.33 \\
\hline ACTIVITY_SCH & All & 120 & 120 & 120 & 120 & 120 & 120 & 120 & 120 & 120 & 120 & 120 & 120 & 120 & 120 & 120 & 120 & 120 & 120 & 120 & 120 & 120 & 120 & 120 & 120 \\
\hline WORK_EFF_SCH & All & 0 & 0 & 0 & 0 & 0 & 0 & 0 & 0 & 0 & 0 & 0 & 0 & 0 & 0 & 0 & 0 & 0 & 0 & 0 & 0 & 0 & 0 & 0 & 0 \\
\hline AIR_VELO_SCH & All & 0.2 & 0.2 & 0.2 & 0.2 & 0.2 & 0.2 & 0.2 & 0.2 & 0.2 & 0.2 & 0.2 & 0.2 & 0.2 & 0.2 & 0.2 & \begin{tabular}{|l|}
0.2 \\
\end{tabular} & 0.2 & 0.2 & 0.2 & 0.2 & 0.2 & 0.2 & 0.2 & 0.2 \\
\hline \multirow[t]{3}{*}{ CLOTHING_SCH } & All & 1 & 1 & 1 & 1 & 1 & 1 & 1 & 1 & 1 & 1 & 1 & 1 & 1 & 1 & 1 & 1 & 1 & 1 & 1 & 1 & 1 & 1 & 1 & 1 \\
\hline & All & 0.5 & 0.5 & 0.5 & 0.5 & 0.5 & 0.5 & 0.5 & 0.5 & 0.5 & 0.5 & 0.5 & 0.5 & 0.5 & 0.5 & 0.5 & 0.5 & 0.5 & 0.5 & 0.5 & 0.5 & 0.5 & 0.5 & 0.5 & 0.5 \\
\hline & All & 1 & 1 & 1 & 1 & 1 & 1 & 1 & 1 & 1 & 1 & 1 & 1 & 1 & 1 & 1 & 1 & 1 & 1 & 1 & 1 & 1 & 1 & 1 & 1 \\
\hline UnitHeater_ClgSP_Sch & All & 40 & 40 & 40 & 40 & 40 & 40 & 40 & 40 & 40 & 40 & 40 & 40 & 40 & 40 & 40 & 40 & 40 & 40 & 40 & 40 & 40 & 40 & 40 & 40 \\
\hline UnitHeater_HtgSP_Sch & All & 15.6 & 15.6 & 15.6 & 15.6 & 15.6 & 15.6 & 15.6 & 15.6 & 15.6 & 15.6 & 15.6 & 15.6 & 15.6 & 15.6 & 15.6 & 15.6 & 15.6 & 15.6 & 15.6 & 15.6 & 15.6 & 15.6 & 15.6 & 15.6 \\
\hline APT_CLGSETP_SCH & All & 23.9 & 23.9 & 23.9 & 23.9 & 23.9 & 23.9 & 23.9 & 23.9 & 23.9 & 23.9 & 23.9 & 23.9 & 23.9 & 23.9 & 23.9 & 23.9 & 23.9 & 23.9 & 23.9 & 23.9 & 23.9 & 23.9 & 23.9 & 23.9 \\
\hline APT_HTGSETP_SCH & All & 21.1 & 21.1 & 21.1 & 21.1 & 21.1 & 21.1 & 21.1 & 21.1 & 21.1 & 21.1 & 21.1 & 21.1 & 21.1 & 21.1 & 21.1 & 21.1 & 21.1 & 21.1 & 21.1 & 21.1 & 21.1 & 21.1 & 21.1 & 21.1 \\
\hline \multirow[t]{2}{*}{ OFF_HTGSETP_SCH } & WD, WinterDesign & 15.6 & 15.6 & 15.6 & 15.6 & 15.6 & 15.6 & 15.6 & 18.3 & 21.1 & 21.1 & 21.1 & 21.1 & 21.1 & 21.1 & 21.1 & 21.1 & 21.1 & 18.3 & 15.6 & 15.6 & 15.6 & 15.6 & 15.6 & 15.6 \\
\hline & Other & 15.6 & 15.6 & 15.6 & 15.6 & 15.6 & 15.6 & 15.6 & 15.6 & 15.6 & 15.6 & 15.6 & 15.6 & 15.6 & 15.6 & 15.6 & 15.6 & 15.6 & 15.6 & 15.6 & 15.6 & 15.6 & 15.6 & 15.6 & 15.6 \\
\hline \multirow{2}{*}{ OFF_CLGSETP_SCH } & WD, SummerDesign & 29.4 & 29.4 & 29.4 & 29.4 & 29.4 & 29.4 & 29.4 & 26.7 & 23.9 & 23.9 & 23.9 & 23.9 & 23.9 & 23.9 & 23.9 & 23.9 & 23.9 & 26.7 & 29.4 & 29.4 & 29.4 & 29.4 & 29.4 & 29.4 \\
\hline & Other & 29.4 & 29.4 & 29.4 & 29.4 & 29.4 & 29.4 & 29.4 & 29.4 & 29.4 & 29.4 & 29.4 & 29.4 & 29.4 & 29.4 & 29.4 & 29.4 & 29.4 & 29.4 & 29.4 & 29.4 & 29.4 & 29.4 & 29.4 & 29.4 \\
\hline Dual Zone Control Type Sched & All & 4 & 4 & 4 & 4 & 4 & 4 & 4 & 4 & 4 & 4 & 4 & 4 & 4 & 4 & 4 & 4 & 4 & 4 & 4 & 4 & 4 & 4 & 4 & 4 \\
\hline Apt_Operation & All & 0 & 0 & 0 & 0 & 0 & 0 & 0 & 0 & 0 & 0 & 0 & 0 & 0 & 0 & 0 & 0 & 0 & 0 & 0 & 0 & 0 & 0 & 0 & 0 \\
\hline \multirow[t]{2}{*}{ Office_Operation } & $\begin{array}{l}\text { WD, SummerDesign, } \\
\text { WinterDesign }\end{array}$ & 0 & 0 & 0 & 0 & 0 & 0 & 0 & 0 & 1 & 1 & 1 & 1 & 1 & 1 & 1 & 1 & 1 & 0 & 0 & 0 & 0 & 0 & 0 & 0 \\
\hline & Other & 0 & 0 & 0 & 0 & 0 & 0 & 0 & 0 & 0 & 0 & 0 & 0 & 0 & 0 & 0 & 0 & 0 & 0 & 0 & 0 & 0 & 0 & 0 & 0 \\
\hline MinOA_Sched & All & 1 & 1 & 1 & 1 & 1 & 1 & 1 & 1 & 1 & 1 & 1 & 1 & 1 & 1 & 1 & 1 & 1 & 1 & 1 & 1 & 1 & 1 & 1 & 1 \\
\hline $\begin{array}{l}\text { Apartment Water Equipment } \\
\text { Latent fract sched }\end{array}$ & All & 0.05 & 0.05 & 0.05 & 0.05 & 0.05 & 0.05 & 0.05 & 0.05 & 0.05 & 0.05 & 0.05 & 0.05 & 0.05 & 0.05 & 0.05 & 0.05 & 0.05 & 0.05 & 0.05 & 0.05 & 0.05 & 0.05 & 0.05 & 0.05 \\
\hline $\begin{array}{l}\text { Apartment Water Equipment } \\
\text { Sensible fract sched }\end{array}$ & All & 0.2 & 0.2 & 0.2 & 0.2 & 0.2 & 0.2 & 0.2 & 0.2 & 0.2 & 0.2 & 0.2 & 0.2 & 0.2 & 0.2 & 0.2 & 0.2 & 0.2 & 0.2 & 0.2 & 0.2 & 0.2 & 0.2 & 0.2 & 0.2 \\
\hline $\begin{array}{l}\text { Apartment Water Equipment } \\
\text { Temp Sched }\end{array}$ & All & 43.3 & 43.3 & 43.3 & 43.3 & 43.3 & 43.3 & 43.3 & 43.3 & 43.3 & 43.3 & 43.3 & 43.3 & 43.3 & 43.3 & 43.3 & 43.3 & 43.3 & 43.3 & 43.3 & 43.3 & 43.3 & 43.3 & 43.3 & 43.3 \\
\hline $\begin{array}{l}\text { Apartment Water Equipment Hot } \\
\text { Supply Temp Sched }\end{array}$ & All & 43.3 & 43.3 & 43.3 & 43.3 & 43.3 & 43.3 & 43.3 & 43.3 & 43.3 & 43.3 & 43.3 & 43.3 & 43.3 & 43.3 & 43.3 & 43.3 & 43.3 & 43.3 & 43.3 & 43.3 & 43.3 & 43.3 & 43.3 & 43.3 \\
\hline SWHSys 1 Water Heater Setpoint & All & 60 & 60 & 60 & 60 & 60 & 60 & 60 & 60 & 60 & 60 & 60 & 60 & 60 & 60 & 60 & 60 & 60 & 60 & 60 & 60 & 60 & 60 & 60 & 60 \\
\hline
\end{tabular}




\begin{tabular}{|c|c|c|c|c|c|c|c|c|c|c|c|c|c|c|c|c|c|c|c|c|c|c|c|c|c|}
\hline Schedule & Day of Week & 1 & 2 & 3 & 4 & 5 & 6 & 7 & 8 & 9 & 10 & 11 & 12 & 13 & 14 & 15 & 16 & 17 & 18 & 19 & 20 & 21 & 22 & 23 & 24 \\
\hline Temperature Schedule Name & & & & & & & & & & & & & & & & & & & & & & & & & \\
\hline $\begin{array}{l}\text { SWHSys1 Water Heater Ambient } \\
\text { Temperature Schedule Name }\end{array}$ & All & 22 & 22 & 22 & 22 & 22 & 22 & 22 & 22 & 22 & 22 & 22 & 22 & 22 & 22 & 22 & 22 & 22 & 22 & 22 & 22 & 22 & 22 & 22 & 22 \\
\hline SWHSys1-Loop-Temp-Schedule & All & 60 & 60 & 60 & 60 & 60 & 60 & 60 & 60 & 60 & 60 & 60 & 60 & 60 & 60 & 60 & 60 & 60 & 60 & 60 & 60 & 60 & 60 & 60 & 60 \\
\hline APT_DHW_SCH & All & 0.08 & 0.04 & 0.01 & 0.01 & 0.04 & 0.27 & 0.94 & 1 & 0.96 & 0.84 & 0.76 & 0.61 & 0.53 & \begin{tabular}{|l|}
0.47 \\
\end{tabular} & 0.41 & 0.47 & 0.55 & 0.73 & 0.86 & 0.82 & 0.75 & 0.61 & 0.53 & 0.29 \\
\hline
\end{tabular}


Table B-7 Outpatient Health Care Hourly Operation Schedules

\begin{tabular}{|c|c|c|c|c|c|c|c|c|c|c|c|c|c|c|c|c|c|c|c|c|c|c|c|c|c|}
\hline Schedule & Day of Week & 1 & 2 & 3 & 4 & 5 & 6 & 7 & 8 & 9 & 10 & 11 & 12 & 13 & 14 & 15 & 16 & 17 & 18 & 19 & 20 & 21 & 22 & 23 & 24 \\
\hline ALWAYS_ON & All & 1 & 1 & 1 & 1 & 1 & 1 & 1 & 1 & 1 & 1 & 1 & 1 & 1 & 1 & 1 & 1 & 1 & 1 & 1 & 1 & 1 & 1 & 1 & 1 \\
\hline \multirow[t]{3}{*}{ BLDG_ELEVATORS } & WD, SummerDesign & 0.05 & 0.05 & 0.05 & 0.05 & 0.05 & 0.05 & 0.05 & 0.5 & 0.75 & 1 & 1 & 1 & 0.75 & 1 & 1 & 1 & 1 & 1 & 0.52 & 0.52 & 0.52 & 0.28 & 0.05 & 0.05 \\
\hline & Sat & 0.05 & 0.05 & 0.05 & 0.05 & 0.05 & 0.05 & 0.05 & 0.4 & 0.46 & 0.7 & 0.7 & 0.7 & 0.51 & 0.51 & 0.51 & 0.51 & 0.51 & 0.25 & 0.05 & 0.05 & 0.05 & 0.05 & 0.05 & 0.05 \\
\hline & Other & 0.05 & 0.05 & 0.05 & 0.05 & 0.05 & 0.05 & 0.05 & 0.05 & 0.4 & 0.4 & 0.4 & 0.4 & 0.4 & 0.4 & \begin{tabular}{|l|}
0.4 \\
\end{tabular} & \begin{tabular}{|l|}
0.4 \\
\end{tabular} & \begin{tabular}{|l|}
0.05 \\
\end{tabular} & \begin{tabular}{|l|}
0.05 \\
\end{tabular} & 0.05 & 0.05 & 0.05 & 0.05 & 0.05 & 0.05 \\
\hline \multirow[t]{3}{*}{ BLDG_EQUIP_SCH } & WD, SummerDesign & 0.3 & 0.3 & 0.3 & 0.3 & 0.5 & 0.5 & 1 & 1 & 1 & 1 & 1 & 1 & 1 & 1 & 1 & 1 & 1 & 1 & 0.5 & 0.5 & 0.3 & 0.3 & 0.3 & 0.3 \\
\hline & Sat & 0.3 & 0.3 & 0.3 & 0.3 & 0.3 & 0.3 & 0.3 & 0.5 & 0.5 & 0.8 & 0.8 & 0.8 & 0.8 & 0.8 & 0.8 & 0.5 & 0.5 & \begin{tabular}{|l|}
0.5 \\
\end{tabular} & 0.5 & 0.5 & 0.3 & 0.3 & 0.3 & 0.3 \\
\hline & Other & 0.3 & 0.3 & 0.3 & 0.3 & 0.3 & 0.3 & 0.3 & 0.3 & 0.5 & 0.5 & 0.5 & 0.5 & 0.5 & 0.5 & 0.5 & 0.5 & 0.5 & \begin{tabular}{|l|}
0.3 \\
\end{tabular} & 0.3 & 0.3 & 0.3 & 0.3 & 0.3 & 0.3 \\
\hline \multirow[t]{3}{*}{ BLDG_LIGHT_SCH } & WD, SummerDesign & 0.1 & 0.1 & 0.1 & 0.1 & 0.3 & 0.3 & 0.6 & 0.9 & 0.9 & 0.9 & 0.9 & 0.9 & 0.9 & 0.9 & 0.9 & 0.9 & 0.9 & \begin{tabular}{|l|}
0.9 \\
\end{tabular} & 0.6 & 0.6 & 0.3 & 0.3 & 0.1 & 0.1 \\
\hline & Sat & 0.1 & 0.1 & 0.1 & 0.1 & 0.1 & 0.1 & 0.1 & 0.3 & 0.3 & 0.4 & 0.4 & 0.4 & 0.4 & 0.4 & 0.4 & 0.3 & 0.3 & \begin{tabular}{|l|}
0.3 \\
\end{tabular} & 0.3 & 0.3 & 0.1 & 0.1 & 0.1 & 0.1 \\
\hline & Other & 0.05 & 0.05 & 0.05 & 0.05 & 0.05 & 0.05 & 0.05 & 0.05 & 0.1 & 0.1 & 0.1 & 0.1 & 0.1 & 0.1 & 0.1 & 0.1 & \begin{tabular}{|l|}
0.1 \\
\end{tabular} & 0.05 & 0.05 & 0.05 & 0.05 & 0.05 & 0.05 & 0.05 \\
\hline \multirow[t]{3}{*}{ BLDG_OCC_SCH } & WD, SummerDesign & 0.05 & 0.05 & 0.05 & 0.05 & 0.2 & 0.2 & 0.5 & 0.9 & 0.9 & 0.9 & 0.9 & 0.9 & 0.9 & 0.9 & 0.9 & 0.9 & \begin{tabular}{|l|}
0.9 \\
\end{tabular} & \begin{tabular}{|l|}
0.9 \\
\end{tabular} & 0.5 & 0.5 & 0.2 & 0.2 & 0.05 & 0.05 \\
\hline & Sat & 0.05 & 0.05 & 0.05 & 0.05 & 0.05 & 0.05 & 0.05 & 0.2 & 0.2 & 0.3 & 0.3 & 0.3 & 0.3 & 0.3 & 0.3 & \begin{tabular}{|l|}
0.2 \\
\end{tabular} & \begin{tabular}{|l|}
0.2 \\
\end{tabular} & \begin{tabular}{|l|}
0.2 \\
\end{tabular} & 0.2 & 0.2 & 0.05 & 0.05 & 0.05 & 0.05 \\
\hline & Other & 0 & 0 & 0 & 0 & 0 & 0 & 0 & 0 & 0.05 & 0.05 & 0.05 & 0.05 & 0.05 & 0.05 & \begin{tabular}{|l|l|}
0.05 \\
\end{tabular} & \begin{tabular}{|l|l|}
0.05 \\
\end{tabular} & 0.05 & 0 & 0 & 0 & 0 & 0 & 0 & 0 \\
\hline \multirow[t]{3}{*}{ CLOTHING_SCH } & All & 1 & 1 & 1 & 1 & 1 & 1 & 1 & 1 & 1 & 1 & 1 & 1 & 1 & 1 & 1 & 1 & 1 & 1 & 1 & 1 & 1 & 1 & 1 & 1 \\
\hline & All & 0.5 & 0.5 & 0.5 & 0.5 & 0.5 & 0.5 & 0.5 & 0.5 & 0.5 & 0.5 & 0.5 & 0.5 & 0.5 & 0.5 & 0.5 & 0.5 & 0.5 & 0.5 & 0.5 & 0.5 & 0.5 & 0.5 & 0.5 & 0.5 \\
\hline & All & 1 & 1 & 1 & 1 & 1 & 1 & 1 & 1 & 1 & 1 & 1 & 1 & 1 & 1 & 1 & 1 & 1 & 1 & 1 & 1 & 1 & 1 & 1 & 1 \\
\hline WORK_EFF_SCH & All & 0 & 0 & 0 & 0 & 0 & 0 & 0 & 0 & 0 & 0 & 0 & 0 & 0 & 0 & 0 & 0 & 0 & 0 & 0 & 0 & 0 & 0 & 0 & 0 \\
\hline AIR_VELO_SCH & All & 0.2 & 0.2 & 0.2 & 0.2 & 0.2 & 0.2 & 0.2 & 0.2 & 0.2 & 0.2 & 0.2 & 0.2 & 0.2 & 0.2 & 0.2 & \begin{tabular}{|l|}
0.2 \\
\end{tabular} & \begin{tabular}{|l|}
0.2 \\
\end{tabular} & \begin{tabular}{|l|}
0.2 \\
\end{tabular} & 0.2 & 0.2 & 0.2 & 0.2 & 0.2 & 0.2 \\
\hline ACTIVITY_SCH & All & 120 & 120 & 120 & 120 & 120 & 120 & 120 & 120 & 120 & 120 & 120 & 120 & 120 & 120 & 120 & 120 & 120 & 120 & 120 & 120 & 120 & 120 & 120 & 120 \\
\hline \multirow[t]{2}{*}{ INFIL_SCH } & \begin{tabular}{|l} 
SummerDesign, \\
WinterDesign
\end{tabular} & 1 & 1 & 1 & 1 & 1 & 1 & 1 & 1 & 1 & 1 & 1 & 1 & 1 & 1 & 1 & 1 & 1 & 1 & 1 & 1 & 1 & 1 & 1 & 1 \\
\hline & Other & 0.5 & 0.5 & 0.5 & 0.5 & 0.5 & 0.5 & 0.5 & 0.5 & 0.5 & 0.5 & 0.5 & 0.5 & 0.5 & 0.5 & 0.5 & 0.5 & 0.5 & 0.5 & 0.5 & 0.5 & 0.5 & 0.5 & 0.5 & 0.5 \\
\hline \multirow[t]{2}{*}{ RADIOLOGY_EQUIP_SCH } & \begin{tabular}{|l|} 
WD, Sat, \\
SummerDesign
\end{tabular} & 0.01 & 0.01 & 0.01 & 0.01 & 0.01 & 0.01 & 0.96 & 0.96 & 0.96 & 0.96 & 0.96 & 0.96 & 0.96 & 0.96 & 0.96 & 0.96 & 0.96 & 0.96 & 0.01 & 0.01 & 0.01 & 0.01 & 0.01 & 0.01 \\
\hline & Other & 0.01 & 0.01 & 0.01 & 0.01 & 0.01 & 0.01 & 0.01 & 0.01 & 0.01 & 0.01 & 0.01 & 0.01 & 0.01 & 0.01 & 0.01 & 0.01 & 0.01 & \begin{tabular}{|l|}
0.01 \\
\end{tabular} & 0.01 & 0.01 & 0.01 & 0.01 & 0.01 & 0.01 \\
\hline OR_CLGSETP_SCH & All & \begin{tabular}{|l|}
22.2 \\
\end{tabular} & 22.2 & 22.2 & 22.2 & 22.2 & 22.2 & 18.3 & 18.3 & 18.3 & 18.3 & 18.3 & 18.3 & 18.3 & 18.3 & 18.3 & \begin{tabular}{|l|}
18.3 \\
\end{tabular} & \begin{tabular}{|c|}
18.3 \\
\end{tabular} & \begin{tabular}{|l|}
22.2 \\
\end{tabular} & 22.2 & 22.2 & 22.2 & 22.2 & 22.2 & 22.2 \\
\hline OR_HTGSETP_SCH & All & 18.3 & 18.3 & 18.3 & 18.3 & 18.3 & 18.3 & 18.3 & 18.3 & 18.3 & 18.3 & 18.3 & 18.3 & 18.3 & 18.3 & 18.3 & 18.3 & 18.3 & 18.3 & 18.3 & 18.3 & 18.3 & 18.3 & 18.3 & 18.3 \\
\hline \multirow[t]{3}{*}{ CLGSETP_SCH } & WD, SummerDesign & 25 & 25 & 25 & 25 & 25 & 22.2 & 22.2 & 22.2 & 22.2 & 22.2 & 22.2 & 22.2 & 22.2 & 22.2 & 22.2 & 22.2 & 22.2 & 22.2 & 25 & 25 & 25 & 25 & 25 & 25 \\
\hline & Sat, WinterDesign & 25 & 25 & 25 & 25 & 25 & 25 & 25 & 22.2 & 22.2 & 22.2 & 22.2 & 22.2 & 22.2 & 22.2 & 22.2 & 25 & 25 & 25 & 25 & 25 & 25 & 25 & 25 & 25 \\
\hline & Other & 25 & 25 & 25 & 25 & 25 & 25 & 25 & 25 & 25 & 25 & 25 & 25 & 25 & 25 & 25 & 25 & 25 & 25 & 25 & 25 & 25 & 25 & 25 & 25 \\
\hline \multirow[t]{3}{*}{ HTGSETP_SCH } & WD, SummerDesign & 18.3 & 18.3 & 18.3 & 18.3 & 18.3 & 21.1 & 21.1 & 21.1 & 21.1 & 21.1 & 21.1 & 21.1 & 21.1 & 21.1 & 21.1 & 21.1 & 21.1 & 21.1 & 18.3 & 18.3 & 18.3 & 18.3 & 18.3 & 18.3 \\
\hline & Sat, WinterDesign & 18.3 & 18.3 & 18.3 & 18.3 & 18.3 & 18.3 & 18.3 & 21.1 & 21.1 & 21.1 & 21.1 & 21.1 & 21.1 & 21.1 & 21.1 & 18.3 & 18.3 & 18.3 & 18.3 & 18.3 & 18.3 & 18.3 & 18.3 & 18.3 \\
\hline & Other & 18.3 & 18.3 & 18.3 & 18.3 & 18.3 & 18.3 & 18.3 & 18.3 & 18.3 & 18.3 & 18.3 & 18.3 & 18.3 & 18.3 & 18.3 & \begin{tabular}{|l|l|}
18.3 \\
\end{tabular} & 18.3 & \begin{tabular}{|l|}
18.3 \\
\end{tabular} & 18.3 & 18.3 & 18.3 & 18.3 & 18.3 & 18.3 \\
\hline $\begin{array}{l}\text { Dual Zone Control Type } \\
\text { Sched }\end{array}$ & All & 4 & 4 & 4 & 4 & 4 & 4 & 4 & 4 & 4 & 4 & 4 & 4 & 4 & 4 & 4 & 4 & 4 & 4 & 4 & 4 & 4 & 4 & 4 & 4 \\
\hline MaxRelHumSetSch & All & 60 & 60 & 60 & 60 & 60 & 60 & 60 & 60 & 60 & 60 & 60 & 60 & 60 & 60 & 60 & 60 & 60 & 60 & 60 & 60 & 60 & 60 & 60 & 60 \\
\hline MinRelHumSetSch & All & 40 & 40 & 40 & 40 & 40 & 40 & 40 & 40 & 40 & 40 & 40 & 40 & 40 & 40 & 40 & 40 & 40 & 40 & 40 & 40 & 40 & 40 & 40 & 40 \\
\hline AHU-1_MinOAFracSchedule & All & 0.33 & 0.33 & 0.33 & 0.33 & 0.33 & 0.33 & 0.33 & 0.33 & 0.33 & 0.33 & 0.33 & 0.33 & 0.33 & 0.33 & 0.33 & 0.33 & 0.33 & 0.33 & 0.33 & 0.33 & 0.33 & 0.33 & 0.33 & 0.33 \\
\hline \multirow[t]{3}{*}{ AHU-1_Fan_Sch } & WD, Sat & 0 & 0 & 0 & 0 & 1 & 1 & 1 & 1 & 1 & 1 & 1 & 1 & 1 & 1 & 1 & 1 & 1 & 1 & 1 & 1 & 1 & 0 & 0 & 0 \\
\hline & $\begin{array}{l}\text { SummerDesign, } \\
\text { WinterDesign }\end{array}$ & 1 & 1 & 1 & 1 & 1 & 1 & 1 & 1 & 1 & 1 & 1 & 1 & 1 & 1 & 1 & 1 & 1 & 1 & 1 & 1 & 1 & 1 & 1 & 1 \\
\hline & Other & 0 & 0 & 0 & 0 & 0 & 0 & 0 & 0 & 0 & 0 & 0 & 0 & 0 & 0 & 0 & 0 & 0 & 0 & 0 & 0 & 0 & 0 & 0 & 0 \\
\hline
\end{tabular}




\begin{tabular}{|c|c|c|c|c|c|c|c|c|c|c|c|c|c|c|c|c|c|c|c|c|c|c|c|c|c|}
\hline Schedule & Day of Week & 1 & 2 & 3 & 4 & 5 & 6 & 7 & 8 & 9 & 10 & 11 & 12 & 13 & 14 & 15 & 16 & 17 & 18 & 19 & 20 & 21 & 22 & 23 & 24 \\
\hline IAHU-2_Fan_Sch & WD, Sat & 0 & 0 & 0 & 0 & 0 & 0 & 1 & 1 & 1 & 1 & 1 & 1 & 11 & 1 & 1 & 1 & 1 & 1 & 0 & 0 & 0 & 0 & 0 & 0 \\
\hline & \begin{tabular}{|l|} 
SummerDesign, \\
WinterDesign
\end{tabular} & 1 & 1 & 1 & 1 & 1 & 1 & 1 & 1 & 1 & 1 & 1 & 1 & 1 & 1 & 1 & 1 & 1 & 1 & 1 & 1 & 1 & 1 & 1 & 1 \\
\hline & Other & 0 & 0 & 0 & 0 & 0 & 0 & 0 & 0 & 0 & 0 & 0 & 0 & 0 & 0 & 0 & 0 & 0 & 0 & 0 & 0 & 0 & 0 & 0 & 0 \\
\hline $\begin{array}{l}\text { VAV_SAT_SCH } \\
\end{array}$ & All & 12.8 & 12.8 & 12.8 & 12.8 & 12.8 & 12.8 & 12.8 & 12.8 & 12.8 & 12.8 & 12.8 & 12.8 & 12.8 & 12.8 & 12.8 & 12.8 & 12.8 & 12.8 & 12.8 & 12.8 & 12.8 & 12.8 & 12.8 & 12.8 \\
\hline CAV_SAT_SCH & All & 11.1 & 11.1 & 11.1 & 11.1 & 11.1 & 11.1 & 11.1 & 11.1 & 11.1 & 11.1 & 11.1 & 11.1 & 11.1 & 11.1 & 11.1 & 11.1 & 11.1 & 11.1 & 11.1 & 11.1 & 11.1 & 11.1 & 11.1 & 11.1 \\
\hline \begin{tabular}{|l} 
HW-Loop-Temp-Schedule \\
\end{tabular} & All & 60 & 60 & 60 & 60 & 60 & 60 & 60 & 60 & 60 & 60 & 60 & 60 & 60 & 60 & 60 & 60 & 60 & 60 & 60 & 60 & 60 & 60 & 60 & 60 \\
\hline \begin{tabular}{|l|} 
PlantOnSched \\
\end{tabular} & All & 1 & 1 & 1 & 1 & 1 & 1 & 1 & 1 & 1 & 1 & 1 & 1 & 1 & 1 & 1 & 1 & 1 & 1 & 1 & 1 & 1 & 1 & 1 & 1 \\
\hline CW-Loop-Temp-Schedule & All & 6.7 & 6.7 & 6.7 & 6.7 & 6.7 & 6.7 & 6.7 & 6.7 & 6.7 & 6.7 & 6.7 & 6.7 & 6.7 & 6.7 & 6.7 & 6.7 & 6.7 & 6.7 & 6.7 & 6.7 & 6.7 & 6.7 & 6.7 & 6.7 \\
\hline $\begin{array}{l}\text { HeatSys1 Loop Setpoint } \\
\text { Sched }\end{array}$ & All & 82.2 & 82.2 & 82.2 & 82.2 & 82.2 & 82.2 & 82.2 & 82.2 & 82.2 & 82.2 & 82.2 & 82.2 & 82.2 & 82.2 & 82.2 & 82.2 & 82.2 & 82.2 & 82.2 & 82.2 & 82.2 & 82.2 & 82.2 & 82.2 \\
\hline BLDG_SWH_SCH & WD, SummerDesign & 0.01 & 0.01 & 0.01 & 0.01 & 0.01 & 0.01 & 0.01 & 0.17 & 0.58 & 0.66 & 0.78 & 0.82 & 0.71 & 0.82 & 0.78 & 0.74 & 0.63 & 0.41 & 0.18 & 0.18 & 0.18 & 0.1 & \begin{tabular}{|l|}
0.01 \\
\end{tabular} & 0.01 \\
\hline & Sat & 0.01 & 0.01 & 0.01 & 0.01 & 0.01 & 0.01 & 0.01 & 0.01 & 0.2 & 0.28 & 0.3 & 0.3 & 0.24 & 0.24 & 0.23 & 0.23 & 0.23 & 0.1 & 0.01 & 0.01 & 0.01 & 0.01 & 0.01 & 0.01 \\
\hline & Other & 0.01 & 0.01 & 0.01 & 0.01 & 0.01 & 0.01 & 0.01 & 0.01 & 0.01 & 0.01 & 0.01 & 0.01 & 0.01 & 0.01 & 0.01 & 0.01 & 0.01 & 0.01 & 0.01 & 0.01 & 0.01 & 0.01 & 0.01 & 0.01 \\
\hline $\begin{array}{l}\text { Water Equipment Latent } \\
\text { fract sched }\end{array}$ & All & 0.05 & 0.05 & 0.05 & 0.05 & 0.05 & 0.05 & 0.05 & 0.05 & 0.05 & 0.05 & 0.05 & 0.05 & 0.05 & 0.05 & 0.05 & 0.05 & 0.05 & 0.05 & 0.05 & 0.05 & 0.05 & 0.05 & 0.05 & 0.05 \\
\hline $\begin{array}{l}\text { Water Equipment Sensible } \\
\text { fract sched }\end{array}$ & All & 0.2 & 0.2 & 0.2 & 0.2 & 0.2 & 0.2 & 0.2 & 0.2 & 0.2 & 0.2 & 0.2 & 0.2 & 0.2 & 0.2 & 0.2 & 0.2 & 0.2 & 0.2 & 0.2 & 0.2 & 0.2 & 0.2 & 0.2 & 0.2 \\
\hline $\begin{array}{l}\text { Water Equipment Hot Supply } \\
\text { Temp Sched }\end{array}$ & All & 43.3 & 43.3 & 43.3 & 43.3 & 43.3 & 43.3 & 43.3 & 43.3 & 43.3 & 43.3 & 43.3 & 43.3 & 43.3 & 43.3 & 43.3 & 43.3 & 43.3 & 43.3 & 43.3 & 43.3 & 43.3 & 43.3 & 43.3 & 43.3 \\
\hline $\begin{array}{l}\text { Water Equipment Temp } \\
\text { Sched }\end{array}$ & All & 43.3 & 43.3 & 43.3 & 43.3 & 43.3 & 43.3 & 43.3 & 43.3 & 43.3 & 43.3 & 43.3 & 43.3 & 43.3 & 43.3 & 43.3 & 43.3 & 43.3 & 43.3 & 43.3 & 43.3 & 43.3 & 43.3 & 43.3 & 43.3 \\
\hline $\begin{array}{l}\text { SWHSys1 Water Heater } \\
\text { Ambient Temperature } \\
\text { Schedule Name }\end{array}$ & All & 22 & 22 & 22 & 22 & 22 & 22 & 22 & 22 & 22 & 22 & 22 & 22 & 22 & 22 & 22 & 22 & 22 & 22 & 22 & 22 & 22 & 22 & 22 & 22 \\
\hline $\begin{array}{l}\text { SWHSys } 1 \text { Water Heater } \\
\text { Setpoint Temperature } \\
\text { Schedule Name } \\
\end{array}$ & All & 60 & 60 & 60 & 60 & 60 & 60 & 60 & 60 & 60 & 60 & 60 & 60 & 60 & 60 & 60 & 60 & 60 & 60 & 60 & 60 & 60 & 60 & 60 & 60 \\
\hline $\begin{array}{l}\text { SWHSys1-Loop-Temp- } \\
\text { Schedule }\end{array}$ & All & 60 & 60 & 60 & 60 & 60 & 60 & 60 & 60 & 60 & 60 & 60 & 60 & 60 & 60 & 60 & 60 & 60 & 60 & 60 & 60 & 60 & 60 & 60 & 60 \\
\hline
\end{tabular}


Table B-8 Primary School Hourly Operation Schedules

\begin{tabular}{|c|c|c|c|c|c|c|c|c|c|c|c|c|c|c|c|c|c|c|c|c|c|c|c|c|c|c|}
\hline Schedule & $\begin{array}{c}\begin{array}{c}\text { Through } \\
\text { (Date) }\end{array} \\
\end{array}$ & Day & 1 & 2 & 3 & 4 & 5 & 6 & 7 & 8 & 9 & 10 & 11 & 12 & 13 & 14 & 15 & 16 & 17 & 18 & 19 & 20 & 21 & 22 & 23 & 24 \\
\hline ALWAYS_ON & $12 / 31$ & All & 1 & 1 & 1 & 1 & 1 & 1 & 1 & 1 & 1 & 1 & 1 & 1 & 1 & 1 & 1 & 1 & 1 & 1 & 1 & 1 & 1 & 1 & 1 & 1 \\
\hline \multirow[t]{6}{*}{ BLDG_EQUIP_SCH } & $6 / 30$ & WD, SummerDesign & 0.35 & 0.35 & 0.35 & 0.35 & 0.35 & 0.35 & 0.35 & 0.35 & 0.95 & 0.95 & 0.95 & 0.95 & 0.95 & 0.95 & 0.95 & 0.95 & 0.95 & 0.35 & 0.35 & 0.35 & 0.35 & 0.35 & 0.35 & 0.35 \\
\hline & & Other & 0.35 & 0.35 & 0.35 & 0.35 & 0.35 & 0.35 & 0.35 & 0.35 & 0.35 & 0.35 & 0.35 & 0.35 & 0.35 & 0.35 & 0.35 & 0.35 & 0.35 & 0.35 & 0.35 & 0.35 & 0.35 & 0.35 & 0.35 & 0.35 \\
\hline & $9 / 1$ & WD, SummerDesign & 0.25 & 0.25 & 0.25 & 0.25 & 0.25 & 0.25 & 0.25 & 0.25 & 0.5 & 0.5 & 0.5 & 0.5 & 0.5 & 0.5 & 0.5 & 0.5 & 0.5 & 0.25 & 0.25 & 0.25 & 0.25 & 0.25 & 0.25 & \begin{tabular}{|l|l|} 
& 0.25 \\
\end{tabular} \\
\hline & & Other & 0.25 & 0.25 & 0.25 & 0.25 & 0.25 & 0.25 & 0.25 & 0.25 & 0.25 & 0.25 & 0.25 & 0.25 & 0.25 & 0.25 & 0.25 & 0.25 & 0.25 & 0.25 & 0.25 & 0.25 & 0.25 & 0.25 & 0.25 & 0.25 \\
\hline & $12 / 31$ & WD, SummerDesign & 0.35 & 0.35 & 0.35 & 0.35 & 0.35 & 0.35 & 0.35 & 0.35 & 0.95 & 0.95 & 0.95 & 0.95 & 0.95 & 0.95 & 0.95 & 0.95 & 0.95 & 0.35 & 0.35 & 0.35 & 0.35 & 0.35 & 0.35 & 0.35 \\
\hline & & Other & 0.35 & 0.35 & 0.35 & 0.35 & 0.35 & 0.35 & 0.35 & 0.35 & 0.35 & 0.35 & 0.35 & 0.35 & 0.35 & 0.35 & 0.35 & 0.35 & 0.35 & 0.35 & 0.35 & 0.35 & 0.35 & 0.35 & 0.35 & 0.35 \\
\hline \multirow[t]{6}{*}{ BLDG_LIGHT_SCH } & $6 / 30$ & WD, SummerDesign & 0.18 & 0.18 & 0.18 & 0.18 & 0.18 & 0.18 & 0.18 & 0.9 & 0.9 & 0.9 & 0.9 & 0.9 & \begin{tabular}{|l|}
0.9 \\
\end{tabular} & 0.9 & 0.9 & 0.9 & 0.9 & 0.9 & 0.9 & 0.9 & 0.9 & 0.18 & 0.18 & 0.18 \\
\hline & & Other & 0.18 & 0.18 & 0.18 & 0.18 & 0.18 & 0.18 & 0.18 & 0.18 & 0.18 & 0.18 & 0.18 & 0.18 & 0.18 & 0.18 & 0.18 & 0.18 & 0.18 & 0.18 & 0.18 & 0.18 & 0.18 & 0.18 & 0.18 & 0.18 \\
\hline & 9/1 & WD, SummerDesign & 0.18 & 0.18 & 0.18 & 0.18 & 0.18 & 0.18 & 0.18 & 0.18 & 0.5 & 0.5 & 0.5 & 0.5 & 0.5 & 0.5 & 0.5 & 0.5 & 0.5 & 0.5 & 0.5 & 0.5 & 0.18 & 0.18 & 0.18 & 0.18 \\
\hline & & Other & 0.18 & 0.18 & 0.18 & 0.18 & 0.18 & 0.18 & 0.18 & 0.18 & 0.18 & 0.18 & 0.18 & 0.18 & 0.18 & 0.18 & 0.18 & 0.18 & 0.18 & 0.18 & 0.18 & 0.18 & 0.18 & 0.18 & 0.18 & 0.18 \\
\hline & $12 / 31$ & WD, SummerDesign & 0.18 & 0.18 & 0.18 & 0.18 & 0.18 & 0.18 & 0.18 & 0.9 & 0.9 & 0.9 & 0.9 & \begin{tabular}{|l|}
0.9 \\
\end{tabular} & 0.9 & 0.9 & 0.9 & 0.9 & 0.9 & 0.9 & 0.9 & 0.9 & 0.9 & 0.18 & 0.18 & 0.18 \\
\hline & & Other & 0.18 & 0.18 & 0.18 & 0.18 & 0.18 & 0.18 & 0.18 & 0.18 & 0.18 & 0.18 & 0.18 & 0.18 & 0.18 & 0.18 & 0.18 & 0.18 & 0.18 & 0.18 & 0.18 & 0.18 & 0.18 & 0.18 & 0.18 & 0.18 \\
\hline \multirow[t]{6}{*}{ BLDG_OCC_SCH } & $6 / 30$ & WD, SummerDesign & 0 & 0 & 0 & 0 & 0 & 0 & 0 & 0 & 0.75 & 0.75 & 0.75 & 0.75 & 0.75 & 0.75 & 0.75 & 0.75 & 0.15 & 0.15 & 0.15 & 0.15 & 0.15 & 0 & 0 & 0 \\
\hline & & Other & 0 & 0 & 0 & 0 & 0 & 0 & 0 & 0 & 0 & 0 & 0 & 0 & 0 & 0 & 0 & 0 & 0 & 0 & 0 & 0 & 0 & 0 & 0 & 0 \\
\hline & 9/1 & WD, SummerDesign & 0 & 0 & 0 & 0 & 0 & 0 & 0 & 0 & 0.15 & 0.15 & 0.15 & 0.15 & 0.15 & 0.15 & 0.15 & 0.15 & 0.15 & 0.15 & 0.15 & 0.15 & 0.15 & 0 & 0 & 0 \\
\hline & & Other & 0 & 0 & 0 & 0 & 0 & 0 & 0 & 0 & 0 & 0 & 0 & 0 & 0 & 0 & 0 & 0 & 0 & 0 & 0 & 0 & 0 & 0 & 0 & 0 \\
\hline & $12 / 31$ & WD, SummerDesign & 0 & 0 & 0 & 0 & 0 & 0 & 0 & 0 & 0.75 & 0.75 & 0.75 & 0.75 & 0.75 & 0.75 & 0.75 & 0.75 & 0.15 & 0.15 & 0.15 & 0.15 & 0.15 & 0 & 0 & 0 \\
\hline & & Other & 0 & 0 & 0 & 0 & 0 & 0 & 0 & 0 & 0 & 0 & 0 & 0 & 0 & 0 & 0 & 0 & 0 & 0 & 0 & 0 & 0 & 0 & 0 & 0 \\
\hline \multirow[t]{6}{*}{ BLDG_OCC_SCH_Cafeteria } & $6 / 30$ & WD, SummerDesign & 0 & 0 & 0 & 0 & 0 & 0 & 0 & 0.15 & 0.15 & 0.05 & 0.05 & 0.95 & 0.95 & 0.15 & 0.15 & 0 & 0 & 0 & 0 & 0 & 0 & 0 & 0 & 0 \\
\hline & & Other & 0 & 0 & 0 & 0 & 0 & 0 & 0 & 0 & 0 & 0 & 0 & 0 & 0 & 0 & 0 & 0 & 0 & 0 & 0 & 0 & 0 & 0 & 0 & 0 \\
\hline & 9/1 & WD, SummerDesign & 0 & 0 & 0 & 0 & 0 & 0 & 0 & 0 & 0 & 0.25 & 0.25 & 0.25 & 0.25 & 0.25 & 0.25 & 0 & 0 & 0 & 0 & 0 & 0 & 0 & 0 & 0 \\
\hline & & Other & 0 & 0 & 0 & 0 & 0 & 0 & 0 & 0 & 0 & 0 & 0 & 0 & 0 & 0 & 0 & 0 & 0 & 0 & 0 & 0 & 0 & 0 & 0 & 0 \\
\hline & $12 / 31$ & WD, SummerDesign & 0 & 0 & 0 & 0 & 0 & 0 & 0 & 0.15 & 0.15 & 0.05 & 0.05 & 0.95 & 0.95 & 0.15 & 0.15 & 0 & 0 & 0 & 0 & 0 & 0 & 0 & 0 & 0 \\
\hline & & Other & 0 & 0 & 0 & 0 & 0 & 0 & 0 & 0 & 0 & 0 & 0 & 0 & 0 & 0 & 0 & 0 & 0 & 0 & 0 & 0 & 0 & 0 & 0 & 0 \\
\hline \multirow[t]{6}{*}{ BLDG_OCC_SCH_Gym } & $6 / 30$ & WD, SummerDesign & 0 & 0 & 0 & 0 & 0 & 0 & 0 & 0 & 0.35 & 0.35 & 0.35 & 0.35 & 0.35 & 0.35 & 0.35 & 0.35 & 0.95 & 0.95 & 0.95 & 0.95 & 0.95 & 0 & 0 & 0 \\
\hline & & Other & 0 & 0 & 0 & 0 & 0 & 0 & 0 & 0 & 0 & 0 & 0 & 0 & 0 & 0 & 0 & 0 & 0 & 0 & 0 & 0 & 0 & 0 & 0 & 0 \\
\hline & 9/1 & WD, SummerDesign & 0 & 0 & 0 & 0 & 0 & 0 & 0 & 0 & 0.35 & 0.35 & 0.35 & 0.35 & 0.35 & 0.35 & 0.35 & 0.35 & 0.35 & 0.35 & 0.35 & 0.35 & 0.35 & 0 & 0 & 0 \\
\hline & & Other & 0 & 0 & 0 & 0 & 0 & 0 & 0 & 0 & 0 & 0 & 0 & 0 & 0 & 0 & 0 & 0 & 0 & 0 & 0 & 0 & 0 & 0 & 0 & 0 \\
\hline & $12 / 31$ & WD, SummerDesign & 0 & 0 & 0 & 0 & 0 & 0 & 0 & 0 & 0.35 & 0.35 & 0.35 & 0.35 & 0.35 & 0.35 & 0.35 & 0.35 & 0.95 & 0.95 & 0.95 & 0.95 & 0.95 & 0 & 0 & 0 \\
\hline & & Other & 0 & 0 & 0 & 0 & 0 & 0 & 0 & 0 & 0 & 0 & 0 & 0 & 0 & 0 & 0 & 0 & 0 & 0 & 0 & 0 & 0 & 0 & 0 & 0 \\
\hline \multirow[t]{6}{*}{ BLDG_OCC_SCH_Offices } & $6 / 30$ & WD, SummerDesign & 0 & 0 & 0 & 0 & 0 & 0 & 0 & 0 & 0.95 & 0.95 & 0.95 & 0.95 & 0.95 & 0.95 & 0.95 & 0.95 & 0.95 & 0.15 & 0.15 & 0.15 & 0.15 & 0 & 0 & 0 \\
\hline & & Other & 0 & 0 & 0 & 0 & 0 & 0 & 0 & 0 & 0 & 0 & 0 & 0 & 0 & 0 & 0 & 0 & 0 & 0 & 0 & 0 & 0 & 0 & 0 & 0 \\
\hline & 9/1 & WD, SummerDesign & 0 & 0 & 0 & 0 & 0 & 0 & 0 & 0 & 0.5 & 0.5 & 0.5 & 0.5 & 0.5 & 0.5 & 0.5 & 0.5 & 0.5 & 0 & 0 & 0 & 0 & 0 & 0 & 0 \\
\hline & & Other & 0 & 0 & 0 & 0 & 0 & 0 & 0 & 0 & 0 & 0 & 0 & 0 & 0 & 0 & 0 & 0 & 0 & 0 & 0 & 0 & 0 & 0 & 0 & 0 \\
\hline & $12 / 31$ & WD, SummerDesign & 0 & 0 & 0 & 0 & 0 & 0 & 0 & 0 & 0.95 & 0.95 & 0.95 & 0.95 & 0.95 & 0.95 & 0.95 & 0.95 & 0.95 & 0.15 & 0.15 & 0.15 & 0.15 & 0 & 0 & 0 \\
\hline & & Other & 0 & 0 & 0 & 0 & 0 & 0 & 0 & 0 & 0 & 0 & 0 & 0 & 0 & 0 & 0 & 0 & 0 & 0 & 0 & 0 & 0 & 0 & 0 & 0 \\
\hline \multirow[t]{5}{*}{ KITCHEN_ELEC_EQUIP_SCH } & $6 / 30$ & WD, SummerDesign & 0.1 & 0.1 & 0.1 & 0.1 & 0.1 & 0.1 & 0.1 & 0.1 & 0.15 & 0.15 & 0.25 & 0.25 & 0.25 & 0.15 & 0.15 & \begin{tabular}{|l|}
0.1 \\
\end{tabular} & $\begin{array}{ll}0.1 \\
\end{array}$ & 0.1 & 0.1 & 0.1 & 0.1 & 0.1 & 0.1 & 0.1 \\
\hline & & Other & 0.1 & 0.1 & 0.1 & 0.1 & 0.1 & 0.1 & 0.1 & 0.1 & 0.1 & 0.1 & 0.1 & 0.1 & 0.1 & 0.1 & 0.1 & 0.1 & 0.1 & 0.1 & 0.1 & 0.1 & 0.1 & 0.1 & 0.1 & 0.1 \\
\hline & 9/1 & WD, SummerDesign & 0.1 & 0.1 & 0.1 & 0.1 & 0.1 & 0.1 & 0.1 & 0.1 & 0.13 & 0.13 & 0.2 & 0.2 & 0.2 & 0.13 & 0.13 & 0.1 & 0.1 & 0.1 & 0.1 & 0.1 & 0.1 & 0.1 & 0.1 & 0.1 \\
\hline & & Other & 0.1 & 0.1 & 0.1 & 0.1 & 0.1 & 0.1 & 0.1 & 0.1 & 0.1 & 0.1 & 0.1 & 0.1 & 0.1 & 0.1 & 0.1 & 0.1 & 0.1 & 0.1 & 0.1 & 0.1 & 0.1 & 0.1 & 0.1 & 0.1 \\
\hline & $12 / 31$ & WD, SummerDesign & 0.1 & 0.1 & 0.1 & 0.1 & 0.1 & 0.1 & 0.1 & 0.1 & 0.15 & 0.15 & 0.25 & 0.25 & 0.25 & 0.15 & 0.15 & 0.1 & 0.1 & 0.1 & 0.1 & 0.1 & 0.1 & 0.1 & 0.1 & 0.1 \\
\hline
\end{tabular}




\begin{tabular}{|c|c|c|c|c|c|c|c|c|c|c|c|c|c|c|c|c|c|c|c|c|c|c|c|c|c|c|}
\hline Schedule & $\begin{array}{c}\text { Through } \\
\text { (Date) }\end{array}$ & Day & 1 & 2 & 3 & 4 & 5 & 6 & 7 & 8 & 9 & 10 & 11 & 12 & 13 & 14 & 15 & 16 & 17 & 18 & 19 & 20 & 21 & 22 & 23 & 24 \\
\hline & & \begin{tabular}{|l} 
Other \\
\end{tabular} & 0.1 & 0.1 & 0.1 & 0.1 & 0.1 & 0.1 & 0.1 & 0.1 & \begin{tabular}{|l|}
0.1 \\
\end{tabular} & 0.1 & \begin{tabular}{|l|}
0.1 \\
\end{tabular} & \begin{tabular}{|l|}
0.1 \\
\end{tabular} & 0.1 & 0.1 & \begin{tabular}{|l|}
0.1 \\
\end{tabular} & 0.1 & \begin{tabular}{|l|}
0.1 \\
\end{tabular} & 0.1 & 0.1 & \begin{tabular}{|l|}
0.1 \\
\end{tabular} & 0.1 & 0.1 & \begin{tabular}{|l|}
0.1 \\
\end{tabular} & 0.1 \\
\hline \multirow[t]{6}{*}{ KITCHEN_GAS_EQUIP_SCH } & $6 / 30$ & WD, SummerDesign & 0.02 & 0.02 & 0.02 & 0.02 & 0.02 & 0.02 & 0.02 & 0.02 & 0.15 & 0.15 & 0.2 & \begin{tabular}{|l|l}
0.2 \\
\end{tabular} & 0.2 & 0.1 & \begin{tabular}{|l|}
0.1 \\
\end{tabular} & 0.02 & 0.02 & 0.02 & 0.02 & 0.02 & 0.02 & 0.02 & 0.02 & 0.02 \\
\hline & & Other & 0.02 & 0.02 & 0.02 & 0.02 & 0.02 & 0.02 & 0.02 & 0.02 & 0.02 & 0.02 & 0.02 & \begin{tabular}{|l|}
0.02 \\
\end{tabular} & 0.02 & 0.02 & 0.02 & 0.02 & 0.02 & 0.02 & 0.02 & 0.02 & 0.02 & 0.02 & 0.02 & 0.02 \\
\hline & $9 / 1$ & WD, SummerDesign & 0.02 & 0.02 & 0.02 & 0.02 & 0.02 & 0.02 & 0.02 & 0.02 & 0.1 & 0.1 & 0.15 & 0.15 & 0.15 & 0.1 & 0.1 & 0.02 & 0.02 & 0.02 & 0.02 & 0.02 & 0.02 & 0.02 & 0.02 & 0.02 \\
\hline & & Other & 0.02 & 0.02 & 0.02 & 0.02 & 0.02 & 0.02 & 0.02 & 0.02 & 0.02 & 0.02 & 0.02 & 0.02 & 0.02 & 0.02 & 0.02 & 0.02 & 0.02 & 0.02 & 0.02 & 0.02 & 0.02 & 0.02 & 0.02 & 0.02 \\
\hline & $12 / 31$ & WD, SummerDesign & 0.02 & 0.02 & 0.02 & 0.02 & 0.02 & 0.02 & 0.02 & 0.02 & 0.15 & 0.15 & 0.2 & \begin{tabular}{|l|l|}
0.2 \\
\end{tabular} & 0.2 & 0.1 & 0.1 & 0.02 & 0.02 & 0.02 & 0.02 & 0.02 & 0.02 & 0.02 & 0.02 & 0.02 \\
\hline & & Other & 0.02 & 0.02 & 0.02 & 0.02 & 0.02 & 0.02 & 0.02 & 0.02 & 0.02 & 0.02 & 0.02 & \begin{tabular}{|l|}
0.02 \\
\end{tabular} & 0.02 & 0.02 & 0.02 & 0.02 & 0.02 & 0.02 & 0.02 & 0.02 & 0.02 & 0.02 & 0.02 & 0.02 \\
\hline \multirow[t]{2}{*}{ Kitchen_Exhaust_SCH } & $12 / 31$ & WD, SummerDesign & 0 & 0 & 0 & 0 & 0 & 0 & 1 & 1 & 1 & 1 & 1 & 1 & 1 & 1 & 1 & 1 & 1 & 1 & 1 & 1 & 1 & 0 & 0 & 0 \\
\hline & & Other & 0 & 0 & 0 & 0 & 0 & 0 & 0 & 0 & 0 & 0 & 0 & 0 & 0 & 0 & 0 & 0 & 0 & 0 & 0 & 0 & 0 & 0 & 0 & 0 \\
\hline INFIL_SCH & $12 / 31$ & All & 1 & 1 & 1 & 1 & 1 & 1 & 1 & 0.5 & 0.5 & 0.5 & 0.5 & \begin{tabular}{|l|}
0.5 \\
\end{tabular} & 0.5 & 0.5 & 0.5 & 0.5 & 0.5 & 0.5 & 0.5 & 0.5 & 0.5 & 1 & 1 & 1 \\
\hline WORK_EFF_SCH & $12 / 31$ & All & 0 & 0 & 0 & 0 & 0 & 0 & 0 & 0 & 0 & 0 & 0 & 0 & 0 & 0 & 0 & 0 & 0 & 0 & 0 & 0 & 0 & 0 & 0 & 0 \\
\hline \multirow[t]{3}{*}{ CLOTHING_SCH } & $04 / 30$ & All & 1.1 & 1.1 & 1.1 & 1.1 & 1.1 & 1.1 & 1.1 & 1.1 & 1.1 & 1.1 & 1.1 & \begin{tabular}{|l|}
1.1 \\
\end{tabular} & 1.1 & 1.1 & 1.1 & 1.1 & 1.1 & 1.1 & 1.1 & 1.1 & 1.1 & 1.1 & 1.1 & 1.1 \\
\hline & $09 / 30$ & All & 0.6 & 0.6 & 0.6 & 0.6 & 0.6 & 0.6 & 0.6 & 0.6 & \begin{tabular}{|l|}
0.6 \\
\end{tabular} & 0.6 & \begin{tabular}{|l|}
0.6 \\
\end{tabular} & \begin{tabular}{|l|l|}
0.6 \\
\end{tabular} & 0.6 & 0.6 & \begin{tabular}{|l|}
0.6 \\
\end{tabular} & 0.6 & \begin{tabular}{|l|}
0.6 \\
\end{tabular} & 0.6 & 0.6 & \begin{tabular}{|l|}
0.6 \\
\end{tabular} & 0.6 & 0.6 & 0.6 & 0.6 \\
\hline & $12 / 31$ & All & 1.1 & 1.1 & 1.1 & 1.1 & 1.1 & 1.1 & 1.1 & 1.1 & \begin{tabular}{|l|l|}
1.1 \\
\end{tabular} & 1.1 & 1.1 & \begin{tabular}{|l|}
1.1 \\
\end{tabular} & 1.1 & 1.1 & \begin{tabular}{|l|}
1.1 \\
\end{tabular} & 1.1 & \begin{tabular}{|l|}
1.1 \\
\end{tabular} & 1.1 & 1.1 & \begin{tabular}{|l|}
1.1 \\
\end{tabular} & 1.1 & 1.1 & \begin{tabular}{|l|}
1.1 \\
\end{tabular} & 1.1 \\
\hline ACTIVITY_SCH & $12 / 31$ & All & 120 & 120 & 120 & 120 & 120 & 120 & 120 & 120 & 120 & 120 & 120 & 120 & 120 & 120 & 120 & 120 & 120 & 120 & 120 & 120 & 120 & 120 & 120 & 120 \\
\hline AIR_VELO_SCH & $12 / 31$ & All & 0.2 & 0.2 & 0.2 & 0.2 & 0.2 & 0.2 & 0.2 & 0.2 & \begin{tabular}{|l|}
0.2 \\
\end{tabular} & 0.2 & \begin{tabular}{|l|}
0.2 \\
\end{tabular} & \begin{tabular}{|l|}
0.2 \\
\end{tabular} & \begin{tabular}{|l|}
0.2 \\
\end{tabular} & 0.2 & \begin{tabular}{|l|}
0.2 \\
\end{tabular} & 0.2 & \begin{tabular}{|l|}
0.2 \\
\end{tabular} & 0.2 & 0.2 & \begin{tabular}{|l|}
0.2 \\
\end{tabular} & 0.2 & 0.2 & 0.2 & 0.2 \\
\hline \multirow[t]{9}{*}{ CLGSETP_SCH } & $6 / 30$ & SummerDesign & 24 & 24 & 24 & 24 & 24 & 24 & 24 & 24 & 24 & 24 & 24 & 24 & 24 & 24 & 24 & 24 & 24 & 24 & 24 & 24 & 24 & 24 & 24 & 24 \\
\hline & & \begin{tabular}{|l} 
WE, Hol, \\
WinterDesign
\end{tabular} & 27 & 27 & 27 & 27 & 27 & 27 & 27 & 27 & 27 & 27 & 27 & 27 & 27 & 27 & 27 & 27 & 27 & 27 & 27 & 27 & 27 & 27 & 27 & 27 \\
\hline & & \begin{tabular}{|l|} 
Other \\
\end{tabular} & 27 & 27 & 27 & 27 & 27 & 27 & 24 & 24 & 24 & 24 & 24 & 24 & 24 & 24 & 24 & 24 & 24 & 24 & 24 & 24 & 24 & 27 & 27 & 27 \\
\hline & $9 / 1$ & SummerDesign & 24 & 24 & 24 & 24 & 24 & 24 & 24 & 24 & 24 & 24 & 24 & 24 & 24 & 24 & 24 & 24 & 24 & 24 & 24 & 24 & 24 & 24 & 24 & 24 \\
\hline & & $\begin{array}{l}\text { WE, Hol, } \\
\text { WinterDesign }\end{array}$ & 27 & 27 & 27 & 27 & 27 & 27 & 27 & 27 & 27 & 27 & 27 & 27 & 27 & 27 & 27 & 27 & 27 & 27 & 27 & 27 & 27 & 27 & 27 & 27 \\
\hline & & \begin{tabular}{|l} 
Other \\
\end{tabular} & 27 & 27 & 27 & 27 & 27 & 27 & 27 & 24 & \begin{tabular}{|l|}
24 \\
\end{tabular} & 24 & 24 & \begin{tabular}{|l|}
24 \\
\end{tabular} & 24 & 24 & 24 & 24 & \begin{tabular}{|l|}
24 \\
\end{tabular} & 24 & 27 & \begin{tabular}{|l|}
27 \\
\end{tabular} & 27 & 27 & 27 & 27 \\
\hline & $12 / 31$ & SummerDesign & 24 & 24 & 24 & 24 & 24 & 24 & 24 & 24 & 24 & 24 & 24 & 24 & 24 & 24 & 24 & 24 & 24 & 24 & 24 & 24 & 24 & 24 & 24 & 24 \\
\hline & & $\begin{array}{l}\text { WE, Hol, } \\
\text { WinterDesign }\end{array}$ & 27 & 27 & 27 & 27 & 27 & 27 & 27 & 27 & 27 & 27 & 27 & 27 & 27 & 27 & 27 & 27 & 27 & 27 & 27 & 27 & 27 & 27 & 27 & 27 \\
\hline & & Other & 27 & 27 & 27 & 27 & 27 & 27 & 24 & 24 & 24 & 24 & 24 & 24 & 24 & 24 & 24 & 24 & 24 & 24 & 24 & 24 & 24 & 27 & 27 & 27 \\
\hline \multirow[t]{2}{*}{ CLGSETP_SCH_BathCorrMechKitchen } & $12 / 31$ & SummerDesign & 27 & 27 & 27 & 27 & 27 & 27 & 24 & 24 & 24 & 24 & 24 & 24 & 24 & 24 & 24 & 24 & 24 & 24 & 24 & 24 & 24 & 27 & 27 & 27 \\
\hline & & Other & 27 & 27 & 27 & 27 & 27 & 27 & 27 & 27 & 27 & 27 & 27 & 27 & 27 & 27 & 27 & 27 & 27 & 27 & 27 & 27 & 27 & 27 & 27 & 27 \\
\hline \multirow[t]{9}{*}{ HTGSETP_SCH } & $6 / 30$ & WinterDesign & 21 & 21 & 21 & 21 & 21 & 21 & 21 & 21 & 21 & 21 & 21 & 21 & 21 & 21 & 21 & 21 & 21 & 21 & 21 & $21 \mid$ & 21 & 21 & 21 & 21 \\
\hline & & \begin{tabular}{|l|} 
WE, Hol, \\
SummerDesign \\
\end{tabular} & 16 & 16 & 16 & 16 & 16 & 16 & 16 & 16 & 16 & 16 & 16 & 16 & 16 & 16 & 16 & 16 & 16 & 16 & 16 & 16 & 16 & 16 & 16 & 16 \\
\hline & & \begin{tabular}{|l} 
Other \\
\end{tabular} & 16 & 16 & 16 & 16 & 16 & 16 & 21 & 21 & 21 & 21 & 21 & \begin{tabular}{|l|}
21 \\
\end{tabular} & 21 & 21 & 21 & 21 & \begin{tabular}{|l|}
21 \\
\end{tabular} & 21 & 21 & \begin{tabular}{|l|}
21 \\
\end{tabular} & 21 & 16 & 16 & 16 \\
\hline & $9 / 1$ & WinterDesign & 21 & 21 & 21 & 21 & 21 & 21 & 21 & 21 & 21 & 21 & 21 & 21 & 21 & 21 & 21 & 21 & 21 & 21 & 21 & 21 & 21 & 21 & 21 & 21 \\
\hline & & \begin{tabular}{|l|} 
WE, Hol, \\
SummerDesign
\end{tabular} & 16 & 16 & 16 & 16 & 16 & 16 & 16 & 16 & 16 & 16 & 16 & 16 & 16 & 16 & 16 & 16 & 16 & 16 & 16 & 16 & 16 & 16 & 16 & 16 \\
\hline & & Other & 16 & 16 & 16 & 16 & 16 & 16 & 16 & 21 & 21 & 21 & 21 & 21 & 21 & 21 & 21 & 21 & 21 & 21 & 16 & 16 & 16 & 16 & 16 & 16 \\
\hline & $12 / 31$ & WinterDesign & 21 & 21 & 21 & 21 & 21 & 21 & 21 & 21 & 21 & 21 & 21 & \begin{tabular}{|l|}
21 \\
\end{tabular} & 21 & 21 & 21 & 21 & 21 & 21 & 21 & 21 & 21 & 21 & 21 & 21 \\
\hline & & \begin{tabular}{|l|} 
WE, Hol, \\
SummerDesign \\
\end{tabular} & 16 & 16 & 16 & 16 & 16 & 16 & 16 & 16 & 16 & 16 & 16 & 16 & 16 & 16 & 16 & 16 & 16 & 16 & 16 & 16 & 16 & 16 & 16 & 16 \\
\hline & & \begin{tabular}{|l} 
Other \\
\end{tabular} & 16 & 16 & 16 & 16 & 16 & 16 & 21 & 21 & 21 & 21 & 21 & \begin{tabular}{|l|}
21 \\
\end{tabular} & 21 & 21 & 21 & 21 & 21 & 21 & 21 & 21 & 21 & 16 & 16 & 16 \\
\hline \multirow[t]{2}{*}{ HTGSETP_SCH_BathCorrMechKitchen } & $12 / 31$ & WinterDesign & 16 & 16 & 16 & 16 & 16 & 16 & 21 & 21 & 21 & 21 & 21 & 21 & 21 & 21 & 21 & 21 & 21 & 21 & 21 & 21 & 21 & 16 & 16 & 16 \\
\hline & & Other & 16 & 16 & 16 & 16 & 16 & 16 & 16 & 16 & 16 & 16 & 16 & 16 & 16 & 16 & 16 & 16 & 16 & 16 & 16 & 16 & 16 & 16 & 16 & 16 \\
\hline \multirow[t]{2}{*}{ HVACOperationSchd } & $12 / 31$ & WD, SummerDesign & 0 & 0 & 0 & 0 & 0 & 0 & 1 & 1 & 1 & 1 & 1 & 1 & 1 & 1 & 1 & 1 & 1 & 1 & 1 & 1 & 1 & 0 & 0 & 0 \\
\hline & & Other & 0 & 0 & 0 & 0 & 0 & 0 & 0 & 0 & 0 & 0 & 0 & 0 & 0 & 0 & 0 & 0 & 0 & 0 & 0 & 0 & 0 & 0 & 0 & 0 \\
\hline
\end{tabular}




\begin{tabular}{|c|c|c|c|c|c|c|c|c|c|c|c|c|c|c|c|c|c|c|c|c|c|c|c|c|c|c|}
\hline Schedule & $\begin{array}{c}\text { Through } \\
\text { (Date) }\end{array}$ & Day & 1 & 2 & 3 & 4 & 5 & 6 & 7 & 8 & 9 & 10 & 11 & 12 & 13 & 14 & 15 & 16 & 17 & 18 & 19 & 20 & 21 & 22 & 23 & 24 \\
\hline MinOA_Sched & $12 / 31$ & WD, SummerDesign & 0 & 0 & 0 & 0 & 0 & 0 & 1 & 1 & 1 & 1 & 1 & 1 & 1 & 1 & 1 & 1 & 1 & 1 & 1 & 1 & 1 & 0 & 0 & 0 \\
\hline & & Other & 0 & 0 & 0 & 0 & 0 & 0 & 0 & 0 & 0 & 0 & 0 & 0 & 0 & 0 & 0 & 0 & 0 & 0 & 0 & 0 & 0 & 0 & 0 & 0 \\
\hline Seasonal-Reset-Supply-Air-Temp-Sch & $12 / 31$ & All & 12.8 & 12.8 & 12.8 & 12.8 & 12.8 & 12.8 & 12.8 & 12.8 & 12.8 & 12.8 & 12.8 & 12.8 & 12.8 & 12.8 & 12.8 & 12.8 & 12.8 & 12.8 & 12.8 & 12.8 & 12.8 & 12.8 & 12.8 & 12.8 \\
\hline Dual Zone Control Type Sched & $12 / 31$ & All & 4 & 4 & 4 & 4 & 4 & 4 & 4 & 4 & 4 & 4 & 4 & 4 & 4 & 4 & 4 & 4 & 4 & 4 & 4 & 4 & 4 & 4 & 4 & 4 \\
\hline HW-Loop-Temp-Schedule & $12 / 31$ & All & 67 & 67 & 67 & 67 & 67 & 67 & 67 & 67 & 67 & 67 & 67 & 67 & 67 & 67 & 67 & 67 & 67 & 67 & 67 & 67 & 67 & 67 & 67 & 67 \\
\hline PlantOnSched & $12 / 31$ & All & 1 & 1 & 1 & 1 & 1 & 1 & 1 & 1 & 1 & 1 & 1 & 1 & 1 & 1 & 1 & 1 & 1 & 1 & 1 & 1 & 1 & 1 & 1 & 1 \\
\hline $\begin{array}{l}\text { Kitchen_ZN_1_FLR_1_Case:1_WALKIN } \\
\text { FREEZER_CaseCreditReduxSched }\end{array}$ & $12 / 31$ & All & 0.2 & 0.2 & 0.2 & 0.2 & 0.2 & 0.2 & 0.2 & 0.4 & 0.4 & 0.4 & 0.4 & 0.4 & 0.4 & 0.4 & 0.4 & 0.4 & 0.4 & 0.4 & 0.4 & 0.4 & 0.4 & 0.2 & 0.2 & 0.2 \\
\hline $\begin{array}{l}\text { Kitchen_ZN_1_FLR_1_Case:1_WALKIN } \\
\text { FREEZER_CaseDefrost2aDaySched }\end{array}$ & $12 / 31$ & All & 0 & 0 & 0 & 0 & 0 & 0 & 0 & 0 & 0 & 0 & 0 & 0 & 0 & 0 & 0 & 0 & 0 & 0 & 0 & 0 & 0 & 0 & 0 & 0 \\
\hline $\begin{array}{l}\text { Kitchen_ZN_1_FLR_1_Case:1_WALKIN } \\
\text { FREEZER_CaseDripDown2aDaySched }\end{array}$ & $12 / 31$ & All & 0 & 0 & 0 & 0 & 0 & 0 & 0 & 0 & 0 & 0 & 0 & 0 & 0 & 0 & 0 & 0 & 0 & 0 & 0 & 0 & 0 & 0 & 0 & 0 \\
\hline $\begin{array}{l}\text { Kitchen_ZN_1_FLR_1_Case:1_WALKIN } \\
\text { FREEZER_WalkInStockingSched }\end{array}$ & $12 / 31$ & Tue, Fri & 0 & 0 & 0 & 0 & 725 & 417 & 290 & 0 & 0 & 0 & 0 & 0 & 0 & 0 & 0 & 0 & 0 & 0 & 0 & 0 & 0 & 0 & 0 & 0 \\
\hline & & \begin{tabular}{|l|} 
Other \\
\end{tabular} & 0 & 0 & 0 & 0 & 125 & 117 & 90 & 0 & 0 & 0 & 0 & 0 & 0 & 0 & 0 & 0 & 0 & 0 & 0 & 125 & 117 & 90 & 0 & 0 \\
\hline $\begin{array}{l}\text { Kitchen_ZN_1_FLR_1_Case:2_SELFCO } \\
\text { NTAINEDDISPLAYCASE_CaseStocking } \\
\text { Sched }\end{array}$ & $12 / 31$ & All & 0 & 0 & 0 & 0 & 0 & 0 & 50 & 70 & 70 & 80 & 70 & 50 & 50 & 80 & 90 & 80 & 0 & 0 & 0 & 0 & 0 & 0 & 0 & 0 \\
\hline BLDG_SWH_SCH & $6 / 30$ & WD, SummerDesign & 0.05 & 0.05 & 0.05 & 0.05 & 0.05 & 0.05 & 0.05 & 0.1 & 0.34 & 0.6 & 0.63 & 0.72 & 0.79 & 0.83 & 0.61 & 0.65 & 0.1 & \begin{tabular}{|l|}
0.1 \\
\end{tabular} & 0.19 & 0.25 & 0.22 & 0.22 & 0.12 & 0.09 \\
\hline & & Sat, WinterDesign & 0.03 & 0.03 & 0.03 & 0.03 & 0.03 & 0.03 & 0.03 & 0.03 & 0.03 & 0.05 & 0.05 & 0.05 & 0.05 & 0.03 & 0.03 & 0.03 & 0.03 & 0.03 & 0.03 & 0.03 & 0.03 & 0.03 & 0.03 & 0.03 \\
\hline & & Other & 0.03 & 0.03 & 0.03 & 0.03 & 0.03 & 0.03 & 0.03 & 0.03 & 0.05 & 0.05 & 0.05 & 0.05 & 0.05 & 0.05 & 0.03 & 0.03 & 0.03 & 0.03 & 0.03 & 0.03 & 0.03 & 0.03 & 0.03 & 0.03 \\
\hline & $9 / 1$ & WD, SummerDesign & 0.05 & 0.05 & 0.05 & 0.05 & 0.05 & 0.05 & 0.05 & 0.1 & 0.1 & 0.1 & 0.1 & 0.1 & 0.1 & 0.1 & 0.1 & 0.1 & 0.1 & 0.1 & 0.19 & 0.25 & 0.22 & 0.22 & 0.12 & 0.09 \\
\hline & & Sat, WinterDesign & 0.03 & 0.03 & 0.03 & 0.03 & 0.03 & 0.03 & 0.03 & 0.03 & 0.03 & 0.05 & 0.05 & 0.05 & 0.05 & 0.03 & 0.03 & 0.03 & 0.03 & 0.03 & 0.03 & 0.03 & 0.03 & 0.03 & 0.03 & 0.03 \\
\hline & & Other & 0.03 & 0.03 & 0.03 & 0.03 & 0.03 & 0.03 & 0.03 & 0.03 & 0.05 & 0.05 & 0.05 & 0.05 & 0.05 & 0.05 & 0.03 & 0.03 & 0.03 & 0.03 & 0.03 & 0.03 & 0.03 & 0.03 & 0.03 & 0.03 \\
\hline & $12 / 31$ & WD, SummerDesign & 0.05 & 0.05 & 0.05 & 0.05 & 0.05 & 0.05 & 0.05 & 0.1 & 0.34 & 0.6 & 0.63 & 0.72 & 0.79 & 0.83 & 0.61 & 0.65 & $\mid 0.1$ & \begin{tabular}{|l|}
0.1 \\
\end{tabular} & 0.19 & 0.25 & 0.22 & 0.22 & 0.12 & 0.09 \\
\hline & & Sat, WinterDesign & 0.03 & 0.03 & 0.03 & 0.03 & 0.03 & 0.03 & 0.03 & 0.03 & 0.03 & 0.05 & 0.05 & 0.05 & 0.05 & 0.03 & 0.03 & 0.03 & 0.03 & 0.03 & 0.03 & 0.03 & 0.03 & 0.03 & 0.03 & 0.03 \\
\hline & & Other & 0.03 & 0.03 & 0.03 & 0.03 & 0.03 & 0.03 & 0.03 & 0.03 & 0.05 & 0.05 & 0.05 & 0.05 & 0.05 & 0.05 & 0.03 & 0.03 & 0.03 & 0.03 & 0.03 & 0.03 & 0.03 & 0.03 & 0.03 & 0.03 \\
\hline SHW_default Latent fract sched & $12 / 31$ & All & 0.05 & 0.05 & 0.05 & 0.05 & 0.05 & 0.05 & 0.05 & 0.05 & 0.05 & 0.05 & 0.05 & 0.05 & 0.05 & 0.05 & 0.05 & 0.05 & 0.05 & 0.05 & 0.05 & 0.05 & 0.05 & 0.05 & 0.05 & 0.05 \\
\hline SHW_default Sensible fract sched & $12 / 31$ & All & 0.2 & 0.2 & 0.2 & 0.2 & 0.2 & 0.2 & 0.2 & 0.2 & 0.2 & 0.2 & 0.2 & 0.2 & 0.2 & 0.2 & 0.2 & 0.2 & 0.2 & 0.2 & 0.2 & 0.2 & 0.2 & 0.2 & 0.2 & 0.2 \\
\hline SHW_Bath Hot Supply Temp Sched & $12 / 31$ & All & 43.3 & 43.3 & 43.3 & 43.3 & 43.3 & 43.3 & 43.3 & 43.3 & 43.3 & 43.3 & 43.3 & 43.3 & 43.3 & 43.3 & 43.3 & 43.3 & 43.3 & 43.3 & 43.3 & 43.3 & 43.3 & 43.3 & 43.3 & 43.3 \\
\hline SHW_Bath Temp Sched & $12 / 31$ & All & 43.3 & 43.3 & 43.3 & 43.3 & 43.3 & 43.3 & 43.3 & 43.3 & 43.3 & 43.3 & 43.3 & 43.3 & 43.3 & 43.3 & 43.3 & 43.3 & 43.3 & 43.3 & 43.3 & 43.3 & 43.3 & 43.3 & 43.3 & 43.3 \\
\hline SHW_Kitchen Hot Supply Temp Sched & $12 / 31$ & All & 49 & 49 & 49 & 49 & 49 & 49 & 49 & 49 & 49 & 49 & 49 & 49 & 49 & 49 & 49 & 49 & 49 & 49 & 49 & 49 & 49 & 49 & 49 & 49 \\
\hline SHW_Kitchen Temp Sched & $12 / 31$ & All & 49 & 49 & 49 & 49 & 49 & 49 & 49 & 49 & 49 & 49 & 49 & 49 & 49 & 49 & 49 & 49 & 49 & 49 & 49 & 49 & 49 & 49 & 49 & 49 \\
\hline $\begin{array}{l}\text { SWHSys } 1 \text { Water Heater Ambient } \\
\text { Temperature Schedule Name }\end{array}$ & 1 & All & 22 & 22 & 22 & 22 & 22 & 22 & 22 & 22 & 22 & 22 & 22 & 22 & 22 & 22 & 22 & 22 & 22 & 22 & 22 & 22 & 22 & 22 & 22 & 22 \\
\hline $\begin{array}{l}\text { SWHSys1 Water Heater Setpoint } \\
\text { Temperature Schedule Name }\end{array}$ & $12 / 31$ & All & 60 & 60 & 60 & 60 & 60 & 60 & 60 & 60 & 60 & 60 & 60 & 60 & 60 & 60 & 60 & 60 & 60 & 60 & 60 & 60 & 60 & 60 & 60 & 60 \\
\hline SWHSys1-Loop-Temp-Schedule & $12 / 31$ & All & 60 & 60 & 60 & 60 & 60 & 60 & 60 & 60 & \begin{tabular}{|l|l|}
60 \\
\end{tabular} & 60 & 60 & \begin{tabular}{|l|}
60 \\
\end{tabular} & 60 & 60 & \begin{tabular}{|l|}
60 \\
\end{tabular} & 60 & 60 & 60 & 60 & 60 & 60 & 60 & 60 & 60 \\
\hline
\end{tabular}


Table B-9 Retail Hourly Operation Schedules

\begin{tabular}{|c|c|c|c|c|c|c|c|c|c|c|c|c|c|c|c|c|c|c|c|c|c|c|c|c|c|}
\hline Schedule & Day of Week & 1 & 2 & 3 & 4 & 5 & 6 & 7 & 8 & 9 & 10 & 11 & 12 & 13 & 14 & 15 & 16 & 17 & 18 & 19 & 20 & 21 & 22 & 23 & 24 \\
\hline ALWAYS_ON & All & 1 & 1 & 1 & 1 & 1 & 1 & 1 & 1 & 1 & 1 & 1 & 1 & 1 & 1 & 1 & 1 & 1 & 1 & 1 & 1 & 1 & 1 & 1 & 1 \\
\hline \multirow{5}{*}{ BLDG_EQUIP_SCH } & WD & 0.2 & 0.2 & 0.2 & 0.2 & 0.2 & 0.2 & 0.2 & 0.4 & 0.7 & 0.9 & 0.9 & 0.9 & 0.9 & 0.9 & 0.9 & 0.9 & 0.9 & 0.9 & 0.8 & 0.8 & 0.7 & 0.4 & 0.2 & 0.2 \\
\hline & Sat & 0.15 & 0.15 & 0.15 & 0.15 & 0.15 & 0.15 & 0.15 & 0.3 & 0.5 & 0.8 & 0.9 & 0.9 & 0.9 & 0.9 & 0.9 & 0.9 & 0.9 & 0.9 & 0.7 & 0.5 & 0.5 & 0.3 & 0.15 & 0.15 \\
\hline & SummerDesign & 1 & 1 & 1 & 1 & 1 & 1 & 1 & 1 & 1 & 1 & 1 & 1 & 1 & 1 & 1 & 1 & 1 & 1 & 1 & 1 & 1 & 1 & 1 & 1 \\
\hline & WinterDesign & 0 & 0 & 0 & 0 & 0 & 0 & 0 & 0 & 0 & 0 & 0 & 0 & 0 & 0 & 0 & 0 & 0 & 0 & 0 & 0 & 0 & 0 & 0 & 0 \\
\hline & Other & 0.15 & 0.15 & 0.15 & 0.15 & 0.15 & 0.15 & 0.15 & 0.15 & 0.3 & 0.3 & 0.6 & 0.6 & 0.8 & 0.8 & 0.8 & 0.8 & 0.8 & 0.6 & 0.4 & 0.15 & 0.15 & 0.15 & 0.15 & 0.15 \\
\hline \multirow[t]{5}{*}{ BLDG_LIGHT_SCH } & WD & 0.05 & 0.05 & 0.05 & 0.05 & 0.05 & 0.05 & 0.05 & 0.2 & 0.5 & 0.9 & 0.9 & 0.9 & 0.9 & 0.9 & 0.9 & 0.9 & 0.9 & 0.9 & 0.6 & 0.6 & 0.5 & 0.2 & 0.05 & 0.05 \\
\hline & Sat & 0.05 & 0.05 & 0.05 & 0.05 & 0.05 & 0.05 & 0.05 & 0.1 & 0.3 & 0.6 & 0.9 & 0.9 & 0.9 & 0.9 & 0.9 & 0.9 & 0.9 & 0.9 & 0.5 & 0.3 & 0.3 & 0.1 & 0.05 & 0.05 \\
\hline & SummerDesign & 1 & 1 & 1 & 1 & 1 & 1 & 1 & 1 & 1 & 1 & 1 & 1 & 1 & 1 & 1 & 1 & 1 & 1 & 1 & 1 & 1 & 1 & 1 & 1 \\
\hline & WinterDesign & 0 & 0 & 0 & 0 & 0 & 0 & 0 & 0 & 0 & 0 & 0 & 0 & 0 & 0 & 0 & 0 & 0 & 0 & 0 & 0 & 0 & 0 & 0 & 0 \\
\hline & Other & 0.05 & 0.05 & 0.05 & 0.05 & 0.05 & 0.05 & 0.05 & 0.05 & 0.1 & 0.1 & 0.4 & 0.4 & 0.6 & 0.6 & 0.6 & 0.6 & 0.6 & 0.4 & 0.2 & 0.05 & 0.05 & 0.05 & 0.05 & 0.05 \\
\hline \multirow[t]{4}{*}{ BLDG_OCC_SCH } & WD & 0 & 0 & 0 & 0 & 0 & 0 & 0 & 0.1 & 0.2 & 0.5 & 0.5 & 0.7 & 0.7 & 0.7 & 0.7 & 0.8 & 0.7 & 0.5 & 0.5 & 0.3 & 0.3 & 0 & 0 & 0 \\
\hline & $\begin{array}{l}\text { SummerDesign, } \\
\text { WinterDesign }\end{array}$ & 1 & 1 & 1 & 1 & 1 & 1 & 1 & 1 & 1 & 1 & 1 & 1 & 1 & 1 & 1 & 1 & 1 & 1 & 1 & 1 & 1 & 1 & 1 & 1 \\
\hline & Sat & 0 & 0 & 0 & 0 & 0 & 0 & 0 & 0.1 & 0.2 & 0.5 & 0.6 & 0.8 & 0.8 & 0.8 & 0.8 & 0.8 & 0.8 & 0.6 & 0.2 & 0.2 & 0.2 & 0.1 & 0 & 0 \\
\hline & Other & 0 & 0 & 0 & 0 & 0 & 0 & 0 & 0 & 0 & 0.1 & 0.2 & 0.2 & 0.4 & 0.4 & 0.4 & 0.4 & 0.4 & 0.2 & 0.1 & 0 & 0 & 0 & 0 & 0 \\
\hline \multirow[t]{4}{*}{ INFIL_HALF_ON_SCH } & WD, SummerDesign & 1 & 1 & 1 & 1 & 1 & 1 & 0.5 & 0.5 & 0.5 & 0.5 & 0.5 & 0.5 & 0.5 & 0.5 & 0.5 & 0.5 & 0.5 & 0.5 & 0.5 & 0.5 & 0.5 & 1 & 1 & 1 \\
\hline & Sat & 1 & 1 & 1 & 1 & 1 & 1 & 0.5 & 0.5 & 0.5 & 0.5 & 0.5 & 0.5 & 0.5 & 0.5 & 0.5 & 0.5 & 0.5 & 0.5 & 0.5 & 0.5 & 0.5 & 0.5 & 1 & 1 \\
\hline & WinterDesign & 1 & 1 & 1 & 1 & 1 & 1 & 1 & 1 & 1 & 1 & 1 & 1 & 1 & 1 & 1 & 1 & 1 & 1 & 1 & 1 & 1 & 1 & 1 & 1 \\
\hline & Other & 1 & 1 & 1 & 1 & 1 & 1 & 1 & 1 & 0.5 & 0.5 & 0.5 & 0.5 & 0.5 & 0.5 & 0.5 & 0.5 & 0.5 & 1 & 1 & 1 & 1 & 1 & 1 & 1 \\
\hline \multirow[t]{4}{*}{ INFIL_FRONT_SCH } & WD, SummerDesign & 0.25 & 0.25 & 0.25 & 0.25 & 0.25 & 0.25 & 1 & 1 & 1 & 1 & 1 & 1 & 1 & 1 & 1 & 1 & 1 & 1 & 1 & 1 & 1 & 0.25 & 0.25 & 0.25 \\
\hline & Sat & 0.25 & 0.25 & 0.25 & 0.25 & 0.25 & 0.25 & 1 & 1 & 1 & 1 & 1 & 1 & 1 & 1 & 1 & 1 & 1 & 1 & 1 & 1 & 1 & 1 & 0.25 & 0.25 \\
\hline & WinterDesign & 1 & 1 & 1 & 1 & 1 & 1 & 1 & 1 & 1 & 1 & 1 & 1 & 1 & 1 & 1 & 1 & 1 & 1 & 1 & 1 & 1 & 1 & 1 & 1 \\
\hline & Other & 0.25 & 0.25 & 0.25 & 0.25 & 0.25 & 0.25 & 0.25 & 0.25 & 1 & 1 & 1 & 1 & 1 & 1 & 1 & 1 & 1 & 0.25 & 0.25 & 0.25 & 0.25 & 0.25 & 0.25 & 0.25 \\
\hline WORK_EFF_SCH & All & 0 & 0 & 0 & 0 & 0 & 0 & 0 & 0 & 0 & 0 & 0 & 0 & 0 & 0 & 0 & 0 & 0 & 0 & 0 & 0 & 0 & 0 & 0 & 0 \\
\hline ACTIVITY_SCH & All & 120 & 120 & 120 & 120 & 120 & 120 & 120 & 120 & 120 & 120 & 120 & 120 & 120 & 120 & 120 & 120 & 120 & 120 & 120 & 120 & 120 & 120 & 120 & 120 \\
\hline AIR_VELO_SCH & All & 0.2 & 0.2 & 0.2 & 0.2 & 0.2 & 0.2 & 0.2 & 0.2 & 0.2 & 0.2 & 0.2 & 0.2 & 0.2 & 0.2 & 0.2 & 0.2 & 0.2 & 0.2 & 0.2 & 0.2 & 0.2 & 0.2 & 0.2 & 0.2 \\
\hline \multirow[t]{3}{*}{ CLOTHING_SCH } & All & 1 & 1 & 1 & 1 & 1 & 1 & 1 & 1 & 1 & 1 & 1 & 1 & 1 & 1 & 1 & 1 & 1 & 1 & 1 & 1 & 1 & 1 & 1 & 1 \\
\hline & All & 0.5 & 0.5 & 0.5 & 0.5 & 0.5 & 0.5 & 0.5 & 0.5 & 0.5 & 0.5 & 0.5 & 0.5 & 0.5 & 0.5 & 0.5 & 0.5 & 0.5 & 0.5 & 0.5 & 0.5 & 0.5 & 0.5 & 0.5 & 0.5 \\
\hline & All & 1 & 1 & 1 & 1 & 1 & 1 & 1 & 1 & 1 & 1 & 1 & 1 & 1 & 1 & 1 & 1 & 1 & 1 & 1 & 1 & 1 & 1 & 1 & 1 \\
\hline \multirow{4}{*}{ CLGSETP_SCH } & WD, SummerDesign & 30 & 30 & 30 & 30 & 30 & 30 & 24 & 24 & 24 & 24 & 24 & 24 & 24 & 24 & 24 & 24 & 24 & 24 & 24 & 24 & 24 & 30 & 30 & 30 \\
\hline & Sat & 30 & 30 & 30 & 30 & 30 & 30 & 24 & 24 & 24 & 24 & 24 & 24 & 24 & 24 & 24 & 24 & 24 & 24 & 24 & 24 & 24 & 24 & 30 & 30 \\
\hline & WinterDesign & 30 & 30 & 30 & 30 & 30 & 30 & 30 & 30 & 30 & 30 & 30 & 30 & 30 & 30 & 30 & 30 & 30 & 30 & 30 & 30 & 30 & 30 & 30 & 30 \\
\hline & Sun, Hol, Other & 30 & 30 & 30 & 30 & 30 & 30 & 30 & 30 & 24 & 24 & 24 & 24 & 24 & 24 & 24 & 24 & 24 & 24 & 24 & 30 & 30 & 30 & 30 & 30 \\
\hline Dual Zone Control Type Sched & All & 4 & 4 & 4 & 4 & 4 & 4 & 4 & 4 & 4 & 4 & 4 & 4 & 4 & 4 & 4 & 4 & 4 & 4 & 4 & 4 & 4 & 4 & 4 & 4 \\
\hline FRONT_ENTRY_COOLING & All & 90 & 90 & 90 & 90 & 90 & 90 & 90 & 90 & 90 & 90 & 90 & 90 & 90 & 90 & 90 & 90 & 90 & 90 & 90 & 90 & 90 & 90 & 90 & 90 \\
\hline \multirow[t]{5}{*}{ HTGSETP_SCH } & WD & 15.6 & 15.6 & 15.6 & 15.6 & 15.6 & 15.6 & 21 & 21 & 21 & 21 & 21 & 21 & 21 & 21 & 21 & 21 & 21 & 21 & 21 & 21 & 21 & 15.6 & 15.6 & 15.6 \\
\hline & SummerDesign & 15.6 & 15.6 & 15.6 & 15.6 & 15.6 & 15.6 & 15.6 & 15.6 & 15.6 & 15.6 & 15.6 & 15.6 & 15.6 & 15.6 & 15.6 & 15.6 & 15.6 & 15.6 & 15.6 & 15.6 & 15.6 & 15.6 & 15.6 & 15.6 \\
\hline & WinterDesign & 21 & 21 & 21 & 21 & 21 & 21 & 21 & 21 & 21 & 21 & 21 & 21 & 21 & 21 & 21 & 21 & 21 & 21 & 21 & 21 & 21 & 21 & 21 & 21 \\
\hline & Sat & 15.6 & 15.6 & 15.6 & 15.6 & 15.6 & 15.6 & 21 & 21 & 21 & 21 & 21 & 21 & 21 & 21 & 21 & 21 & 21 & 21 & 21 & 21 & 21 & 21 & 15.6 & 15.6 \\
\hline & Sun, Hol, Other & 15.6 & 15.6 & 15.6 & 15.6 & 15.6 & 15.6 & 15.6 & 15.6 & 21 & 21 & 21 & 21 & 21 & 21 & 21 & 21 & 21 & 21 & 21 & 15.6 & 15.6 & 15.6 & 15.6 & 15.6 \\
\hline \multirow[t]{3}{*}{ HVACOperationSchd } & WD, SummerDesign & 0 & 0 & 0 & 0 & 0 & 0 & 1 & 1 & 1 & 1 & 1 & 1 & 1 & 1 & 1 & 1 & 1 & 1 & 1 & 1 & 1 & 0 & 0 & 0 \\
\hline & Sat, WinterDesign & 0 & 0 & 0 & 0 & 0 & 0 & 1 & 1 & 1 & 1 & 1 & 1 & 1 & 1 & 1 & 1 & 1 & 1 & 1 & 1 & 1 & 1 & 0 & 0 \\
\hline & Other & 0 & 0 & 0 & 0 & 0 & 0 & 0 & 0 & 1 & 1 & 1 & 1 & 1 & 1 & 1 & 1 & 1 & 1 & 1 & 0 & 0 & 0 & 0 & 0 \\
\hline
\end{tabular}


Table B-10 Secondary School Hourly Operation Schedules

\begin{tabular}{|c|c|c|c|c|c|c|c|c|c|c|c|c|c|c|c|c|c|c|c|c|c|c|c|c|c|c|}
\hline Schedule & Through & Day & 1 & 2 & 3 & 4 & 5 & 6 & 7 & 8 & 9 & 10 & 11 & 12 & 13 & 14 & 15 & 16 & 17 & 18 & 19 & 20 & 21 & 22 & 23 & 24 \\
\hline ALWAYS_ON & $12 / 31$ & All & 11 & 1 & 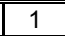 & 1 & 1 & 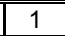 & 1 & 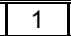 & 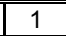 & 1 & 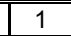 & 1 & 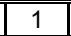 & 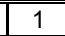 & 1 & 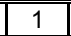 & 1 & 1 & 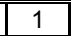 & 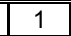 & 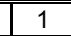 & 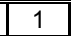 & 1 & 1 \\
\hline \multirow[t]{2}{*}{ Kitchen_Exhaust_SCH } & $12 / 31$ & WD, SummerDesign & 0 & 0 & 0 & 0 & 0 & 0 & 1 & 1 & 1 & 1 & 1 & 1 & 1 & 1 & 1 & 1 & 1 & 1 & 1 & 1 & 1 & 0 & 0 & 0 \\
\hline & & Other & 0 & 0 & 0 & 0 & 0 & 0 & 0 & 0 & 0 & 0 & 0 & 0 & 0 & 0 & 0 & 0 & 0 & 0 & 0 & 0 & 0 & 0 & 0 & 0 \\
\hline \multirow[t]{2}{*}{ BLDG_ELEVATORS } & $12 / 31$ & WD, SummerDesign & 0 & 0 & 0 & 0 & 0 & 0 & 0 & 0 & 0.3 & 0.3 & 0.3 & 0.3 & 0.3 & 0.3 & 0.3 & 0.15 & 0 & 0 & 0 & 0 & 0 & 0 & 0 & 0 \\
\hline & & Other & 0 & 0 & 0 & 0 & 0 & 0 & 0 & 0 & 0 & 0 & 0 & 0 & 0 & 0 & 0 & 0 & 0 & 0 & 0 & 0 & 0 & 0 & 0 & 0 \\
\hline \multirow{6}{*}{\begin{tabular}{|l|} 
BLDG_EQUIP_SCH \\
\end{tabular}} & $6 / 30$ & WD, SummerDesign & 0.35 & 0.35 & 0.35 & 0.35 & 0.35 & 0.35 & 0.35 & 0.35 & 0.95 & 0.95 & 0.95 & 0.95 & 0.95 & 0.95 & \begin{tabular}{|l|l|}
5 & 0.95 \\
\end{tabular} & 0.95 & 0.95 & 0.35 & 0.35 & 0.35 & 0.35 & 0.35 & 0.35 & 0.35 \\
\hline & & Other & 0.35 & 0.35 & 0.35 & 0.35 & 0.35 & 0.35 & 0.35 & 0.35 & 0.35 & 0.35 & 0.35 & 0.35 & 0.35 & 0.35 & \begin{tabular}{|l|l|}
5 & 0.35 \\
\end{tabular} & 0.35 & 0.35 & 0.35 & 0.35 & 0.35 & 0.35 & 0.35 & 0.35 & 0.35 \\
\hline & 9/1 & WD, SummerDesign & 0.25 & 0.25 & 0.25 & 0.25 & 0.25 & 0.25 & 0.25 & 0.25 & 0.5 & 0.5 & 0.5 & 0.5 & 0.5 & 0.5 & 0.5 & 0.5 & 0.5 & 0.25 & 0.25 & 0.25 & 0.25 & 0.25 & 0.25 & 0.25 \\
\hline & & Other & 0.25 & 0.25 & 0.25 & 0.25 & 0.25 & 0.25 & 0.25 & 0.25 & 0.25 & 0.25 & 0.25 & 0.25 & 0.25 & 0.25 & 0.25 & 0.25 & 0.25 & 0.25 & 0.25 & 0.25 & 0.25 & 0.25 & 0.25 & 0.25 \\
\hline & $12 / 31$ & WD, SummerDesign & 0.35 & 0.35 & 0.35 & 0.35 & 0.35 & 0.35 & 0.35 & 0.35 & 0.95 & 0.95 & 0.95 & 0.95 & 0.95 & 0.95 & 0.95 & 0.95 & 0.95 & 0.35 & 0.35 & 0.35 & 0.35 & 0.35 & 0.35 & 0.35 \\
\hline & & Other & 0.35 & 0.35 & 0.35 & 0.35 & 0.35 & 0.35 & 0.35 & 0.35 & 0.35 & 0.35 & 0.35 & 0.35 & 0.35 & 0.35 & \begin{tabular}{|l|l|}
5 & 0.35 \\
\end{tabular} & 0.35 & 0.35 & 0.35 & 0.35 & 0.35 & 0.35 & 0.35 & 0.35 & 0.35 \\
\hline \multirow[t]{6}{*}{ BLDG_LIGHT_SCH } & $6 / 30$ & WD, SummerDesign & 0.18 & 0.18 & 0.18 & 0.18 & 0.18 & 0.18 & 0.18 & 0.9 & 0.9 & 0.9 & 0.9 & 0.9 & 0.9 & 0.9 & 0.9 & 0.9 & 0.9 & 0.9 & 0.9 & 0.9 & 0.9 & 0.18 & 0.18 & 0.18 \\
\hline & & Other & 0.18 & 0.18 & 0.18 & 0.18 & 0.18 & 0.18 & 0.18 & 0.18 & 0.18 & 0.18 & 0.18 & 0.18 & 0.18 & 0.18 & \begin{tabular}{|l|l|}
3 & 0.18 \\
\end{tabular} & 0.18 & 0.18 & 0.18 & 0.18 & 0.18 & 0.18 & 0.18 & 0.18 & 0.18 \\
\hline & 9/1 & WD, SummerDesign & 0.18 & 0.18 & 0.18 & 0.18 & 0.18 & 0.18 & 0.18 & 0.18 & 0.5 & 0.5 & 0.5 & 0.5 & 0.5 & 0.5 & 0.5 & 0.5 & 0.5 & 0.5 & 0.5 & 0.5 & 0.18 & 0.18 & 0.18 & 0.18 \\
\hline & & Other & 0.18 & 0.18 & 0.18 & 0.18 & 0.18 & 0.18 & 0.18 & 0.18 & 0.18 & 0.18 & 0.18 & 0.18 & 0.18 & 0.18 & \begin{tabular}{l|l}
3 & 0.18 \\
\end{tabular} & 0.18 & 0.18 & 0.18 & 0.18 & 0.18 & 0.18 & 0.18 & 0.18 & 0.18 \\
\hline & $12 / 31$ & WD, SummerDesign & 0.18 & 0.18 & 0.18 & 0.18 & 0.18 & 0.18 & 0.18 & 0.9 & 0.9 & 0.9 & 0.9 & 0.9 & 0.9 & 0.9 & 0.9 & 0.9 & 0.9 & 0.9 & 0.9 & 0.9 & 0.9 & 0.18 & 0.18 & 0.18 \\
\hline & & Other & 0.18 & 0.18 & 0.18 & 0.18 & 0.18 & 0.18 & 0.18 & 0.18 & 0.18 & 0.18 & 0.18 & \begin{tabular}{|l|l|}
3 & 0.18 \\
\end{tabular} & 0.18 & 0.18 & \begin{tabular}{|l|l|}
3 & 0.18 \\
\end{tabular} & 0.18 & 0.18 & 0.18 & 0.18 & 0.18 & 0.18 & 0.18 & 0.18 & 0.18 \\
\hline \multirow[t]{6}{*}{ BLDG_OCC_SCH } & $6 / 30$ & WD, SummerDesign & 0 & 0 & 0 & 0 & 0 & 0 & 0 & 0 & 0.7 & \begin{tabular}{|l|}
0.7 \\
\end{tabular} & 0.7 & \begin{tabular}{|l|}
0.7 \\
\end{tabular} & 0.7 & 0.7 & 0.7 & \begin{tabular}{|l|}
0.7 \\
\end{tabular} & 0.15 & 0.15 & 0.15 & 0.15 & 0.15 & 0 & 0 & 0 \\
\hline & & Other & 0 & 0 & 0 & 0 & 0 & 0 & 0 & 0 & 0 & 0 & 0 & 0 & 0 & 0 & 0 & 0 & 0 & 0 & 0 & 0 & 0 & 0 & 0 & 0 \\
\hline & $9 / 1$ & WD, SummerDesign & 0 & 0 & 0 & 0 & 0 & 0 & 0 & 0 & 0.15 & 0.15 & 0.15 & 0.15 & 0.15 & 0.15 & 0.15 & 0.15 & 0.15 & 0.15 & 0.15 & 0.15 & 0.15 & 0 & 0 & 0 \\
\hline & & Other & 0 & 0 & 0 & 0 & 0 & 0 & 0 & 0 & 0 & 0 & 0 & 0 & 0 & 0 & 0 & 0 & 0 & 0 & 0 & 0 & 0 & 0 & 0 & 0 \\
\hline & $12 / 31$ & WD, SummerDesign & 0 & 0 & 0 & 0 & 0 & 0 & 0 & 0 & 0.7 & 0.7 & 0.7 & 0.7 & 0.7 & 0.7 & 0.7 & 0.7 & 0.15 & 0.15 & 0.15 & 0.15 & 0.15 & 0 & 0 & 0 \\
\hline & & Other & 0 & 0 & 0 & 0 & 0 & 0 & 0 & 0 & 0 & 0 & 0 & 0 & 0 & 0 & 0 & 0 & 0 & 0 & 0 & 0 & 0 & 0 & 0 & 0 \\
\hline \multirow{6}{*}{ BLDG_OCC_SCH_Auditorium } & $6 / 30$ & WD, SummerDesign & 0 & 0 & 0 & 0 & 0 & 0 & 0 & 0 & 0.25 & 0.25 & 0.25 & 0.25 & 0.25 & 0.25 & 0.25 & 0.95 & 0.95 & \begin{tabular}{|l|}
0.1 \\
\end{tabular} & 0.1 & 0.1 & 0 & 0 & 0 & 0 \\
\hline & & Other & 0 & 0 & 0 & 0 & 0 & 0 & 0 & 0 & 0 & 0 & 0 & 0 & 0 & 0 & 0 & 0 & 0 & 0 & 0 & 0 & 0 & 0 & 0 & 0 \\
\hline & $9 / 1$ & WD, SummerDesign & 0 & 0 & 0 & 0 & 0 & 0 & 0 & 0 & 0.15 & 0.15 & 0.15 & 0.15 & 0.15 & 0.15 & 0.15 & 0.15 & 0.15 & 0.35 & 0.35 & 0 & 0 & 0 & 0 & 0 \\
\hline & & Other & 0 & 0 & 0 & 0 & 0 & 0 & 0 & 0 & 0 & 0 & 0 & 0 & 0 & 0 & 0 & 0 & 0 & 0 & 0 & 0 & 0 & 0 & 0 & 0 \\
\hline & $12 / 31$ & WD, SummerDesign & 0 & 0 & 0 & 0 & 0 & 0 & 0 & 0 & 0.25 & 0.25 & 0.25 & 0.25 & 0.25 & 0.25 & 0.25 & 0.95 & 0.95 & \begin{tabular}{|l|}
0.1 \\
\end{tabular} & 0.1 & 0.1 & 0 & 0 & 0 & 0 \\
\hline & & Other & 0 & 0 & 0 & 0 & 0 & 0 & 0 & 0 & 0 & 0 & 0 & 0 & 0 & 0 & 0 & 0 & 0 & 0 & 0 & 0 & 0 & 0 & 0 & 0 \\
\hline \multirow[t]{6}{*}{ BLDG_OCC_SCH_Cafeteria } & $6 / 30$ & WD, SummerDesign & 0 & 0 & 0 & 0 & 0 & 0 & 0 & 0.15 & 0.15 & 0.05 & 0.05 & 0.95 & 0.95 & 0.15 & 0.15 & 0 & 0 & 0 & 0 & 0 & 0 & 0 & 0 & 0 \\
\hline & & Other & 0 & 0 & 0 & 0 & 0 & 0 & 0 & 0 & 0 & 0 & 0 & 0 & 0 & 0 & 0 & 0 & 0 & 0 & 0 & 0 & 0 & 0 & 0 & 0 \\
\hline & $9 / 1$ & WD, SummerDesign & 0 & 0 & 0 & 0 & 0 & 0 & 0 & 0 & 0 & 0.25 & 0.25 & 0.25 & 0.25 & 0.25 & 0.25 & 0 & 0 & 0 & 0 & 0 & 0 & 0 & 0 & 0 \\
\hline & & Other & 0 & 0 & 0 & 0 & 0 & 0 & 0 & 0 & 0 & 0 & 0 & 0 & 0 & 0 & 0 & 0 & 0 & 0 & 0 & 0 & 0 & 0 & 0 & 0 \\
\hline & $12 / 31$ & WD, SummerDesign & 0 & 0 & 0 & 0 & 0 & 0 & 0 & 0.15 & 0.15 & 0.05 & 0.05 & 0.95 & 0.95 & 0.15 & 0.15 & 0 & 0 & 0 & 0 & 0 & 0 & 0 & 0 & 0 \\
\hline & & Other & 0 & 0 & 0 & 0 & 0 & 0 & 0 & 0 & 0 & 0 & 0 & 0 & 0 & 0 & 0 & 0 & 0 & 0 & 0 & 0 & 0 & 0 & 0 & 0 \\
\hline \multirow[t]{6}{*}{ BLDG_OCC_SCH_Extend } & $6 / 30$ & WD, SummerDesign & 0 & 0 & 0 & 0 & 0 & 0 & 0 & 0 & 0.7 & \begin{tabular}{|l|}
0.7 \\
\end{tabular} & 0.7 & 0.7 & 0.7 & \begin{tabular}{|l|}
0.7 \\
\end{tabular} & 0.7 & 0.7 & 0.7 & 0.7 & 0.7 & 0.7 & 0.7 & 0 & 0 & 0 \\
\hline & & Other & 0 & 0 & 0 & 0 & 0 & 0 & 0 & 0 & 0 & 0 & 0 & 0 & 0 & 0 & 0 & 0 & 0 & 0 & 0 & 0 & 0 & 0 & 0 & 0 \\
\hline & 9/1 & WD, SummerDesign & 0 & 0 & 0 & 0 & 0 & 0 & 0 & 0 & 0.5 & 0.5 & 0.5 & 0.5 & 0.5 & 0.5 & 0.5 & 0.5 & 0.5 & 0.5 & 0.5 & 0.5 & 0.5 & 0 & 0 & 0 \\
\hline & & Other & 0 & 0 & 0 & 0 & 0 & 0 & 0 & 0 & 0 & 0 & 0 & 0 & 0 & 0 & 0 & 0 & 0 & 0 & 0 & 0 & 0 & 0 & 0 & 0 \\
\hline & $12 / 31$ & WD, SummerDesign & 0 & 0 & 0 & 0 & 0 & 0 & 0 & 0 & 0.7 & \begin{tabular}{|l|}
0.7 \\
\end{tabular} & 0.7 & 0.7 & 0.7 & \begin{tabular}{|l|}
0.7 \\
\end{tabular} & 0.7 & \begin{tabular}{|l|}
0.7 \\
\end{tabular} & 0.7 & \begin{tabular}{|l|l|}
0.7 & \\
\end{tabular} & 0.7 & 0.7 & 0.7 & 0 & 0 & 0 \\
\hline & & Other & 0 & 0 & 0 & 0 & 0 & 0 & 0 & 0 & 0 & 0 & 0 & 0 & 0 & 0 & 0 & 0 & 0 & 0 & 0 & 0 & 0 & 0 & 0 & 0 \\
\hline \multirow[t]{2}{*}{ BLDG_OCC_SCH_Gym } & $6 / 30$ & WD, SummerDesign & 0 & 0 & 0 & 0 & 0 & 0 & 0 & 0 & 0.35 & 0.35 & 0.35 & 0.35 & 0.35 & 0.35 & 0.35 & 0.35 & 0.95 & 0.95 & 0.95 & 0.95 & 0.95 & 0 & 0 & 0 \\
\hline & & Other & 0 & 0 & 0 & 0 & 0 & 0 & 0 & 0 & 0 & 0 & 0 & 0 & 0 & 0 & 0 & 0 & 0 & 0 & 0 & 0 & 0 & 0 & 0 & 0 \\
\hline
\end{tabular}




\begin{tabular}{|c|c|c|c|c|c|c|c|c|c|c|c|c|c|c|c|c|c|c|c|c|c|c|c|c|c|c|}
\hline Schedule & Through & Day & 1 & 2 & 3 & 4 & 5 & 6 & 7 & 8 & 9 & 10 & 11 & 12 & 13 & 14 & 15 & 16 & 17 & 18 & 19 & 20 & 21 & 22 & 23 & 24 \\
\hline & 9/1 & WD, SummerDesign & 0 & 0 & 0 & 0 & 0 & 0 & 0 & 0 & 0.35 & 0.35 & 0.35 & 0.35 & 0.35 & 0.35 & 0.35 & 0.35 & 0.35 & 0.35 & 0.35 & 0.35 & 0.35 & 0 & 0 & 0 \\
\hline & & Other & 0 & 0 & 0 & 0 & 0 & 0 & 0 & 0 & 0 & 0 & 0 & 0 & 0 & 0 & 0 & 0 & 0 & 0 & 0 & 0 & 0 & 0 & 0 & 0 \\
\hline & $12 / 31$ & WD, SummerDesign & 0 & 0 & 0 & 0 & 0 & 0 & 0 & 0 & 0.35 & 0.35 & 0.35 & 0.35 & 0.35 & 0.35 & 0.35 & 0.35 & 0.95 & 0.95 & 0.95 & 0.95 & 0.95 & 0 & 0 & 0 \\
\hline & & Other & 0 & 0 & 0 & 0 & 0 & 0 & 0 & 0 & 0 & 0 & 0 & 0 & 0 & 0 & 0 & 0 & 0 & 0 & 0 & 0 & 0 & 0 & 0 & 0 \\
\hline \multirow[t]{6}{*}{ BLDG_OCC_SCH_Offices } & $6 / 30$ & WD, SummerDesign & 0 & 0 & 0 & 0 & 0 & 0 & 0 & 0 & 0.95 & 0.95 & 0.95 & 0.95 & 0.95 & 0.95 & 0.95 & 0.95 & 0.95 & 0.15 & 0.15 & 0.15 & 0.15 & 0 & 0 & 0 \\
\hline & & Other & 0 & 0 & 0 & 0 & 0 & 0 & 0 & 0 & 0 & 0 & 0 & 0 & 0 & 0 & 0 & 0 & 0 & 0 & 0 & 0 & 0 & 0 & 0 & 0 \\
\hline & $9 / 1$ & WD, SummerDesign & 0 & 0 & 0 & 0 & 0 & 0 & 0 & 0 & 0.5 & 0.5 & \begin{tabular}{|l|l|}
0.5 \\
\end{tabular} & 0.5 & 0.5 & \begin{tabular}{|l|l|}
0.5 \\
\end{tabular} & 0.5 & 0.5 & \begin{tabular}{|l|l|}
0.5 \\
\end{tabular} & 0 & 0 & 0 & 0 & 0 & 0 & 0 \\
\hline & & Other & 0 & 0 & 0 & 0 & 0 & 0 & 0 & 0 & 0 & 0 & 0 & 0 & 0 & 0 & 0 & 0 & 0 & 0 & 0 & 0 & 0 & 0 & 0 & 0 \\
\hline & $12 / 31$ & WD, SummerDesign & 0 & 0 & 0 & 0 & 0 & 0 & 0 & 0 & 0.95 & 0.95 & 0.95 & 0.95 & 0.95 & 0.95 & 0.95 & 0.95 & 0.95 & 0.15 & 0.15 & 0.15 & 0.15 & 0 & 0 & 0 \\
\hline & & Other & 0 & 0 & 0 & 0 & 0 & 0 & 0 & 0 & 0 & 0 & 0 & 0 & 0 & 0 & 0 & 0 & 0 & 0 & 0 & 0 & 0 & 0 & 0 & 0 \\
\hline \multirow[t]{6}{*}{ KITCHEN_ELEC_EQUIP_SCH } & $6 / 30$ & WD, SummerDesign & 0.1 & \begin{tabular}{|l|l|}
0.1 \\
\end{tabular} & 0.1 & 0.1 & \begin{tabular}{|l|l|}
0.1 \\
\end{tabular} & 0.1 & \begin{tabular}{|l|l|}
0.1 \\
\end{tabular} & \begin{tabular}{|l|l|}
0.1 \\
\end{tabular} & 0.15 & 0.15 & 0.25 & 0.25 & 0.25 & 0.15 & 0.15 & 0.1 & \begin{tabular}{|l|}
0.1 \\
\end{tabular} & 0.1 & \begin{tabular}{|l|l|}
0.1 \\
\end{tabular} & 0.1 & 0.1 & 0.1 & 0.1 & 0.1 \\
\hline & & Other & 0.1 & \begin{tabular}{|l|l|}
0.1 \\
\end{tabular} & 0.1 & \begin{tabular}{l|l}
0.1 \\
\end{tabular} & \begin{tabular}{|l|l|}
0.1 \\
\end{tabular} & 0.1 & \begin{tabular}{|l|}
0.1 \\
\end{tabular} & \begin{tabular}{|l|l}
0.1 \\
\end{tabular} & 0.1 & \begin{tabular}{|l|}
0.1 \\
\end{tabular} & \begin{tabular}{|l|l|}
0.1 \\
\end{tabular} & 0.1 & 0.1 & \begin{tabular}{|l|l|}
0.1 \\
\end{tabular} & 0.1 & 0.1 & 0.1 & 0.1 & \begin{tabular}{|l|}
0.1 \\
\end{tabular} & 0.1 & 0.1 & 0.1 & 0.1 & 0.1 \\
\hline & 9/1 & WD, SummerDesign & 0.1 & \begin{tabular}{|l|}
0.1 \\
\end{tabular} & 0.1 & 0.1 & \begin{tabular}{|l|}
0.1 \\
\end{tabular} & 0.1 & \begin{tabular}{|l|}
0.1 \\
\end{tabular} & \begin{tabular}{|l|l}
0.1 \\
\end{tabular} & 0.13 & 0.13 & \begin{tabular}{|l|l|}
0.2 \\
\end{tabular} & 0.2 & 0.2 & 0.13 & 0.13 & 0.1 & 0.1 & 0.1 & \begin{tabular}{|l|l}
0.1 \\
\end{tabular} & 0.1 & 0.1 & 0.1 & 0.1 & 0.1 \\
\hline & & Other & 0.1 & \begin{tabular}{|l|l}
0.1 \\
\end{tabular} & 0.1 & 0.1 & \begin{tabular}{|l|}
0.1 \\
\end{tabular} & 0.1 & \begin{tabular}{|l|l}
0.1 \\
\end{tabular} & \begin{tabular}{|l|}
0.1 \\
\end{tabular} & 0.1 & 0.1 & \begin{tabular}{|l|}
0.1 \\
\end{tabular} & 0.1 & 0.1 & \begin{tabular}{|l|}
0.1 \\
\end{tabular} & 0.1 & 0.1 & 0.1 & 0.1 & 0.1 & 0.1 & 0.1 & 0.1 & 0.1 & 0.1 \\
\hline & $12 / 31$ & WD, SummerDesign & 0.1 & \begin{tabular}{|l|l|}
0.1 \\
\end{tabular} & 0.1 & \begin{tabular}{l|l}
0.1 \\
\end{tabular} & \begin{tabular}{|l|}
0.1 \\
\end{tabular} & 0.1 & \begin{tabular}{|l|}
0.1 \\
\end{tabular} & \begin{tabular}{|l|l}
0.1 \\
\end{tabular} & 0.15 & 0.15 & 0.25 & 0.25 & 0.25 & 0.15 & 0.15 & 0.1 & 0.1 & 0.1 & \begin{tabular}{|l|l|}
0.1 \\
\end{tabular} & 0.1 & 0.1 & 0.1 & 0.1 & 0.1 \\
\hline & & Other & 0.1 & \begin{tabular}{|l|l|}
0.1 \\
\end{tabular} & 0.1 & 0.1 & \begin{tabular}{|l|l|}
0.1 \\
\end{tabular} & 0.1 & \begin{tabular}{|l|l|}
0.1 \\
\end{tabular} & \begin{tabular}{|l|l|}
0.1 \\
\end{tabular} & 0.1 & \begin{tabular}{|l|}
0.1 \\
\end{tabular} & \begin{tabular}{|l|l|}
0.1 \\
\end{tabular} & 0.1 & \begin{tabular}{|l|}
0.1 \\
\end{tabular} & \begin{tabular}{|l|l|}
0.1 \\
\end{tabular} & 0.1 & 0.1 & 0.1 & 0.1 & \begin{tabular}{|l|l|}
0.1 \\
\end{tabular} & 0.1 & 0.1 & 0.1 & 0.1 & 0.1 \\
\hline \multirow[t]{6}{*}{ KITCHEN_GAS_EQUIP_SCH } & $6 / 30$ & WD, SummerDesign & 0.02 & 0.02 & 0.02 & 0.02 & 0.02 & 0.02 & 0.02 & 0.02 & 0.15 & 0.15 & 0.2 & 0.2 & 0.2 & 0.1 & 0.1 & 0.02 & 0.02 & 0.02 & 0.02 & 0.02 & 0.02 & 0.02 & 0.02 & 0.02 \\
\hline & & Other & 0.02 & 0.02 & 0.02 & 0.02 & 0.02 & 0.02 & 0.02 & 0.02 & 0.02 & 0.02 & 0.02 & 0.02 & 0.02 & 0.02 & 0.02 & 0.02 & 0.02 & 0.02 & 0.02 & 0.02 & 0.02 & 0.02 & 0.02 & 0.02 \\
\hline & 9/1 & WD, SummerDesign & 0.02 & 0.02 & 0.02 & 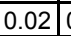 & \begin{tabular}{|l|}
0.02 \\
\end{tabular} & 0.02 & \begin{tabular}{|l|}
0.02 \\
\end{tabular} & 0.02 & 0.1 & 0.1 & 0.15 & 0.15 & 0.15 & 0.1 & 0.1 & 0.02 & 0.02 & 0.02 & 0.02 & 0.02 & 0.02 & 0.02 & 0.02 & 0.02 \\
\hline & & WE, WinterDesign, Hol, Other & 0.02 & 0.02 & 0.02 & 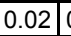 & 0.02 & 0.02 & 0.02 & 0.02 & 0.02 & 0.02 & 0.02 & 0.02 & 0.02 & 0.02 & 0.02 & 0.02 & 0.02 & 0.02 & 0.02 & 0.02 & 0.02 & 0.02 & 0.02 & 0.02 \\
\hline & $12 / 31$ & WD, SummerDesign & 0.02 & 0.02 & 0.02 & 0.02 & 0.02 & 0.02 & 0.02 & 0.02 & 0.15 & 0.15 & \begin{tabular}{|l|l|}
0.2 \\
\end{tabular} & 0.2 & 0.2 & \begin{tabular}{|l|}
0.1 \\
\end{tabular} & 0.1 & 0.02 & 0.02 & 0.02 & 0.02 & 0.02 & 0.02 & 0.02 & 0.02 & 0.02 \\
\hline & & WE, WinterDesign, Hol, Other & 0.02 & 0.02 & 0.02 & 0.02 & 0.02 & 0.02 & 0.02 & 0.02 & 0.02 & 0.02 & 0.02 & 0.02 & 0.02 & 0.02 & 0.02 & 0.02 & 0.02 & 0.02 & 0.02 & 0.02 & 0.02 & 0.02 & 0.02 & 0.02 \\
\hline INFIL_SCH & $12 / 31$ & All & 1 & 1 & 1 & 1 & 1 & 1 & 1 & \begin{tabular}{|l|l|}
0.5 \\
\end{tabular} & 0.5 & 0.5 & \begin{tabular}{|l|l}
0.5 \\
\end{tabular} & 0.5 & 0.5 & \begin{tabular}{|l|l|}
0.5 \\
\end{tabular} & 0.5 & 0.5 & 0.5 & 0.5 & \begin{tabular}{|l|l}
0.5 \\
\end{tabular} & 0.5 & 0.5 & 1 & 1 & 1 \\
\hline ACTIVITY_SCH & $12 / 31$ & All & 120 & \begin{tabular}{|l|l|}
120 \\
\end{tabular} & 120 & 120 & \begin{tabular}{|l|l|}
120 \\
\end{tabular} & 120 & \begin{tabular}{|l|l|}
120 \\
\end{tabular} & \begin{tabular}{|l|l|}
120 \\
\end{tabular} & 120 & 120 & 120 & 120 & 120 & 120 & 120 & 120 & 120 & 120 & 120 & 120 & 120 & 120 & 120 & 120 \\
\hline AIR_VELO_SCH & $12 / 31$ & All & 0.2 & 0.2 & 0.2 & 0.2 & \begin{tabular}{|l|l|}
0.2 \\
\end{tabular} & 0.2 & \begin{tabular}{|l|l|}
0.2 \\
\end{tabular} & \begin{tabular}{|l|l|}
0.2 \\
\end{tabular} & 0.2 & 0.2 & 0.2 & 0.2 & 0.2 & 0.2 & 0.2 & 0.2 & 0.2 & 0.2 & 0.2 & 0.2 & 0.2 & 0.2 & 0.2 & 0.2 \\
\hline \multirow[t]{3}{*}{ CLOTHING_SCH } & $04 / 30$ & All & 1.1 & \begin{tabular}{|l|}
1.1 \\
\end{tabular} & 1.1 & 1.1 & \begin{tabular}{|l|}
1.1 \\
\end{tabular} & 1.1 & \begin{tabular}{|l|}
1.1 \\
\end{tabular} & \begin{tabular}{|l|}
1.1 \\
\end{tabular} & 1.1 & 1.1 & \begin{tabular}{|l|l|}
1.1 \\
\end{tabular} & 1.1 & 1.1 & \begin{tabular}{|l|}
1.1 \\
\end{tabular} & 1.1 & 1.1 & 1.1 & 1.1 & \begin{tabular}{|l|l|}
1.1 \\
\end{tabular} & 1.1 & 1.1 & 1.1 & 1.1 & 1.1 \\
\hline & $09 / 30$ & All & 0.6 & \begin{tabular}{|l|l|}
0.6 \\
\end{tabular} & 0.6 & \begin{tabular}{l|l}
0.6 \\
\end{tabular} & \begin{tabular}{|l|l|}
0.6 \\
\end{tabular} & 0.6 & \begin{tabular}{|l|l|}
0.6 \\
\end{tabular} & \begin{tabular}{|l|l|}
0.6 \\
\end{tabular} & 0.6 & \begin{tabular}{|l|l|}
0.6 \\
\end{tabular} & \begin{tabular}{|l|l|}
0.6 \\
\end{tabular} & 0.6 & 0.6 & \begin{tabular}{|l|l|}
0.6 \\
\end{tabular} & 0.6 & 0.6 & \begin{tabular}{|l|}
0.6 \\
\end{tabular} & 0.6 & \begin{tabular}{|l|l|}
0.6 \\
\end{tabular} & 0.6 & 0.6 & 0.6 & 0.6 & 0.6 \\
\hline & $12 / 31$ & All & 1.1 & \begin{tabular}{|l|}
1.1 \\
\end{tabular} & 1.1 & 1.1 & 1.1 & 1.1 & 1.1 & 1.1 & 1.1 & 1.1 & \begin{tabular}{|l|}
1.1 \\
\end{tabular} & 1.1 & $\mid 1.1$ & 1.1 & 1.1 & 1.1 & 1.1 & 1.1 & \begin{tabular}{|l|}
1.1 \\
\end{tabular} & 1.1 & 1.1 & 1.1 & 1.1 & 1.1 \\
\hline WORK_EFF_SCH & $12 / 31$ & All & 0 & 0 & 0 & 0 & 0 & 0 & 0 & 0 & 0 & 0 & 0 & 0 & 0 & 0 & 0 & 0 & 0 & 0 & 0 & 0 & 0 & 0 & 0 & 0 \\
\hline \multirow[t]{9}{*}{ CLGSETP_SCH } & $6 / 30$ & \begin{tabular}{|l|} 
SummerDesign \\
\end{tabular} & 24 & 24 & 24 & 24 & 24 & 24 & \begin{tabular}{|l|}
24 \\
\end{tabular} & 24 & 24 & 24 & 24 & 24 & 24 & 24 & 24 & 24 & 24 & 24 & 24 & 24 & 24 & 24 & 24 & 24 \\
\hline & & WE, Hol, WinterDesign & 27 & \begin{tabular}{|l|}
27 \\
\end{tabular} & 27 & 27 & \begin{tabular}{|l|}
27 \\
\end{tabular} & 27 & \begin{tabular}{|l|l|}
27 & \\
\end{tabular} & \begin{tabular}{|l|}
27 \\
\end{tabular} & 27 & 27 & \begin{tabular}{|l|}
27 \\
\end{tabular} & 27 & 27 & 27 & 27 & 27 & 27 & 27 & \begin{tabular}{|l|}
27 \\
\end{tabular} & 27 & 27 & 27 & 27 & 27 \\
\hline & & Other & 27 & \begin{tabular}{|l|}
27 \\
\end{tabular} & 27 & 27 & \begin{tabular}{|l|}
27 \\
\end{tabular} & 27 & 24 & 24 & 24 & 24 & 24 & 24 & 24 & 24 & 24 & 24 & 24 & 24 & 24 & 24 & 24 & 27 & 27 & 27 \\
\hline & $9 / 1$ & \begin{tabular}{|l} 
SummerDesign \\
\end{tabular} & 24 & 24 & 24 & 24 & 24 & 24 & \begin{tabular}{|l|}
24 \\
\end{tabular} & 24 & 24 & 24 & 24 & 24 & 24 & 24 & 24 & 24 & 24 & 24 & 24 & 24 & 24 & 24 & 24 & 24 \\
\hline & & WE, Hol, WinterDesign & 27 & 27 & 27 & 27 & 27 & 27 & \begin{tabular}{|l|}
27 \\
\end{tabular} & 27 & 27 & 27 & 27 & 27 & 27 & 27 & 27 & 27 & 27 & 27 & 27 & 27 & 27 & 27 & 27 & 27 \\
\hline & & Other & 27 & 27 & 27 & 27 & 27 & 27 & \begin{tabular}{|l|}
27 \\
\end{tabular} & 24 & 24 & 24 & 24 & 24 & 24 & 24 & 24 & 24 & 24 & 24 & 27 & 27 & 27 & 27 & 27 & 27 \\
\hline & $12 / 31$ & \begin{tabular}{|l|} 
SummerDesign \\
\end{tabular} & 24 & 24 & 24 & 24 & 24 & 24 & 24 & 24 & 24 & 24 & 24 & 24 & 24 & 24 & 24 & 24 & 24 & 24 & 24 & 24 & 24 & 24 & 24 & 24 \\
\hline & & WE, Hol, WinterDesign & 27 & 27 & 27 & 27 & 27 & 27 & \begin{tabular}{|l|}
27 \\
\end{tabular} & 27 & 27 & 27 & 27 & 27 & 27 & 27 & 27 & 27 & 27 & 27 & 27 & 27 & 27 & 27 & 27 & 27 \\
\hline & & Other & 27 & 27 & 27 & 27 & \begin{tabular}{|l|l|}
27 \\
\end{tabular} & 27 & 24 & 24 & 24 & 24 & 24 & 24 & 24 & 24 & 24 & 24 & 24 & 24 & 24 & 24 & 24 & 27 & 27 & 27 \\
\hline \multirow[t]{2}{*}{ CLGSETP_SCH_BathCorrMechKitchen } & $12 / 31$ & \begin{tabular}{|l|} 
SummerDesign \\
\end{tabular} & 27 & 27 & 27 & 27 & 27 & 27 & 24 & 24 & 24 & 24 & 24 & 24 & 24 & 24 & 24 & 24 & 24 & 24 & 24 & 24 & 24 & 27 & 27 & 27 \\
\hline & & Other & 27 & 27 & 27 & 27 & \begin{tabular}{|l|}
27 \\
\end{tabular} & 27 & \begin{tabular}{|l|}
27 \\
\end{tabular} & 27 & 27 & 27 & \begin{tabular}{|l|}
27 \\
\end{tabular} & 27 & 27 & 27 & 27 & 27 & 27 & 27 & 27 & 27 & 27 & 27 & 27 & 27 \\
\hline \multirow[t]{6}{*}{ HTGSETP_SCH } & $6 / 30$ & WinterDesign & 21 & 21 & 21 & 21 & \begin{tabular}{|l|}
21 \\
\end{tabular} & 21 & 21 & 21 & 21 & 21 & 21 & 21 & 21 & 21 & 21 & 21 & 21 & 21 & 21 & 21 & 21 & 21 & 21 & 21 \\
\hline & & WE, Hol, SummerDesign & 16 & 16 & 16 & 16 & 16 & 16 & 16 & 16 & 16 & 16 & 16 & 16 & 16 & 16 & 16 & 16 & 16 & 16 & 16 & 16 & 16 & 16 & 16 & 16 \\
\hline & & Other & 16 & 16 & 16 & 16 & 16 & 16 & 21 & 21 & 21 & 21 & 21 & 21 & 21 & 21 & 21 & 21 & 21 & 21 & 21 & 21 & 21 & 16 & 16 & 16 \\
\hline & $9 / 1$ & WinterDesign & 21 & 21 & 21 & 21 & 21 & 21 & 21 & 21 & 21 & 21 & 21 & 21 & 21 & 21 & 21 & 21 & 21 & 21 & 21 & 21 & 21 & 21 & 21 & 21 \\
\hline & & WE, Hol, SummerDesign & 16 & 16 & 16 & 16 & 16 & 16 & 16 & 16 & 16 & 16 & 16 & 16 & 16 & 16 & 16 & 16 & 16 & 16 & 16 & 16 & 16 & 16 & 16 & 16 \\
\hline & & Other & 16 & 16 & \begin{tabular}{|l|}
16 \\
\end{tabular} & 16 & 16 & \begin{tabular}{|l|}
16 \\
\end{tabular} & 16 & 21 & 21 & 21 & 21 & 21 & 21 & \begin{tabular}{l|l}
21 \\
\end{tabular} & 21 & 21 & \begin{tabular}{l|l}
21 \\
\end{tabular} & 21 & 16 & 16 & 16 & 16 & 16 & 16 \\
\hline
\end{tabular}




\begin{tabular}{|c|c|c|c|c|c|c|c|c|c|c|c|c|c|c|c|c|c|c|c|c|c|c|c|c|c|c|}
\hline Schedule & Through & Day & 1 & 2 & 3 & 4 & 5 & 6 & 7 & 8 & 9 & 10 & 11 & 12 & 13 & 14 & 15 & 16 & 17 & 18 & 19 & 20 & 21 & 22 & 23 & 24 \\
\hline & $12 / 31$ & WinterDesign & 21 & 21 & 21 & \begin{tabular}{|l|}
21 \\
\end{tabular} & 21 & 21 & 21 & 21 & 21 & 21 & 21 & 21 & \begin{tabular}{|l|}
21 \\
\end{tabular} & 21 & 21 & 21 & 21 & 21 & 21 & 21 & 21 & 21 & 21 & 21 \\
\hline & & WE, Hol, SummerDesign & 16 & 16 & 16 & 16 & 16 & 16 & 16 & 16 & 16 & 16 & 16 & 16 & 16 & 16 & 16 & 16 & 16 & 16 & 16 & 16 & 16 & 16 & 16 & 16 \\
\hline & & Other & 16 & 16 & 16 & 16 & 16 & 16 & 21 & 21 & 21 & 21 & 21 & 21 & 21 & 21 & 21 & 21 & 21 & 21 & 21 & 21 & 21 & 16 & 16 & 16 \\
\hline \multirow[t]{2}{*}{ HTGSETP_SCH_BathCorrMechKitchen } & $12 / 31$ & WinterDesign & 16 & 16 & 16 & 16 & 16 & 16 & 21 & 21 & 21 & 21 & 21 & 21 & 21 & 21 & 21 & 21 & 21 & 21 & 21 & 21 & 21 & 16 & 16 & 16 \\
\hline & & Other & 16 & 16 & 16 & 16 & 16 & 16 & 16 & 16 & 16 & 16 & 16 & 16 & 16 & 16 & 16 & 16 & 16 & 16 & 16 & 16 & 16 & 16 & 16 & 16 \\
\hline \multirow[t]{2}{*}{ HVACOperationSchd } & $12 / 31$ & WD, SummerDesign & 0 & 0 & 0 & 0 & 0 & 0 & 1 & 1 & 1 & 1 & 1 & 1 & 1 & 1 & 1 & 1 & 1 & 1 & 1 & 1 & 1 & 0 & 0 & 0 \\
\hline & & Other & 0 & 0 & 0 & 0 & 0 & 0 & 0 & 0 & 0 & 0 & 0 & 0 & 0 & 0 & 0 & 0 & 0 & 0 & 0 & 0 & 0 & 0 & 0 & 0 \\
\hline \multirow[t]{2}{*}{ MinOA_Sched } & $12 / 31$ & WD, SummerDesign & 0 & 0 & 0 & 0 & 0 & 0 & 1 & 1 & 1 & 1 & 1 & 1 & 1 & 1 & 1 & 1 & 1 & 1 & 1 & 1 & 1 & 0 & 0 & 0 \\
\hline & & Other & 0 & 0 & 0 & 0 & 0 & 0 & 0 & 0 & 0 & 0 & 0 & 0 & 0 & 0 & 0 & 0 & 0 & 0 & 0 & 0 & 0 & 0 & 0 & 0 \\
\hline Seasonal-Reset-Supply-Air-Temp-Sch & $12 / 31$ & All & 12.8 & 12.8 & 12.8 & 12.8 & 12.8 & 12.8 & 12.8 & 12.8 & 12.8 & 12.8 & 12.8 & 12.8 & 12.8 & 12.8 & 12.8 & 12.8 & 12.8 & 12.8 & 12.8 & 12.8 & 12.8 & 12.8 & 12.8 & 12.8 \\
\hline Dual Zone Control Type Sched & $12 / 31$ & All & 4 & 4 & 4 & 4 & 4 & 4 & 4 & 4 & 4 & 4 & 4 & 4 & 4 & 4 & 4 & 4 & 4 & 4 & 4 & 4 & 4 & 4 & 4 & 4 \\
\hline CW-Loop-Temp-Schedule & $12 / 31$ & All & 6.7 & 6.7 & 6.7 & 6.7 & 6.7 & 6.7 & 6.7 & 6.7 & 6.7 & 6.7 & 6.7 & 6.7 & 6.7 & 6.7 & 6.7 & 6.7 & 6.7 & 6.7 & 6.7 & 6.7 & 6.7 & 6.7 & 6.7 & 6.7 \\
\hline HW-Loop-Temp-Schedule & $12 / 31$ & All & 67 & 67 & 67 & 67 & 67 & 67 & 67 & 67 & 67 & 67 & 67 & 67 & 67 & 67 & 67 & 67 & 67 & 67 & 67 & 67 & 67 & 67 & 67 & 67 \\
\hline PlantOnSched & $12 / 31$ & All & 1 & 1 & 1 & 1 & 1 & 1 & 1 & 1 & 1 & 1 & 1 & 1 & 1 & 1 & 1 & 1 & 1 & 1 & 1 & 1 & 1 & 1 & 1 & 1 \\
\hline $\begin{array}{l}\text { Kitchen_ZN_1_FLR_1_Case:1_WALKINFR } \\
\text { EEZER_CaseCreditReduxSched }\end{array}$ & $12 / 31$ & All & 0.2 & 0.2 & 0.2 & 0.2 & 0.2 & 0.2 & 0.2 & 0.4 & 0.4 & 0.4 & 0.4 & 0.4 & 0.4 & 0.4 & 0.4 & 0.4 & 0.4 & 0.4 & 0.4 & 0.4 & 0.4 & 0.2 & 0.2 & 0.2 \\
\hline $\begin{array}{l}\text { Kitchen_ZN_1_FLR_1_Case:1_WALKINFR } \\
\text { EEZER_CaseDefrost2aDaySched }\end{array}$ & $12 / 31$ & All & 0 & 0 & 0 & 0 & 0 & 0 & 0 & 0 & 0 & 0 & 0 & 0 & 0 & 0 & 0 & 0 & 0 & 0 & 0 & 0 & 0 & 0 & 0 & 0 \\
\hline $\begin{array}{l}\text { Kitchen_ZN_1_FLR_1_Case:1_WALKINFR } \\
\text { EEZER_CaseDripDown2aDaySched }\end{array}$ & $12 / 31$ & All & 0 & 0 & 0 & 0 & 0 & 0 & 0 & 0 & 0 & 0 & 0 & 0 & 0 & 0 & 0 & 0 & 0 & 0 & 0 & 0 & 0 & 0 & 0 & 0 \\
\hline \multirow[t]{2}{*}{$\begin{array}{l}\text { Kitchen_ZN_1_FLR_1_Case:1_WALKINFR } \\
\text { EEZER_WalkInStockingSched }\end{array}$} & $12 / 31$ & Tue, Fri & 0 & 0 & 0 & 0 & 725 & 417 & 290 & 0 & 0 & 0 & 0 & 0 & 0 & 0 & 0 & 0 & 0 & 0 & 0 & 0 & 0 & 0 & 0 & 0 \\
\hline & & Other & 0 & 0 & 0 & 0 & 125 & 117 & 90 & 0 & 0 & 0 & 0 & 0 & 0 & 0 & 0 & 0 & 0 & 0 & 0 & 125 & 117 & 90 & 0 & 0 \\
\hline $\begin{array}{l}\text { Kitchen_ZN_1_FLR_1_Case:2_SELFCONT } \\
\text { AINEDDISPLAYCASE_CaseStockingSched }\end{array}$ & $12 / 31$ & All & 0 & 0 & 0 & 0 & 0 & 0 & 50 & 70 & 70 & 80 & 70 & 50 & 50 & 80 & 90 & 80 & 0 & 0 & 0 & 0 & 0 & 0 & 0 & 0 \\
\hline \multirow[t]{9}{*}{ BLDG_SWH_SCH } & $6 / 15$ & WD, SummerDesign & 0.05 & 0.05 & 0.05 & 0.05 & 0.05 & 0.05 & 0.05 & 0.1 & 0.34 & 0.6 & 0.63 & 0.72 & 0.79 & 0.83 & 0.61 & 0.65 & 0.1 & 0.1 & 0.19 & 0.25 & 0.22 & 0.22 & 0.12 & 0.09 \\
\hline & & Sat, WinterDesign & 0.03 & 0.03 & 0.03 & 0.03 & 0.03 & 0.03 & 0.03 & 0.03 & 0.03 & 0.05 & 0.05 & 0.05 & 0.05 & 0.03 & 0.03 & 0.03 & 0.03 & 0.03 & 0.03 & 0.03 & 0.03 & 0.03 & 0.03 & 0.03 \\
\hline & & Sun, Hol, Other & 0.03 & 0.03 & 0.03 & 0.03 & 0.03 & 0.03 & 0.03 & 0.03 & 0.05 & 0.05 & 0.05 & 0.05 & 0.05 & 0.05 & 0.03 & 0.03 & 0.03 & 0.03 & 0.03 & 0.03 & 0.03 & 0.03 & 0.03 & 0.03 \\
\hline & 9/15 & WD, SummerDesign & 0.05 & 0.05 & 0.05 & 0.05 & 0.05 & 0.05 & 0.05 & 0.1 & 0.1 & 0.1 & 0.1 & 0.1 & 0.1 & 0.1 & 0.1 & 0.1 & 0.1 & 0.1 & 0.19 & 0.25 & 0.22 & 0.22 & 0.12 & 0.09 \\
\hline & & Sat, WinterDesign & 0.03 & 0.03 & 0.03 & 0.03 & 0.03 & 0.03 & 0.03 & 0.03 & 0.03 & 0.05 & 0.05 & 0.05 & 0.05 & 0.03 & 0.03 & 0.03 & 0.03 & 0.03 & 0.03 & 0.03 & 0.03 & 0.03 & 0.03 & 0.03 \\
\hline & & Sun, Hol, Other & 0.03 & 0.03 & 0.03 & 0.03 & 0.03 & 0.03 & 0.03 & 0.03 & 0.05 & 0.05 & 0.05 & 0.05 & 0.05 & 0.05 & 0.03 & 0.03 & 0.03 & 0.03 & 0.03 & 0.03 & 0.03 & 0.03 & 0.03 & 0.03 \\
\hline & $12 / 31$ & WD, SummerDesign & 0.05 & 0.05 & 0.05 & 0.05 & 0.05 & 0.05 & 0.05 & 0.1 & 0.34 & 0.6 & 0.63 & 0.72 & 0.79 & 0.83 & 0.61 & 0.65 & 0.1 & 0.1 & 0.19 & 0.25 & 0.22 & 0.22 & 0.12 & 0.09 \\
\hline & & Sat, WinterDesign & 0.03 & 0.03 & 0.03 & 0.03 & 0.03 & 0.03 & 0.03 & 0.03 & 0.03 & 0.05 & 0.05 & 0.05 & 0.05 & 0.03 & 0.03 & 0.03 & 0.03 & 0.03 & 0.03 & 0.03 & 0.03 & 0.03 & 0.03 & 0.03 \\
\hline & & Sun, Hol, Other & 0.03 & 0.03 & 0.03 & 0.03 & 0.03 & 0.03 & 0.03 & 0.03 & 0.05 & 0.05 & 0.05 & 0.05 & 0.05 & 0.05 & 0.03 & 0.03 & 0.03 & 0.03 & 0.03 & 0.03 & 0.03 & 0.03 & 0.03 & 0.03 \\
\hline \multirow{8}{*}{ Showers_SWH_SCH } & $6 / 30$ & WD, SummerDesign & 0 & 0 & 0 & 0 & 0 & 0 & 0 & 0.6 & 0.5 & 0.5 & 0.5 & 0.5 & 0.5 & 0.5 & 0.5 & 0.5 & 1 & 1 & 1 & 0 & 0 & 0 & 0 & 0 \\
\hline & & WE & 0 & 0 & 0 & 0 & 0 & 0 & 0 & 0 & 0 & 0 & 0.4 & 0.14 & 0.14 & 0.14 & 0.14 & 0.14 & 0 & 0 & 0 & 0 & 0 & 0.8 & 0 & 0 \\
\hline & & WinterDesign, Hol, Other & 0 & 0 & 0 & 0 & 0 & 0 & 0 & 0 & 0 & 0 & 0 & 0 & 0 & 0 & 0 & 0 & 0 & 0 & 0 & 0 & 0 & 0 & 0 & 0 \\
\hline & 9/1 & WD, SummerDesign & 0 & 0 & 0 & 0 & 0 & 0 & 0 & 0 & 0.3 & 0.1 & 0.1 & 0.1 & 0.1 & 0.1 & 0.1 & 0.1 & 0 & 0 & 0 & 0 & 0 & 0 & 0 & 0 \\
\hline & & WE, WinterDesign, Hol, Other & 0 & 0 & 0 & 0 & 0 & 0 & 0 & 0 & 0 & 0 & 0 & 0 & 0 & 0 & 0 & 0 & 0 & 0 & 0 & 0 & 0 & 0 & 0 & 0 \\
\hline & $12 / 31$ & WD, SummerDesign & 0 & 0 & 0 & 0 & 0 & 0 & 0 & 0.6 & 0.5 & 0.5 & 0.5 & 0.5 & 0.5 & 0.5 & 0.5 & 0.5 & 1 & 1 & 1 & 0 & 0 & 0 & 0 & 0 \\
\hline & & WE & 0 & 0 & 0 & 0 & 0 & 0 & 0 & 0 & 0 & 0 & 0.4 & 0.14 & 0.14 & 0.14 & 0.14 & 0.14 & 0 & 0 & 0 & 0 & 0 & 0.8 & 0 & 0 \\
\hline & & WinterDesign, Hol, Other & 0 & 0 & 0 & 0 & 0 & 0 & 0 & 0 & 0 & 0 & 0 & 0 & 0 & 0 & 0 & 0 & 0 & 0 & 0 & 0 & 0 & 0 & 0 & 0 \\
\hline Latent fract sched & $12 / 31$ & All & 0.05 & 0.05 & 0.05 & 0.05 & 0.05 & 0.05 & 0.05 & 0.05 & 0.05 & 0.05 & 0.05 & 0.05 & 0.05 & 0.05 & 0.05 & 0.05 & 0.05 & 0.05 & 0.05 & 0.05 & 0.05 & 0.05 & 0.05 & 0.05 \\
\hline Sensible fract sched & $12 / 31$ & All & 0.2 & 0.2 & 0.2 & 0.2 & 0.2 & 0.2 & 0.2 & 0.2 & 0.2 & 0.2 & 0.2 & 0.2 & 0.2 & 0.2 & 0.2 & 0.2 & 0.2 & 0.2 & 0.2 & 0.2 & 0.2 & 0.2 & 0.2 & 0.2 \\
\hline Hot Supply Temp Sched & $12 / 31$ & All & 43.3 & 43.3 & 43.3 & 43.3 & 43.3 & 43.3 & 43.3 & 43.3 & 43.3 & 43.3 & 43.3 & 43.3 & 43.3 & 43.3 & 43.3 & 43.3 & 43.3 & 43.3 & 43.3 & 43.3 & 43.3 & 43.3 & 43.3 & 43.3 \\
\hline SHW_default Temp Sched & $12 / 31$ & All & 43.3 & 43.3 & 43.3 & 43.3 & 43.3 & 43.3 & 43.3 & 43.3 & 43.3 & 43.3 & 43.3 & 43.3 & 43.3 & 43.3 & 43.3 & 43.3 & 43.3 & 43.3 & 43.3 & 43.3 & 43.3 & 43.3 & 43.3 & 43.3 \\
\hline Kitchen Hot Supply Temp Sched & $12 / 31$ & All & 49 & 49 & 49 & 49 & 49 & 49 & 49 & 49 & 49 & 49 & 49 & 49 & 49 & 49 & 49 & 49 & 49 & 49 & 49 & 49 & 49 & 49 & 49 & 49 \\
\hline
\end{tabular}


Schedule

\begin{tabular}{|l|c|l|l|}
\hline \multicolumn{1}{|c|}{ Schedule } & Through & \multicolumn{1}{c|}{ Day } & \\
\hline \hline SHW_Kitchen Temp Sched & $12 / 31$ & All & \\
\hline $\begin{array}{l}\text { SWHSys1 Water Heater Ambient } \\
\text { Temperature Schedule Name }\end{array}$ & $12 / 31$ & All & \\
\hline $\begin{array}{l}\text { SWHSys1 Water Heater Setpoint } \\
\text { Temperature Schedule Name }\end{array}$ & $12 / 31$ & All & \\
\hline SWHSys1-Loop-Temp-Schedule & $12 / 31$ & All & \\
\hline
\end{tabular}
\begin{tabular}{|c|c|c|c|c|c|c|c|c|c|c|c|c|c|c|c|c|c|c|c|c|c|c|c|}
\hline $\mathbf{1}$ & $\mathbf{2}$ & $\mathbf{3}$ & $\mathbf{4}$ & $\mathbf{5}$ & $\mathbf{6}$ & $\mathbf{7}$ & $\mathbf{8}$ & $\mathbf{9}$ & $\mathbf{1 0}$ & $\mathbf{1 1}$ & $\mathbf{1 2}$ & $\mathbf{1 3}$ & $\mathbf{1 4}$ & $\mathbf{1 5}$ & $\mathbf{1 6}$ & $\mathbf{1 7}$ & $\mathbf{1 8}$ & $\mathbf{1 9}$ & $\mathbf{2 0}$ & $\mathbf{2 1}$ & $\mathbf{2 2}$ & $\mathbf{2 3}$ & $\mathbf{2 4}$ \\
\hline 49 & 49 & 49 & 49 & 49 & 49 & 49 & 49 & 49 & 49 & 49 & 49 & 49 & 49 & 49 & 49 & 49 & 49 & 49 & 49 & 49 & 49 & 49 & 49 \\
\hline
\end{tabular} \begin{tabular}{|l|l|l|l|l|l|l|l|l|l|l|l|l|l|l|l|l|l|l|l|l|l|l|l}
22 & 22 & 22 & 22 & 22 & 22 & 22 & 22 & 22 & 22 & 22 & 22 & 22 & 22 & 22 & 22 & 22 & 22 & 22 & 22 & 22 & 22 & 22 & 22 \\
\hline
\end{tabular}

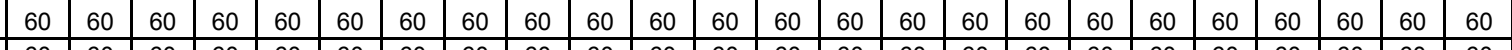

SWHSys1-Loop-Temp-Schedule 
Table B-11 Full Service Restaurant Hourly Operation Schedules

\begin{tabular}{|c|c|c|c|c|c|c|c|c|c|c|c|c|c|c|c|c|c|c|c|c|c|c|c|c|c|}
\hline Schedule & Day of Week & 1 & 2 & 3 & 4 & 5 & 6 & 7 & 8 & 9 & 10 & 11 & 12 & 13 & 14 & 15 & 16 & 17 & 18 & 19 & 20 & 21 & 22 & 23 & 24 \\
\hline ALWAYS_ON & All & 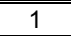 & 1 & 1 & 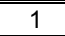 & 1 & 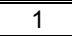 & 1 & 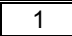 & 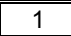 & 1 & 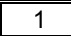 & 1 & 1 & 1 & 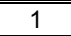 & 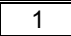 & 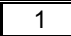 & 1 & 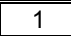 & 1 & 1 & 1 & 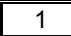 & 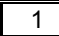 \\
\hline ACTIVITY_SCH & All & 120 & 120 & 120 & 120 & 120 & 120 & 120 & 120 & 120 & 120 & 120 & 120 & 120 & 120 & 120 & 120 & 120 & 120 & 120 & 120 & 120 & 120 & 120 & 120 \\
\hline AIR_VELO_SCH & All & 0.2 & 0.2 & 0.2 & 0.2 & 0.2 & \begin{tabular}{|l|}
0.2 \\
\end{tabular} & 0.2 & 0.2 & \begin{tabular}{|l|}
0.2 \\
\end{tabular} & 0.2 & 0.2 & \begin{tabular}{|l|}
0.2 \\
\end{tabular} & \begin{tabular}{|l|}
0.2 \\
\end{tabular} & 0.2 & 0.2 & 0.2 & 0.2 & 0.2 & \begin{tabular}{|l|}
0.2 \\
\end{tabular} & 0.2 & 0.2 & 0.2 & 0.2 & 0.2 \\
\hline \multirow[t]{5}{*}{ BLDG_EQUIP_SCH } & Weekday & 0.1 & \begin{tabular}{|l|}
0.1 \\
\end{tabular} & 0.1 & 0.1 & \begin{tabular}{|l|}
0.1 \\
\end{tabular} & \begin{tabular}{|l|}
0.1 \\
\end{tabular} & 0.25 & 0.35 & \begin{tabular}{|l|}
0.35 \\
\end{tabular} & 0.25 & 0.35 & \begin{tabular}{|l|}
0.35 \\
\end{tabular} & \begin{tabular}{|l|}
0.35 \\
\end{tabular} & 0.25 & 0.25 & \begin{tabular}{|l|}
0.25 \\
\end{tabular} & 0.35 & 0.35 & \begin{tabular}{|l|}
0.35 \\
\end{tabular} & 0.25 & 0.25 & 0.25 & 0.25 & 0.25 \\
\hline & Sat & 0.1 & 0.1 & 0.1 & 0.1 & 0.1 & 0.1 & 0.25 & 0.35 & 0.35 & 0.25 & 0.35 & 0.35 & 0.35 & 0.25 & 0.25 & 0.25 & 0.35 & 0.35 & 0.35 & 0.25 & 0.25 & 0.25 & 0.25 & 0.25 \\
\hline & SummerDesign & 0.35 & 0.35 & 0.35 & 0.35 & 0.35 & 0.35 & 0.35 & 0.35 & 0.35 & 0.35 & 0.35 & 0.35 & 0.35 & 0.35 & 0.35 & 0.35 & 0.35 & 0.35 & 0.35 & 0.35 & 0.35 & 0.35 & 0.35 & 0.35 \\
\hline & WinterDesign & 0 & 0 & 0 & 0 & 0 & 0 & 0 & 0 & 0 & 0 & 0 & 0 & 0 & 0 & 0 & 0 & 0 & 0 & 0 & 0 & 0 & 0 & 0 & 0 \\
\hline & \begin{tabular}{|l} 
Sun, $\mathrm{Hol}$, Other \\
\end{tabular} & 0.1 & \begin{tabular}{|l|}
0.1 \\
\end{tabular} & 0.1 & 0.1 & \begin{tabular}{|l|}
0.1 \\
\end{tabular} & \begin{tabular}{|l|}
0.1 \\
\end{tabular} & 0.25 & 0.35 & 0.35 & 0.25 & 0.35 & 0.35 & 0.35 & \begin{tabular}{|l|}
0.25 \\
\end{tabular} & 0.25 & 0.25 & \begin{tabular}{|l|}
0.35 \\
\end{tabular} & 0.35 & 0.35 & \begin{tabular}{|l|}
0.25 \\
\end{tabular} & \begin{tabular}{|l|}
0.25 \\
\end{tabular} & 0.25 & \begin{tabular}{|l|}
0.25 \\
\end{tabular} & 0.25 \\
\hline \multirow[t]{3}{*}{ BLDG_LIGHT_SCH } & SummerDesign & 1 & 1 & 1 & 1 & 1 & 1 & 1 & 1 & 1 & 1 & 1 & 1 & 1 & 1 & 1 & 1 & 1 & 1 & 1 & 1 & 1 & 1 & 1 & 1 \\
\hline & WinterDesign & 0 & 0 & 0 & 0 & 0 & 0 & 0 & 0 & 0 & 0 & 0 & 0 & 0 & 0 & 0 & 0 & 0 & 0 & 0 & 0 & 0 & 0 & 0 & 0 \\
\hline & $\begin{array}{l}\text { Weekday, Sat, } \\
\text { Sun, Hol, Other }\end{array}$ & 0.45 & 0.15 & 0.15 & 0.15 & 0.15 & 0.45 & 0.9 & 0.9 & 0.9 & 0.9 & 0.9 & 0.9 & 0.9 & 0.9 & 0.9 & 0.9 & 0.9 & 0.9 & 0.9 & 0.9 & 0.9 & 0.9 & 0.9 & 0.9 \\
\hline \multirow[t]{5}{*}{ BLDG_OCC_SCH } & WD & 0.05 & 0 & 0 & 0 & 0 & 0.05 & 0.1 & \begin{tabular}{|l|}
0.4 \\
\end{tabular} & \begin{tabular}{|l|}
0.4 \\
\end{tabular} & \begin{tabular}{|l|}
0.4 \\
\end{tabular} & 0.2 & \begin{tabular}{|l|}
0.5 \\
\end{tabular} & \begin{tabular}{|l|}
0.8 \\
\end{tabular} & 0.7 & 0.4 & \begin{tabular}{|l|}
0.2 \\
\end{tabular} & \begin{tabular}{|l|l|}
0.25 \\
\end{tabular} & \begin{tabular}{|l|}
0.5 \\
\end{tabular} & \begin{tabular}{|l|}
0.8 \\
\end{tabular} & 0.8 & 0.8 & 0.5 & \begin{tabular}{|l|l|}
0.35 \\
\end{tabular} & 0.2 \\
\hline & \begin{tabular}{|l} 
SummerDesign \\
\end{tabular} & 1 & 1 & 1 & 1 & 1 & 1 & 1 & 1 & 1 & 1 & 1 & 1 & 1 & 1 & 1 & 1 & 1 & 1 & 1 & 1 & 1 & 1 & 1 & 1 \\
\hline & WinterDesign & 0 & 0 & 0 & 0 & 0 & 0 & 0 & 0 & 0 & 0 & 0 & 0 & 0 & 0 & 0 & 0 & 0 & 0 & 0 & 0 & 0 & 0 & 0 & 0 \\
\hline & Sat & 0.05 & 0 & 0 & 0 & 0 & 0 & 0.05 & 0.5 & \begin{tabular}{|l|}
0.5 \\
\end{tabular} & \begin{tabular}{|l|}
0.4 \\
\end{tabular} & 0.2 & \begin{tabular}{|l|}
0.45 \\
\end{tabular} & \begin{tabular}{|l|}
0.5 \\
\end{tabular} & 0.5 & 0.35 & \begin{tabular}{|l|}
0.3 \\
\end{tabular} & 0.3 & 0.3 & \begin{tabular}{|l|}
0.7 \\
\end{tabular} & 0.9 & \begin{tabular}{|l|l|}
0.7 \\
\end{tabular} & 0.65 & 0.55 & 0.35 \\
\hline & Sun, Hol, Other & 0.05 & 0 & 0 & 0 & 0 & 0 & 0.05 & \begin{tabular}{|l|}
0.5 \\
\end{tabular} & \begin{tabular}{|l|}
0.5 \\
\end{tabular} & \begin{tabular}{|l|}
0.2 \\
\end{tabular} & 0.2 & \begin{tabular}{|l|}
0.3 \\
\end{tabular} & 0.5 & 0.5 & 0.3 & \begin{tabular}{|l|}
0.2 \\
\end{tabular} & 0.25 & 0.35 & 0.55 & 0.65 & \begin{tabular}{|l|l|}
0.7 \\
\end{tabular} & 0.35 & 0.2 & 0.2 \\
\hline \multirow[t]{3}{*}{ CLOTHING_SCH } & All & 1 & 1 & 1 & 1 & 1 & 1 & 1 & 1 & 1 & 1 & 1 & 1 & 1 & 1 & 1 & 1 & 1 & 1 & 1 & 1 & 1 & 1 & 1 & 1 \\
\hline & All & 0.5 & \begin{tabular}{|l|}
0.5 \\
\end{tabular} & 0.5 & 0.5 & 0.5 & \begin{tabular}{|l|}
0.5 \\
\end{tabular} & 0.5 & 0.5 & \begin{tabular}{|l|}
0.5 \\
\end{tabular} & \begin{tabular}{|l|}
0.5 \\
\end{tabular} & 0.5 & \begin{tabular}{|l|}
0.5 \\
\end{tabular} & \begin{tabular}{|l|}
0.5 \\
\end{tabular} & 0.5 & 0.5 & 0.5 & 0.5 & \begin{tabular}{|l|}
0.5 \\
\end{tabular} & 0.5 & 0.5 & 0.5 & 0.5 & 0.5 & 0.5 \\
\hline & All & 1 & 1 & 1 & 1 & 1 & 1 & 1 & 1 & 1 & 1 & 1 & 1 & 1 & 1 & 1 & 1 & 1 & 1 & 1 & 1 & 1 & 1 & 1 & 1 \\
\hline \multirow[t]{4}{*}{ GAS_EQUIP_SCH } & WD, Sat & 0.02 & \begin{tabular}{|l|}
0.02 \\
\end{tabular} & 0.02 & 0.02 & \begin{tabular}{|l|}
0.02 \\
\end{tabular} & \begin{tabular}{|l|}
0.05 \\
\end{tabular} & 0.1 & 0.15 & 0.2 & \begin{tabular}{|l|}
0.15 \\
\end{tabular} & 0.25 & \begin{tabular}{|l|}
0.25 \\
\end{tabular} & 0.25 & 0.2 & 0.15 & \begin{tabular}{|l|}
0.2 \\
\end{tabular} & 0.3 & 0.3 & 0.3 & 0.2 & 0.2 & 0.15 & 0.1 & 0.05 \\
\hline & SummerDesign & 0.25 & 0.25 & 0.25 & 0.25 & 0.25 & 0.25 & 0.25 & 0.25 & 0.25 & 0.25 & 0.25 & 0.25 & 0.25 & 0.25 & 0.25 & 0.25 & 0.25 & 0.25 & 0.25 & 0.25 & 0.25 & 0.25 & 0.25 & 0.25 \\
\hline & WinterDesign & 0 & 0 & 0 & 0 & 0 & 0 & 0 & 0 & 0 & 0 & 0 & 0 & 0 & 0 & 0 & 0 & 0 & 0 & 0 & 0 & 0 & 0 & 0 & 0 \\
\hline & Sun, Hol, Other & 0.02 & 0.02 & 0.02 & 0.02 & 0.02 & 0.05 & 0.1 & 0.15 & \begin{tabular}{|l|}
0.2 \\
\end{tabular} & 0.15 & 0.25 & 0.25 & 0.25 & \begin{tabular}{|l|}
0.2 \\
\end{tabular} & 0.15 & 0.2 & 0.3 & 0.3 & \begin{tabular}{|l|}
0.3 \\
\end{tabular} & 0.2 & \begin{tabular}{|l|}
0.2 \\
\end{tabular} & 0.15 & 0.1 & 0.05 \\
\hline Kitchen_Exhaust_SCH & All & 1 & 0 & 0 & 0 & 0 & 1 & 1 & 1 & 1 & 1 & 1 & 1 & 1 & 1 & 1 & 1 & 1 & 1 & 1 & 1 & 1 & 1 & 1 & 1 \\
\hline \multirow[t]{3}{*}{ INFIL_HALF_ON_SCH } & $\begin{array}{l}\text { WD, } \\
\text { SummerDesign }\end{array}$ & 1 & 1 & 1 & 1 & 1 & 0.5 & 0.5 & 0.5 & 0.5 & 0.5 & 0.5 & 0.5 & 0.5 & 0.5 & 0.5 & 0.5 & 0.5 & 0.5 & 0.5 & 0.5 & 0.5 & 0.5 & 0.5 & 0.5 \\
\hline & Sat, WinterDesign & 1 & 1 & 1 & 1 & 1 & 0.5 & 0.5 & 0.5 & \begin{tabular}{|l|}
0.5 \\
\end{tabular} & 0.5 & 0.5 & \begin{tabular}{|l|}
0.5 \\
\end{tabular} & 0.5 & 0.5 & 0.5 & 0.5 & 0.5 & 0.5 & \begin{tabular}{|l|}
0.5 \\
\end{tabular} & 0.5 & 0.5 & 0.5 & 0.5 & 0.5 \\
\hline & Sun, $\mathrm{Hol}$, Other & 1 & 1 & 1 & 1 & 1 & \begin{tabular}{|l|}
0.5 \\
\end{tabular} & 0.5 & \begin{tabular}{|l|}
0.5 \\
\end{tabular} & \begin{tabular}{|l|}
0.5 \\
\end{tabular} & 0.5 & 0.5 & \begin{tabular}{|l|}
0.5 \\
\end{tabular} & \begin{tabular}{|l|}
0.5 \\
\end{tabular} & \begin{tabular}{|l|}
0.5 \\
\end{tabular} & 0.5 & \begin{tabular}{|l|}
0.5 \\
\end{tabular} & 0.5 & 0.5 & \begin{tabular}{|l|}
0.5 \\
\end{tabular} & 0.5 & 0.5 & 0.5 & 0.5 & 0.5 \\
\hline WORK_EFF_SCH & All & 0 & 0 & 0 & 0 & 0 & 0 & 0 & 0 & 0 & 0 & 0 & 0 & 0 & 0 & 0 & 0 & 0 & 0 & 0 & 0 & 0 & 0 & 0 & 0 \\
\hline Dual Zone Control Type Sched & All & 4 & 4 & 4 & 4 & 4 & 4 & 4 & 4 & 4 & 4 & 4 & 4 & 4 & 4 & 4 & 4 & 4 & 4 & 4 & 4 & 4 & 4 & 4 & 4 \\
\hline \multirow[t]{2}{*}{ CLGSETP_KITCHEN_SCH } & WinterDesign & 30 & 30 & 30 & 30 & 30 & 30 & 30 & 30 & 30 & 30 & 30 & 30 & 30 & 30 & 30 & 30 & 30 & 30 & 30 & 30 & 30 & 30 & 30 & 30 \\
\hline & Other & 26 & 30 & 30 & 30 & 30 & 26 & 26 & 26 & 26 & 26 & 26 & 26 & 26 & 26 & 26 & 26 & 26 & 26 & 26 & 26 & 26 & 26 & 26 & 26 \\
\hline \multirow[t]{3}{*}{ HTGSETP_KITCHEN_SCH } & SummerDesign & 15.6 & 15.6 & 15.6 & 15.6 & 15.6 & 15.6 & 15.6 & 15.6 & 15.6 & 15.6 & 15.6 & 15.6 & 15.6 & 15.6 & 15.6 & 15.6 & 15.6 & 15.6 & 15.6 & 15.6 & 15.6 & 15.6 & 15.6 & 15.6 \\
\hline & WinterDesign & 19 & 19 & 19 & 19 & 19 & 19 & 19 & 19 & 19 & 19 & 19 & 19 & 19 & 19 & 19 & 19 & 19 & 19 & 19 & 19 & 19 & 19 & 19 & 19 \\
\hline & Other & 19 & 15.6 & 15.6 & 15.6 & 15.6 & 19 & 19 & 19 & 19 & 19 & 19 & 19 & 19 & 19 & 19 & 19 & 19 & 19 & 19 & 19 & 19 & 19 & 19 & 19 \\
\hline \multirow[t]{2}{*}{ CLGSETP_SCH } & WinterDesign & 30 & 30 & 30 & 30 & 30 & 30 & 30 & 30 & 30 & 30 & 30 & 30 & 30 & 30 & 30 & 30 & 30 & 30 & 30 & 30 & 30 & 30 & 30 & 30 \\
\hline & Other & 24 & 30 & 30 & 30 & 30 & 24 & 24 & 24 & 24 & 24 & 24 & 24 & 24 & 24 & 24 & 24 & 24 & 24 & 24 & 24 & 24 & 24 & 24 & 24 \\
\hline \multirow[t]{3}{*}{ HTGSETP_SCH } & SummerDesign & 15.6 & 15.6 & 15.6 & 15.6 & 15.6 & 15.6 & 15.6 & 15.6 & 15.6 & 15.6 & 15.6 & 15.6 & 15.6 & 15.6 & 15.6 & 15.6 & 15.6 & 15.6 & 15.6 & 15.6 & 15.6 & 15.6 & 15.6 & 15.6 \\
\hline & WinterDesign & 21 & 21 & 21 & 21 & 21 & 21 & 21 & 21 & 21 & 21 & 21 & 21 & 21 & 21 & 21 & 21 & 21 & 21 & 21 & 21 & 21 & 21 & 21 & 21 \\
\hline & Other & 21 & 15.6 & 15.6 & 15.6 & 15.6 & 21 & 21 & 21 & 21 & 21 & 21 & 21 & 21 & 21 & 21 & 21 & 21 & 21 & 21 & 21 & 21 & 21 & 21 & 21 \\
\hline HVACOperationSchd & All & 1 & 0 & 0 & 0 & 0 & 1 & 1 & 1 & 1 & 1 & 1 & 1 & 1 & 1 & 1 & 1 & 1 & 1 & 1 & 1 & 1 & 1 & 1 & 1 \\
\hline MinOA_Sched & All & 1 & 0 & 0 & 0 & 0 & 1 & 1 & 1 & 1 & 1 & 1 & 1 & 1 & 1 & 1 & 1 & 1 & 1 & 1 & 1 & 1 & 1 & 1 & 1 \\
\hline
\end{tabular}




\begin{tabular}{|c|c|c|c|c|c|c|c|c|c|c|c|c|c|c|c|c|c|c|c|c|c|c|c|c|c|}
\hline Schedule & Day of Week & 1 & 2 & 3 & 4 & 5 & 6 & 7 & 8 & 9 & 10 & 11 & 12 & 13 & 14 & 15 & 16 & 17 & 18 & 19 & 20 & 21 & 22 & 23 & 24 \\
\hline $\begin{array}{l}\text { Kitchen_Case:1_WALKINFREEZER_ } \\
\text { CaseCreditReduxSched }\end{array}$ & All & 0.2 & 0.2 & 0.2 & 0.2 & 0.2 & 0.2 & 0.2 & 0.4 & 0.4 & 0.4 & 0.4 & 0.4 & 0.4 & 0.4 & 0.4 & 0.4 & 0.4 & 0.4 & 0.4 & 0.4 & 0.4 & 0.2 & 0.2 & 0.2 \\
\hline $\begin{array}{l}\text { Kitchen_Case:1_WALKINFREEZER_ } \\
\text { CaseDefrost2aDaySched }\end{array}$ & All & 0 & 0 & 0 & 0 & 0 & 0 & 0 & 0 & 0 & 0 & 0 & 0 & 0 & 0 & 0 & 0 & 0 & 0 & 0 & 0 & 0 & 0 & 0 & 0 \\
\hline $\begin{array}{l}\text { Kitchen_Case:1_WALKINFREEZER_ } \\
\text { CaseDripDown2aDaySched }\end{array}$ & All & 0 & 0 & 0 & 0 & 0 & 0 & 0 & 0 & 0 & 0 & 0 & 0 & 0 & 0 & 0 & 0 & 0 & 0 & 0 & 0 & 0 & 0 & 0 & 0 \\
\hline $\begin{array}{l}\text { Kitchen_Case:1_WALKINFREEZER_ } \\
\text { WalkInStockingSched }\end{array}$ & Tue, Fri & 0 & 0 & 0 & 0 & 725 & 417 & 290 & 0 & 0 & 0 & 0 & 0 & 0 & 0 & 0 & 0 & 0 & 0 & 0 & 0 & 0 & 0 & 0 & 0 \\
\hline & Other & 0 & 0 & 0 & 0 & 125 & 117 & 90 & 0 & 0 & 0 & 0 & 0 & 0 & 0 & 0 & 0 & 0 & 0 & 0 & 125 & 117 & 90 & 0 & 0 \\
\hline $\begin{array}{l}\text { Kitchen_Case:2_SELFCONTAINEDDI } \\
\text { SPLAYCASE_CaseStockingSched }\end{array}$ & All & 0 & 0 & 0 & 0 & 0 & 0 & 50 & 70 & 70 & 80 & 70 & 50 & 50 & 80 & 90 & 80 & 0 & 0 & 0 & 0 & 0 & 0 & 0 & 0 \\
\hline BLDG_SWH_SCH & $\begin{array}{l}\text { WD, } \\
\text { SummerDesign }\end{array}$ & 0.2 & 0 & 0 & 0 & 0 & 0 & 0.15 & 0.6 & 0.55 & 0.45 & 0.4 & 0.45 & 0.4 & 0.35 & 0.3 & 0.3 & 0.3 & 0.4 & 0.55 & 0.6 & 0.5 & 0.55 & 0.45 & 0.25 \\
\hline & Sat, WinterDesign & 0.2 & 0 & 0 & 0 & 0 & 0 & 0.15 & 0.15 & 0.15 & 0.5 & 0.45 & 0.5 & 0.5 & 0.45 & 0.4 & 0.4 & 0.35 & \begin{tabular}{|l|}
0.4 \\
\end{tabular} & 0.55 & 0.55 & \begin{tabular}{|l|}
0.5 \\
\end{tabular} & 0.55 & \begin{tabular}{|l|}
0.4 \\
\end{tabular} & 0.3 \\
\hline & Sun, Hol, Other & 0.25 & 0 & 0 & 0 & 0 & 0 & 0.15 & 0.15 & 0.15 & 0.15 & 0.5 & 0.5 & 0.4 & 0.4 & 0.3 & 0.3 & 0.3 & 0.4 & 0.5 & 0.5 & 0.4 & 0.5 & 0.4 & 0.2 \\
\hline $\begin{array}{l}\text { Kitchen Water Equipment Hot Supply } \\
\text { Temp Sched }\end{array}$ & All & 49 & 49 & 49 & 49 & 49 & 49 & 49 & 49 & 49 & 49 & 49 & 49 & 49 & 49 & 49 & 49 & 49 & 49 & 49 & 49 & 49 & 49 & 49 & 49 \\
\hline $\begin{array}{l}\text { Kitchen Water Equipment Latent fract } \\
\text { sched }\end{array}$ & All & 0.05 & 0.05 & 0.05 & 0.05 & 0.05 & 0.05 & 0.05 & 0.05 & 0.05 & 0.05 & 0.05 & 0.05 & 0.05 & 0.05 & 0.05 & 0.05 & 0.05 & 0.05 & 0.05 & 0.05 & 0.05 & 0.05 & 0.05 & 0.05 \\
\hline $\begin{array}{l}\text { Kitchen Water Equipment Sensible } \\
\text { fract sched }\end{array}$ & All & 0.2 & 0.2 & 0.2 & 0.2 & 0.2 & 0.2 & 0.2 & 0.2 & 0.2 & 0.2 & 0.2 & 0.2 & 0.2 & 0.2 & 0.2 & 0.2 & 0.2 & 0.2 & 0.2 & 0.2 & 0.2 & 0.2 & 0.2 & 0.2 \\
\hline $\begin{array}{l}\text { Kitchen Water Equipment Temp } \\
\text { Sched }\end{array}$ & All & 49 & 49 & 49 & 49 & 49 & 49 & 49 & 49 & 49 & 49 & 49 & 49 & 49 & 49 & 49 & 49 & 49 & 49 & 49 & 49 & 49 & 49 & 49 & 49 \\
\hline PlantOnSched & All & 1 & 1 & 1 & 1 & 1 & 1 & 1 & 1 & 1 & 1 & 1 & 1 & 1 & 1 & 1 & 1 & 1 & 1 & 1 & 1 & 1 & 1 & 1 & 1 \\
\hline $\begin{array}{l}\text { SWHSys } 1 \text { Water Heater Ambient } \\
\text { Temperature Schedule Name }\end{array}$ & All & 22 & 22 & 22 & 22 & 22 & 22 & 22 & 22 & 22 & 22 & 22 & 22 & 22 & 22 & 22 & 22 & 22 & 22 & 22 & 22 & 22 & 22 & 22 & 22 \\
\hline $\begin{array}{l}\text { SWHSys } 1 \text { Water Heater Setpoint } \\
\text { Temperature Schedule Name }\end{array}$ & All & 60 & 60 & 60 & 60 & 60 & 60 & 60 & 60 & 60 & 60 & 60 & 60 & 60 & 60 & 60 & 60 & 60 & 60 & 60 & 60 & 60 & 60 & 60 & 60 \\
\hline SWHSys1-Loop-Temp-Schedule & All & 60 & 60 & 60 & 60 & 60 & 60 & 60 & 60 & 60 & 60 & 60 & 60 & 60 & 60 & 60 & 60 & 60 & 60 & 60 & 60 & 60 & 60 & 60 & 60 \\
\hline
\end{tabular}


Table B-12 Small Hotel Hourly Operation Schedules

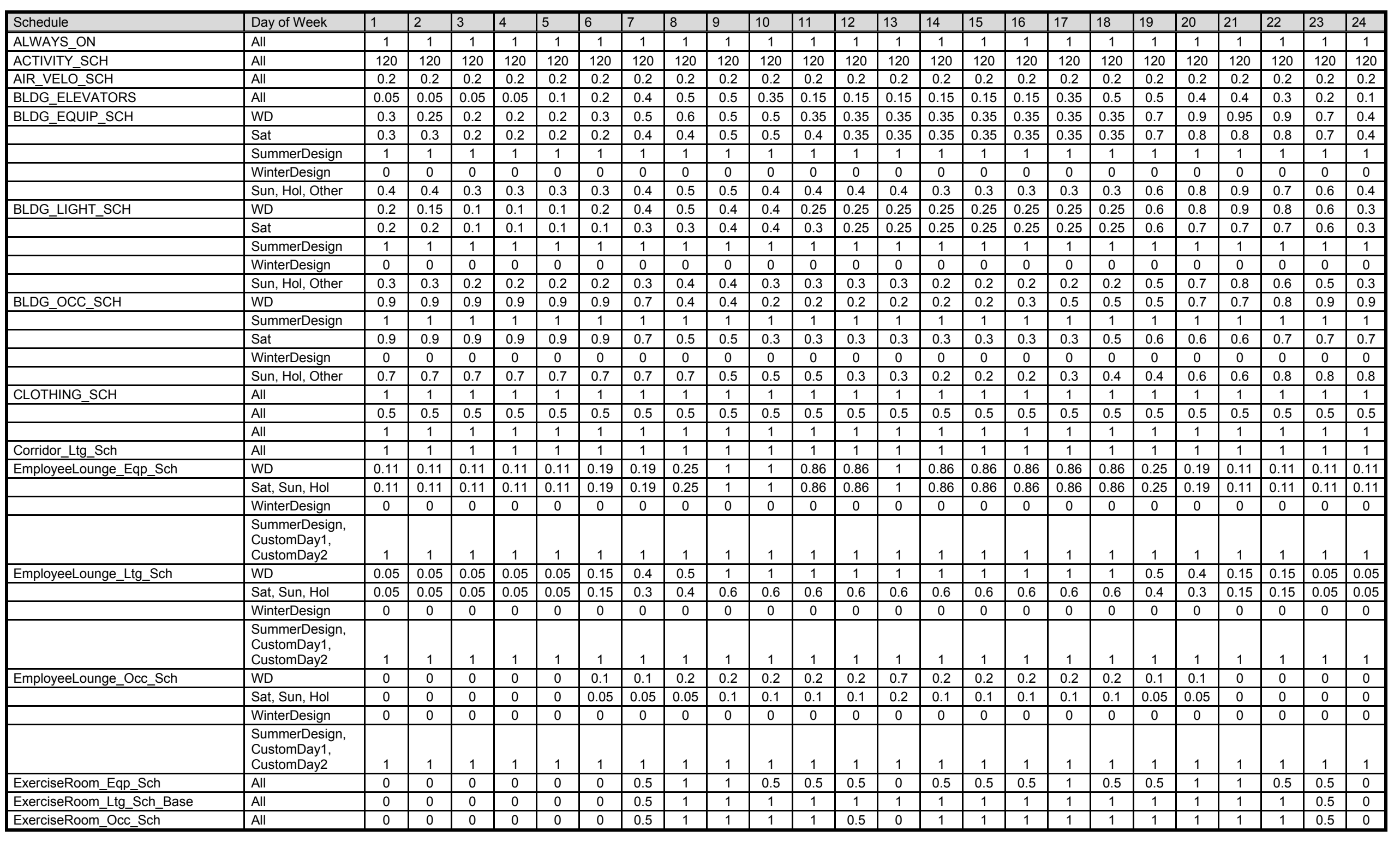




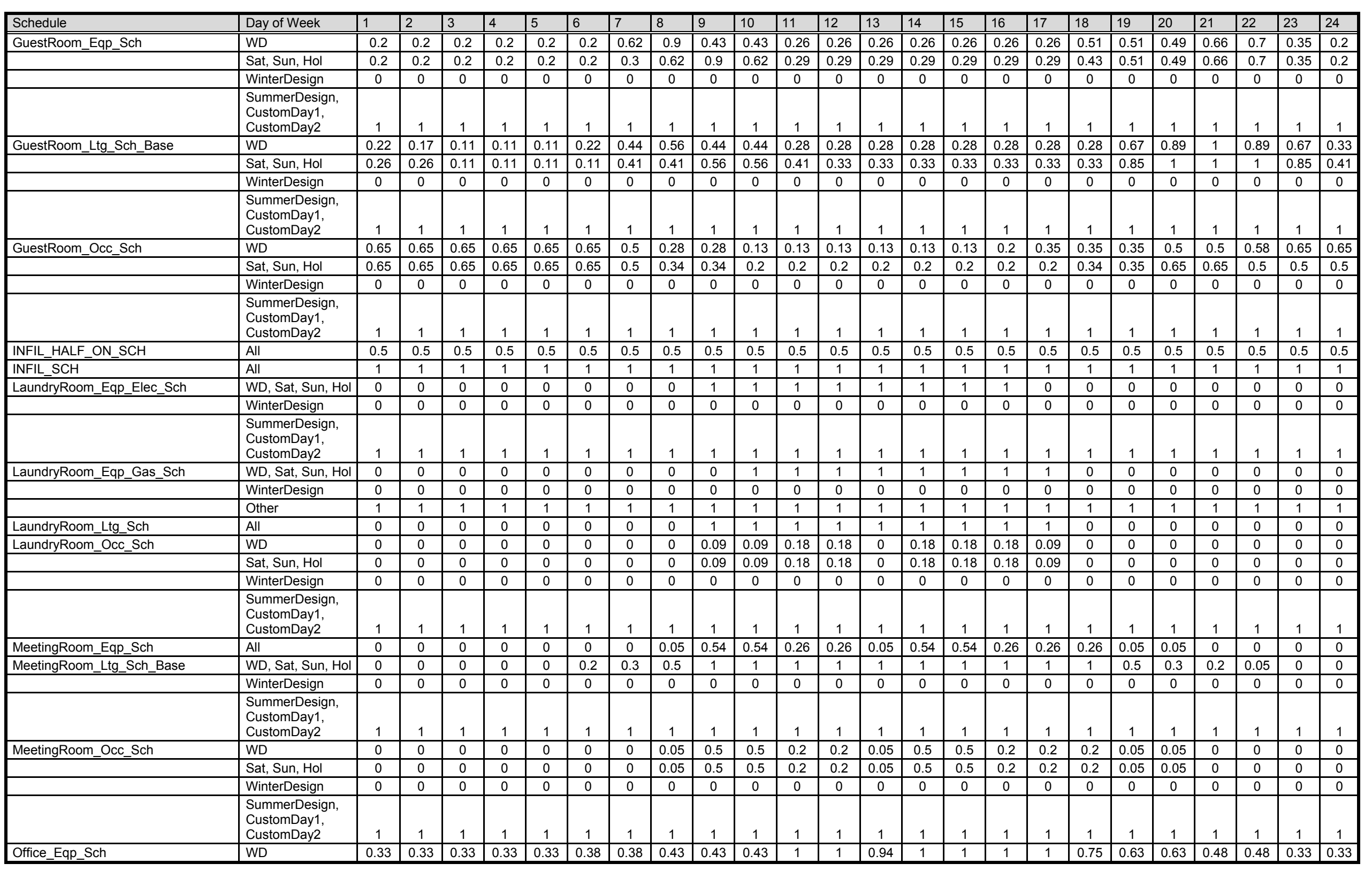




\begin{tabular}{|c|c|c|c|c|c|c|c|c|c|c|c|c|c|c|c|c|c|c|c|c|c|c|c|c|c|}
\hline Schedule & Day of Week & 1 & 2 & 3 & 4 & 5 & 6 & 7 & 8 & 9 & 10 & 11 & 12 & 13 & 14 & 15 & 16 & 17 & 18 & 19 & 20 & 21 & 22 & 23 & 24 \\
\hline & Sat, Sun, Hol & 0.33 & 0.33 & 0.33 & 0.33 & 0.33 & 0.38 & 0.38 & 0.43 & 0.63 & 0.63 & 0.63 & 0.63 & 0.63 & 0.63 & 0.63 & 0.63 & 0.63 & \begin{tabular}{|l|}
0.63 \\
\end{tabular} & 0.48 & 0.48 & 0.48 & 0.48 & 0.33 & 0.33 \\
\hline & \begin{tabular}{|l|} 
WinterDesign \\
\end{tabular} & 0 & 0 & 0 & 0 & 0 & 0 & 0 & 0 & 0 & 0 & 0 & 0 & 0 & 0 & 0 & 0 & 0 & 0 & 0 & 0 & 0 & 0 & 0 & 0 \\
\hline & $\begin{array}{l}\text { SummerDesign, } \\
\text { CustomDay1, } \\
\text { CustomDay2 }\end{array}$ & 1 & 1 & 1 & 1 & 1 & 1 & 1 & 1 & 1 & 1 & 1 & 1 & 1 & 1 & 1 & 1 & 1 & 1 & 1 & 1 & 1 & 1 & 1 & 1 \\
\hline \multirow[t]{3}{*}{ Office_Ltg_Sch_Base } & WD, Sat, Sun, $\mathrm{Hol}$ & 0.5 & 0.5 & 0.5 & 0.5 & 0.5 & 0.5 & 0.5 & 0.61 & 0.9 & 0.9 & 0.9 & 0.9 & 0.8 & 0.9 & 0.9 & 0.9 & 0.9 & \begin{tabular}{|l|}
0.61 \\
\end{tabular} & 0.5 & 0.5 & 0.5 & 0.5 & 0.5 & 0.5 \\
\hline & \begin{tabular}{|l|} 
WinterDesign \\
\end{tabular} & 0 & 0 & 0 & 0 & 0 & 0 & 0 & 0 & 0 & 0 & 0 & 0 & 0 & 0 & 0 & 0 & 0 & 0 & 0 & 0 & 0 & 0 & 0 & 0 \\
\hline & \begin{tabular}{|l} 
SummerDesign, \\
CustomDay1, \\
CustomDay2 \\
\end{tabular} & 1 & 1 & 1 & 1 & 1 & 1 & 1 & 1 & 1 & 1 & 1 & 1 & 1 & 1 & 1 & 1 & 1 & 1 & 1 & 1 & 1 & 1 & 1 & 1 \\
\hline \multirow{3}{*}{ Office_Occ_Sch } & Sat, Sun, $\mathrm{Hol}$ & 0.2 & 0.2 & 0.2 & 0.2 & 0.2 & 0.2 & 0.2 & 0.3 & 0.5 & 0.5 & 0.5 & 0.5 & 0.5 & 0.5 & 0.5 & 0.5 & 0.5 & 0.3 & 0.2 & 0.2 & 0.2 & 0.2 & 0.2 & \begin{tabular}{|l|}
0.2 \\
\end{tabular} \\
\hline & WinterDesign & 0 & 0 & 0 & 0 & 0 & 0 & 0 & 0 & 0 & 0 & 0 & 0 & 0 & 0 & 0 & 0 & 0 & 0 & 0 & 0 & 0 & 0 & 0 & 0 \\
\hline & $\begin{array}{l}\text { SummerDesign, } \\
\text { CustomDay1, } \\
\text { CustomDay2 }\end{array}$ & 1 & 1 & 1 & 1 & 1 & 1 & 1 & 1 & 1 & 1 & 1 & 1 & 1 & 1 & 1 & 1 & 1 & 1 & 1 & 1 & 1 & 1 & 1 & 1 \\
\hline \multirow[t]{4}{*}{ Storage_Ltg_Sch } & WD & 0.1 & 0.1 & 0.1 & 0.1 & 0.1 & 0.1 & 0.1 & 0.2 & 0.4 & 0.4 & 0.4 & 0.4 & 0.4 & 0.4 & 0.4 & 0.4 & 0.4 & 0.4 & 0.2 & 0.2 & 0.2 & 0.2 & 0.1 & \begin{tabular}{|l|}
0.1 \\
\end{tabular} \\
\hline & Sat, Sun, Hol & 0.1 & 0.1 & 0.1 & 0.1 & 0.1 & 0.1 & 0.1 & 0.2 & 0.4 & 0.4 & 0.4 & 0.4 & 0.4 & 0.4 & 0.4 & 0.4 & 0.4 & 0.4 & 0.2 & 0.2 & 0.2 & 0.2 & 0.1 & 0.1 \\
\hline & WinterDesign & 0 & 0 & 0 & 0 & 0 & 0 & 0 & 0 & 0 & 0 & 0 & 0 & 0 & 0 & 0 & 0 & 0 & 0 & 0 & 0 & 0 & 0 & 0 & 0 \\
\hline & \begin{tabular}{|l|} 
SummerDesign, \\
CustomDay1, \\
CustomDay2 \\
\end{tabular} & 1 & 1 & 1 & 1 & 1 & 1 & 1 & 1 & 1 & 1 & 1 & 1 & 1 & 1 & 1 & 1 & 1 & 1 & 1 & 1 & 1 & 1 & 1 & 1 \\
\hline WORK_EFF_SCH & All & 0 & 0 & 0 & 0 & 0 & 0 & 0 & 0 & 0 & 0 & 0 & 0 & 0 & 0 & 0 & 0 & 0 & 0 & 0 & 0 & 0 & 0 & 0 & 0 \\
\hline ALWAYS_OFF & All & 0 & 0 & 0 & 0 & 0 & 0 & 0 & 0 & 0 & 0 & 0 & 0 & 0 & 0 & 0 & 0 & 0 & 0 & 0 & 0 & 0 & 0 & 0 & 0 \\
\hline CLGSETP SCH & All & 24 & 24 & 24 & 24 & 24 & 24 & 24 & 24 & 24 & 24 & 24 & 24 & 24 & 24 & 24 & 24 & 24 & 24 & 24 & 24 & 24 & 24 & 24 & 24 \\
\hline Dual Zone Control Type Sched & All & 4 & 4 & 4 & 4 & 4 & 4 & 4 & 4 & 4 & 4 & 4 & 4 & 4 & 4 & 4 & 4 & 4 & 4 & 4 & 4 & 4 & 4 & 4 & 4 \\
\hline HTGSETP_SCH & All & 21 & 21 & 21 & 21 & 21 & 21 & 21 & 21 & 21 & 21 & 21 & 21 & 21 & 21 & 21 & 21 & 21 & 21 & 21 & 21 & 21 & 21 & 21 & 21 \\
\hline HVACOperationSchd & All & 1 & 1 & 1 & 1 & 1 & 1 & 1 & 1 & 1 & 1 & 1 & 1 & 1 & 1 & 1 & 1 & 1 & 1 & 1 & 1 & 1 & 1 & 1 & 1 \\
\hline MinOA_Sched & All & 1 & 1 & 1 & 1 & 1 & 1 & 1 & 1 & 1 & 1 & 1 & 1 & 1 & 1 & 1 & 1 & 1 & 1 & 1 & 1 & 1 & 1 & 1 & 1 \\
\hline UnitHeater_ClgSP_Sch & All & 40 & 40 & 40 & 40 & 40 & 40 & 40 & 40 & 40 & 40 & 40 & 40 & 40 & 40 & 40 & 40 & 40 & 40 & 40 & 40 & 40 & 40 & 40 & 40 \\
\hline UnitHeater_HtgSP_Sch & All & 15.6 & 15.6 & 15.6 & 15.6 & 15.6 & 15.6 & 15.6 & 15.6 & 15.6 & 15.6 & 15.6 & 15.6 & 15.6 & 15.6 & 15.6 & 15.6 & 15.6 & \begin{tabular}{|l|}
15.6 \\
\end{tabular} & 15.6 & 15.6 & \begin{tabular}{|l|}
15.6 \\
\end{tabular} & 15.6 & 15.6 & 15.6 \\
\hline \multirow[t]{2}{*}{ GuestRoom_SWH_Sch } & WD & 0.2 & 0.15 & 0.15 & 0.15 & 0.2 & 0.35 & 0.6 & 0.8 & 0.55 & 0.4 & 0.3 & 0.2 & 0.2 & 0.2 & 0.2 & 0.2 & 0.2 & 0.3 & 0.55 & 0.4 & 0.4 & 0.6 & 0.45 & 0.25 \\
\hline & Other & 0.2 & \begin{tabular}{|l|}
0.15 \\
\end{tabular} & 0.15 & 0.15 & 0.2 & \begin{tabular}{|l|}
0.25 \\
\end{tabular} & \begin{tabular}{|l|}
0.35 \\
\end{tabular} & 0.6 & 0.8 & 0.55 & 0.4 & 0.3 & 0.2 & 0.2 & 0.2 & 0.2 & 0.2 & \begin{tabular}{|c|}
0.025 \\
0.25
\end{tabular} & 0.3 & 0.4 & 0.4 & 0.4 & 0.6 & \begin{tabular}{|l}
0.35 \\
0.35
\end{tabular} \\
\hline LaundryRoom_SWH_Sch & All & 0 & 0 & 0 & 0 & 0 & 0 & 0 & 0 & 1 & 1 & 1 & 1 & 1 & 1 & 1 & 1 & 0 & 0 & 0 & 0 & 0 & 0 & 0 & 0 \\
\hline Water Equipment Latent fract sched & All & 0.05 & 0.05 & 0.05 & 0.05 & 0.05 & 0.05 & 0.05 & 0.05 & 0.05 & 0.05 & 0.05 & 0.05 & 0.05 & 0.05 & 0.05 & 0.05 & 0.05 & 0.05 & 0.05 & 0.05 & 0.05 & 0.05 & 0.05 & 0.05 \\
\hline Water Equipment Sensible fract sched & All & 0.2 & 0.2 & 0.2 & 0.2 & 0.2 & 0.2 & 0.2 & 0.2 & 0.2 & 0.2 & 0.2 & 0.2 & 0.2 & 0.2 & 0.2 & 0.2 & 0.2 & 0.2 & 0.2 & 0.2 & 0.2 & 0.2 & 0.2 & 0.2 \\
\hline $\begin{array}{l}\text { Water Equipment Hot Supply Temp } \\
\text { Sched }\end{array}$ & All & 43.3 & 43.3 & 43.3 & 43.3 & 43.3 & 43.3 & 43.3 & 43.3 & 43.3 & 43.3 & 43.3 & 43.3 & 43.3 & 43.3 & 43.3 & 43.3 & 43.3 & 43.3 & 43.3 & 43.3 & 43.3 & 43.3 & 43.3 & 43.3 \\
\hline Water Equipment Temp Sched & All & 43.3 & 43.3 & 43.3 & 43.3 & 43.3 & 43.3 & 43.3 & 43.3 & 43.3 & 43.3 & 43.3 & 43.3 & 43.3 & 43.3 & 43.3 & 43.3 & 43.3 & \begin{tabular}{|l|}
43.3 \\
\end{tabular} & 43.3 & 43.3 & \begin{tabular}{|l|}
43.3 \\
\end{tabular} & 43.3 & \begin{tabular}{|l|}
43.3 \\
\end{tabular} & 43.3 \\
\hline $\begin{array}{l}\text { Laundry Water Equipment Hot Supply } \\
\text { Temp Sched }\end{array}$ & All & 60 & 60 & 60 & 6 & 60 & 60 & 6 & 60 & 60 & 60 & 60 & 60 & 60 & 60 & 60 & 60 & 60 & 60 & 60 & 60 & 60 & 60 & 60 & 60 \\
\hline $\begin{array}{l}\text { Laundry Water Equipment Temp } \\
\text { Sched }\end{array}$ & All & 60 & 60 & 60 & 60 & 60 & 60 & 60 & 60 & 60 & 60 & 60 & 60 & 60 & 60 & 60 & 60 & 60 & 60 & 60 & 60 & 60 & 60 & 60 & 60 \\
\hline $\begin{array}{l}\text { SWHSys } 1 \text { Water Heater Setpoint } \\
\text { Temperature Schedule Name }\end{array}$ & All & 60 & 60 & 60 & 60 & 60 & 60 & 60 & 60 & 60 & 60 & 60 & 60 & 60 & 60 & 60 & 60 & 60 & 60 & 60 & 60 & 60 & 60 & 60 & 60 \\
\hline SWHSys1-Loop-Temp-Schedule & All & 60 & 60 & 60 & 60 & 60 & 60 & 60 & 60 & 60 & 60 & 60 & 60 & 60 & 60 & 60 & 60 & 60 & 60 & 60 & 60 & 60 & 60 & 60 & 60 \\
\hline
\end{tabular}


Table B-13 Small Office Hourly Operation Schedules

\begin{tabular}{|c|c|c|c|c|c|c|c|c|c|c|c|c|c|c|c|c|c|c|c|c|c|c|c|c|c|}
\hline Schedule & Day of Week & 1 & 2 & 3 & 4 & 5 & 6 & 7 & 8 & 9 & 10 & 11 & 12 & 13 & 14 & 15 & 16 & 17 & 18 & 19 & 20 & 21 & 22 & 23 & 24 \\
\hline ALWAYS_ON & All & 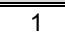 & 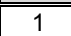 & 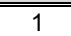 & $\overline{c 1}$ & 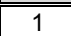 & 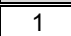 & 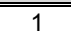 & 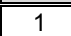 & 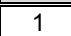 & 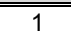 & 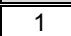 & 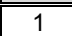 & $\overline{c 1}$ & 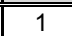 & 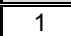 & 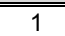 & 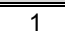 & 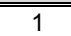 & 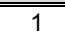 & 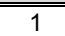 & 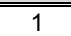 & 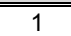 & $\bar{~} 1$ & 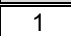 \\
\hline \multirow[t]{3}{*}{ INFIL_QUARTER_ON_SCH } & WD, SummerDesign & 1 & 1 & 1 & 1 & 1 & 1 & 0.25 & 0.25 & 0.25 & 0.25 & 0.25 & 0.25 & 0.25 & 0.25 & 0.25 & 0.25 & 0.25 & 0.25 & 0.25 & 0.25 & 0.25 & 0.25 & 1 & 1 \\
\hline & Sat, WinterDesign & 1 & 1 & 1 & 1 & 1 & 1 & 0.25 & 0.25 & 0.25 & 0.25 & 0.25 & 0.25 & 0.25 & 0.25 & 0.25 & 0.25 & 0.25 & 0.25 & 1 & 1 & 1 & 1 & 1 & 1 \\
\hline & Sun, Hol, Other & 1 & 1 & 1 & 1 & 1 & 1 & 1 & 1 & 1 & 1 & 1 & 1 & 1 & 1 & 1 & 1 & 1 & 1 & 1 & 1 & 1 & 1 & 1 & 1 \\
\hline \multirow[t]{4}{*}{ BLDG_OCC_SCH } & SummerDesign & 0 & 0 & 0 & 0 & 0 & 0 & 1 & 1 & 1 & 1 & 1 & 1 & 1 & 1 & 1 & 1 & 1 & 1 & 1 & 1 & 1 & 1 & 0.05 & 0.05 \\
\hline & WD & 0 & 0 & 0 & 0 & 0 & 0 & \begin{tabular}{|l|}
0.1 \\
\end{tabular} & 0.2 & 0.95 & 0.95 & 0.95 & 0.95 & 0.5 & 0.95 & 0.95 & 0.95 & 0.95 & \begin{tabular}{|l|}
0.3 \\
\end{tabular} & 0.1 & 0.1 & 0.05 & 0.05 & 0.05 & 0.05 \\
\hline & Sat & 0 & 0 & 0 & 0 & 0 & 0 & \begin{tabular}{|l|}
0.1 \\
\end{tabular} & 0.1 & \begin{tabular}{|l|}
0.3 \\
\end{tabular} & \begin{tabular}{|l|}
0.3 \\
\end{tabular} & 0.3 & 0.3 & 0.1 & 0.1 & 0.1 & 0.1 & 0.1 & 0 & 0 & 0 & 0 & 0 & 0 & 0 \\
\hline & Other & 0 & 0 & 0 & 0 & 0 & 0 & 0 & 0 & 0 & 0 & 0 & 0 & 0 & 0 & 0 & 0 & 0 & 0 & 0 & 0 & 0 & 0 & 0 & 0 \\
\hline \multirow[t]{5}{*}{ BLDG_LIGHT_SCH } & WD & 0.05 & 0.05 & 0.05 & 0.05 & 0.05 & 0.1 & 0.1 & 0.3 & 0.9 & 0.9 & 0.9 & 0.9 & 0.9 & 0.9 & 0.9 & 0.9 & 0.9 & 0.5 & 0.3 & 0.3 & 0.2 & 0.2 & 0.1 & 0.05 \\
\hline & Sat & 0.05 & 0.05 & \begin{tabular}{|l|}
0.05 \\
\end{tabular} & 0.05 & 0.05 & \begin{tabular}{|l|}
0.05 \\
\end{tabular} & \begin{tabular}{|l|}
0.1 \\
\end{tabular} & 0.1 & \begin{tabular}{|l|}
0.3 \\
\end{tabular} & \begin{tabular}{|l|}
0.3 \\
\end{tabular} & 0.3 & 0.3 & 0.15 & 0.15 & 0.15 & 0.15 & 0.15 & \begin{tabular}{|l|}
0.05 \\
\end{tabular} & 0.05 & 0.05 & \begin{tabular}{|l|}
0.05 \\
\end{tabular} & \begin{tabular}{|l|}
0.05 \\
\end{tabular} & 0.05 & \begin{tabular}{|l|}
0.05 \\
\end{tabular} \\
\hline & SummerDesign & 1 & 1 & 1 & 1 & 1 & 1 & 1 & 1 & 1 & 1 & 1 & 1 & 1 & 1 & 1 & 1 & 1 & 1 & 1 & 1 & 1 & 1 & 1 & 1 \\
\hline & WinterDesign & 0 & 0 & 0 & 0 & 0 & 0 & 0 & 0 & 0 & 0 & 0 & 0 & 0 & 0 & 0 & 0 & 0 & 0 & 0 & 0 & 0 & 0 & 0 & 0 \\
\hline & Other & 0.05 & 0.05 & 0.05 & 0.05 & 0.05 & 0.05 & 0.05 & 0.05 & 0.05 & 0.05 & 0.05 & \begin{tabular}{|l|}
0.05 \\
\end{tabular} & 0.05 & 0.05 & 0.05 & 0.05 & 0.05 & 0.05 & 0.05 & 0.05 & 0.05 & 0.05 & 0.05 & 0.05 \\
\hline \multirow[t]{5}{*}{ BLDG_EQUIP_SCH } & WD & 0.4 & 0.4 & \begin{tabular}{|l|}
0.4 \\
\end{tabular} & 0.4 & 0.4 & \begin{tabular}{|l|}
0.4 \\
\end{tabular} & \begin{tabular}{|l|}
0.4 \\
\end{tabular} & 0.4 & \begin{tabular}{|l|}
0.9 \\
\end{tabular} & 0.9 & 0.9 & \begin{tabular}{|l|}
0.9 \\
\end{tabular} & 0.8 & 0.9 & 0.9 & 0.9 & 0.9 & \begin{tabular}{|l|}
0.5 \\
\end{tabular} & 0.4 & 0.4 & \begin{tabular}{|l|}
0.4 \\
\end{tabular} & \begin{tabular}{|l|}
0.4 \\
\end{tabular} & 0.4 & \begin{tabular}{|l|}
0.4 \\
\end{tabular} \\
\hline & Sat & 0.3 & 0.3 & 0.3 & 0.3 & 0.3 & 0.3 & 0.4 & 0.4 & \begin{tabular}{|l|}
0.5 \\
\end{tabular} & 0.5 & 0.5 & 0.5 & 0.35 & 0.35 & 0.35 & 0.35 & 0.35 & 0.3 & 0.3 & 0.3 & 0.3 & 0.3 & 0.3 & 0.3 \\
\hline & SummerDesign & 1 & 1 & 1 & 1 & 1 & 1 & 1 & 1 & 1 & 1 & 1 & 1 & 1 & 1 & 1 & 1 & 1 & 1 & 1 & 1 & 1 & 1 & 1 & 1 \\
\hline & WinterDesign & 0 & 0 & 0 & 0 & 0 & 0 & 0 & 0 & 0 & 0 & 0 & 0 & 0 & 0 & 0 & 0 & 0 & 0 & 0 & 0 & 0 & 0 & 0 & 0 \\
\hline & Other & 0.3 & 0.3 & 0.3 & 0.3 & 0.3 & 0.3 & \begin{tabular}{|l|}
0.3 \\
\end{tabular} & 0.3 & \begin{tabular}{|l|}
0.3 \\
\end{tabular} & 0.3 & 0.3 & 0.3 & 0.3 & 0.3 & 0.3 & 0.3 & 0.3 & \begin{tabular}{|l|}
0.3 \\
\end{tabular} & 0.3 & 0.3 & \begin{tabular}{|l|}
0.3 \\
\end{tabular} & \begin{tabular}{|l|}
0.3 \\
\end{tabular} & 0.3 & \begin{tabular}{|l|}
0.3 \\
\end{tabular} \\
\hline ACTIVITY_SCH & All & 120 & 120 & 120 & 120 & 120 & 120 & 120 & 120 & 120 & 120 & 120 & 120 & 120 & 120 & 120 & 120 & 120 & 120 & 120 & 120 & 120 & 120 & 120 & 120 \\
\hline WORK_EFF_SCH & All & 0 & 0 & 0 & 0 & 0 & 0 & 0 & 0 & 0 & 0 & 0 & 0 & 0 & 0 & 0 & 0 & 0 & 0 & 0 & 0 & 0 & 0 & 0 & 0 \\
\hline AIR_VELO_SCH & All & 0.2 & 0.2 & 0.2 & 0.2 & 0.2 & 0.2 & 0.2 & 0.2 & \begin{tabular}{|l|}
0.2 \\
\end{tabular} & 0.2 & 0.2 & 0.2 & 0.2 & 0.2 & 0.2 & 0.2 & 0.2 & \begin{tabular}{|l|}
0.2 \\
\end{tabular} & 0.2 & 0.2 & \begin{tabular}{|l|}
0.2 \\
\end{tabular} & \begin{tabular}{|l|}
0.2 \\
\end{tabular} & 0.2 & 0.2 \\
\hline \multirow[t]{3}{*}{ CLOTHING_SCH } & All & 1 & 1 & 1 & 1 & 1 & 1 & 1 & 1 & 1 & 1 & 1 & 1 & 1 & 1 & 1 & 1 & 1 & 1 & 1 & 1 & 1 & 1 & 1 & 1 \\
\hline & All & 0.5 & 0.5 & 0.5 & 0.5 & 0.5 & 0.5 & 0.5 & 0.5 & 0.5 & 0.5 & 0.5 & 0.5 & 0.5 & 0.5 & 0.5 & 0.5 & 0.5 & 0.5 & 0.5 & 0.5 & 0.5 & 0.5 & 0.5 & 0.5 \\
\hline & All & 1 & 1 & 1 & 1 & 1 & 1 & 1 & 1 & 1 & 1 & 1 & 1 & 1 & 1 & 1 & 1 & 1 & 1 & 1 & 1 & 1 & 1 & 1 & 1 \\
\hline \multirow[t]{3}{*}{ CLGSETP_SCH } & WD, SummerDesign & 26.7 & \begin{tabular}{|l|}
26.7 \\
\end{tabular} & 26.7 & 26.7 & 26.7 & \begin{tabular}{|l|}
26.7 \\
\end{tabular} & 24 & 24 & 24 & 24 & 24 & 24 & 24 & 24 & 24 & 24 & 24 & 24 & 24 & 24 & 24 & 24 & 26.7 & \begin{tabular}{|l|}
26.7 \\
\end{tabular} \\
\hline & Sat & 26.7 & 26.7 & \begin{tabular}{|l|}
26.7 \\
\end{tabular} & 26.7 & 26.7 & \begin{tabular}{|l|}
26.7 \\
\end{tabular} & 24 & 24 & 24 & 24 & 24 & 24 & 24 & 24 & 24 & 24 & 24 & 24 & 26.7 & 26.7 & \begin{tabular}{|l|}
26.7 \\
\end{tabular} & \begin{tabular}{|l|}
26.7 \\
\end{tabular} & 26.7 & \begin{tabular}{|l|}
26.7 \\
\end{tabular} \\
\hline & Other & 26.7 & \begin{tabular}{|l|}
26.7 \\
\end{tabular} & \begin{tabular}{|l|}
26.7 \\
\end{tabular} & 26.7 & \begin{tabular}{|l|}
26.7 \\
\end{tabular} & \begin{tabular}{|l|}
26.7 \\
\end{tabular} & \begin{tabular}{|l|}
26.7 \\
\end{tabular} & 26.7 & \begin{tabular}{|l|}
26.7 \\
\end{tabular} & \begin{tabular}{|l|}
26.7 \\
\end{tabular} & 26.7 & \begin{tabular}{|l|}
26.7 \\
\end{tabular} & 26.7 & 26.7 & 26.7 & 26.7 & 26.7 & \begin{tabular}{|l|}
26.7 \\
\end{tabular} & 26.7 & 26.7 & \begin{tabular}{|l|}
26.7 \\
\end{tabular} & \begin{tabular}{|l|}
26.7 \\
\end{tabular} & 26.7 & \begin{tabular}{|l|}
26.7 \\
\end{tabular} \\
\hline \multirow[t]{4}{*}{ HTGSETP_SCH } & WD & 15.6 & 15.6 & 15.6 & 15.6 & 15.6 & 15.6 & 21 & 21 & 21 & 21 & 21 & 21 & 21 & 21 & 21 & 21 & 21 & 21 & 21 & 21 & 21 & 21 & 15.6 & 15.6 \\
\hline & Sat & 15.6 & 15.6 & 15.6 & 15.6 & 15.6 & 15.6 & 21 & 21 & 21 & 21 & 21 & 21 & 21 & 21 & 21 & 21 & 21 & 21 & 15.6 & 15.6 & 15.6 & 15.6 & 15.6 & 15.6 \\
\hline & WinterDesign & 21 & 21 & 21 & 21 & 21 & 21 & 21 & 21 & 21 & 21 & 21 & 21 & 21 & 21 & 21 & 21 & 21 & 21 & 21 & 21 & 21 & 21 & 21 & 21 \\
\hline & Other & 15.6 & 15.6 & 15.6 & 15.6 & 15.6 & 15.6 & 15.6 & 15.6 & 15.6 & 15.6 & 15.6 & \begin{tabular}{|l|}
15.6 \\
\end{tabular} & 15.6 & 15.6 & 15.6 & 15.6 & 15.6 & 15.6 & 15.6 & 15.6 & 15.6 & 15.6 & 15.6 & 15.6 \\
\hline \multirow[t]{3}{*}{ MinOA_Sched } & WD, SummerDesign & 0 & 0 & 0 & 0 & 0 & 0 & 0 & 1 & 1 & 1 & 1 & 1 & 1 & 1 & 1 & 1 & 1 & 1 & 1 & 1 & 1 & 1 & 0 & 0 \\
\hline & Sat, WinterDesign & 0 & 0 & 0 & 0 & 0 & 0 & 0 & 1 & 1 & 1 & 1 & 1 & 1 & 1 & 1 & 1 & 1 & 1 & 0 & 0 & 0 & 0 & 0 & 0 \\
\hline & Other & 0 & 0 & 0 & 0 & 0 & 0 & 0 & 0 & 0 & 0 & 0 & 0 & 0 & 0 & 0 & 0 & 0 & 0 & 0 & 0 & 0 & 0 & 0 & 0 \\
\hline Dual Zone Control Type Sched & All & 4 & 4 & 4 & 4 & 4 & 4 & 4 & 4 & 4 & 4 & 4 & 4 & 4 & 4 & 4 & 4 & 4 & 4 & 4 & 4 & 4 & 4 & 4 & 4 \\
\hline \multirow[t]{3}{*}{ HVACOperationSchd } & WD, SummerDesign & 0 & 0 & 0 & 0 & 0 & 0 & 1 & 1 & 1 & 1 & 1 & 1 & 1 & 1 & 1 & 1 & 1 & 1 & 1 & 1 & 1 & 1 & 0 & 0 \\
\hline & Sat, WinterDesign & 0 & 0 & 0 & 0 & 0 & 0 & 1 & 1 & 1 & 1 & 1 & 1 & 1 & 1 & 1 & 1 & 1 & 1 & 0 & 0 & 0 & 0 & 0 & 0 \\
\hline & Other & 0 & 0 & 0 & 0 & 0 & 0 & 0 & 0 & 0 & 0 & 0 & 0 & 0 & 0 & 0 & 0 & 0 & 0 & 0 & 0 & 0 & 0 & 0 & 0 \\
\hline \multirow[t]{3}{*}{ BLDG_SWH_SCH } & WD, SummerDesign & 0.05 & 0.05 & 0.05 & 0.05 & 0.05 & 0.08 & 0.07 & 0.19 & 0.35 & 0.38 & 0.39 & 0.47 & 0.57 & 0.54 & 0.34 & 0.33 & 0.44 & 0.26 & 0.21 & 0.15 & \begin{tabular}{|l|l|}
0.17 \\
\end{tabular} & 0.08 & 0.05 & 0.05 \\
\hline & Sat, WinterDesign & 0.05 & 0.05 & 0.05 & 0.05 & 0.05 & \begin{tabular}{|l|}
0.08 \\
\end{tabular} & 0.07 & \begin{tabular}{|l|l|}
0.11 \\
\end{tabular} & 0.15 & 0.21 & 0.19 & 0.23 & 0.2 & 0.19 & 0.15 & 0.13 & 0.14 & 0.07 & 0.07 & 0.07 & 0.07 & 0.09 & 0.05 & 0.05 \\
\hline & Other & 0.04 & \begin{tabular}{|l|l|}
0.04 \\
\end{tabular} & \begin{tabular}{|l|l|}
0.04 \\
\end{tabular} & 0.04 & \begin{tabular}{|l|l|}
0.04 \\
\end{tabular} & \begin{tabular}{|l|l|}
0.07 \\
\end{tabular} & \begin{tabular}{|l|l|}
0.04 \\
\end{tabular} & \begin{tabular}{|l|l|}
0.04 \\
\end{tabular} & \begin{tabular}{|l|l|}
0.04 \\
\end{tabular} & \begin{tabular}{|l|l|}
0.04 \\
\end{tabular} & \begin{tabular}{|l|l|}
0.04 \\
\end{tabular} & \begin{tabular}{|l|l|}
0.06 \\
\end{tabular} & 0.06 & \begin{tabular}{|l|l|}
0.09 \\
\end{tabular} & \begin{tabular}{|l|l|}
0.06 \\
\end{tabular} & 0.04 & 0.04 & \begin{tabular}{|l|l|}
0.04 \\
\end{tabular} & 0.04 & 0.04 & \begin{tabular}{|l|l|}
0.04 \\
\end{tabular} & \begin{tabular}{|l|l|}
0.07 \\
\end{tabular} & 0.04 & \begin{tabular}{|l|l|}
0.04 \\
\end{tabular} \\
\hline $\begin{array}{l}\text { Water Equipment Latent fract } \\
\text { sched }\end{array}$ & All & 0.05 & 0.05 & 0.05 & 0.05 & 0.05 & 0.05 & 0.05 & 0.05 & 0.05 & 0.05 & 0.05 & 0.05 & 0.05 & 0.05 & 0.05 & 0.05 & 0.05 & 0.05 & 0.05 & 0.05 & 0.05 & 0.05 & 0.05 & 0.05 \\
\hline
\end{tabular}




\begin{tabular}{|c|c|c|c|c|c|c|c|c|c|c|c|c|c|c|c|c|c|c|c|c|c|c|c|c|c|}
\hline Schedule & Day of Week & 1 & 2 & 3 & 4 & 5 & 6 & 7 & 8 & 9 & 10 & 11 & 12 & 13 & 14 & 15 & 16 & 17 & 18 & 19 & 20 & 21 & 22 & 23 & 24 \\
\hline $\begin{array}{l}\text { Water Equipment Sensible fract } \\
\text { sched }\end{array}$ & All & 0.2 & 0.2 & 0.2 & 0.2 & 0.2 & 0.2 & 0.2 & 0.2 & 0.2 & 0.2 & 0.2 & 0.2 & 0.2 & 0.2 & 0.2 & 0.2 & 0.2 & 0.2 & 0.2 & 0.2 & 0.2 & 0.2 & 0.2 & 0.2 \\
\hline $\begin{array}{l}\text { SWHSys } 1 \text { Water Heater Ambient } \\
\text { Temperature Schedule Name }\end{array}$ & All & 22 & 22 & 22 & 22 & 22 & 22 & 22 & 22 & 22 & 22 & 22 & 22 & 22 & 22 & 22 & 22 & 22 & 22 & 22 & 22 & 22 & 22 & 22 & 22 \\
\hline Water Equipment Temp Sched & All & 43.3 & 43.3 & 43.3 & 43.3 & 43.3 & 43.3 & 43.3 & 43.3 & 43.3 & 43.3 & 43.3 & 43.3 & 43.3 & 43.3 & 43.3 & 43.3 & 43.3 & 43.3 & 43.3 & 43.3 & 43.3 & 43.3 & 43.3 & 43.3 \\
\hline $\begin{array}{l}\text { Water Equipment Hot Supply } \\
\text { Temp Sched }\end{array}$ & All & 43.3 & 43.3 & 43.3 & 43.3 & 43.3 & 43.3 & 43.3 & 43.3 & 43.3 & 43.3 & 43.3 & 43.3 & 43.3 & 43.3 & 43.3 & 43.3 & 43.3 & 43.3 & 43.3 & 43.3 & 43.3 & 43.3 & 43.3 & 43.3 \\
\hline $\begin{array}{l}\text { SWHSys1 Water Heater Setpoint } \\
\text { Temperature Schedule Name }\end{array}$ & All & 60 & 60 & 60 & 60 & 60 & 60 & 60 & 60 & 60 & 60 & 60 & 60 & 60 & 60 & 60 & 60 & 60 & 60 & 60 & 60 & 60 & 60 & 60 & 60 \\
\hline SWHSys1-Loop-Temp-Schedule & All & 60 & 60 & 60 & 60 & 60 & 60 & 60 & 60 & 60 & 60 & 60 & 60 & 60 & 60 & 60 & 60 & 60 & 60 & 60 & 60 & 60 & 60 & 60 & 60 \\
\hline
\end{tabular}


Table B-14 Strip Mall Hourly Operation Schedules

\begin{tabular}{|c|c|c|c|c|c|c|c|c|c|c|c|c|c|c|c|c|c|c|c|c|c|c|c|c|c|}
\hline Schedule & Day of Week & 1 & 2 & 3 & 4 & 5 & 6 & 7 & 8 & 9 & 10 & 11 & 12 & 13 & 14 & 15 & 16 & 17 & 18 & 19 & 20 & 21 & 22 & 23 & 24 \\
\hline ALWAYS_ON & All & $\bar{~} 1$ & $\overline{11}$ & $\overline{11}$ & $\bar{~} 1$ & $\bar{~} 1$ & $\overline{11}$ & $\bar{~} 1$ & $\overline{11}$ & $\overline{11}$ & $\bar{~} 1$ & $\bar{~} 1$ & $\bar{~} 1$ & $\bar{~} 1$ & $\bar{~} 1$ & $\bar{~} 1$ & $\bar{~} 1$ & 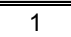 & 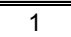 & $\bar{~} 1$ & $\bar{~} 1$ & $\bar{~} 1$ & $\bar{~} 1$ & $\bar{~} 1$ & 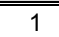 \\
\hline \multirow[t]{5}{*}{ BLDG_EQUIP_SCH } & WD & 0.2 & 0.2 & 0.2 & 0.2 & 0.2 & 0.2 & 0.2 & 0.4 & 0.7 & 0.9 & 0.9 & 0.9 & 0.9 & 0.9 & 0.9 & 0.9 & 0.9 & 0.9 & 0.8 & 0.8 & 0.7 & 0.4 & 0.2 & 0.2 \\
\hline & Sat & 0.15 & 0.15 & 0.15 & 0.15 & 0.15 & 0.15 & 0.15 & 0.3 & 0.5 & \begin{tabular}{|l|l|}
0.8 & \\
\end{tabular} & 0.9 & 0.9 & 0.9 & 0.9 & 0.9 & 0.9 & 0.9 & 0.9 & 0.7 & 0.5 & 0.5 & 0.3 & 0.15 & 0.15 \\
\hline & SummerDesign & 1 & 1 & 1 & 1 & 1 & 1 & 1 & 1 & 1 & 1 & 1 & 1 & 1 & 1 & 1 & 1 & 1 & 1 & 1 & 1 & 1 & 1 & 1 & 1 \\
\hline & WinterDesign & 0 & 0 & 0 & 0 & 0 & 0 & 0 & 0 & 0 & 0 & 0 & 0 & 0 & 0 & 0 & 0 & 0 & 0 & 0 & 0 & 0 & 0 & 0 & 0 \\
\hline & Sun, Hol, Other & 0.15 & 0.15 & 0.15 & 0.15 & 0.15 & 0.15 & 0.15 & \begin{tabular}{|l|}
0.15 \\
\end{tabular} & 0.3 & \begin{tabular}{|l|}
0.3 \\
\end{tabular} & 0.6 & 0.6 & 0.8 & 0.8 & 0.8 & 0.8 & 0.8 & 0.6 & 0.4 & 0.15 & 0.15 & 0.15 & 0.15 & 0.15 \\
\hline \multirow[t]{5}{*}{ BLDG_LIGHT_SCH } & WD & 0.05 & 0.05 & 0.05 & 0.05 & 0.05 & 0.05 & 0.05 & \begin{tabular}{|l|}
0.2 \\
\end{tabular} & 0.5 & 0.9 & 0.9 & 0.9 & 0.9 & 0.9 & 0.9 & 0.9 & 0.9 & 0.9 & 0.6 & 0.6 & 0.5 & 0.2 & 0.05 & 0.05 \\
\hline & Sat & 0.05 & 0.05 & 0.05 & 0.05 & 0.05 & 0.05 & \begin{tabular}{|l|}
0.05 \\
\end{tabular} & \begin{tabular}{|l|}
0.1 \\
\end{tabular} & 0.3 & \begin{tabular}{|l|}
0.6 \\
\end{tabular} & 0.9 & 0.9 & 0.9 & 0.9 & 0.9 & 0.9 & 0.9 & 0.9 & 0.5 & 0.3 & 0.3 & 0.1 & 0.05 & 0.05 \\
\hline & \begin{tabular}{|l|} 
SummerDesign \\
\end{tabular} & 1 & 1 & 1 & 1 & 1 & 1 & 1 & 1 & 1 & 1 & 1 & 1 & 1 & 1 & 1 & 1 & 1 & 1 & 1 & 1 & 1 & 1 & 1 & 1 \\
\hline & WinterDesign & 0 & 0 & 0 & 0 & 0 & 0 & 0 & 0 & 0 & 0 & 0 & 0 & 0 & 0 & 0 & 0 & 0 & 0 & 0 & 0 & 0 & 0 & 0 & 0 \\
\hline & \begin{tabular}{|l|} 
Sun, Hol, Other \\
\end{tabular} & 0.05 & 0.05 & 0.05 & 0.05 & 0.05 & 0.05 & \begin{tabular}{|l|}
0.05 \\
\end{tabular} & \begin{tabular}{|l|}
0.05 \\
\end{tabular} & 0.1 & \begin{tabular}{|l|}
0.1 \\
\end{tabular} & 0.4 & 0.4 & 0.6 & 0.6 & 0.6 & 0.6 & 0.6 & 0.4 & 0.2 & 0.05 & 0.05 & 0.05 & 0.05 & 0.05 \\
\hline \multirow[t]{4}{*}{ BLDG_OCC_SCH } & WD & 0 & 0 & 0 & 0 & 0 & 0 & 0 & \begin{tabular}{|l|}
0.1 \\
\end{tabular} & 0.2 & \begin{tabular}{|l|}
0.5 \\
\end{tabular} & 0.5 & 0.7 & 0.7 & 0.7 & 0.7 & 0.8 & 0.7 & 0.5 & 0.5 & 0.3 & 0.3 & 0 & 0 & 0 \\
\hline & $\begin{array}{l}\text { SummerDesign, } \\
\text { WinterDesign }\end{array}$ & 1 & 1 & 1 & 1 & 1 & 1 & 1 & 1 & 1 & 1 & 1 & 1 & 1 & 1 & 1 & 1 & 1 & 1 & 1 & 1 & 1 & 1 & 1 & 1 \\
\hline & Sat & 0 & 0 & 0 & 0 & 0 & 0 & 0 & 0.1 & 0.2 & 0.5 & 0.6 & 0.8 & 0.8 & 0.8 & 0.8 & 0.8 & 0.8 & 0.6 & 0.2 & 0.2 & 0.2 & 0.1 & 0 & 0 \\
\hline & Other & 0 & 0 & 0 & 0 & 0 & 0 & 0 & 0 & 0 & \begin{tabular}{|l|}
0.1 \\
\end{tabular} & 0.2 & 0.2 & 0.4 & 0.4 & 0.4 & 0.4 & 0.4 & 0.2 & 0.1 & 0 & 0 & 0 & 0 & 0 \\
\hline \multirow[t]{4}{*}{ INFIL_HALF_ON_SCH } & WD, SummerDesign & 1 & 1 & 1 & 1 & 1 & 1 & 0.5 & \begin{tabular}{|l|}
0.5 \\
\end{tabular} & 0.5 & 0.5 & 0.5 & 0.5 & 0.5 & 0.5 & 0.5 & 0.5 & 0.5 & 0.5 & 0.5 & 0.5 & 0.5 & 1 & 1 & 1 \\
\hline & Sat & 1 & 1 & 1 & 1 & 1 & 1 & 0.5 & 0.5 & 0.5 & 0.5 & 0.5 & 0.5 & 0.5 & 0.5 & 0.5 & 0.5 & 0.5 & 0.5 & 0.5 & 0.5 & 0.5 & 0.5 & 1 & 1 \\
\hline & WinterDesign & 1 & 1 & 1 & 1 & 1 & 1 & 1 & 1 & 1 & 1 & 1 & 1 & 1 & 1 & 1 & 1 & 1 & 1 & 1 & 1 & 1 & 1 & 1 & 1 \\
\hline & Sun, Hol, Other & 1 & 1 & 1 & 1 & 1 & 1 & 1 & 1 & 0.5 & \begin{tabular}{|l|}
0.5 \\
\end{tabular} & 0.5 & 0.5 & 0.5 & 0.5 & 0.5 & 0.5 & 0.5 & 1 & 1 & 1 & 1 & 1 & 1 & 1 \\
\hline \multirow[t]{3}{*}{ CLOTHING_SCH } & All & 1 & 1 & 1 & 1 & 1 & 1 & 1 & 1 & 1 & 1 & 1 & 1 & 1 & 1 & 1 & 1 & 1 & 1 & 1 & 1 & 1 & 1 & 1 & 1 \\
\hline & All & 0.5 & 0.5 & 0.5 & 0.5 & 0.5 & 0.5 & 0.5 & \begin{tabular}{|l|}
0.5 \\
\end{tabular} & 0.5 & 0.5 & 0.5 & 0.5 & 0.5 & 0.5 & 0.5 & 0.5 & 0.5 & 0.5 & 0.5 & 0.5 & 0.5 & 0.5 & 0.5 & 0.5 \\
\hline & All & 1 & 1 & 1 & 1 & 1 & 1 & 1 & 1 & 1 & 1 & 1 & 1 & 1 & 1 & 1 & 1 & 1 & 1 & 1 & 1 & 1 & 1 & 1 & 1 \\
\hline \begin{tabular}{|l|} 
ACTIVITY_SCH \\
\end{tabular} & All & 120 & 120 & 120 & 120 & 120 & 120 & 120 & 120 & 120 & 120 & 120 & 120 & 120 & 120 & 120 & 120 & 120 & 120 & 120 & 120 & 120 & 120 & 120 & 120 \\
\hline AIR_VELO_SCH & All & 0.2 & 0.2 & 0.2 & 0.2 & 0.2 & 0.2 & \begin{tabular}{|l|}
0.2 \\
\end{tabular} & \begin{tabular}{|l|}
0.2 \\
\end{tabular} & 0.2 & \begin{tabular}{|l|}
0.2 \\
\end{tabular} & 0.2 & 0.2 & 0.2 & 0.2 & 0.2 & 0.2 & 0.2 & 0.2 & 0.2 & 0.2 & 0.2 & 0.2 & 0.2 & 0.2 \\
\hline WORK_EFF_SCH & All & 0 & 0 & 0 & 0 & 0 & 0 & 0 & 0 & 0 & 0 & 0 & 0 & 0 & 0 & 0 & 0 & 0 & 0 & 0 & 0 & 0 & 0 & 0 & 0 \\
\hline \multirow[t]{4}{*}{ CLGSETP_SCH } & WD, SummerDesign & 30 & 30 & 30 & 30 & 30 & 30 & 24 & 24 & 24 & 24 & 24 & 24 & 24 & 24 & 24 & 24 & 24 & 24 & 24 & 24 & 24 & 30 & 30 & 30 \\
\hline & Sat & 30 & 30 & 30 & 30 & 30 & 30 & 24 & 24 & 24 & 24 & 24 & 24 & 24 & 24 & 24 & 24 & 24 & 24 & 24 & 24 & 24 & 24 & 30 & 30 \\
\hline & WinterDesign & 30 & 30 & 30 & 30 & 30 & 30 & 30 & 30 & 30 & 30 & 30 & 30 & 30 & 30 & 30 & 30 & 30 & 30 & 30 & 30 & 30 & 30 & 30 & 30 \\
\hline & \begin{tabular}{|l} 
Sun, Hol, Other \\
\end{tabular} & 30 & 30 & 30 & 30 & 30 & 30 & 30 & 30 & 24 & 24 & 24 & 24 & 24 & 24 & 24 & 24 & 24 & 24 & 24 & 30 & 30 & 30 & 30 & 30 \\
\hline Dual Zone Control Type Sched & All & 4 & 4 & 4 & 4 & 4 & 4 & 4 & 4 & 4 & 4 & 4 & 4 & 4 & 4 & 4 & 4 & 4 & 4 & 4 & 4 & 4 & 4 & 4 & 4 \\
\hline \multirow[t]{5}{*}{ HTGSETP_SCH } & WD & 15.6 & 15.6 & 15.6 & 15.6 & 15.6 & 15.6 & 21 & 21 & 21 & 21 & 21 & 21 & 21 & 21 & 21 & 21 & 21 & 21 & 21 & 21 & 21 & 15.6 & 15.6 & 15.6 \\
\hline & \begin{tabular}{|l|} 
SummerDesign \\
\end{tabular} & 15.6 & 15.6 & 15.6 & 15.6 & 15.6 & 15.6 & 15.6 & 15.6 & 15.6 & 15.6 & 15.6 & 15.6 & 15.6 & 15.6 & 15.6 & 15.6 & 15.6 & 15.6 & 15.6 & 15.6 & 15.6 & 15.6 & 15.6 & 15.6 \\
\hline & \begin{tabular}{|l|} 
WinterDesign \\
\end{tabular} & 21 & 21 & 21 & 21 & 21 & 21 & 21 & 21 & 21 & 21 & 21 & 21 & 21 & 21 & 21 & 21 & 21 & 21 & 21 & 21 & 21 & 21 & 21 & 21 \\
\hline & Sat & 15.6 & 15.6 & 15.6 & 15.6 & 15.6 & 15.6 & 21 & 21 & 21 & 21 & 21 & 21 & 21 & 21 & 21 & 21 & 21 & 21 & 21 & 21 & 21 & 21 & 15.6 & 15.6 \\
\hline & Other & 15.6 & 15.6 & 15.6 & 15.6 & 15.6 & 15.6 & \begin{tabular}{|l|}
15.6 \\
\end{tabular} & \begin{tabular}{|l|}
15.6 \\
\end{tabular} & 21 & 21 & 21 & 21 & 21 & 21 & 21 & 21 & 21 & 21 & 21 & 15.6 & 15.6 & 15.6 & 15.6 & 15.6 \\
\hline \multirow[t]{3}{*}{ HVACOperationSchd } & WD, SummerDesign & 0 & 0 & 0 & 0 & 0 & 0 & 1 & 1 & 1 & 1 & 1 & 1 & 1 & 1 & 1 & 1 & 1 & 1 & 1 & 1 & 1 & 0 & 0 & 0 \\
\hline & Sat, WinterDesign & 0 & 0 & 0 & 0 & 0 & 0 & 1 & 1 & 1 & 1 & 1 & 1 & 1 & 1 & 1 & 1 & 1 & 1 & 1 & 1 & 1 & 1 & 0 & 0 \\
\hline & \begin{tabular}{|l} 
Other \\
\end{tabular} & 0 & 0 & 0 & 0 & 0 & 0 & 0 & 0 & 1 & 1 & 1 & 1 & 1 & 1 & 1 & 1 & 1 & 1 & 1 & 0 & 0 & 0 & 0 & 0 \\
\hline \multirow[t]{3}{*}{ MinOA_Sched } & WD, SummerDesign & 0 & 0 & 0 & 0 & 0 & 0 & 1 & 1 & 1 & 1 & 1 & 1 & 1 & 1 & 1 & 1 & 1 & 1 & 1 & 1 & 1 & 0 & 0 & 0 \\
\hline & Sat, WinterDesign & 0 & 0 & 0 & 0 & 0 & 0 & 1 & 1 & 1 & 1 & 1 & 1 & 1 & 1 & 1 & 1 & 1 & 1 & 1 & 1 & 1 & 1 & 0 & 0 \\
\hline & Other & 0 & 0 & 0 & 0 & 0 & 0 & 0 & 0 & 1 & 1 & 1 & 1 & 1 & 1 & 1 & 1 & 1 & 1 & 1 & 0 & 0 & 0 & 0 & 0 \\
\hline
\end{tabular}


Table B-15 Supermarket Hourly Operation Schedules

\begin{tabular}{|c|c|c|c|c|c|c|c|c|c|c|c|c|c|c|c|c|c|c|c|c|c|c|c|c|c|}
\hline Schedule & Day of Week & 1 & 2 & 3 & 4 & 5 & 6 & $\overline{7}$ & 8 & 9 & 10 & 11 & 12 & 13 & 14 & 15 & 16 & 17 & 18 & 19 & 20 & 21 & 22 & 23 & 24 \\
\hline ALWAYS_ON & All & 1 & 1 & 1 & 1 & 1 & 1 & 1 & 1 & 1 & 1 & 1 & 1 & 1 & 1 & 1 & 1 & 1 & 1 & 1 & 1 & 1 & 1 & 1 & 1 \\
\hline \multirow[t]{2}{*}{ Deli_Exhaust_SCH } & \begin{tabular}{|l|} 
WinterDesign, \\
SummerDesign
\end{tabular} & 1 & 1 & 1 & 1 & 1 & 1 & 1 & 1 & 1 & 1 & 1 & 1 & 1 & 1 & 1 & 1 & 1 & 1 & 1 & 1 & 1 & 1 & 1 & 1 \\
\hline & Other & 0 & 0 & 0 & 0 & 0 & 0 & 1 & 1 & 1 & 1 & 1 & 1 & 1 & 1 & 1 & 1 & 1 & 1 & 1 & 1 & 1 & 1 & 0 & 0 \\
\hline \multirow[t]{5}{*}{ BLDG_EQUIP_SCH } & WD & 0.2 & 0.2 & 0.2 & 0.2 & 0.2 & 0.2 & 0.4 & 0.4 & 0.7 & 0.9 & 0.9 & 0.9 & 0.9 & 0.9 & 0.9 & 0.9 & 0.9 & 0.9 & 0.8 & \begin{tabular}{|l|l}
0.8 \\
\end{tabular} & 0.7 & 0.4 & 0.2 & 0.2 \\
\hline & Sat & 0.15 & 0.15 & 0.15 & 0.15 & 0.15 & 0.15 & 0.3 & 0.3 & 0.5 & 0.8 & 0.9 & 0.9 & 0.9 & 0.9 & 0.9 & 0.9 & 0.9 & 0.9 & 0.7 & 0.5 & 0.5 & 0.3 & 0.15 & 0.15 \\
\hline & SummerDesign & 1 & 1 & 1 & 1 & 1 & 1 & 1 & 1 & 1 & 1 & 1 & 1 & 1 & 1 & 1 & 1 & 1 & 1 & 1 & 1 & 1 & 1 & 1 & 1 \\
\hline & WinterDesign & 0 & 0 & 0 & 0 & 0 & 0 & 0 & 0 & 0 & 0 & 0 & 0 & 0 & 0 & 0 & 0 & 0 & 0 & 0 & 0 & 0 & 0 & 0 & 0 \\
\hline & Sun, Hol, Other & \begin{tabular}{|l|}
0.15 \\
\end{tabular} & 0.15 & 0.15 & 0.15 & 0.15 & 0.15 & 0.3 & 0.3 & 0.3 & 0.3 & 0.6 & 0.6 & 0.8 & 0.8 & 0.8 & 0.8 & 0.8 & 0.6 & 0.4 & \begin{tabular}{|l|l}
0.4 \\
\end{tabular} & 0.4 & 0.4 & 0.15 & 0.15 \\
\hline \multirow[t]{5}{*}{ BLDG_LIGHT_SCH } & WD & 0.05 & 0.05 & 0.05 & 0.05 & 0.05 & 0.05 & 0.2 & 0.2 & 0.5 & 0.9 & 0.9 & 0.9 & 0.9 & 0.9 & 0.9 & 0.9 & 0.9 & 0.9 & 0.6 & 0.6 & 0.5 & 0.2 & 0.05 & 0.05 \\
\hline & Sat & 0.05 & 0.05 & 0.05 & 0.05 & 0.05 & 0.05 & 0.1 & 0.1 & 0.3 & 0.6 & 0.9 & 0.9 & 0.9 & 0.9 & 0.9 & 0.9 & 0.9 & 0.9 & 0.5 & \begin{tabular}{|l|}
0.3 \\
\end{tabular} & 0.3 & 0.1 & 0.05 & 0.05 \\
\hline & SummerDesign & 1 & 1 & 1 & 1 & 1 & 1 & 1 & 1 & 1 & 1 & 1 & 1 & 1 & 1 & 1 & 1 & 1 & 1 & 1 & 1 & 1 & 1 & 1 & 1 \\
\hline & \begin{tabular}{|l|} 
WinterDesign \\
\end{tabular} & 0 & 0 & 0 & 0 & 0 & 0 & 0 & 0 & 0 & 0 & 0 & 0 & 0 & 0 & 0 & 0 & 0 & 0 & 0 & 0 & 0 & 0 & 0 & 0 \\
\hline & Sun, Hol, Other & 0.05 & 0.05 & 0.05 & 0.05 & 0.05 & 0.05 & 0.1 & 0.1 & 0.1 & 0.1 & 0.4 & 0.4 & 0.6 & 0.6 & 0.6 & 0.6 & 0.6 & 0.4 & 0.2 & \begin{tabular}{|l|l}
0.2 \\
\end{tabular} & 0.2 & 0.2 & 0.05 & 0.05 \\
\hline \multirow[t]{5}{*}{ BLDG_OCC_SCH } & WD & 0 & 0 & 0 & 0 & 0 & 0 & 0.1 & 0.1 & 0.2 & 0.5 & 0.5 & 0.7 & 0.7 & 0.7 & 0.7 & 0.8 & 0.7 & 0.5 & 0.5 & \begin{tabular}{|l|l}
0.3 \\
\end{tabular} & 0.3 & 0.3 & 0 & 0 \\
\hline & \begin{tabular}{|l|} 
SummerDesign \\
\end{tabular} & 1 & 1 & 1 & 1 & 1 & 1 & 1 & 1 & 1 & 1 & 1 & 1 & 1 & 1 & 1 & 1 & 1 & 1 & 1 & 1 & 1 & 1 & 1 & 1 \\
\hline & Sat & 0 & 0 & 0 & 0 & 0 & 0 & 0.1 & 0.1 & 0.2 & 0.5 & 0.6 & 0.8 & 0.8 & 0.8 & 0.8 & 0.8 & 0.8 & 0.6 & 0.2 & 0.2 & 0.2 & 0.1 & 0 & 0 \\
\hline & WinterDesign & 0 & 0 & 0 & 0 & 0 & 0 & 0 & 0 & 0 & 0 & 0 & 0 & 0 & 0 & 0 & 0 & 0 & 0 & 0 & 0 & 0 & 0 & 0 & 0 \\
\hline & \begin{tabular}{|l} 
Sun, Hol, Other \\
\end{tabular} & 0 & 0 & 0 & 0 & 0 & 0 & 0.1 & 0.1 & 0.1 & 0.1 & 0.2 & 0.2 & 0.4 & 0.4 & 0.4 & 0.4 & 0.4 & 0.2 & 0.1 & \begin{tabular}{|l|l|}
0.1 \\
\end{tabular} & 0.1 & 0.1 & 0 & 0 \\
\hline \multirow[t]{4}{*}{ INFIL_HALF_ON_SCH } & WD, SummerDesign & 1 & 1 & 1 & 1 & 1 & 1 & 0.5 & 0.5 & 0.5 & 0.5 & 0.5 & 0.5 & 0.5 & 0.5 & 0.5 & 0.5 & 0.5 & 0.5 & 0.5 & \begin{tabular}{|l|l}
0.5 \\
\end{tabular} & 0.5 & 0.5 & 1 & 1 \\
\hline & Sat & 1 & 1 & 1 & 1 & 1 & 1 & 0.5 & 0.5 & 0.5 & 0.5 & 0.5 & 0.5 & 0.5 & 0.5 & 0.5 & 0.5 & 0.5 & 0.5 & 0.5 & 0.5 & 0.5 & 0.5 & 1 & 1 \\
\hline & WinterDesign & 1 & 1 & 1 & 1 & 1 & 1 & 1 & 1 & 1 & 1 & 1 & 1 & 1 & 1 & 1 & 1 & 1 & 1 & 1 & 1 & 1 & 1 & 1 & 1 \\
\hline & Sun, Hol, Other & 1 & 1 & 1 & 1 & 1 & 1 & 1 & 1 & 0.5 & 0.5 & 0.5 & 0.5 & 0.5 & 0.5 & 0.5 & 0.5 & 0.5 & 1 & 1 & 1 & 1 & 1 & 1 & 1 \\
\hline \multirow[t]{3}{*}{ CLOTHING_SCH } & All & 1 & 1 & 1 & 1 & 1 & 1 & 1 & 1 & 1 & 1 & 1 & 1 & 1 & 1 & 1 & 1 & 1 & 1 & 1 & 1 & 1 & 1 & 1 & 1 \\
\hline & All & 0.5 & 0.5 & 0.5 & 0.5 & 0.5 & 0.5 & 0.5 & 0.5 & 0.5 & 0.5 & 0.5 & 0.5 & 0.5 & 0.5 & 0.5 & 0.5 & 0.5 & 0.5 & 0.5 & 0.5 & 0.5 & 0.5 & 0.5 & 0.5 \\
\hline & All & 1 & 1 & 1 & 1 & 1 & 1 & 1 & 1 & 1 & 1 & 1 & 1 & 1 & 1 & 1 & 1 & 1 & 1 & 1 & 1 & 1 & 1 & 1 & 1 \\
\hline WORK_EFF_SCH & All & 0 & 0 & 0 & 0 & 0 & 0 & 0 & 0 & 0 & 0 & 0 & 0 & 0 & 0 & 0 & 0 & 0 & 0 & 0 & 0 & 0 & 0 & 0 & 0 \\
\hline ACTIVITY_SCH & All & 120 & 120 & 120 & 120 & 120 & 120 & 120 & 120 & 120 & 120 & 120 & 120 & 120 & 120 & 120 & 120 & 120 & 120 & 120 & 120 & 120 & 120 & 120 & 120 \\
\hline AIR_VELO_SCH & All & 0.2 & 0.2 & 0.2 & 0.2 & 0.2 & 0.2 & 0.2 & 0.2 & 0.2 & 0.2 & 0.2 & 0.2 & 0.2 & 0.2 & 0.2 & 0.2 & 0.2 & 0.2 & 0.2 & 0.2 & 0.2 & 0.2 & 0.2 & 0.2 \\
\hline \multirow[t]{2}{*}{ CLGSETP_SCH } & WinterDesign & 30 & 30 & 30 & 30 & 30 & 30 & 30 & 30 & 30 & 30 & 30 & 30 & 30 & 30 & 30 & 30 & 30 & 30 & 30 & 30 & 30 & 30 & 30 & 30 \\
\hline & Other & 30 & 30 & 30 & 30 & 30 & 30 & 24 & 24 & 24 & 24 & 24 & 24 & 24 & 24 & 24 & 24 & 24 & 24 & 24 & 24 & 24 & 24 & 30 & 30 \\
\hline \multirow[t]{2}{*}{ HTGSETP_SCH } & SummerDesign & 15.6 & 15.6 & 15.6 & 15.6 & 15.6 & 15.6 & 15.6 & 15.6 & 15.6 & 15.6 & 15.6 & 15.6 & 15.6 & 15.6 & 15.6 & 15.6 & 15.6 & 15.6 & 15.6 & 15.6 & 15.6 & 15.6 & 15.6 & 15.6 \\
\hline & Other & 15.6 & 15.6 & 15.6 & 15.6 & 15.6 & 15.6 & 21 & 21 & 21 & 21 & 21 & 21 & 21 & 21 & 21 & 21 & 21 & 21 & 21 & 21 & 21 & 21 & 15.6 & 15.6 \\
\hline HVACOperationSchd & All & 0 & 0 & 0 & 0 & 0 & 0 & 1 & 1 & 1 & 1 & 1 & 1 & 1 & 1 & 1 & 1 & 1 & 1 & 1 & 1 & 1 & 1 & 0 & 0 \\
\hline MinOA_Sched & All & 0 & 0 & 0 & 0 & 0 & 0 & 1 & 1 & 1 & 1 & 1 & 1 & 1 & 1 & 1 & 1 & 1 & 1 & 1 & 1 & 1 & 1 & 0 & 0 \\
\hline Dual Zone Control Type Sched & All & 4 & 4 & 4 & 4 & 4 & 4 & 4 & 4 & 4 & 4 & 4 & 4 & 4 & 4 & 4 & 4 & 4 & 4 & 4 & 4 & 4 & 4 & 4 & 4 \\
\hline $\begin{array}{l}\text { Bakery_Case:1_WALKINFREEZER } \\
\text { CaseCreditReduxSched }\end{array}$ & All & 0.2 & 0.2 & 0.2 & 0.2 & 0.2 & 0.2 & 0.2 & 0.4 & 0.4 & 0.4 & 0.4 & 0.4 & 0.4 & 0.4 & 0.4 & 0.4 & 0.4 & 0.4 & 0.4 & 0.4 & 0.4 & 0.2 & 0.2 & 0.2 \\
\hline $\begin{array}{l}\text { Bakery_Case:1_WALKINFREEZER } \\
\text { CaseDefrost2aDaySched }\end{array}$ & All & 0 & 0 & 0 & 0 & 0 & 0 & 0 & 0 & 0 & 0 & 0 & 0 & 0 & 0 & 0 & 0 & 0 & 0 & 0 & 0 & 0 & 0 & 0 & 0 \\
\hline $\begin{array}{l}\text { Bakery_Case:1_WALKINFREEZER } \\
\text { CaseDripDown2aDaySched }\end{array}$ & All & 0 & 0 & 0 & 0 & 0 & 0 & 0 & 0 & 0 & 0 & 0 & 0 & 0 & 0 & 0 & 0 & 0 & 0 & 0 & 0 & 0 & 0 & 0 & 0 \\
\hline $\begin{array}{l}\text { Bakery_Case:1_WALKINFREEZER } \\
\text { _WalkInStockingSched }\end{array}$ & Tue, Fri & 0 & 0 & 0 & 0 & 725 & 417 & 290 & 0 & 0 & 0 & 0 & 0 & 0 & 0 & 0 & 0 & 0 & 0 & 0 & 0 & 0 & 0 & 0 & 0 \\
\hline
\end{tabular}




\begin{tabular}{|c|c|c|c|c|c|c|c|c|c|c|c|c|c|c|c|c|c|c|c|c|c|c|c|c|c|}
\hline Schedule & Day of Week & 1 & 2 & 3 & 4 & 5 & 6 & 7 & 8 & 9 & 10 & 11 & 12 & 13 & 14 & 15 & 16 & 17 & 18 & 19 & 20 & 21 & 22 & 23 & 24 \\
\hline & Other & 0 & 0 & 0 & 0 & 125 & 117 & 90 & 0 & 0 & 0 & 0 & 0 & 0 & 0 & 0 & 0 & 0 & 0 & 0 & 125 & 1117 & 90 & 0 & 0 \\
\hline $\begin{array}{l}\text { Deli_Case:1_- } \\
\text { MULTIDECKDIARYANDDELICASE } \\
\text { CaseCreditReduxSched }\end{array}$ & All & 0.2 & 0.2 & 0.2 & 0.2 & 0.2 & 0.2 & 0.2 & 0.6 & 0.6 & 0.6 & 0.6 & 0.6 & 0.6 & 0.6 & 0.6 & 0.6 & 0.6 & 0.6 & 0.6 & 0.6 & 0.6 & 0.2 & 0.2 & 0.2 \\
\hline $\begin{array}{l}\text { Deli_Case:1_- } \\
\text { MULTIDECKDIARYANDDELICASE } \\
\text { CaseDefrost2aDaySched }\end{array}$ & All & 0 & 0 & 0 & 0 & 0 & 0 & 0 & 0 & 0 & 0 & 0 & 0 & 0 & 0 & 0 & 0 & 0 & 0 & 0 & 0 & 0 & 0 & 0 & 0 \\
\hline $\begin{array}{l}\text { Deli_Case:1_- } \\
\text { MULTIDECKDIARYANDDELICASE } \\
\text { CCaseDripDown2aDaySched }\end{array}$ & All & 0 & 0 & 0 & 0 & 0 & 0 & 0 & 0 & 0 & 0 & 0 & 0 & 0 & 0 & 0 & 0 & 0 & 0 & 0 & 0 & 0 & 0 & 0 & 0 \\
\hline $\begin{array}{l}\text { Deli_Case:1_- } \\
\text { MULTIDECKDIARYANDDELICASE } \\
\text { CaseStockingSched }\end{array}$ & All & 0 & 0 & 0 & 0 & 0 & 0 & 0 & 0 & 0 & 0 & 0 & 0 & 0 & 50 & 35 & 0 & 0 & 0 & 0 & 0 & 0 & 0 & 0 & 0 \\
\hline $\begin{array}{l}\text { Deli_Case:2_WALKINFREEZER_C } \\
\text { aseCreditReduxSched }\end{array}$ & All & 0.2 & 0.2 & 0.2 & 0.2 & 0.2 & 0.2 & 0.2 & 0.4 & 0.4 & 0.4 & 0.4 & 0.4 & 0.4 & 0.4 & 0.4 & 0.4 & 0.4 & 0.4 & 0.4 & 0.4 & 0.4 & 0.2 & 0.2 & 0.2 \\
\hline $\begin{array}{l}\text { Deli_Case:2_WALKINFREEZER_C } \\
\text { aseDefrost2aDaySched }\end{array}$ & All & 0 & 0 & 0 & 0 & 0 & 0 & 0 & 0 & 0 & 0 & 0 & 0 & 0 & 0 & 0 & 0 & 0 & 0 & 0 & 0 & 0 & 0 & 0 & 0 \\
\hline $\begin{array}{l}\text { Deli_Case:2_WALKINFREEZER_C } \\
\text { aseDripDown2aDaySched }\end{array}$ & All & 0 & 0 & 0 & 0 & 0 & 0 & 0 & 0 & 0 & 0 & 0 & 0 & 0 & 0 & 0 & 0 & 0 & 0 & 0 & 0 & 0 & 0 & 0 & 0 \\
\hline $\begin{array}{l}\text { Deli_Case:2_WALKINFREEZER_W } \\
\text { alkInStockingSched }\end{array}$ & Tue, Fri & 0 & 0 & 0 & 0 & 725 & 417 & 290 & 0 & 0 & 0 & 0 & 0 & 0 & 0 & 0 & 0 & 0 & 0 & 0 & 0 & 0 & 0 & 0 & 0 \\
\hline & Other & 0 & 0 & 0 & 0 & 125 & 117 & 90 & 0 & 0 & 0 & 0 & 0 & 0 & 0 & 0 & 0 & 0 & 0 & 0 & \begin{tabular}{|l|}
125 \\
\end{tabular} & 117 & 90 & 0 & 0 \\
\hline $\begin{array}{l}\text { Produce_Case:1 } \\
\text { MULTIDECKDIARYANDDELICASE_ } \\
\text { CaseCreditReduxSched }\end{array}$ & All & 0.2 & 0.2 & 0.2 & 0.2 & 0.2 & 0.2 & 0.2 & 0.6 & 0.6 & 0.6 & 0.6 & 0.6 & 0.6 & 0.6 & 0.6 & 0.6 & 0.6 & 0.6 & 0.6 & 0.6 & 0.6 & 0.2 & 0.2 & 0.2 \\
\hline $\begin{array}{l}\text { Produce_Case: } 1 \\
\text { MULTIDECKDIARYANDDELICASE_ } \\
\text { CaseDefrost2aDaySched }\end{array}$ & All & 0 & 0 & 0 & 0 & 0 & 0 & 0 & 0 & 0 & 0 & 0 & 0 & 0 & 0 & 0 & 0 & 0 & 0 & 0 & 0 & 0 & 0 & 0 & 0 \\
\hline $\begin{array}{l}\text { Produce_Case: } 1 \\
\text { MULTIDECKDIARYANDDELICASE_ } \\
\text { CaseDripDown2aDaySched }\end{array}$ & All & 0 & 0 & 0 & 0 & 0 & 0 & 0 & 0 & 0 & 0 & 0 & 0 & 0 & 0 & 0 & 0 & 0 & 0 & 0 & 0 & 0 & 0 & 0 & 0 \\
\hline $\begin{array}{l}\text { Produce_Case: } 1 \\
\text { MULTIDĒCKDIARYAANDDELICASE_ } \\
\text { CaseStockingSched }\end{array}$ & All & 0 & 0 & 0 & 0 & 0 & 0 & 0 & 0 & 0 & 0 & 0 & 0 & 0 & 50 & 35 & 0 & 0 & 0 & 0 & 0 & 0 & 0 & 0 & 0 \\
\hline $\begin{array}{l}\text { Sales_Case:1_MEATDISPLAYCASE } \\
\text { CaseDefrost2aDaySched }\end{array}$ & All & 0 & 0 & 0 & 0 & 0 & 0 & 0 & 0 & 0 & 0 & 0 & 0 & 0 & 0 & 0 & 0 & 0 & 0 & 0 & 0 & 0 & 0 & 0 & 0 \\
\hline $\begin{array}{l}\text { Sales_Case:1_MEATDISPLAYCASE } \\
\text { CaseDripDown2aDaySched }\end{array}$ & All & 0 & 0 & 0 & 0 & 0 & 0 & 0 & 0 & 0 & 0 & 0 & 0 & 0 & 0 & 0 & 0 & 0 & 0 & 0 & 0 & 0 & 0 & 0 & 0 \\
\hline $\begin{array}{l}\text { Sales_Case:1_MEATDISPLAYCASE } \\
\text { CaseStockingSched }\end{array}$ & All & 0 & 0 & 0 & 0 & 0 & 0 & 0 & 0 & 0 & 0 & 0 & 0 & 0 & 50 & 35 & 0 & 0 & 0 & 0 & 0 & 0 & 0 & 0 & 0 \\
\hline $\begin{array}{l}\text { Sales_Case:2 } \\
\text { MULTIDECKDIARYANDDELICASE_ } \\
\text { CaseCreditReduxSched }\end{array}$ & All & 0.2 & 0.2 & 0.2 & 0.2 & 0.2 & 0.2 & 0.2 & 0.6 & 0.6 & 0.6 & 0.6 & 0.6 & 0.6 & 0.6 & 0.6 & 0.6 & 0.6 & 0.6 & 0.6 & 0.6 & 0.6 & 0.2 & 0.2 & 0.2 \\
\hline $\begin{array}{l}\text { Sales_Case:2_- } \\
\text { MULTIDECKDIARYANDDELICASE_ } \\
\text { CaseDefrost2aDaySched }\end{array}$ & All & 0 & 0 & 0 & 0 & 0 & 0 & 0 & 0 & 0 & 0 & 0 & 0 & 0 & 0 & 0 & 0 & 0 & 0 & 0 & 0 & 0 & 0 & 0 & 0 \\
\hline $\begin{array}{l}\text { Sales_Case:2 } \\
\text { MULTIDECKDIARYANDDELICASE_ } \\
\text { CaseDripDown2aDaySched }\end{array}$ & All & 0 & 0 & 0 & 0 & 0 & 0 & 0 & 0 & 0 & 0 & 0 & 0 & 0 & 0 & 0 & 0 & 0 & 0 & 0 & 0 & 0 & 0 & 0 & 0 \\
\hline
\end{tabular}




\begin{tabular}{|c|c|c|c|c|c|c|c|c|c|c|c|c|c|c|c|c|c|c|c|c|c|c|c|c|c|}
\hline Schedule & Day of Week & 1 & 2 & 3 & 4 & 5 & 6 & 7 & 8 & 9 & 10 & 11 & 12 & 13 & 14 & 15 & 16 & 17 & 18 & 19 & 20 & 21 & 22 & 23 & 24 \\
\hline $\begin{array}{l}\text { Sales_Case:2 } \\
\text { MULTIDECKDIARYANDDELICASE_ } \\
\text { CaseStockingSched }\end{array}$ & All & 0 & 0 & 0 & 0 & 0 & 0 & 0 & 0 & 0 & 0 & 0 & 0 & 0 & 50 & 35 & 0 & 0 & 0 & 0 & 0 & 0 & 0 & 0 & 0 \\
\hline $\begin{array}{l}\text { Sales_Case:3_GLASSDOORFROZE } \\
\text { NFOOD_CaseCreditReduxSched }\end{array}$ & All & 0.2 & 0.2 & 0.2 & 0.2 & 0.2 & 0.2 & 0.2 & 0.6 & 0.6 & 0.6 & 0.6 & 0.6 & 0.6 & 0.6 & 0.6 & 0.6 & 0.6 & 0.6 & 0.6 & 0.6 & 0.6 & 0.2 & 0.2 & 0.2 \\
\hline $\begin{array}{l}\text { Sales_Case:3_GLASSDOORFROZE } \\
\text { NFOOD_CaseDefrost2aDaySched } \\
\end{array}$ & All & 0 & 0 & 0 & 0 & 0 & 0 & 0 & 0 & 0 & 0 & 0 & 0 & 0 & 0 & 0 & 0 & 0 & 0 & 0 & 0 & 0 & 0 & 0 & 0 \\
\hline $\begin{array}{l}\text { Sales_Case:3_GLASSDOORFROZE } \\
\text { NFOOD_CaseDripDown2aDaySched }\end{array}$ & All & 0 & 0 & 0 & 0 & 0 & 0 & 0 & 0 & 0 & 0 & 0 & 0 & 0 & 0 & 0 & 0 & 0 & 0 & 0 & 0 & 0 & 0 & 0 & 0 \\
\hline $\begin{array}{l}\text { Sales_Case:3_GLASSDOORFROZE } \\
\text { NFOOD_CaseStockingSched }\end{array}$ & All & 0 & 0 & 0 & 0 & 0 & 0 & 0 & 0 & 0 & 0 & 0 & 0 & 0 & 50 & 35 & 0 & 0 & 0 & 0 & 0 & 0 & 0 & 0 & 0 \\
\hline $\begin{array}{l}\text { Sales_Case:4_OPENWELLICECRE } \\
\text { AMDISPLAYCASE_CaseCreditRedu } \\
\text { xSched }\end{array}$ & All & 0.2 & 0.2 & 0.2 & 0.2 & 0.2 & 0.2 & 0.2 & 0.6 & 0.6 & 0.6 & 0.6 & 0.6 & 0.6 & 0.6 & 0.6 & 0.6 & 0.6 & 0.6 & 0.6 & 0.6 & 0.6 & 0.2 & 0.2 & 0.2 \\
\hline $\begin{array}{l}\text { Sales_Case:4_OPENWELLICECRE } \\
\text { AMDISPLAYCASE_CaseDefrost2aD } \\
\text { aySched }\end{array}$ & All & 0 & 0 & 0 & 0 & 0 & 0 & 0 & 0 & 0 & 0 & 0 & 0 & 0 & 0 & 0 & 0 & 0 & 0 & 0 & 0 & 0 & 0 & 0 & 0 \\
\hline $\begin{array}{l}\text { Sales_Case:4_OPENWELLICECRE } \\
\text { AMDISPLAYCASE_CaseDripDown2 } \\
\text { aDaySched }\end{array}$ & All & 0 & 0 & 0 & 0 & 0 & 0 & 0 & 0 & 0 & 0 & 0 & 0 & 0 & 0 & 0 & 0 & 0 & 0 & 0 & 0 & 0 & 0 & 0 & 0 \\
\hline $\begin{array}{l}\text { Sales_Case:4_OPENWELLICECRE } \\
\text { AMDISPLAYCASE_CaseStockingSc } \\
\text { hed }\end{array}$ & All & 0 & 0 & 0 & 0 & 0 & 0 & 0 & 0 & 0 & 0 & 0 & 0 & 0 & 50 & 35 & 0 & 0 & 0 & 0 & 0 & 0 & 0 & 0 & 0 \\
\hline $\begin{array}{l}\text { Sales_Case:5_WALKINFREEZER_C } \\
\text { aseCreditReduXSched }\end{array}$ & All & 0.2 & 0.2 & 0.2 & 0.2 & 0.2 & 0.2 & 0.2 & 0.4 & 0.4 & 0.4 & 0.4 & 0.4 & 0.4 & 0.4 & 0.4 & 0.4 & 0.4 & 0.4 & 0.4 & 0.4 & 0.4 & 0.2 & 0.2 & 0.2 \\
\hline $\begin{array}{l}\text { Sales_Case:5_WALKINFREEZER_C } \\
\text { aseDefrost2aDaySched }\end{array}$ & All & 0 & 0 & 0 & 0 & 0 & 0 & 0 & 0 & 0 & 0 & 0 & 0 & 0 & 0 & 0 & 0 & 0 & 0 & 0 & 0 & 0 & 0 & 0 & 0 \\
\hline $\begin{array}{l}\text { Sales_Case:5_WALKINFREEZER_C } \\
\text { aseDripDown2aDaySched }\end{array}$ & All & 0 & 0 & 0 & 0 & 0 & 0 & 0 & 0 & 0 & 0 & 0 & 0 & 0 & 0 & 0 & 0 & 0 & 0 & 0 & 0 & 0 & 0 & 0 & 0 \\
\hline $\begin{array}{l}\text { Sales_Case:5_WALKINFREEZER_ } \\
\text { WalkInStockingSched }\end{array}$ & Tue, Fri & 0 & 0 & 0 & 0 & 725 & 417 & 290 & 0 & 0 & 0 & 0 & 0 & 0 & 0 & 0 & 0 & 0 & 0 & 0 & 0 & 0 & 0 & 0 & 0 \\
\hline & Other & 0 & 0 & 0 & 0 & 125 & 117 & 90 & 0 & 0 & 0 & 0 & 0 & 0 & 0 & 0 & 0 & 0 & 0 & 0 & 125 & 117 & 90 & 0 & 0 \\
\hline $\begin{array}{l}\text { Sales_Case:6_WALKINFREEZER_C } \\
\text { aseCreditReduxSched }\end{array}$ & All & 0.2 & 0.2 & 0.2 & 0.2 & 0.2 & 0.2 & 0.2 & 0.4 & 0.4 & 0.4 & 0.4 & 0.4 & 0.4 & 0.4 & 0.4 & 0.4 & 0.4 & 0.4 & 0.4 & 0.4 & 0.4 & 0.2 & 0.2 & 0.2 \\
\hline $\begin{array}{l}\text { Sales_Case:6_WALKINFREEZER_C } \\
\text { aseDefrost2aDaySched }\end{array}$ & All & 0 & 0 & 0 & 0 & 0 & 0 & 0 & 0 & 0 & 0 & 0 & 0 & 0 & 0 & 0 & 0 & 0 & 0 & 0 & 0 & 0 & 0 & 0 & 0 \\
\hline $\begin{array}{l}\text { Sales_Case:6_WALKINFREEZER_C } \\
\text { aseDripDown2aDaySched }\end{array}$ & All & 0 & 0 & 0 & 0 & 0 & 0 & 0 & 0 & 0 & 0 & 0 & 0 & 0 & 0 & 0 & 0 & 0 & 0 & 0 & 0 & 0 & 0 & 0 & 0 \\
\hline $\begin{array}{l}\text { Sales_Case:6_WALKINFREEZER_ } \\
\text { WalkInStockingSched }\end{array}$ & Tue, Fri & 0 & 0 & 0 & 0 & 725 & 417 & 290 & 0 & 0 & 0 & 0 & 0 & 0 & 0 & 0 & 0 & 0 & 0 & 0 & 0 & 0 & 0 & 0 & 0 \\
\hline & Other & 0 & 0 & 0 & 0 & 125 & 117 & 90 & 0 & 0 & 0 & 0 & 0 & 0 & 0 & 0 & 0 & 0 & 0 & 0 & 125 & 117 & 90 & 0 & 0 \\
\hline $\begin{array}{l}\text { Sales_Case:7_WALKINFREEZER_C } \\
\text { aseCreditReduxSched }\end{array}$ & All & 0 & 0 & 0 & 0 & 0 & 0 & 0 & 0 & 0 & 0 & 0 & 0 & 0 & 0 & 0 & 0 & 0 & 0 & 0 & 0 & 0 & 0 & 0 & 0 \\
\hline $\begin{array}{l}\text { Sales_Case:7_WALKINFREEZER_C } \\
\text { aseDefrost2aDaySched }\end{array}$ & All & 0 & 0 & 0 & 0 & 0 & 0 & 0 & 0 & 0 & 0 & 0 & 0 & 0 & 0 & 0 & 0 & 0 & 0 & 0 & 0 & 0 & 0 & 0 & 0 \\
\hline $\begin{array}{l}\text { Sales_Case:7_WALKINFREEZER_C } \\
\text { aseDripDown2aDaySched }\end{array}$ & All & 0 & 0 & 0 & 0 & 0 & 0 & 0 & 0 & 0 & 0 & 0 & 0 & 0 & 0 & 0 & 0 & 0 & 0 & 0 & 0 & 0 & 0 & 0 & 0 \\
\hline $\begin{array}{l}\text { Sales_Case:7_WALKINFREEZER_ } \\
\text { WalkInStockingSched }\end{array}$ & Tue, Fri & 0 & 0 & 0 & 0 & 725 & 417 & 290 & 0 & 0 & 0 & 0 & 0 & 0 & 0 & 0 & 0 & 0 & 0 & 0 & 0 & 0 & 0 & 0 & 0 \\
\hline & Other & 0 & 0 & 0 & 0 & 125 & 117 & 90 & 0 & 0 & 0 & 0 & 0 & 0 & 0 & 0 & 0 & 0 & 0 & 0 & \begin{tabular}{|l|}
125 \\
\end{tabular} & 117 & 90 & 0 & 0 \\
\hline BLDG_SWH_SCH & WD, SummerDesign & \begin{tabular}{|l|}
0.04 \\
\end{tabular} & 0.05 & 0.05 & 0.04 & 0.04 & 0.04 & 0.04 & 0.15 & 0.23 & 0.32 & 0.41 & 0.57 & 0.62 & 0.61 & 0.5 & 0.45 & 0.46 & 0.47 & 0.42 & \begin{tabular}{|l|l|}
0.34 \\
\end{tabular} & 0.33 & 0.23 & 0.13 & 0.08 \\
\hline
\end{tabular}




\begin{tabular}{|c|c|c|c|c|c|c|c|c|c|c|c|c|c|c|c|c|c|c|c|c|c|c|c|c|c|}
\hline Schedule & Day of Week & 1 & 2 & 3 & 4 & 5 & 6 & 7 & 8 & 9 & 10 & 11 & 12 & 13 & 14 & 15 & 16 & 17 & 18 & 19 & 20 & 21 & 22 & 23 & 24 \\
\hline & Sat, WinterDesign & 0.11 & 0.1 & 0.08 & 0.06 & 0.06 & 0.06 & 0.07 & 0.2 & 0.24 & 0.27 & 0.42 & 0.54 & 0.59 & 0.6 & 0.49 & 0.48 & 0.47 & 0.46 & 0.44 & 0.36 & 0.29 & 0.22 & 0.16 & 0.13 \\
\hline & Sun, Hol, Other & 0.07 & 0.07 & 0.07 & 0.06 & 0.06 & 0.06 & 0.07 & 0.1 & 0.12 & 0.14 & 0.29 & 0.31 & 0.36 & 0.36 & 0.34 & 0.35 & 0.37 & 0.34 & 0.25 & 0.27 & 0.21 & 0.16 & 0.1 & 0.06 \\
\hline Water Equipment Latent fract sched & All & 0.05 & 0.05 & 0.05 & 0.05 & 0.05 & 0.05 & 0.05 & 0.05 & 0.05 & 0.05 & 0.05 & 0.05 & 0.05 & 0.05 & 0.05 & 0.05 & 0.05 & 0.05 & 0.05 & 0.05 & 0.05 & 0.05 & 0.05 & 0.05 \\
\hline $\begin{array}{l}\text { Water Equipment Sensible fract } \\
\text { sched }\end{array}$ & All & 0.2 & 0.2 & 0.2 & 0.2 & 0.2 & 0.2 & 0.2 & 0.2 & 0.2 & 0.2 & 0.2 & 0.2 & 0.2 & 0.2 & 0.2 & 0.2 & 0.2 & 0.2 & 0.2 & 0.2 & 0.2 & 0.2 & 0.2 & 0.2 \\
\hline $\begin{array}{l}\text { Water Equipment Hot Supply Temp } \\
\text { Sched }\end{array}$ & All & 49 & 49 & 49 & 49 & 49 & 49 & 49 & 49 & 49 & 49 & 49 & 49 & 49 & 49 & 49 & 49 & 49 & 49 & 49 & 49 & 49 & 49 & 49 & 49 \\
\hline Water Equipment Temp Sched & All & 49 & 49 & 49 & 49 & 49 & 49 & 49 & 49 & 49 & 49 & 49 & 49 & 49 & 49 & 49 & 49 & 49 & 49 & 49 & 49 & 49 & 49 & 49 & 49 \\
\hline PlantOnSched & All & 1 & 1 & 1 & 1 & 1 & 1 & 1 & 1 & 1 & 1 & 1 & 1 & 1 & 1 & 1 & 1 & 1 & 1 & 1 & 1 & 1 & 1 & 1 & 1 \\
\hline $\begin{array}{l}\text { SWHSys } 1 \text { Water Heater Ambient } \\
\text { Temperature Schedule Name }\end{array}$ & All & 22 & 22 & 22 & 22 & 22 & 22 & 22 & 22 & 22 & 22 & 22 & 22 & 22 & 22 & 22 & 22 & 22 & 22 & 22 & 22 & 22 & 22 & 22 & 22 \\
\hline $\begin{array}{l}\text { SWHSys1 Water Heater Setpoint } \\
\text { Temperature Schedule Name }\end{array}$ & All & 60 & 60 & 60 & 60 & 60 & 60 & 60 & 60 & 60 & 60 & 60 & 60 & 60 & 60 & 60 & 60 & 60 & 60 & 60 & 60 & 60 & 60 & 60 & 60 \\
\hline SWHSys1-Loop-Temp-Schedule & All & 60 & 60 & 60 & 60 & 60 & 60 & 60 & 60 & 60 & 60 & 60 & 60 & 60 & 60 & 60 & 60 & 60 & 60 & 60 & 60 & 60 & 60 & 60 & 60 \\
\hline
\end{tabular}


Table B-16 Warehouse Hourly Operation Schedules

\begin{tabular}{|c|c|c|c|c|c|c|c|c|c|c|c|c|c|c|c|c|c|c|c|c|c|c|c|c|c|}
\hline Schedule & Day of Week & 1 & 2 & 3 & 4 & 5 & 6 & 7 & 8 & 9 & 10 & 11 & 12 & 13 & 14 & 15 & 16 & 17 & 18 & 19 & 20 & 21 & 22 & 23 & 24 \\
\hline $\begin{array}{l}\text { ALWAYS_ON } \\
\end{array}$ & All & $\overline{11}$ & $\overline{11}$ & $\overline{11}$ & 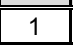 & 1 & 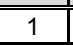 & $\overline{11}$ & $\overline{11}$ & $\overline{11}$ & $\overline{11}$ & $\overline{11}$ & $\overline{11}$ & $\overline{11}$ & $\overline{11}$ & 1 & 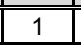 & $\overline{11}$ & $\overline{11}$ & $\overline{11}$ & $\overline{11}$ & $\overline{11}$ & $\overline{11}$ & $\overline{11}$ & 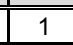 \\
\hline ACTIVITY_SCH & All & 120 & 120 & 120 & 120 & 120 & 120 & 120 & 120 & 120 & 120 & 120 & 120 & 120 & 120 & 120 & 120 & 120 & 120 & 120 & 120 & 120 & 120 & 120 & 120 \\
\hline AIR_VELO_SCH & All & 0.2 & \begin{tabular}{|l|}
0.2 \\
\end{tabular} & 0.2 & \begin{tabular}{|l|}
0.2 \\
\end{tabular} & \begin{tabular}{|l|}
0.2 \\
\end{tabular} & 0.2 & 0.2 & 0.2 & 0.2 & 0.2 & \begin{tabular}{|l|}
0.2 \\
\end{tabular} & \begin{tabular}{|l|}
0.2 \\
\end{tabular} & \begin{tabular}{|l|}
0.2 \\
\end{tabular} & 0.2 & 0.2 & 0.2 & 0.2 & 0.2 & \begin{tabular}{|l|}
0.2 \\
\end{tabular} & 0.2 & \begin{tabular}{|l|}
0.2 \\
\end{tabular} & 0.2 & \begin{tabular}{|l|}
0.2 \\
\end{tabular} & 0.2 \\
\hline \multirow[t]{5}{*}{ BLDG_EQUIP_SCH } & WD & \begin{tabular}{|l|} 
\\
\end{tabular} & \begin{tabular}{|l|}
0.1 \\
\end{tabular} & \begin{tabular}{|l|}
0.1 \\
\end{tabular} & \begin{tabular}{|l|}
0.1 \\
\end{tabular} & \begin{tabular}{|l|}
0.1 \\
\end{tabular} & 0.1 & 0.1 & 0.5 & \begin{tabular}{|l|l|}
0.8 \\
\end{tabular} & \begin{tabular}{|l|}
0.9 \\
\end{tabular} & 0.9 & \begin{tabular}{|l|}
0.9 \\
\end{tabular} & \begin{tabular}{|l|}
0.8 \\
\end{tabular} & 0.9 & 0.9 & 0.9 & 0.9 & 0.4 & \begin{tabular}{|l|}
0.1 \\
\end{tabular} & 0.1 & \begin{tabular}{|l|}
0.1 \\
\end{tabular} & 0.1 & 0.1 & 0.1 \\
\hline & Sat & 0.1 & \begin{tabular}{|l|}
0.1 \\
\end{tabular} & \begin{tabular}{|l|}
0.1 \\
\end{tabular} & \begin{tabular}{|l|}
0.1 \\
\end{tabular} & \begin{tabular}{|l|}
0.1 \\
\end{tabular} & 0.1 & 0.1 & \begin{tabular}{|l|l|}
0.1 \\
\end{tabular} & \begin{tabular}{|l|}
0.2 \\
\end{tabular} & \begin{tabular}{|l|}
0.4 \\
\end{tabular} & 0.4 & \begin{tabular}{|l|}
0.4 \\
\end{tabular} & \begin{tabular}{|l|}
0.1 \\
\end{tabular} & \begin{tabular}{|l|}
0.1 \\
\end{tabular} & \begin{tabular}{|l|}
0.1 \\
\end{tabular} & \begin{tabular}{|l|}
0.1 \\
\end{tabular} & \begin{tabular}{|l|}
0.1 \\
\end{tabular} & \begin{tabular}{|l|}
0.1 \\
\end{tabular} & \begin{tabular}{|l|}
0.1 \\
\end{tabular} & 0.1 & \begin{tabular}{|l|}
0.1 \\
\end{tabular} & 0.1 & 0.1 & 0.1 \\
\hline & SummerDesign & 1 & 1 & 1 & 1 & 1 & 1 & 1 & 1 & 1 & 1 & 1 & 1 & 1 & 1 & 1 & 1 & 1 & 1 & 1 & 1 & 1 & 1 & 1 & 1 \\
\hline & WinterDesign & 0 & 0 & 0 & 0 & 0 & 0 & 0 & 0 & 0 & 0 & 0 & 0 & 0 & 0 & 0 & 0 & 0 & 0 & 0 & 0 & 0 & 0 & 0 & 0 \\
\hline & Sun, $\mathrm{Hol}$, Other & 0.1 & \begin{tabular}{|l|}
0.1 \\
\end{tabular} & \begin{tabular}{|l|}
0.1 \\
\end{tabular} & \begin{tabular}{|l|}
0.1 \\
\end{tabular} & \begin{tabular}{|l|}
0.1 \\
\end{tabular} & 0.1 & 0.1 & \begin{tabular}{|l|}
0.1 \\
\end{tabular} & \begin{tabular}{|l|}
0.1 \\
\end{tabular} & \begin{tabular}{|l|}
0.1 \\
\end{tabular} & 0.1 & \begin{tabular}{|l|}
0.1 \\
\end{tabular} & 0.1 & \begin{tabular}{|l|}
0.1 \\
\end{tabular} & 0.1 & \begin{tabular}{|l|}
0.1 \\
\end{tabular} & \begin{tabular}{|l|}
0.1 \\
\end{tabular} & \begin{tabular}{|l|}
0.1 \\
\end{tabular} & \begin{tabular}{|l|}
0.1 \\
\end{tabular} & 0.1 & \begin{tabular}{|l|}
0.1 \\
\end{tabular} & 0.1 & 0.1 & 0.1 \\
\hline \multirow{5}{*}{ BLDG_LIGHT_SCH } & WD & 0.1 & \begin{tabular}{|l|}
0.1 \\
\end{tabular} & \begin{tabular}{|c|}
0.1 \\
\end{tabular} & \begin{tabular}{|l|}
0.1 \\
\end{tabular} & \begin{tabular}{|l|}
0.1 \\
\end{tabular} & \begin{tabular}{|c|}
0.1 \\
\end{tabular} & 0.1 & 0.4 & \begin{tabular}{|l|l}
0.7 \\
\end{tabular} & \begin{tabular}{|l|}
0.9 \\
\end{tabular} & \begin{tabular}{|c|}
0.9 \\
\end{tabular} & \begin{tabular}{|l|}
0.9 \\
\end{tabular} & \begin{tabular}{|l|}
0.8 \\
\end{tabular} & 0.9 & 0.9 & 0.9 & 0.9 & 0.3 & \begin{tabular}{|l|}
0.1 \\
\end{tabular} & 0.1 & \begin{tabular}{|l|}
0.1 \\
\end{tabular} & 0.1 & 0.1 & 0.1 \\
\hline & Sat & 0.1 & \begin{tabular}{|l|}
0.1 \\
\end{tabular} & \begin{tabular}{|l|}
0.1 \\
\end{tabular} & \begin{tabular}{|l|}
0.1 \\
\end{tabular} & \begin{tabular}{|l|}
0.1 \\
\end{tabular} & \begin{tabular}{|l|}
0.1 \\
\end{tabular} & 0.1 & \begin{tabular}{|l|}
0.1 \\
\end{tabular} & \begin{tabular}{|l|}
0.1 \\
\end{tabular} & 0.24 & 0.24 & \begin{tabular}{|l|}
0.24 \\
\end{tabular} & 0.1 & 0.1 & 0.1 & 0.1 & 0.1 & 0.1 & \begin{tabular}{|l|}
0.1 \\
\end{tabular} & 0.1 & \begin{tabular}{|l|}
0.1 \\
\end{tabular} & 0.1 & 0.1 & 0.1 \\
\hline & SummerDesign & 1 & 1 & 1 & 1 & 1 & 1 & 1 & 1 & 1 & 1 & 1 & 1 & 1 & 1 & 1 & 1 & 1 & 1 & 1 & 1 & 1 & 1 & 1 & 1 \\
\hline & WinterDesign & 0 & 0 & 0 & 0 & 0 & 0 & 0 & 0 & 0 & 0 & 0 & 0 & 0 & 0 & 0 & 0 & 0 & 0 & 0 & 0 & 0 & 0 & 0 & 0 \\
\hline & Sun, Hol, Other & 0.1 & \begin{tabular}{|l|}
0.1 \\
\end{tabular} & \begin{tabular}{|l|}
0.1 \\
\end{tabular} & \begin{tabular}{|l|}
0.1 \\
\end{tabular} & \begin{tabular}{|l|}
0.1 \\
\end{tabular} & 0.1 & 0.1 & 0.1 & 0.1 & \begin{tabular}{|l|}
0.1 \\
\end{tabular} & 0.1 & \begin{tabular}{|l|}
0.1 \\
\end{tabular} & \begin{tabular}{|l|}
0.1 \\
\end{tabular} & 0.1 & 0.1 & 0.1 & 0.1 & 0.1 & \begin{tabular}{|l|}
0.1 \\
\end{tabular} & 0.1 & \begin{tabular}{|l|}
0.1 \\
\end{tabular} & 0.1 & 0.1 & 0.1 \\
\hline \multirow[t]{5}{*}{ BLDG_OCC_SCH } & WD & 0 & \begin{tabular}{|l|l|}
0 \\
\end{tabular} & 0 & \begin{tabular}{|l|l|}
0 \\
\end{tabular} & 0 & 0 & 0 & \begin{tabular}{|l|}
0.15 \\
\end{tabular} & \begin{tabular}{|l|l|}
0.7 \\
\end{tabular} & \begin{tabular}{|l|}
0.9 \\
\end{tabular} & \begin{tabular}{|l|l|}
0.9 \\
\end{tabular} & \begin{tabular}{|l|}
0.9 \\
\end{tabular} & \begin{tabular}{|l|}
0.5 \\
\end{tabular} & \begin{tabular}{|l|}
0.85 \\
\end{tabular} & \begin{tabular}{|l|}
0.85 \\
\end{tabular} & \begin{tabular}{|l|}
0.85 \\
0.9
\end{tabular} & \begin{tabular}{|l|l|}
0.2 \\
\end{tabular} & 0 & 0 & 0 & \begin{tabular}{|l|l|}
0 \\
\end{tabular} & 0 & 0 & 0 \\
\hline & SummerDesign & 1 & 1 & 1 & 1 & 1 & 1 & 1 & 1 & 1 & 1 & 1 & \begin{tabular}{|c|}
1 \\
\end{tabular} & \begin{tabular}{|l|}
1 \\
\end{tabular} & 1 & 1 & 1 & \begin{tabular}{|c|}
1 \\
\end{tabular} & 1 & 1 & 1 & 1 & 1 & 1 & 1 \\
\hline & Sat & 0 & 0 & 0 & 0 & 0 & 0 & 0 & 0 & 0.2 & \begin{tabular}{|l|}
0.2 \\
\end{tabular} & \begin{tabular}{|l|}
0.2 \\
\end{tabular} & \begin{tabular}{|l|}
0.2 \\
\end{tabular} & \begin{tabular}{|l|}
0.1 \\
\end{tabular} & 0.1 & 0.1 & 0.1 & 0 & 0 & 0 & 0 & 0 & 0 & 0 & 0 \\
\hline & WinterDesign & 0 & 0 & 0 & 0 & 0 & 0 & 0 & 0 & \begin{tabular}{|l}
0 \\
0
\end{tabular} & \begin{tabular}{|l}
0 \\
\end{tabular} & 0 & \begin{tabular}{|l|}
0 \\
0
\end{tabular} & 0 & 0 & 0 & 0 & 0 & 0 & 0 & 0 & 0 & 0 & 0 & 0 \\
\hline & Sun, $\mathrm{Hol}$, Other & 0 & 0 & 0 & 0 & 0 & 0 & 0 & 0 & 0 & 0 & 0 & 0 & 0 & 0 & 0 & 0 & 0 & 0 & 0 & 0 & 0 & 0 & 0 & 0 \\
\hline \multirow[t]{3}{*}{ CLOTHING_SCH } & All & 1 & 1 & 1 & 1 & 1 & 1 & 1 & 1 & 1 & 1 & 1 & 1 & 1 & 1 & 1 & 1 & 1 & 1 & 1 & 1 & 1 & 1 & 1 & 1 \\
\hline & All & 0.5 & \begin{tabular}{|l|}
0.5 \\
\end{tabular} & \begin{tabular}{|l|}
0.5 \\
\end{tabular} & \begin{tabular}{|l|}
0.5 \\
\end{tabular} & \begin{tabular}{|l|}
0.5 \\
\end{tabular} & \begin{tabular}{|l|}
0.5 \\
\end{tabular} & 0.5 & 0.5 & 0.5 & \begin{tabular}{|l|}
0.5 \\
\end{tabular} & 0.5 & \begin{tabular}{|l|}
0.5 \\
\end{tabular} & 0.5 & 0.5 & 0.5 & 0.5 & 0.5 & 0.5 & \begin{tabular}{|l|}
0.5 \\
\end{tabular} & 0.5 & 0.5 & 0.5 & 0.5 & 0.5 \\
\hline & All & 1 & \begin{tabular}{|l|}
1 \\
1
\end{tabular} & 1 & \begin{tabular}{|l|}
1 \\
\end{tabular} & 1 & 1 & 1 & \begin{tabular}{|l|l|}
1 \\
\end{tabular} & \begin{tabular}{|c|}
1 \\
\end{tabular} & 1 & 1 & \begin{tabular}{|l|l}
1 \\
\end{tabular} & 1 & 1 & $\frac{1}{1}$ & 1 & 1 & 1 & 1 & 1 & 1 & 1 & 1 & $\frac{1}{1}$ \\
\hline WORK_EFF_SCH & All & 0 & 0 & 0 & 0 & 0 & 0 & 0 & 0 & 0 & 0 & 0 & 0 & 0 & 0 & 0 & 0 & 0 & 0 & 0 & 0 & 0 & 0 & 0 & 0 \\
\hline CLGSETP_FineStorage_SCH & All & 26.7 & \begin{tabular}{|l|}
26.7 \\
\end{tabular} & 26.7 & \begin{tabular}{|l|}
26.7 \\
\end{tabular} & \begin{tabular}{|l|}
26.7 \\
\end{tabular} & 26.7 & 26.7 & \begin{tabular}{|l|l|}
26.7 \\
\end{tabular} & \begin{tabular}{|l|l|}
26.7 \\
\end{tabular} & 26.7 & 26.7 & 26.7 & 26.7 & \begin{tabular}{|l|}
26.7 \\
\end{tabular} & 26.7 . & 26.7 & \begin{tabular}{|l|l|}
26.7 \\
\end{tabular} & 26.7 & 26.7 & 26.7 & 26.7 & 26.7 & 26.7 & 26.7 \\
\hline \multirow[t]{3}{*}{ CLGSETP_SCH } & WD, SummerDesign & 30 & \begin{tabular}{|l|}
30 \\
\end{tabular} & 30 & \begin{tabular}{|l|}
30 \\
\end{tabular} & \begin{tabular}{|l|}
30 \\
30
\end{tabular} & 30 & \begin{tabular}{|l|}
30 \\
\end{tabular} & \begin{tabular}{|l|l|}
24 & \\
\end{tabular} & 24 & \begin{tabular}{|l|}
24 \\
\end{tabular} & 24 & \begin{tabular}{|l|}
24 \\
\end{tabular} & \begin{tabular}{|l|}
24 \\
\end{tabular} & 24 & 24 & \begin{tabular}{|l|l|}
24 \\
\end{tabular} & \begin{tabular}{|l|l|}
24 & \\
\end{tabular} & 30 & \begin{tabular}{|l|}
30 \\
\end{tabular} & 30 & \begin{tabular}{|l|}
30 \\
\end{tabular} & 30 & 30 & 30 \\
\hline & Sat & 30 & 30 & 30 & 30 & 30 & 30 & 30 & 30 & 24 & 24 & 24 & 24 & 24 & 24 & 24 & 24 & 30 & 30 & 30 & 30 & 30 & 30 & 30 & 30 \\
\hline & Other & 30 & 30 & 30 & 30 & 30 & 30 & 30 & 30 & 30 & 30 & 30 & 30 & 30 & 30 & 30 & 30 & 30 & 30 & 30 & 30 & 30 & 30 & 30 & 30 \\
\hline Dual Zone Control Type Sched & All & 4 & \begin{tabular}{|c|c|}
4 & \\
\end{tabular} & 4 & \begin{tabular}{|c|}
4 \\
\end{tabular} & \begin{tabular}{|c|c|}
4 \\
\end{tabular} & 4 & 4 & 4 & \begin{tabular}{|c|c|}
4 & \\
\end{tabular} & \begin{tabular}{|c|}
4 \\
\end{tabular} & 4 & \begin{tabular}{|c|}
4 \\
\end{tabular} & 4 & 4 & 4 & 4 & 4 & 4 & 4 & 4 & 4 & 4 & 4 & $\frac{4}{4}$ \\
\hline HTGSETP_BulkStorage_SCH & All & 7.2 & 7.2 & 7.2 & 7.2 & 7.2 & 7.2 & 7.2 & 7.2 & 7.2 & 7.2 & 7.2 & 7.2 & 7.2 & 7.2 & 7.2 & 7.2 & 7.2 & 7.2 & 7.2 & 7.2 & 7.2 & 7.2 & 7.2 & 7.2 \\
\hline HTGSETP_FineStorage_SCH & All & 15.6 & 15.6 & 15.6 & \begin{tabular}{|l|}
15.6 \\
\end{tabular} & \begin{tabular}{|c|}
15.6 \\
\end{tabular} & 15.6 & 15.6 & \begin{tabular}{|l|l}
15.6 \\
\end{tabular} & \begin{tabular}{|l|l}
15.6 & \\
\end{tabular} & 15.6 & \begin{tabular}{|c|}
15.6 \\
\end{tabular} & \begin{tabular}{|l|}
15.6 \\
\end{tabular} & 15.6 & 15.6 & 15.6 & 15.6 & \begin{tabular}{|l|}
15.6 \\
\end{tabular} & 15.6 & \begin{tabular}{|l|}
15.6 \\
\end{tabular} & 15.6 & 15.6 & 15.6 & 15.6 & 15.6 \\
\hline \multirow{4}{*}{ HTGSETP_SCH } & WD & 15.5 & \begin{tabular}{|l|}
15.5 \\
\end{tabular} & 15.5 & \begin{tabular}{|c|}
15.5 \\
\end{tabular} & \begin{tabular}{|l|}
15.5 \\
\end{tabular} & 15.5 & \begin{tabular}{|l|}
21 \\
21
\end{tabular} & \begin{tabular}{|l|l|}
21 & \\
\end{tabular} & \begin{tabular}{|l|l|}
21 & \\
\end{tabular} & \begin{tabular}{|l|}
21 \\
\end{tabular} & \begin{tabular}{|l|}
21 \\
\end{tabular} & \begin{tabular}{|l|}
21 \\
\end{tabular} & \begin{tabular}{|l|}
21 \\
\end{tabular} & \begin{tabular}{|l|}
21 \\
21
\end{tabular} & \begin{tabular}{|l|}
21 \\
\end{tabular} & \begin{tabular}{|l|}
21 \\
21
\end{tabular} & \begin{tabular}{|l|}
21 \\
21
\end{tabular} & \begin{tabular}{|l|}
15.5 \\
\end{tabular} & \begin{tabular}{|l|}
15.5 \\
\end{tabular} & 15.5 & \begin{tabular}{|c|}
15.5 \\
\end{tabular} & 15.5 & 15.5 & 15.5 \\
\hline & WinterDesign & 21 & 21 & 21 & \begin{tabular}{|l|}
21 \\
\end{tabular} & 21 & 21 & 21 & 21 & 21 & 21 & 21 & 21 & 21 & 21 & 21 & 21 & 21 & 21 & 21 & 21 & 21 & 21 & 21 & 21 \\
\hline & Sat & 15.5 & \begin{tabular}{|l|}
15.5 \\
\end{tabular} & 15.5 & 15.5 & \begin{tabular}{|l|}
15.5 \\
\end{tabular} & 15.5 & 15.5 & 21 & 21 & \begin{tabular}{|l|}
21 \\
\end{tabular} & 21 & 21 & \begin{tabular}{|l|}
21 \\
\end{tabular} & 21 & 21 & 21 & \begin{tabular}{|c|}
15.5 \\
\end{tabular} & 15.5 & 15.5 & 15.5 & 15.5 & 15.5 & 15.5 & 15.5 \\
\hline & Other & 15.5 & \begin{tabular}{|l|}
15.5 \\
\end{tabular} & 15.5 & \begin{tabular}{|l|}
15.5 \\
\end{tabular} & \begin{tabular}{|l|}
15.5 \\
\end{tabular} & 15.5 & \begin{tabular}{|l|}
15.5 \\
\end{tabular} & \begin{tabular}{|l|l|}
15.5 \\
\end{tabular} & \begin{tabular}{|l|l|}
15.5 & \\
\end{tabular} & \begin{tabular}{|l|}
15.5 \\
\end{tabular} & \begin{tabular}{|c|}
15.5 \\
\end{tabular} & \begin{tabular}{|l|}
15.5 \\
\end{tabular} & \begin{tabular}{|l|}
15.5 \\
\end{tabular} & \begin{tabular}{|l|}
15.5 \\
\end{tabular} & \begin{tabular}{|l|}
15.5 \\
\end{tabular} & \begin{tabular}{|l|}
21 \\
15.5 \\
\end{tabular} & \begin{tabular}{|l|}
15.5 \\
\end{tabular} & \begin{tabular}{|l|}
15.5 \\
\end{tabular} & \begin{tabular}{|l|}
15.5 \\
\end{tabular} & 15.5 & \begin{tabular}{|l|}
15.5 \\
\end{tabular} & 15.5 & 15.5 & 15.5 \\
\hline \multirow[t]{3}{*}{ HVACOperationSchd } & WD, SummerDesign & 0 & 0 & 0 & 0 & 0 & 0 & 1 & 1 & 1 & 1 & 1 & \begin{tabular}{|c|}
1 \\
\end{tabular} & 1 & 1 & 1 & 1 & 1 & 0 & 0 & 0 & 0 & 0 & 0 & 0 \\
\hline & Sat, WinterDesign & 0 & 0 & 0 & 0 & 0 & 0 & 0 & 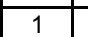 & 1 & 1 & 1 & 1 & 1 & 1 & 1 & 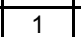 & 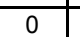 & 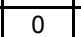 & 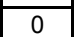 & 0 & 0 & 0 & 0 & 0 \\
\hline & Other & 0 & 0 & 0 & 0 & 0 & 0 & 0 & 0 & 0 & 0 & 0 & 0 & 0 & 0 & 0 & 0 & 0 & 0 & 0 & 0 & 0 & 0 & 0 & 0 \\
\hline \multirow[t]{3}{*}{ MinOA_Sched } & WD, SummerDesign & 0 & 0 & 0 & 0 & 0 & 0 & 1 & 1 & 1 & 1 & 1 & 1 & 1 & 1 & 1 & 1 & 1 & 0 & 0 & 0 & 0 & 0 & 0 & 0 \\
\hline & Sat, WinterDesign & 0 & 0 & 0 & 0 & 0 & 0 & 0 & 1 & 1 & 1 & 1 & 1 & 1 & 1 & 1 & 1 & 0 & 0 & 0 & 0 & 0 & 0 & 0 & 0 \\
\hline & Other & 0 & 0 & 0 & 0 & 0 & 0 & 0 & 0 & 0 & 0 & 0 & 0 & 0 & 0 & 0 & 0 & 0 & 0 & 0 & 0 & 0 & 0 & 0 & 0 \\
\hline ALWAYS_ON & All & 1 & 1 & 1 & 1 & 1 & 1 & 1 & 1 & 1 & 1 & 1 & 1 & 1 & 1 & 1 & 1 & 1 & 1 & 1 & 1 & 1 & 1 & 1 & 1 \\
\hline ACTIVITY_SCH & All & 120 & \begin{tabular}{|l|}
120 \\
\end{tabular} & 120 & 120 & \begin{tabular}{|l|}
120 \\
\end{tabular} & 120 & 120 & 120 & 120 & 120 & 120 & 120 & 120 & 120 & 120 & 120 & 120 & 120 & 120 & 120 & 120 & 120 & 120 & 120 \\
\hline AIR_VELO_SCH & All & 0.2 & \begin{tabular}{|l|}
0.2 \\
0
\end{tabular} & \begin{tabular}{|l|l|}
0.2 \\
\end{tabular} & \begin{tabular}{|l|}
0.2 \\
\end{tabular} & \begin{tabular}{|l|}
0.2 \\
0
\end{tabular} & \begin{tabular}{|l|}
0.2 \\
0.2
\end{tabular} & \begin{tabular}{|l|}
10.2 \\
0
\end{tabular} & \begin{tabular}{|l|l|}
0.2 \\
0
\end{tabular} & \begin{tabular}{|l|l|}
0.2 \\
\end{tabular} & \begin{tabular}{|l|}
0.2 \\
0
\end{tabular} & 0.2 & \begin{tabular}{|l|}
0.2 \\
0
\end{tabular} & \begin{tabular}{|l|}
120 \\
0.2 \\
\end{tabular} & \begin{tabular}{|l|}
$1<0$ \\
0.2 \\
\end{tabular} & \begin{tabular}{|l|l|}
0.2 \\
0
\end{tabular} & 0.2 & 0.2 & \begin{tabular}{|l|l|}
0.2 \\
0
\end{tabular} & \begin{tabular}{|l|}
0.2 \\
0.2
\end{tabular} & \begin{tabular}{|l|}
120 \\
0.2 \\
\end{tabular} & \begin{tabular}{|l|}
0.2 \\
0.2
\end{tabular} & \begin{tabular}{|l|}
120 \\
0.2 \\
\end{tabular} & \begin{tabular}{|l|}
120 \\
0.2 \\
\end{tabular} & 0.2 \\
\hline \multirow[t]{2}{*}{ BLDG_EQUIP_SCH } & WD & 0.1 & \begin{tabular}{|l|l|}
0.1 & \\
\end{tabular} & \begin{tabular}{|l|}
0.1 \\
\end{tabular} & \begin{tabular}{|l|}
0.1 \\
\end{tabular} & \begin{tabular}{|l|}
0.1 \\
\end{tabular} & \begin{tabular}{|l|}
0.1 \\
\end{tabular} & \begin{tabular}{|l|}
0.1 \\
\end{tabular} & \begin{tabular}{|l|}
0.5 \\
\end{tabular} & \begin{tabular}{|l|l|}
0.8 \\
\end{tabular} & \begin{tabular}{|l|}
0.9 \\
\end{tabular} & 0.9 & \begin{tabular}{|l|}
0.9 \\
\end{tabular} & \begin{tabular}{|l|}
0.8 \\
\end{tabular} & \begin{tabular}{|l|}
0.9 \\
\end{tabular} & \begin{tabular}{|l|l|}
0.9 \\
\end{tabular} & 0.9 & 0.9 & \begin{tabular}{|l|l|}
0.4 \\
\end{tabular} & \begin{tabular}{|l|}
0.1 \\
\end{tabular} & \begin{tabular}{|l|}
0.1 \\
\end{tabular} & \begin{tabular}{|l|}
0.1 \\
\end{tabular} & 0.1 & 0.1 & 0.1 \\
\hline & Sat & 0.1 & \begin{tabular}{|l|}
0.1 \\
\end{tabular} & \begin{tabular}{|l|}
0.1 \\
\end{tabular} & \begin{tabular}{|l|}
0.1 \\
\end{tabular} & \begin{tabular}{|l|}
0.1 \\
\end{tabular} & 0.1 & \begin{tabular}{|l|}
0.1 \\
\end{tabular} & \begin{tabular}{|l|l|}
0.1 & \\
\end{tabular} & \begin{tabular}{|l|}
0.2 \\
\end{tabular} & \begin{tabular}{|l|}
0.4 \\
\end{tabular} & 0.4 & \begin{tabular}{|l|}
0.4 \\
\end{tabular} & 0.1 & 0.1 & 0.1 & 0.1 & 0.1 & \begin{tabular}{|l|l|}
0.1 \\
\end{tabular} & \begin{tabular}{|l|}
0.1 \\
\end{tabular} & 0.1 & \begin{tabular}{|l|}
0.1 \\
\end{tabular} & 0.1 & 0.1 & 0.1 \\
\hline
\end{tabular}




\begin{tabular}{|c|c|c|c|c|c|c|c|c|c|c|c|c|c|c|c|c|c|c|c|c|c|c|c|c|c|}
\hline Schedule & Day of Week & 1 & 2 & 3 & 4 & 5 & 6 & 7 & 8 & 9 & 10 & 11 & 12 & 13 & 14 & 15 & 16 & 17 & 18 & 19 & 20 & 21 & 22 & 23 & 24 \\
\hline & SummerDesign & 1 & 1 & 1 & 1 & 1 & 1 & 1 & 1 & 1 & 1 & 1 & 1 & 1 & 1 & 1 & 1 & 1 & 1 & 1 & 1 & 1 & 1 & 1 & 1 \\
\hline & WinterDesign & 0 & 0 & 0 & 0 & 0 & 0 & 0 & 0 & 0 & 0 & 0 & 0 & 0 & 0 & 0 & 0 & 0 & 0 & 0 & 0 & 0 & 0 & 0 & 0 \\
\hline & Sun, Hol, Other & 0.1 & \begin{tabular}{|l|}
0.1 \\
\end{tabular} & \begin{tabular}{|l|}
0.1 \\
\end{tabular} & \begin{tabular}{|l|}
0.1 \\
\end{tabular} & \begin{tabular}{|l|}
0.1 \\
\end{tabular} & 0.1 & 0.1 & 0.1 & 0.1 & 0.1 & 0.1 & 0.1 & \begin{tabular}{|l|}
0.1 \\
\end{tabular} & 0.1 & \begin{tabular}{|l|}
0.1 \\
\end{tabular} & 0.1 & 0.1 & 0.1 & 0.1 & 0.1 & 0.1 & 0.1 & 0.1 & 0.1 \\
\hline \multirow[t]{5}{*}{ BLDG_LIGHT_SCH } & WD & 0.1 & 0.1 & 0.1 & $\begin{array}{ll}0.1 \\
\end{array}$ & \begin{tabular}{|l|}
0.1 \\
\end{tabular} & 0.1 & 0.1 & 0.4 & 0.7 & 0.9 & 0.9 & 0.9 & 0.8 & 0.9 & 0.9 & 0.9 & 0.9 & 0.3 & 0.1 & 0.1 & 0.1 & 0.1 & 0.1 & 0.1 \\
\hline & Sat & 0.1 & \begin{tabular}{|l|}
0.1 \\
\end{tabular} & \begin{tabular}{|l|}
0.1 \\
\end{tabular} & \begin{tabular}{|l|}
0.1 \\
\end{tabular} & \begin{tabular}{|l|}
0.1 \\
\end{tabular} & \begin{tabular}{|l|}
0.1 \\
\end{tabular} & 0.1 & 0.1 & 0.1 & 0.24 & 0.24 & \begin{tabular}{|l|}
0.24 \\
\end{tabular} & 0.1 & 0.1 & \begin{tabular}{|l|}
0.1 \\
\end{tabular} & \begin{tabular}{|l|}
0.1 \\
\end{tabular} & \begin{tabular}{|l|}
0.1 \\
\end{tabular} & \begin{tabular}{|l|}
0.1 \\
\end{tabular} & \begin{tabular}{|l|}
0.1 \\
\end{tabular} & 0.1 & 0.1 & \begin{tabular}{|l|}
0.1 \\
\end{tabular} & \begin{tabular}{|l|}
0.1 \\
\end{tabular} & 0.1 \\
\hline & SummerDesign & 1 & 1 & 1 & 1 & 1 & 1 & 1 & 1 & 1 & 1 & 1 & 1 & 1 & 1 & 1 & 1 & 1 & 1 & 1 & 1 & 1 & 1 & 1 & 1 \\
\hline & WinterDesign & 0 & 0 & 0 & 0 & 0 & 0 & 0 & 0 & 0 & 0 & 0 & 0 & 0 & 0 & 0 & 0 & 0 & 0 & 0 & 0 & 0 & 0 & 0 & 0 \\
\hline & Sun, Hol, Other & 0.1 & \begin{tabular}{|l|}
0.1 \\
\end{tabular} & 0.1 & $\begin{array}{ll}0.1 \\
\end{array}$ & \begin{tabular}{|l|}
0.1 \\
\end{tabular} & 0.1 & 0.1 & 0.1 & 0.1 & 0.1 & 0.1 & 0.1 & 0.1 & 0.1 & 0.1 & 0.1 & 0.1 & 0.1 & 0.1 & 0.1 & 0.1 & 0.1 & 0.1 & 0.1 \\
\hline \multirow[t]{5}{*}{ BLDG_OCC_SCH } & WD & 0 & 0 & 0 & 0 & 0 & 0 & 0 & 0.15 & 0.7 & 0.9 & 0.9 & 0.9 & 0.5 & 0.85 & 0.85 & 0.85 & \begin{tabular}{|l|}
0.2 \\
\end{tabular} & 0 & 0 & 0 & 0 & 0 & 0 & 0 \\
\hline & SummerDesign & 1 & 1 & 1 & 1 & 1 & 1 & 1 & 1 & 1 & 1 & 1 & 1 & 1 & 1 & 1 & 1 & 1 & 1 & 1 & 1 & 1 & 1 & 1 & 1 \\
\hline & Sat & 0 & 0 & 0 & 0 & 0 & 0 & 0 & 0 & 0.2 & 0.2 & 0.2 & \begin{tabular}{|l|}
0.2 \\
\end{tabular} & \begin{tabular}{|l|}
0.1 \\
\end{tabular} & 0.1 & \begin{tabular}{|l|}
0.1 \\
\end{tabular} & 0.1 & 0 & 0 & 0 & 0 & 0 & 0 & 0 & 0 \\
\hline & WinterDesign & 0 & 0 & 0 & 0 & 0 & 0 & 0 & 0 & 0 & 0 & 0 & 0 & 0 & 0 & 0 & 0 & 0 & 0 & 0 & 0 & 0 & 0 & 0 & 0 \\
\hline & Sun, Hol, Other & 0 & 0 & 0 & 0 & 0 & 0 & 0 & 0 & 0 & 0 & 0 & 0 & 0 & 0 & 0 & 0 & 0 & 0 & 0 & 0 & 0 & 0 & 0 & 0 \\
\hline \multirow[t]{3}{*}{ CLOTHING_SCH } & All & 1 & 1 & 1 & 1 & 1 & 1 & 1 & 1 & 1 & 1 & 1 & 1 & 1 & 1 & 1 & 1 & 1 & 1 & 1 & 1 & 1 & 1 & 1 & 1 \\
\hline & All & 0.5 & 0.5 & 0.5 & 0.5 & \begin{tabular}{|l|}
0.5 \\
\end{tabular} & 0.5 & 0.5 & 0.5 & 0.5 & 0.5 & 0.5 & 0.5 & 0.5 & 0.5 & 0.5 & 0.5 & \begin{tabular}{|l|}
0.5 \\
\end{tabular} & 0.5 & 0.5 & 0.5 & 0.5 & \begin{tabular}{|l|}
0.5 \\
\end{tabular} & \begin{tabular}{|l|}
0.5 \\
\end{tabular} & 0.5 \\
\hline & All & 1 & 1 & 1 & 1 & 1 & 1 & 1 & 1 & 1 & 1 & 1 & 1 & 1 & 1 & 1 & 1 & 1 & 1 & 1 & 1 & 1 & 1 & 1 & 1 \\
\hline WORK_EFF_SCH & All & 0 & 0 & 0 & 0 & 0 & 0 & 0 & 0 & 0 & 0 & 0 & 0 & 0 & 0 & 0 & 0 & 0 & 0 & 0 & 0 & 0 & 0 & 0 & 0 \\
\hline CLGSETP_FineStorage_SCH & All & 26.7 & 26.7 & 26.7 & 26.7 & 26.7 & 26.7 & 26.7 & 26.7 & 26.7 & 26.7 & 26.7 & 26.7 & 26.7 & 26.7 & 26.7 & 26.7 & 26.7 & 26.7 & 26.7 & 26.7 & 26.7 & 26.7 & 26.7 & 26.7 \\
\hline \multirow[t]{3}{*}{ CLGSETP_SCH } & WD, SummerDesign & 30 & 30 & 30 & 30 & 30 & 30 & 30 & 24 & 24 & 24 & 24 & 24 & 24 & 24 & 24 & 24 & 24 & 30 & 30 & 30 & 30 & 30 & 30 & 30 \\
\hline & Sat & 30 & 30 & 30 & 30 & 30 & 30 & 30 & 30 & 24 & 24 & 24 & 24 & 24 & 24 & 24 & 24 & 30 & 30 & 30 & 30 & 30 & 30 & 30 & 30 \\
\hline & Other & 30 & 30 & 30 & 30 & 30 & 30 & 30 & 30 & 30 & 30 & 30 & 30 & 30 & 30 & 30 & 30 & 30 & 30 & 30 & 30 & 30 & 30 & 30 & 30 \\
\hline Dual Zone Control Type Sched & All & 4 & 4 & 4 & 4 & 4 & 4 & 4 & 4 & 4 & 4 & 4 & 4 & 4 & 4 & 4 & 4 & 4 & 4 & 4 & 4 & 4 & 4 & 4 & 4 \\
\hline HTGSETP_BulkStorage_SCH & All & 7.2 & 7.2 & 7.2 & 7.2 & 7.2 & 7.2 & 7.2 & 7.2 & 7.2 & 7.2 & 7.2 & 7.2 & 7.2 & 7.2 & 7.2 & 7.2 & 7.2 & 7.2 & 7.2 & 7.2 & 7.2 & 7.2 & 7.2 & 7.2 \\
\hline HTGSETP_FineStorage_SCH & All & 15.6 & 15.6 & 15.6 & 15.6 & 15.6 & 15.6 & 15.6 & 15.6 & 15.6 & 15.6 & 15.6 & 15.6 & 15.6 & 15.6 & 15.6 & 15.6 & 15.6 & 15.6 & 15.6 & 15.6 & 15.6 & 15.6 & 15.6 & 15.6 \\
\hline \multirow[t]{4}{*}{ HTGSETP_SCH } & WD & 15.5 & 15.5 & 15.5 & 15.5 & 15.5 & 15.5 & 21 & 21 & 21 & 21 & 21 & 21 & 21 & 21 & 21 & 21 & 21 & 15.5 & 15.5 & 15.5 & 15.5 & 15.5 & 15.5 & 15.5 \\
\hline & \begin{tabular}{|l|l} 
WinterDesign \\
\end{tabular} & 21 & 21 & 21 & 21 & 21 & 21 & 21 & 21 & 21 & 21 & 21 & 21 & 21 & 21 & 21 & 21 & 21 & 21 & 21 & 21 & 21 & 21 & 21 & 21 \\
\hline & Sat & 15.5 & 15.5 & 15.5 & 15.5 & 15.5 & 15.5 & 15.5 & 21 & 21 & 21 & 21 & 21 & 21 & 21 & 21 & 21 & 15.5 & 15.5 & 15.5 & 15.5 & 15.5 & 15.5 & 15.5 & 15.5 \\
\hline & Other & 15.5 & 15.5 & 15.5 & 15.5 & 15.5 & 15.5 & 15.5 & 15.5 & 15.5 & 15.5 & 15.5 & 15.5 & 15.5 & 15.5 & 15.5 & 15.5 & 15.5 & 15.5 & 15.5 & 15.5 & 15.5 & 15.5 & 15.5 & 15.5 \\
\hline \multirow[t]{3}{*}{ HVACOperationSchd } & WD, SummerDesign & 0 & 0 & 0 & 0 & 0 & 0 & 1 & 1 & 1 & 1 & 1 & 1 & 1 & 1 & 1 & 1 & 1 & 0 & 0 & 0 & 0 & 0 & 0 & 0 \\
\hline & Sat, WinterDesign & 0 & 0 & 0 & 0 & 0 & 0 & 0 & 1 & 1 & 1 & 1 & 1 & 1 & 1 & 1 & 1 & 0 & 0 & 0 & 0 & 0 & 0 & 0 & 0 \\
\hline & Other & 0 & 0 & 0 & 0 & 0 & 0 & 0 & 0 & 0 & 0 & 0 & 0 & 0 & 0 & 0 & 0 & 0 & 0 & 0 & 0 & 0 & 0 & 0 & 0 \\
\hline \multirow[t]{3}{*}{ MinOA_Sched } & WD, SummerDesign & 0 & 0 & 0 & 0 & 0 & 0 & 1 & 1 & 1 & 1 & 1 & 1 & 1 & 1 & 1 & 1 & 1 & 0 & 0 & 0 & 0 & 0 & 0 & 0 \\
\hline & Sat, WinterDesign & 0 & 0 & 0 & 0 & 0 & 0 & 0 & 1 & 1 & 1 & 1 & 1 & 1 & 1 & 1 & 1 & 0 & 0 & 0 & 0 & 0 & 0 & 0 & 0 \\
\hline & Other & 0 & 0 & 0 & 0 & 0 & 0 & 0 & 0 & 0 & 0 & 0 & 0 & 0 & 0 & 0 & 0 & 0 & 0 & 0 & 0 & 0 & 0 & 0 & 0 \\
\hline ALWAYS_ON & All & 1 & 1 & 1 & 1 & 1 & 1 & 1 & 1 & 1 & 1 & 1 & 1 & 1 & 1 & 1 & 1 & 1 & 1 & 1 & 1 & 1 & 1 & 1 & 1 \\
\hline ACTIVITY_SCH & All & 120 & 120 & \begin{tabular}{|l|}
120 \\
\end{tabular} & 120 & 120 & 120 & \begin{tabular}{|l|}
120 \\
\end{tabular} & 120 & 120 & 120 & 120 & 120 & 120 & 120 & 120 & 120 & 120 & \begin{tabular}{|l|}
120 \\
\end{tabular} & 120 & 120 & 120 & 120 & 120 & 120 \\
\hline AIR_VELO_SCH & All & 0.2 & 0.2 & 0.2 & \begin{tabular}{|l|}
0.2 \\
\end{tabular} & 0.2 & 0.2 & 0.2 & 0.2 & 0.2 & 0.2 & 0.2 & 0.2 & 0.2 & 0.2 & 0.2 & 0.2 & 0.2 & 0.2 & 0.2 & 0.2 & 0.2 & 0.2 & 0.2 & 0.2 \\
\hline
\end{tabular}




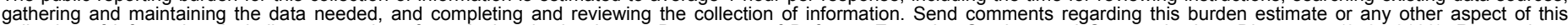

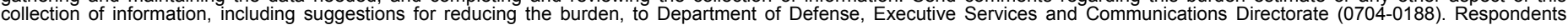

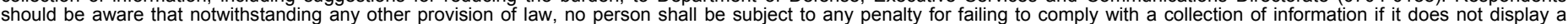

currently valid

PLEASE DO NOT RETURN YOUR FORM TO THE ABOVE ORGANIZATION.

\begin{tabular}{l|l|l|l} 
1. REPORT DATE $(D D-M M-Y Y Y Y)$ & 2. REPORT TYPE & 3. DATES COVERED (FrOm - TO)
\end{tabular}

February 2011

Technical Report

4. TITLE AND SUBTITLE

U.S. Department of Energy Commercial Reference Building Models

of the National Building Stock

5a. CONTRACT NUMBER

DE-AC36-08G028308

5b. GRANT NUMBER

5c. PROGRAM ELEMENT NUMBER

5d. PROJECT NUMBER

NREL/TP-5500-46861

Michael Deru, Kristin Field, Daniel Studer, Kyle Benne, Brent

Griffith, and Paul Torcellini (National Renewable Energy Laboratory)

Bing Liu, Mark Halverson, Dave Winiarski, and Michael Rosenberg

(Pacific Northwest National Laboratory)

Mehry Yazdanian (Lawrence Berkeley National Laboratory)

Joe Huang (Formerly of Lawrence Berkeley National Laboratory)

Drury Crawley (Formerly of the U.S. Department of Energy)

7. PERFORMING ORGANIZATION NAME(S) AND ADDRESS(ES)

National Renewable Energy Laboratory

1617 Cole Blvd.

Golden, CO 80401-3393

5e. TASK NUMBER

BEC7.1304

5f. WORK UNIT NUMBER
9. SPONSORING/MONITORING AGENCY NAME(S) AND ADDRESS(ES)
8. PERFORMING ORGANIZATION REPORT NUMBER NREL/TP-5500-46861
10. SPONSOR/MONITOR'S ACRONYM(S) NREL

11. SPONSORING/MONITORING AGENCY REPORT NUMBER

12. DISTRIBUTION AVAILABILITY STATEMENT

National Technical Information Service

U.S. Department of Commerce

5285 Port Royal Road

Springfield, VA 22161

13. SUPPLEMENTARY NOTES

14. ABSTRACT (Maximum 200 Words)

The U.S. Department of Energy (DOE) Building Technologies Program has set the aggressive goal of producing marketable net-zero energy buildings by 2025 . This goal will require collaboration between the DOE laboratories and the building industry. We developed standard or reference energy models for the most common commercial buildings to serve as starting points for energy efficiency research. These models represent fairly realistic buildings and typical construction practices. Fifteen commercial building types and one multifamily residential building were determined by consensus between DOE, the National Renewable Energy Laboratory, Pacific Northwest National Laboratory, and Lawrence Berkeley National Laboratory, and represent approximately two-thirds of the commercial building stock.

15. SUBJECT TERMS

net-zero energy; reference building; energy efficiency; energy simulation

\begin{tabular}{|c|c|c|}
\hline $\begin{array}{l}\text { a. REPORT } \\
\text { Unclassified }\end{array}$ & $\begin{array}{l}\text { b. ABSTRACT } \\
\text { Unclassified }\end{array}$ & $\begin{array}{l}\text { c. THIS PAGE } \\
\text { Unclassified }\end{array}$ \\
\hline
\end{tabular}

17. LIMITATION
OF ABSTRACT
UL

19a. NAME OF RESPONSIBLE PERSON

19b. TELEPHONE NUMBER (Include area code) 